\title{
DISERTASI
}

\section{METAFORA EMOSI BAHASA INDONESIA}

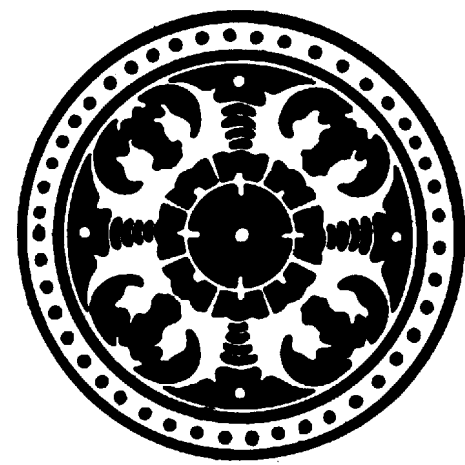

I MADE RAJEG

PROGRAM PASCASARJANA

UNIVERSITAS UDAYANA

DENPASAR

2013 


\section{DISERTASI}

\section{METAFORA EMOSI BAHASA INDONESIA}

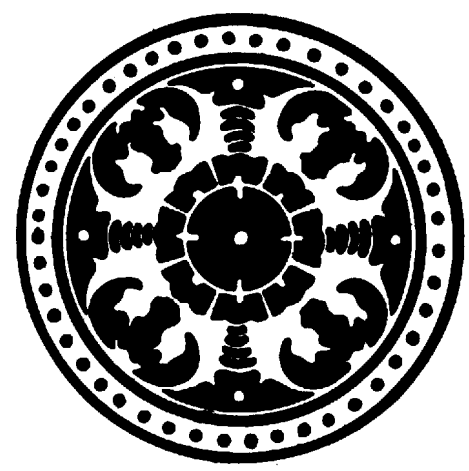

I MADE RAJEG

NIM 0890171009

PROGRAM DOKTOR

PROGRAM STUDI LINGUISTIK

PROGRAM PASCASARJANA

UNIVERSITAS UDAYANA

DENPASAR

2013 


\section{METAFORA EMOSI BAHASA INDONESIA}

Disertasi untuk memperoleh Gelar Doktor pada Program Doktor Program Studi Linguistik

Program Pascasarjana Universitas Udayana

I MADE RAJEG

NIM 0890171009

\section{PROGRAM DOKTOR \\ PROGRAM STUDI LINGUISTIK \\ PROGRAM PASCASARJANA \\ UNIVERSITAS UDAYANA \\ DENPASAR}

2013 


\section{Lembar Pengesahan}

\section{DISERTASI INI TELAH DISETUJUI}

TANGGAL. 26 September 2013

\section{Promotor.}

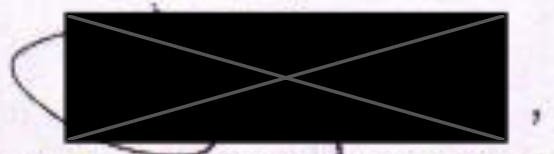

Prof. Dr. Ni Luh Sutjiati Beratha, M.A. NIP 195909171984032002

Kopromotor I,

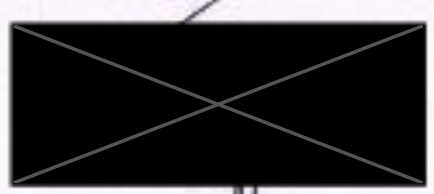

Prof. Dr. I Nengal/Sudipa, M.A. NIP 195407311979111001
Kopromotor II,



Prof. Dr. I Ketut Darma Laksana, M.Hum NIP 19520901198103 | 001

Mengetahui

Ketua Program Doktor Linguistik Program Pascasarjana

Universitas Udayana,
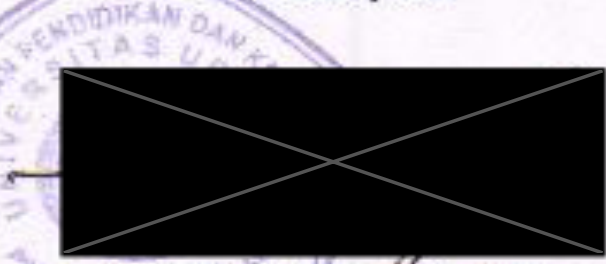

Prof. Dr. Arón Meko Mbetc NIP 19470n131980031001

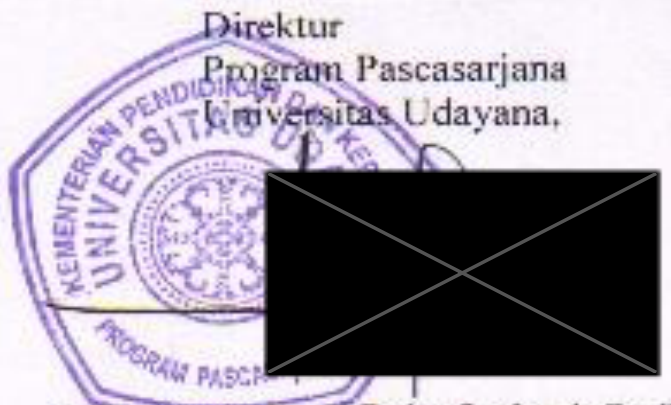

Prol. Dr.dr. A.A. Raka Sudewi, Sp.S. (K) NIP 195902151985102001 


\section{Disertasi ini Telah Diuji pada Ujian Tertutup}

Tanggal 19 Agustus 2013

Panitia Penguji Disertasi

Berdasarkan SK Rektor Universitas Udayana

Nomor: 1483/UN.14.4/HK/2013

Ketua : Prof. Dr. Drs. Ida Bagus Putra Yadnya, M.A.

Anggota: :

1. Prof. Dr. Ni Luh Sutjiati Beratha, M.A. (Promotor)

2. Prof. Dr. I Nengah Sudipa, M.A. (Kopromotor I)

3. Prof. Dr. I Ketut Darma Laksana, M.Hum. (Kopromotor II)

4. Prof. Drs. I Dewa Komang Tantra, M.Sc., Ph.D.

5. Prof. Dr. I Gusti Made Sutjaja, M.A.

6. Prof. Drs. Ketut Artawa, M.A., Ph.D.

7. Prof. Dr. Aron Meko Mbete 


\section{PERNYATAAN BEBAS PLAGIAT}

Nama : I Made Rajeg

NIM : 0890171009

Program Studi : Program Doktor (S3) Pascasarjana Universitas Udayana

Dengan ini menyatakan bahwa karya ilmiah disertasi ini bebas plagiat. Apabila dikemudian hari terbukti terdapat plagiat dalam karya ilmiah ini, maka saya bersedia menerima sanksi sesuai dengan Peraturan Mendiknas RI No. 17 Tahun 2010 dan peraturan perundang-undangan yang berlaku.

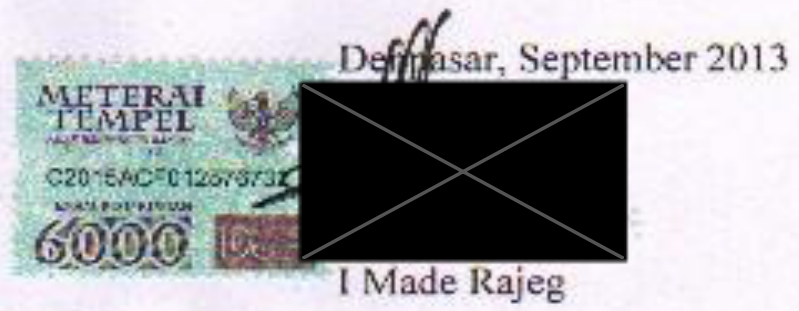




\section{UCAPAN TERIMA KASIH}

Penulis memanjatkan puja dan puji syukur kepada Tuhan Yang Mahaesa, Ida Sang Hyang Widhi Wasa atas berkat yang telah menggetarkan jiwa dan raga penulis untuk menyelesaikan disertasi yang berjudul "Metafora Emosi Bahasa Indonesia” ini. Selain berkat Tuhan, penulis juga telah menerima banyak bantuan dan dukungan dari banyak pihak, baik secara langsung maupun secara tidak langsung. Oleh karena itu, pantaslah melalui media ini, penulis menyampaikan rasa terima kasih yang tulus dan penghargaan yang setinggi-tingginya kepada beberapa pihak yang terkait.

Pertama-tama, penulis menyampaikan ucapan terima kasih yang tulus dan penghargaan yang tinggi kepada Prof. Dr. Ni Luh Sutjiati Beratha, M.A. selaku Promotor Utama atas bimbingan, arahan, dan masukan yang sangat berharga selama proses penyelesaian disertasi ini. Demikian juga kepada Prof. Dr. I Nengah Sudipa, M.A. selaku Kopromotor I dan Prof. Dr. I Ketut Darma Laksana, M.Hum. selaku Kopromotor II, Prof. Dr. I Gusti Made Sutjaja, M.A. selaku pembimbing akademis, penulis menyampaikan ucapan yang sama.

Berikutnya, ucapan terima kasih dan penghargaan yang tinggi disampaikan kepada Pemerintah Republik Indonesia, terutama Menteri Pendidikan dan Kebudayaan atas dukungan dana berupa tunjangan belajar dan beasiswa BPPS serta dana bantuan penyelesaian disertasi; Rektor Universitas Udayana, Prof. Dr. dr. Ketut Suastika, Sp. PD-KEM.D atas kesempatan yang diberikan kepada penulis untuk mengikuti pendidikan doktor; Direktur Program 
Pascasarjana Universitas Udayana, Prof. Dr. dr. A. A. Raka Sudewi, Sp. S(K), Asisten Direktur bidang akademik, Prof. Dr. Made Budiarsa, M. A., Asisten Direktur bidang keuangan, Prof. Dr. I Ketut Budi Susrusa, M.S.; Ketua Program Doktor Linguistik, Prof. Dr. Aron Meko Mbete, Sekretaris Program Doktor Linguistik, Dr. A. A. Putu Putra, M. Hum.; Mantan Dekan Fakultas Sastra dan Budaya, Prof. Dr. I Wayan Ardika, M.A, dan Dekan serta para pembantu Dekan Fakultas Sastra dan Budaya Universitas Udayana atas segala fasilitas yang diberikan kepada penulis selama masa pendidikan.

Ucapan terima kasih dan penghargaan yang tinggi juga disampaikan kepada tim penguji disertasi penulis, Prof. Drs. I Dewa Komang Tantra, M.Sc., Ph.D, Prof. Dr. I Gusti Made Sutjaja, M.A., Prof. Dr. Aron Meko Mbete, Prof. Drs. Ketut Artawa, M.A., Ph.D., Prof. Dr. Drs. Ida Bagus Putra Yadnya, M.A. atas pertanyaan, kritik, saran, sanggahan, dan koreksi yang diarahkan untuk menjadikan disertasi ini lebih baik.

Kepada para dosen pengajar Program Doktor Linguistik, Prof. Dr. I G. M. Sutjaja, M. A., Prof. Dr. I Wayan Jendra, S.U., Prof. Dr. Aron Meko Mbete, Prof. Dr. Ketut Riana, S.U., Prof. Dr. I Nengah Sudipa, M.A., Prof. Dr. N. L. Sutjiati Beratha, M.A., Prof. Drs. Ketut Artawa, M.A., Ph.D., Prof. Dr. Drs. Ida Bagus Putra Yadnya, M.A., Prof. Dr. Made Budiarsa, M. A., Prof. Drs. I Made Suastra, Ph.D., Prof. Dr. I Ketut Darma Laksana, M.Hum., Prof. Dr. I Wayan Pastika, M.S., Dr. Ni Made Dhanawaty, M.S. penulis mengucapkan terima kasih dengan penuh rasa hormat dan penghargaan yang setinggi-tingginya atas ilmu dan 
wawasan kelinguistikan yang dibagikan kepada penulis melalui kepakarannya masing-masing.

Penulis mengucapkan terima kasih dan penghargaan yang tidak terhingga kepada semua kolega pada Jurusan Sastra Inggris Fakultas Sastra Universitas Udayana, terutama mantan Ketua dan Sekretaris Jurusan, Drs. I Gde Budiasa, M.A. dan I Gusti Ngurah Partama, S. S., M. Hum. atas izin, restu, dan doa untuk kesuksesan pendidikan penulis; Dr. Nyoman Seri Malini, S.S., M.Hum. Dr. Ida Ayu Made Puspani, M.Hum., Dr. Frans I Made Berata, M.Hum., Dr. I Made Netra, S.S., M.Hum., yang telah dengan tulus membagikan pengalaman studinya pada masa awal studi doktor penulis; I Nyoman Arya Wibawa, S.S., M.A., Ph.D atas pernyataan ketertarikannya terhadap topik yang penulis teliti telah menyemangati penulis; semua kolega lain yang tidak dapat disebutkan satu per satu juga diucapkan terima kasih yang tulus.

Terima kasih dan penghargaan juga disampaikan kepada seluruh staf administrasi Program Pascasarjana Universitas Udayana, terutama staf Program Studi Linguistik, I Ketut Ebuh, S.Sos., I Nyoman Sadra, S.S., Ida Bagus Suanda, S.Sos., I Gusti Ayu Putu Supadmini, Nyoman Adi Triani, S.E., Nyoman Sukartini, dan Nyoman Sumerti atas pelayanan administrasi yang prima.

Ucapan terima kasih yang tulus juga disampaikan kepada teman-teman kuliah pada Program Doktor Linguistik Universitas Udayana atas kerja sama, keakraban, dan bantuan selama ini khususnya kepada Dr. Agus Subiyanto, M.A., Drs. Jekmen Sinulingga, M.Hum., Dr. Abdulrahman Syahputra, M.Hum., Dr. Mulyadi, M.Hum., Dr. Wisman Hadi, M.Hum., Dr. I Ketut Yudha, M.Hum., Drs. 
I Wayan Resen, M.A. M. App Ling., Dr. Luh Ketut Mas Indrawati, M.A., Dr. Ni Wayan Sukarini, M.Hum., Dr. Made Iwan Indrawan Jendra, M.Hum., Dr. I G.A.G. Sosiowati, M.A., Dr. Ni Made Suryati, M. Hum., Drs. Hugo Warami, M.Hum., Drs. I Made Madia, M.Hum., dan teman-teman lain yang tidak dapat disebutkan satu per satu pada kesempatan ini.

Penulis mengucapkan terima kasih yang setulus-tulusnya dan penghargaan yang setinggi-tingginya kepada Dr. Thomas Marshall Hunter dan Dr. Wayan Ariati atas kesediaannya membaca, mengedit, dan memberikan masukan pada bagian kecil disertasi yang dipresentasikan pada Konferensi Internasional Masyarakat Linguistik Indonesia (KIMLI) di Batu, Malang pada tahun 2009 dan atas izinnya memanfaatkan perpustakaan yang sesungguhnya disiapkan untuk mahasiswa-mahasiswi School for International Training Study Abroad; Drs. I Wayan Sidakarya, M.A. dan I Made Yudiana, S.S. atas buku-buku referensi yang berhubungan dengan penelitian penulis, terutama buku-buku linguistik kognitif.

Ucapan terima kasih dan penghargaan yang setinggi-tingginya disampaikan kepada Ketua Program BIPA (Bahasa Indonesia untuk Penutur Asing) Universitas Udayana, Drs. I Nengah Sukartha, S.U., dan Ni Ketut Sri Rahayuni, M.Hum. (Sekretaris Program BIPAS) atas pengertian, dukungan moril, dan motivasinya kepada penulis; Drs, I Wayan Teguh, M.Hum., yang telah berjasa mengedit bahasa Indonesia pada proposal dan disertasi penulis; Wayan Ariastini, S.E., I Wayan Sukerta, S.Sos., I Nyoman Alus, dan I Nyoman Agus Suryantara, S.S. atas segala bantuan teknis yang diberikan kepada penulis. 
Ungkapan terima kasih yang sangat dalam dan penghargaan yang setinggitingginya penulis sampaikan kepada para penulis novel, cerpen, cerita rakyat, naskah drama, dan lain-lain yang tidak dapat disebutkan satu per satu atas karyakaryanya yang berharga bagi pembanggunan korpus penelitian ini; kepada pemilik situs www.cafenovel.com, http://cerpen.net, http://banknaskah-fs. blogspot.com, http://leebirkin.blogspot.com, http://kumpulan-cerpen.blogspot. com, http://forum.dudung.net, http://bandarnaskah.blogspot.com, http://www. bangfad.com, http://harukafujiyama.wordpress.com, http://ebookgratis.info, http:// anindyablog.blogspot.com, http://ebook-gratis-kirara.blogspot.com, dan http:// www.indonesiaindonesia.com yang telah mengunggah naskah-naskah di atas dan mengizinkan penulis mengunduhnya untuk kepentingan penelitian ini juga diucapkan terima kasih yang tidak terhingga.

Kepada sejumlah mahasiswa Jurusan Sastra Inggris Fakultas Sastra Universitas Udayana, khususnya Balina Puspita Sari, S.S. yang telah banyak membantu proses pengumpulan materi korpus untuk disertasi ini diucapkan terima kasih yang setulus-tulusnya.

Terima kasih yang tulus, rasa hormat, dan penghargaan yang setinggitingginya disampaikan kepada kedua orang tua penulis, almarhum ayahanda, I Nyoman Sayang dan almarhumah ibunda, Nengah Ruci, yang melalui cinta kasih dan kemuliaan hatinya telah dengan kuat mendorong, mendukung, menasihati, dan medoakan dengan sepenuh hati untuk keberhasilan pendidikan penulis; ungkapan yang sama juga penulis sampaikan kepada kedua mertua penulis, I Nyoman Rauh Sudarsana (almarhum) dan Ni Nengah Sari Suastini (almarhumah), 
yang dengan ikhlas mendoakan dan memberikan bantuan baik material maupun spiritual, untuk keberhasilan penulis; kepada saudara-saudara penulis Ni Nengah Muter, Ni Wayan Pastini, dan Ni Nyoman Sumitri juga disampaikan terima kasih yang tulus atas dukungan, bantuan, dan doa yang tiada henti; kepada saudara ipar, I Ketut Guntur Agung Parwata, S.H., Diah Rukmini, S.E., I Wayan Tjatra (almarhum), dan Nengah Sinteg Warnia, penulis mengucapkan terima kasih yang tulus atas doa dan dukungannya demi keberhasilan pendidikan penulis; kepada tetua-tetua penulis yang selalu mendorong, mendukung, membimbing, dan mendoakan keberhasilan penulis, Drs. Komang Redhana Wirata, M.Kes., Dra. Ida Ayu Putu Astika, Drs. I Wayan Pageh, Ni Wayan Candrawati, S.H., M.M., Prof. Dr. I Nengah Sudipa, M.A., dan Dra. Ni Made Suapti Karma diucapkan terima kasih dan penghargaan yang setinggi-tingginya.

Penulis mengucapkan terima kasih yang tulus kepada istri tercinta, Dra. Luh Putu Laksminy, M.Hum., atas doa, cinta kasih, dan kesetiaan yang mendalam telah mendampingi, mendorong, mendukung, dan memperhatikan penulis serta keluarga besar dalam segala hal demi keberhasilan pendidikan doktor ini. Terima kasih yang tulus juga disampaikan kepada anak-anak tersayang, Gede Primahadi Wijaya R., S.S., M.Hum., atas kecerdasan, ketekunan, dan tanggung jawab yang tinggi membantu penulis menyediakan buku-buku referensi, terutama buku-buku yang menyangkut linguistik dan semantik kognitif, membaca bersama-sama dan mendiskusikannya di meja makan, di dalam kendaraan, dan di setiap kesempatan untuk membangkitkan inspirasi, membantu menemukan buku statistik $\mathrm{R}$ dan teknologi statistik R, Kadek Dedy Prawirajaya R., S.S. dan Komang Surya 
Bhuana R., S.Ked., atas kegigihan, ketekunan, semangat belajar yang tinggi dengan gaya masing-masing, dan keikhlasan membantu mengerjakan hal-hal praktis, sehingga secara tidak langsung telah memotivasi penulis untuk segera merampungkan disertasi ini. Ucapan terima kasih juga disampaikan kepada tetua adat, I Wayan Pageh dan keponakan-keponakan tercinta, terutama I Wayan Buda Parwata, S.P, atas dukungan moralnya.

Terima kasih dan rasa hormat yang tulus disampaikan kepada GMCKS, Master Herminia J Corcuera, Master Faith Saway, Master Nona Castro, Bapak Bernard Prasodjo, Ir. Nyoman Gede Astawa, S.P., Ibu Arsiningsih, S.E., Prof. Dr. I Wayan Sandi Adnyana, M.S., Ida Bagus Candi, Ida Bagus Putu Sutama, S.H., dan teman-teman lain pada jalur yang sama atas jasa-jasanya telah memampukan penulis untuk mengatasi hal-hal yang rumit dengan cara-cara sederhana dan melakukan banyak hal pada waktu yang sama dengan gerakan-gerakan sederhana.

Akhirnya, penulis berharap semoga disertasi ini dapat bermanfaat dan memberikan kontribusi positif untuk kemajuan ilmu linguistik, khususnya penelitian semantik kognitif seperti metafora kognitif atau Metafora Konseptual yang relatif baru berkembang di Indonesia. Dengan senang hati penulis membuka pintu dan jendela kritik atau saran untuk perbaikan disertasi ini, karena telah disadari sepenuhnya bahwa "Tiada gading yang tak retak", demikian kata pepatah. 


\section{ABSTRAK \\ METAFORA EMOSI BAHASA INDONESIA}

Penelitian ini berfokus pada metafora emosi bahasa Indonesia (BI). Masalah yang dikaji ialah (1) metafora linguistik dan metafora konseptual, (2) pola-pola metaforis, (3) metafora khas emosi, dan (4) makna metafora. Data penelitian diperoleh dari sumber korpus elektronik tertulis berjumlah 5.317.433 kata dengan memanfaatkan metode kualitatif. Metode kualitatif tersebut didukung dengan metode kuantitatif, Linguistik Korpus (LKorp) dan Analisis Pola Metaforis (APM). Teori yang mendasari penelitian ini ialah Teori Metafora Konseptual (TMK) yang diusulkan dan dikembangkan oleh Lakoff (1980, 1987, 1993, 2006). Hasil analisis disajikan dengan metode formal dan informal.

Penelitian ini mengharapkan 5.000 sitiran yang mengandung kelima leksikon emosi yang diteliti. Akan tetapi, ditemukan 3.999 sitiran yang terdiri dari 940 sitiran bermakna literal dan 3.059 sitiran berupa metafora linguistik (ML) yang berpola. ML tersebut mencerminkan 258 metafora konseptual (MK). MK tersebut melibatkan 88 jenis ranah sumber (RS) metaforis yang digunakan untuk memetakan ranah target (RT) emosi. Misalnya, ML api amarah, menyulut amarah, dan amarah padam diidentifikasi sebagai cermin dari MK AMARAH ADALAH API; gelombang amarah, amarah surut, dan banjir amarah dikenali sebagai cermin dari AMARAH ADALAH KEKUATAN ALAM.

MK yang khas emosi dalam BI ialah KONTROL OBJEK BERGERAK, UNSUR DALAM WADAH BERTEKANAN, TINGGI/RENDAH, dan KEKUATAN ALAM untuk emosi amarah; MUSUH/LAWAN dan MELAKUKAN SESUATU DISERTAI/ DITEMANI OBJEK PENYERTA untuk emosi ketakutan; KEPEMILIKAN, MEMBERIKAN SUATU OBJEK, MENDAPAT/MENERIMA SUATU OBJEK, MENCARI/ MENGEJAR/MEMBURU SUATU OBJEK, MENEMUKAN/ MERAIH SUATU OBJEK, PERJALANAN, OBJEK RAPUH/PECAH BELAH, MENJADI DI ATAS/MELAYANG, dan SANTAPAN (MAKANAN/ MINUMAN) untuk emosi kebahagiaan; BERADA DI BAWAH, BEBAN, dan CAIRAN untuk emosi kesedihan; dan PERGERAKAN AKSIDENTAL, IKATAN, CERITA, UNGKAPAN VERBAL, OBJEK BERWARNA, dan OBJEK BERKEILAHIAN untuk emosi cinta.

Makna metafora emosi menyoroti beberapa unsur penting. Metafora AMARAH menyoroti unsur 'pengendalian tindakan emosional' dan 'intensitas emosi'; metafora KETAKUTAN menyoroti unsur 'keberadaan emosi pada diri' serta 'pergumulan diri dan emosi'; metafora KEBAHAGIAAN menyoroti unsur 'potensi untuk menyebabkan penerima menjadi bahagia', 'potensi perubahan keadaan menjadi bahagia', 'keberadaan emosi pada diri', 'usaha/upaya menjadi bahagia', 'menjadi bahagia', 'tahapan menjadi bahagia', 'merasakan kebahagiaan', 'ketahanan keadaan bahagia', dan 'kepositifan keadaan bahagia'; metafora KESEDIHAN berfokus pada unsur 'kenegatifan keadaan sedih', 'kesulitan emosional', dan 'tanggapan emosional'; dan metafora CINTA menyoroti unsur 'perubahan emosional secara aksidental/tidak terduga', 'keterhubungan dua sejoli secara emosional', 'penceritaan kisah kasih sejoli', 'keterungkapan perasaan cinta secara verbal','pencirian cinta', dan 'kualitas cinta'. 
Kata Kunci: metafora emosi, metafora konseptual, metafora linguistik, linguistik korpus, pola metaforis, metafora khas 


\section{ABSTRACT \\ METAPHORS OF EMOTION IN INDONESIAN LANGUAGE}

This study focuses on the metaphors of emotion in Indonesian Language. The problems under study cover (1) the linguistic metaphors and conceptual metaphors, (2) the metaphorical patterns, (3) the specific metaphors of emotions, and (4) the meaning of the metaphors. The data were obtained from written electronic corpus totaling 5,317,433 words by utilizing a qualitative method. The qualitative method is supported by the quantitative methods of Corpus Linguistics and Metaphor Pattern Analyses. The study is based on the Conceptual Metaphor Theory which is proposed and developed by Lakoff (1980, 1987, 1993, 2006). The results of the analyses are presented in formal and informal methods.

The study expects 5,000 citations containing the five lexicons of emotion under study. Nevertheless, 3,999 citations that consist of 940 citations with literal emotion meanings and 3,059 citations of patterned linguistic metaphors are found. The linguistic metaphors reflect 258 conceptual metaphors. The conceptual metaphors involve 88 different metaphorical source domains that are used to map the target domain of emotion. For example, the linguistic metaphors api amarah 'a fire of anger', menyulut amarah 'to ignite anger', and amarah padam 'anger extincts' are identified as the reflections of ANGER IS FIRE conceptual metaphor; gelombang amarah 'a wave of anger', amarah surut 'anger recedes, and banjir amarah 'a flood of anger' are recognized as the reflections of ANGER IS A NATURAL FORCE.

Conceptual metaphors that are specific to emotion in Indonesian are CONTROL OF A MOVING OBJECT, A SUBSTANCE IN A CONTAINER (UNDER PRESSURE), HIGH/LOW, and A NATURAL FORCE for anger; AN OPPONENT and TO DO SOMETHING ACCOMPANIED BY AN OBJECT for fear; POSSESSION, TRANSFERING AN OBJECT, RECEIVING AN OBJECT, TO LOOK FOR/RUN AFTER/SEARCH AN OBJECT, TO FIND AN OBJECT, A JOURNEY, A FRAGILE OBJECT, TO BE OFF THE GROUND, and NUTRIENT (FOOD/DRINK) for happiness; DOWN, A BURDEN, and A FLUID for sadness; and AN ACCIDENTAL MOVEMENT TO A LOCATION, A BOND, A STORY, A VERBAL EXPRESSION, A COLOURED OBJECT, and A DEVINE OBJECT for love.

The meanings of emotion metaphors are focused on some important elements. Metaphors of ANGER focus on elements of 'the control of emotional actions', and 'the emotional intensity'; metaphors of FEAR focus on elements of 'the existance of emotion within self' and 'the struggle between self and emotion'; metaphors of happiness focus on elements of '(potentially) making someone happy', '(potentially) becomes happy', 'the existance of emotion within self', 'an effort to become happy', 'becoming happy', 'stages to be happy', 'to be happy', 'the resistance of HAPPINESS', dan 'the positivity of happiness'; metaphors of SADNESS focus on elements of 'the negativity of sadness', 'the emotional difficulties', and 'the emotional responses'; and metaphors of LOVE focus on elements of 'the accidental emotional changes', 'the emotionally bond lovers', 'the telling of the love story of lovers', 'the verbal expressions of love feelings', 'the characterization of love', and 'the quality of love'. 
Key words: metaphors of emotion, conceptual metaphors, linguistics metaphors, corpus linguistics, metaphorical patterns, and specific metaphors 


\section{RINGKASAN}

\section{METAFORA EMOSI BAHASA INDONESIA}

\section{Pendahuluan \\ 1.1 Latar Belakang}

Kajian metafora selama ini lebih banyak berfokus pada fenomena bahasa metaforis dan meminggirkan peran pikiran dalam pemakaian bahasa. Padahal, metafora merupakan proses berpikir manusia yang tidak dapat dihindarkan (Lakoff \& Johnson, 1980; Lakoff, 2006; Kövecses, 2002; 2006; 2010; Geeraerts, 2010). Penelitian ini mengkaji metafora linguistik (ML) sebagai fenomena bahasa dan metafora konseptual (MK) sebagai fenomena pikiran. Metafora yang dikaji difokuskan pada metafora emosi dalam bahasa Indonesia (BI).

Metafora emosi dikaji karena metafora tersebut merupakan fenomena yang menarik, dapat ditemukan dalam kehidupan sehari-hari, dan belum ada kajian mendalam tentang hal ini, terutama dalam bentuk disertasi. Sementara itu, penelitian metafora konseptual, khususnya metafora emosi, menjadi isu yang sangat penting akhir-akhir ini. Penelitian metafora emosi telah dilakukan dalam bahasa Inggris (BIng.), Polandia, Hungaria, China, Jepang, dan lain-lain. Isu keuniversalan dan kekhasan metafora secara lintas bahasa menjadi perhatian utama para peneliti.

Keuniversalan metafora dapat ditentukan melalui kajian lintas bahasa. Kovecses (2000) telah membicarakan masalah metafora emosi universal dan metafora emosi khas budaya tertentu. Akan tetapi, kajiannya belum menyatakan secara tegas RS mana yang secara signifikan khas emosi tertentu dalam satu bahasa. Dalam hal ini, Kovecses meneliti metafora emosi dalam BIng. Sementara itu, Stefanowitsch (2006) juga telah melakukan kajian metafora emosi dan dapat menunjukkan metafora yang khas emosi tertentu. Akan tetapi, bahasa yang dikaji juga bahasa Inggris.

Penelitian ini mampu mengukur signifikansi sebuah metafora dengan menggunakan metode kualitatif, didukung dengan metode kuantitatif, Linguistik Korpus (LKorp.) dan Analisis Pola Metaforis (APM). Penggunaan metode kuantitatif yang didukung dengan alat uji statistik dapat menentukan RS mana yang secara signifikan tertarik atau tertolak oleh emosi tertentu.

Bukti-bukti linguistik yang ditemukan menunjukkan beberapa hal penting untuk diutarakan di sini. Pertama, pemakaian metafora sangat berlimpah dalam kehidupan pemakai BI sehari-hari. Terbukti bahwa secara empiris ditemukan 3.999 sitiran mengandung leksikon emosi, 3.059 di antaranya merupakan pola metaforis dan 940 merupakan sitiran bermakna literal. Kedua, lebih besarnya jumlah sitiran metaforis dibandingkan dengan sitiran literal menunjukkan bahwa metafora bukan hal yang bersifat figuratif, melainkan inti dalam pemakaian bahasa (Deignan, 2005:13). Ketiga, ML yang demikian besar jumlahnya tidak terjadi secara acak, tetapi dimotivasi oleh pikiran metaforis atau MK. Sejumlah 258 MK ditemukan telah memotivasi ML. Keempat, MK universal dan MK khas emosi dan budaya yang sebelumnya tidak dibatasi secara tegas dalam literatur 
Kövecses (2000), kali ini dapat dibatasi dengan pasti melalui metode LKorp dan APM serta pengujian statistik. Kelima, ditemukan 22 unsur makna yang disoroti dalam pemakaian metafora emosi yang diteliti. Unsur makna tersebut ditemukan melalui kebanyakan penyontohan ranah sumber yang muncul dalam pola linguistik dominan (Kövecses, 2000). Pola linguistik dominan tersebut ditemukan melalui frekuensi pemakaian pola metaforis. Makin tinggi frekuensi pemakaian suatu pola metaforis (emosi tertentu) makin jelas dan makin kuat dominasi makna utama yang disoroti atau difokuskan.

\subsection{Masalah}

Penelitian ini merumuskan empat masalah. Pertama, bagaimanakah emosi pemakai BI diekspresikan secara linguistik metaforis? MK apa saja yang tercermin dari ekspresi linguistik metaforis tersebut? Kedua, bagaimanakah polapola metaforis menyangkut emosi BI? Ketiga, metafora manakah yang khas emosi BI? Keempat, bagaimanakah makna metafora emosi BI?

\section{Kajian Pustaka, Konsep, dan Landasan Teori \\ 2.1 Kajian Pustaka}

Kajian MK secara lintas bahasa yang dilakukan oleh Kramadibrata (2003) membandingkan metafora bahasa Jerman dengan BI menggunakan model budaya yang berbeda. Temuannya menjelaskan bahwa metafora bahasa Jerman menunjukkan sifat gerakan, kadang-kadang agresivitas. Sementara itu, metafora BI memperlihatkan sifat bukan gerakan. Penelitian tersebut berkontribusi secara teoretis terhadap penelitian ini dalam menganalisis makna metafora lintas bahasa.

Yumarmanto (2003) mengkaji metafora dengan pendekatan komplementer antara pemetaan komponensial dan MK. Pemetaan komponen mampu menangani metafora sederhana, tetapi tidak berdaya ketika berhadapan dengan metafora kompleks dan tidak jelas komponen perbandingannya. Relevansi penelitiannya terletak pada kekuatan metafora konseptual dalam menganalisis metafora kompleks.

Selanjutnya, Siregar (2004) melacak perubahan kemasyarakatan melalui perilaku bahasa pada media massa dengan menggunakan Teori Metafora Konseptual (TMK) dan skema citra. Temuannya menggambarkan pentingnya peran pikiran selain bahasa dalam bermetafora. Bahasa metaforis dimotivasi oleh pikiran yang metaforis. Kontribusi penelitian Seregar terletak pada teori dalam menganalisis metafora.

Penelitian metafora emosi secara lintas bahasa dilakukan oleh King (1989) terhadap BIng. dan bahasa Cina. Kajiannya bertujuan menemukan konsep-konsep emosi yang universal dari emosi worry, sadness/grief, fear, happniness/joy, dan anger. Kelebihan penelitian King terletak pada kemampuan menemukan metafora universal, seperti PANAS, TEKANAN, dan GEJOLAK PADA TUBUH. King tidak mengkaji metafora yang khas emosi tertentu tetapi King mejelaskan metafora yang khas budaya China. Sumbangan teoretis dan isu keuniversalan konsep merupakan hal yang penting dari penelitian King terhadap penelitian ini.

Peneliti berikutnya, Gevaert (2007) merekonstruksi medan leksikal dari emosi AMARAH. Gevaert menggunakan pendekatan diakronis untuk menelusuri 
perubahan medan makna emosi AMARAH. Datanya diambil dari BIng. zaman Inggris Lama sampai dengan masa Awal Inggris Modern. Klaimnya menyatakan bahwa perubahan medan leksikal dipengaruhi oleh unsur budaya, bukan fisiologis. Klaim yang bertentangan dengan peneliti-peneliti metafora emosi sebelumnya disebabkan oleh pendekatan yang digunakan berbeda dengan peneliti metafora emosi lainnya yang menggunakan pedekatan sinkronis. Signifikansi penelitian ini terletak pada pemanfaatan teori dan isu keuniversalan metafora.

$\mathrm{Yu}$ (1995) membandingkan metafora emosi AMARAH dan KEBAHAGIAAN dalam BIng. dan bahasa Cina untuk menemukan konsep-konsep yang memotivasi pemakaian bahasa metaforis, baik yang bersifat universal maupun khas. Misalnya, metafora "API dan CAIRAN" khas BIng dan metafora "API dan GAS" khas bahasa Cina; metafora "KE ATAS, "CAHAYA", dan "WADAH" merupakan konsep universal dari kedua bahasa. Konseptualisasi makna metafora yang dibahas oleh Yu menjadi kekuatan penelitiannya. Namun, kekuatan tersebut belum didukung dengan bukti-bukti metafora linguistik yang cukup besar. Penelitian ini memeroleh manfaat dari konseptualisasi yang telah dilakukan oleh $\mathrm{Yu}$.

Keuniversalan dan kekhasan metafora emosi AMARAH secara lintas bahasa- bahasa Jepang dan BIng Amerika diteliti oleh Matsuki (1995). Temuannya menunjukkan bahwa, baik Bahasa Jepang maupun BIng Amerika, memiliki metafora dan metonimia yang sama dalam membangun kerangka konseptual AMARAH. Matsuki tidak secara tegas menyatakan konsep mana yang benar-benar universal dari kedua bahasa itu. Namun, secara tegas dinyatakan bahwa hara 'perut', mune 'dada', dan atama 'kepala' merupakan metafora khas budaya Jepang. Seperti halnya penelitian Yu, penelitian Matsuki berkontribusi positif terhadap penelitian ini dalam hal konseptualisasi metafora universal dan khas budaya.

Kajian metafora emosi AMARAH lintas bahasa secara lebih luas menyangkut bahasa Inggris, Jepang, Cina, Hungaria, Tahiti, dan Wolof dilakukan oleh Kövecses (1995). Tiga hal yang membedakan ungkapan emotif metaforis suatu bahasa menurut Kövecses, yaitu terminologi emosi, cara mengonseptualisasikan emosi (teori masyarakat dan teori ahli tentang emosi), dan pengalaman emosi. Sebagian besar pengalaman emosi berupa pengalaman fisiologis. Sebagian besar keberadaan ungkapan emosional dimotivasi oleh fisiologi emosi atau konseptualisasi emosi (pengalaman fisiologis). Klaimnya adalah bahwa metafora WADAH paling banyak ditemukan dalam konsep amarah dan dianggap sebagai metafora universal. Kajian Kövecses sangat penting dalam penelitian ini untuk menentukan metafora universal dan metafora khas emosi dalam BI.

Rajeg (2009 dan 2010) meneliti metafora emosi CINTA dan AMARAH dalam BI untuk menemukan konsep-konsep yang mendasari digunakannya metafora tersebut. Data terbatas diperoleh secara instrospektif sehingga belum mampu menggambarkan kekuatan konsep yang ditemukan dan belum dapat menunjukkan konsep-konsep universal dan khas. Akan tetapi, penelitian Rajeg sangat penting dalam penelitian ini, terutama dalam hal konseptualisasi emosi dan teori yang digunakan. 
Selanjutnya, Rajeg (2012) meneliti emosi KEBAHAGIAAN pada korpus BI yang cukup besar untuk menemukan pola metaforis dan MK yang mendorongnya. Penelitiannya berhasil menemukan metafora universal, tetapi belum mencakup metafora khas emosi dalam BI. Teori, model data, dan metode yang digunakan memberikan sumbangan besar tehadap penelitian ini.

Mulyadi (2010) dalam artikelnya memaparkan sejumlah metafora linguistik yang membuktikan adanya konseptualisasi EMOSI ADALAH CAIRAN, LAWAN, BINATANG BUAS, MUSUH TERSEMBUNYI, BEBAN, TEMPAT, DAYA ALAM, dan DAYA FISIK dalam BI. Kajian Mulyadi berkontribusi pada pemanfaatan teori dan konseptualisasi metafora emosi. Akan tetapi, kajiannya belum menyangkut metafora universal dan metafora khas budaya.

Yuditha (2012) meneliti konseptualisasi emosi amarah dalam BI. Data penelitiannya diperoleh dari media elektronik berupa teks yang tersimpan pada jejaring (wesite) dan dianalisis dengan TMK. Temuannya menunjukkan bahwa BI dan BIng memiliki konsep emosi yang universal. Yuditha juga menemukan sejumlah metafora variasi budaya Indonesia yang secara khas menjadi ciri metafora emosi dalam BI dan tidak ditemukan dalam BIng.

Meskipun Yuditha telah menemukan metafora khas BI, penelitiannya tidak menggambarkan apakah pemakaian metafora khas BI yang ditemukan terjadi secara bermakna atau terjadi secara kebetulan saja mengingat besarnya korpus yang digunakan tidak dinyatakan secara jelas. Selain itu, juga tidak dinyatakan frekuensi pemakaian metafora sebagai indikator kebermaknaan suatu metafora. Kebermaknaan pemakaian metafora khas emosi tertentu dalam BI diuji dengan mengunakan statistik dalam penelitian ini.

Stefanowitsch (2006) meneliti metafora emosi anger 'amarah', disgust 'kemuakan', fear 'ketakutan', happiness 'kebahagiaan', sadness 'kesedihan' dalam BIng dengan metode korpus. Data penelitiannya diperoleh dari British National Corpus (BNC). Metode yang digunakan untuk menemukan dan menganalisis data ialah metode Analisis Pola Metaforis (APM), suatu metode baru yang diusulkan oleh Stefanowitsch sendiri untuk mengembangkan TMK.

Melalui APM, Stefanowitsch dapat mengidentifikasi sebagian besar metafora yang didiskusikan dalam pustaka-pustaka sebelumnya yang diperoleh melalui penelitian dengan metode istrospektif, seperti Kovecses (1995, 1996), Lakoff (1987), dan yang lainnya. Keunggulan metode APM juga dibuktikan dengan temuan, baik berupa MK maupun ML, yang jauh lebih banyak dibandingkan dengan temuan peneliti sebelumnya, meskipun bahasa yang diteliti sama, yaitu BIng.

Meskipun penelitian Stefanowitsch menggunakan data BIng, relevansinya terhadap penelitian ini sangat tinggi mengingat metode APM yang digunakan mampu memberikan bukti-bukti linguistik bersama dengan nilai kekerapannya untuk menemukan pola-pola metaforis, MK, keuniversalan, dan kekhasan metafora emosi BI. 


\subsection{Konsep}

Konsep-konsep yang digunakan dalam kajian ini ialah metafora klasik, metafora konseptual (modern), emosi, dan bahasa emosi. Konsep metafora klasik mengacu pada kias yang mengandung unsur perbandingan (dapat juga dibaca pada, antara lain Ortony, 1979; Lakoff dan Johnson, 1980; 1987; 2006; Cormac, 1985; Kövecses, 2002; 2005; 2006). Konsep metafora konseptual mengacu pada perbandingan dengan cara memahami dan mengalami satu hal melalui hal yang lain dengan cara pemetaan elemen RS ke RT (Lakoff, 1980; Kövecses, 2006). Konsep emosi merujuk pada daya (force) yang membangkitkan tanggapan atau efek tertentu (Kövecses 2000). Bahasa emosi merujuk pada bahasa yang bersifat figuratif yang dapat menjelaskan, bahkan menciptakan pengalaman emosional (Kövecses, 2000).

\subsection{Landasan Teori}

Penelitian ini menggunakan Teori Metafora Konseptual (TMK). Teori ini dipelopori oleh Lakoff dan Johnson (1980) dan dikembangkan melalui publikasibublikasi berikutnya, seperti Lakoff $(1987$; 2006). Kemudian, pengikutpengikutnya, di antaranya Cormac (1985) dan Kövecses (2000, 2002, 2005, 2006, 2010) secara intensif turut mengembangkan teori tersebut.

TMK memandang bahwa seseorang bermetafora tidak hanya dengan bahasa, tetapi juga dengan pikirannya. Metafora digunakan tidak hanya untuk tujuan estetika, tetapi digunakan dalam kehidupan sehari-hari. Metafora memegang peran sangat penting dalam pikiran manusia sebagai dasar yang digunakan untuk mengonseptualisasikan dunia dan segala kegiatannya (Lakoff \& Johnson, 1980:3; Gibbs, 2008:3). Lakoff dan pengikutnya mengklaim bahwa topik-topik yang bersifat abstrak dan penting bagi kehidupan manusia (misalnya, kelahiran, cinta, kehidupan, dsb.) sebagian besar, bahkan sepenuhnya diekspresikan dan lebih cepat dipahami melalui metafora. Lebih jauh Gibbs (2008: 4) menyatakan bahwa metafora muncul dari multiinteraksi antara otak, tubuh, bahasa, dan budaya. Langlotz (2006: 67--68) menyatakan bahwa MK berfungsi untuk menyediakan akses kognitif yang lebih mudah, menstrukturkan, dan mengontologikan RT yang secara empiris lebih abstrak (misalnya. emosi, karier, kognisi, waktu, dan sebagainya).

TMK dipilih karena TMK dipandang sangat berdaya guna dan mampu menjelaskan metafora emosi secara baik, baik di tingkat kata, frasa, kalimat, paragraf, maupun wacana. TMK, bahkan mampu membongkar ideologi yang terkandung dalam mitos dan hal-hal yang bersifat nonlinguistik. TMK memiliki kekuatan alat bedah metafora secara sistematik yang dikenal dengan pemetaan (mapping).

TMK mampu membangun sebuah asumsi baru yang sangat penting dalam perkembangan linguistik kognitif selama ini, yaitu bahwa metafora tidak hanya dipandang sebagai permainan bahasa dalam imajinasi puitika dan tidak juga hanya sebagai hiasan retoris. Akan tetapi, metafora meresap dan memenuhi kehidupan manusia sehari-hari, tidak hanya dalam bahasa dan pikiran, tetapi juga dalam tindakan. Sistem konseptual yang dikenal sehari-hari, yaitu berpikir dan bertindak, pada dasarnya bersifat metaforis. Jika diasumsikan bahwa sistem konseptual 
sebagian besar metaforis, maka yang dipikirkan, dialami, dan dilakukan setiap hari lebih banyak merupakan perkara metafora (Lakoff \& Johnson, 1980:3; Lakoff, 2006:187).

\section{Metode Penelitian}

Penelitian ini menggunakan metode kualitatif dan didukung dengan kuantitatif (Angouri, 2010: 31). Metode kualitatif dimanfaatkan sejak tahap awal pemerolehan data. Metode ini digunakan untuk (1) mengekplorasi dan memahami makna masing-masing ungkapan yang muncul dalam konkordansi; (2) menentukan pola-pola metaforis yang muncul dalam konkordansi untuk dicatat sebagai data. Pola-pola metaforis ini ditentukan dengan cara menemukan kata kunci dari leksikon ranah target (RT) dan leksikon ranah sumber (RS) dalam satu ungkapan, misalnya api amarah, di mana api merupakan RS dan amarah merupakan RT; (3) menentukan MK yang memotivasi ML dalam pemakaian BI; dan (4) menentukan pemetaan utama (PU) dari MK yang dianggap khas emosi dalam BI.

Metode kuantitatif juga dimanfaatkan sejak awal pemerolehan data. Metode ini dimanfaatkan untuk (1) menghitung kekerapan kemunculan data yang muncul dalam konkordansi; (2) menguji distribusi variabel, yaitu metafora dan emosi, (3) menguji signifikansi ketertarikan dan ketertolakan RS tertentu terhadap RT tertentu; (4) menguji signifikansi sorot makna utama (SMU) dari metafora konseptual yang telah ditentukan sebagai metafora khas emosi BI.

Data tulis metafora emosi BI bersumber dari korpus khusus (lihat Gries, 2009a:9) yang memuat 5.317.433 kata dan dijaring dengan metode Linguistik Korpus (LKorp) (Deignan, 2005; Stefanowitsch, 2006; Gries, 2009a; Baker, 2010). Instrumen yang digunakan untuk menjelajah, menemukan, memproses, dan menghitung keberadaan data pada korpus ialah program aplikasi komputer komersial Wordsmith Tools Version 5.0. Alat ini mampu menghasilkan daftar konkordansi yang sangat panjang seperti di bawah ini.

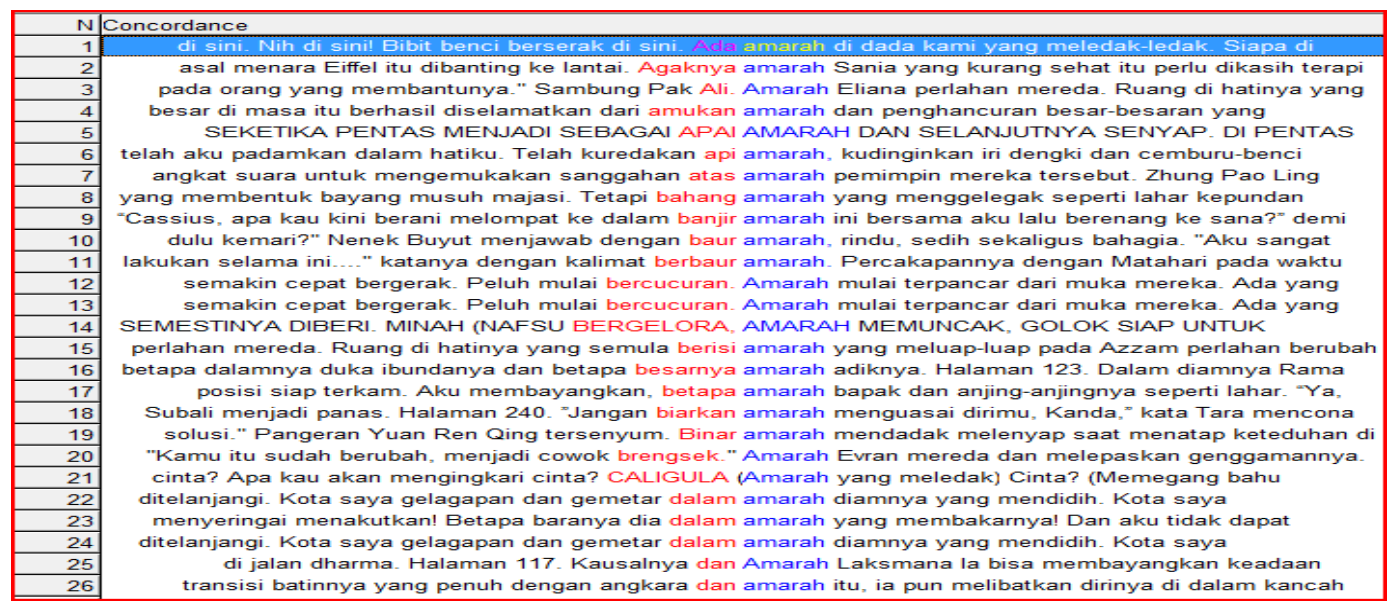

Analisis data menggunakan metode Analisis Pola Metaforis (APM) (Stefanowitch, 2006:66). Metode APM berguna untuk menemukan pola-pola metaforis dengan menggunakan kata kunci. Penelitian ini menggunakan kata-kata 
kunci dari ranah target (RT). Selain itu, metode APM juga menawarkan kemungkinan kepada peneliti untuk menghitung pentingnya suatu pola metaforis bagi kosakata emosi yang sedang diteliti. APM juga memungkinkan peneliti membuat generalisasi tentang pentingnya MK yang mendasari pola-pola metaforis (Stefanowitch, 2006:65).

Ada empat tahap analisis yang dilakukan. Pertama, menentukan pola metaforis (Stefanowitch, 2006:65). Kedua, menentukan sejauh mana pola metaforis tertentu dimotivasi oleh pemetaan metafora (konseptual) tertentu dan mengetahui kekuatan atau produktivitas metafora sebagai calon MK. Ketiga, menentukan ketertarikan dan ketertolakan RS terhadap RT emosi untuk melihat kemungkinan adanya metafora yang khas berasosiasi dengan emosi tertentu melalui pengujian secara statistik menggunakan metode Configural Frequency Analysis (CFA) (Gries, 2009). Kempat, menganalisis makna metafora melalui SMU dan PU (Kövecses, 2010: 140).

Hasil analisis data disajikan dengan metode formal dan informal (Sudaryanto, 1993:145). Metode informal diwujudkan dalam bentuk kata-kata atau kalimat dan metode formal direalisasikan melalui pemakaian tanda-tanda, lambang-lambang, tabel, dan bagan.

\section{Hasil Penelitian}

\subsection{Metafora Konseptual dan Metafora Linguistik untuk Emosi}

Penelitian ini menemukan 3.999 sitiran yang mengandung leksikon RT emosi, yaitu amarah/kemarahan, ketakutan, kebahagiaan, kesedihan, dan cinta. Sitiran-sitiran tersebut mengandung $3.059 \mathrm{ML}$, seperti api amarah, ancaman ketakutan, (X mencapai) puncak/mahkota kebahagiaan, X bangkit/bangun dari kesedihan, dan pengembara cinta dan 940 sitiran bermakna literal. ML tersebut dimotivasi oleh $258 \mathrm{MK}$, seperti (a) AMARAH/ KEMARAHAN (/MENJADI MARAH) ADALAH API (b) KETAKUTAN(/MENJADI TAKUT) ADALAH MUSUH/LAWAN DALAM SUATU PERJUANGAN, (c) KEBAHAGIAAN (/MENJADI BAHAGIA) ADALAH (BERADA DI) ATAS (UP), (d) KESEDIHAN (/MENJADI SEDIH) ADALAH (BERADA/ MENJADI DI/KE) BAWAH, (e) CINTA ADALAH PERJALANAN, dan lain-lain. Semua MK yang ditemukan dibangun dari 88 RS metaforis, di antaranya API, BEBAN, CAIRAN, CAIRAN PANAS DALAM WADAH, BINATANG TAWANAN/BUAS, PERJALANAN, IKATAN, dan lain-lain.

\subsection{Pola Metafora}

Pola metaforis adalah ungkapan multikata dari RS tertentu yang mengandung satu leksikon khusus RT atau lebih yang dipetakan (Stefanowitch, 2006:66).

Pola metaforis emosi BI dibangun dari unsur-unsur leksikon emosi amarah/kemarahan, ketakutan, kebahagiaan, kesedihan, dan cinta dengan leksikon yang memetakannya, seperti verba (menggelegak, meluap, memuntahkan), nomina (api, luapan, gelombang), dan adverbia (di dalam, di bawah). Contoh pola metaforis yang ditemukan, di antaranya amarahnya meluap, api amarah, gelombang cinta, dalam ketakutan, di bawah kemarahan. 


\subsection{Metafora Khas Emosi BI}

Berdasarkan sejumlah pustaka yang telah ditelusuri dalam rangka penelitian ini, kajian yang berkaitan dengan (i) metafora emosi BI berbasis metode LKorp dan (ii) penelusuran RS metaforis khas RT EMOSI BI belum pernah ditemukan sejauh ini. Jadi, hasil analisis statistik terhadap data kekerapan pemetaan metafora emosi yang ditemukan dalam korpus BI dapat dipandang sebagai kajian pertama yang mengungkap keintian suatu RS metaforis bagi RT EMOSI tertentu dalam BI.

Pengungkapan ini pada akhirnya mengikutkan sebuah perihal menarik terkait dengan keberagaman dan kesemestaan metafora (Kövecses, 2000, 2002, 2005, 2010). Penelitian-penelitian metafora emosi yang sebelumnya telah dilakukan terutama oleh Kövecses $(2000,2002$, 2005, 2008) dan penelitian dengan metode LKorp oleh Stefanowitsch (2004a, 2006a) menggunakan data BIng. Sebaliknya, data penelitian ini berasal dari BI, salah satu rumpun bahasa yang bukan Indo-Eropa. Muncul keberagaman, bahkan kesemestaan, terkait dengan RS metaforis khas emosi tertentu yang dimiliki oleh guyub tutur BI jika dibandingkan dengan Bing, sebagaimana tertera pada tabel 4.1.

Tabel 4.1

Nukilan Enam Konfigurasi Signifikan Teratas Variabel METAFORA X EMOSI

\begin{tabular}{llllllll}
\hline METAFORA & EMOSI & Frek & Har & $\chi^{2}$ & P.adj.Holm & Put & K \\
\hline $\begin{array}{l}\text { PERGERAKAN } \\
\text { AKSIDENTAL }\end{array}$ & CINTA & 91 & 20.6 & 239.75 & $8.96 \mathrm{E}-28$ & $* * *$ & 0.023 \\
KEPEMILIKAN & KEBAHAGIAAN & 103 & 44.8 & 75.71 & $1.81 \mathrm{E}-11$ & $* * *$ & 0.019 \\
KEPEMILIKAN & AMARAH & 23 & 73.9 & 35.05 & $1.21 \mathrm{E}-09$ & $* * *$ & 0.017 \\
$\begin{array}{l}\text { KONTROL OBJEK } \\
\text { BERGERAK }\end{array}$ & AMARAH & 75 & 27.5 & 82.18 & $1.86 \mathrm{E}-11$ & $* * *$ & 0.016 \\
$\begin{array}{l}\text { UNSUR DALAM WADAH } \\
\text { (BERTEKANAN) }\end{array}$ & AMARAH & 94 & 51.6 & 34.84 & $2.38 \mathrm{E}-05$ & $* * *$ & 0.014 \\
$\begin{array}{l}\text { (SECARA POTENSIAL) } \\
\text { MEMBERIKAN SUATU }\end{array}$ & KEBAHAGIAAN & 54 & 17.6 & 75.47 & $8.75 \mathrm{E}-10$ & $* * *$ & 0.012 \\
OBJEK & & & & & & & \\
\hline
\end{tabular}

Selain enam konfigurasi teratas, penelitian ini menghasilkan metafora yang khas bagi RT emosi KETAKUTAN dan KESEDIHAN. Metafora khas emosi KETAKUTAN di BI ialah (i) EMOSI (KETAKUTAN) ADALAH MUSUH/LAWAN dan (ii) (BERTINDAK) EMOSI(ONAL) ADALAH MELAKUKAN SESUATU/ DISERTAI/TEMANI OBJEK PENYERTA. Sementara itu, metafora khas emosi KESEDIHAN di BI ialah (i) EMOSI (KESEDIHAN) ADALAH BEBAN, (ii) EMOSI (KESEDIHAN) ADALAH CAIRAN, dan (iii) EMOSI (KESEDIHAN) ADALAH (MENJADI) BERADA DI BAWAH.

\subsection{Makna Metafora Emosi}

Sinergi penerapan TMK, metode LKorp, dan APM memampukan penelitian ini menemukan pola linguistik dominan (Kövecses, 2002) dengan menelusuri frekeunsi pemakaian pola metaforis. Frekuensi inilah yang 
dimanfaatkan untuk menentukan SMU metafora yang diteliti. SMU tersebut dihubungkan dengan MK khas emosi yang dibicarakan sebelumnya.

SMU metafora (1) KONTROL AMARAH ADALAH KONTROL OBJEK BERGERAK ialah 'pengendalian tindakan emosional'. Sementara itu, metafora (2) AMARAH ADALAH UNSUR DALAM WADAH (BERTEKANAN), (3) AMARAH ADALAH CAIRAN DALAM WADAH, (4) AMARAH ADALAH CAIRAN PANAS DALAM WADAH, (5) AMARAH ADALAH PANAS/DINGIN, (6) AMARAH ADALAH API, (7) AMARAH ADALAH TINGGI/RENDAH, dan (8) AMARAH ADALAH KEKUATAN ALAM yang masing-masing menyoroti unsur 'intensitas emosi'.

SMU metafora KETAKUTAN ADALAH MELAKUKAN SESUATU DISERTAI OBJEK PENYERTA ialah 'keberadaan emosi pada diri' dan SMU metafora KETAKUTAN ADALAH MUSUH/LAWAN ialah 'pergumulan diri dan emosi'

Sembilan metafora khas KEBAHAGIAAN menunjukkan SMU yang berbeda-beda. SMU metafora (1) KEBAHAGIAAN ADALAH (SECARA POTENSIAL) MEMBERIKAN SUATU OBJEK ialah 'potensi untuk menyebabkan penerima menjadi bahagia', (2) KEBAHAGIAAN ADALAH (SECARA POTENSIAL) MENERIMA SUATU OBJEK ialah 'potensi perubahan keadaan menjadi bahagia', (3) KEBAHAGIAAN ADALAH KEPEMILIKAN ialah 'keberadaan emosi pada diri', (4) KEBAHAGIAAN ADALAH MENCARI/MEMBURU SUATU OBJEK ialah 'usaha/upaya menjadi bahagia', (5) KEBAHAGIAAN ADALAH MENEMUKAN/MERAIH SUATU OBJEK ialah 'menjadi bahagia', (6) KEBAHAGIAAN ADALAH PERJALANAN ialah 'tahapan menjadi bahagia', (7) KEBAHAGIAAN ADALAH SANTAPAN ialah 'merasakan kebahagiaan', (8) KEBAHAGIAAN ADALAH OBJEK RAPUH/PECAH BELAH ialah 'ketahanan keadaan bahagia', (9) KEBAHAGIAAN ADALAH BERADA DI ATAS/MELAYANG ialah 'kepositifan keadaan bahagia'.

Tiga metafora khas emosi KESEDIHAN, masing-masing menujukkan SMU berbeda, yaitu metafora (1) KESEDIHAN ADALAH BERADA DI BAWAH menyoroti unsur 'kenegatifan keadaan sedih', (2) KESEDIHAN ADALAH BEBAN menyoroti unsur 'kesulitan emosional', (3) KESEDIHAN ADALAH CAIRAN menyoroti unsur 'tanggapan emosional'.

Sementara itu, enam metafora yang khas berasosiasi dengan emosi CINTA, yaitu (1) CINTA ADALAH PERGERAKAN AKSIDENTAL menyoroti unsur 'perubahan emosional secara aksidental/tidak terduga', (2) CINTA ADALAH IKATAN menyoroti unsur 'keterhubungan dua sejoli secara emosional', (3) CINTA ADALAH CERITA menyoroti unsur 'penceritaan kisah kasih sejoli', (4) CINTA ADALAH UNGKAPAN VERBAL menyoroti unsur 'keterungkapan perasaan cinta secara verbal', (5) CINTA ADALAH OBJEK BERWARNA menyoroti unsur 'pencirian cinta', (6) CINTA ADALAH OBJEK BERKEILAHIAN menyoroti unsur 'kualitas cinta'.

\section{Temuan Penelitian}

Kajian metafora emosi BI dalam bentuk disertasi, utamanya penerapan TMK pada korpus modern merupakan kajian pertama. Oleh karena itu, semua hasil penelitian ini merupakan temuan baru. Berikut ini disajikan rangkuman temuan penelitian yang menyangkut temuan teoritis, metodologis, dan empiris.

Temuan teoretis menyangkut aplikasi TMK menunjukkan bahwa TMK dapat diterapkan pada data BI dengan sangat tepat dan tanpa kendala. Hasil 
penerapan TMK pada data BI memiliki beberapa implikasi positif terhadap pembelajaran bahasa, khususnya pembelajaran metafora.

(1) TMK dapat dimanfaatkan untuk tujuan pembelajaran metafora secara lebih sistematis, baik untuk pembelajaran ML maupun MK. Dengan menentukan satu leksikon ranah tertentu, misalnya ranah emosi, pembelajar dapat menemukan leksikon ranah lain yang memetakan leksikon ranah emosi secara sistematis. Secara lebih konkret, dapat dijelaskan bahwa dengan menentukan satu leksikon RT (misalnya amarah), pembelajar dapat menemukan leksikon RS yang memetakannya, seperti leksikon api dan bahang dalam api amarah dan bahang amarah.

(2) TMK dapat dimanfaatkan untuk menjelaskan motivasi pembentukan sebuah kata. Misalnya, kata meledak-ledak dan meletup-letup memiliki motivasi metaforis. Maksudnya, pemakaian kata-kata tersebut didorong oleh MK AMARAH ADALAH UNSUR DALAM WADAH BERTEKANAN.

(3) TMK dapat digunakan untuk menjelaskan kewajaran suatu kolokasi tertentu. Misalnya, bagaimana kata bahang, panas, padam, bakar, dan sulut, berkolokasi dengan kata amarah; bagaimana juga kata badai, angin, topan, gelombang, reda, dan landa berkolokasi dengan amarah. Jika dipandang dari sudut linguistik, tampak tidak ada hubungan kedekatan (kolokasi) antara amarah dengan bahang atau badai. Akan tetapi, jika dilihat dari MK AMARAH ADALAH API dan AMARAH ADALAH KEKUATAN ALAM yang melatarbelakangi hubungan tersebut, maka kolokasi itu menjadi wajar.

(4) TMK dapat digunakan untuk menjeaskan konsep-konsep absrtak yang sulit dejelaskan secara literal. Misalnya, konsep emosi amarah dijelaskan dengan konsep kekuatan alam, seperti gelombang. Ketika seseorang diterjang gelombang, maka orang tersebut berusaha melawan. Akan tetapi, karena kuatnya gelombang tersebut, maka orang itu tidak mampu melawannya. Dalam keadaan seperti ini seseorang akan pasrah dan membiarkan dirinya dihempas gelombang. Konsep kekuatan alam ini, salah satunya, digunakan untuk menjelaskan konsep emosi amarah. Ketika seseorang mengalami emosi amarah, maka dia akan mencoba mengatasi amarahnya. Akan tetapi karena kuatnya tekanan emosi, maka seseorang akan membiarkan dirinya mengalami amarah itu tanpa perlawanan.

Temuan yang menyangkut penerapan metode menggambarkan bahwa (1) derajat kekerapan pemakaian suatu pola metaforis emosi tertentu menunjukkan derajat keterpatrian relatif suatu MK yang memotivasi pola metaforis tersebut, (2) tingginya kekerapan pemakaian $\mathrm{MK}$ emosi tertentu secara signifikan dibandingkan dengan emosi yang lain menunjukkan kekhasan MK tersebut bagi emosi itu, (3) tingginya kekerapan pemakaian suatu pola metaforis emosi tertentu menunjukkan kejelasan aspek makna utama yang ditonjolkan atau disoroti.

Temuan sehubungan dengan pemakaian bahasa secara empiris dalam penelitian ini ialah sebagai berikut:

(1) Ditemukan 3.999 sitiran mengandung leksikon emosi, 3.059 di antaranya merupakan pola metaforis dan 940 merupakan sitiran bermakna literal. Tingkat pemakaian leksikon paling tinggi diduduki oleh emosi ketakutan 
disusul berturut-turut oleh emosi cinta, amarah/kemarahan, kebahagiaan, dan kesedihan.

(2) Dari 3.059 pola metaforis yang ditemukan, tingkat pemakaian metafora emosi amarah/kemarahan menduduki posisi paling atas. Kemudian, emosi cinta, kebahagiaan, kesedihan dan ketakutan. Ke-3.059 pola metaforis tersebut dimotivasi oleh 258 MK EMOSI. MK EMOSI yang dimaksud, di antaranya ialah (1) AMARAH/KEMARAHAN ADALAH CAIRAN PANAS DALAM WADAH, (2) KETAKUTAN ADALAH BEBAN, (3) KEBAHAGIAAN ADALAH OBJEK DI SUATU LOKASI, (4) KESEDIHAN ADALAH (MENJADI) BERADA DI BAWAH, dan (5) CINTA ADALAH PERJALANAN.

(3) Ditemukan 88 ranah sumber (RS) yang digunakan untuk memetakan ranah target (RT) EMOSI. Beberapa di antaranya ialah API, BEBAN, WADAH, KEKUATAN ALAM, dan MUSUH/LAWAN.

(4) Penelitian ini menemukan delapan MK yang signifikan tertarik (khas) dan enam MK yang signifikan ditolak (tidak khas) oleh RT AMARAH/ KEMARAHAN; Dua MK yang khas dan dua MK yang tidak khas EMOSI KETAKUTAN; Sembilan MK yang khas dan empat MK tidak khas EMOSI KEBAHAGIAAN; Tiga MK yang khas dan satu MK yang tidak khas EMOSI KESEDIHAN; Enam MK yang khas dan lima yang tidak khas EMOSI CINTA.

(5) Ditemukan 4 MK universal menyangkut emosi CINTA dalam BI, yaitu (i) CINTA ADALAH API, seperti direalisasikan pada api cinta, (ii) CINTA ADALAH SIHIR (MAGIC), seperti pada pesona cinta, (iii) CINTA ADALAH KEKUATAN FISIK, seperti pada cinta di X cuma kekuatan yang mendorong ke arah $Y$, dan (iv) CINTA ADALAH MUSUH, seperti direalisasikan pada rasa cinta mengalahkan $Y$

(6) Metafora WADAH ditemukan sebagai MK universal dalam BI. Keuniversalan metafora ini telah diteliti pada bahasa Inggris (BIng.), bahasa Hungaria, bahasa China, dan bahasa Jepang. MK WADAH yang dapat dicontohkan ialah TUBUH ADALAH WADAH BAGI EMOSI dan AMARAH ADALAH SUATU UNSUR (CAIRAN/GAS) DI DALAM WADAH yang direpresentasikan dengan ML, seperti penuh amarah dan dipenuhi amarah.

(7) Penelitian ini menemukan metafora WADAH yang khas budaya Indonesia. Kekhasan metafora WADAH ditemukan pada tingkat yang lebih terperinci secara semantis, yaitu WADAH metaforis dari leksikon "anggota tubuh", yaitu "hati" dan "dada" seperti pada "Hatinya penuh amarah" dan Amarah bergejolak di dalam dadaku.

(8) Berdasarkan hasil analisis kekhasan metafora emosi dapat dirumuskan "model" emosi dalam BI. Model emosi yang dimaksudkan dalam temuan ini adalah alur berpikir yang paling menonjol (selient) dari pemakai BI dalam memahami emosi.

1) AMARAH/KEMARAHAN dalam BI dapat dipahami sebagai unsur atau cairan dan manusia dipahami sebagai wadah dari unsur atau cairan. Ketika unsur atau cairan mendapat panas, maka suhu dan intensitas cairan meningkat. Ketika suhu dan intensitas meningkat, maka dinding wadah terdesak oleh makin kuatnya suhu dan intensitas unsur atau cairan. Wadah yang tertekan berusaha menahan/mengontrol tekanan dari dalam yang terus menguat. 
Apabila wadah tidak mampu lagi menahan/mengotrol tekanan, maka wadah akan meledak. Ketika wadah meledak, unsur atau cairan keluar seketika dan wadah hanya pasrah tanpa daya dan mengalami kuatnya aliran unsur atau cairan tersebut.

2) KETAKUTAN dalam BI dipahami sebagai musuh dan manusia dipahami sebagai lawan dari musuh. Musuh berada sangat dekat dengan lawan dan musuh berusaha menyerang lawan. Ketika musuh menyerang, lawan mencoba mengendalikan dan mengalahkan musuh. Karena besarnya kekuatan musuh, maka lawan lebih sering dikendalikan dan dikalahkan oleh musuh.

3) KEBAHAGIAAN dalam BI dipahami sebagai objek dan manusia dipahami sebagai pencari, pengejar, pemberi, dan penerima objek. Manusia mengejar, mencari, dan mendapatkan objek untuk dimiliki dan dinikmati. Ketika objek tersebut diperoleh, diterima, atau diberikan kepada orang lain, maka manusia akan merasa berada di atas dan objek akan dipertahankan, dijaga dari kemungkinan kehancuran karena objek tersebut rapuh adanya.

4) KESEDIHAN dalam BI dipahami sebagai beban dan manusia dipahami sebagai penyandang beban. Ketika beban bertambah berat, manusia berusaha menyangga dengan lebih kuat untuk mengurangi tekanan beban. Ketika beban bertambah, manusia akan semakin tertekan dan ketika manusia tidak mampu lagi menyangga, maka ia terpuruk.

5) CINTA dalam BI dipahami secara beragam. Pertama, cinta dipahami sebagai objek yang dapat diungkapkan. Kedua, cinta dipahami sebagai objek dengan kualitas dan ciri tertentu (objek berwarna dan objek berkeilahian). Ketiga, cinta dipahami sebagai kejadian seketika yang dialami oleh manusia.

(9) Unsur makna yang disoroti pada MK AMARAH/ KEMARAHAN ialah 'pengendalian tindakan emosional dan intensitas emosi'. MK KETAKUTAN menyoroti unsur 'keberadaan emosi pada diri dan pergumulan diri dan emosi'. MK KEBAHAGIAAN berfokus pada unsur 'potensi untuk menyebabkan penerima menjadi bahagia, potensi perubahan keadaan menjadi bahagia, keberadaan emosi pada diri, usaha/upaya menjadi bahagia, menjadi bahagia, tahapan menjadi bahagia, merasakan kebahagiaan, ketahanan keadaan bahagia, dan kepositifan keadaan bahagia. MK KESEDIHAN berfokus pada unsur 'kenegatifan keadaan sedih', 'kesulitan emosional', dan 'tanggapan emosional'. MK CINTA menyoroti unsur 'perubahan emosional secara aksidental/tidak terduga', 'keterhubungan dua sejoli secara emosional', 'penceritaan kisah kasih sejoli', 'keterungkapan perasaan cinta secara verbal','pencirian cinta', dan 'kualitas cinta'.

\section{Simpulan dan Saran}

\subsection{Simpulan}

Secara linguistik, pengalaman emosi pemakai BI lebih banyak diekspresikan secara metaforis dibandingkan dengan cara-cara literal. Pernyataan ini didukung oleh data kuantitatif yang menyatakan bahwa 76,50\% (3.059) sitiran 
yang ditemukan bermakna metaforis sekaligus merupakan pola metaforis dan sisanya, yaitu 23,50\% (940) bermakna literal. Pola metaforis yang ditemukan tidak terjadi secara acak. Akan tetapi, pola-pola tersebut dimotivasi oleh MK yang berjumlah 258. Pernyataan ini sekaligus menegaskan bahwa pemakaian metafora, khususnya metafora emosi, dalam kehidupan sehari-hari tidak bersifat figuran, tetapi bersifat inti dan merupakan bagian dari konsep berpikir metaforis yang mendorong pemakaian bahasa metaforis. Temuan ini juga mengesahkan pentingnya serta relevannya teori MK yang digunakan dalam penelitian ini.

Profil pola metaforis emosi dalam BI dibangun dari unsur-unsur leksikon emosi amarah/ kemarahan, ketakutan, kebahagiaan, kesedihan, dan cinta dengan leksikon yang memetakannya, seperti verba (menggelegak, meluap, memuntahkan), nomina (api, luapan, korban), dan adverbia (di dalam, di bawah). Misalnya, pola api amarah, terdiri atas leksikon api (nomina [RS yang memetakan]) dan amarah (nomina [RT yang dipetakan]).

Untuk emosi BI, MK yang signifikan tertarik (khas) pada RT EMOSI (AMARAH) ) ialah (1) KONTROL EMOSI ADALAH KONTROL OBJEK BERGERAK, (2) EMOSI ADALAH UNSUR DALAM WADAH BERTEKANAN, (3) EMOSI ADALAH CAIRAN DALAM WADAH, (4) EMOSI ADALAH CAIRAN PANAS DALAM WADAH, (5) EMOSI ADALAH API, (6) EMOSI ADALAH PANAS/DINGIN SUATU OBJEK, (7) INTENSITAS EMOSI ADALAH TINGGI/RENDAH, dan (8) EMOSI ADALAH KEKUATAN ALAM. Hasil ini mengindikasikan pentingnya penggunaan metode LKorp dan penyertaan pengujian secara statistik sebagai pelengkap kajian kualitatif.

Ditinjau dari segi makna, metafora EMOSI BI menyoroti beberapa unsur makna utama. Metafora AMARAH menyoti unsur 'pengendalian tindakan emosional' dan 'intensitas emosi'; metafora KETAKUTAN menyoroti unsur 'keberadaan emosi pada diri' serta 'pergumulan diri dan emosi'; metafora KEBAHAGIAAN menyoroti unsur 'potensi untuk menyebabkan penerima menjadi bahagia', 'potensi perubahan keadaan menjadi bahagia', 'keberadaan emosi pada diri', 'usaha/upaya menjadi bahagia', 'menjadi bahagia', 'tahapan menjadi bahagia', 'merasakan kebahagiaan', 'ketahanan keadaan bahagia', dan 'kepositifan keadaan bahagia'; metafora KESEDIHAN berfokus pada unsur 'kenegatifan keadaan sedih', 'kesulitan emosional', dan 'tanggapan emosional'; dan metafora CINTA menyoroti unsur 'perubahan emosional secara aksidental/tidak terduga', 'keterhubungan dua sejoli secara emosional', 'penceritaan kisah kasih sejoli', 'keterungkapan perasaan cinta secara verbal','pencirian cinta', dan 'kualitas cinta'. Hasil SMU di atas menegaskan pentingnya pola linguistik dominan (Kövecses, 2000) dalam mengungkap makna tersorot. Dalam penelitian ini, pola linguistik dominan ditelusuri melalui frekuensi pemakaian pola metaforis.

\subsection{Saran}

Aplikasi padu antara TMK, metode LKorp, APM, dan penyertaan uji statistik dapat dilakukan lebih lanjut karena penelitian ini telah membuktikan keberhasilannya dalam menemukan, mengolah, dan menganalisis data secara tuntas sepanjang berhubungan dengan masalah yang diajukan. 
Penelitian ini belum mempertimbangkan ukuran, keseimbangan, dan keterwakilan korpus karena luasnya cakupan BI dan terbatasnya waktu penelitian. Demikian juga pelibatan RT yang masih terbatas. Oleh karena itu, penelitian yang melibatkan korpus yang lebih besar, seimbang, dan terwakili serta penyertaan RT yang lebih banyak jumlahnya akan mampu menemukan kekuatan metafora dengan lebih baik, variasi pola metaforis yang lebih banyak, serta MK yang lebih luas sehingga keterpatrian suatu konsep yang memotivasi digunakannya ML dapat ditentukan dengan lebih baik. Selain itu, isu keuniversalan dan kekhasan metafora juga akan dapat dijelaskan dengan lebih baik. Sementara itu, kekuatan SMU dan PU juga akan dapat diukur dengan lebih baik. 


\section{DAFTAR ISI}

Halaman

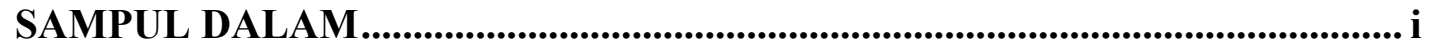



LEMBAR PENGESAHAN ........................................Error! Bookmark not defined.

PENETAPAN PANITIA PENGUJI ................................................................... iv

PERNYATAAN BEBAS PLAGIAT .................................................................... V

UCAPAN TERIMA KASIH ....................................................................... vi

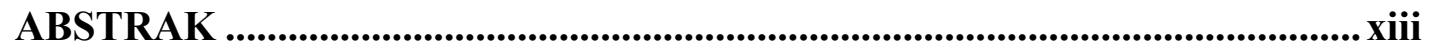

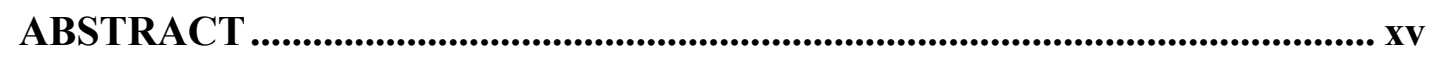

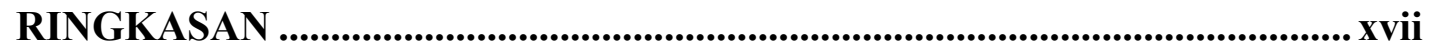

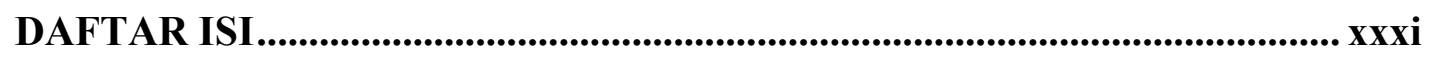

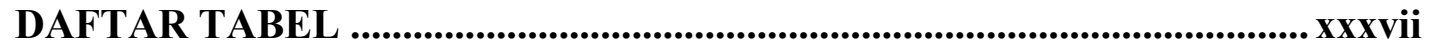

DAFTAR BAGAN

DAFTAR SINGKATAN ................................................................................. xlii

KONVENSI GAYA TULISAN ..........................................................................xliii

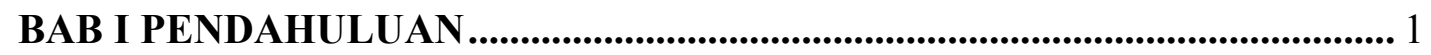

1.1 Latar Belakang ......................................................................................... 1

1.2 Rumusan Masalah ......................................................................................... 12

1.3 Tujuan Penelitian ............................................................................................................... 12

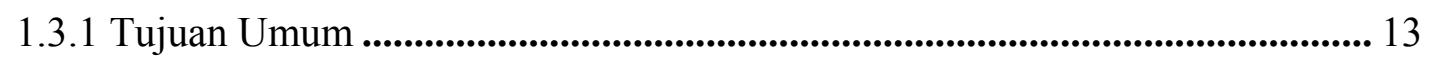

1.3.2 Tujuan Khusus ................................................................................................ 13

1.4 Manfaat Penelitian ........................................................................................ 13

1.4.1 Manfaat Akademis ......................................................................................... 13

1.4.2 Manfaat Praktis .................................................................................... 14

Catatan Akhir ............................................................................................ 16

BAB II KAJIAN PUSTAKA, KONSEP, DAN KERANGKA TEORI .............. 18

2.1 Kajian Pustaka.................................................................................................... 18

2.1.1 Penelitian Metafora Klasik........................................................................... 19

2.1.2 Penelitian Metafora Konseptual........................................................................ 22

2.1.3 Penelitian Metafora Emosi ........................................................................... 24

2.2 Konsep-Konsep Dasar.......................................................................................... 36

2.3 Landasan Teori............................................................................................ 37

2.3.1 Teori Metafora Konseptual ....................................................................... 50 
2.3.1.1 Komponen Metafora ........................................................................................ 51

2.3.1.2 Jangkauan Metafora .......................................................................................... 55

2.3.1.3 Sorot Makna Utama (SMU) ....................................................................... 55

2.3.1.4 Pemetaan Utama (PU)..................................................................................... 57

2.3.1.5 Keajegan Arah Pemetaan Metafora .................................................................. 58

2.3.1.6 Metafora Struktur Peristiwa ................................................................... 59

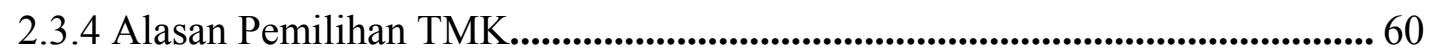

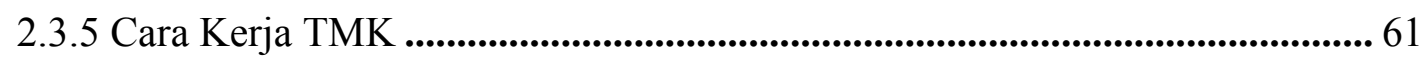

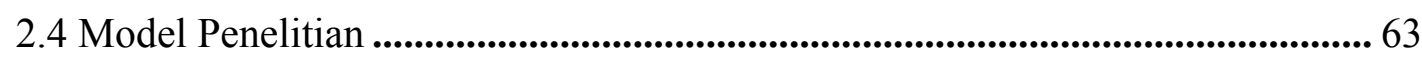

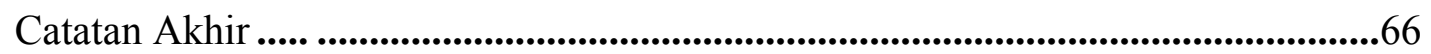

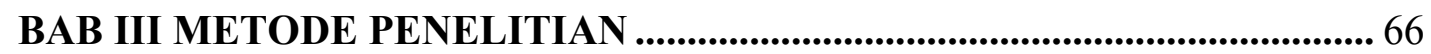

3.1 Landasan Filosofis Penelitian ................................................................................ 66

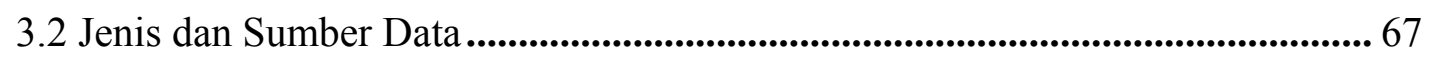

3.3 Instrumen Penelitian ................................................................................................ 68

3.4 Metode dan Teknik Penyediaan Data ................................................................... 70

3.4.1 Metode LKorp .......................................................................................................... 71

3.5 Metode dan Teknik Analisis Data........................................................................ 72

3.6 Metode dan Teknik Penyajian Hasil Analisis ....................................................... 79

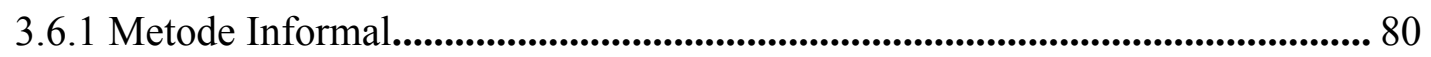

3.6.2 Metode Formal .............................................................................................. 80

BAB IV KONSEPSI BAHASA EMOSI, METAFORA, KORPUS, DAN

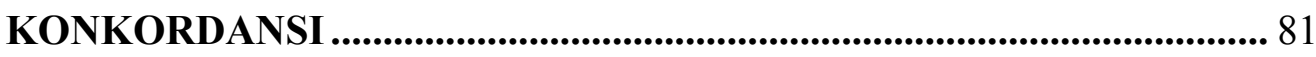

4.1 Leksikon yang Behubungan dengan Emosi ......................................................... 82

4.1.1 Emosi Ekspresif dan Emosi Deskriptif ......................................................... 82

4.1.2 Istilah Emosi Dasar ........................................................................................ 83

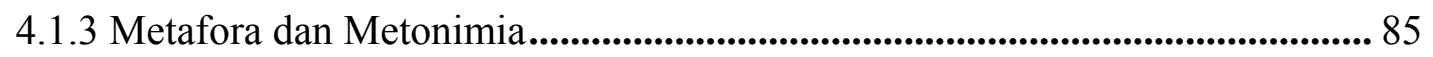

4.1.4 Motivasi Eksperiensial Metafora ...................................................................... 88

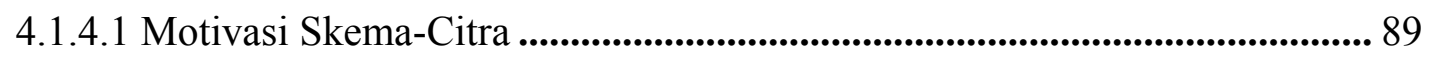

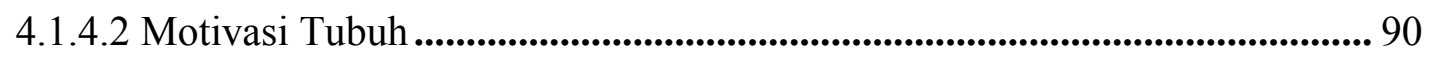

4.1.4.3 Motivasi Persepsi .................................................................................... 91

4.1.4.4 Motivasi Budaya .............................................................................................. 91

4.1.5 Kekonvensionalan Metafora ${ }^{2}$.................................................................. 91

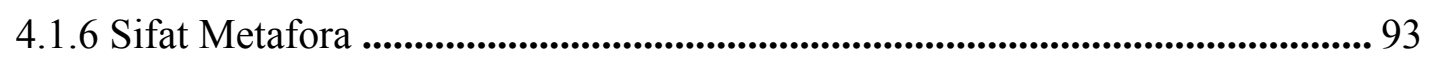

4.1.7 Struktur Metafora ................................................................................................. 93

4.1.8 Metafora dan Idiom...................................................................................... 94 
4.2 Korpus dan Konkordansi ................................................................................. 94

4.2.1 Korpus .............................................................................................................................. 95

4.2.1.1 Pengertian Korpus ................................................................................ 95

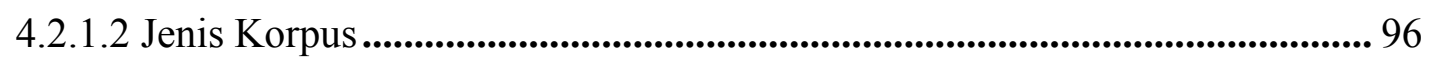

4.2.1.3 Maanfaat Korpus ...................................................................................... 98

4.2.1.4 Daftar Kekerapan .................................................................................. 99

4.2.1 Konkordansi ................................................................................................ 100

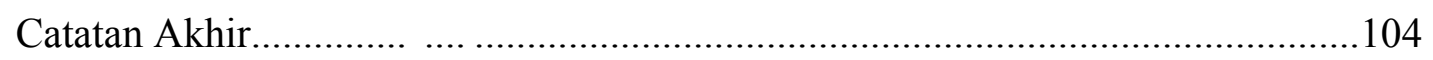

BAB V METAFORA KONSEPTUAL DAN METAFORA LINGUISTIK UNTUK EMOSI BAHASA INDONESIA........................................ 103

5.1 Pengantar............................................................................................................. 103

5.2 Metafora AMARAH/KEMARAHAN ................................................................. 105

5.2.1 Metafora AMARAH/KEMARAHAN dalam Kövecses (2000).............................. 108

5.2.2 Metafora AMARAH/KEMARAHAN yang Tidak Dibicarakan dalam Pustaka .....113

5.2.3 Metafora AMARAH/KEMARAHAN yang Munculnya Jarang ........................... 119

5.2.4 Metafora Struktur Peristiwa untuk AMARAH/ KEMARAHAN .......................... 121

5.3 Metafora KETAKUTAN ................................................................................... 127

5.3.1 Metafora KETAKUTAN yang Dibicarakan dalam Pustaka .............................. 128

5.3.2 Metafora KETAKUTAN yang Tidak Dibicarakan dalam Pustaka..................... 131

5.3.3 Metafora KETAKUTAN yang Jarang Digunakan............................................... 134

5.3.4 Metafora Struktur Peristiwa untuk KETAKUTAN ............................................ 136

5.4 Metafora KEBAHAGIAAN ........................................................................... 140

5.4.1 Metafora KEBAHAGIAAN yang Dibicarakan dalam Pustaka.......................... 141

5.4.2 Metafora KEBAHAGIAAN yang Tidak Dibicarakan dalam Pustaka................ 145

5.4.3 Metafora KEBAHAGIAAN yang Munculnya Jarang...................................... 149

5.4.4 Metafora Struktur Peristiwa untuk KEBAHAGIAAN ........................................ 150

5.5 Metafora KESEDIHAN ............................................................................ 155

5.5.1 Metafora KESEDIHAN yang Dibicarakan dalam Pustaka ............................... 156

4.5.2 Metafora KESEDIHAN yang Tidak Dibicarakan dalam Pustaka ..................... 160

5.5.3 Metafora KESEDIHAN yang Munculnya Jarang................................................. 163

5.5.4 Metafora Struktur Peristiwa untuk KESEDIHAN........................................... 165

5.6 Metafora CINTA..................................................................................... 169

5.6.1 Metafora CINTA yang Dibicarakan dalam Pustaka ....................................... 171

5.6.2 Metafora CINTA yang Tidak Dibicarakan dalam Pustaka ............................... 176

5.6.3 Metafora CINTA yang Munculnya Jarang ................................................... 181

5.6.4 Metafora Struktur Peristiwa untuk CINTA....................................................... 183 
BAB VI METAFORA KHAS EMOSI BAHASA INDONESIA............................ 189

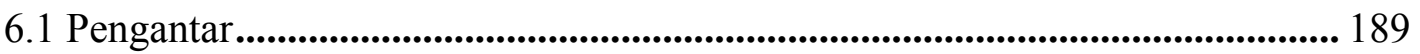

6.2 Metodologi Analisis Ketertarikan antara RT Emosi dan RS Metaforis............ 198

6.3 Hasil Analisis CFA dan Pembahasan............................................................... 208

6.3.1 Metafora yang Signifikan Tertarik pada RT AMARAH ................................. 211

6.3.2 Metafora yang Signifikan Tertarik pada RT KETAKUTAN ............................ 215

6.3.3 Metafora yang Signifikan Tertarik pada RT KEBAHAGIAAN ......................... 216

6.3.4 Metafora yang Signifikan Tertarik pada RT KESEDIHAN ............................. 219

6.3.5 Metafora yang Signifikan Tertarik pada RT CINTA........................................ 220

6.3.6 Metafora WADAH Khas BI ..................................................................... 222

Catatan Akhir ............................................................................................ 225

BAB VII MAKNA METAFORA EMOSI BAHASA INDONESIA ................. 226

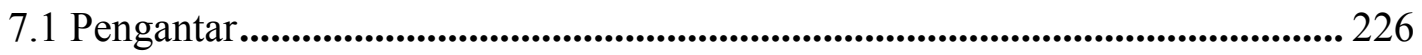

7.2 Sorot Makna Utama ......................................................................................... 230

7.3 Pemetaan Utama................................................................................................ 231

7.4 Sorot Makna Utama, Pemetaan Utama, dan Metode Analisis Pola

Metaforis \& Linguistik Korpus....................................................................... 233

7.5 Sorot Makna Utama dan Pemetaan Utama Metafora AMARAH...................... 236

7.5.1 Metafora KONTROL AMARAH ADALAH KONTROL OBJEK BERGERAK........... 236

7.5.2 Metafora AMARAH ADALAH UNSUR DALAM WADAH (BERTEKANAN) ......... 239

7.5.3 Metafora AMARAH ADALAH CAIRAN DALAM WADAH ................................... 246

7.5.4 Metafora AMARAH ADALAH CAIRAN PANAS DALAM WADAH ...................... 250

7.5.5 Metafora AMARAH ADALAH PANAS/DINGIN............................................... 254

7.5.6 Metafora AMARAH ADALAH API ................................................................ 257

7.5.7 Metafora AMARAH ADALAH TINGGI/RENDAH ............................................ 261

7.5.8 Metafora AMARAH ADALAH KEKUATAN ALAM ........................................... 265

7.6 Sorot Makna Utama dan Pemetaan Utama Metafora KETAKUTAN ............... 270

7.6.1 Metafora KETAKUTAN ADALAH MELAKUKAN SESUATU DISERTAI OBJEK

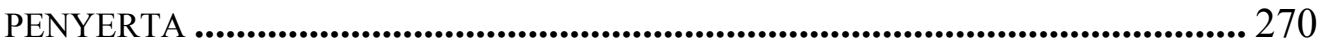

7.6.2 Metafora KETAKUTAN ADALAH MUSUH/LAWAN.......................................... 272

7.7 Sorot Makna Utama dan Pemetaan Utama Metafora KEBAHAGIAAN........... 277

7.7.1 Metafora KEBAHAGIAAN ADALAH (SECARA POTENSIAL) MEMBERIKAN SUATU OBJEK ...................................................................................... 277

7.7.2 Metafora KEBAHAGIAAN ADALAH (SECARA POTENSIAL) MENERIMA SUATU OBJEK 
7.7.3 Metafora KEBAHAGIAAN ADALAH KEPEMILIKAN .............................. 283

7.7.4 Metafora KEBAHAGIAAN ADALAH MENCARI/MEMBURU SUATU OBJEK 285

7.7.5 Metafora KEBAHAGIAAN ADALAH MENEMUKAN/MERAIH SUATU OBJEK 288

7.7.6 Metafora KEBAHAGIAAN ADALAH PERJALANAN ............................................. 289

7.7.7 Metafora KEBAHAGIAAN ADALAH SANTAPAN.............................................. 292

7.7.8 Metafora KEBAHAGIAAN ADALAH OBJEK RAPUH/PECAH BELAH .................. 294

7.7.9 Metafora KEBAHAGIAAN ADALAH BERADA DI ATAS/MELAYANG ................. 296

7.8 Sorot Makna Utama dan Pemetaan Utama Metafora KESEDIHAN.................. 297

7.8.1 Metafora KESEDIHAN ADALAH BERADA DI BAWAH....................................... 298

7.8.2 Metafora KESEDIHAN ADALAH BEBAN .......................................................... 300

7.8.3 Metafora KESEDIHAN ADALAH CAIRAN ..................................................... 302

7.9 Sorot Makna Utama dan Pemetaan Utama Metafora CINTA ........................... 304

7.9.1 Metafora CINTA ADALAH PERGERAKAN AKSIDENTAL................................... 305

7.9.2 Metafora CINTA ADALAH IKATAN .............................................................. 305

7.9.3 Metafora CINTA ADALAH CERITA .................................................................... 309

7.9.4 Metafora CINTA ADALAH UNGKAPAN VERBAL ............................................ 310

7.9.5 Metafora CINTA ADALAH OBJEK BERWARNA................................................. 311

7.9.6 Metafora CINTA ADALAH OBJEK BERKEILAHIAN.......................................... 313

BAB VIII TEMUAN PENELITIAN ............................................................... 316

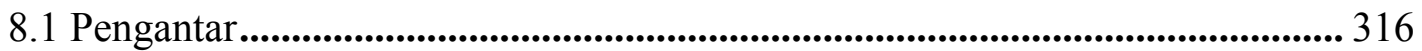

8.2 Temuan Teoretis...................................................................................... 316

8.3 Temuan Metodologis ................................................................................. 318

8.4 Temuan Empiris ............................................................................................ 319

8.4.1 Pola Metafora Emosi................................................................................... 319

8.4.2 Tingkat Pemakaian Leksikon RT EMOSI ....................................................... 319

8.4.3 Tingkat Pemakaian Metafora Emosi ............................................................ 320

8.4.4 MK Emosi BI ...................................................................................... 320

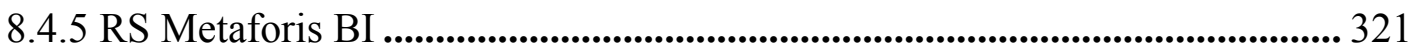

8.4.6 MK Khas Emosi BI................................................................................... 321

8.4.6.1 MK Khas Emosi AMARAH ............................................................................ 321

8.4.6.2 MK Khas Emosi KETAKUTAN ............................................................ 322

8.4.6.3 MK Khas Emosi KEBAHAGIAAN ............................................................ 322

8.4.6.4 MK Khas Emosi KESEDIHAN................................................................. 323

8.4.6.5 MK Khas Emosi CINTA.......................................................................... 323 
8.4.7 MK EMOSI Universal ...................................................................................... 323

8.4.7.1 MK Universal Menyangkut Emosi CINTA ................................................... 324

8.4.7.2 MK Universal Menyangkut WADAH..................................................... 324

8.4.7.3 Metafora WADAH Khas BI ........................................................................ 325

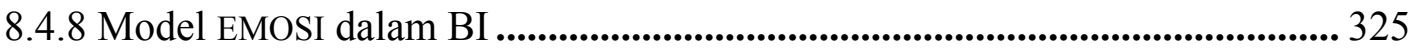

8.4.8.1 Model Emosi AMARAH/ KEMARAHAN........................................................ 325

8.4.8.2 Model Emosi KETAKUTAN .................................................................. 326

8.4.8.3 Model Emosi KEBAHAGIAAN ............................................................. 326

8.4.8.4 Model Emosi KESEDIHAN ..................................................................... 326

8.4.8.5 Model Emosi CINTA............................................................................................... 327

8.4.9 Makna Metafora EMOSI BI...................................................................... 327

8.4.9.1 Makna Metafora AMARAH ............................................................................. 327

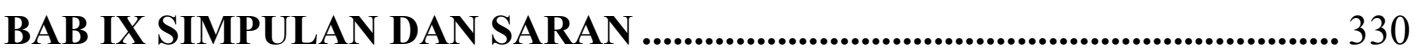

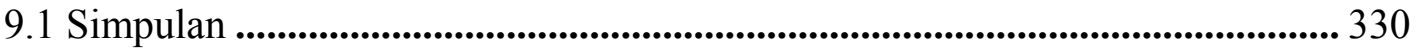

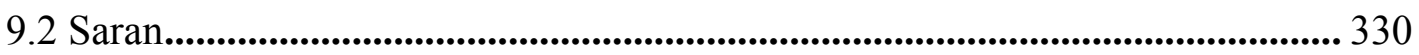

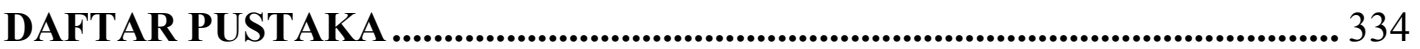

LAMPIRAN:

LAMPIRAN 1: Hasil Analisis CFA untuk Variabel Metafora dan Emosi ............. 343

LAMPIRAN 2: Metafora Konseptual Emosi BI................................................. 361

LAMPIRAN 3: 88 Ranah Sumber Metaforis BI yang Ditemukan .......................... 367

LAMPIRAN 4: Metafora Konseptual Universal untuk Emosi Cinta ..................... 370

LAMPIRAN 5: Metafora Universal "WADAH" dan Contoh MLnya ................... 372

LAMPIRAN 6: Persebaran Leksikon "Anggota Tubuh" RT Emosi ...................... 373

LAMPIRAN 7: Riwayat Hidup .......................................................................... 374 


\section{DAFTAR TABEL}

Halaman

2.1 Ringkasan Kajian Metafora yang Dilakukan Sebelumnya ....................... $\quad 35$

2.2 Prinsip Dasar Semantik Kognitif .......................................................... 48

3.1 Contoh Konkordansi untuk Ranah Target Amarah ................................... $\quad 69$

3.2 Contoh APM untuk Ranah Target Amarah .............................................. $\quad 77$

5.2a MK Amarah/Kemarahan dalam Kövecses (2000) dan Realisasi Pola Metaforis BI ................................................................................ 110

5.2b MK dan Pola Metaforis Amarah/Kemarahan yang Tidak Dibicarakan 116 dalam Pustaka

5.2c MK dan Pola Metaforis Amarah/Kemarahan yang Munculnya Jarang 121

5.2d MK dan Pola MSP untuk Amarah/Kemarahan ...................................... 124

5.3a MK Ketakutan dalam Kövecses (2000) dan Realisasi Pola Metaforis BI 130

5.3b MK dan Pola Metaforis Ketakutan yang Tidak Dibicarakan dalam Pustaka ....................................................................................... 132

5.3c MK dan Pola Metaforis Ketakutan yang Munculnya Jarang ................... 135

5.3d MK dan Pola MSP untuk Ketakutan ..................................................... 138

5.4a MK Kebahagiaan dalam Kövecses (2000) dan Realisasi Pola Metaforis BI

5.4b MK dan Pola Metaforis Kebahagiaan yang tidak Dibicarakan dalam Pustaka

5.4c MK dan Pola Metaforis Kebahagiaan yang Munculnya Jarang .............. 150

5.4d MK dan Pola MSP untuk Kebahagiaan .................................................. 152

5.5a MK Kesedihan dalam Kövecses (2000) dan Realisasi Pola Metaforis BI 158

5.5b MK dan Pola Metaforis Kesedihan yang Tidak Dibicarakan dalam Pustaka

5.5c MK dan Pola Metaforis Kesedihan yang Munculnya Jarang ................ 164

5.5d MK dan Pola MSP untuk Kesedihan .................................................... 167

5.6a MK Cinta dalam Kövecses (2000) dan Realisasi Pola Metaforis BI ....... 174

5.6b MK dan Pola Metaforis Cinta yang Tidak Dibicarakan dalam Pustaka 178

5.6c MK dan Pola Metaforis Cinta yang Munculnya Jarang ......................... 182

5.6d MK dan Pola MSP untuk Cinta ........................................................ 185 
5.7 Rekapitulasi MK dan ML Menyangkut Emosi Amarah/Kemarahan,

Ketakutan, Kebahagiaan, Ketakutan, dan Cinta

6.1 Aplikasi RS metaforis terhadap RT EMOSI (Kövecses, 2000:36-40) ......... 191

6.2 Nukilan Tabulasi Tingkatan Variabel METAFORA X EMOSI ...................... 203

6.3 Nukilan Enam Konfigurasi Signifikan Teratas Variabel METAFORA dan EMOSI

6.4 Kekerapan Leksikon “Anggota Tubuh” sebagai WADAH EMOSI

6.5 Persebaran Leksikon “Anggota Tubuh” berdasarkan RT EMOSI

7.5.1 PM untuk MK KONTROL AMARAH ADALAH KONTROL OBJEK BERGERAK

7.5.2a PM untuk MK AMARAH ADALAH UNSUR DALAM WADAH (BERTEKANAN)

7.5.2b PM dan Pengikutan Metaforis Unsur Makna ‘intensitas' dari MK AMARAH ADALAH CAIRAN DALAM WADAH

7.5.3 PM dan Pengikutan Metaforis Unsur Makna 'intensitas' dari MK .......AMARAH ADALAH CAIRAN DALAM WADAH ....

7.5.4 PM dan Pengikutan Metaforis Unsur Makna 'intensitas' dari MK

.......AMARAH ADALAH CAIRAN PANAS DALAM WADAH

253

7.5.5 PM dan Pengikutan Metaforis Unsur Makna 'intensitas' dari MK .......AMARAH ADALAH PANAS/DINGIN .... 256

7.5.6a PM untuk MK AMARAH ADALAH API 258

7.5.6b PM dan Pengikutan Metaforis Unsur Makna 'intensitas' dari MK AMARAH ADALAH API

7.5.7 PM dan Pengikutan Metaforis Unsur Makna 'intensitas' dari MK ......AMARAH ADALAH TINGGI/RENDAH .. 263

7.5.8a PM untuk MK AMARAH ADALAH KEKUATAN ALAM

7.5.8b PM dan Pengikutan Metaforis Unsur Makna ‘intensitas’ dari MK .AMARAH ADALAH KEKUATAN ALAM

7.6.1 PM untuk MK KETAKUTAN ADALAH MELAKUKAN SESUATU DISERTAI OBJEK PENYERTA

7.6.2a PM untuk MK KETAKUTAN ADALAH MUSUH/LAWAN

7.6.2b PM dan Pengikutan Metaforis Unsur Makna 'pergumulan diri dan emosi' dari MK KETAKUTAN ADALAH MUSUH/LAWAN ...

7.7.1 PM dan Pengikutan Metaforis Unsur Makna 'potensi menyebabkan' dari MK KEBAHAGIAAN ADALAH MEMBERIKAN SUATU OBJEK

7.7.2 PM dan Pengikutan Metaforis Unsur Makna 'potensi perubahan 
keadaan' dari MK KEBAHAGIAAN ADALAH MENERIMA SUATU OBJEK....

7.7.3 PM dan Pengikutan Metaforis Unsur Makna 'keberadaan emosi' dari MK KEBAHAGIAAN ADALAH KEPEMILIKAN

7.7.4 PM dan Pengikutan Metaforis Unsur Makna 'usaha/upaya' dari MK KEBAHAGIAAN ADALAH MENCARI/MEMBURU SUATU OBJEK

7.7.5 PM untuk MK KEBAHAGIAAN ADALAH MENEMUKAN/ MERAIH SUATU OBJEK.

288

7.7.6 PM untuk MK KEBAHAGIAAN ADALAH PERJALANAN ................... 290

7.7.7 PM untuk MK KEBAHAGIAAN ADALAH SANTAPAN ..................... 292

7.7.8 PM dan Pengikutan Metaforis Unsur Makna 'ketahanan keadaan bahagia' dari MK KEBAHAGIAAN ADALAH OBJEK RAPUH/PECAH BELAH

7.7.9 PM untuk MK KEBAHAGIAAN ADALAH BERADA DI ATAS/MELAYANG .

7.8.1 PM dan Pengikutan Metaforis Unsur Makna 'kenegatifan' dari MK KESEDIHAN ADALAH BERADA DI BAWAH

7.8.2 PM dan Pengikutan Metaforis Unsur Makna 'kesulitan emosional' dari MK KESEDIHAN ADALAH BEBAN

301

7.8.3 PM untuk MK KESEDIHAN ADALAH CAIRAN .......................... 303

7.9.1a PM untuk MK CINTA ADALAH IKATAN ............................. 306

7.9.1b PM dan Pengikutan Metaforis Unsur Makna 'kebersatuan emosional' dari MK CINTA ADALAH IKATAN ......................... 308

7.9.2 PM untuk MK CINTA ADALAH UNGKAPAN VERBAL .................... 311

7.9.3 PM untuk MK CINTA ADALAH OBJEK BERWARNA ..................... 312

7.9.4 PM dan Pengikutan Metaforis Unsur Makna 'kualitas cinta' dari MK

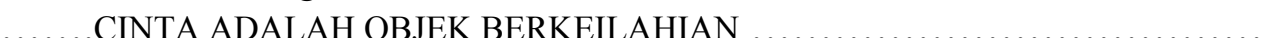




\section{DAFTAR BAGAN}

Halaman

2.1 Penelitian tentang Makna dan Tata Bahasa dalam Linguistik Kognitif .. $\quad 43$

2.2 Posisi TMK dalam Semantik Kognitif .................................................. 49

2.3 Sistem Kompleks ......................................................................... 56

2.4 Model Penelitian ..................................................................................... 64

4.1 Hierarki Vertikal Istilah Emosi ............................................................ 84

4.2 Istilah Emosi Prototipe dan Bukan Prototipe pada Tataran Horizontal

Dalam Pengorganisasian Konseptual ................................................ 85

4.3 Tipe Bahasa Emosi ............................................................................. 87

7.5.1 Distribusi Unsur Makna MK KONTROL AMARAH ADALAH KONTROL OBJEK BERGERAK ........................................ 238

7.5.2a PM untuk MK AMARAH ADALAH UNSUR DALAM WADAH (BERTEKANAN) .............................................. 242

7.5.2b PM dan Pengikutan Metaforis Unsur Makna ‘intensitas’ dari MK AMARAH ADALAH CAIRAN DALAM WADAH ........................

7.5.3 Distribusi Pengikutan Metaforis Unsur Makna 'intensitas' dari MK

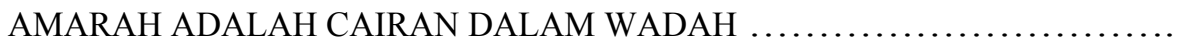

7.5.4 Distribusi Pengikutan Metaforis Unsur Makna 'intensitas' dari MK AMARAH ADALAH CAIRAN PANAS DALAM WADAH $. . . \ldots \ldots \ldots \ldots \ldots . . . .$.

7.5.5 Distribusi Pengikutan Metaforis Unsur Makna 'intensitas' dari MK

7.5.6a Distribusi Unsur Makna MK AMARAH ADALAH API ................... 259

7.5.6b Distribusi Pengikutan Metaforis Unsur Makna ‘intensitas’ dari MK AMARAH ADALAH API

7.5.7 Distribusi Pengikutan Metaforis Unsur Makna 'intensitas' dari MK AMARAH ADALAH TINGGI/RENDAH

7.5.8a Distribusi Unsur Makna MK AMARAH ADALAH KEKUATAN ALAM

7.5.8b Distribusi Pengikutan Metaforis Unsur Makna ‘intensitas' dari MK AMARAH ADALAH KEKUATAN ALAM ...............................

7.6.1 Distribusi Unsur Makna MK KETAKUTAN ADALAH MELAKUKAN SESUATU DISERTAI OBJEK PENYERTA

7.6.2a Distribusi Unsur Makna MK KETAKUTAN ADALAH MUSUH/ LAWAN 
7.6.2b Distribusi Pengikutan Metaforis Unsur Makna 'pergumulan diri dan emosi' dari MK KETAKUTAN ADALAH MUSUH/LAWAN

7.7.1 Distribusi Pengikutan Metaforis Unsur Makna 'potensi menyebabkan' dari MK KEBAHAGIAAN ADALAH MEMBERIKAN SUATU OBJEK

7.7.2 Distribusi Pengikutan Metaforis Unsur Makna 'potensi perubahan keadaan' dari MK KEBAHAGIAAN ADALAH MENERIMA SUATU OBJEK

7.7.3 Distribusi Pengikutan Metaforis Unsur Makna 'keberadaan emosi' dari MK KEBAHAGIAAN ADALAH KEPEMILIKAN

7.7.4 Distribusi Pengikutan Metaforis Unsur Makna 'usaha/upaya' dari MK KEBAHAGIAAN ADALAH MENCARI/MEMBURU SUATU OBJEK......

7.7.5 Distribusi Unsur Makna MK KEBAHAGIAAN ADALAH PERJALANAN...

7.7.6 Distribusi Unsur Makna MK KEBAHAGIAAN ADALAH SANTAPAN

7.7.7 Distribusi Pengikutan Metaforis Unsur Makna 'ketahanan keadaan bahagia' dari MK KEBAHAGIAAN ADALAH OBJEK RAPUH/

.......PECAH BELAH ....

7.8.1 Distribusi Pengikutan Metaforis Unsur Makna 'kenegatifan' dari MK KESEDIHAN ADALAH BERADA DI BAWAH

7.8.2 Distribusi Pengikutan Metaforis Unsur Makna 'kesulitan emosional' dari MK KESEDIHAN ADALAH BEBAN

7.8.3 Distribusi Unsur Makna MK KESEDIHAN ADALAH CAIRAN

7.9.1a Distribusi Unsur Makna MK CINTA ADALAH IKATAN

7.9.1b Distribusi Pengikutan Metaforis Unsur Makna 'kebersatuan emosional' dari MK CINTA ADALAH IKATAN

7.9.3 Distribusi Unsur Makna MK CINTA ADALAH OBJEK BERWARNA

7.9.4 Distribusi Pengikutan Metaforis Unsur Makna 'kualitas cinta' dari MK CINTA ADALAH OBJEK BERKEILAHIAN 


\title{
DAFTAR SINGKATAN
}

\author{
APM : Analisis Pola Metaforis \\ BI : Bahasa Indonesia \\ BIng. : Bahasa Inggris \\ CFA : Configural Frequency Analysis \\ DSB : Dan sebagainya \\ E : Emosi \\ HCFA : Hierarchical Configural Frequency Analysis \\ IHSG : Indeks Harga Saham Gabungan \\ LK : Linguistik Kognitif \\ LKorp : Linguistik Korpus \\ MK : Metafora Konseptual \\ ML : Metafora Linguistik \\ MSP : Metafora Struktur Peristiwa \\ PM : Pola Metaforis \\ PU : Pemetaan Utama \\ RS : Ranah Sumber \\ RT : Ranah Target \\ SMU : Sorot Makna Utama \\ TK : Tata Bahasa Kognitif \\ TMK : Teori Metafora Konseptual
}




\section{KONVENSI GAYA TULISAN}

Telah menjadi kesepakatan praktis dalam pendekatan linguistik kognitif bahwa huruf kapital digunakan untuk mewakili pikiran abstrak yang mendasari metafora (biasanya disebut metafora konseptual). Kata, frasa, atau ungkapan yang menjadi fokus kajian ditulis dengan spasi tunggal. Kata, frasa, atau ungkapan yang telah diidentifikasi secara pasti sebagai metafora dicetak miring dan tebal untuk memberi penekanan khusus.

Contoh: Metafora konseptual: AMARAH ADALAH API

Ungkapan metaforis: api amarah

api amarah panas membakar

kobaran api amarah 


\section{BAB I}

\section{PENDAHULUAN}

\subsection{Latar Belakang}

Linguistik kognitif (LK) merupakan aliran modern tentang linguistik dan pikiran yang awalnya muncul pada awal tahun 1970 dari ketidakpuasan sejumlah ahli bahasa terhadap pendekatan formal tentang bahasa. LK berakar kuat pada munculnya ilmu kognitif modern pada tahun 1960-an dan 1970-an, khususnya dalam karya-karya yang berhubungan dengan kategorisasi manusia dan dalam tradisi sebelumnya seperti Psikologi Gestalt ${ }^{1}$ (Evans, 2006:3).

Penelitian awal, antara tahun 1970-an dan 1980-an, didominasi oleh sejumlah kecil peneliti. Pada awal 1990-an terjadi perkembangan penelitian pada bidang ini, dan para peneliti mengidentifikasi diri mereka sebagai 'ahli LK'. Pada tahun 1989--1990, didirikan Masyarakat Linguistik Kognitif International bersama dengan jurnal Cognitive Linguistics. Langacker (1991) menyebutkan bahwa peristiwa tersebut dianggap tonggak lahirnya LK sebagai gerakan intelektual berkesadaran sendiri dan dengan alasan yang jelas (broadly grounded).

LK dipandang sebagai 'gerakan' (movement) atau 'usaha' (enterprise) karena LK bukan sebuah teori yang khusus. Akan tetapi, LK merupakan suatu pendekatan yang mengadopsi serangkaian prinsip-pinsip panduan umum, asumsi, dan perspektif yang mengarah pada keberagaman teori yang tumpang-tindih dan saling melengkapi (kadang-kadang bersaing) (Evans, 2006:3).

Dalam sebuah makalah pada tahun 1990, George Lakoff, salah seorang 
pionir dalam LK, berpendapat bahwa LK dicirikan oleh dua prinsip kunci. Prinsip-prinsip yang dimaksud ialah (1) prinsip generalisasi, suatu pencirian prinsip umum yang bertanggung jawab terhadap semua aspek bahasa manusia dan (2) prinsip kognitif, suatu prinsip yang memberikan ciri umum terhadap bahasa yang sesuai dengan minda ${ }^{2}$ dan otak ilmu yang lain. Kedua prinsip ini melandasi orientasi dan pendekatan yang diadopsi oleh praktisi LK, baik asumsi maupun metodologi yang diterapkan pada kedua cabang utama linguistik kogninif, yaitu semantik kognitif dan pendekatan kognitif terhadap tata bahasa (Evans, 2006:27).

Isu semantik kognitif dimulai pada tahun 1970-an sebagai reaksi terhadap para ahli bahasa yang memandang dunia secara objektif. Pandangan objektif ini diasumsikan oleh tradisi Anglo-Amerika dalam filsafat dan pendekatan yang terkait, yaitu semantik kebenaran bersyarat (truth-conditional semantics) yang dikembangkan dalam linguistik formal. Sebaliknya, semantik kognitif memandang makna bahasa sebagai representasi struktur konseptual. Salah seorang pionir semantik kognitif ialah Leonard Talmy (Evans, 2006:156). Semantik kognitif memiliki empat asumsi utama, yaitu (1) struktur konsep mewujud, (2) struktur semantik adalah struktur konseptual, (3) representasi makna besifat ensiklopedis, dan (4) konstruksi makna adalah konseptualisasi (Evans, 2006:157).

Menurut Evans (2006:176), dua prinsip utama semantik kognitif ialah (1) tesis yang mengatakan bahwa struktur konsep bermula dari perwujudan (embodiment) yang juga disebut tesis kognisi mewujud dan (2) tesis yang mengatakan bahwa struktur semantik merefleksikan struktur konsep. Salah satu 
pusat perhatian para ahli semantik kognitif sehubungan dengan perwujudan struktur konsep adalah Metafora Konseptual (MK). Teori Metafora Konseptual (TMK) dipelopori oleh Lakoff dan Johnson. TMK diperkenalkan pada tahun 1980-an melalui bukunya Metaphor We Live By. TMK juga dikenal sebagai teori kontemporer tentang metafora.

TMK membantah teori metafora klasik sebelumnya. Metafora klasik dipahami sebagai kias, yaitu satu hal dibandingkan dengan hal yang lain (Lakoff dan Johnson,1980; Kövecses, 2002; 2010). Menurut Encyclopedia Britannica, metafora merupakan kias yang menyatakan perbandingan antara dua entitas yang berbeda. Kamus Oxford Advanced Learners' Dictionary mendefinisikan bahwa metafora adalah kata atau frasa yang digunakan menggambarkan seseorang atau sesuatu yang lain secara kias untuk menunjukkan bahwa kedua hal itu memiliki kemiripan sifat dan untuk membuat sebuah deskripsi menjadi lebih kuat. Misalnya, "Luh Sari ialah bunga desa itu." Kata "bunga" pada kalimat tersebut diidentifikasi sebagai metafora karena antara "Luh Sari" dan "bunga" dipandang memiliki kemiripan sifat, yaitu 'cantik' atau 'indah'.

Metafora klasik ditandai dengan lima fitur yang paling umum, yaitu (1) metafora merupakan fenomena linguistik semata melalui pemakaian kata-kata; (2) metafora digunakan untuk tujuan seni dan retoris; (3) pemakaian metafora didasari oleh kemiripan dua entitas yang dapat dikenali dan dibandingkan; (4) pemilihan dan pemakaian kata-kata dalam metafora disadari dan disengaja oleh pemakainya; dan (5) metafora sebagai bagian dari ujaran digunakan untuk menimbulkan kesan atau efek khusus dan tidak merupakan bagian dari 
komunikasi sehari-hari. Selain itu, metafora tidak dipandang sebagai bagian dari proses berpikir manusia pada kehidupannya sehari-hari (Kövecses, 2002; 2006; 2010).

MK adalah pemetaan antara ranah- ranah sumber (RS) dan ranah target (RT) -pada sistem konsep. Istilah ungkapan metaforis yang digunakan dalam penelitian ini merujuk pada ungkapan linguistik atau metafora linguistik (ML) (berupa kata, frasa, atau kalimat) yang berperan sebagai realisasi luaran dari pemetaan antarranah tersebut (Lakoff, 2006:185--186). Metafora jenis ini dikenal dengan metafora konseptual atau metafora kognitif (MK). Ritchie (2013:10) berusaha memperjelas hubungan antara MK dan ML dengan memadukan terminologi metafora klasik sebelumnya yang dikenal dengan topic 'topik' dan vehicle 'wahana'. MK diasosiasikan dengan topik dan ML dengan wahana. Secara klasik, topik diasosiasikan dengan RT dan wahana diasosiasikan dengan RS.

MK memiliki lima fitur utama, yaitu (1) metafora merupakan bagian dari konsep, bukan kata-kata semata; (2) fungsi metafora ialah untuk memahami konsep-konsep tertentu dengan lebih baik, bukan hanya untuk tujuan artistik atau estetika; (3) metafora sering tidak berbasis pada kemiripan; (4) dalam kehidupan sehari-hari, metafora digunakan secara tidak disadari oleh masyarakat pada umumnya dan tidak hanya dipakai oleh orang-orang yang memiliki kemampuan khusus untuk itu; (5) metafora merupakan proses berpikir manusia yang tidak dapat dihindarkan (Lakoff \& Johnson, 1980; Lakoff, 2006; Kövecses, 2002; 2006; 2010; Geeraerts, 2010). Bahkan, Deignan (2005:13) menegaskan bahwa secara 
konseptual metafora dipandang sebagai inti pikiran (central to thought). Oleh karena itu, metafora juga merupakan inti bahasa.

Saat ini kajian metafora mengalami kemajuan yang sangat pesat, terutama di Eropa dan Amerika. Kemajuan tersebut dapat dilihat melalui publikasi hasilhasil penelitian yang dilakukan baik oleh Lakoff sendiri, tokoh-tokoh linguistik kognitif, maupun penekun-penekun aliran kognitif lainnya, seperti Deignan (1997, 2005); Stefanowitsch (2004a, 2006b); Stefanowitsch dan Gries (2006); King (1989); Yu (1995); Matsuki (1995); Kövecses (1995, 2002, 2006, 2010); dan yang lainnya. Metafora banyak diteliti karena perannya yang penting pada berbagai ranah, seperti ranah penceritaan (storytelling) humor, sastra, politik, agama, filsafat, ilmu pengetahuan, dan sebagainya. Penelitian-penelitian metafora ditujukan untuk mengetahui bagaimana metafora dipahami dan bagaimana memanfaatkan metafora untuk memahami ranah-ranah lain (Ritchie, 2013:208).

Fenomena menarik dari publikasi atau hasil-hasil penelitian mereka adalah bahwa kebanyakan dari mereka tertarik untuk meneliti metafora pada ranah emosi. Misalnya, Lakoff dan Kovecses (1987) meneliti metafora emosi amarah pada bahasa Inggris Amerika. Stefanowitsch (2004a) meneliti pola-pola metafora emosi kebahagiaan dalam bahasa Inggris dan Jerman. Kovecses (2000) mendiskusikan metafora emosi dari bahasa Inggris, Polandia, China, dan Jepang. King (1989) meneliti metafora emosi bahasa China. Yu (1995) meneliti metafora emosi amarah dan kebahagiaan dalam bahasa Inggris dan China. Matsuki (1995) meneliti metafora emosi amarah dalam bahasa Jepang. 
Menariknya RS emosi bagi para peneliti di atas mengundang isu keuniversalan $^{3}$ dan kekhasan metafora. Kovecses (2008:53) menyatakan bahwa pada beberapa bahasa yang tidak sekerabat mungkin dapat ditemukan MK emosi tertentu yang universal. Salah satu konsep emosi yang dimaksud adalah kebahagiaan. Ada tiga MK kebahagiaan yang dianggap universal oleh Kovecses (2008:54), yaitu (1) HAPPY IS UP (I'm feeling up 'Saya merasa di atas'), (2) HAPPINES IS LIGHT (She brighten up 'Dia cerah'), dan (3) HAPPINES IS FLUED IN A CONTAINER (He's bursting with joy 'Dia meledak bersama kebahagiaan.') Secara universal, ketiga metafora ini ditemukan keberadaannya dalam bahasa Inggris (BIng), bahasa Mandarin, dan bahasa Polandia.

Pertanyaannya adalah bagaimana mungkin satu konsep digunakan pada bahasa dan budaya yang berbeda? Ada tiga hal yang kemungkinan dapat digunakan untuk menjawab pertanyaan tersebut, yaitu (1) hal itu terjadi secara kebetulan, (2) suatu bahasa meminjam metafora dari bahasa lain, dan (3) terdapat beberapa motivasi yang bersifat universal yang memungkinkan suatu metafora dipakai pada budaya-budaya itu (Kovecses, 2008:55). Jika benar pernyataan para ahli linguistik kognitif yang mengklaim bahwa metafora "utama" atau "sederhana" dimotivasi oleh korelasi universal dari pengalaman jasmani (Lakoff, 1987; Kovecses, 2002), maka penjelasan (3) merupakan jawaban dari pertanyaan di atas (Kovecses, 2008:55). Jadi, metafora universal dilatarbelakangi oleh pengalaman jasmani yang sifatnya universal.

Kekhasan metafora dilihat dari dua dimensi oleh Kovecses (2008: 55--58; 2005:67--88), yaitu dimensi variasi lintas budaya dan variasi di dalam budaya. 
Secara lintas budaya, variasi metafora dapat dilihat melalui kasus di mana suatu budaya menggunakan serangkaian RS sebagai RT. Sebaliknya, budaya tertentu memanfaatkan RS tertentu untuk mengonseptualisasikan serangkaian RT. Pada situasi berbeda, serangkaian MK digunakan untuk RT tertentu secara hampir sama pada dua bahasa atau budaya, tetapi suatu bahasa atau budaya menunjukkan kelebihtertarikan pada beberapa MK yang digunakan. Ada juga metafora yang tampak unik atau khas bagi bahasa atau budaya tertentu. Sementara itu, variasi metafora di dalam budaya dapat dilihat melalui dimensi sosial, regional, stilistika, subkultur, dan variasi individu.

Unsur-unsur metafora yang terlibat dalam variasi metafora ialah pengalaman, RS, RT, hubungan antara RS dan RT, ungkapan linguistik metaforis, pemetaan, penyertaan metaforis ${ }^{4}$, pemaduan metaforis ${ }^{5}$, realisasi bukan linguistik, dan model budaya (Kovecses, 2008: 61; 2005: 117).

Penelitian ini memusatkan perhatian pada metafora ranah emosi dalam bahasa Indonesia (BI). Metafora dipilih karena secara kognitif, metafora dipandang sebagai inti dari pikiran (central to thought). Oleh karena itu, metafora juga merupakan inti dari bahasa. Pemakaian bahasa secara metaforis didorong oleh pikiran yang metaforis (Deignan, 2005:13). Selain itu, pemakaian metafora dapat ditemukan di mana-mana karena metafora merupakan bagian dari kehidupan manusia dan merasuk ke dalam kehidupan manusia sehari-hari (Lakoff, 1980).

Ranah emosi dipilih karena emosi memiliki struktur konsep yang sangat kompleks dan dapat membangkitkan bermacam-macam penafsiran (Lakoff, 1987: 
380). Emosi juga merupakan daya (force) yang membangkitkan tanggapan atau efek tertentu (Kövecses, 2000: 61). Sementara itu, bahasa emosi bukan sekadar kelompok kata harfiah yang menunjukkan kategori dan fakta emosi yang telah dikenal sebelumnya. Akan tetapi, bahasa emosi dipandang sebagai bahasa yang bersifat figuratif yang dapat menjelaskan, bahkan menciptakan pengalaman emosional (Kövecses, 2000: xii).

BI dipilih sebagai objek kajian karena beberapa alasan yang sangat kuat. Pertama, BI dipakai secara luas, baik sebagai bahasa resmi maupun sebagai bahasa pergaulan. Dilihat dari peringkat dan jumlah pemakai, BI menduduki peringkat kesembilan dari sepuluh bahasa terbanyak digunakan di dunia dengan jumlah pemakai 159 juta orang (www.bahasa.kompasiana.com/ 2011/09/16). Kedua, fenomena metafora emosi berlimpah dalam pemakaian BI sehari-hari. Ketiga, sampai saat ini, belum cukup banyak ditemukan kajian tentang metafora emosi BI secara mendalam, terutama dari sudut pandang MK. Keempat, metafora emosi BI belum pernah diteliti sebagai sebuah disertasi sehingga penelitian ini merupakan tantangan tersendiri. Adapun penelitian Rajeg (2009) tentang MK CINTA BI, metafora KEBAHAGIAAN BI (2012), MK AMARAH dalam bahasa Bali (2010), dan penelitian Yuditha (2012) tentang metafora MARAH masih bersifat parsial, yaitu sebatas MK dengan beberapa ungkapan metaforis yang mendukungnya. Penelitiannya belum dapat menggambarkan keberadaan dan pemakaian MK yang secara signifikan khas emosi. Oleh karena itu, kajian ini dapat dipandang sebagai kajian yang baru, sangat menarik untuk dibicarakan, dan sangat perlu dikaji sebagai upaya untuk mengembangkan ilmu linguistik kognitif 
di Indonesia dan untuk melengkapi kajian-kajian yang menyangkut ilmu linguistik objektif yang telah banyak dilakukan sebelumnya.

Penelitian ini bertujuan untuk menemukan konsep-konsep berpikir metaforis pemakai BI dan untuk menemukan pola-pola ungkapan linguistik metaforis, terutama yang menyangkut ranah emosi. Penelitian ini juga diarahkan untuk menemukan metafora emosi yang universal secara lintas bahasa dan metafora emosi khas bahasa atau budaya Indonesia. Selain itu, penelitian ini dimaksudkan untuk menemukan makna metafora emosi, terutama makna yang paling disoroti oleh pemakai BI.

Fenomena keuniversalan metafora emosi dalam kasus metafora WADAH untuk emosi AMARAH secara lintas bahasa ditemukan pada beberapa bahasa yang tidak berkerabat, termasuk di antaranya BIng, bahasa Hungaria, Jepang, Cina, Zulu, Polandia, Wolof, dan Tahiti (Kövecses, 2010:198). Rajeg (2010) menemukan kasus metafora WADAH untuk AMARAH dalam bahasa Bali dan Rajeg juga menemukan kasus metafora WADAH untuk CINTA (2009) dan WADAH untuk AMARAH (2010) dalam BI. Yuditha (2012) menemukan salah satu di antaranya metafora WADAH untuk kasus emosi MARAH dalam BI. Sementara itu, Yuditha (2012) juga menemukan metafora emosi khas BI dalam kasus MARAH SEBAGAI ENTITAS, NADA MUSIK, SENJATA, TANAMAN, PENYAKIT MENULAR, dan MAKANAN. Temuan Rajeg dan Yuditha telah memberikan indikasi bahwa terdapat keuniversalan dan kekhasan konsep metafora emosi dalam BI.

Untuk mencapai tujuan tersebut, sebagai penelitian awal, penelitian ini memanfaatkan lima leksikal untuk konsep emosi BI, yaitu amarah, ketakutan, 
kebahagiaan, kesedihan, dan cinta. Konsep-konsep tersebut dianggap mewakili konsep emosi yang lain. Alasannya ialah sebagian dari konsep emosi tersebut merupakan prototipe ${ }^{6}$ konsep emosi dan dapat ditemukan pada sebagian besar daftar "emosi dasar" (misalnya emosi amarah, ketakutan, kebahagiaan, kesedihan) dan cinta mewakili kelompok "emosi dasar". Kövecses (2000:20 dan 36) mengatakan bahwa konsep emosi, seperti amarah, ketakutan, kebahagiaan, kesedihan, cinta, nafsu (seks), kebanggaan, malu, dan keheranan telah mendapat perhatian yang besar dari para peneliti sebelumnya.

Penelitian ini mengaplikasikan TMK, sebuah teori yang dipayungi dengan pendekatan Linguistik Kognitif (LK) yang juga memayungi teori-teori kognitif lain, seperti Tata bahasa Kognitif (TK) (Tylor 2002; Langacker, 2007, 2008; Radden \& Dirven, 2007), Teori Metafora Konseptual (TMK) (Lakoff, 2006; Lakoff \& Johnson, 2003; Kövecses, 2000, 2002, 2010). LK merupakan pendekatan baru yang berkembang pesat di beberapa belahan dunia. Hal ini terbukti dengan banyaknya kajian metafora yang menggunakan pendekatan ini untuk mengkaji bahasa-bahasa di dunia. Kövecses (2010:196--197) telah mengidentifikasi kajian-kajian bahasa yang menggunakan LK, khususnya TMK. Di antara bahasa-bahasa yang dikaji dengan pendekatan ini ialah BIng, bahasa Polandia, Hungaria, Zulu, Wolof, Tahiti, China, dan Jepang. Hal ini menunjukkan bahwa TMK telah teruji dan mampu menangani data dari bahasa-bahasa yang berbeda. Diasumsikan bahwa TMK juga mampu menangani data BI. Sementara itu, di Indonesia, LK secara lebih spesifik, TMK belum banyak diaplikasikan. Oleh karena itu, penerapan TMK pada data BI dalam sebuah disertasi merupakan 
titik awal perkembangan LK di Indonesia pada umumnya dan di Universitas Udayana pada khususnya.

Metode yang digunakan dalam penelitian ini ialah metode Linguistik Korpus (LKorp) (Deignan, 2005; Hunston \& Francis, 2000; Hilpert, 2006; Gries, 2009a) dan Analisis Pola Metaforis (APM) (Stefanowitsch, 2006). Metode LKorp dan APM merupakan metode mutakhir yang digunakan untuk menyelidiki bahasa dengan mengobservasi sejumlah besar wacana yang terjadi secara alamiah dan tersimpan secara elektronik, dengan menggunakan perangkat lunak yang mampu memilih, memilah, memadukan, menghitung, dan memerinci data (Huston \& Francis, 2000:15; Gries, 2009a). Titik temu LK (TMK), LKorp, dan APM terletak pada unsur kealamiahan data. LKorp dan APM mengakar pada kealamiahan dan kekerapan data. Sementara itu, LK, termasuk teori-teori yang dipayungi, menganut asas, salah satu di antaranya asas berbasis pemakaian (usage-based thesis) (Langacker, 2007, 2008; Evans \& Green, 2006; Tylor, 2002).

Jalan mulus yang ditawarkan LKorp dan APM untuk dikombinasikan dengan aplikasi TMK adalah kemutakhiran metode dan teknik LKorp dan APM yang mampu mengintai, mengamati, dan menunjukkan pola-pola linguistik metaforis yang kemudian digunakan untuk menentukan MK yang tercermin serta makna yang terkandung. Selain itu, kekerapan pemakaian bahasa yang alamiah dari suatu pola juga ditawarkan LKorp dan APM untuk merefleksikan keterpatrian representasi kognitif dari khazanah kebahasaan, terutama dalam pola tersebut, dalam minda pemakainya (Langacker, 2008). 
Paparan tentang fenomena metafora serta kebaruan teori dan metode di atas menunjukkan pentingnya kajian metafora pada penelitian ini.

\subsection{Rumusan Masalah}

Melalui paparan fenomena metafora yang terjadi, konteks teori, dan metodologi yang digunakan, penelitian ini diarahkan untuk menemukenali dan mengategorisasikan metafora emosi BI dari sudut pandang ML yang diungkapkan dan MK yang tercermin di dalamnya; menemukan pola-pola metaforis menyangkut emosi BI, meganalisis dan menemukan metafora yang khas emosi, dan menganalisis makna metafora emosi BI. Masalah yang diteliti dapat dirumuskan sebagai berikut.

1. Bagaimanakah emosi pemakai BI diekspresikan secara linguistik metaforis? MK apa saja yang tercermin dari ekspresi linguistik metaforis tersebut?

2. Bagaimanakah pola-pola metaforis menyangkut emosi BI?

3. Metafora manakah yang khas untuk emosi BI?

4. Bagaimanakah makna metafora emosi BI?

\subsection{Tujuan Penelitian}

Tujuan penelitian yang dibicarakan di sini menyangkut dua hal penting, yaitu tujuan umum dan tujuan khusus, seperti berikut ini. 


\subsubsection{Tujuan umum}

Tujuan umum penelitian ini ialah untuk menemukenali ungkapanungkapan linguistik metaforis dan MK yang mencerminkan emosi pemakai BI. Secara teoretis dan metodologis, penelitian ini bertujuan untuk menerapkan teori semantik baru dan metode baru terhadap data metafora emosi BI, yaitu LK, khususnya TMK, LKorp, dan APM.

\subsubsection{Tujuan khusus}

Secara khusus, penelitian ini bertujuan untuk (1) menemukan pola-pola metaforis menyangkut emosi BI, (2) menganalisis dan menjelaskan metafora khas emosi BI, dan (3) menganalisis makna metafora emosi BI.

\subsection{Manfaat Penelitian}

Penelitian ini diproyeksikan untuk memberikan manfaat yang cukup besar bagi pengembangan ilmu linguistik, terutama bagi mereka yang menekuni dan tertarik pada bidang linguistik kognitif, baik secara akademis maupun praktis. Selain itu, penelitian ini memberikan manfaat bagi pemakai BI untuk mengetahui konsep-konsep metaforis tentang emosi.

\subsubsection{Manfaat Akademis}

Secara akademis, penelitian ini bermanfaat bagi pengembangan ilmu linguistik yang selama ini belum cukup mendapat perhatian dari para peneliti bahasa, baik di Indonesia secara umum maupun di Bali khususnya, yaitu ilmu 
linguistik kognitif, terutama semantik kognitif. TMK memberikan manfaat bagi para peneliti yang berminat mengamati metafora dari sudut pandang fenomena bahasa dan pikiran. Metode LKorp bermanfaat bagi peneliti yang bermaksud menggabungkan pendekatan, baik kualitatif maupun kuantitatif, dalam penelitianpenelitian bahasa.

Hasil penelitian ini juga bermanfaat bagi para ahli semantik kognitif, khususnya ahli MK untuk mengetahui keuniversalan dan kekhasan metafora emosi BI sebagai dasar untuk melakukan penelitian metafora secara lintas bahasa guna menemukan keuniversalan yang lebih luas dan kekhasan dari bahasa-bahasa di dunia.

Bagi para mahasiswa, penelitian ini bermanfaat untuk memperluas wawasan berpikir kelinguistikan, terutama yang berkaitan dengan LK, TMK, dan metode LKorp dan perkembangannya, cara mengungkapkan emosi secara metaforis, metafora khas emosi, dan makna metafora emosi BI. Dengan demikian, mahasiswa dapat memahami liku-liku metafora emosi yang dituturkan sehari-hari secara tidak disadari sebagai bagian dari cara berpikir dan merupakan budaya mereka.

\subsubsection{Manfaat Praktis}

Sejumlah manfaat praktis dapat ditemukan dalam penelitian ini. Pertama, melalui penelitian ini, dapat ditemukenali pola-pola metaforis emosi BI. Kedua, dapat dipahami RS dan RT dari metafora emosi BI yang digunakan sebagai dasar untuk memahami konsep berpikir pemakai BI. Ketiga, dapat diketahui MK yang 
universal dan khas BI. Keempat, pola-pola metaforis emosi dan MK yang ditemukan dapat dijadikan bahan untuk menyusun daftar metafora emosi BI, baik secara linguistik maupun secara konseptual.

Hasil penelitian ini juga bermanfaat bagi orang-orang yang bukan orang Indonesia untuk mengetahui cara berpikir tentang emosi pemakai BI dan bagaimana mereka mengungkapkannya melalui bahasa, terutama mengungkapkan pengalaman emosinya. 


\section{Catatan Akhir}

1. Gestalt adalah sebuah unit yang terorganisasi. Gagasan sentral dalam gerakan yang dikenal sebagai psikologi Gestalt. Psikologi Gestalt merupakan sebuah gerakan dalam psikologi yang muncul pada akhir abad kesembilan belas, yang mewakili perpindahan dari pandangan atomistik yang telah lazim dalam psikologi, terutama dalam hal penelitian persepsi. Psikologi Gestalt dimulai dengan gagasan gestalt, dan dengan demikian mendalilkan bahwa dalam hal persepsi, yang disebut keseluruhan adalah lebih dari jumlah bagian-bagiannya. Psikologi Gestalt memformalkan mekanisme persepsi yang memfasilitasi pengalaman kita.

Para ahli psikologi Gestalt seperti Max Wertheimer (1880--1943), Wolfgang Köhler (1887-1967), dan Kurt Koffka (1886--1941) tertarik pada prinsip-prinsip yang memungkinkan mekanisme persepsi bawah sadar untuk membangun keutuhan atau gestalt dari masukan persepsi yang tidak lengkap. Misalnya, jika benda yang lebih kecil terletak di depan objek yang lebih besar, kita merasakan bagian yang menonjol dari objek yang lebih besar sebagai bagian dari keseluruhan objek yang lebih besar, bahkan meskipun kita tidak dapat melihat keseluruhan objek besar tersebut karena bagian-bagian yang tidak kontinum (discontinuous). Hal ini dikenal sebagai Prinsip Berkelanjutan. Prinsip gestalt seperti ini diadakan untuk menangkap mekanisme penataan bawaan yang membatasi persepsi. Psikologi Gestalt ini berpengaruh pada LK dalam hal ini psikologi gestalt memberikan bukti bahwa proses mental bawah sadar membatasi pengalaman. Posisi umum ini diadopsi oleh ahli bahasa kognitif dalam menyangkal ahli semantik objektif (Evans, 2007:90--91)

2. Kata "minda" diadaptasi dari kata mind oleh Dardjowidjojo (2005).

3. Keuniversalan konsep metafora diklaim oleh Kövecses (2000:139). Dinyatakan bahwa terdapat metafora konseptual yang bersifat universal atau mendekati universal. Keuniversalan tersebut didasari oleh unsur universal dari fungsi tubuh dalam keadaan emosional. Pada saat yang sama, diklaim bahwa terdapat ruang bagi variasi konsep yang terikat oleh budaya.

4. Penyertaan metaforis (metaphoric entailment): Selain pemetaan antarranah yang dimiliki oleh MK, MK juga dapat memberikan pengetahuan tambahan, kadang-kadang cukup terperinci. Hal ini karena unsur RS yang tidak secara eksplisit dinyatakan dalam pemetaan dapat ditafsirkan dan dipetakan ke RS dengan ungkapan linguistik tertentu. Dengan cara ini, pemetaan metaforis dapat memberikan interpretasi yang kaya dan dikenal sebagai penyertaan metaforis (Evans, 2007:139).

5. Pemaduan metaforis (metaphoric blend ): Sebuah metafora dapat dianalisis dari perspektif Teori Pemaduan (Blending Theory). Dilihat dari perspektif ini metafora melibatkan proyeksi bingkai tidak simetris (frame-proyeksi asimetri). Ketika kedua ruang masukan berisi bingkai yang berbeda, hanya bingkai dari salah satu masukanlah (RS dalam Teori Metafora konseptual, bingkai masukan dalam Teori pemaduan) yang diproyeksikan ke ruang campuran. Meskipun jaringan lingkup tunggal merupakan prototipe untuk metafora campuran/pemaduan, jaringan integrasi jenis lain dapat menunjukkan kerangka proyeksi tidak simetris pada derajat yang bervariasi sehingga dapat dianggap sebagai metafora campuran. Salah satu contohnya ‘digging your own grave’ menggali kubur sendiri (Evans, 2007:139).

6. Prototipe adalah sebuah representasi mental yang relatif abstrak yang merakit atribut kunci atau fitur yang paling mewakili contoh dari kategori tertentu. Dengan demikian, prototipe dipandang sebagai representasi skematis dari karakteristik yang paling menonjol atau sentral yang terkait dengan anggota dari kategori tersebut. Menurut Teori Prototipe (Rosch, 1977), prototipe menyediakan struktur dan berfungsi untuk mengatur kategori tertentu, sebuah fenomena yang dikenal dengan struktur prototipe. Konsekuensi penting dari hal ini adalah bahwa kategori menunjukkan efek kekhasan (Evan, 2007: 175). 
Teori prototipe adalah sebuah teori kategorisasi manusia yang diasumsikan oleh Eleanor Rosch untuk menjelaskan temuan eksperimental yang ditemukan oleh Rosch dan rekanrekannya pada tahun 1970-an. Teori prototipe menyatakan bahwa ada dua prinsip dasar yang memandu pembentukan kategori dalam pikiran manusia: (1) prinsip ekonomi kognitif dan (2) prinsip struktur dunia yang dirasakan. Prinsip-prinsip ini bersama-sama menimbulkan sistem kategorisasi manusia (Evan, 2007: 176). 


\section{BAB II}

\section{KAJIAN PUSTAKA, KONSEP, DAN KERANGKA TEORI}

\subsection{Kajian Pustaka}

Tinjauan kritis tentang kepustakaan yang bertautan dengan metafora dipaparkan pada bagian ini dengan maksud untuk menggambarkan perkembangan kajian metafora yang ditemukan dalam pustaka-pustaka terbaru. Kajian kepustakaan ini akan diarahkan pada kajian disertasi dan jurnal-jurnal yang relevan dengan metafora untuk melihat model, arah, dan hasil yang dicapai. Selain itu, kajian ini diarahkan untuk menunjukkan pentingnya penelitian yang telah dilakukan terhadap penelitian ini serta hubungan penelitian ini dengan penelitian sebelumnya, terutama menyangkut metode, model, konsep, teori, dan data yang telah dimanfaatkan sebelumnya.

Kajian tentang metafora klasik sudah cukup banyak dilakukan di Indonesia, baik menyangkut pemakaian BI maupun bahasa-bahasa daerah. Sementara itu, penelitian tentang MK, terutama MK emosi belum banyak dilakukan di Indonesia. Akan tetapi beberapa kajian berupa makalah telah dilakukan oleh beberapa sarjana. Untuk memperoleh gambaran tentang penelitian metafora yang memadai, berikut ini dikaji beberapa hasil penelitian metafora, baik

metafora dengan pendekatan klasik maupun metafora dengan pendekatan konseptual. 


\subsubsection{Penelitian Metafora Klasik}

Oktavianus (2005) dalam sebuah disertasi telah mengkaji metafora (dalam disertasinya digunakan istilah kias sebagai pengganti istilah metafora) dalam bahasa Minangkabau. Oktavianus meneliti bentuk, fungsi, makna dan nilai kias dalam bahasa Minangkabau dan menemukan bahwa bentuk kias bahasa Minangkabau ada yang berkonotasi negatif dan yang berkonotasi positif. Fungsi kias dalam bahasa Minangkabau berfungsi sebagai pewaris budaya lokal, representasional, ekspresif, dan penegas. Sementara itu, nilai yang diinterpretasikan berupa nilai ketangguhan, kearifan, sopan santun, egaliter, kewaspadaan, budaya rajin, solidaritas, pesan moral, gotong royong, musyawarah, mufakat, keadilan, dan religius.

Penelitian Oktavianus merupakan penelitian ML sehingga klasifikasi bentuk, fungsi, makna, dan nilai metafora yang ditemukan tidak menggambarkan MK yang mendasari kias tertentu di dalam bahasa Minangkabau. Penelitian ini akan menggunakan konsep-konsep metaforis untuk mengetahui apa yang mendasari digunakannya ML oleh pemakai BI karena MK memiliki peran yang sangat penting dalam menentukan fungsi, makna, dan nilai metafora. Selain itu, penelitian ini menggunakan ML untuk melacak konsep metaforis yang mendasarinya. Kontribusi penelitian Oktavianus terhadap penelitian ini terletak pada data ML yang digunakan.

Metafora bahasa Jawa diteliti oleh Wahab (1986). Datanya diperoleh dari sumber data wacana tulis berupa majalah, surat kabar, cerita rakyat, dan yang lain. Wahab mengacu pada konsep metafora dalam arti luas. Denga bersandar pada 
teori Haley, Wahab meneliti (a) model-model metafora, (b) kategori-kategori yang membangunnya, (c) kaitan metafora dengan retorika umum dan retorika dalam bahasa Jawa, (d) kesemestaan metafora bahasa Jawa dan kaitannya dengan unsur budaya yang terdapat dalam lingkungan masyarakat Jawa.

Temuannya, menunjukkan bahwa terdapat empat klasifikasi struktur metafora dalam bahasa Jawa, yaitu metafora nomina subjek, metafora nomina objek, metafora predikat, dan metafora kalimat. Diketahui bahwa terdapat hubungan pemakaian bahasa metaforis dengan kehidupan masyarakat melalui simpulannya yang mengatakan bahwa makna metafora bahasa Jawa menunjukkan kepribadian masyarakat Jawa. Kepribadian yang dimaksud adalah wedi (takut), isin (malu), dan sungkan (segan) terhadap orang-orang yang diajak berbicara. Selain itu, pemakaian metafora memiliki keterkaitan antara bahasa, sastra, kehidupan, masyarakat, dan latar belakang budaya.

Penelitian Wahab tidak membahas unsur-unsur kenapa sebuah leksikon digunakan dalam sebuah metafora. Penelitiannya tidak membicarakan hal apa yang memotivasi penggunaan suatu leksikon dalam metafora tertentu. Penelitian ini akan menjelaskan unsur-unsur yang memotivasi munculnya sebuah leksikon dalam sebuah metafora melalui pemetaan. Pentingnya penelitian Wahab terhadap penelitian ini terletak pada isu kesemestaan dan kekhasan metafora.

Antara (2007) meneliti metafora bahasa Bali di Kabupaten Buleleng. Penelitiannya berfokus pada bentuk, fungsi, dan makna metafora yang digunakan oleh masyarakat di Kabupaten Buleleng. Antara menerapkan teori secara ekletik untuk membahas bentuk, fungsi, dan makna metafora bahasa Bali. Temuannya 
menunjukkan bahwa metafora bahasa Bali memiliki beberapa pola tuturan, struktur, dan fungsi sintaksis. Unsur penanda metafora bahasa Bali ditemukan berkategori nomina dan yang bukan berkategori nomina. Fungsi metafora bahasa Bali yang ditemukan berjumlah lima jenis, yaitu fungsi informasional, ekspresif, direktif, fatik, dan puitik (estetik). Sementara itu, metafora bahasa Bali dinyatakan bermakna konotatif, stilistik, afektif, replektif, dan lokatif.

Kajian yang dilakukan Antara sepenuhnya merupakan kajian ML menurut pandangan klasik. Dalam penelitiannya tidak dibahas motivasi pemakaian leksikon dalam sebuah metafora. Demikian pula, fungsi metafora sebagai alat untuk memahami konsep dengan libih baik, terutama konsep abstrak tidak dibicarakan dalam kajiannya. Penelitian ini akan mengkaji leksikon metaforis dan melihat motivasi yang ada di balik munculnya sebuah leksikon yang digunakan secara metaforis. Selain itu, penelitian ini memfokuskan perhatian pada fungsi metafora sebagai alat untuk memahami konsep, terutama konsep yang abstrak.

Data linguistik yang ditemukan Antara memberi sumbangan berarti bagi penelitian ini, terutama tentang bagaimana masyarakat memahami metafora selama ini sehingga perbedaan dan persamaan metafora klasik dan MK dapat dipahami dengan lebih baik. Selain pemahaman tersebut, kajian-kajian di atas telah memberikan gambaran tentang ekspresi-ekspresi lingual metaforis dalam rangka menentukan konsep-konsep yang membangun ungkapan-ungkapan metaforis. 


\subsubsection{Penelitian Metafora Konseptual}

Kajian MK telah dilakukan oleh Kramadibrata (2003). Kramadibrata membandingkan metafora BI dengan bahasa Jerman melalui penggunaan model budaya yang berbeda. Kramadibrata mencoba membongkar perbedaan dan kemiripan RS dan RT dari metafora dua bahasa dan budaya yang berbeda serta memeriksa hubungan persepsi antara representasi simbolik dengan objek nyata untuk mengetahui apakah keduanya memiliki sifat yang sama atau berbeda melalui pengalaman mental.

Ditemukan bahwa norma-norma metaforis dari kedua bahasa yang diteliti memang berbeda sebagaimana ditunjukkan oleh struktur gramatikanya. Metafora bahasa Jerman menunjukkan sifat gerakan, kadang-kadang agresivitas melalui preposisinya. Sementara itu, metafora BI menunjukkan sifat dan perilakunya melalui metafora bukan gerakan. Selain perbedaan tersebut, juga ditemukan persamaan bahwa baik BI maupun bahasa Jerman memanfaatkan bagian tubuh dalam bermetafora, baik sebagai RS maupun RT. Misalnya, besar kepala, tangan kanan, dan di depan hidung saya.

Kajian MK yang dilakukan oleh Kramadibrata bersifat umum dan tidak menyinggung ranah emosi. Akan tetapi, penelitiannya bermanfaat dalam memahami konsep-konsep metafora dan teori yang digunakan.

Yumarmanto (2003) mengkaji metafora dengan dua pendekatan, yaitu pemetaan komponen dan MK. Analisis melalui pemetaan komponen sangat dimungkinkan bagi metafora sederhana. Akan tetapi, model ini tidak sepenuhnya mampu menganalisis metafora yang kompleks dan tidak jelas komponen 
perbandingannya. Model analisis MK sangat relevan digunakan untuk menangani metafora yang kompleks karena model ini dapat membongkar komponen yang sebenarnya diperbandingkan sebelum akhirnya dipetakan elemen-elemannya. Yumarmanto memanfaatkan kedua pendekatan tersebut sebagai pendekatan yang komplementer dalam menganalisis metafora, baik yang sederhana maupun yang kompleks.

Yumarmanto menampilkan data metafora dari ranah yang relatif umum dan tidak menyangkut metafora emosi. Namun, kajiannya cukup relevan dengan penelitian yang dilakukan saat ini, terutama dalam hal teori MK.

Siregar (2004) mengkaji metafora kekuasaan dan metafora melalui kekuasaan untuk melacak perubahan kemasyarakatan dari perilaku bahasa melalui sebuah penelitian yang dilakukannya pada tahun 2001--2003. Data penelitiannya diperoleh dari media massa, cetak dan elektronik. Teori yang digunakan untuk membedah data metaforis itu adalah TMK dan skema citra (image-schema) yang dikembangkan oleh Lakoff (2006).

Hasil penelitiannya menyatakan bahwa penggunaan bahasa, khususnya melalui MK, memiliki kekuatan tersendiri untuk melacak perubahan-perubahan kemasyarakatan. Semantik kognitif mengindikasikan bahwa metafora tidak hanya merupakan gejala bahasa, tetapi juga gejala pikiran. Dengan demikian, metafora tidak digunakan secara acak dari perbendaharaan bahasa pemakai (bahasa harfiah dan metaforis), tetapi metafora digunakan untuk mewakili pemahaman dan pengalaman pemakai terhadap realita dunia. 
Lebih jauh dinyatakan bahwa metafora telah menjadi bagian dari keseharian, baik di wilayah legislatif, politik, maupun media pers. Dari situ dapat ditemukenali metafora kekuasaan dan metafora melalui kekuasaan. Metafora kekuasaan digunakan untuk mengonseptualisasikan sejumlah konsep kekuasaan yang cenderung abstrak, seperti negara, kepemerintahan, kepemimpinan, relasi kekuasaan (demokrasi), reformasi, hukum, politik, dan ekonomi. Metafora tersebut digunakan melalui kekuasaan media dan kekuasaan legislatif. Untuk melacak perubahan kemasyarakatan, metafora disintegrasi bangsa dimanfaatkannya melalui pemetaan konseptual (mapping) antara RS dan RT.

Siregar tidak menyinggung pemakaian metafora emosi dalam kajiannya. Akan tetapi, penelitian Siregar sangat relevan dengan penelitian ini. Relevansinya terletak pada teori yang digunakan, yaitu TMK.

\subsubsection{Penelitian Metafora Emosi}

King (1989) meneliti hubungan gerak tubuh dengan emosi pada kepercayaan masyarakat Cina, membandingkan konsep-konsep metafora bahasa Cina dan BIng, serta melihat keterkaitan kategori emosi bahasa Cina dengan keuniversalan emosi budaya Barat. King menggunakan TMK dan metode bukan korpus modern untuk menangani masalah yang diteliti. Lima konsep emosi dasar dalam bahasa Cina yang diteliti, yaitu kekhawatiran (worry), kesedihan (sadness/grief), ketakutan (fear), kebahagiaan (happiness/joy), dan amarah (anger). Kemudian, konsep-konsep emosi bahasa Cina tersebut dibandingkan 
dengan konsep-konsep emosi BIng untuk menemukan konsep emosi yang universal.

King mengklaim bahwa terdapat korelasi antara kesehatan dengan amarah dalam masyarakat Cina. Dalam masyarakat Cina, emosi disejajarkan dengan $q i^{1}$ yang ada dalam tubuh manusia dan dapat memengaruhi tubuh dengan beberapa cara, termasuk menunjukkan gejala somatik, seperti sakit kepala, sakit perut, pusing, dan lain-lain akibat dari ketidakstabilan emosi atau qi. Konsep PANAS, TEKANAN dan GEJOLAK PADA TUBUH merupakan konsep yang universal karena ditemukan baik dalam bahasa Cina maupun BIng.

Penelitian ini menggunakan teori yang sama dengan penelitian King, yaitu TMK. Akan tetapi metode yang digunakan berbeda. Penelitian ini menggunakan metode LKorp dan APM untuk memeriksa lima emosi dasar, yaitu amarah/kemarahan, ketakutan, kebahagiaan, kesedihan, dan cinta sebagai leksikal yang digunakan untuk mengungkap ideologi atau konsep-konsep metafora emosi yang digunakan oleh pemakai BI dalam kehidupan sehari-hari. Hasil dari penelitian ini akan mampu menunjukkan apakah klaim King tentang metafora universal dapat dibenarkan atau ditolak. Pentingnya penelitian King pada penelitian ini terletak pada model data, teori yang digunakan, serta isu keuniversalan dan kekhasan metafora.

Gevaert (2007), dalam disertasinya yang berjudul "The History of ANGER: The Lexical Field of ANGER from Old to Early Modern English" merekonstruksi evolusi medan leksikal dari emosi AMARAH dari zaman Inggris Lama sampai dengan masa Awal Inggris Modern, menelusuri pengaruh budaya terhadap 
konseptualisasi PANAS, dan terhadap seluruh medan konsep dan medan leksikal emosi AMARAH.

Gevaert berasumsi bahwa selalu ada satu atau lebih ungkapan yang tidak termasuk dalam konsep tertentu, tetapi mengacu pada emosi AMARAH secara harfiah. Karena itu, sejumlah ungkapan dipandang sebagai bentuk harfiah. Berangkat dari asumsinya itu, Gevaert menemukan bahwa evolusi kata irre dan belgan sebagai ungkapan harfiah pada masa Inggris Lama yang bermakna amarah. Kemudian, kata belgan menghilang dan kata irre menurun pemakaiannya diganti dengan kata wrath sebagai ungkapan harfiah yang penting pada masa Inggris Pertengahan. Setelah itu, anger (amarah) menjadi alternatif yang lebih banyak digunakan dibandingkan dengan wrath pada masa Awal Inggris Modern. Melalui temuannya, Gevaert membantah asumsi peneliti-peneliti MK sebelumnya yang mengatakan bahwa metafora digunakan di mana-mana (dalam bebagai segi kehidupan).

Menurut Gevaert, perubahan medan leksikal dan konsep yang berlangsung terus-menerus itu dipengaruhi oleh budaya. Empat elemen budaya yang dianggap telah memengaruhi terjadinya perubahan tersebut, yaitu perubahan sosial budaya yang mendorong munculnya anger (amarah), pengaruh bahasa Latin pada zaman Inggris Lama, pengaruh bahasa Romawi pada masa Awal Inggris Modern, dan ada kemungkinan teori psikologi yang mendasari munculnya konseptualisasi PANAS. Yang dianggap paling berperan dalam evolusi medan leksikal AMARAH BIng ialah pengaruh dua bahasa asing, yaitu bahasa Latin pada masa Inggris Lama dan bahasa Romawi pada masa Pertengahan dan Awal Inggris Modern. 
Akhirnya, Gevaert menyimpulkan bahwa medan leksikal dan konsep AMARAH sangat dipengaruhi dan ditentukan oleh unsur-unsur budaya, bukan konsep yang didasari oleh fisiologi manusia yang bersifat universal. Jika konsep PANAS ternyata didasari oleh pengalaman fisiologis saat ini, dia menganggapnya sebagai suatu tahapan dalam evolusi konsep, bukan prinsip yang abadi dan universal.

Klaim Gevaert tentang perubahan suatu medan leksikal dan konseptualisasinya ditentukan oleh unsur-unsur budaya itu, mungkin bisa dibenarkan karena perubahan suatu peradaban sangat mungkin memengaruhi pergerakan makna suatu leksikal. Akan tetapi, klaimnya tidak dapat menggagalkan pandangan peneliti-peneliti ranah emosi sebelumnya yang mengkalim bahwa konsep emosi dipengaruhi oleh pengalaman fisiologis karena secara faktual, perubahan suatu emosi memengaruhi fisiologi seseorang. Misalnya, ketika seseorang sangat marah, akan terjadi perubahan fisiologi, seperti muka memerah, mata memerah, tubuh bergetar, dan lain-lain. Oleh karena itu, memandang perubahan suatu medan leksikal dan koseptualisasinya baik secara budaya maupun secara fisiologis menjadi pilihan dalam penelitian ini.

Yang membedakan penelitian Gevaert dengan penelitian ini adalah bahwa penelian Gevaert bersifat diakronis, sedangkan penelitian ini bersifat sinkronis. Signifikansi kajian Gevaert bagi penelitian ini terletak pada isu keuniversalan dan kekhasan metafora emosi serta konsep-konsep metafora emosi.

Rajeg (2009) dalam makalahnya berjudul “CINTANYA BERTEPUK SEBELAH TANGAN: Metaphoric and Metonymic Conceptualisation of LOVE in Indonesian", 
mengkaji metafora dan metonimia cinta. Penelitian ini mengungkap konsepkonsep emosi cinta BI dengan menggunakan TMK. Penelitiannya membahas hanya satu konsep emosi dan datanya sangat terbatas sehingga konsep-konsep emosi dan isu keuniversalan metafora emosi BI belum terungkap secara lengkap.

Rajeg (2010) dalam sebuah makalah berjudul KEBUS BASANGE: Metaphoric and Metonymic Conceptualisation of ANGER in Balinese, mengaplikasikan TMK untuk mengkaji metafora emosi "amarah" dalam bahasa Bali. Penelitian ini juga mengungkap konsep-konsep emosi amarah secara terbatas dengan data yang terbatas pula sehingga konsep emosi "amarah" dan isu keuniversalan metafora emosi belum sepenuhnya terungkap.

Rajeg (2010) dalam sebuah makalah berjudul HATINYA MEMBARA: Metaphoric and Metonymic Conceptualisation of ANGER in Indonesian, lebih jauh meneliti metafora emosi "amarah" BI dengan memeriksa data yang lebih banyak, tetapi tidak dimaksudkan untuk mengungkapkan konsep emosi "amarah" secara lebih luas sehingga penelitian lebih mendalam tentang emosi tersebut sangat perlu dilakukan.

Rajeg (2012) meneliti emosi KEBAHAGIAAN dan menyajikannya dalam bentuk makalah berjudul “NIKMATILAH KEBAHAGIAAN INI." Metafora Emosi KebahagiaAn BI: Analisis Pola Metaforis Berbasis Korpus. Penelitiannya ini memeriksa kurang lebih 5 juta kata dalam korpus BI. Temuannya menunjukkan pola-pola metaforis menyangkut kebahagiaan dan MK yang sangat banyak, tetapi belum dapat menunjukkan metafora khas emosi BI. Pentingnya keempat 
penelitian Rajeg terhadap kajian yang dilakukan saat ini terletak pada teori, model data, dan metode dan arah analisis metafora emosi BI.

Mulyadi (2010), secara ringkas memaparkan sembilan MK menyangkut ranah sumber berupa CAIRAN, BENDA, LAWAN, BINATANG BUAS, MUSUH TERSEMBUNYI, BEBAN, TEMPAT, DAYA ALAMI, dan DAYA FISIK yang digunakan untuk memahami ranah target EMOSI BI. Konseptualisasi yang dilakukan didukung oleh bukti ML yang masih terbatas. Kekuatan konseptualisasi yang diajukan perlu dibuktikan dengan memeriksa lebih banyak ML. Metode APM dan LKorp yang digunakan dalam penelitian ini mampu membuktikan daya konseptualisasi yang diusulkan oleh Mulyadi.

$\mathrm{Yu}$ (1995) meneliti metafora emosi amarah dan kebahagiaan dalam BIng dan bahasa Cina. Yu menemukan bahwa BIng dan bahasa Cina memiliki kesamaan MK sentral, yaitu AMARAH ADALAH PANAS yang kemudian dibagi menjadi dua subbagian. BIng memilih metafora "API" dan "CAIRAN". Sementara itu, bahasa Cina memilih metafora "API' dan "GAS" untuk mengonseptualisasikan emosi amarah. Untuk mengonseptualisasikan emosi kebahagiaan, baik BIng maupun bahasa Cina menggunakan metafora "KE ATAS", "RINGAN', dan "WADAH”.

Kedua bahasa yang diteliti oleh Yu mengikuti prinsip metonimia yang sama dalam membicarakan amarah dan kebahagiaan, yaitu dengan menggambarkan efek fisiologis dari kedua emosi tersebut. Akan tetapi, perbedaan yang diamati ialah bahwa bahasa Cina menggunakan bagian tubuh, terutama 
tubuh bagian dalam, lebih banyak daripada BIng dalam kasus metafora amarah, kebahagiaan, dan keadaan emosi yang lain.

Perbedaan yang paling dasar antara kedua bahasa ini disebabkan oleh adanya teori yin-yan dan lima elemen pengobatan Cina, yaitu kayu, api, tanah, metal, dan air. Teori tersebut membangun sebuah model budaya atau model kognitif yang mendasari konseptualisasi metafora bahasa Cina. Maka, metafora amarah dan kebahagiaan pada kedua bahasa itu paling banyak didasari oleh pengalaman jasmani yang sama dengan beberapa perbedaan lintas bahasa di tingkat permukaan dan hal ini dapat dijelaskan melalui perspektif budaya.

Penelitian $\mathrm{Yu}$ memaparkan konsep emosi universal dan konsep emosi yang terikat budaya melalui emosi amarah dan kebahagiaan. Sementara itu, penelitian ini memanfaatkan lima leksikon konsep emosi untuk mengetahui konsep emosi universal dan konsep emosi yang memiliki kekhasan budaya. Urgensi dari penelitian Yu terhadap penelitian ini terletak pada teori dan konsepkonsep emosi yang telah diteliti.

Matsuki (1995) dalam artikel yang berjudul "Metaphors of Anger in Japanese" meneliti struktur konsep amarah dalam bahasa Jepang. Matsuki membandingkan konsep amarah dalam bahasa Jepang dan BIng Amerika untuk melihat bagaimana amarah dikonseptualisasikan dalam bahasa Jepang dan BIng Amerika serta melihat unsur-unsur yang merupakan kekhasan budaya dan keuniversalan kedua bahasa tersebut. Matsuki mengamati bahwa semua metafora Amarah dalam BIng yang telah dibahasa oleh Lakoff dan Kovecses (1987) dapat 
ditemukan dalam bahasa Jepang.Hal ini menunjukkan bahwa memang ada metafora yang universal, paling tidak, jika dilihat dari kedua bahasa tersebut.

Dilihat dari kekhasan budaya, terdapat tiga bagian tubuh yang dipahami sebagai tempat amarah oleh pemakai bahasa Jepang, yaitu hara 'perut', mune 'dada', dan atama 'kepala'. Untuk menunjukkan amarah, pemakai bahasa Jepang dapat mengatakan hara berdiri, simpan di hara, atau tahan di hara. Ketika amarah tidak dapat ditahan di hara, maka amarah itu akan meningkat, seperti cairan panas, ke mune. Misalnya, "Mune saya terasa sesak karena hara saya naik." Ketika seseorang tidak lagi mampu mengendalikan emosinya, maka amarah itu akan naik ke atama. Dengan demikian, muncullah ungkapan "amarahku sampai berbunyi ceklek di atama," atau "akhirnya amarahku naik ke atama." Hara, mune, dan atama mewakili tiga wilayah yang menjadi wadah amarah dalam tubuh. Selain itu, ketiga wilayah itu mewakili proses meningkatnya emosi amarah.

Kajian Matsuki baru sebatas menunjukkan bahwa hara 'perut' khas bagi budaya Jepang jika dihadapkan dengan emosi amarah. Akan tetapi, penelitiannya belum menunjukkan apakah hara khas hanya untuk emosi amarah? Apakah ada kemungkinan bahwa hara juga dapat digunakan pada emosi lain, semisal emosi ketakutan? Penelitian Matsuki ini sangat penting bagi penelitian ini untuk memastikan apakah memang benar terdapat metafora universal dalam bahasabahasa di dunia, termasuk BI. Kalau ada, metafora mana yang benar-benar universal jika dihadapkan dengan bahasa lain seperti BI, dan metafora mana yang khas untuk masing-masing emosi? Sementara itu, konsep dan teori yang digunakan oleh Matsuki sangat relevan dengan penelitian ini. 
Kövecses (1995) menulis artikel yang berjudul "Anger: Its Language, Conceptualization, and Physiology in the Light of Cross-Cultural Evidence”. Kövecses mempertanyakan serangkaian ungkapan yang benar-benar berbeda untuk emosi pada suatu bahasa. Dinyatakan bahwa ada tiga hal yang berhubungan dengan isu tersebut. Pertama, kita memiliki terminologi emosi (terdiri atas katakata dan frasa yang digunakan untuk membicarakan emosi); kedua, kita memiliki cara tertentu untuk mengonseptualisasikan emosi (teori masyarakat dan teori ahli tentang emosi); ketiga, kita memiliki pengalaman emosi. Sebagian besar pengalaman emosi berupa pengalaman fisiologis.

Menurut Kövecses, yang memotivasi keberadaan serangkaian ungkapan emosional ialah konseptualisasi emosi atau fisiologi emosi. Maksudnya, bahasa emosi dimotivasi oleh konseptualisasi atau pengalaman fisiologis. Akan tetapi, hal ini belum dapat sepenuhnya memahami hubungan antara bahasa, konseptualisasi, tubuh manusia, dan konteks budaya dalam kasus amarah. Untuk membuktikan klaimnya, Kövecses memeriksa sejumlah data dari budaya yang berbeda, di antaranya BIng, bahasa Jepang, bahasa Cina, dan bahasa Hungaria.

Dengan memeriksa sejumlah data metafora secara lintas bahasa dan lintas budaya ditemukan bahwa metafora WADAH merupakan metafora yang paling banyak digunakan dalam konsep amarah (dan emosi secara umum). Itu berarti bahwa budaya yang berbeda memiliki konsep amarah yang sama. Pemahaman tentang amarah sebagai daya (suatu cairan), bahwa daya ada pada wadah yang bertekanan, bahwa daya memberikan tekanan pada dinding wadah, bahwa cairan 
tersebut panas, bahwa terdapat bahaya ledakan, dan lain-lain merupakan elemen konsep amarah yang hadir pada sejumlah budaya yang berbeda.

Kövecses juga menyatakan bahwa faktor yang menjadi hambatan dalam konseptualisasi amarah pada banyak budaya ialah tubuh manusia dan fungsi fisiologis dalam emosi. Klaimnya mengatakan bahwa pemahaman metafora amarah didasari dengan adanya kesamaan ide tentang tubuh manusia dan proses fisiologis yang dihubungkan dengan amarah. Misalnya, metonimi panas tubuh ditemukan keberadaannya pada BIng, Jepang, Hungaria, Tahiti, dan Wolof. Metonimi tekanan dalam ditemukan keberadaannya pada BIng, Cina, Jepang, Hungaria, Tahiti, dan Wolof. Metonimi merah pada wajah dan leher ditemukan pada BIng, Cina, Jepang, Hungaria, Tahiti, dan Wolof.

Kajian Kövecses terbatas pada satu ranah emosi. Namun, kajian tersebut sangat relevan dengan kajian metafora emosi BI yang akan dilakukan. Relevansinya terletak pada konsep-konsep emosi, model analisis, dan teori yang digunakan.

Yuditha (2012) meneliti konseptualisasi emosi amarah dalam BI. Data penelitiannya diperoleh dari media elektronik berupa teks yang tersimapan pada jejaring (wesite) dan dianalisis dengan TMK. Temuannya menunjukkan bahwa BI dan BIng memiliki konsep emosi yang universal. Contohnya, mentafora ANGER IS FIRE dalam BIng juga ditemukan dalam BI, yaitu metafora AMARAH ADALAH API seperti dicontohkan dalam ML "Tetapi ia tidak mau hangus terbakar oleh kemarahannya". Yuditha juga menemukan sejumlah metafora variasi budaya Indonesia yang secara khas menjadi ciri metafora emosi dalam BI dan tidak 
ditemukan dalam BIng. Salah satu contohnya, AMARAH ADALAH MAKANAN yang direpresentasikan dengan ML "Marah bikin kenyang".

Meskipun Yuditha telah menemukan metafora khas BI, penelitiannya tidak menggambarkan apakah pemakaian metafora khas BI yang ditemukan terjadi secara bermakna atau terjadi secara kebetulan saja mengingat besarnya korpus yang digunakan tidak dinyatakan secara jelas. Selain itu, tidak juga dinyatakan frekuensi pemakaian metafora sebagai indikator kebermaknaan suatu metafora. Kebermaknaan pemakaian metafora khas emosi tertentu dalam BI akan diuji dengan mengunakan statistik dalam penelitian ini.

Stefanowitsch (2006) meneliti metafora emosi anger 'amarah', disgust 'kemuakan', fear 'ketakutan', happiness 'kebahagiaan', sadness 'kesedihan' dalam BIng dengan pendekatan berbasis korpus. Data penelitiannya diperoleh dari British National Corpus (BNC). Metode yang digunakan untuk menemukan dan menganalisis data ialah metode Analisis Pola Metaforis (APM), suatu metode baru yang diusulkan oleh Stefanowitsch sendiri untuk mengembangkan TMK.

Menurut Stefanowitsch, APM mampu mengidentifikasi sebagian besar metafora yang didiskusikan dalam pustaka-pustaka sebelumnya yang diperoleh melalui penelitian dengan metode istrospektif, seperti Kovecses (1995, 1996), Lakoff (1987), dan yang lainnya. Keunggulan metode APM juga dibuktikan dengan temuan, baik berupa MK maupun ML yang jauh lebih banyak dibandingkan dengan temuan peneliti sebelumnya, meskipun bahasa yang diteliti sama, yaitu BIng. 
Meskipun penelitian Stefanowitsch menggunakan data BIng, relevansinya terhadap penelitian ini sangat tinggi mengingat metode APM yang digunakan mampu memberikan bukti-bukti linguistik bersama dengan nilai kekerapannya untuk menemukan produktivitas suatu metafora, keuniversalan dan kekhasan metafora emosi BI.

Tabel 2.1

Ringkasan Kajian Metafora yang Dilakukan Sebelumnya

\begin{tabular}{|c|c|c|c|}
\hline \multirow[b]{2}{*}{$\begin{array}{c}\text { Nama } \\
\text { Peneliti \& Tahun } \\
\text { Penelitian }\end{array}$} & \multicolumn{3}{|c|}{ Metafora } \\
\hline & $\begin{array}{l}\text { Linguistik } \\
\text { Bahasa }\end{array}$ & $\begin{array}{c}\text { Konseptual } \\
\text { Bahasa }\end{array}$ & $\begin{array}{c}\text { Konseptual } \\
\text { Emosi } \\
\text { Bahasa }\end{array}$ \\
\hline Oktavianus, 2005 & Minangkabau & - & - \\
\hline Wahab, 1986 & Jawa & - & - \\
\hline Antara, 2007 & Bali & - & - \\
\hline Kramadibrata, 2003 & - & $\begin{array}{c}\text { Indonesia dan } \\
\text { Jerman }\end{array}$ & - \\
\hline Yumarmanto, 2003 & - & Indonesia & - \\
\hline Siregar, 2004 & - & Indonesia & - \\
\hline King, 1989 & - & - & Cina dan Inggris \\
\hline Gavaert, 2007 & - & - & Inggris \\
\hline $\begin{array}{l}\text { Rajeg, 2009, 2010, } \\
2012\end{array}$ & - & - & $\begin{array}{c}\text { Indonesia dan } \\
\text { Bali }\end{array}$ \\
\hline Mulyadi, 2010 & - & - & Indonesia \\
\hline Yu, 1995 & - & - & Cina dan Inggris \\
\hline Matsuki, 1995 & - & - & Jepang \\
\hline Kövecses, 1995 & - & - & Lintas Bahasa \\
\hline Yuditha, 2012 & - & - & Indonesia \\
\hline Stefanowitsch, 2006 & - & - & Inggris \\
\hline
\end{tabular}

Kajian-kajian tentang metafora emosi yang telah dipaparkan sangat berkaitan erat dengan kajian ini, baik dari segi konsep, metode, model teori, maupun model analisisnya. Oleh karena itu, semua kajian tersebut akan sangat 
bermanfaat bagi kajian ini. Secara ringkas hasil-hasil kajian metafora yang telah dipaparkan di depan dapat digambarkan pada tabel 2.1 .

\subsection{Konsep-Konsep Dasar}

Disadari bahwa konsep merupakan jembatan pemahaman bagi tema kajian yang akan dipaparkan kemudian. Konsep yang akan dijelaskan berikut ini, yaitu metafora klasik, MK, emosi, dan bahasa emosi.

\section{Metafora Klasik}

Metafora klasik, dalam arti luas, adalah kias yang mengandung unsur perbandingan (periksa, antara lain Ortony, 1979; Lakoff dan Johnson, 1980; 1987; 2006; Cormac, 1985; Kövecses, 2002; 2005; 2006). Sementara itu, metafora dalam arti sempit, merupakan kias yang ditunjukkan dengan perbandingan tanpa bantuan kata atau ungkapan seperti atau bagaikan dan selalu memiliki tiga unsur: topik, citra, dan kemiripan.

\section{Metafora (Modern) Konseptual}

Metafora konseptual adalah perbandingan dengan cara memahami dan mengalami satu hal dengan hal yang lain. Pemahaman tersebut diperoleh melalui serangkaian korespondensi semantik atau pemetaan antara dua ranah: RS yang lebih nyata dan RT yang lebih abstrak (Lakoff dan Johnson, 1980: 5, Lakoff, 1987,1993; Kövecses, 2006: 367; Richie, 2013:8). 


\section{Emosi}

Emosi memiliki struktur konsep yang sangat kompleks yang dapat membangkitkan bermacam-macam penafsiran (Lakoff, 1987: 380). Kövecses (2000:61), mendefinisakan bahwa emosi adalah daya (force) yang membangkitkan tanggapan atau efek tertentu, sedangkan Daldiyono (2011:10), menyatakan bahwa emosi adalah suatu keadaan subjektif dalam mengekspresikan perasaan, ketika menghadapi orang, peristiwa, atau benda.

Dilihat dari ilmu psikologi, emosi dipandang sebagai tanggagapan terhadap rangsangan yang menyangkut perubahan ciri-ciri psikologis, seperti meningkatnya denyut nadi, meningkatnya suhu tubuh, lebih giatnya atau kurang giatnya aktivitas kelenjar tertentu, perubahan laju nafas, yang cederung mendorong seseorang melakukan aktivitas lebih jauh (The Columbia Electronic Encyclopaedia).

\section{Bahasa Emosi}

Bahasa emosi ialah bahasa yang tidak dipandang sebagai sekelompok kata harfiah yang menunjukkan kategori dan fakta emosi yang telah dikenal sebelumnya, tetapi dipandang sebagai bahasa yang bersifat figuratif yang dapat menjelaskan, bahkan menciptakan pengalaman emosional (Kövecses, 2000: xii)

\subsection{Landasan Teori}

Penelitian ini menerapkan sebuah teori yang sangat relevan, yaitu TMK. Teori ini dioperasikan untuk menjelaskan semua unsur yang dilibatkan dalam 
kajian, baik unsur bentuk maupun makna. Secara lebih rinci, teori ini dipaparkan pada sub-bab 2.3.1, termasuk alasan pemilihan teori dan mekanisme kerja teori dalam membedah metafora emosi BI. Akan tetapi, sebelum memaparkan TMK, dipandang perlu menjelaskan secara singkat pemahaman tentang linguistik kognitif dan semantik kognitif sehingga posisi TMK dalam tataran semantik menjadi jelas.

\section{A. Linguistik Kognitif}

Linguistik kognitif diperkenalkan pada awal tahun 80an oleh tokoh-tokoh seperti Lakoff, Langacker, dan Talmy. Linguistik kognitif dipandang sebagai sebuah pendekatan yang digunakan untuk mengkaji bahasa alamiah. Menurut Geeraerts (2006:2), linguistik kognitif bukan sebuah teori bahasa yang tunggal, tetapi merupakan pendekatan interdisipliner yang harmonis (compartible). Pendekatan ini berfokus pada fungsi bahasa sebagai piranti untuk menata, mengolah, dan menyampaikan informasi (Geeraerts dan Cuyckens, 2007:3).

\section{B. Prinsip Linguistik Kognitif}

Gerakan linguistik kognitif ditandai dengan dua prinsip kunci, yaitu Prinsip Generalisasi dan Prinsip Kognitif (Lakoff, 2006: 193; Evans \& Green, 2006:27--48). Kedua prinsip ini mendasari orientasi dan pendekatan yang diadopsi oleh para ahli dan penekun linguistik kognitif beserta asumsi dan metodologi yang dimanfaatkan dalam dua cabang utama linguistik kognitif, yaitu semantik kognitif dan pendekatan kognitif terhadap tata bahasa. 
Prinsip Generalisasi adalah sebuah prinsip yang memberi ciri kepada prinsip-prinsip umum pengampu semua unsur kebahasaan manusia. Prinsip ini mengasumsikan bahwa terdapat prinsip penstrukturan umum yang mampu menangani berbagai unsur kebahasaan, dan bahwa fungsi penting dari linguistik adalah mengidentifikasi prinsip-prinsip yang umum tersebut.

Linguistik kognitif memandang bahwa untuk tujuan kepraktisan, wilayah seperti sintaksis, semantik, dan fonologi sering lebih bermanfaat bila diperlakukan berbeda secara nosi. Misalnya, penelitian sintaksis, paling tidak sebagian, perlu menyertakan perbedaan sekilas tentang fenomena linguistik dan kognisi dibandingkan dengan hanya meneliti sintaksis. Hal ini disebabkan oleh adanya tiga fitur bahasa yang dimiliki bersama oleh komponen bahasa yang tampak berbeda itu. Fitur-fitur itu ialah (1) kategorisasi, (2) polisemi, dan (3) metafora (Evans \& Green, 2006:28).

Prinsip Kognitif mewakili pandangan bahwa prinsip-prinsip struktur linguistik sebaiknya mencerminkan kognisi manusia dari disiplin lain, terutama ilmu kognitif yang lain (filsafat, psikologi, artificial intelligence, dan ilmu syaraf). Dengan kata lain, pengaturan bahasa dan linguistik sebaiknya lebih mencerminkan prinsip kognisi umum dibandingkan dengan prinsip kognisi khusus untuk bahasa saja. Dengan demikian, linguistik kognitif mengesampingkan teori modular minda (kata minda diadaptasi dari kata mind oleh Dardjowidjojo, 2005) yang menyatakan bahwa pengaturan dan struktur linguistik berbeda dengan unsurunsur kognisi yang lain (Evans \& Green, 2006:41). 


\section{Minda Mengejawantah (The Embodied Mind)}

Perwujudan (embodiment) merupakan ide sentral dalam linguistik kognitif. Evans \& Green (2006:44) menjelaskan bahwa sejak abad ke-17 seorang Filsuf Perancis, Rene Descartes, mengembangkan pandangan bahwa minda dan jasmani merupakan entitas yang berbeda. Asumsi umum dalam ilmu filsafat dan ilmu kognitif lain mengatakan bahwa minda dapat dipelajari tanpa bantuan jasmani, begitu juga tanpa bantuan perwujudan (embodiment). Dalam linguistik modern pendekatan rasionalis seperti ini menjadi hal yang paling jelas dalam pendekatan formal seperti pendekatan Tata Bahasa Generatif yang dikembangkan oleh Noam Chomsky dan pendekatan semantik formal yang dikembangkan oleh Richard Montague.

Sebaliknya, linguistik kognitif tidak bersifat rasional, akan tetapi memperoleh inspirasi dari tradisi psikologi dan filsafat yang menekankan pada pentingnya pengalaman jasmani manusia, dan struktur kognitif khas manusia yang memengaruhi pengalaman kita. Pandangan empiris ini meyakini bahwa minda manusia - demikian juga bahasa - tidak dapat diteliti secara terpisah dari perwujudan manusia.

Evans \& Green (2006:45--47) menyitir tiga jenis perwujudan, yaitu (1) pengalaman mengejawantah, (2) kognisi mewujud, dan (3) realita pengalaman.

1) Pengalaman Mengejawantah

Pengalaman yang mengejawantah berarti bahwa manusia memiliki pandangan khusus terhadap dunia akibat dari sifat unik jasmaninya. Dengan kata 
lain, pemahaman tentang realita sebagian besar dimediatori oleh sifat jasmani (Evans \& Green, 2006:45).

2) Kognisi Mengejawantah

Kenyataan bahwa pengalaman mengejawantah - yaitu sebagian dibentuk oleh sifat jasmani yang dimiliki dan sebagian yang lain oleh pengaturan saraf memiliki konsekuensi terhadap kognisi. Maksudnya, akses konsep yang dimiliki dan sifat realita yang dipikirkan dan dibicarakan merupakan fungsi perwujudan (embodiment): kita hanya dapat berbicara tentang apa yang dapat dirasakan dan dipahami, dan hal yang dirasakan dan dipahami itu berasal dari pengalaman yang mengejawantah. (Evans \& Green, 2006:46).

3) Realita Pengalaman

Konsekuensi penting dari cara memandang pengalaman dan konseptualisasi sebagai perwujudan akan memengaruhi pandangan kita tentang realita. Pandangan umum dalam semantik formal menyebutkan bahwa peran bahasa ialah untuk mendeskripsikan keadaan di dunia. Hal ini mengasumsikan bahwa terdapat dunia objek yang direfleksikan oleh bahasa. Akan tetapi, ahli linguistik kognitif mengatakan bahwa pendekatan objektif tidak memperhatikan adanya realita objektif yang dapat direfleksikan secara langsung oleh bahasa, karena realita bukan berupa objek. Akan tetapi, realita sebagian besar dibentuk oleh perwujudan manusia yang unik. Ini tidak berarti bahwa ahli linguistik 
kognitif menolak keberadaan objek fisik di luar manusia (Evans \& Green, 2006:47).

Hal ini berarti bahwa bahasa tidak secara langsung merefleksikan dunia. Bahasa lebih condong merefleksikan penafsiran manusia yang unik tentang dunia, pandangan tentang dunia tampak bagi kita melalui lensa perwujudan. Pandangan realita seperti ini disebut paham pengalaman (experientialism) atau realisme pengalaman (experiential realism) oleh pelopor linguistik kognitif George Lakoff dan Mark Johnson (Evans \& Green, 2006:48).

D. Semantik Kognitif dan Pendekatan Tata Bahasa Kognitif

Evans \& Green (2006:48) membedakan linguistik kognitif menjadi dua wilayah utama, semantik kognitif dan (pendekatan) tata bahasa kognitif. Dinyatakan bahwa pendekatan linguistik formal sering menekankan peran tata bahasa, tetapi linguistik kognitif menekankan peran makna. Semantik kognitif memandang bahwa model makna (semantik kognitif) harus digambarkan sebelum model tata bahasa kognitif dapat dikembangkan. Oleh karena itu, tata bahasa kognitif memerlukan semantik kognitif dan tata bahasa kognitif bergantung pada semantik kognitif. Sebab, tata bahasa dipandang berada di dalam kerangka kognitif sebagai sistem yang bermakna sehingga tata bahasa kognitif bersamasama memiliki sifat-sifat penting dengan sistem makna linguistik dan tidak dapat dipisahkan.

Ahli semantik kognitif meneliti representasi pengetahuan (struktur konsep) dan konstruksi makna (koseptualisasi). Semantik kognitif memanfaatkan bahasa sebagai cermin untuk menginvestigasi fenomena kognitif. Hal itu berarti bahwa 
semantik kognitif merupakan sebuah model minda dan sebuah model makna linguistik. Sementara itu, ahli (pendekatan) tata bahasa kognitif tidak terbatas pada penelitian unsur struktur tata bahasa yang terpisah dari makna sebagaimana dilakukan dalam tradisi formal, tetapi penelitian dengan (pendekatan) tata bahasa kognitif mencakup semua penelitian unit linguistik yang disebut pasangan bentuk dan makna (form-meaning pairing).

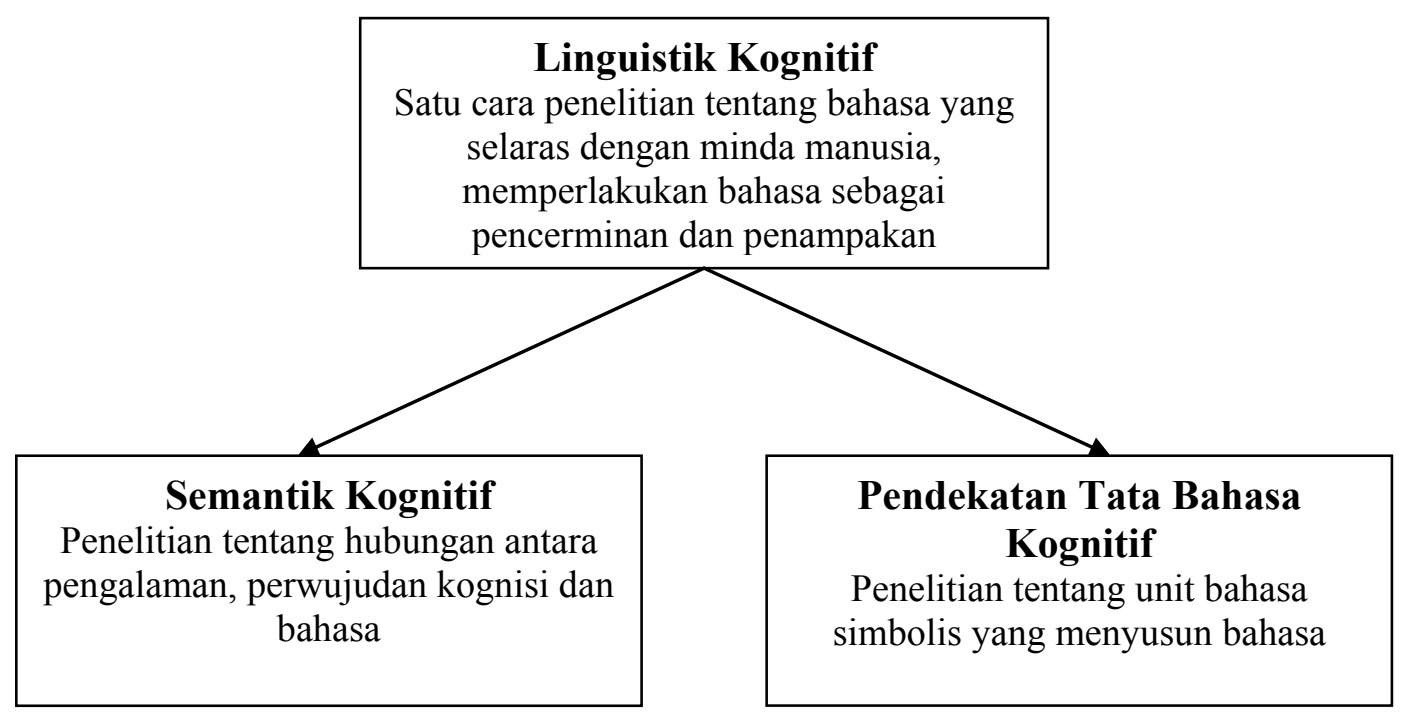

Bagan 2.1

\section{Penelitian tentang Makna dan Tata Bahasa dalam Linguistik Kognitif}

(Diterjemahkan dari Evans \& Green,2006:50)

Dengan kata lain, makna dan tata bahasa dipandang sebagai dua sisi koin yang sama. Meneliti bahasa dengan menggunakan pendekatan tata bahasa kognitif berarti meneliti unit-unit bahasa dan karena itu juga meneliti sistem bahasanya. Meneliti bahasa dengan menggunakan pendekatan semantik kognitif berarti berusaha memahami bagaimana sistem bahasa dihubungkan dengan sistem 
konsep yang pada gilirannya dihubungkan dengan pengalaman mengejawantah (embodied experience). Jadi, perhatian semantik kognitif dan pendekatan tata bahasa kognitif bersifat komplementer seperti digambarkan pada bagan 2.2.

\section{E. Semantik Kognitif}

Linguistik formal memandang makna sebagai hubungan antara kata-kata dan dunia, semantik yang berbasis pada kebenaran (truth-conditional semantics) mengesampingkan struktur atau organisasi kognitif dari sistem bahasa (Evans \& Green,2006:50). Sementara itu, semantik kognitif memandang makna bahasa sebagai manifestasi dari struktur konsep. Semantik kognitif berpegang pada empat asumsi utama, yaitu:

1. Struktur konsep bersifat mengejawantah

2. Struktur semantik sama dengan struktur konsep

3. Representasi makna bersifat ensiklopedis

4. Konstruksi makna sama dengan konseptualisasi

1) Struktur Konsep Bersifat Mengejawantah

Salah satu hal yang diperhatikan dalam semantik kognitif ialah hubungan antara struktur konsep dengan dunia luar melalui pengalaman indrawi (sensory). Maksudnya, ahli semantik kognitif meneliti perilaku interaksi manusia bersama dengan kesadaran dunia luar, dan membangun teori struktur konsep yang sesuai dengan cara kita mengalami dunia. Ide yang timbul dalam usaha menjelaskan pengorganisasian konsep yang berbasis pada interaksi dunia fisik ialah tesis 
kognisi mengejawantah (embodied cognition thesis). Tesis ini meyakini bahwa pengorganisasian konsep terjadi karena adanya pengalaman jasmani. Jadi, sebagian yang membuat struktur konsep menjadi bermakna ialah pengalaman jasmani (Evans \& Green,2006:50).

Sebagai ilustrasi, Evans \& Green (2006:158) mencontohkan seorang manusia yang berada di kamar terkunci. Sebuah kamar memiliki sifat-sifat struktur yang diasosiasikan dengan tempat yang tertutup (bounded landmark). Kamar tersebut memiliki sisi-sisi tertutup, interior, pembatas, dan eksterior. Sebagai akibat dari keadaan ini, tempat yang tertutup ini memiliki sifat dari fungsi tambahannya yaitu wadah (containment). Manusia tersebut tidak mampu keluar dari kamar itu. Contoh wadah ini sebagian merupakan akibat dari sifat tempat tertutup dan sebagian akibat dari sifat jasmani manusia. Manusia tidak dapat melewati celah seperti halnya gas atau merangkak melaui lubang kecil di bawah pintu seperti yang dilakukan oleh semut. Jadi, wadah merupakan akibat bermakna dari hubungan jasmani tertentu yang dialami dalam berinteraksi dengan dunia luar.

2) Struktur Semantik Sama dengan Struktur Konsep

Prinsip ini menyatakan bahwa bahasa lebih condong mengacu pada konsep yang ada pada minda pembicara daripada mengacu pada objek di dunia luar. Artinya, struktur semantik (makna yang secara konvensional diasosiasikan dengan kata-kata dan unit-unit bahasa yang lain) dapat disamakan dengan konsep. 
Makna konvensional yang diasosiasikan dengan kata-kata ialah konsep linguistik atau konsep leksikal, yaitu suatu bentuk konvensional yang dibutuhkan oleh struktur konsep agar dapat disandikan (to be encoded) dalam bentuk bahasa (Evans \& Green,2006:159).

3) Representasi Makna Bersifat Ensiklopedis

Prinsip dasar yang ketiga dari semantik kognitif menyatakan bahwa struktur semantik bersifat ensiklopedis. Hal ini berarti bahwa kata-kata tidak secara pasti mewakili sepaket makna yang luas (the dictionary view), tetapi katakata bertindak sebagai titik masuk ke ranah pengetahuan yang luas dan berhubungan dengan konsep tertentu atau ranah konsep (Evans \& Green,2006:160). Hal ini tidak berarti bahwa kata-kata memiliki makna konvensional yang diasosiasikan dengan kata-kata tersebut. Fakta bahwa contoh kalimat (1) bermakna berbeda dengan contoh kalimat (2) merupakan akibat dari rangkaian makna konvensional yang diasosiasikan dengan kata safe dan happy.

(1) John is safe. John aman

(2) John is happy. (Evans \& Green,2006:160) John bahagia

Ahli semantik kognitif menyatakan bahwa makna konvensional yang diasosiasikan dengan kata tertentu hanya sebagai pengawal (prompt) untuk memproses konstruksi makna, yaitu seleksi interpretasi yang sesuai dengan konteks wicara. Misalnya, kata safe memiliki serangkaian makna, dan makna yang kita pilih terjadi akibat konteks di mana kata tersebut muncul atau 
digunakan. Sebagai ilustrasi, dapat diperhatikan contoh (3) dengan konteks anakanak yang bermain di pantai.

(3) a. The child is safe. Anak itu aman.

b. The beach is safe. Pantai itu aman.

c. The shovel is safe.

Sekop itu aman. (Evans \& Green,2006:160).

Pada konteks di atas, kalimat (3a) diinterpretasikan bahwa anak itu tidak akan mendapat bahaya. Akan tetapi, (3b) tidak berarti bahwa pantai tidak mendapat bahaya. Kalimat (3b) berarti bahwa pantai itu merupakan lingkungan yang memiliki resiko bahaya yang sangat kecil bagi anak itu. Demikian juga (3c) tidak berarti bahwa sekop itu tidak mendapat bahaya. Akan tetapi, sekop itu tidak akan menyebabkan bahaya bagi anak itu. Contoh 3a, 3b, dan 3c menunjukkan bahwa tidak ada satu makna pasti yang dimiliki oleh kata safe terhadap kata child, beach, dan shovel. Untuk memahami apa yang disampaikan oleh pembicara, kita perlu mengeluarkan semua pengetahuan ensiklopedis yang berhubungan dengan child, beach, dan shovel dan pengetahuan tentang apa yang dimaksud dengan safe. Kemudian, makna dikonstruksi dengan menyeleksi sebuah makna yang sesuai dengan konteks wicara (Evans \& Green,2006:160).

4) Konstruksi Makna Sama dengan Konseptualisasi

Prinsip ke empat dari semantik kognitif ialah bahwa bahasa sendiri tidak menyandikan makna (Evans \& Green, 2006:162). Sementara itu, kata-kata (dan unit-unit linguistik yang lain) hanyalah merupakan kata-kata awal dari (prompts) 
konstruksi makna. Menurut pandangan semantik kognitif, makna dikonstruksi pada tingkat konsep, yaitu konstruksi makna disamakan dengan konseptualisasi, suatu proses dinamis di mana unit-unit bahasa bertindak sebagai kata-kata awal (prompt) bagi serentetan kerja konsep dan pengerahan latar belakang pengetahuan. Hal ini berarti bahwa makna lebih banyak dipandang sebagai sebuah proses, bukan sebagai hal yang memiliki ciri-ciri tersendiri (Evans \& Green, 2006:162). Tabel 2.3 berikut menampilkan rangkuman dari empat asumsi kunci semantik kognitif.

Tabel 2.2

Prinsip Dasar Semantik Kognitif

\begin{tabular}{|l|l|}
\hline $\begin{array}{l}\text { Struktur konsep bersifat } \\
\text { mengejawantah }\end{array}$ & $\begin{array}{l}\text { Struktur konseptual muncul akibat dari } \\
\text { pengalaman jasmani }\end{array}$ \\
\hline $\begin{array}{l}\text { Struktur semantik sama } \\
\text { dengan struktur konsep }\end{array}$ & $\begin{array}{l}\text { Struktur semantik (makna yang secara } \\
\text { konvensional diasosiasikan dengan kata-kata dan } \\
\text { unit-unit bahasa yang lain) sama dengan konsep }\end{array}$ \\
\hline $\begin{array}{l}\text { Representasi makna bersifat } \\
\text { ensiklopedis }\end{array}$ & $\begin{array}{l}\text { Kata-kata (dan unit-unit linguistik yang lain) } \\
\text { diperlakukan sebagai titik masuk ke gudang } \\
\text { besar pengetahuan yang berhubungan dengan } \\
\text { konsep }\end{array}$ \\
\hline $\begin{array}{l}\text { Konstruksi makna sama } \\
\text { dengan konseptualisasi }\end{array}$ & $\begin{array}{l}\text { Konstruksi makna sama dengan konseptualisasi, } \\
\text { proses dinamik di mana unit linguistik bertindak } \\
\text { sebagai kata-kata awal dari serentetan kerja } \\
\text { konsep dan perekrutan latar belakang } \\
\text { pengetahuan }\end{array}$ \\
\hline
\end{tabular}




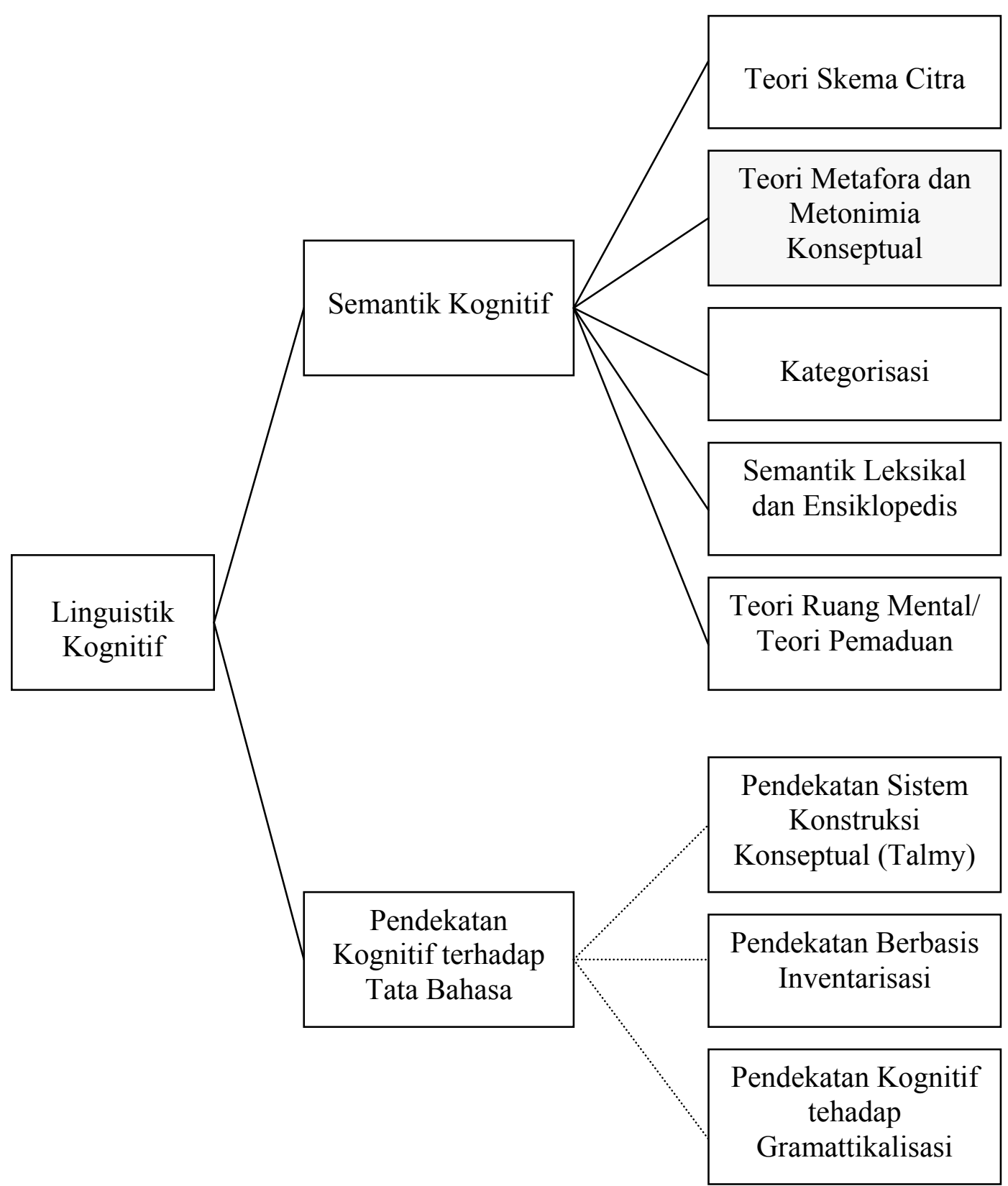

Bagan 2.2

Posisi TMK dalam Semantik Kognitif

Pembahasan terdahulu tentang linguistik kognitif dan semantik kognitif menuntun sebuah simpulan bahwa TMK berada pada tataran di bawah semantik kognitif, sebagaimana tergambar pada bagan 2.2 di atas. 


\subsubsection{Teori Metafora Konseptual}

TMK adalah sebuah teori metafora kontemporer yang mendapat perhatian sangat besar dari para ahli linguistik kognitif dewasa ini. TMK juga sangat berpengaruh baik dalam linguistik kognitif maupun dalam ilmu-ilmu sosial dan ilmu-ilmu kognitif, khususnya disiplin-disiplin yang berdekatan, seperti psikologi kognitif dan antropologi (Evans \& Green, 2006:296). TMK dipelopori oleh Lakoff dan Johnson (1980) dan dikembangkan melalui publikasi-bublikasi berikutnya, seperti Lakoff $(1987 ;$ 2006). Kemudian, pengikut-pengikutnya, di antaranya Cormac (1985) dan Kövecses (2000, 2002, 2005, 2006, 2010) secara intensif turut mengembangkan teori tersebut. Mereka memandang metafora sebagai pikiran. Bertolak dari pandangan itu, mereka berargumen bahwa metafora merasuk ke dalam kehidupan manusia sehari-hari yang meliputi bukan hanya bahasa, melainkan juga pikiran dan perilaku manusia.

Metafora memegang peran sangat penting dalam pikiran manusia sebagai dasar yang digunakan untuk mengonseptualisasikan dunia dan segala kegiatannya (Lakoff \& Johnson, 1980:3; Gibbs, 2008:3). Lakoff dan pengikutnya mengklaim bahwa topik-topik yang bersifat abstrak dan penting bagi kehidupan manusia (misalnya kelahiran, cinta, kehidupan, dsb.) sebagian besar, bahkan sepenuhnya diekspresikan dan lebih cepat dipahami melalui metafora. Lebih jauh Gibbs (2008: 4) menyatakan bahwa metafora muncul dari multiinteraksi antara otak, tubuh, bahasa, dan budaya. Langlotz (2006: 67--68) menyatakan bahwa MK berfungsi untuk menyediakan akses kognitif yang lebih mudah, menstrukturkan, 
dan mengontologikan RT yang secara empiris lebih abstrak (misalnya. emosi, karier, kognisi, waktu, dan sebagainya).

\subsubsection{Komponen Metafora}

TMK merupakan sebuah teori yang kompleks. Dalam TMK, metafora dipandang sebagai hal yang dibangun oleh bermacam-macam bagian, unsur atau komponen yang berinteraksi satu dengan yang lain (Kövecses 2005: 5). Komponen yang membangun metafora menyangkut: 1) Ranah Sumber (RS) dan 2) Ranah Target (RT), 3) basis pada pengalaman, 4) struktur syaraf yang berkorespondensi dengan RS dan RT di dalam otak, 5) hubungan RS dan RT, 6) ungkapan linguistik metaforis, 7) pemetaan (mapping), 8) penyertaan (entailments), 9) pemaduan (blending), 10) realisasi non-linguistik, dan 11) model budaya (Kövecses, 2005: 5). Komponen-komponen dimaksud secara lebih jelas dipaparkan di bawah ini.

1--2. Metafora memiliki RS (1) dan RT (2). RS bersifat lebih nyata atau fisik dan RT lebih abstrak.

Misalnya: RS: KEHANGATAN, PERJALANAN

RT: CINTA, KEHIDUPAN

Metafora: CINTA ADALAH KEHANGATAN; CINTA ADALAH

PERJALANAN; KEHIDUPAN ADALAH PERJALANAN

3. Penentuan RS tertentu untuk bergandengan dengan RT tertentu dimotivasi oleh basis pengalaman, yaitu pengalaman yang mengejawantah. 
Misalnya: Cinta berkorelasi dengan kehangatan tubuh; daya (forces) sering bertindak sebagai penyebab; gerakan/ mosi sebagai peristiwa.

4. Pengalaman mengejawantah menyebabkan adanya keterhubungan syaraf tertentu antara wilayah-wilayah di otak (wilayah-wilayah ini berkorespondensi antara RS dan RT).

Contoh potensial: Ketika wilayah-wilayah di otak yang berkorespondensi dengan cinta diaktifkan, maka wilayah yang berhubungan dengan kehangatan juga teraktifkan.

5. Hubungan RS dan RT menyebabkan sebuah RS memiliki kemungkinan berpasangan dengan beberapa RT dan sebuah RT mungkin saja berpasangan dengan beberapa RS

Misalnya: Ranah PERJALANAN berpasangan dengan ranah KEHIDUPAN dan CINTA dalam kasus metafora linguistik BI.

6. Pasangan RS dan RT tertentu memicu ungkapan linguistik metaforis; Karena itu, ungkapan linguistik berasal dari hubungan dua ranah konseptual.

Misalnya: "hubungan hangat" (berasal dari CINTA ADALAH KEHANGATAN).

7. Terjadi pemetaan dasar, esensial, atau korespondensi konseptual antara RS dan RT.

Misalnya: MK CINTA ADALAH PERJALANAN

Pemetaan (mapping): (diadaptasi dari Kövecses, 2005: 6)
RS: PERJALANAN
RT: CINTA
pelancong
$\rightarrow$ pecinta/ kekasih 


$\begin{array}{ll}\text { kendaraan } & \rightarrow \text { hubungan percintaan } \\ \text { destinasi } & \rightarrow \text { tujuan hubungan } \\ \text { jarak yang ditempuh } & \rightarrow \text { kemajuan yang telah dialami } \\ \text { dalam hubungan } & \text { kesulitan yang dihadapi dalam } \\ \text { hambatan sepanjang jalan } & \rightarrow\end{array}$

8. RS sering memetakan ide-ide ke RT melebihi korespondensi dasar. Pemetaan tambahan ini disebut penyertaan (entailments), atau simpulan (inferences).

Misalnya: Jika cinta dikonseptualisasikan sebagai perjalanan dan kendaraan berkorespondensi dengan hubungan, maka pengetahuan kita tentang kendaraan dapat digunakan untuk memahami hubungan cinta. Jika kendaraan rusak, paling tidak kita memiliki tiga pilihan: (1) keluar dari kendaraan dan mencoba mencapai tujuan dengan cara yang lain; (2) mencoba memperbaiki kendaraan itu; atau (3) tetap berada di dalam kendaraan dan tidak melakukan apa-apa. Sejalan dengan itu, jika hubungan cinta rusak, kita dapat (1) meninggalkan hubungan itu; (2) mencoba memperbaiki hubungan itu; atau (3) tetap melakukan hubungan (dan menderita).

9. Penggabungan RS dan RT sering menimbulkan pemaduan, yaitu materi konseptual yang baru bagi RS dan RT.

Misalnya: Kalimat "Dia sangat marah, telinganya berasap." Pada contoh ini, orang yang marah diposisikan sebagai RT dan asap di dalam wadah sebagai RS. RT (orang yang marah) sejatinya tidak mengeluarkan asap dan RS (wadah dengan cairan panas) tidak memiliki telinga. Akan tetapi, contoh tersebut mengintegrasikan 
keduanya: Wadah bertelinga yang mengeluarkan asap. Pemaduan ini disebut blending (Fauconnier dan Turner, 2003).

10. MK sering mengejewantah, atau mewujud, secara non-linguistik. Perwujudan tersebut tidak terjadi hanya pada bahasa dan pikiran tetapi juga pada realitas dan praktek sosial secara nyata.

Contohnya: metafora PENTING ADALAH SENTRAL dan manifestasi linguistiknya (seperti isu sentral, kantor pusat), dalam pertemuanpertemuan dan berbagai peristiwa sosial lainnya, orang-orang penting (misalnya, orang-orang yang berposisi tinggi) cenderung menempati lokasi fisik yang lebih sentral dibandingkan dengan orang-orang yang kurang penting.

11. MK berkorvergensi dan sering menimbulkan model budaya yang berkerja dalam pikiran. Hal ini merupakan struktur budaya sekaligus kognisi (maka istilahnya, model budaya, atau model kognisi), dalam hal ini, struktur tersebut merupakan representasi mental khas budaya tentang unsur dunia.

Misalnya: Bagian integral dari pemahaman kita tentang waktu ialah bahwa waktu dianggap sebuah entitas yang bergerak. Hal ini disebabkan oleh model budaya kita tentang waktu didasarkan pada metafora WAKTU ADALAH ENTITAS BERGERAK. 


\subsubsection{Jangkauan Metafora}

Sebuah RT dicirikan oleh sejumlah RS. Misalnya, KEBAHAGIAAN ADALAH KE/DI ATAS, KEBAHAGIAAN ADALAH CAHAYA, KEBAHAGIAAN ADALAH CAIRAN DALAM WADAH, dan lain-lain. Jangkauan metafora dimaksudkan untuk menjelaskan seberapa banyak dan jenis RT apa saja yang dapat dicirikan oleh sebuah RS (Kövecses, 2010: 136). Dalam kasus BIng, Kövecses mencontohkan sebuah RS BANGUNAN dapat mencirikan sejumlah RT, seperti TEORI, HUBUNGAN, KARIR, PERUSAHAAN, SISTEM EKONOMI, KELOMPOK SOSIAL, dan KEHIDUPAN. Sebagai contoh pemetaannya adalah TEORI ADALAH BANGUNAN dengan contoh linguistik, seperti membangun teori, menguatkan teori, dan merobohkan teori. Kata-kata membangun, menguatkan, dan merobohkan biasanya digunakan dalam ranah konstruksi/ bangunan tetapi digunakan secara metaforis pada ranah teori yang abstrak.

\subsubsection{Sorot Makna Utama (SMU)}

Benang merah MK (seperti TEORI ADALAH BANGUNAN, HUBUNGAN ADALAH BANGUNAN, dsb.) ialah bahwa semuanya terkait dengan ciri khas sistem yang kompleks, yaitu pembuatan struktur yang kuat dan stabil untuk sebuah system kompleks. Kebanyakan ungkapan linguistik menggunakan ketiga ciri yang saling berhubungan dengan sistem kompleks, seperti pembuatanya, strukturnya, dan kestabilan strukturnya (Kövecses, 2010: 137). Hal ini dapat dilihat dengan jelas dari korespondensi ungkapan linguistik, seperti membangun teori, merekonstruksi teori, dasar teori yang kuat, tanpa dasar teori, teori yang kokoh, 
menghancurkan teori, memadatkan teori, dan lain-lain. Pemetaan seperti tersebut di atas diyakini memiliki SMU, boleh juga dikatakan tema utama. Yang menentukan orientasi makna utama ialah pasangan RS-RT seperti SISTEM KOMPLEKS ADALAH BANGUNAN (Kövecses, 2010: 138).

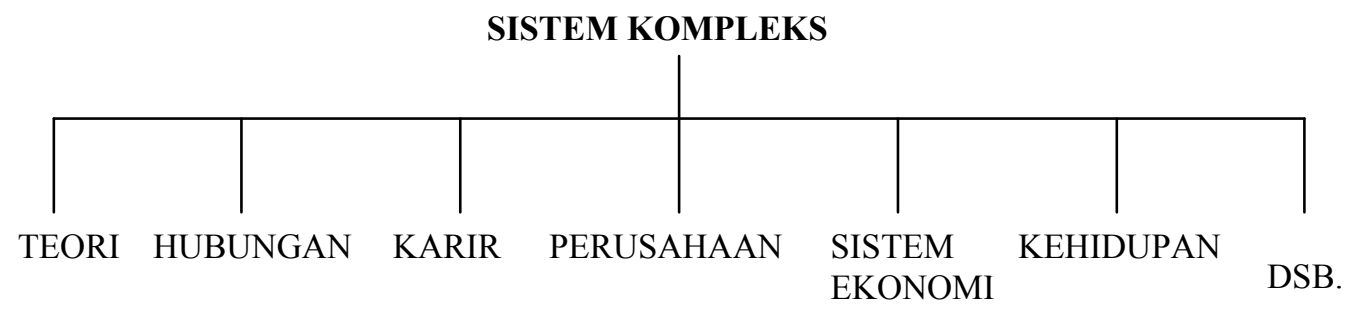

\section{Bagan 2. 3 \\ Sistem Kompleks}

Kövecses (2010: 138) lebih jauh menjelaskan bahwa setiap RS bertugas memainkan peran khusus dalam mencirikan sejumlah RT yang dipetakan. Peran yang dimaksud dinyatakan seperti kutipan berikut:

Setiap RS diasosiasikan dengan sorotan khusus makna (atau fosi) yang dipetakan ke RT. Sorotan makna ini ditetapkan secara konvensional dan disetujui oleh masyarakat tutur; Hal ini bersifat khas pada kebanyakan kasus RS; dan ini merupakan ciri khusus bagi RS. RT bertugas mewarisi sorotan makna utama (atau fosi) dari RS (Kövecses, 2010: 138).

Kutipan di atas mengindikasikan bahwa sebuah RS berkontribusi kepada RT tidak secara manasuka tetapi materi konseptualnya telah ditentukan dan disetujui oleh masyarakat tutur (Kövecses, 2010: 138). Jadi, SMU merepresentasikan pengetahuan dasar menyangkut RS yang telah dipahami secara luas dalam masyarakat tutur. Sorotan tersebut dapat ditemukan pada kebanyakan RS dan memberi ciri yang unik kepada RS. 


\subsubsection{Pemetaan Utama (PU)}

Pemetaan Utama adalah pengetahuan sentral yang digunakan dalam pemetaan yang mencirikan sebuah metafora. Dilihat dari bukti linguistik, metafora SISTEM KOMPLEKS ADALAH BANGUNAN, sebagai contoh, dibangun oleh pemetaan berikut:

\section{SISTEM KOMPLEKS ADALAH BANGUNAN}
a. fondasi
$\rightarrow \quad$ dasar yang menyangga seluruh sistem
b. kerangka
$\rightarrow \quad$ keseluruhan struktur elemen yang menyusun sistem
c. elemen tambahan $\rightarrow$ elemen tambahan yang mendukung pendukung kerangka struktur sistem
d. rancangan $\rightarrow$ struktur logis sebuah sistem
e. arsitek $\rightarrow$ pembuat/ pembangun sistem
f. proses pembangunan $\rightarrow$ proses pembuatan sistem
g. kekuatan $\rightarrow$ kekuatan/ stabilitas sistem
h. roboh $\rightarrow$ kegagalan sistem (Kövecses, (2010: 139)

Delapan pemetaan di atas dapat dipadatkan menjadi tiga tanpa kehilangan informasi mengenai SMU dari metafora SISTEM KOMPLEKS ADALAH BANGUNAN. Melalui pemetaan berikut, kita sudah bisa menemukan SMU:

(1) bangunan

(2) struktur fisik

(3) kekuatan fisik (struktur untuk berdiri) $\rightarrow \quad$ kreasi atau konstruksi sistem (dari pemetaan e dan $\mathrm{f}$ )

$\rightarrow \quad$ struktur abstrak (dari pemetaan $\mathrm{a}-\mathrm{d}$ )

$\rightarrow \quad$ stabilitas abstrak/ ketahanan (dari pemetaan a dan d)

Pemetaan (1--3) dapat disusun kembali menjadi tiga metafora, yaitu KREASI ADALAH BANGUNAN, STRUKTUR ABSTRAK ADALAH STRUKTUR FISIK, dan STABILITAS ABSTRAK ADALAH KEKUATAN FISIK (SEBUAH UNTUK BERDIRI). Metafora-metafora ini merupakan sub-metafora dari metafora SISTEM KOMPLEKS 
ADALAH BANGUNAN. Pemetaan umum seperti (1--3) oleh Kövecses (2010: 140) disebut PU.

Kövecses (2010: 140) mengajukan empat ciri penting sebuah PU, yaitu (a) secara konseptual, PU menyebabkan munculnya pemetaan lain, baik konstituen dasar pemetaan atau penyertaan metaforis; (b) secara budaya, PU merefleksikan perhatian utama manusia sehubungan dengan RS tertentu; (c) secara motivasi, PU sebagian besar dimotivasi oleh pengalaman- baik pengalaman budaya maupun pengalaman fisik; (d) secara linguistik, PU menimbulkan ungkapan metaforis yang mendominasi sebuah metafora.

\subsubsection{Keajegan Arah Pemetaan Metafora}

Pemetaan MK mengatut prinsip pemetaan satu arah. Hal ini berarti bahwa metafora memetakan struktur dari RS ke RT, bukan sebaliknya. Misalnya, ketika kita mengoseptualisasikan CINTA dari sudut pandang PERJALANAN, secara konvensional kita tidak dapat menstrukturkan PERJALANAN dari sudut pandang CINTA. Artinya, secara konvensional pelancong tidak digambarkan sebagai orang yang bercinta atau tabrakan mobil digambarkan dari sudut pandang patah hati dan sebagainya. Kerena itu, istilah RT dan RS menyandikan kesearahan pemetaan (Evans \& Green,2006:297; Evans, 2007:216).

Keajegan arah pemetaan metafora menimbulkan dua titik perhatian. Yang pertama, apakah ada sebuah pola yang menentukan ranah konseptual mana yang khusus berfungsi sebagai RS dan mana yang berfungsi sebagai RT. Yang kedua, apa yang kemungkinan memotivasi pola tersebut (Evans \& Green,2006:297). 
Kövecses (2010:18--22), menemukan bahwa kebanyakan RS yang digunakan untuk memetakan metafora BIng menyangkut ranah yang berhubungan dengan TUBUH MANUSIA (the heart of the problem), BINATANG (a sly fox), TANAMAN (the fruit of her labour), MAKANAN (he cooked up a story), dan DAYA (don't push me!). Sementara itu, RT menyangkut kategori konseptual seperti EMOSI (she was deeply moved), MORALITAS (she resisted the temptation), PIKIRAN (I see your point), HUBUNGAN KEMANUSIAAN (they build a strong marriage), dan WAKTU (time flies). Konsep-konsep target cenderung lebih abstrak, kurang memiliki sifat fisik dan karena itu lebih sulit dipahami dan dibicarakan dengan menggunakan konsep itu sendiri. Sebaliknya, RS cenderung lebih konkret dan karenanya lebih mudah dipahami (Evans \& Green,2006:297--298; Kövecses, 2002:20).

\subsubsection{Metafora Struktur Peristiwa}

Metafora Struktur Peristiwa (MSP) merupakan sistem metafora umum yang digunakan untuk memverbalkan "nosi atau gagasan seperti keadaan, perubahan, proses, aksi, penyebab, tujuan, dan cara” (Lakoff, 2006:204). Walaupun demikian, MSP juga dapat digunakan untuk memverbalkan emosi. Lakoff (2006: 204) menemukan 10 MSP dalam kasus BIng. sebagai berikut:

a. Keadaan adalah lokasi (terkungkung).

b. Perubahan adalah pergerakan (keluar atau masuk ke dalam lokasi terkungkung).

c. Penyebab adalah daya.

d. Aksi adalah pergerakan dengan sendirinya

e. Tujuan adalah tempat tujuan.

f. Cara adalah jalan (ke tempat tujuan).

g. Kesulitan adalah hambatan bagi pergerakan.

h. Kemajuan yang diharapkan adalah jadwal perjalanan; sebuah jadwal adalah pelancong maya yang mencapai tempat tujuan yang tidak 
ditentukan sebelumnya pada waktu yang belum ditentukan sebelumnya.

i. Peristiwa eksternal adalah objek besar yang bergerak

j. Kegiatan jangka panjang yang memiliki tujuan adalah perjalanan.

\subsubsection{Alasan Pemilihan TMK}

TMK dipandang sangat berdayaguna dan mampu menjelaskan metafora emosi secara baik, baik di tingkat kata, frasa, kalimat, paragraf, maupun wacana. TMK bahkan mampu membongkar ideologi yang terkandung dalam mitos dan hal-hal yang bersifat nonlinguistik. TMK memiliki kekuatan alat bedah metafora secara sistematik yang dikenal dengan pemetaan (mapping). Melalui proses pemetaan, perilaku dan elemen semantik sebuah metafora dapat diuraikan sehingga makna sebuah metafora dapat dipahami dengan lebih mudah karena TMK menggunakan hal-hal yang konkret untuk menjelaskan hal-hal yang abstrak.

TMK mampu membangun sebuah asumsi baru yang sangat penting dalam perkembangan linguistik kognitif selama ini, yaitu bahwa metafora tidak hanya dipandang sebagai permainan bahasa dalam imajinasi puitika dan tidak juga hanya sebagai hiasan retoris. Akan tetapi, metafora meresap dan memenuhi kehidupan manusia sehari-hari, tidak hanya dalam bahasa, tetapi juga dalam tindakan. Sistem konsep yang dikenal sehari-hari, yaitu berpikir dan bertindak, pada dasarnya bersifat metaforis. Oleh karena itu, sistem konsep memegang peranan penting dalam kenyataan hidup sehari-hari. Jika diasumsikan bahwa sistem konsep sebagian besar metaforis, maka yang dipikirkan, dialami, dan dilakukan setiap hari lebih banyak merupakan perkara metafora (Lakoff \& Johnson, 1980:3; Lakoff, 2006:187). 
Lebih jauh diasumsikan bahwa sistem konsep bukan merupakan hal yang biasanya disadari. Kebanyakan hal kecil yang dilakukan sehari-hari merupakan hasil berpikir dan bertindak. Oleh sebab itu, untuk mengetahui dan menyadari suatu konsep, perlu dilihat bahasanya. Karena komunikasi berbasis pada sistem konsep yang sama untuk berpikir dan bertindak, maka bahasa merupakan sumber yang penting untuk mengetahui sistem yang dimaksud. Lakoff \& Johnson (1980:4; Lakoff, 2006: 204) mengatakan bahwa melalui bukti-bukti linguistik telah ditemukan bahwa kebanyakan sistem konsep berifat metaforis. Dengan demikian, TMK dianggap sangat cocok digunakan untuk membedah metafora emosi BI dan mengungkap makna-makna yang dikandungnya.

\subsubsection{Cara Kerja TMK}

TMK bekerja secara sistematis dengan kekuatan pemetaan (mapping) dua ranah, RS-RT. Para ahli linguistik kognitif menggunakan kata "memahami" untuk memberi ciri hubungan dua konsep (A dan B) dalam proses metafora. A dipahami melalui B, dimaksudkan bahwa korespondensi sistematis antara RS (B) dan RT (A) - dalam arti bahwa elemen konstituen konsep pada B berkorespondensi dengan elemen konstituen konsep pada A. Korespondensi ini secara teknis disebut mapping (Lakoff, 1980; 1992: 210; Kövecses, 2010:7; 2006:122--123).

Untuk memperjelas cara kerja TMK dapat ditunjukkan sebuah contoh di mana elemen-elemen pada RS dipetakan ke dalam elemen-elemen pada RT. Misalnya, metafora CINTA ADALAH PERJALANAN. Ketika kita mengatakan "Kami sedang di persimpangan jalan.” Ekspresi di persimpangan jalan menunjukkan 
suatu perjalanan ke suatu tujuan, dalam hal ini perjalanan yang membingungkan. Kata kami jelaslah menunjuk pada orang yang melakukan perjalanan. Ungkapan di atas menunjukkan adanya tiga elemen konstituen tentang perjalanan: orang yang melakukan perjalanan, perjalanan itu sendiri, dan tempat tujuan yang hendak dicapai. Ketika dinyatakan dalam konteks yang wajar, ungkapan di atas dapat ditafsirkan sebagai ungkapan mengenai cinta, dan kita akan mengerti bahwa pembicara tersebut tidak sedang memikirkan orang yang melakukan perjalanan, tetapi tentang pacarnya, bukan perjalanan secara fisik, melainkan peristiwa dalam hubungan percintaan, bukan tentang tempat tujuan yang sebenarnya, melainkan tentang tujuan dari hubungan percintaan itu.

Jika diasumsikan bahwa metafora CINTA ADALAH PERJALANAN diinterpretasikan seperti di atas, kita dapat memaparkan korespondensi atau pemetaan antara elemen-elemen konstituen RS dan RT. Ketika memetakan metafora, urutan MK “target-sumber" ditukarkan menjadi urutan "sumber-target". Urutan ini dipertahankan untuk memberi penekanan bahwa pemahaman metafora beranjak dari konsep yang lebih konkret ke konsep yang lebih abstrak.

Melalui pemetaan kelihatan seolah-olah bahwa elemen pada RT memang sudah ada dan orang-orang bermetafora seperti itu karena telah ada kemiripan sebelumnya antarelemen pada kedua ranah tersebut. Akan tetapi, sebenarnya tidak demikian. Ranah CINTA tidak memiliki elemen-elemen itu sebelum dipolakan dengan ranah PERJALANAN. Jadi, elemen-elemen konsep CINTA pada RT dimungkinkan karena adanya aplikasi ranah PERJALANAN terhadap ranah CINTA 
tersebut. Lebih tepat lagi, dapat dikatakan bahwa konsep PERJALAN-lah yang menciptakan konsep CINTA.

\subsection{Model Penelitian}

Penelitian ini dirancang sedemikian rupa sehingga menggambarkan hubungan antara permasalahan yang diajukan dengan metode dan landasan teori yang digunakan untuk membedah permasalahan itu. Alur berpikir dan kerangka kerja teori yang diajukan berikut ini mampu menangani persolaan metafora $\mathrm{BI}$ secara efektif dan efisien.

Bagan 2.5 menjelaskan bahwa metafora emosi BI dikaji dari segi struktur konseptual yang mendasari digunakannya ML yang berhubungan dengan emosi pemakai BI. Kemudian, penelitian diarahkan untuk menemukan pola-pola metaforis yang digunakan untuk menyatakan emosi pemakai BI. Selain itu, penelitian ini juga dimaksudkan untuk menemukan metafora yang khas emosi BI. Akhirnya, penelitian ini akan menganalisis makna metafora emosi BI untuk menemukan SMU dan PU dari metafora tersebut.

Metode yang dimanfaatkan untuk menemukan data metafora emosi BI, yaitu metode LKorp dan APM. Sementara itu, teori yang digunakan untuk menjawab semua permasalahan yang diajukan ialah TMK. Dengan teori ini konsep-konsep yang memotivasi ML, pola-pola metaforis, metafora khas emosi BI dapat dijelaskna. Selain itu, perilaku semantik MK BI dapat dikenali dan dijelaskan melalui pemetaan konseptual. 
Teori dan metode yang digunakan mampu menangani perkara metafora emosi BI secara tuntas sehingga temuan-temuannya dapat bermanfaat bagi pemakai BI dan pengembangan ilmu bahasa khususnya semantik kognitif di Indonesia.

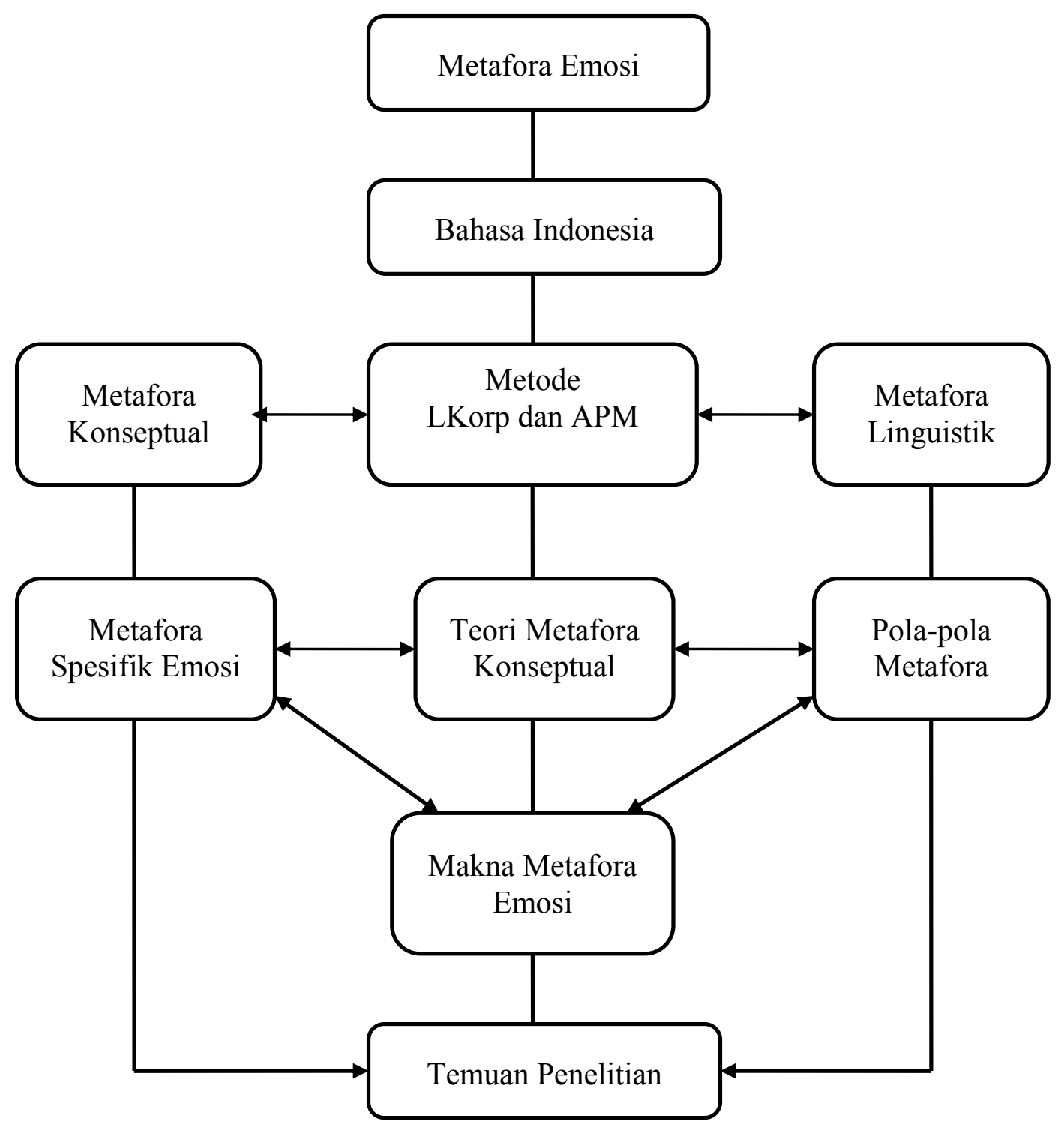

Bagan 2.4

Model Penelitian 


\section{Catatan Akhir}

1. $Q i$ adalah bahasa Cina yang berarti daya atau energi. 


\section{BAB III}

\section{METODE PENELITIAN}

\subsection{Landasan Filosofis Penelitian}

Penelitian ini menganut alur berpikir fenomenologis-empiris (Creswell, 2009: 13; Bernard, 2006: 23; Moleong, 1995; Muhadjir, 1989). Fenomenologi lebih banyak menekankan penelitian pada pemakaian bahasa dan pengalaman peneliti dibandingkan penjelasan dan penyebab (Bernard, 2006: 24). Dengan pendekatan ini metafora BI dipandang sebagai fenomena yang hidup dan berkembang dalam kehidupan sehari-hari sebagai alat untuk mengekspresikan perasaan dan emosi pemakainya. Salah satu cara kerja pendekatan fenomenologi adalah dengan mengobservasi atau mengamati fenomena pemakaian bahasa yang diteliti secara saksama.

Penelitian ini digolongkan ke dalam penelitian kualitatif dan kuantitatif. Tujuan dari memadukan dua pendekatan ialah untuk saling melengkapi kebutuhan dalam rangka menjawab masalah penelitian, karena data yang diharapkan tidak hanya teks dalam bentuk ungkapan metaforis, tetapi juga angka-angka kekerapan kemunculan ungkapan metaforis tersebut. Perkembangan teknologi komputer dan teknologi maya (virtual technology) telah memungkinkan terciptanya korpus modern atau korpus elektronik sehingga penelitian dengan pendekatan kualitatif dan kuantitatif sangat dimungkinkan saat ini (Angouri, 2010: 31). Lebih-lebih, penelitian dengan menerapkan dua pendekatan sekaligus menjadi populer saat ini (Creswell, 2009:203). Selain itu, penerapan pendekatan kualitatif dan kuantitatif 
diharapkan dapat meminimalkan subjektifitas peneliti dalam menampilkan hasil analisis.

\subsection{Jenis dan Sumber Data}

Jenis data penelitian ini berbentuk pola-pola ujaran, kalimat-kalimat, serta leksikon yang mengekspresikan pemakaian BI secara metaforis dan yang tergolong metafora emosi. Kualifikasi data dibatasi pada fenomena lingual yang ditemukan pada korpus BI. Korpus dibangun dari bahan-bahan seperti novel, cerita pendek, dongeng, lakon, monolog, dialog dan naskah teater yang tersimpan dalam web site (situs jejaring) dan bahan-bahan tercetak yang telah ditransfer menjadi naskah elektronik. Bahan-bahan korpus tersebut terlebih dahulu diunduh dan diolah ke dalam format text file. Kemudian, naskah-naskah tersebut dikelompokkan ke dalam beberapa folder dan selanjutnya dimanfaatkan sebagai korpus khusus untuk tujuan penelitian ini. Gries (2009a: 9) membedakan korpus menjadi dua kelompok utama, yaitu korpus umum (general corpora) dan korpus khusus (specific corpora). Korpus yang dimanfaatkan dalam penelitian ini termasuk korpus khusus.

Korpus khusus (Gries, 2009a: 9) memuat 5.317 .433 (lima juta tigaratus tujuhbelas ribu empatratus tigapuluh tiga) kata dan disiapkan sendiri oleh peneliti, karena di Indonesia maupun di tempat lain belum tersedia atau terpublikasi korpus BI yang baku seperti halnya BIng yang telah memiliki korpus-korpus besar (Mega Corpus) seperti National British Corpus(BNC) berisi 100 juta kata, Cobuild Bank of English berisi 300 juta kata, dan beberapa korpus generasi pertama yang lebih 
kecil, seperti Brown Corpus berisi satu juta kata, Australian Corpus of English (ACE) berisi satu juta kata, London-Lund (LLC) berisi 500 ribu kata, dan lain-lain (http://www.uni-hamburg.de/stefanowitsch/docs/corp_corpora.pdf).

Jenis korpus yang digunakan dalam penelitian ini termasuk korpus khusus yang masih mentah (raw corpora) (Gries, 2009a:9). Korpus mentah adalah korpus yang belum bermarkah linguistik (linguistic markup) dan belum beranotasi semantik (semantic annotation). Pemarkahan dan penganotasian tidak dilakukan karena pekerjaan ini memerlukan waktu yang sangat panjang. Selain itu, melalui korpus mentah (raw corpora) pencarian data metafora emosi sudah dapat dilakukan dengan baik.

Penentuan bahan-bahan korpus tersebut didasari pertimbangan bahwa bahan-bahan tersebut (a) memenuhi syarat kebahasaan dalam pemakaian BI, (b) mewakili penggunaan BI dalam berbagai segi kehidupan dan latar belakang sosial budaya, dan (3) diyakini bahwa sejumlah besar fakta, baik fakta linguistik maupun fakta sosial budaya tersimpan dalam bahan-bahan itu.

\subsection{Instrumen Penelitian}

Instrumen penelitian merupakan alat yang digunakan dalam pengumpulan data. Instrumen dipilih berdasarkan jenis data yang ingin disediakan. Keterjaringan data sangat ditentukan oleh instrumen. Instrumen yang baik akan mampu menjaring data yang berkualitas dan sesuai dengan tujuan penelitian. Instrumen yang diperlukan untuk mengumpulkan data ialah sebagai berikut. 
1. Catatan manual dan elektronik, digunakan untuk mencatat data yang ditemukan.

2. Program aplikasi komputer komersial (perangkat lunak) Wordsmith Tools Version 5.0 digunakan untuk menjelajah dan memproses keberadaan data pada korpus. Program ini memiliki kemampuan untuk menjelajah dan memproses data pada korpus yang sangat besar dan memunculkan leksikon yang diinginkan beserta konteks linguistik yang menyertainya dengan lebih cepat dibandingkan dengan penjelajahan data secara manual.

Di bawah ini disajikan contoh calon data berupa konkordansi hasil penjelajahan korpus dengan peranti lunak Wordsmith Tools Version 5.0.

\section{Tabel 3.1}

\section{Contoh Konkordansi untuk Ranah Target Amarah}

\begin{tabular}{|c|c|}
\hline \multicolumn{2}{|c|}{$\mathrm{N}$ Concordance } \\
\hline & di sini \\
\hline 2 & \multirow{25}{*}{  } \\
\hline 3 & \\
\hline 4 & \\
\hline 5 & \\
\hline 6 & \\
\hline- & \\
\hline 8 & \\
\hline & \\
\hline 10 & \\
\hline & \\
\hline & \\
\hline & \\
\hline & \\
\hline & \\
\hline & \\
\hline & \\
\hline & \\
\hline & \\
\hline & \\
\hline & \\
\hline & \\
\hline & \\
\hline & \\
\hline & \\
\hline & \\
\hline
\end{tabular}

Selain memiliki kemampuan untuk menjelajah dan memunculkan daftar konkordansi data dengan konteks yang dibatasi, seperti pada tabel 3.1, peranti 
lunak tersebut juga dapat digunakan untuk memeriksa data dengan konteks yang lebih luas. Hal ini dapat dilakukan dengan cara memblokir salah satu daftar konkordansi yang ingin diketahui konteks luasnya, lalu mengklik tombol source text 'teks sumber'. Untuk tujuan yang sama, dapat juga dilakukan dengan cara mengklik dua kali salah satu daftar konkordansi yang ingin diperiksa. Misalnya, daftar konkordansi nomor 3 pada tabel 3.1 diklik dua kali, maka progam konkordansi mampu menunjukkan teks sumber dari data yang diperiksa, seperti contoh kutipan paragraf di bawah ini.

Amarah Eliana perlahan mereda. Ruang di hatinya yang semula berisi amarah yang meluap-luap pada Azzam perlahan berubah diisi rasa kasihan. Ia menyesal sudah sedemikian emosi dan marah, sementara orang yang akan dimarahinya sedemikian tulus padanya. Diam-diam menyusup ke dalam dadanya rasa malu pada dirinya sendiri. Ia menyadari apa yang disampaikan Pak Ali ada benarnya. Penjual tempe yang pandai masak itu memang sudah banyak membantunya. (Teks Sumber berupa novel berjudul "Ketika Cinta Bertasbih" karya Habiburrahman El Shirazy, cetakan ke-11 tahun 2008: 58)

\subsection{Metode dan Teknik Penyediaan Data}

Untuk menyediakan data yang diinginkan, dipilih metode yang dianggap sangat memadai, yaitu metode LKorp (Deignan, 2005) dan APM (Stefanowitsch, 2006). Metode ini mampu menyediakan data yang sangat banyak yang diekstrak dari korpus yang sangat besar dan dalam waktu yang cepat dibandingkan dengan metode introspektif lainya. Selain kemampuan tersebut, metode ini memiliki kemampuan untuk menunjukkan daftar kekerapan pemakaian bahasa yang sedang diteliti. Dengan demikian metode ini menghasilkan model data yang saling melengkapi sehingga terbangun data yang terpercaya, baik secara kualitatif 
maupun kuantitatif. Secara khusus metode LKorp dimanfaatkan untuk memunculkan calon data berupa konkordansi bersama dengan nilai kekerapannya. Sementara itu, metode APM digunakan untuk menganalisis dan menentukan polapola metaforis yang dicatat sebagai data.

\subsubsection{Metode LKorp}

Metode LKorp (Deignan, 2005; Stefanowitsch, 2006; Gries, 2009a; Baker, 2010) memanfaatkan fungsi memori dan kesupercepatan pemrosesan sumber data oleh sebuah komputer. Secara teknis metode ini memanfaatkan teknik automatic atau semi-automatic concordancing. Metode ini dipilih karena komputer modern yang canggih mampu melakukan tugas sederhana, tetapi dilakukan berulangulang ribuan kali lebih cepat daripada yang dapat dilakukan oleh manusia. Selain itu, komputer mampu melakukan tugas dengan lebih cermat dibandingkan dengan manusia. Metode LKorp digunakan untuk memperoleh data dari korpus yang telah dibangun untuk tujuan penelitian ini. Penelitian korpus ini menggunakan program aplikasi komputer Woordsmith Tools Versian 5.0 yang mampu menghasilkan konkordansi (daftar kata yang disusun secara alfabetis dengan menunjuk ke halaman-halaman naskah). Program ini memungkinkan peneliti mencermati kata atau frasa bersama dengan konteks linguistiknya dengan memperhatikan sejumlah sitiran (citation). Program ini mampu menampilkan data dalam bentuk kata kunci dengan konteksnya (Key Word in Context [KWIC]). Dari deretan kata atau frasa dan konteksnya, bentuk-bentuk ML emosi BI dapat dikenali. Kemudian, dari ML tersebut dapat ditentukan MK yang memotivasinya. 
Keunggulan metode LKorp terletak pada kemungkinan peneliti untuk mendeteksi pola-pola pemakaian bahasa dengan lebih cepat dibandingkan dengan pemakaian intuisi maupun pemanfaatan teks secara terpisah-pisah. Selain itu, data korpus dapat membantu peneliti agar terhindar dari subjektivitas analisis kebahasaan, karena penelitian korpus besar secara sistematis mampu menghasilkan informasi tentang pemakaian bahasa yang tidak dapat ditemukan melalui pemakaian intuisi tanpa bantuan alat (Deignan, 1997: 157).

Teknik yang digunakan untuk menyediakan data yang diinginkan ialah dengan menggunakan kata kunci dari RT (amarah/kemarahan, ketakutan, kebahagiaan, kesedihan, dan cinta) untuk mengekstraksi (contoh-contoh) pemakaiannya di dalam korpus. Hal ini dilakukan karena pemetaan konseptual sering menyangkut RT tertentu dan pemetaan konsep yang membangunnya (Stefanowitch, 2006:2). Dari contoh-contoh yang muncul dalam konkordansi peneliti dapat mengidentifikasi ungkapan-ungkapan metaforis yang mengandung kosakata emosi yang sedang diteliti. Kemudian, ungkapan-ungkapan metaforis yang ditemukan dikelopokkan ke dalam kelopok koheren yang mewakili pemetaan umum. Penelitian dengan teknik seperti ini menuntut peneliti agar lebih banyak bekerja secara bottom-up dibandingkan dengan top-down (Deignan, 1997: 162;. Pragglejaz Group, 2007 dalam Kövecses, 2008)

\subsection{Metode dan Teknik Analisis Data}

Analisis data merupakan tahap yang sangat penting di antara prosedur suatu penelitian. Untuk memperoleh jawaban yang tepat dari permasalahan yang 
diformulasikan diperlukan kemampuan menganalisis data secara tepat dan cermat. Menganalisis data menyangkut pengorganisasian, pengategorian, dan penentuan pola-pola ungkapan yang sedang diteliti secara cermat dan mendalam.

Penelitian ini menggunakan metode kualitatif dan kuantitatif. Kedua pendekatan tersebut memiliki peran masing-masing dan secara bersama-sama bekerja untuk menjawab masalah penelitian.

Pendekatan kualitatif dimanfaatkan sejak tahap awal pemerolehan data. Pendekatan kualitatif sangat penting perannya mengingat korpus yang digunakan tidak beranotasi semantik. Pendekatan ini digunakan untuk (1) mengekplorasi dan memahami makna masing-masing ungkapan yang muncul dalam konkordansi; (2) menentukan pola-pola metaforis yang muncul dalam konkordansi untuk dicatat sebagai data. Pola-pola metaforis ini ditentukan dengan cara menemukan kata kunci dari leksikon ranah target (RT) dan leksikon ranah sumber (RS) dalam satu ungkapan, misalnya api amarah, di mana api merupakan RS dan amarah merupakan RT; (3) menentukan metafora konseptual yang memotivasi ungkapan metaforis dalam pemakaian BI; dan (4) menentukan pemetaan utama (PU) dari metafora konseptual yang dianggap khas emosi dalam BI.

Pendekatan kuantitatif juga dimanfaatkan sejak awal pemerolehan data. Pendekatan ini dimanfaatkan untuk (1) menghitung kekerapan kemunculan data yang berupa pola-pola metaforis dalam konkordansi; (2) menguji distribusi variabel, yaitu metafora dan emosi, (3) menguji signifikansi ketertarikan dan ketertolakan RS tertentu terhadap RT tertentu; (4) menguji signifikansi sorot 
makna utama (SMU) dari metafora konseptual yang telah ditentukan sebagai metafora khas emosi BI.

Perlu dicatat hal yang terkait dengan pemakaian kata "signifikan" dalam tradisi statistik. Suatu efek dikatakan signifikan secara statistik tidak berarti bahwa efek tersebut juga "penting", mengingat bersinoniminya kata "signifikan" dan "penting". Demikian juga, pertanyaan tentang signifikansi suatu distribusi atau efek tidaklah sama dengan pertanyaan tentang adanya suatu hal menarik dari distribusi atau efek tersebut (Stefanowitsch, 2004b). Secara teknis, kata "signifikan" digunakan dalam arti "efek yang ditemukan cukup besar untuk dapat berasumsi bahwa, mengingat besarnya sampel, efek tersebut tidaklah suatu kebetulan" (Gries, 2009b:31; juga Stefanowitsch, 2004b).

Secara lebih khusus, metode analisis yang diterapkan dalam penelitian ini ialah metode APM. Pola metaforis adalah ungkapan multi-kata dari RS tertentu yang mengandung satu atau lebih leksikal spesifik dari RT yang dipetakan (Stefanowitch, 2006:66). Secara krusial, pola metaforis mendasari penelitian berbasis RT untuk memperoleh data pada korpus. Maksudnya, peneliti dapat mengekstrak sejumlah besar contoh-contoh leksikal RT (seperti, amarah/kemarahan, ketakutan, kebahagiaan, kesedihan, dan cinta) yang tersimpan dalam korpus dan mengidentifikasi secara mendalam RS dilingkungan sebelah kanan atau kiri RT yang berpotensi membentuk pola metaforis. Jelaslah, bahwa metode APM menghasilkan pola-pola metaforis yang mengandung kosakata RT dan RS. 
Selain memiliki kemampuan untuk memunculkan pola-pola metaforis secara mendalam, APM juga menawarkan kemungkinan kepada peneliti untuk menghitung pentingnya suatu pola metaforis bagi kosakata emosi yang sedang diteliti. APM juga memungkinkan peneliti membuat generalisasi tentang pentingnya MK yang mendasari pola-pola metaforis (Stefanowitch, 2006:65). Berikut ini ditampilkan contoh analisis metafora emosi BI dengan mengambil kasus kosakata RT amarah.

Tahap pertama ialah menentukan pola metaforis. Penentuan pola metaforis didasari atas kehadiran kosakata RT dan kosakata RS yang memetakannya. Artinya, setiap kemunculan kosakata RT yang dapat dipetakan ke dalam RS dalam satu ungkapan dipandang sebagai pola metaforis (Gries \& Stefanowitsch, 2004:103; Stefanowitsch, 2005:194; Stefanowitsch, 2006:68). Misalnya, penuh amarah dan amarah (yang) meledak. Kata "penuh" dan "meledak" adalah RS, sedangkan kata “amarah” adalah RT. Ketika keduanya (RS dan RT) digunakan secara bersamaan pada celah yang relevan, maka hal ini dianggap pola metaforis. Pola metaforis ditemukan dan dianalisis dengan cara mengobservasi dan mengenali ungkapan-ungkapan linguistik metaforis yang muncul pada daftar konkordansi yang mengandung kosakata RT -- dalam contoh ini kata kunci amarah-- pada simpul (node) konkordansi seperti pada tabel 3.1. Pencarian ungkapan linguistik metaforis tersebut tidak dapat dilakukan secara otomatis dengan piranti lunak konkordansi karena korpus yang dimanfaatkan tidak beranotasi semantis dan sejauh ini belum ditemukan korpus BI yang beranotasi semantis. Bahkan, menurut Stefanowitsch (2006:2) korpus-korpus besar yang 
tersedia saat ini belum beranotasi semantik. Oleh karena itu, pencarian atau indentifikasi ungkapan metaforis dilakukan secara manual oleh peneliti dengan cara memperhatikan perilaku semantis kosakata amarah dan pemetaan metafora kosakata RT amarah.

Tahap kedua, memolakan setiap ungkapan metaforis yang berhasil ditemukan dan mengelompokkannya ke dalam kelompok metafora yang relevan serta menghitung kekerapan pemakaian kosakata RS dan RT seperti tabel 3.2. Kekerapan pemakaian kosakata RS dan RT dimanfaatkan untuk:

a) menentukan sejauh mana pola metaforis tertentu dimotivasi oleh pemetaan metafora (konseptual) tertentu, dan

b) mengetahui kekuatan atau produktifitas metafora sebagai calon MK.

Pada tahap ini telah dapat ditentukan MK yang memotivasi penggunaan sejumlah ungkapan linguistik metaforis tertentu. Misalnya, leksikon RS menggelegak, membludak, mendidih, penuh, meluap, dan sebagainya, biasanya digunakan untuk membicarakan hal-hal yang berhubungan dengan cairan (panas) dan wadah. Contohnya, Air di dalam panci sudah penuh/mendidih/menggelegak/ membludak/ meluap. Leksikon penuh, mendidih, menggelegak, membludak, dan meluap pada contoh kalimat tersebut bermakna literal. Ketika, leksikon-leksikon tersebut berasosiasi dengan leksikon RT amarah dalam satu pola ungkapan, maka leksikon-leksikon RS tesebut bermakna metaforis. MK yang memotivasi penggunaan ungkapan-ungkapan linguistik metaforis itu adalah AMARAH/ KEMARAHAN (/MENJADI MARAH) ADALAH CAIRAN PANAS DALAM WADAH, sebagaimana ditampilkan pada tabel 3.2. 
Tabel 3.2

\section{Contoh APM untuk RT Amarah/Kemarahan BI}

\begin{tabular}{|c|c|c|c|}
\hline No & Metafora Konseptual & Pola metaforis & pan \\
\hline A. & $\begin{array}{l}\text { AMARAH/ KEMARAHAN } \\
\text { (/MENJADI MARAH) } \\
\text { ADALAH CAIRAN } \\
\text { PANAS DALAM WADAH }\end{array}$ & $\begin{array}{l}\text { 1. kemarahan/amarah (semakin/ begitu/dengan segera) } \\
\text { menggelegak (membutuhkan penyaluran) }[3], \\
\text { 2. darah } \mathrm{X} \text { menggelegak oleh amarah, } \\
\text { 3. kemarahan membludak }[2], \\
\text { 4. di dalam dadanya mendidih darah kemarahan, } \\
\text { 5. kepala mendidih dipenuhi kemarahan, } \\
\text { 6. amarah (yang) mendidih, } \\
\text { 7. memuntahkan lahar amarah, } \\
\text { 8. amarah/ kemarahan bagaikan kepundan gunung, } \\
\text { 9. meluapkan kemarahan (kepada } \mathrm{Y} \text { ) [2], } \\
\text { 10. X luapkan kemarahan, } \\
\text { 11. kemarahan meluap (di wajah } \mathrm{X})[8], \\
\text { 12. (di hati } \mathrm{X} \text { berisi) amarah yang meluap-luap/meruap [3], } \\
\text { 13. luapan kemarahan/amarah (dilampiaskan kepada } \mathrm{Y} \text { ) [5] }\end{array}$ & 30 \\
\hline B. & $\begin{array}{l}\text { AMARAH/ KEMARAHAN } \\
\text { (/MENJADI MARAH) } \\
\text { ADALAH API }\end{array}$ &  & 50 \\
\hline
\end{tabular}

Tahap ketiga, menentukan ketertarikan dan ketertolakan RS terhadap RT

emosi. Analisis tahap ini dimaksudkan untuk melihat kemungkinan adanya metafora yang spesifik berhubungan dengan emosi tertentu dalam BI. Misalnya, 
apakah metafora CAIRAN PANAS DALAM WADAH dan metafora API pada tabel 3.2 secara signifikan tertarik atau tertolak oleh emosi amarah. Hal ini dilakukan dengan cara menguji secara statistik menggunakan metode Configural Frequency Analysis (CFA) (Gries, 2009). Dua variabel utama dalam analisis statistik untuk penelitian ini adalah METAFORA dan EMOSI. Hasilnya akan dapat menunjukkan apakah metafora tertentu ditarik secara signifikan atau ditolak secara signifikan oleh emosi tertentu (Stefanowitsch, 2006:91).

Tahap keempat, menentukan pemetaan utama (PU) dan sorot makna utama (SMU) metafora emosi (Kövecses, 2010: 140). Analisis PU bertujuan untuk mengetahui unsur apa yang dipetakan dan unsur apa yang tidak dipetakan dari RS ke RT. Analisis SMU dimaksudkan untuk menemukan unsur apa dari RS yang secara signifikan disoroti sehubungan dengan asosiasinya dengan RT. SMU yang diasosiasikan dengan sebuah metafora (RS) dapat dievaluasi dari ungkapan linguistik metaforis yang mendominasi sebuah metafora (Kövecses, 2010: 140). Sebagai contoh konsep API dalam metafora EMOSI ADALAH (PANAS) API memiliki beberapa metafora yang berhubungan dengan (panas) api, seperti. AMARAH/ KEMARAHAN (/MENJADI MARAH) ADALAH API. Metafora ini dapat dipetakan seperti di bawah ini.

Pemetaan Utama

\begin{tabular}{|c|c|c|}
\hline Api & $\rightarrow$ & amarah \\
\hline sesuatu yang terbakar & $\rightarrow$ & orang yang marah \\
\hline penyebab timbulnya api & $\rightarrow$ & penyebab amarah \\
\hline intensitas api & $\rightarrow$ & intensitas amarah \\
\hline $\begin{array}{l}\text { kerusakan fisik pada benda yang } \\
\text { terbakar }\end{array}$ & $\rightarrow$ & $\begin{array}{l}\text { kerusakan mental pada orang } \\
\text { yang marah }\end{array}$ \\
\hline $\begin{array}{l}\text { kemampuan benda yang terbakar } \\
\text { untuk berfungsi normal }\end{array}$ & $\rightarrow$ & $\begin{array}{l}\text { kemampuan orang yang marah } \\
\text { untuk berfungsi secara normal }\end{array}$ \\
\hline
\end{tabular}


$\begin{array}{lll}\text { objek yang sedang dilalap api } & \rightarrow & \begin{array}{l}\text { orang yang amarahnya berada } \\ \text { pada batas puncak }\end{array} \\ \text { bayaha api bagi benda di sekitarnya } & \rightarrow \quad \begin{array}{l}\text { bahaya orang yang marah bagi } \\ \text { orang lain }\end{array}\end{array}$

Selain pemetaan di atas, kekayaan pengetahuan kita tentang RS memungkinkan kita untuk melakukan pemetaan ikutan (metaphorical entailments) terhadap sebuah meafora konseptual AMARAH/KEMARAHAN (/MENJADI MARAH) ADALAH API. Pemetaan ikutan yang dimaksud ditampilkan berikut ini.

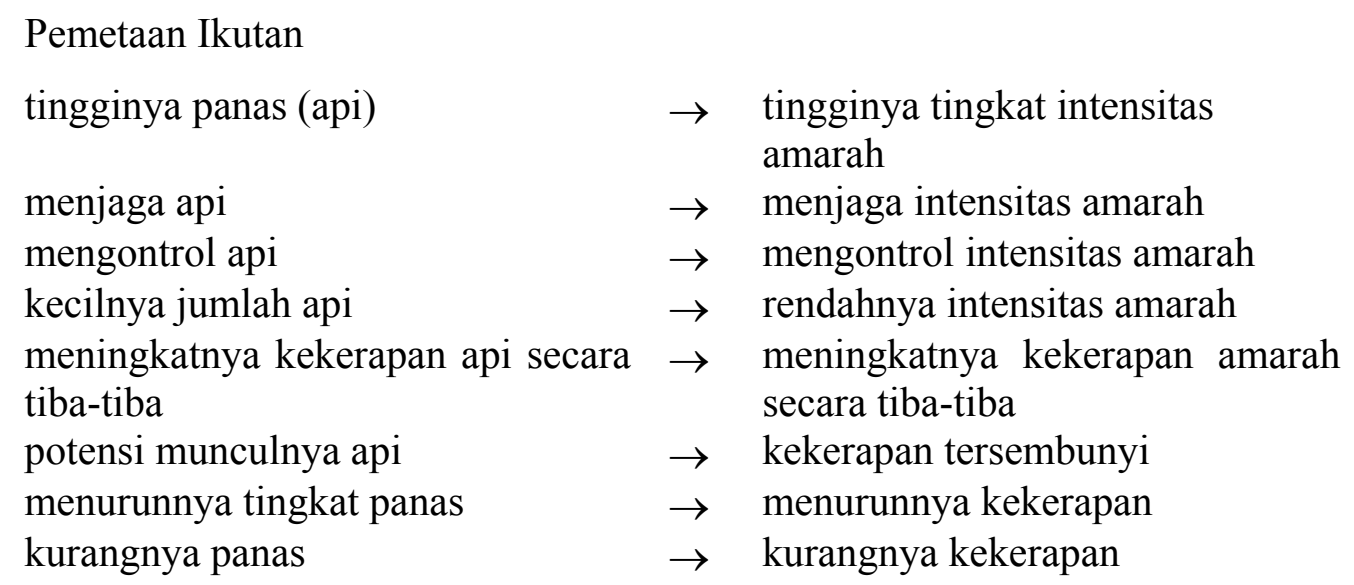

Pemetaan utama dan pemetaan ikutan di atas serta ungkapan-ungkapan linguistik metaforis yang mendominasi seperti pada tabel 3.2, kolom B, menunjukkan bahwa SMU metafora AMARAH/KEMARAHAN (/MENJADI MARAH) ADALAH API adalah intensitas amarah.

\subsection{Metode dan Teknik Penyajian Hasil Analisis}

Langkah yang juga sangat penting dalam suatu penelitian ialah menyajikan temuan-temuan secara sistematis agar mudah dipahami oleh pembaca. Salah satu cara menyajikan temuan adalah dengan menggunakan bahasa yang baik dan lugas sehingga mudah dicerna dan dipahami. Penelitian ini akan 
menyajikan hasil analisis data dengan metode formal dan informal (Sudaryanto, 1993:145). Kedua metode itu diuraikan secara ringkas berikut ini.

\subsubsection{Metode Informal}

Metode informal digunakan untuk menyajikan temuan dengan menggunakan kata-kata atau kalimat. Penerapan metode ini diyakini mampu menjelaskan permasalahan kualitatif dengan lebih baik dibandingkan dengan menggunakan metode yang lain. Penyajian hasil analisis dengan metode statistik juga sangat relevan dalam penelitian ini. Metode-metode ini juga dapat dimanfaatkan, baik secara top-down maupun bottom-up, dengan mengikuti kaidah penulisan formal.

\subsubsection{Metode Formal}

Metode formal dapat direalisasikan dengan menggunakan tanda, lambang, gambar, dan diagram. Tanda dan lambang digunakan pada saat menyajikan contoh-contoh metafora emosi yang dilihat dari sudut representasai linguistiknya. Sementara itu, lambang dan diagram digunakan untuk menyajikan hasil-hasil analisis statistik dan pemetaan makna-makna metafora emosi BI. Dengan menggunakan tanda, lambang, dan diagram, hasil analisis dapat disajikan lebih padat dan lebih mudah dipahami. 


\section{BAB IV}

\section{KONSEPSI BAHASA EMOSI, METAFORA, KORPUS, DAN KONKORDANSI}

Bab ini memaparkan unsur-unsur bahasa emosi dan metafora. Bahasa emosi memiliki peran penting dalam kehidupan manusia. Menurut Kövecses (2000:1), bahasa emosi belum mendapat cukup banyak perhatian dalam penelitian konsep-konsep emosi. Unsur yang paling penting dari bahasa emosi yang dibicarakan ialah bahasa figuratif dalam proses konseptualisasi emosi. Kövecses sendiri mempertanyakan peran metafora dan bahasa figuratif dalam proses berpikir kita tentang emosi. Apakah metafora mencerminkan realita literal yang sudah ada sebelumnya ataukah metafora menciptakan atau membangun realita emosi? Apa yang sedang dipikirkan oleh pemakai BI ketika mengungkapkan amarahnya membara, cintanya karam, dia dicekam ketakutan dan yang lainnya?

Kövecses (2000), meyakini bahwa ungkapan seperti amarahnya membara, cintanya karam, dia dicekam ketakutan memiliki hubungan erat dengan emosi kita. Keyakinannya dibuktikan dengan dua pandangan yang berbeda tentang emosi, yaitu pandangan orang awam dan pandangan ahli. Orang awam mengategorikan emosi sebagai nafsu (passions). Sementara itu, beberapa ahli menggolongkan emosi sebagai keadaan (states) dan beberapa ahli yang lain menggolongkannya sebagai tindakan (actions). Keterhubungan tersebut juga dibuktikan dengan adanya perbedaan cara pandang orang awam tentang emosi dan hubungan manusia atau perbedaannya dengan pikiran rasional. Teori emosi dalam ilmu psikologi, filsafat dan antropologi telah mendukung keyakinannya. 
Kemiripan atau kesamaan cara pikir tentang emosi oleh pemakai beberapa bahasa dan budaya yang berbeda menandakan bahwa ada hubungan yang erat antara metafora dan bahasa figuratif pada umumnya dengan emosi kita.

Agar pemahaman tentang metafora menjadi lebih rinci, terlebih dahulu perlu dipaparkan pemahaman tentang bahasa emosi, konsep emosi, dan isu spesifik yang muncul sehubungan dengan bahasa emosi, yaitu bahasa dan emosi, makna dan emosi, dan beberapa isu yang muncul dalam penelitian konsep emosi sehari-hari.

\subsection{Leksikon yang Behubungan dengan Emosi}

Ahli bahasa pada umumnya mengasumsikan bahwa bahasa emosi terdiri dari sejumlah leksikon, seperti amarah, cinta, ketakutan, kebahagiaan dan sebagainya. Sementara itu, Kövecses (2000:2), mengemukakan bahwa leksikon emosi seperti yang disebutkan di atas hanya sebagian kecil dari bahasa emosi kita. Berikut ini dipaparkan pengorganisasian dan fungsi yang paling umum dari leksikon yang berhubungan dengan emosi dan kelompok terminologi emosi.

\subsubsection{Emosi Ekspresif dan Emosi Deskriptif}

Kövecses (2000:2), membedakan antara kata-kata emosi yang bersifat ekspresif dan yang bersifat deskriptif. Misalnya, kata "bangsat!" atau “wah!" termasuk kata-kata emosi yang ekspresif karena dapat mengekpresikan emosi seseorang. Kata bangsat! diekspresikan ketika seseorang sedang marah, kata wah! diekspresikan ketika orang merasa kagum atau antusias, dan lain sebagainya. 
Akan tetapi, tidak semua emosi dapat diekspresikan seperti itu. Leksikon seperti amarah dan marah, kesenangan dan kebahagiaan, kesedihan dan tertekan biasanya digunakan secara deskriptif atau digunakan untuk mendeskripsikan emosi yang diwakili (signify). Perlu juga dicatat bahwa dalam keadaan tertentu leksikon emosi deskriptif juga dapat mengekspresikan emosi tertentu. Misalnya, kata emosi cinta dalam "Aku cinta padamu!" dapat digunakan baik untuk mengekspresikan maupun mendeskripsikan emosi cinta.

\subsubsection{Istilah Emosi Dasar}

Dipandang dari sudut kategori leksikon emosi deskriptif, istilah emosi dasar dapat dipahami sebagai "lebih dasar atau kurang dasar." Menurut Kövecses (2000: 3), pemakai bahasa tertentu merasa bahwa beberapa leksikon emosi lebih dasar dibandingkan dengan leksikon yang lain. Dalam BIng, leksikon emosi yang dianggap lebih dasar dibandingkan dengan yang lain, termasuk amarah, kesedihan, ketakutan, kegembiraan, dan cinta. Yang dianggap kurang dasar untuk kelompok kata amarah, di antaranya kejengkelan, murka, kegusaran, dan dongkol. Sementara itu, yang dianggap kurang dasar untuk kelompok kata ketakutan 'fear', di antaranya kengerian 'terror', rasa takut 'fright', dan rasa ngeri 'horror'. Phillip dkk. (2001) menemukan lima kategori emosi dasar dalam BI, yaitu cinta, kebahagiaan, amarah, ketakutan, and kesedihan.

Istilah "dasar" memiliki dua makna. Pertama, bahwa leksikon (konsep yang berhubungan dengan leksikon tersebut) menempati posisi tengah pada hierarki kosep vertikal menurut Rosch (1975; 1978 dalam Kövecses, 2000: 3). 
Misalnya, amarah dianggap lebih dasar dibandingkan dengan kejengkelan atau emosi. Amarah dianggap lebih dasar karena amarah (emosi tingkat dasar) terletak di antara emosi (superordinat) dan kejengkelan (subordinat). Hierarki tersebut dapat dilihat pada bagan 4.1 (dikutip dan diadaptasi dari Kövecses, 2000:3) berikut ini.

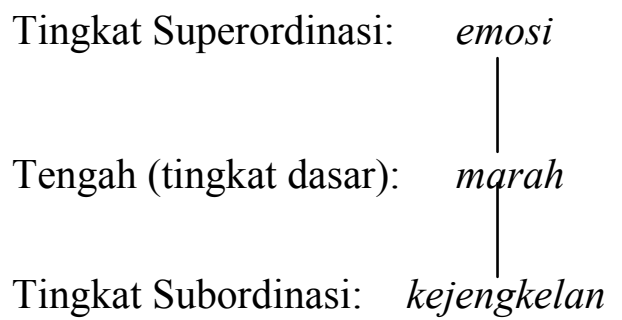

\section{Bagan 4.1}

\section{Hierarki Vertikal Istilah Emosi}

Kedua, istilah "dasar" dapat dilihat dari sudut pandang prototipe. Maksudnya, bahwa kategori emosi tertentu dapat dipandang sebagai emosi yang lebih prototipikal (yaitu contoh yang lebih baik) dibandingkan dengan yang lain pada tingkat garis horizontal yang sama (ini prototipe menurut Rosch, 1975; 1978 dalam Kövecses, 2000:3).

Konsep pengaturan tingkat dasar pada tingkat garis datar (horizontal) ini terjadi bersamaan dengan konsep pengaturan tingkat dasar pada tingkat garis tegak lurus (vertikal). Misalnya, amarah lebih dasar dibandingkan harapan atau kebanggaan meskipun ketiganya berada pada satu garis yang sama seperti terlihat pada bagan 4.2 (dikutip dan diadaptasi dari Kövecses, 2000:4). 


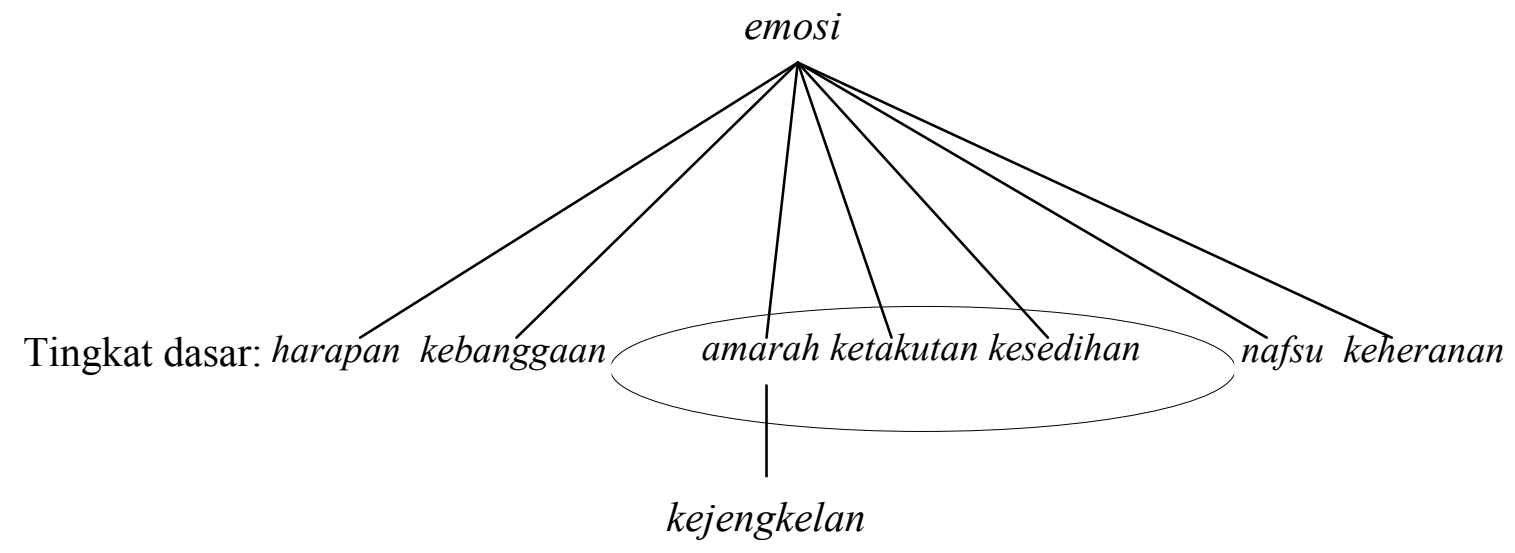

Bagan 4.2

Istilah Emosi Prototipe dan Bukan Prototipe pada Tataran Horizontal Dalam Pengorganisasian Konseptual ${ }^{1}$

\subsubsection{Metafora dan Metonimia}

Terminologi lain yang berhubungan dengan emosi ialah kelompok istilah dan ungkapan figuratif. Istilah figuratif juga mendeskripsikan emosi (dan tidak hanya mengekspresikan emosi) Kövecses (2000:4). Karena itu, kata figuratif dimasukkan ke dalam subkategori kelompok kata deskriptif. Subkelompok ini diasumsikan memiliki anggota lebih besar dibandingkan dengan kombinasi dari dua kelompok yang lain. Kata dan ungkapan figuratif menunjuk berbagai unsur konsep emosi, seperti intensitas, penyebab, kontrol, dan lain sebagainya. Kata atau ungkapan figuratif tersebut dapat bersifat metaforis dan metonimis. Ungkapan metaforis merupakan manifestasi dari MK yang telah diperkenalkan oleh Lakoff dan Johnson (1980). MK membuat dua ranah atau konsep yang berjauhan menjadi dekat atau berkorespondensi satu dengan yang lain. Satu ranah biasanya lebih bersifat fisik atau konkret dibandingkan dengan yang lain (yang 
lebih abstrak). Korespondensi tersebut dibangun untuk memahami ranah atau konsep yang lebih abstrak melalui ranah yang lebih konkret (Kövecses, 2000: 4). Misalnya, darahku mendidih ialah sebuah contoh ML dari MK AMARAH ADALAH CAIRAN PANAS yang sangat produktif (bandingkan Lakoff, 1987; Kövecses, 2000, 2002, 2005, 2010), api cinta merupakan sebuah contoh ML dari MK CINTA ADALAH API, dan meloncat-loncat kegirangan merupakan contoh dari MK KEBAHAGIAAN ADALAH KE/DI ATAS. Ketiga contoh di atas merupakan unsur intensitas dari emosi yang bersangkuan.

Ungkapan-ungkapan linguistik yang termasuk dalam kelompok besar terminologi figuratif dapat berupa metonimia Kövecses (2000:5). Meskipun penelitian ini berkonsentrasi pada metafora dan tidak meneliti unsur metonimia, pembicaraan mengenai metonimia pada bagian ini dimaksudkan untuk memberikan gambaran singkat untuk memperjelas posisi emosi dan metafora. Berbeda halnya dengan MK, metonimia konseptual menyangkut pemanfaatan satu ranah atau konsep. Metonimia bertujuan memberikan akses mental kepada sebuah ranah melalui bagian dari ranah yang sama (atau sebaliknya) atau kepada bagian dari sebuah ranah melalui bagian yang lain pada ranah yang sama. Karena itu, metonimia merupakan hubungan perwakilan, stand-for, (yaitu bagian mewakili semua atau bagian mewakili bagian yang lain) pada satu ranah yang sama. Konsep emosi dipandang sebagai hal yang memiliki banyak bagian atau elemen. Sebagai contoh, satu bagian atau elemen dari ranah amarah adalah gejolak tubuh fisik, dan satu bagian atau elemen dari ranah ketakutan adalah menurunnya suhu tubuh. Karena itu, contoh linguistik dari kedua konsep emosi tersebut termasuk 
tubuhnya bergetar untuk amarah dan tangan dingin untuk ketakutan. Yang pertama adalah contoh metonimia konseptual GEJOLAK FISIK MEWAKILI/ BERARTI AMARAH, sedangkan yang kedua ialah contoh metonimia konseptual MENURUNNYA SUHU TUBUH MEWAKILI/ BERARTI KETAKUTAN (Kövecses, 2000: $5)$.

Kövecses (2000:5) membedakan bahasa emosi menjadi tiga kelompok, yaitu (1) kelompok kata ekspresif, (2) kelompok kata literal yang menunjukkan jenis emosi tertentu, dan (3) kelompok ungkapan kias atau figuratif yang menunjukkan unsur emosi tertentu. Ketiga kelompok tersebut diskemakan seperti pada bagan 4.3.



Bagan 4.3

Tipe Bahasa

Kelompok kias atau figuratif, sejauh ini, dianggap memiliki anggota paling banyak. Akan tetapi kelompok ini mendapat perhatian paling sedikit dalam penelitian-penelitian bahasa emosi. Kias dianggap tidak relevan dan tidak menarik 
sama sekali oleh kebanyakan peneliti yang memandang kias sebagai cara fantastis untuk mengungkapkan sesuatu yang dapat dikatakan secara sederhana dengan bahasa literal. Selain itu, kata-kata yang termasuk kelompok satu, ekspresif, dianggap literal. Itulah sebabnya ungkapan pada kelompok figuratif mendapat perhatian sangat kecil, menurut Kövecses (2000). Lebih jauh Kövecses (2000) berpendapat bahwa faktanya saat ini semakin banyak sarjana yang tidak sepaham dengan pandangan tentang fungsi bahasa pada manusia dalam menciptakan fakta emosionalnya (dapat juga diperiksa, misalnya Baxter, 1992; Duck, 1994; Gibbs, 1994; Holland dan Kipnis, 1995; Kövecses, 1990 dalam Kövecses, 2000:5).

\subsubsection{Motivasi Eksperiensial Metafora}

Para ahli semantik kognitif memandang penting peran pengalaman terhadap konstruksi makna. Diyakini bahwa makna tidak datang secara objektif dan semena-mena dari dunia tempat tinggal pemakai bahasa. Bahwa pemakai bahasa tinggal di sebuah lingkungan dan memiliki pengalaman bersama dalam memperoleh cara pikir yang mirip, tidak identik, terhadap makna suatu objek disekitar mereka. Jadi makna adalah konstruksi pengalaman (eksperiensial) (Lakoff and Johnson, 1980; Lakoff, 1987, 1993, 2006; Kövecses 2002).

Para ahli linguistik kognitif memandang bahwa metafora dimotivasi oleh pengalaman atau berbasis pengalaman. Pengalaman tubuh fisik biasanya banyak diacu menjadi basis metafora. Ranah konsep konkret yang mewakili objek konkret atau fisik di dunia memungkinkan menjadi RS dari pemetaan metafora. Sebaliknya, ranah konsep abstrak biasanya bertindak sebagai RT di mana 
pengetahuan tentang RS dipetakan. RS yang dibangkitkan dari pengalaman manusia yang mengejawantah, menstrukturkan konseptualisasi RT; ranah konsep pengalaman fisik digunakan untuk memahami ranah yang kurang konkret dan konsep yang lebih kompleks, RT (Gibbs, Lima, \& Francozo, 2004 dalam Aldhokayel, 2008). Akan tetapi, pengalaman tidak terbatas pada pengalaman fisik secara langsung seperti misalnya, meraba, berjalan, pergi, tidur, dan lain-lain. Pengalaman juga menyangkut konteks sosial budaya yang lebih besar dan bagaimana pengalaman tersebut memengaruhi konseptualisasi kita terhadap dunia.

Sementara itu, Kövecses (2002 dan 2010) menyatakan bahwa basis metafora bervariasi di antara pengalaman tubuh manusia dengan pengalaman budaya pada umumnya. Di sinilah pentingnya peran para ahli linguistik kognitif dalam mendaftar semua motivasi yang ada. Sejauh ini, mereka telah berhasil mengidentifikasi beberapa kategori umum sehubungan dengan motivasi metafora, seperti motivasi skema-citra, motivasi tubuh, motivasi persepsi, dan motivasi budaya.

\subsubsection{Motivasi Skema-Citra}

Metafora yang termotivasi oleh skema citra merefleksikan cara manusia mengalami dunia fisik di sekitarnya secara berulang-ulang. Pengalamanpengalama inilah yang membangun skema citra dalam sistem konsep kita (Lakoff, 1987). Dari pengalaman-pengalaman itu, kita dapat memahami sesuatu seperti berada di dalam sesuatu dan di luar sesuatu, di belakang dan di depan sesuatu, di 
tengah-tengah (central) sesuatu dan di samping (peripheral) sesuatu dan sebagainya. Manusia menggunakan skema citra dasar seperti itu untuk mengonseptualisasikan konsep abstrak. Metafora yang termotivasi oleh skema citra secara langsung berasal dari pengalaman fisik, tetapi hanya sedikit pengetahuan yang dipetakan dari RS ke RT. Contoh, metafora KEADAAN ADALAH LOKASI di mana keadaan dipahami sebagai daerah terkungkung pada suatu bidang , seperti pada dia menghabiskan hidupnya dalam kebingungan, atau mereka hidup dalam kebahagiaan, tidak banyak pengetahuan yang ditransfer di antara ranahranah itu selain skema citra dari batasan ruang (spatial boundedness), khususnya bagaimana seseorang merasakan sesuatu dan dikelilingi oleh perasaan itu.

\subsubsection{Motivasi Tubuh}

Kövecses (1986), memaparkan bahwa metafora yang termotivasi oleh tubuh manusia menyangkut proses biologis dan psikologis yang dihubungkan dengan keadaan tertentu (misalnya amarah dan kebahagiaan). Amarah, misalnya kadang-kadang dipahami sebagai cairan dalam wadah bertekanan, seperti pada dia meluapkan amarahnya. Dalam hal ini, tubuh manusia diasosiasikan dengan wadah dan suhu panas dalam tubuh manusia yang diasosiasikan dengan keadaan marah dan dibandingkan dengan cairan dalam wadah bertekanan. Karena itu, metafora yang dimunculkan ialah AMARAH ADALAH CAIRAN PANAS DALAM WADAH yang merupakan contoh metafora amarah yang lebih umum, yaitu AMARAH ADALAH PANAS. 


\subsubsection{Motivasi Persepsi}

Sejumlah metafora dimotivasi oleh persepsi indera manusia, yaitu persepsi manusia tentang objek fisik di sekitarnya. Sebagai contoh metafora LEBIH BANYAK ADALAH KE/DI ATAS. Metafora ini dimotivasi oleh korelasi persepsi antara pengalaman menambahkan sesuatu dan meningkatnya kuantiatas; Ketika sesuatu ditumpuk/ ditambah, maka benda itu meningkat. Jadi, biasanya orang mengatakan sesuatu yang meningkat sebagai hal yang ke atas. Karena itu KUANTITAS berkorelasi dengan KEVERTIKALAN (Lakoff \& Johnson, 1980; Lakoff, 2006; Kövecses, 2002)

\subsubsection{Motivasi Budaya}

Metafora yang dimotivasi secara budaya utamanya merefleksikan budaya pemakai suatu bahasa. Lakoff dan Johnson (1980) menyatakan bahwa faktanya semua pengalaman bersifat budaya, bahkan pengalaman tubuh dan persepsi bersifat budaya karena pengalaman itu terjadi dalam kerangka asumsi budaya.

\subsubsection{Kekonvensionalan Metafora ${ }^{2}$}

Menurut Lakoff \& Turner (1989); Kövecses (2002; 2006; 2010), metafora dapat bersifat lebih konvensional dan kurang konvensional. Metafora konvensional adalah metafora yang telah mengakar dengan kuat dan karenanya telah terkenal dan digunakan secara luas oleh masyarakat, seperti LOVE IS FIRE 'CINTA ADALAH API'. Metafora yang kurang konvensional disebut metafora novel. Penekanan diberikan pada perbedaan antara ML dan MK. ML mungkin saja 
merupakan metafora novel dan tidak konvensional. Akan tetapi, ada kemungkinan bahwa metafora tersebut muncul dari MK yang sangat konvensional. Dicontohkan sebuah puisi terkenal dari Robert Frost The Road Not Taken. ML ini tidak konvensional, akan tetapi merupakan realisasi dari MK yang konvensional LIFE IS A JOURNEY 'HIDUP ADALAH PERJALANAN' yang diaktifkan dengan bahasa konvensional dengan ungkapan seperti Hidupku ada di persimpangan jalan (Lakoff \&Turner, 1989). Sementara itu, MK novel mungkin hanya memunculkan ML yang tidak konvensional. Karena itu, menurut (Lakoff \&Turner, 1989), idiosinkresi pikiran memerlukan ideosinkresi bahasa.

MK yang tidak konvensional atau MK novel melibatkan satu metafora citra. Melalui metafora citra inilah struktur citra mental konvensional dipetakan ke struktur citra mental konvensional yang lain. Misalnya, pada my wife whose waist is an hourglass ${ }^{3}$ (Lakoff, 2006: 215), citra mental hourglass (jam pasir) dipetakan ke citra mental tubuh wanita. Di sini, yang dinyatakan hanya hourglass, sedangkan pinggang wanita, tidak dijelaskan dalam ML tentang bagian mana dari hourglass yang berkorespondensi dengan pinggang wanita. Akan tetapi, karena hal ini menyangkut MK, secara otomatis semua citra hourglass dipetakan ke seluruh citra tubuh wanita di mana bagian tengah hourglass berkorespondensi dengan bagian tengah (pinggang) wanita. Kata-kata hanya berperan sebagai pendorong dalam mengaktifkan pemetaan konseptual. 


\subsubsection{Sifat Metafora}

Dipandang dari sifatnya, metafora merupakan mekanisme utama untuk memahami konsep-konsep abstrak dan mempertunjukkan pemikiran abstrak. Banyak perkara, dari yang paling biasa sampai dengan teori yang paling ilmiah, hanya dapat dipahami melalui metafora (Lakoff, 2006:232). Sebagai contoh Ranah teknologi informasi dibincangkan dengan menggunakan beberapa MK termasuk KOMPUTER YANG TERHUBUNG ADALAH TITIK HUBUNG DALAM JEJARING (CONNECTED COMPUTERS ARE NODES IN A WEB) yang dileksikalkan menjadi jejaring 'web' dan (inter)net dalam ML (Deignan, 1997: 19; 2005:13).

Pada dasarnya, metafora bersifat konseptual, bukan linguistik. Ungkapan metaforis merupakan manifestasi permukaan dari MK (Lakoff, 2006:232). Banyak sistem konsep bersifat metaforis. Akan tetapi, sebagian dari sistem konsep yang metaforis itu bersifat non-metaforis karena pemahaman metafora didasari dengan pemahaman non-metaforis. Jadi, metafora memungkinkan seseorang memahami perkara-perkara abstrak atau yang secara inheren tidak terstruktur melaui perkara-perkara yang lebih konkret atau lebih terstruktur

\subsubsection{Struktur Metafora}

Menurut Lakoff (2006), metafora adalah pemetaan lintas ranah yang asimetris dan parsial. Setiap pemetaan merupakan korespondensi ontologis yang tetap antara entitas pada RS dan entitas pada RT. Ketika korespondensi yang tetap tersebut diaktifkan, pemetaan tersebut dapat memroyeksikan pola inferensi RS ke pola inferensi RT. Pemetaan metafora tersebut patuh pada prinsip tanpa perbedaan 
(invariance principle) ${ }^{4}$. Maksudnya, struktur skema citra RS diproyeksikan ke RT dengan cara yang konsisten dengan struktur RT yang melekat (inherent). Pemetaan metafora tidak bersifat manasuka, tetapi didasari oleh pengetahuan dan pengalaman tubuh sehari-hari. Singkatnya, ada dua macam pemetaan, yaitu pemetaan konseptual dan pemetaan citra dan keduanya tunduk pada prinsip tanpa perbedaan.

\subsubsection{Metafora dan Idiom}

Menurut Lakoff, (2006) dan Kövecses (2002), mungkin kebanyakan idiom merupakan produk dari sistem konsep dan bukan perkara bahasa semata (yaitu, masalah leksikon). Idiom bukan ungkapan yang memiliki makna khusus sehubungan dengan makna kata yang membangunnya. Akan tetapi idiom muncul dari pengetahuan tentang dunia yang lebih umum yang mengejawantah dalam sistem konsep. Dengan lain perkataan, idiom (atau sebagian besar idiom) bersifat konseptual, bukan linguistik. Sebagai contoh, idiom dalam Bahasa Inggris He was spitting fire. Contoh ini menunjukkan bahwa ranah konseptual (konsep) api 'fire', bukan kata-kata secara individu yang berperan dalam proses penciptaan ungkapan idiomatik. Kata-kata secara mandiri hanya bertugas mengungkapkan proses konseptualisasi yang lebih dalam.

\subsection{Korpus dan Konkordansi}

Bagian ini menjelaskan dua hal, yaitu korpus dan konkordansi. Pada bagian korpus, dijelaskan hal-hal yang bertautan dengan pengertian, jenis, 
manfaat korpus, dan daftar kekerapan. Sementara itu, pada bagian konkordansi dijelaskan pengertian dan manfaat konkordansi.

\subsubsection{Korpus}

\subsubsection{Pengertian Korpus}

Kata korpus (jamaknya korpora) berasal dari bahasa Latin yang berarti badan. Dalam ilmu bahasa kata korpus dimaknai sebagai kumpulan teks yang tersimpan dalam pangkalan data elektronik (Baker, 2006:55). Gries (2008:7) membedakan tiga hal penting sehubungan dengan korpus, yaitu korpus itu sendiri, arsip berupa teks, dan koleksi contoh-contoh. Korpus adalah kumpulan teks (lisan atau tulis) yang dapat dibaca oleh mesin dan diproduksi secara alamiah. Kumpulan teks tersebut disusun agar (1) seimbang dan representatif sehubungan dengan variasi bahasa tertentu atau register atau genre dan (2) dapat dianalisis secara linguistik.

Ada beberapa istilah yang perlu dijelaskan sehubungan dengan korpus modern, yaitu terbaca oleh mesin, diproduksi secara alamiah, representatif, dan seimbang.

(1) “Terbaca oleh mesin” artinya bahwa saat ini semua korpus tersimpan secara maya dalam bentuk teks unikode yang dapat dimuat, dimanipulasi, dan diproses secara mandiri.

(2) "Diproduksi secara alamiah" maksudnya bahwa teks diucapkan atau ditulis untuk tujuan komunikasi secara otentik, bukan untuk tujuan korpus. Misalnya, artikel-artikel surat kabar dipandang sebagai teks yang diproduksi secara alamiah karena wartawan menulis artikel-artikel tersebut untuk dipublikasikan dalam surat kabar guna mengkomunikasikan sesuatu kepada 
pembacanya, bukan untuk tujuan mengisi korpus yang diperlukan oleh para ahli bahasa.

(3) "Representatif" maksudnya bahwa korpus yang dibangun mewakili variasi suatu bahasa. Misalnya, jika kita bermaksud meneliti pemakaian metafora dalam BI yang digunakan pada surat kabar, maka mengumpulkan artikelartikel dari surat kabar Kompas saja dianggap tidak representatif karena tidak dapat mewakili semua surat kabar.

(4) "Seimbang" sehubungan dengan variasi suatu bahasa. Maksudnya, bahwa semua unsur variasi bahasa disampelkan dalam korpus. Selain itu, proporsi yang ditampilkan dalam korpus harus juga mencerminkan proporsi yang seimbang (Gries, 2008:8).

\subsubsection{Jenis Korpus}

Korpus dapat dibedakan menjadi dua kelopok besar, yaitu korpus umum dan korpus spesifik (Gries, 2008:9). Korpus umum dimaksudkan untuk mewakili semua variasi bahasa secara seimbang, sedangkan korpus spesifik dimaksudkan untuk mewakili variasi, register atau genre tertentu.

Korpus juga dibedakan menjadi korpus mentah dan korpus beranotasi. Korpus mentah adalah kumpulan berkas-berkas materi korpus. Sementara itu, korpus beranotasi adalah kumpulan berkas-berkas materi korpus yang mengandung informasi tambahan. Korpus beranotasi sering dianotasi menurut standar penganotasian korpus yang disebut Corpus Encoding Standard (CES). Korpus beranotasi melibatkan dua bagian penting, yaitu judul (header)dan pokok 
(body). Judul korpus mengandung informasi yang disebut markup. Informasi pada bagian judul menyangkut (1) teks itu sendiri, misalnya dari mana asal data korpus?, bahasa apa yang diwakili?, bagian mana dari (sebuah) surat kabar atau buku yang termasuk dalam korpus?, siapa merekam, kapan dan di mana?, siapa yang memilili hak cipta dari data korpus tersebut? dan informasi menyangkut (2) format teks, pencetakan, proses dan lain-lain. Pokok korpus mengandung data korpus yang tepat. Misalnya, apa yang dikatakan atau ditulis oleh orang dan juga informasi kebahasaan yang biasanya ditulis berdasarkan teori: kelas kata (part of speech) atau pola kalimat (Gries, 2008:10).

Dilihat dari segi waktu, korpus dapat dibedakan menjadi korpus diakronik dan korpus sinkronik. Korpus diakronik dimaksudkan untuk mewakili perubahan bahasa atau variasi bahasa dari waktu ke waktu, sedangkan korpus sinkronik memberikan gambaran bahasa atau variasi bahasa pada satu waktu tertentu. Perbedaan lain yang perlu diungkapkan adalah antara korpus satu bahasa (monolingual corpora) dan korpus paralel (parallel corpora). Korpus satu bahasa, sebagaimana digambarkan oleh namanya, dikumpulkan untuk memberikan informasi tentang satu bahasa atau variasi bahasa tertentu, sedangkan korpus paralel dimaksudkan untuk memberikan teks yang sama dalam beberapa bahasa yang berbeda (Gries, 2008:10).

Perbedaan berikutnya adalah antara korpus statis (static corpora) dan korpus dinamis (dynamic/monitor corpora). Korpus statis memiliki ukuran yang tetap (fixed size), seperti misalnya Brown corpus, the LOB corpus, sedangkan korpus dinamis memiliki ukuran yang berubah-ubah karena ukurannya secara 
terus-menerus diperbesar dengan menambahkan materi baru, misalnya the Bank of English (Gries, 2008:11).

Korpus bahasa Inggris lain yang dikenal dan digunakan oleh para ahli linguistik korpus di antaranya dipaparkan pada http://corpus.byu.edu/ sebagaimana didaftar di bawah ini:

\begin{tabular}{|c|c|c|c|}
\hline Nama Korpus & $\begin{array}{c}\text { Jumlah } \\
\text { Kata }\end{array}$ & $\begin{array}{c}\text { Bahasa/ } \\
\text { Dialek }\end{array}$ & Periode \\
\hline Global Web-Based English (GloWbE) & 1,9 milyar & 20 negara & 2012--2013 \\
\hline $\begin{array}{l}\text { Corpus of Contemporary American } \\
\text { English (COCA) }\end{array}$ & 450 juta & Amerika & $1990--2012$ \\
\hline $\begin{array}{l}\text { Corpus of Historical American English } \\
(\mathrm{COHA)}\end{array}$ & 400 juta & Amerika & 1810--2009 \\
\hline TIME Magazine Corpus & 100 juta & Amerika & 1923--2006 \\
\hline Corpus of American Soap Operas & 100 juta & Amerika & $2001--2012$ \\
\hline British National Corpus (BYU-BNC) & 100 juta & Inggris & 1980an--1993 \\
\hline Strathy Corpus (Canada) & 50 juta & Kanada & 1970an--2000an \\
\hline
\end{tabular}

\subsubsection{Maanfaat Korpus}

Menurut Gries (2008:11), linguistik korpus menawarkan dua hal kepada para peneliti korpus, yaitu:

(a) kekerapan kejadian, yaitu berapa sering suatu morfem, kata, pola gramatikal, dan sebagainya terjadi pada korpus 
(b) kekerapan kejadian bersamaan, yaitu berapa sering suatu morfem atau kata muncul bersama dengan kata tertentu, berapa sering kata tertentu muncul dalam konstruksi tertentu, dan lain-lain.

Korpus tidak menawarkan makna maupun fungsi secara eksplisit. Akan tetapi, penelitilah yang menginterpretasikan fungsi dan kebermaknaan kekerapan kejadian dan kejadian bersamaan tersebut (Gries, 2008:11). Asumsi yang mendasari analisis barbasis korpus adalah bahwa perbedaan resmi (formal difference) berkorespondensi dengan perbedaan fungsi, perbedaan kekerapan kejadian elemen-elemen formal seharusnya mencerminkan keteraturan fungsi. Gries (2008) memahami fungsi dalam arti yang sangat luas, di antaranya fungsi semantik, wacana pragmatik, dan lain-lain yang dimaksudkan untuk menjelaskan fungsi komunikasi tertentu.

\subsubsection{Daftar Kekerapan}

Alat linguistik korpus yang paling dasar adalah daftar kekerapan. Daftar kekerapan digunakan ketika peneliti ingin mengetahui berapa sering kata-kata muncul dalam korpus. Daftar kekerapan korpus biasanya berupa tabel berkolom dua. Satu kolom memuat kata-kata yang muncul dalam korpus dan yang lain memuat nilai kekerapan kemunculan kata-kata tersebut. Gries (2008:12) membedakan antara jenis kata (word type) dan token (token). Misalnya, rangkaian kata "di dalam dan di luar ruang” mengandung enam token (“di”, "dalam”, “dan”, “di", "luar", dan "ruang”) tetapi jenis katanya ada lima (“di”, “dalam”, “dan", "luar", dan "ruang”) karena satu kata "di” muncul dua kali. 


\subsubsection{Konkordansi}

Konkordansi berasal dari kata konkord. Konkord adalah sebuah program yang mampu menghasilkan konkordansi dengan memanfaatkan file DOS, Text Only, ASCII, atau ANSItext (Scott, 2012:123). Program ini memiliki tiga fungsi utama, yaitu:

(1) Concord (kecocokan) dimanfaatkan untuk mewujudkan konkordansi dari korpus yang diteliti melalui fungsi pencarian (search).

(2) Word list (daftar kata) berfungi mendaftar semua kata atau bentuk kata yang terdapat dalam korpus yang dipilih.

(3) Key word (kata kunci) berguna untuk memunculkan semua kata atau bentuk kata menurut kriteria statistik dalam korpus, baik yang kemunculannya signifikan maupun jarang.

Untuk memanfaatkan program ini, pengguna menentukan kata yang akan dijelajah oleh concord di dalam semua teks yang dipilih. Program ini menampilkan konkordansi dan memberikan informasi tentang kolokasi kata yang dicari, petak sebaran (dispersion plots) yang menunjukkan tempat kata tersebut di dalam setiap naskah (file), analisis gugus yang menunjukkan gugus kata atau frasa yang berulang-ulang.

Intinya adalah bahwa konkordansi mampu melihat banyak contoh kata atau frasa pada konteksnya. Pengguna program ini memperoleh banyak gagasan tentang penggunaan kata dengan memeriksa banyak contoh yang mengandung kata tersebut. Dengan melihat dan mendengar kata baru bersama konteksnya secara berulang-ulang seseorang dapat memahami bayak makna kata. Dengan 
melihat konteks seseorang memiliki gagasan yang lebih baik tentang bagaimana memakai kata baru. Scott (2012:123) menyatakan bahwa kamus dapat memberitahu kita tentang makna tetapi tidak banyak memberikan contoh penggunaan kata.

Guru bahasa juga dapat memanfaatkan konkordansi untuk menemukan pola yang mirip untuk membantu siswa. Guru juga dapat menggunakan konkordansi untuk membuat latihan kosa kata, dan lain-lain. Tentu saja, para peneliti bahasa dapat menggunakan konkordansi untuk meneliti banyak hal yang bertautan dengan bahasa dan budaya tertentu. 


\section{Catatan Akhir}

1. Lingkaran yang menandai kata-kata, seperti marah, takut, dan sedih merupakan contoh terminologi emosi yang lebih baik (prototipe) daripada harapan, kebanggaan, heran, dan nafsu.

2. Kekonvensionalan metafora: Cara utama yang dapat dilakukan untuk mengklasifikasikan metafora ialah dengan melihat derajat kekonvensionalannya.

Dengan kata lain, kita bisa bertanya seberapa mapan pemakaian metafora atau seberapa kuat keterpatrian atau keberakaran metafora dalam penggunaan sehari-hari oleh orang-orang biasa untuk keperluan sehari-hari. Gagasan penggunaan konsep "konvensional" dalam hal ini berbeda dengan cara konsep ini biasanya digunakan dalam linguistik, semiotika, dan filsafat bahasa. Aplikasi khas konsep konvensional dalam bidang-bidang identik dengan konsep "manasuka (arbitrary)," terutama karena konsep ini digunakan untuk menjelaskan sifat tandatanda linguistik (di mana ia menunjukkan bahwa "bentuk" dan "makna" terkait antara satu dan yang lain secara manasuka). Namun, istilah "konvensional" yang digunakan di sini mengandung arti mapan dan terpatri atau berakar kuat. Dengan demikian, kita dapat mengatakan bahwa suatu metafora sangat konvensional atau dikonvensinalkan (yaitu mapan dan terpatri atau berakar kuat) dalam penggunaan pada sebuah komunitas bahasa (Kovecses, 2002:33). Misalnya, dalam bahasa Inggris, beberapa metafora konseptual sangat terpatri atau berakar kuat sehingga dikenal dan banyak digunakan dalam guyub tutur (seperti LOVE IS $F I R E$ 'CINTA ADALAH API'), sedangkan yang lain tidak begitu atau kurang dikenal (seperti LOVE IS A COLLABORATIVE WORK OF ART 'CINTA ADALAH KARYA SENI KOLABORATIF'). Metafora yang kurang konvensional bisa disebut metafora (konseptual) novel 'baru'. Ekspresi linguistik metaforis yang merefleksikan metafora konseptual tertentu juga bisa lebih atau kurang konvensional. Ungkapan linguistik metaforis yang kurang konventional atau baru sangat lazim dalam puisi. Jadi, meskipun kedua ungkapan linguistik metaforis berikut dimotivasi oleh metafora konseptual yang sama "LIVE IS A JOURNEY" 'HIDUP ADALAH SEBUAH PERJALANAN', ungkapan bahasa Inggris dalam puisi Frost "Two roads diverged in a wood 'Dua jalan bercabang di hutan,' and 'I took the one less traveled by" "Aku melewati jalan yang jarang dilalui orang' lebih baru daripada ungkapan klise "I'm at a crossroads in life." 'Aku di persimpangan jalan dalam hidup ini' (Kovecses, 2002:324).

3. Menurut kamus Oxford Advanced Learner's Dictionary, hourglass adalah sebuah gelas berisi pasir yang memerlukan waktu tepat satu jam untuk melewati lubang kecil antara bagian atas dan bagian bawah gelas tersebut.

4. Prinsip invarian (juga disebut hipotesis invarian) adalah prinsip yang menangkap kendalakendala yang mengatur pemetaan lintas ranah dalam TMK. Ada dua macam kendala yang ditangkap oleh prinsip invarian. Pertama, menetapkan RS macam apa dapat bertindak sebagai RT tertentu untuk metafora konseptual tertentu. Kedua, menetapkan kendala pada penyertaan (entailments) metafora yang dapat diterapkan pada RT tertentu. Prinsip invarian ini dilakukan dengan menetapkan bahwa dalam pemetaan lintas ranah metaforis, tipologi kognitif (struktur konseptual) terkait dengan RS yang dipertahankan, atau tetap invarian, dalam pengoperasian pemetaan. Namun, ada ketentuan lebih lanjut bahwa apa yang dipetakan dari RS harus tetap konsisten dengan tipologi kognitif RT (Evans, 2007:116). 


\section{BAB V}

\section{METAFORA KONSEPTUAL DAN METAFORA LINGUISTIK UNTUK EMOSI BAHASA INDONESIA}

\subsection{Pengantar}

Bab ini dimaksudkan untuk menjelaskan dan menjawab permasalahan tentang bagaimana pemakai BI mengungkapkan pengalaman emosinya secara metaforis dan MK apa saja yang tercermin dari ungkapan linguistik yang terkait dengan ranah emosi tersebut. Bab ini juga membahas pola-pola metaforis emosi yang ditemukan. Pembicaraan tentang MK dan ML atau pola metaforis ditampilkan dalam lima sub-bab, yaitu 5.2 Metafora AMARAH/ KEMARAHAN, 5.3 Metafora KETAKUTAN, 5.4 Metafora KeBAHAGIAAN, 5.5 Metafora KESEDIHAN, dan 5.6 Metafora CINTA.

Perlu dijelaskan bahwa ML atau ungkapan metaforis dan MK merupakan dua hal yang berbeda. Menurut Lakoff dan Johnson (1980), ML atau ungkapan metaforis adalah ungkapan linguistik yang mencontohi atau merepresentasikan MK. Sedangkan, MK adalah pemetaan mental secara umum dari RS ke RT. Misalnya, X membawa/ melambungkan/menghantar Y ke puncak kebahagiaan dianalisis sebagai ungkapan yang merepresentasikan metafora KEBAHAGIAAN/ (MENJADI BAHAGIA) ADALAH (BERADA DI) ATAS (UP)

Sistematika pengkajian yang dilakukan pada bab ini meliputi, pertama menemukan ML dalam bentuk pola metaforis untuk emosi amarah/kemarahan, 
ketakutan, kebahagiaan, kesedihan dan cinta. Kemudian, menemukan MK yang memotivasi pemakaian ungkapan metaforis berpola yang merepresentasikannya Sistematika pengkajian yang dilakukan pada bab ini meliputi, pertama menemukan ML dalam bentuk pola metaforis untuk emosi amarah/kemarahan, ketakutan, kebahagiaan, kesedihan dan cinta. Kemudian, menemukan MK yang memotivasi pemakaian ungkapan metaforis berpola yang merepresentasikannya.

Sebelum pembahasan lebih lanjut, ada baiknya dijelaskan bagaimana ML, pola metaforis, dan MK ditemukan. Mengingat belum adanya korpus BI yang dipublikasikan secara luas, misalnya British National Corpus (BNC) milik BIng, maka sebagai penelitian awal, penulis memutuskan untuk membangun sendiri korpus untuk tujuan penelitian ini. Korpus terdiri atas novel, cerita pendek, dongeng, lakon, monolog, dan naskah teater dan berjumlah 5.317.433 kata. Lima leksikal yang mewakili RT emosi dipilih dan 1000 sampel sitiran acak dicari dalam korpus menggunakan piranti lunak Word Smith Tools 5.0. Kata kunci pencariannya adalah cinta, amarah*/kemarahan*, ketakutan*, kebahagiaan*, kesedihan*. Kata kunci pencarian dengan tanda bintang (*) akan menghasilkan amarah/amarahku/mu/nya dan sebagainya. Pola pencarian dengan tanda bintang (*) untuk emosi selain cinta dipilih karena pencarian awal dengan kata misalnya kebahagiaan tidak sampai menghasilkan 1000 sitiran dan bahkan dengan menggantinya menjadi kebahagiaan* pun sitiran yang dihasilkan tetap di bawah 1000 meskipun sedikit bertambah dibandingkan dengan pola pencarian awal. Hanya ketakutan* yang akhirnya bisa menghasilkan 1000 sitiran. Sedangkan kata kunci cinta sendiri dapat menghasilkan 1000 sitiran tanpa menggunakan tanda 
bintang (*). Kemudian, amarah/kemarahan digabungkan karena sedikitnya sitiran yang dihasilkan jika hanya salah satu dari kedua kata tersebut yang digunakan. Intinya, pemilihan algoritma pencarian seperti yang dijelaskan sebelumnya bagi semua kata kunci bertujuan untuk memaksimalkan perolehan jumlah sitiran. Berikutnya, keberadaan sitiran ganda dihilangkan. Lalu dengan APM, pemakaian unsur leksikal RT dalam ekspresi dari RS, yang disebut dengan pola metaforis, diidentifikasi serta disaring ke dalam kelompok MK tertentu. Contohnya api amarah mencerminkan metaforan konseptual AMARAH ADALAH API.

Pola metaforis yang telah diidentifikasi ditampilkan dalam bentuk sitiran yang diabstraksi dari sitiran aslinya. Misalnya, bentuk verba ditampilkan apa adanya seperti pada sitiran, celah partisipan ditunjukkan dengan $\mathrm{X}$ atau $\mathrm{Y}$, dan pola yang mirip dipadatkan menggunakan garis miring untuk menyatakan pilihan, dan tanda kurung digunakan untuk mengapit elemen yang manasuka. Sementara itu, pola yang muncul lebih dari satu kali diberikan angka kekerapan kemunculan pada akhir pola dan diapit dengan kurung kurawal [...] dan kekerapan kemunculan seluruh pola yang merepresentasikan pemetaan konsep emosi ditulis sejajar dengan MK.

\subsection{Metafora AMARAH/ KEMARAHAN}

AMARAH/ KEMARAHAN merupakan konsep emosi yang mungkin paling banyak diteliti dari sudut pandang semantik kognitif (Kövecses, 2000:21). Penelitian yang menyangkut emosi amarah dapat ditemukan pada Lakoff (1987), King (1989), Matsuki (1995), Yu (1995) Kövecses (1986, 1995, 2000, 2002, 
2005, 2006, 2010), Deignan (2005), Stefanowitsch (2006), Gevaert (2007), Rajeg (2010a, 2010b), dan Oster (2010). Kövecses (2000:21) menyarikan hasil penelitiannya menyangkut emosi amarah BIng. dengan menampilkan dua belas pemetaan metafora untuk konsep AMARAH. Penelitian ini menggunakan acuan Kovecses (2000) sebagai representasi peneliti-peneliti lain mengingat Kovecses telah mendiskusikan kelima jenis emosi dalam penelitian ini dengan cara mapan. Agar tidak mengaburkan makna aslinya, pemetaan metafora beserta contoh ML yang telah ditetapkan oleh Kövecses (2000) ditampilkan dalam BI dan dalam bentuk aslinya, yaitu BIng. Demikian pula yang dilakukan untuk konsep KETAKUTAN, KEBAHAGIAAN, KESEDIHAN, dan CINTA pada sub-bab berikutnya.

(a) AMARAH ADALAH CAIRAN PANAS DALAM WADAH: Dia mendidih karena amarah. (ANGER IS A HOT FLUED IN A CONTAINER: She is boiling with anger.)

(b) AMARAH ADALAH API: Dia terbakar dengan pelan-pelan. Amarahnya membara. (ANGER IS FIRE: He's doing a slow burn. His anger is smoldering.)

(c) AMARAH ADALAH KEGILAAN: Pria itu gila karena amarah. (ANGER IS INSANITY: The man was insane with rage.)

(d) AMARAH ADALAH MUSUH DALAM SUATU PERJUANGAN: Saya berjuang melawan kemarahan saya. (ANGER IS AN OPPONENT IN A STRUGGLE: I was struggling with my anger.)

(e) AMARAH ADALAH BINATANG TAWANAN: Dia melepaskan kemarahannya. (ANGER IS A CAPTIVE ANIMAL: He unleashed his anger.)

(f) (AMARAH ADALAH BEBAN): Dia membawa kemarahannya bersamanya. (ANGER IS A BURDEN He carries his anger around with him.)

(g) PERILAKU AMARAH ADALAH PERILAKU BINATANG AGRESIF: Jangan menggeramiku! (ANGRY BEHAVIOR IS AGGRESSIVE ANIMAL BEHAVIOR: Don't snarl at me!) 
(h) PENYEBAB AMARAH ADALAH PELANGGARAN/ DOSA: Di sini saya menarik garis. (THE CAUSE OF ANGER IS TRESPASSING: Here I draw the line.)

(i) PENYEBAB AMARAH ADALAH GANGGUAN/ KEJENGKELAN FISIK: Dia sakit di leher.(THE CAUSE OF ANGER IS PHYSICAL ANNOYANCE: He's a pain in the neck.)

(j) AMARAH ADALAH KEKUATAN ALAM: Ini pertemuan yang penuh badai. (ANGER IS A NATURAL FORCE: It was a stormy meeting.)

(k) SESEORANG DALAM KEADAAN MARAH ADALAH MESIN YANG SEDANG HIDUP: Itu benar-benar membuat dia pergi. ( AN ANGRY PERSON IS A FUNCTIONING MACHINE: That really got him going.)

(1) AMARAH ADALAH ATASAN SOSIAL: Tindakannya diatur oleh amarah. (ANGER IS A SOCIAL SUPERIOR: His actions were completely governed by anger.) Kövecses (2000:21)

Sebelum berbicara lebih rinci tentang MK, ML atau ungkapan metaforis AMARAH/KEMARAHAN BI, perlu didiskusikan beberapa hal tentang MK dan ML yang telah dipaparkan oleh Kövecses (2000). Sejumlah ungkapan metaforis yang dicontohkan mengandung leksikal RT, seperti pada (a, c, d, e, f, l) dan yang lain tidak mengandung leksikal RT, seperti (g, h, i, j, k), kecuali (b) memuat dua contoh, yang satu dengan leksikal RT dan yang lain tanpa leksikal RT. Akibatnya, ungkapan metaforis yang tidak mengandung leksikal RT tidak mudah dikenali secara pasti RT mana yang sedang dibicarakan. Sebagai contoh, (b) yang dihubungkan dengan ranah AMARAH tidak jelas pembedanya jika dilihat dari satu contoh "He's doing a slow burn". Akan tetapi, pembedanya akan menjadi jelas jika dilihat dari "His anger is smoldering", karena penggunaan leksikal RT anger. Hal ini tidak berarti bahwa "He's doing a slow burn" tidak berhubungan dengan amarah. Akan tetapi, pemilihan contoh seperti itu tidak segera dapat membuat pembaca mengetahui RT mana yang sedang difokuskan. 
Stefanowitsch (2006:72) yang meneliti metafora emosi BIng. dengan metode korpus modern menemukan lebih banyak metafora dibandingkan dengan apa yang telah dipublikasikan oleh Kövecses (2000). Konsep AMARAH yang ditemukan oleh Stefanowitsch (2006), selain yang telah dibahas Kövecses menyangkut AMARAH SEBAGAI: UNSUR DALAM WADAH (BERTEKANAN), CAIRAN, PANAS/ DINGIN, UNSUR MURNI/ CAMPURAN, CAHAYA, KEGELAPAN, (INTENSITAS) TINGGI/ RENDAH, ORGANISME TERTIDUR, PENYAKIT, ISI PERUT, OBJEK TAJAM, dan TANAMAN.

\subsubsection{Metafora AMARAH/ KEMARAHAN dalam Kövecses (2000)}

Telah dijelaskan sebelumnya bahwa Kövecses (2000:21) telah mengidentifikasi 12 metafora AMARAH BIng dengan metode introspektif atau metode bukan korpus modern. Dengan menggunakan metode korpus modern dan APM yang diaplikasikan pada korpus BI, penelitian ini mampu menemukan sebagian besar metafora AMARAH/ KEMARAHAN yang telah dibicarakan dalam pustaka Kövecses (2000). Pemetaan yang telah dibicarakan dalam pustaka itu, tetapi tidak bermanifestasi dalam BI adalah AMARAH/ KEMARAHAN SEBAGAI PELANGGARAN/ DOSA (TRESPASSING), dan AMARAH KEMARAHAN SEBAGAI MESIN HIDUP (FUNCTIONING MACHINE).

Ada dua alasan yang diduga mendasari ketidakhadiran suatu pemetaan. Pertama, pemetaan seperti tersebut tidak pernah bermanifestasi dalam pola metaforis bahasa yang sedang diteliti. Kedua, karena jarangnya pemakaian metafora seperti itu sehingga tidak pernah muncul dalam 1000 sitiran (Stefanowitsch, 2006:79). Hal ini berarti bahwa ketidakhadiran suatu pemetaan 
hanya merupakan masalah penentuan sampel. Alasan lain yang juga diduga sebagai penyebab ketidakmunculan suatu pemetaan adalah alasan perbedaan budaya. Artinya, metafora yang ditemukan dalam suatu bahasa, tetapi tidak ditemukan pada bahasa lain dapat dipandang sebagai metafora yang khas budaya tertentu. Kemungkinan alasan pertama dan kedua dapat dikonfirmasikan dengan cara memeriksa korpus yang lebih besar, seimbang dan representatif. Hal ini tidak dilakukan dalam penelitian ini, mengingat korpus yang dibangun dan diteliti telah ditentukan besarnya seperti ini.

Ditemukan 10 metafora AMARAH/ KEMARAHAN yang memotivasi $248 \mathrm{ML}$ dalam korpus yang diteliti. Jumlah ini mewakili $26,56 \%$ dari seluruh metafora yang ditemukan melalui metode APM. Hal ini berarti bahwa penelitian Kövecses (2000) meluputkan sebagian besar metafora AMARAH yang potensial dapat ditemukan melalui APM.

Metafora AMARAH/ KEMARAHAN yang telah diidentifikasi oleh Kövecses (2000) dan juga ditemukan dalam BI dapat dipaparkan di bawah ini disertai dengan contoh-contoh ML yang merepresentasikannya. Sementara itu, pola metaforis dan pemetaannya secara lengkap dipaparkan pada tabel 5.2a di bawahnya. Metafora yang dimaksud ialah AMARAH/KEMARAHAN (/MENJADI MARAH) ADALAH:

(5-1) CAIRAN PANAS DALAM WADAH

a. Winne sudah lebih dulu meluapkan kemarahannya kepada Arisna dengan cara yang sadis.

b. [...] seakan di dalam dadanya telah mendidih darah kemarahan.

(5-2) API

a. Seluruh badanku panas! Panas terbakar api amarah! 
b. Matanya memancarkan api kemarahan, mencari [...].

(5-3) KEGILAAN (INSANITY)

a. [...] saya mabuk karena kemarahan kepada Pandawa.

(5-4) MUSUH/LAWAN DALAM SUATU PERJUANGAN

a. Yang akan dia pergunakan untuk menghadapi kemarahan Tuan.

b. Sekarang saya telah mengatasi kemarahan saya terhadap Pandawa.

(5-5) BINATANG TAWANAN (CAPTIVE ANIMAL)

a. Ranzel! Kendalikan amarahmu!

b. Kuti yang gampang sekali mengumbar amarah manakala ada hal yang membuatnya tidak senang.

(5-6) BEBAN

a. Kemarahan dewata tidak saja menimpa dirimu, [...]

b. Dengan suara pelahan tertindih amarah, dengan mata menyala, ia berkata cepat.

(5-7) PERILAKU BINATANG AGRESIF (AGGRESSIVE ANIMAL BEHAVIOUR)

a. "Bahkan lebih garang dari amarah maupun gejolak neraka jahim.".

b. Toji membuka pintu, disambut oleh raungan kemarahan, [...] .

(5-8) GANGGUAN FISIK (PHYSICAL ANNOYANCE)

a. Ia kerutkan gigi karena amarah.

b. Kemarahan menyebabkan napasnya tersengal.

(5-9) KEKUATAN ALAM

a. "Tapi hentikan dulu badai kemarahanmu itu, Buron!"

b. Karena itu ia berusaha meredakan kemarahan Iori.

(5-10) ATASAN SOSIAL (SOCIAL SUPERIOR)

a. Dhristharasthra telah bebas dari kemarahannya, [...].

b. "Atau karena menuruti kemarahanmu saja?"

Tabel 5.2a

MK Amarah/Kemarahan dalam Kövecses (2000) dan Realisasi Pola Metaforis BI

\begin{tabular}{llll}
\hline No & Metafora Konseptual & Pola metaforis & Kekerapan \\
\hline a. AMARAH/ & 1. kemarahan/ amarah (semakin/ begitu/dengan segera) & 30 \\
& KEMARAHAN & & menggelegak (membutuhkan penyaluran) [3], \\
(/MENJADI MARAH) & 2. darah X menggelegak oleh amarah, \\
ADALAH CAIRAN & 3. kemarahan membludak [2], \\
PANAS DALAM & 4. di dalam dadanya mendidih darah kemarahan, \\
WADAH & 5. kemarahan seperti lahar \\
\hline
\end{tabular}


6. amarah (yang) mendidih,

7. memuntahkan lahar amarah,

8. amarah/kemarahan bagaikan kepundan gunung,

9. meluapkan kemarahan (kepada Y) [2],

10. X luapkan kemarahan,

11. kemarahan meluap (di wajah X) [8],

12. (di hati $\mathrm{X}$ berisi) amarah yang meluap-luap/meruap [3],

13. luapan kemarahan/amarah (dilampiaskan kepada Y) [5]

\begin{tabular}{|c|c|}
\hline $\begin{array}{l}\text { b. } \\
\text { AMARAH/ } \\
\text { KEMARAHAN } \\
\text { (/MENJADI MARAH) } \\
\text { ADALAH API }\end{array}$ & $\begin{array}{l}\text { 1. api amarah [4], } \\
\text { 2. panas terbakar/dibakar terus oleh api amarah [2], } \\
\text { 3. X (merah hitam) dibakar (oleh) (api) kemarahan/ amarah } \\
\text { (dan cemburu) [5], } \\
\text { 4. terbakar oleh amarah, } \\
\text { 5. api amarah panas membakar, } \\
\text { 6. X menyemburkan/memancar- kan api kemarahan [2], } \\
\text { 7. ledakan api kemarahan, } \\
\text { 8. kobaran api amarah, } \\
\text { 9. X (redakan/) padamkan api amarah [2], } \\
\text { 10. amarah padam, } \\
\text { 11. api amarah/kemarahan berkobar-kobar [3], } \\
\text { 12. (emosi) kemarahan berkobar/bergelora [2], } \\
\text { 13. mengobarkan amarah, } \\
\text { 14. amarah (dan kecewa) seperti kobaran api membakar X, } \\
\text { 15. kemarahan/ amarah membakar wajah/hati X [2], } \\
\text { 16. baranya X dalam amarah (yang membakar X, } \\
\text { 17. kemarahan/amarah meng-/ bergejolak (di dalam dada) [2], } \\
\text { 18. meredakan/merasakan/menahan gejolak kemarahan [3], } \\
\text { 19. bara kemarahan, emosi kemarahan/ amarah membara [2], } \\
\text { 20. kemarahan tersulut [2], } \\
\text { 21. menyulut amarah/kemarahan [6], } \\
\text { 22. X tersulut (oleh) kemarahan [2], } \\
\text { 23. X mengibaskan/menyiram kemarahan/amarah [2], } \\
\text { 24. obor adalah penanda kemarahan }\end{array}$ \\
\hline
\end{tabular}
c. AMARAH/
KEMARAHAN
(/MENJADI MARAH)
ADALAH KEGILAAN
(INSANITY)

1. X mabuk karena amarah

d. AMARAH/

KEMARAHAN

(/MENJADI MARAH)

ADALAH MUSUH/

LAWAN DALAM

SUATU PERJUANGAN
1. (emosi dan) amarah merupakan/adalah musuh/lawan [2],

2. X (di) selamat(kan) dari (amukan) amarah/kemarahan [2],

3. (emosi/kesedihan dan) amarah/kemarahan mengganggu/ mencelakakan X [2],

4. X menjadi/ adalah korban (dari) kemarahan/amarah [3],

5. amarah timbulkan korban,

6. X bertikai/bertempur dengan/meladeni/menghadapi/ mengimbangi/mengatasi/menindas/menyergah kemarahan/ amarah [15],

7. pertempuran antara $\mathrm{X}$ dan nafsu amarah,

8. X dilibas/disergap amarah [2],

9. amarah/kemarahan mengakibatkan kekalahan/ 
mengalahkan Y [2],

10. kemarahan melemah,

11. kesumat amarah,

12. X membalaskan kemarahan,

13. X terancam (oleh)/tergebah kemarahan/amarah [3],

14. X mengalah pada kemarahan,

15. jangan memberi kesempatan pada kemarahan untuk membunuh,

16. reaksi amarah,

17. amarah merucah/melenyapkan X [2],

18. X khawatir akan/dengan/takut akan/terhadap/pada amarah/ kemarahan [6],

19. kemarahan tak gentar oleh $X$,

20. X dikuasai/ (nyaris) tidak bisa menguasai amarah [3],

21. (jangan biarkan) amarah/ kemarahan menguasai X [3],

22. X didera kemarahan/amarah [2],

23. kemarahan menghantam $\mathrm{X}$

\begin{tabular}{ll}
\hline e. & AMARAH/ \\
KEMARAHAN \\
(/MENJADI MARAH) \\
ADALAH BINATANG \\
TAWANAN (CAPTIVE \\
ANIMAL)
\end{tabular}

1. amarah tidak terkendali/kehilangan kendali [2],

2. kendalikan amarah [2],

3. X (belum mampu/[hampir] t[id]ak dapat [lagi]/harus bisa) mengendalikan amarah/kemarahan [6],

4. X (tidak dapat) mengontrol kemarahan (dan kesedihan),

5. X memelihara kemarahan,

6. X (tanpa/ jangan) (meng) umbar kemarahan/amarah [5]

\begin{tabular}{lll}
\hline f. AMARAH/ & 1. kemarahan menimpa X, \\
KEMARAHAN & 2. X tertindih amarah, \\
(/MENJADI MARAH) & 3. menjatuhkan amarah (ke)pada X [2], \\
ADALAH BEBAN & 4. kemarahan demikian hebat untuk ditanggung sendirian
\end{tabular}

\begin{tabular}{lll}
\hline g. AMARAH/ & 1. X lebih garang dari amarah, & 10 \\
KEMARAHAN & 2. X beringas oleh amarah, \\
(/MENJADI MARAH) & 3. raungan/(suara) $($ ke $)$ geram(an) amarah/kemarahan $[8]$ \\
ADALAH PERILAKU & & \\
BINATANG AGRESIF & & \\
(AGGRESSIVE ANIMAL & \\
BEHAVIOUR)
\end{tabular}
h. AMARAH/
KEMARAHAN
(/MENJADI MARAH)
ADALAH
PELANGGARAN/ DOSA
(TRESPASSING)

\begin{tabular}{lll}
\hline i. & AMARAH/ & 1. X ditingkahi amarah, \\
KEMARAHAN & 2. X menggigil oleh amarah, \\
(/MENJADI MARAH) & 3. (X dihiasi) kerutan amarah, \\
ADALAH GANGGUAN & 4. X menggertakkan/ kerutkan gigi oleh/ karena kemarahan/ \\
$\begin{array}{ll}\text { FISIK (PHYSICAL } & \text { amarah [2], } \\
\text { ANNOYANCE) } & \text { 5. wajahnya tegang dengan kemarahan, } \\
& \text { 6. kemarahan menyebabkan napasnya tersengal, } \\
& \text { 7. nafas memburu karena kemarahan }\end{array}$
\end{tabular}




\begin{tabular}{|c|c|}
\hline $\begin{array}{ll}\mathrm{j} . & \text { AMARAH/ } \\
& \text { KEMARAHAN } \\
& \text { (/MENJADI MARAH) } \\
& \text { ADALAH KEKUATAN } \\
& \text { ALAM }\end{array}$ & $\begin{array}{l}\text { 1. badai kemarahan }[3], \\
\text { 2. reda(nya) (emosi) kemarahan/amarah }[2], \\
\text { 3. kemarahan/amarah menjadi reda/ mereda/reda/surut [23], } \\
\text { 4. X meredakan kemarahan/amarah }[12], \\
\text { 5. kemarahan diredakan, } \\
\text { 6. angin/topan kemarahan }[2], \\
\text { 7. guntur/taufan/(melompat ke dalam) banjir amarah }[3], \\
\text { 8. X tersesat dalam pusaran/dibawa/larut dalam arus } \\
\text { kemarahan }[3], \\
\text { 9. dada X mengombak oleh amarah }[2], \\
\text { 10. kemarahan melanda hatinya, } \\
\text { 11. X dilanda kemarahan }[2], \\
\text { 12. amarah surut, gemuruh amarah, } \\
\text { 13. mengalirkan gemuruh amarah bagaikan banjir bandang, } \\
\text { 14. gelombang kemarahan/amarah }[2]\end{array}$ \\
\hline
\end{tabular}
k. AMARAH/
KEMARAHAN
(/MENJADI MARAH)
ADALAH MESIN HIDUP
(FUNCTIONING
MACHINE)
1. AMARAH/
KEMARAHAN (/MENJADI MARAH)
ADALAH ATASAN
SOSIAL (SOCIAL
SUPERIOR)

1. X menuruti kemarahan [2],

2. kemarahan diwakili oleh $\mathrm{X}$,

3. amarah tiada diindahkan $\mathrm{Y}$,

4. X (ter)bebas/terlepas dari kemarahan [3]

\subsubsection{Metafora AMARAH/ KEMARAHAN yang Tidak Dibicarakan dalam Pustaka}

Selain mampu menemukan sebagian besar metafora AMARAH yang telah diidentifikasi oleh Kövecses (2000), penelitian ini juga berhasil menemukan lebih banyak lagi metafora AMARAH yang tidak dibicarakan dalam temuan Kövecses (2000). Ditemukan 19 metafora AMARAH lain yang direpresentasikan dengan 397 pola metaforis atau $42,51 \%$ dari jumlah metafora AMARAH seperti pada $(23-41)$. Setiap MK diberikan contoh ML untuk mewakili metafora yang ditemukan. Pola metaforis untuk amarah selengkapnya ditampilkan dalam bentuk tabel pada tabel 
5.2b. Metafora yang dimaksud adalah AMARAH/KEMARAHAN (/MENJADI MARAH)

ADALAH:

(5-11) UNSUR DALAM WADAH (BERTEKANAN)

a. Akhirnya, dalam ledakan kemarahan ia pun melompat keluar.

b. Ta Yun meletupkan amarahnya yang belum menyurut.

(5-12) CAIRAN DALAM WADAH

a. Fa Mulan tidak dapat membendung amarah yang mengubun di kepalanya.

b. Setelah puas melampiaskan amarahnya, Lara langsung kembali.

(5-13) UNSUR CAMPURAN

a. Ia menggigit bibir bawahnya dengan penuh kecewa, bercampur kemarahan, [...].

b. Larut kemarahan yang semula menggejolak dalam hati Banjar.

(5-14) PANAS/DINGIN (SUATU OBJEK)

a. Aku tahu jalan untuk mendinginkan kemarahan mereka (576).

b. Kata-kata Pak Ali masuk ke dalam hatinya. Menyejukkan panas amarahnya.

(5-15) CAHAYA

a. Wajahnya memancarkan sinar kemarahan.

b. Tak ada lagi sinar kemarahan di mata itu.

(5-16) (KE)GELAP(AN)

a. Matanya diliputi kemarahan atas kelancanganku.

b. Tadi mataku tertutup kabut amarah.

(5-17) OBJEK (TAK)TERSEMBUNYI/TAMPAK

a. Subianto menyembunyikan kemarahannya dengan senyuman.

b. [...] bola matanya jelas memperlihatkan kemarahan.

(5-18) UNGKAPAN VERBAL/BAHASA

a. Mulut Karmila yang mengeluarkan keluhan amarah, $[\ldots]$.

b. Dengan gerakan yang menterjemahkan kemarahan ia cabut cepukcepuk subang itu.

(5-19) MAKHLUK HIDUP/MANUSIA/ORGANISME (TERTIDUR/TENANG/DIAM)

a. [...] karena tahu hal itu akan membangkitkan kemarahan Osugi.

b. [...] sebuah peristiwa yang mengusik kemarahannya.

(5-20) TANAMAN

a. Wiku mulai merasakan amarahnya menjalari pembuluh darahnya. 
b. Duka mendalam membuahkan kemarahan.

(5-21) TINGGI/RENDAH

a. Pendekar Gila kali ini sudah pada puncak kemarahannya.

b. Amarahnya mengubun.

(5-22) KUATNYA AKIBAT DARI SUATU TENAGA (FISIK DESTRUKTIF)

a. Amarahnya serasa akan memecahkan ubun-ubunnya.

b. Sesudah menjatuhkan pukulan kemarahan terakhir ke kepalanya, $[\ldots]$

(5-23) KERAS/ LEMBUT

a. Dan luluhlah sudah amarah Sang Adipati, [...].

b. Perlahan gumpalan kemarahan yang menyesaki dada [...].

(5-24) SUARA (SOUND)

a. Ada nada amarah dalam kata-kata Mari.

b. "Keparaaat...!!" terdengar suara kemarahannya menggema memenuhi alam [...].

(5-25) MAKANAN/ MINUMAN

a. Gadis itu benar-benar menelan kemarahannya, seperti mengganjal tenggorokannya.

b. Mereka juga menikmati suguhan amarah yang sama.

(5-26) GAS/UDARA/NAFAS

a. Napas kemarahan sang Dewi Ular cukup membahayakan jika tidak segera dihindari.

b. Angin panas mulai datang dari hembusan napas kemarahan Marong terhadap dirinya, [...].

(5-27) PENYAKIT

a. Dia memang begitu kalau amarahnya sudah kumat.

b. Brion berhasil mengobati kemarahan Tante Cristy dengan menaburkan kenikmatan secara bertubi-tubi.

(5-28) ROH/ MAKHLUK SPIRITUAL

a. Tapi ketawa yang berulang-ulang itu telah menjelma menjadi amarah, $[\ldots]$.

b. Saya kalau dirasuk nafsu amarah sering lupa diri.

(5-29) NODA KOTORAN

a. Laksmana adikku, hapuslah amarahmu.

b. Hapuslah perasaan benci, iri hati, buruk sangka, loba, amarah, dan mabuk kekuasaan. 


\section{Tabel 5.2b}

\section{MK dan Pola Metaforis Amarah/Kemarahan yang Tidak Dibicarakan dalam Pustaka}

\begin{tabular}{|c|c|c|}
\hline No Metafora Konseptual & Pola Metaforis & pan \\
\hline 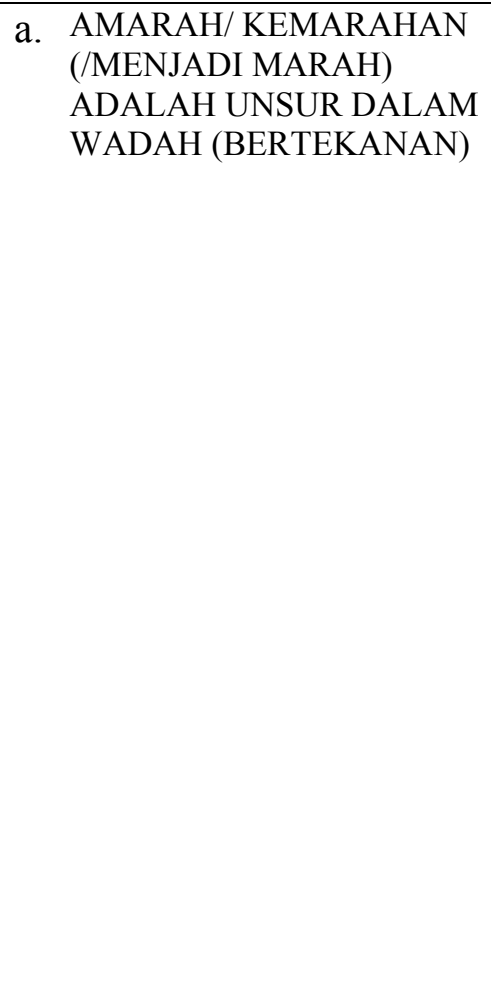 & 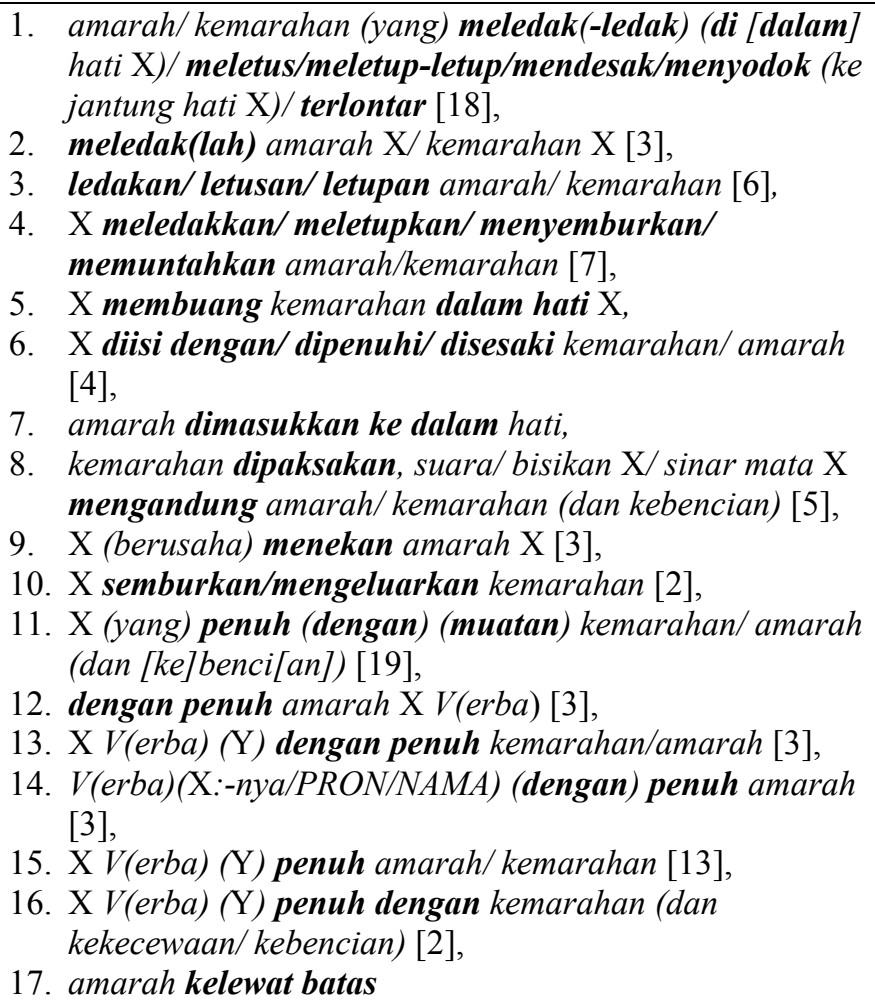 & 95 \\
\hline
\end{tabular}

b. AMARAH/ KEMARAHAN (/MENJADI MARAH) ADALAH CAIRAN DALAM WADAH
1. X (berusaha/ tidak dapat/ berhasil) menahan air mata/ membendung kemarahan/amarah [3],

2. X menuntaskan/menyalurkan amarah/kemarahan [5],

3. kemarahan tak terbendung/butuh penyaluran/meruah/ tumpah/menguap [5],

4. pelampiasan amarah/kemarahan (kepada X) [2],

5. X menumpahkan/(me-/nge-)lampiaskan/-in/ menuangkan kemarahan/amarah ([ke]pada/ke/dalam Y) [24],

6. amarah ditumpahkan $(\mathrm{X}) /$ dilimpahkan kepada $\mathrm{Y}$,

7. jebolnya tanggul kemarahan c. AMARAH/ KEMARAHAN (/MENJADI MARAH) ADALAH UNSUR CAMPURAN
1. EMOSI campur aduk dengan/bercampur kemarahan [2],

2. EMOSI dan amarah bercampur jadi/menjadi satu (di dalam jiwaX) [2],

3. KEJADIAN dan kemarahan menyatu menjadi $\mathrm{X}$,

4. kemarahan, EMOSI, dan EMOSI campur aduk menjadi satu/bercampur aduk [2], 
5. kemarahan (yang) membuncah [2],

6. kemarahan larut/mengendap [2],

7. X melarutkan kemarahan/amarah [2],

8. X menetralisir kemarahan
d. AMARAH/ KEMARAHAN
(/MENJADI MARAH)
1. $\mathrm{X} /$ wajah $\mathrm{X} /$ darah $\mathrm{X}$ merah (padam)/mendidih oleh
ADALAH PANAS/DINGIN amarah [3],
(SUATU OBJEK)
2. kemarahan mendingin,
3. X mendinginkan kemarahan,
4. X menyejukkan panas amarah,
5. hawa panas kemarahan,
6. hawa amarah (yang hangat),
7. X membakar(-bakar) kemarahan/amarah [4],
8. (me)rona kemarahan (dan kepanikan) [2],
9. bahang/membahangkan amarah [2]
e. AMARAH/ KEMARAHAN (/MENJADI MARAH)
ADALAH CAHAYA

1. amarah/kemarahan menyala [3],

2. (sinar) amarah/kemarahan (dan kekecewaan) terpancar dari muka/ mata X [3],

3. ([tak] ada) sinar kemarahan di mata,

4. pancaran amarah pada mata $\mathrm{X}$,

5. wajah/mata/pandangan/X memancarkan (sinar) kemarahan/ amarah (dan dendam) [6],

6. di kening X terbayang sinar kemarahan, terbias kemarahan dari mata dan raut wajah $\mathrm{X}$,

7. X meredam amarah/kemarahan [9],

8. X mencucuh/menerbitkan amarah [2],

9. binar amarah
f. AMARAH/ KEMARAHAN (/MENJADI MARAH)
1. kemarahan menyebar gelap ke/ terbayang di X [2], ADALAH (KE)GELAP(AN)
2. kemarahan membutakan X,
3. bayangan kemarahan,
4. X tertutup kabut/diliputi amarah/kemarahan (dan rasa benci) [4]

\begin{tabular}{ll}
\hline g. & AMARAH/ KEMARAHAN \\
& (MENJADI MARAH) \\
& ADALAH OBJEK \\
& (TAK)TERSEMBUNYI/ \\
& TAMPAK
\end{tabular}

1. X menyembunyikan/menyimpan/memendam kemarahan/ amarah [9],

2. X menunjukkan/(mem)perlihatkan/menampakkan/ menimbulkan/(meng)ungkapkan/mengisyaratkan/ memunculkan kemarahan/amarah (kepada/terhadap Y) (di matamu) [29],

3. X menggambarkan/mengekspresikan/mengutarakan/ memproklamirkan/mewartakan amarah/kemarahan [5],

4. kemarahan diungkapkan kepada Y,

5. kemarahan/ amarah timbul (dalam hati) [3],

6. amarah/kemarahan terlihat/terpendam/tampak pada/ kelihatan dari/terbaca dari/tergambar di $\mathrm{X}$ (wajah(nya)/ urat leher(nya)) [6],

7. X membaca/melihat (gelagat) kemarahan/amarah (di mata/wajah Y) [7],

8. ungkapan kemarahan

\begin{tabular}{lll} 
h. AMARAH/ KEMARAHAN & 1. kutukan/ keluhan kemarahan/ amarah, [2] & 4 \\
$($ MENJADI MARAH) & 2. kata-kata kemarahan, & \\
\hline
\end{tabular}




\begin{tabular}{|c|c|c|c|}
\hline & $\begin{array}{l}\text { ADALAH UNGKAPAN } \\
\text { VERBAL/BAHASA }\end{array}$ & 3. X menterjemahkan kemarahan & \\
\hline i. & $\begin{array}{l}\text { AMARAH/ KEMARAHAN } \\
\text { (/MENJADI MARAH) } \\
\text { ADALAH MAKHLUK } \\
\text { HIDUP/MANUSIA/ORGAN } \\
\text { ISME (TERTIDUR/ } \\
\text { TENANG/DIAM) }\end{array}$ & $\begin{array}{l}\text { 1. kemarahan/amarah bangkit [4], } \\
\text { 2. X membangkitkan kemarahan/(nafsu) amarah [7], } \\
\text { 3. X mengundang/mengusik/merangsang kemarahan [3], } \\
\text { 4. X memancing (datangnya) amarah/kemarahan [9], } \\
\text { 5. (jangan) pancing kemarahan, kemarahan (bagaikan) } \\
\text { terpancing [2], } \\
\text { 6. amarah/kemarahan terpancing [5], } \\
\text { 7. demi kepuasan amarah, } \\
\text { 8. persetubuhan amarah dan harga diri, } \\
\text { 9. biang kemarahan, X lahir dari kemarahan, } \\
\text { 10. amarah dan dendam adalah saudara sekandung, } \\
\text { 11. kemarahan melihat/mengabaikan/(tidak bisa) } \\
\text { menolong X [3], } \\
\text { 12. kemarahan berkata, } \\
\text { 13. kemarahan menunjukkan (bahwa), } \\
\text { 14. kaki kemarahan yang rapuh }\end{array}$ & 44 \\
\hline $\mathrm{j}$. & $\begin{array}{l}\text { AMARAH/ KEMARAHAN } \\
\text { (/MENJADI MARAH) } \\
\text { ADALAH TANAMAN }\end{array}$ & $\begin{array}{l}\text { 1. dendam dan amarah menyemak, } \\
\text { 2. kemarahan/ amarah menjalar ke/ menjalari tubuh/ } \\
\text { pembuluh darah, } \\
\text { 3. X meluruhkan amarah, } \\
\text { 4. X menanam emosi kemarahan, } \\
\text { 5. X membuahkan kemarahan }\end{array}$ & 6 \\
\hline $\mathrm{k}$. & $\begin{array}{l}\text { AMARAH/ KEMARAHAN } \\
\text { (/MENJADI MARAH) } \\
\text { ADALAH TINGGI/ } \\
\text { RENDAH }\end{array}$ & 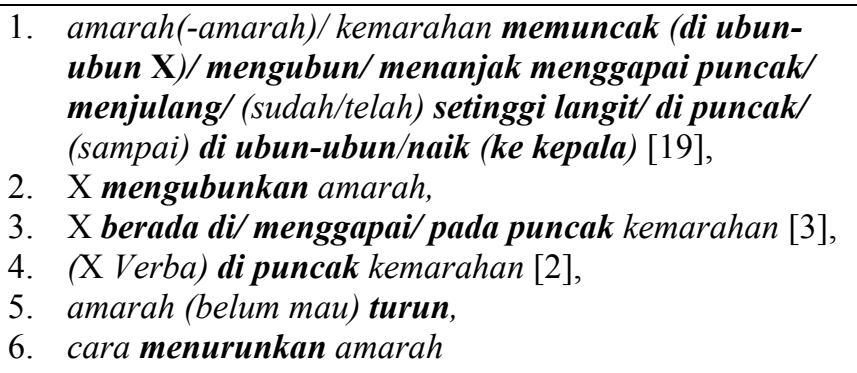 & 27 \\
\hline 1. & $\begin{array}{l}\text { AMARAH/ KEMARAHAN } \\
\text { (/MENJADI MARAH) } \\
\text { ADALAH KUATNYA } \\
\text { AKIBAT DARI SUATU } \\
\text { TENAGA (FISIK } \\
\text { DESTRUKTIF) }\end{array}$ & $\begin{array}{l}\text { 1. X (tersobek-sobek, tergulung-gulung, terbanting- } \\
\text { banting, diremas-remas hingga) luluh oleh amarah, } \\
\text { 2. X hancur karena kemarahan, } \\
\text { 3. amarah/ kemarahan meretakkan/memecahkan/ } \\
\text { menggetarkan /merusak X [4], } \\
\text { 4. (gelombang) getaran akibat/dari (emosi) kemarahan/ } \\
\text { amarah [2], } \\
\text { 5. kemarahan menjadikan/membuat X rusak/(menjadi) } \\
\text { bergetar [3], } \\
\text { 6. X menjatuhkan pukulan kemarahan ke } \mathrm{Y}, \\
\text { 7. kemarahan memperkuat daya kerja X, } \\
\text { 8. hasrat berubah menjadi kekuatan amarah, } \\
\text { 9. emosi kemarahan menimbulkan gelombang getaran } \\
\text { 10. }\end{array}$ & 15 \\
\hline $\mathrm{m}$. & $\begin{array}{l}\text { AMARAH/ KEMARAHAN } \\
\text { (/MENJADI MARAH) } \\
\text { ADALAH KERAS/ }\end{array}$ & $\begin{array}{l}\text { 1. X melunakkan amarah, } \\
\text { 2. X (badan) terlalu lunak untuk amarah, } \\
\text { 3. luluhlah amarah, }\end{array}$ & 6 \\
\hline
\end{tabular}


LEMBUT 4. gumpalan kemarahan [2],

5. kemarahan menggumpal di X (urat nadi)
n. AMARAH/ KEMARAHAN 1. jerit/lengking/nyanyian kemarahan/ amarah [3], (/MENJADI MARAH) $\quad$ 2. nada kemarahan/ amarah (pada kalimat/ dalam kata- ADALAH SUARA kata) [2],
(SOUND)
3. (terdengar/X mengeluarkan) suara kemarahan/ amarah (menggema) [3],
4. X membiramakan amarah deraunya,
5. X meneriakkan kemarahan (dan kegeraman),
6. X mendengar amarah

\begin{tabular}{|c|c|c|c|}
\hline & $\begin{array}{l}\text { AMARAH/ KEMARAHAN } \\
\text { (/MENJADI MARAH) } \\
\text { ADALAH MAKANAN/ } \\
\text { MINUMAN }\end{array}$ & $\begin{array}{l}\mathrm{X} \text { menelan/menyeruput/menikmati suguhan/mematangkan } \\
\text { amarah/kemarahan }\end{array}$ & 7 \\
\hline p. & $\begin{array}{l}\text { AMARAH/ KEMARAHAN } \\
\text { (/MENJADI MARAH) } \\
\text { ADALAH GAS/ UDARA/ } \\
\text { NAFAS }\end{array}$ & $\begin{array}{l}\text { 1. } \quad \text { amarah jadi udara, } \\
\text { 2. (hembusan) nafas kemarahan [2], } \\
\text { 3. X mendenguskan nafas amarah }\end{array}$ & 4 \\
\hline q. & $\begin{array}{l}\text { AMARAH/ KEMARAHAN } \\
\text { (/MENJADI MARAH) } \\
\text { ADALAH PENYAKIT }\end{array}$ & $\begin{array}{l}\text { 1. radang amarah, } \\
\text { 2. amarah } \text { kumat, } \\
\text { 3. X mengobati amarah }\end{array}$ & 3 \\
\hline r. & $\begin{array}{l}\text { AMARAH/ KEMARAHAN } \\
\text { (/MENJADI MARAH) } \\
\text { ADALAH ROH/MAKHLUK } \\
\text { SPIRITUAL }\end{array}$ & $\begin{array}{l}\text { 1. amarah merasuk di X(dada pemiliknya), } \\
\text { 2. X dirasuk/menjelma menjadi (nafsu) amarah [2] }\end{array}$ & 3 \\
\hline S. & $\begin{array}{l}\text { AMARAH/ KEMARAHAN } \\
\text { (/MENJADI MARAH) } \\
\text { ADALAH } \\
\text { NODA/KOTORAN }\end{array}$ & $\begin{array}{l}\text { 1. hapuslah amarah }[2] \text {, } \\
\text { 2. X berlepotan amarah }\end{array}$ & 3 \\
\hline
\end{tabular}

\subsubsection{Metafora AMARAH/ KEMARAHAN yang Munculnya Jarang}

Selain menemukan sejumlah besar metafora AMARAH yang tidak dibicarakan dalam pustaka, penelitian ini juga menemukan sejumlah MK yang munculnya tidak begitu sering dan tidak dibicarakan dalam pustaka. Meskipun munculnya ungkapan metaforis tertentu tidak begitu sering, tidak berarti bahwa kita tidak dapat menentukan MK yang mendasarinya. Satu kemunculan pola 
metaforis sudah cukup jelas mewakili MK tertentu. Hal ini menunjukkan bahwa APM tidak perlu meluputkan data yang ditemukan, meskipun jumlahnya kecil. Itu berarti, APM dapat menuntaskan setiap data yang muncul dalam korpus.

Ditemukan 8 metafora AMARAH yang direpresentasikan dengan 11 pola metaforis yang jarang digunakan. Jumlah tersebut mewakili $1,17 \%$ dari jumlah metafora AMARAH seperti digambarkan pada (5-30 - 5-37). Setiap MK diberikan satu contoh ML sebagai bukti adanya keterhubungan antara MK dan ML. Pola metaforis amarah selengkapnya ditampilkan dalam bentuk tabel pada tabel 5.2c. Metafora yang dimaksud adalah AMARAH/KEMARAHAN (/MENJADI MARAH) ADALAH:

(5-30) WARNA

Para tetangga Kayun hanya memandangi dengan seribu warna, warna kemarahan.

(5-31) BAU

Berturut-turut mati tertikam oleh keris dengan pamor berbau amarah itu.

(5-32) UNSUR PELEDAK

Kemarahan rakyat nantinya akan dipicu oleh masalah yang sangat sederhana, [...].

(5-33) DURASI

Barangkali kemarahan Srintil akan berkepanjangan.

(5-34) IKATAN

Ucapan permaisuri Turuk Bali itu menohok, tetapi sekaligus menjadi pembuka simpul kemarahannya.

(5-35) RACUN

[...], kau dipersilakan mencernakan bisa kemarahanmu.

(5-36) TEORI

Setelah mengibaskan jubahnya dengan satu entakan keras - jelas merupakan aplikasi kemarahannya. 
(5-37) OBJEK/ BENDA TAJAM

$[\ldots]$ kanvas kosong yang bisa digores amarah atau tawa $[\ldots]$.

Tabel 5.2c

MK dan Pola Metaforis Amarah/Kemarahan yang Munculnya Jarang

\begin{tabular}{|c|c|c|c|}
\hline & Metafora Konseptual & Pola Metaforis & Kekerapan \\
\hline a. & $\begin{array}{l}\text { AMARAH/ KEMARAHAN (/MENJADI } \\
\text { MARAH) ADALAH WARNA }\end{array}$ & $\begin{array}{l}\text { 1. kemarahan adalah warna hati, } \\
\text { 2. warna kemarahan }\end{array}$ & 2 \\
\hline b. & $\begin{array}{l}\text { AMARAH/ KEMARAHAN (/MENJADI } \\
\text { MARAH) ADALAH BAU }\end{array}$ & X beraroma/berbau kemarahan/ amarah & 2 \\
\hline & $\begin{array}{l}\text { AMARAH/ KEMARAHAN (/MENJADI } \\
\text { MARAH) ADALAH UNSUR PELEDAK }\end{array}$ & $\begin{array}{l}\text { 1. X memicu amarah, } \\
\text { 2. kemarahan dipicu oleh } \mathrm{X}\end{array}$ & 2 \\
\hline & $\begin{array}{l}\text { AMARAH/ KEMARAHAN (/MENJADI } \\
\text { MARAH) ADALAH DURASI }\end{array}$ & kemarahan (X) berkepanjangan & 1 \\
\hline & $\begin{array}{l}\text { AMARAH/ KEMARAHAN (/MENJADI } \\
\text { MARAH) ADALAH IKATAN }\end{array}$ & X menjadi pembuka simpul kemarahan & 1 \\
\hline f. & $\begin{array}{l}\text { AMARAH/ KEMARAHAN (/MENJADI } \\
\text { MARAH) ADALAH RACUN }\end{array}$ & bisa kemarahan & 1 \\
\hline & $\begin{array}{l}\text { AMARAH/ KEMARAHAN (/MENJADI } \\
\text { MARAH) ADALAH TEORI }\end{array}$ & X merupakan aplikasi kemarahan & 1 \\
\hline & $\begin{array}{l}\text { AMARAH/ KEMARAHAN (/MENJADI } \\
\text { MARAH) ADALAH OBJEK/BENDA } \\
\text { TAJAM }\end{array}$ & $\mathrm{X}$ digores amarah & 1 \\
\hline
\end{tabular}

\subsubsection{Metafora Struktur Peristiwa untuk AMARAH/ KEMARAHAN}

Penelitian ini menyertakan kajian metafora emosi yang termasuk MSP (Lakoff, 2006) karena metafora jenis ini bersifat umum dan berlaku untuk semua konsep emosi. Stefanowitsch (2006:73) menduga bahwa kemungkinan lain yang menyebabkan luputnya perhatian Kövecses terhadap sejumlah besar pola metaforis yakni tidak diikutkannya MSP ini. Dibuktikan dalam penelitian ini 
bahwa metafora jenis ini sangat banyak ditemukan dalam BI. Pemaparan menyangkut metafora kelompok ini ditampilkan di bawah ini.

Lakoff (1993:225 \& 2006:204) dan juga dapat ditemukan pada Stefanowitsch (2006:75), mengklasifikasikan dua sistem MSP: sistem lokasi, di mana perubahan dikonseptualisasikan sebagai "gerakan benda yang berubah dari satu lokasi ke satu lokasi lain/baru", dan sistem objek, di mana perubahan dikonseptualisasikan sebagai "gerakan objek yang menjauhi atau mendekati benda yang berubah.” Sementara itu, sub-kasus yang spesifik berupa sistem objek, disebut sistem kepemilikan, di mana "objek yang bergerak dikonseptualisasikan sebagai milik (possession) dan benda yang berubah sebagai pemilik (possessor)"”. Keterlibatan MSP menyangkut emosi amarah BI dapat dibuktikan melalui pola metaforis yang dipaparkan pada tabel 5.2d.

Ditemukan 2 MK yang direalisasikan dengan 20 ML yang menunjukkan bahwa AMARAH dikonseptualisasikan sebagai lokasi, dan pengalam berada di lokasi itu, bergerak atau digerakkan ke dalam lokasi atau ke luar lokasi tersebut. Metafora yang dimaksud adalah AMARAH/KEMARAHAN(/MENJADI MARAH) ADALAH:

(5-38) LOKASI (TERKUNGKUNG/ WADAH)

a. Tapi aku, apa aku harus merangkak di bawah kemarahanmu yang menjengkelkan?

b. Dalam kemarahannya sebenarnya Banjar butuh penyaluran, [...].

(5-39) BERTINDAK/ MELAKUKAN SESUATU DI DALAM SUATU LOKASI

a. Dalam kemarahannya, ia mengutuk mereka [...].

b. Wak Katok dalam kemarahan hatinya ketika itu mengatakan, [...]. 
Sementara itu, sistem objek dan sistem kepemilikan direalisasikan dengan $258 \mathrm{ML}$ yang dimotivasi oleh $15 \mathrm{MK}$. Hal ini mengindikasikan bahwa sebagian besar MSP diwakili oleh sistem objek dan sistem kepemilikan. Dengan sistem ini, keadaan marah dapat dikonseptualisasikan sebagai memiliki sebuah objek. Metafora tersebut adalah AMARAH/ KEMARAHAN (/MENJADI MARAH) ADALAH:

(5-40) LANDASAN/ DASAR/ FONDASI

a. Ya, apa sesungguhnya dasar kemarahanku pada gadis remaja yang baik hati itu?

b. Karena dilandasi oleh amarahnya sendiri, Seto terpental ke belakang.

(5-41) MELAKUKAN SESUATU DISERTAI/ DITEMANI DENGAN OBJEK (INSTRUMEN)

a. Gagak Bongol berkata dengan amarah yang terpaksa harus ditelan.

b. Kali ini ia bergerak dengan tenaga penuh dan kemarahan [...].

(5-42) (SECARA POTENSIAL) MEMBERI/MENTRANSFER SUATU OBJEK

a. Ada seseorang yang mengirimkan kemarahan gaibnya dari arah datangnya angin tersebut.

b. Tempik dan sorak, kemarahan dan hasutan, dialamatkan pada rombongan Ronggur.

(5-43) (SECARA POTENSIAL) MENERIMA/MENDAPAT SUATU OBJEK

a. Handoko menerima kemarahan lewat kabel itu.

b. Di sini mereka menerima kemarahan lagi dari Laksamana.

(5-44) KEPEMILIKAN

a. Kemarahan kalian itu adalah kemarahanku dulu.

b. Kemarahanmu itu tidak lebih dari kedengkian pribadi.

(5-45) OBJEK YANG DIARAHKAN/ DIGERAKKAN (KEPADA SESEORANG)

a. Aku tidak mau dijadikan sasaran kemarahan dia terus-terusan.

b. Menoleh ke bapak Kiyai, melempar kemarahannya secara langsung.

(5-46) OBJEK BERGERAK

a. Sebab amarah itu datang biasanya karena rasa tidak senang.

b. Kemarahannya tidak juga berhenti.

(5-47) KONTROL OBJEK BERGERAK

a. Aku mengepalkan tangan. Menahan amarah.

b. Kumala tetap tenang, mampu menahan kemarahannya. 
(5-48) PENGHALANG

a. Sampai detik ini saya masih mencoba mengindari amarah.

b. Marsinah tersendat oleh kemarahan yang mendadak mendesaknya.

(5-49) PERGERAKAN TERDORONG SUATU OBJEK (OTHER PROPELLED MOTION)

a. Ia berdiri, setengahnya digerakkan oleh kemarahan sendiri.

b. Melihat Rawana yang terdorong amarah, Akampana memberanikan diri berkata, $[\ldots]$.

(5-50) PENYEBAB

a. Amarah membuat kami lupa diri.

b. Kemarahan itu malah membangkitkan kecantikan [...].

(5-51) UKURAN/KUANTITAS

a. Kemarahanku lebih besar daripada yang pernah kualami sebelumnya.

b. Kemarahanku bertambah, Ibu, tiap kali aku mencoba [...].

(5-52) OBJEK DI SUATU LOKASI

a. Ada amarah di dada kami yang meledak-ledak.

b. Kemarahan dalam hatinya hal lain lagi.

(5-53) ADANYA/ KEBERADAAN/ KEHADIRAN FISIK SUATU OBJEK

a. [...] seolah kemarahannya tidak ada sama sekali.

b. Amarahnya belum mau juga sirna seluruhnya.

(5-54) OBJEK FISIK

a. Pengakuan dan penyerahan ini merubah kemarahan dewi Gandhari

menjadi kasih sayang.

b. Kalau kau bisa [...] bisa mewujudkan kemarahanmu.

Tabel 5.2d

MK dan Pola MSP untuk Amarah/Kemarahan

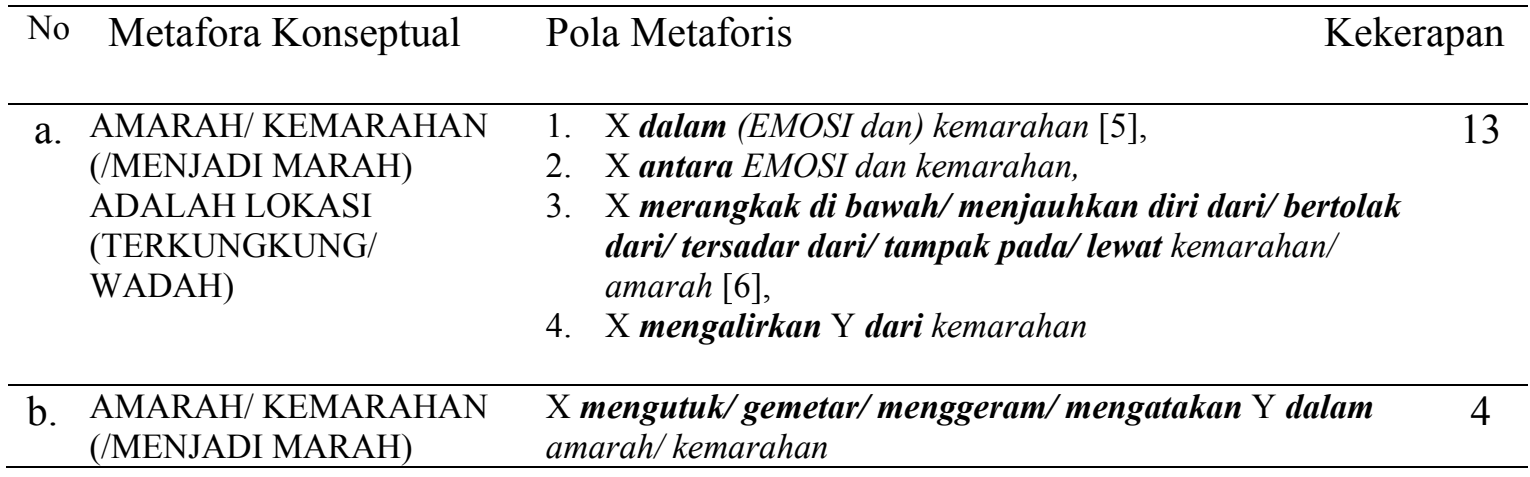


ADALAH BERTINDAK/

MELAKUKAN SESUATU

DI DALAM SUATU

LOKASI

c. AMARAH/ KEMARAHAN

1. dasar kemarahan,

(/MENJADI MARAH)

2. X dilandasi (oleh) amarah [2]

ADALAH LANDASAN/

DASAR/FONDASI

d. AMARAH/ KEMARAHAN (/MENJADI MARAH)

1. X membentak/melontarkan cacian/mengutuk/

ADALAH MELAKUKAN

SESUATU DISERTAI/ mencecar dengan kemarahan/amarah [5],

TEMANI DENGAN OBJEK (INSTRUMEN)

2. X berkata/bicara/berteriak dengan kemarahan/amarah (dan EMOSI) [5],

3. X bergerak/muncul/sibuk/memandang kepada $\mathrm{Y}$ dengan amarah/ kemarahan [4],

4. dibelah $\mathrm{X}(-$-nya)/dilemparkan $\mathrm{X} /$ dikejar $\mathrm{X}$ dengan kemarahan [3],

5. X ditimpali/diakhiri dengan kemarahan/amarah [2],

6. X iringkan/menyambut/menjalani/meninggalkan/ membanting/menjatuhkan/membunuh/memasuki $\mathrm{Y}$ dengan kemarahan/(rasa) amarah [8],

7. $\mathrm{X}(\mathrm{ku}$-) masuki/singkirkan $\mathrm{Y}$ dengan kemarahan/ amarah [2],

8. X dengan (EMOSI dan) kemarahan [2],

9. bicaralah/bunuh X tanpa (nafsu) amarah/kemarahan [2]

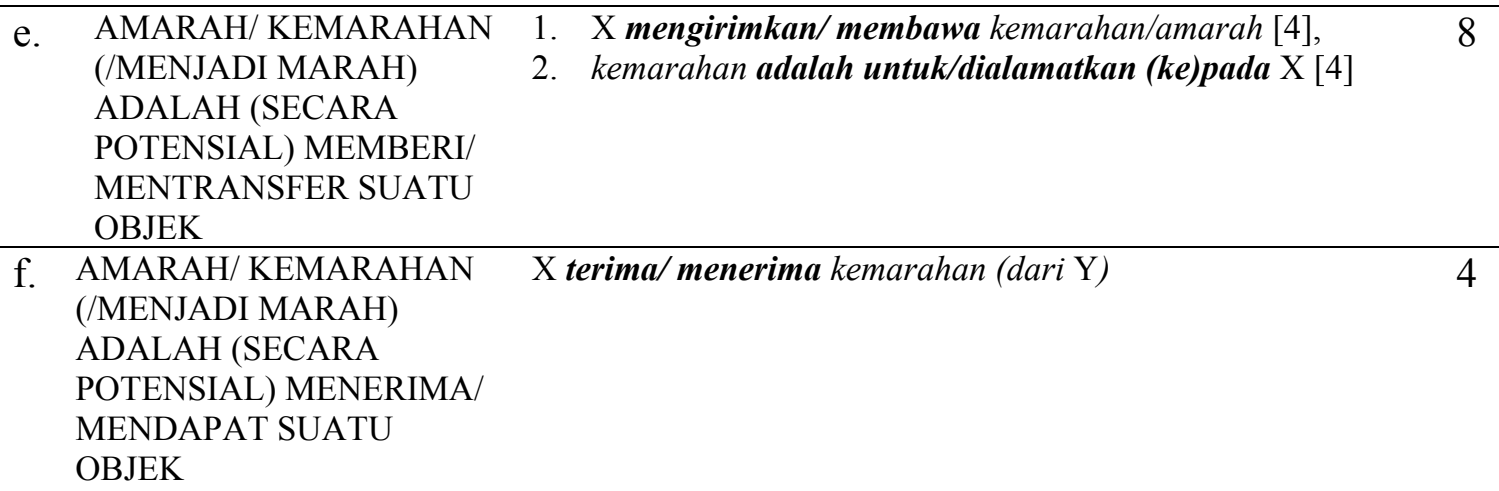

g. AMARAH/ KEMARAHAN (/MENJADI MARAH) ADALAH KEPEMILIKAN

1. X menggenggam/terlahir dengan deposit amarah [2],

2. X kehilangan amarah sendiri, kemarahanku/mu/nya (sendiri) [7],

3. kemarahan pronomina/nama diri/nomina umum [7],

4. amarahnya,

5. amarah pronomina/nama diri/nomina umum [6]

h. AMARAH/ KEMARAHAN (MENJADI MARAH)

1. kemarahan tertuju (ke)pada/ kepada X [5],

2. X mengarahkan tatapan kemarahan kepada $\mathrm{Y}$, ADALAH OBJEK YANG

3. X melempar/melontarkan/menggeser/membuang/ DIARAH/GERAKKAN menghempaskan kemarahan/amarah [6], (KEPADA SESEORANG)

4. (X adalah/menjadi/dijadikan) sasaran (bagi) kemarahan [4]

i. AMARAH/ KEMARAHAN 1 1. amarah/kemarahan datang/masuk/keluar/tak 


\begin{tabular}{|c|c|c|c|}
\hline & $\begin{array}{l}\text { (/MENJADI MARAH) } \\
\text { ADALAH OBJEK } \\
\text { BERGERAK }\end{array}$ & & $\begin{array}{l}\text { ketentuan arah/ke segenap arah /pergi/ berhenti/lewat } \\
{[9],} \\
\text { yang keluar adalah amarah, } \\
\text { jejak kemarahan }\end{array}$ \\
\hline $\mathrm{j}$. & $\begin{array}{l}\text { AMARAH/ KEMARAHAN } \\
\text { (/MENJADI MARAH) } \\
\text { ADALAH KONTROL } \\
\text { OBJEK BERGERAK }\end{array}$ & $\begin{array}{l}5 . \\
6 . \\
7 . \\
8 . \\
9 .\end{array}$ & $\begin{array}{l}\text { kemarahan ditunda, } \\
\text { (jangan) teruskan kemarahan, } \\
\mathrm{X} \text { (tidak) melanjutkan amarah, } \\
\mathrm{X} \text { (berusaha) menghentikan/(mau) mengakhiri/(tak) } \\
\text { mengurungkan/mencegah kemarahan/amarah [4], } \\
\text { kemarahan yang tertahan, } \\
\text { amarah/kemarahan (t[id]ak [bisa/dapat]) } \\
\text { tertahan/ditahan(-tahan) [4], } \\
\text { tahan(lah) amarah/kemarahan }[2], \\
\text { kemarahan (kepada } \mathrm{Y}) \text { harus X tahan, } \\
\mathrm{X}(t[\text { id] ak bisa/dapat/ [ber]kuasa/mampu) menahan } \\
\text { amarah/kemarahan }[60]\end{array}$ \\
\hline
\end{tabular}

k. AMARAH/ KEMARAHAN X menghindari/tersendat oleh amarah/ kemarahan 2 (/MENJADI MARAH) ADALAH PENGHALANG

1. AMARAH/ KEMARAHAN (/MENJADI MARAH) ADALAH PERGERAKAN TERDORONG SUATU OBJEK (OTHERPROPELLED MOTION)

1. X di-/terdorong/digerakkan/dipompa/terpancing 9 (oleh) kemarahan/ amarah [8],

2. dorongan amarah

m. AMARAH/ KEMARAHAN (/MENJADI MARAH) ADALAH PENYEBAB

1. kemarahan/amarah membuat/memaksa X V(erba) [6], 10

2. amarah/kemarahan mengejutkan/berimbas pada/ membangkitkan X [3],

3. kemarahan mendatangkan $\mathrm{X}$ bagi $\mathrm{Y}$

n. AMARAH/ KEMARAHAN (/MENJADI MARAH)

1. kemarahan (semakin) membesar/ (menjadi) lebih besar [3], ADALAH UKURAN/

2. (se)be(rapa/tapa) besar(nya) kemarahan/amarah [3], KUANTITAS

3. amarah/kemarahan bertambah/berlebihan / berlapiklapik/meluas/([se]makin) menjadi(-jadi) [9],

4. berbagai kemarahan(-kemarahan),

5. X mengikis habis/(pergi) menyisakan amarah [3],

6. sisa kemarahan [2],

7. kemarahan/amarah berkurang/menyusut/susut [4],

8. yang tersisa adalah amarah,

9. kurangi sedikit kemarahan

o. AMARAH/ KEMARAHAN

1. kemarahan pada/dari X/di luar [3],

(/MENJADI MARAH)

2. (ada) amarah/kemarahan di/dalam $\mathrm{X}$ (dada/mata/hati/ucapan) [5], SUATU LOKASI

3. pandangan/tatapan mata amarah [2],

4. (jangan) beri tempat bagi amarah

p. AMARAH/ KEMARAHAN

1. X merasakan amarah/kemarahan [2], (/MENJADI MARAH)

2. yang X rasakan adalah kemarahan, ADALAH ADANYA/

3. yang ada hanya amarah,

KEBERADAAN/

4. (tak) ada (nya) kemarahan [2], KEHADIRAN FISIK

5. kemarahan (t[id]ak) ada [2], 
SUATU OBJEK

q. AMARAH/ KEMARAHAN (/MENJADI MARAH) ADALAH OBJEK FISIK
6. kemarahan/amarah hilang/lenyap/sirna [7]

1. EMOSI/Xabstrak berubah menjadi kemarahan/amarah [6],

2. X me(r/ng)ubah kemarahan/amarah (men)jadi EMOSI/Zabstrak [2],

3. kemarahan/amarah berubah menjadi Yabstrak [2],

4. X mewujudkan/menandai/memanfaatkan kemarahan/amarah [3],

5. kemarahan menandakan X (klausa)

\subsection{Metafora KETAKUTAN}

Kövecses (2000:23) telah mengidentifikasi sebelas (11) metafora KETAKUTAN BIng. seperti pada (a--k) di bawah ini. Dinyatakan bahwa ketakutan ditandai dengan metafora emosi yang umum, seperti CAIRAN DALAM WADAH, MUSUH, BEBAN, dan juga ditandai dengan metafora yang sangat spesifik. Kelompok metafora yang spesifik termasuk MUSUH TERSEMBUNYI dan MAKHLUK SUPRANATURAL. Dalam BIng., CAIRAN DALAM WADAH bukan satusatunya cara untuk memahami ketakutan. Akan tetapi, ketakutan juga dipahami melalui metonimi konseptual, seperti MENURUNNYA SUHU TUBUH, GEJOLAK FISIK, dan MENINGKATNYA DENYUT JANTUNG dan lain-lain. Penelitian ini berfokus pada metafora semata dan tidak membicarakan metonomi. Berikut ini ditampilkan metafora yang dimaksud dengan terjemahan BI secara literal.

(a) KETAKUTAN ADALAH CAIRAN DALAM WADAH: Pandangan itu memenuhinya dengan ketakutan. (FEAR IS A FLUID IN A CONTAINER: The sight filled her with fear.)

(b) KETAKUTAN ADALAH MUSUH TERSEMBUNYI: (Ketakutan perlahanlahan merangkak naik pada dirinya. (FEAR IS A HIDDEN ENEMY: Fear slowly crept up on him.) 
(c) KETAKUTAN ADALAH PENYIKSA: Ibuku disiksa oleh ketakutan. (FEAR IS A TORMENTOR: My mother was tormented by fear.)

(d) KETAKUTAN ADALAH MAHLUK SUPRANATURAL: Dia dihantui oleh ketakutan. (FEAR IS A SUPERNATURAL BEING: He was haunted by fear.)

(e) KETAKUTAN ADALAH PENYAKIT: Jill sakit karena ketakutan. (FEAR IS AN ILLNESS: Jill was sick with fright.)

(f) KETAKUTAN ADALAH KEGILAAN): Jack gila karena ketakutan. (FEAR IS INSANITY: Jack was insane with fear.)

(g) SUBJEK KETAKUTAN ADALAH DIRI TERBAGI: Aku berada di samping diriku dengan ketakutan. (THE SUBJECT OF FEAR IS A DIVIDED SELF: I was beside myself with fear.)

(h) KETAKUTAN ADALAH MUSUH DALAM PERJUANGAN: Ketakutan menggenggam saya. (FEAR IS AN OPPONENT IN A STRUGGLE: Fear took hold of me.)

(i) KETAKUTAN ADALAH BEBAN: Ketakutan sangat membebani mereka. (FEAR IS A BURDEN: Fear weighed heavily on them.)

(j) KETAKUTAN ADALAH KEKUATAN ALAM: Dia dilanda kepanikan. (FEAR IS A NATURAL FORCE: She was engulfed by panic.)

(k) KETAKUTAN ADALAH ATASAN SOSIAL: Tindakannya didikte oleh rasa takut. (FEAR IS A SOCIAL SUPERIOR: His actions were dictated by fear.) (Kövecses (2000:23)

\subsubsection{Metafora KETAKUTAN yang Dibicarakan dalam Pustaka}

Setelah dilakukan penjelajahan korpus BI untuk menemukan metafora KETAKUTAN seperti yang dipaparkan pada (5.3a--k) di depan diketahui bahwa sebagian besar metafora KETAKUTAN yang telah diidentifikasi oleh Kövecses (2000:23), melalui metode bukan korpus modern, dapat ditemukan dalam BI dengan metode APM, kecuali KETAKUTAN SEBAGAI KEGILAAN, dan KETAKUTAN SEBAGAI OBJEK TAK LENGKAP/DIRI YANG TERPISAH. $\quad$ Ditemukan 7 metafora KETAKUTAN yang memotivasi 73 ungkapan linguistik BI. Jumlah ini mewakili 
$19,78 \%$ dari seluruh metafora KETAKUTAN yang ditemukan melalui metode APM. Hal ini berarti bahwa penelitian Kövecses (2000) meluputkan sebagian besar metafora KETAKUTAN yang potensial dapat ditemukan melalui APM.

Metafora KETAKUTAN yang telah diidentifikasi oleh Kövecses (2000) dan juga ditemukan dalam BI dapat dipaparkan di bawah ini disertai masing-masing dengan contoh ML. Sementara itu, pola metaforis dan pemetaannya secara lengkap dipaparkan pada tabel 5.3a. Metafora yang dimaksud adalah KETAKUTAN (/MENJADI TAKUT) ADALAH:

(5-55) CAIRAN DALAM WADAH

a. ... lama-kelamaan ketakutan orang pada mereka meruap terbang.

(5-56) MUSUH/LAWAN DALAM SUATU PERJUANGAN

a. Ia lebih banyak bertempur menaklukkan ketakutan dan kekecilan hati sendiri dan cemburu sendiri.

b. Dia mungkin mengadakan perlawanan atas ketakutan ini.

(5-57) ROH/ MAKHLUK SPIRITUAL

a. Ketakutan menghantui kami.

b. Kepalanya dihantui oleh berbagai ketakutan.

(5-58) PENYAKIT

a. Ketakutan anaknya tiba-tiba menular.

b. [...] anak-anak yang menderita ketakutan akan masa depan.

(5-59) BEBAN

a. Hatinya selalu dirundung ketakutan.

b. Orang-orang yang menanggung kelaparan dan kelelahan dalam tindisan ketakutan $[\ldots]$.

(5-60) KEKUATAN ALAM

a. Pandangan mata mereka padaku meredakan ketakutanku.

b. Ketakutan kembali datang melanda.

(5-61) ATASAN SOSIAL

a. Terpengaruh oleh kelemahan dan ketakutannya sendiri, [...].

b. Kamu mati untuk hidup di dalam jiwa kami untuk membabat habis raksasa supaya kita bebas dari ketakutan. 
Tabel 5.3a

MK Ketakutan dalam Kövecses (2000) dan Realisasi Pola Metaforis BI

\begin{tabular}{|c|c|c|c|}
\hline & Metafora Konseptual & Pola Metaforis & pan \\
\hline a. & $\begin{array}{l}\text { KETAKUTAN(/MENJADI } \\
\text { TAKUT) ADALAH } \\
\text { CAIRAN DALAM WADAH }\end{array}$ & ketakutan meruap & 1 \\
\hline b. & $\begin{array}{l}\text { KETAKUTAN(/MENJADI } \\
\text { TAKUT) ADALAH } \\
\text { MUSUH/LAWAN DALAM } \\
\text { SUATU PERJUANGAN }\end{array}$ & 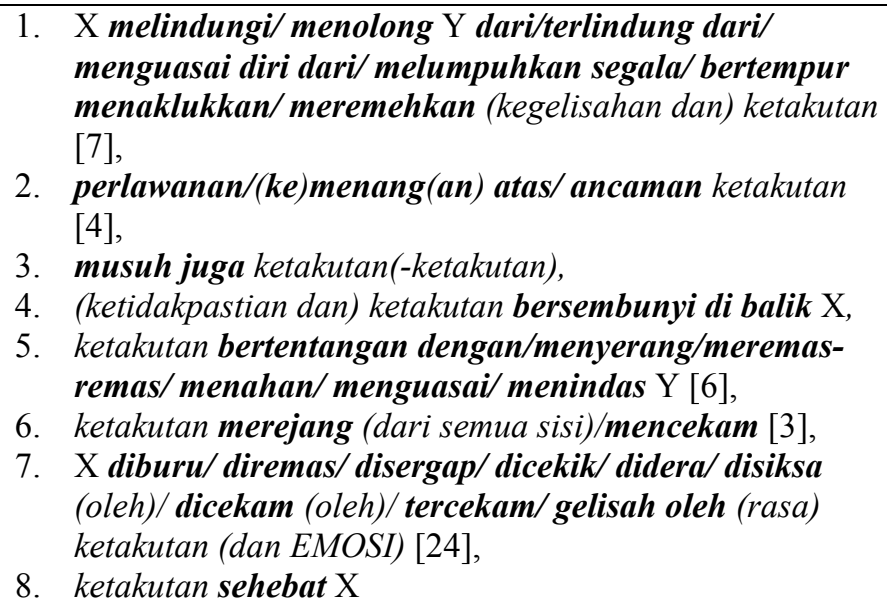 & 47 \\
\hline c. & $\begin{array}{l}\text { KETAKUTAN(/MENJADI } \\
\text { TAKUT) ADALAH } \\
\text { ROH/MAKHLUK } \\
\text { SPIRITUAL }\end{array}$ & $\begin{array}{l}\text { 1. X dihantui oleh ketakutan [2], } \\
\text { 2. ketakutan menghantu }(\mathrm{i} X) \text { [2] }\end{array}$ & 4 \\
\hline $\mathrm{d}$. & $\begin{array}{l}\text { KETAKUTAN(/MENJADI } \\
\text { TAKUT) ADALAH } \\
\text { PENYAKIT }\end{array}$ &  & 8 \\
\hline & $\begin{array}{l}\text { KETAKUTAN(/MENJADI } \\
\text { TAKUT) ADALAH } \\
\text { KEGILAAN (INSANITY) }\end{array}$ & - & 0 \\
\hline f. & $\begin{array}{l}\text { KETAKUTAN (/MENJADI } \\
\text { TAKUT) ADALAH OBJEK } \\
\text { TAK LENGKAP/ DIRI } \\
\text { YANG TERPISAH } \\
(\text { INCOMPLETE } \\
\text { OBJECT/DIVIDED SELF) }\end{array}$ & - & 0 \\
\hline & $\begin{array}{l}\text { KETAKUTAN(/MENJADI } \\
\text { TAKUT) ADALAH BEBAN }\end{array}$ & $\begin{array}{l}\text { 1. tindisan ketakutan, } \\
\text { 2. X dirundung ketakutan (dan kecemasan) [2] }\end{array}$ & 3 \\
\hline h. & $\begin{array}{l}\text { KETAKUTAN(/MENJADI } \\
\text { TAKUT) ADALAH } \\
\text { KEKUATAN ALAM }\end{array}$ & $\begin{array}{l}\text { 1. } \mathrm{X} \text { reda dari/meredakan ketakutan [2], } \\
\text { 2. X dilanda ketakutan }[3], \\
\text { 3. } \\
\text { ketakutan datang melanda }\end{array}$ & 6 \\
\hline
\end{tabular}



i. $\quad$ KETAKUTAN(/MENJADI $\quad$ 1. X bebas dari/terpengaruh oleh (kelemahan dan) 4
TAKUT) ADALAH
ATASAN SOSIAL ketakutan [3],
2. X membebaskan $\mathrm{Y}$ dari ketakutan (, kebimbangan, kekeliruan)

\subsubsection{Metafora KETAKUTAN yang Tidak Dibicarakan dalam Pustaka}

Ditemukan 12 metafora KETAKUTAN yang memotivasi 115 ungkapan linguistik yang tidak dibicarakan dalam pustaka yang dirujuk. Jumlah ini mewakili 31,17 \% dari seluruh metafora KETAKUTAN yang berhasil diidentifikasi. Metafora kelompok ini secara lengkap ditampilkan pada tabel 5.3b. Metafora tersebut adalah KETAKUTAN (/MENJADI TAKUT) ADALAH:

(5-62) UNSUR DALAM WADAH (BERTEKANAN)

a. Dia memandang berkeliling penuh ketakutan, tetapi tiba-tiba [...].

b. Dadanya terasa akan meledak karena ketakutan dan kengerian.

(5-63) CAIRAN

a. Aku merasakan tubuhku dialiri ketakutan luar biasa, [...].

b. Suatu getaran ketakutan yang tersembunyi akan mengaliri tubuhku.

(5-64) UNSUR CAMPURAN

a. Kau merasakan kesedihan bercampur ketakutan dan juga penyesalan atas [...].

b. Ketakutan yang amat kental bercampur duka [...].

(5-65) CAHAYA

a. Matanya menyorotkan sinar ketakutan.

b. Wajahnya memancarkan ketakutan yang teramat sangat.

(5-66) (KE)GELAP(AN)

a. Semuanya berada dalam bayangan ketakutan.

b. Mereka ikut menangis dan diliputi ketakutan setelah [...].

(5-67) OBJEK (TAK)TERSEMBUNYI/TAMPAK

a. Matanya blingsatan masih menampakkan sisa ketakutan.

b. Nafsu kian menutupi ketakutan Rafi'I.

(5-68) MAKHLUK HIDUP/MANUSIA/ORGANISME (TERTIDUR/ TENANG) a. Ia adalah sekedar hiasan tentang kerapuhan dan santapan bagi 
ketakutan yang terus dipelihara atas nama dunia.

b. [...] perhatian kami habis oleh ketakutan [...].

(5-69) (PERILAKU) BINATANG BUAS/TAWANAN

a. Brion tak mampu lagi mengendalikan emosi ketakutannya dan ketegangannya.

b. Seterusnya, kembali aku diterkam ketakutan yang menyengat [...].

(5-70) SUARA/ BUNYI (SOUND)

a. Tiba-tiba terdengar teriakan ketakutan seorang laki-laki.

b. Suroso meratap dengan nada ketakutan sekali.

(5-71) KUATNYA AKIBAT DARI SUATU TENAGA (FISIK YANG MENGHANCURKAN/DESTRUKTIF)

a. Orang itu berusaha bangkit, tetapi terjatuh oleh ketakutan yang lebih kuat mencengkeram nyalinya.

b. Jika kerbau ambruk karena ketakutannya sendiri, harimau [...].

(5-72) WARNA

a. Ketakutan masih menjadi warna yang paling menyolok pada wajahwajah mereka.

b. Rona ketakutan kian jelas di wajah cantik itu.

(5-73) NODA/ KOTORAN

a. Selalu berbalur ketakutan demi ketakutan, terutama yang memiliki anak gadis.

b. [...] memamerkan raut wajah berlepotan ketakutan dan ketidakmampuan.

Tabel 5.3b

MK dan Pola Metaforis Ketakutan yang Tidak Dibicarakan dalam Pustaka

\begin{tabular}{|c|c|c|c|}
\hline \multicolumn{4}{|c|}{ Kekerapan } \\
\hline a. & $\begin{array}{l}\text { KETAKUTAN(/MENJADI } \\
\text { TAKUT) ADALAH UNSUR } \\
\text { DALAM WADAH } \\
\text { (BERTEKANAN) }\end{array}$ & $\begin{array}{l}\text { 1. X (V[erba]) penuh ketakutan (dan/serta gugup/ } \\
\text { kesedihan) [7], } \\
\text { 2. X (otak) terlalu banyak dijejali ketakutan (dan } \\
\text { kecemasan), } \\
\text { 3. ketakutan (hati) menggeletar, } \\
\text { 4. X terbuka untuk/mengandung tenaga sugestif/ } \\
\text { menahan/meletupkan ketakutan (dan amarah) [4], } \\
\text { 5. dadanya (terasa akan) meledak karena ketakutan (dan } \\
\text { kengerian) }\end{array}$ & 14 \\
\hline b. & $\begin{array}{l}\text { KETAKUTAN(/MENJADI } \\
\text { TAKUT) ADALAH } \\
\text { CAIRAN }\end{array}$ & $\begin{array}{l}\text { 1. X(air mata) bersumber dari (kepiluan dan) ketakutan, } \\
\text { 2. sumber ketakutan, } \\
\text { 3. ketakutan mengaliri tubuh, } \\
\text { 4. tubuh dialiri ketakutan, }\end{array}$ & 14 \\
\hline
\end{tabular}


5. diresapi $\mathrm{X}($ nya) ketakutan,

6. X larut dalam ketakutan

c. KETAKUTAN(/MENJADI TAKUT) ADALAH UNSUR CAMPURAN
1. (ada) EMOSI bercampur ketakutan [2],

2. ketakutan (yang amat kental) bercampur (baur dengan) EMOSI [2],

3. X V(erba) bercampur ketakutan d. KETAKUTAN(/MENJADI TAKUT) ADALAH CAHAYA
1. mata(nya/X)/wajah(nya/X)/ pandang membiaskan/ menyorotkan sinar/memancarkan (perasaan) ketakutan (dan/atau EMOSI) [6],

2. pada mata X terpancar ketakutan (dan kegelisahan),

3. semburat ketakutan e. KETAKUTAN(/MENJADI TAKUT) ADALAH (KE)GELAP(AN)
1. (X berada dalam) bayangan ketakutan [2],

2. bayang-bayang ketakutan [2],

3. X dibayang-bayangi/diliptui ketakutan [2],

4. ketakutan membayangi/menyelimuti $\mathrm{Y}[3]$,

5. ketakutan menyebabkan wajahnya jadi ungu,

6. mata suram oleh ketakutan
f. KETAKUTAN (/MENJADI 1. airmuka/ekspresi ketakutan [2], TAKUT) ADALAH OBJEK 2. wajah X adalah gambar ketakutan (dan kengerian), (TAK)TERSEMBUNYI/TA

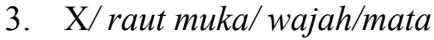 MPAK memperlihatkan/menampakkan/menimbulkan/ mengekspresikan/menggambarkan ketakutan (dan/atau EMOSI) [7],
4. di/ pada/ dalam X (wajah, mata, kata-kata) nampak/ tersirat/terbersit ketakutan (dan kekuatiran) [4],
5. X memperhatikan/melihat (ekspresi) ketakutan (dan kegelisahan) (pada keriput wajah/di sana) [4],
6. X membungkus (segenap)/menutup(i)/ menyembunyikan/menyimpan ketakutan (- ketakutan/Y]) [8],
7. ketakutan muncul [3]

\begin{tabular}{|c|c|c|c|}
\hline $\mathrm{g}$. & $\begin{array}{l}\text { KETAKUTAN(/MENJADI } \\
\text { TAKUT) ADALAH } \\
\text { MAKHLUK } \\
\text { HIDUP/MANUSIA/ORGAN } \\
\text { ISME (TERTIDUR/ } \\
\text { TENANG) }\end{array}$ & $\begin{array}{l}\text { 1. X mengembari/berjalan sebagai/mengundang/ } \\
\text { terselamatkan/menabahkan/adalah santapan bagi/ } \\
\text { habis oleh/dihinggapi (rasa) ketakutan [8], } \\
\text { 2. (kegentaran dan) ketakutan ditanamkan pada hati X, } \\
\text { 3. saraf ketakutan mulai bekerja }\end{array}$ & 10 \\
\hline h. & $\begin{array}{l}\text { KETAKUTAN (/MENJADI } \\
\text { TAKUT) ADALAH } \\
\text { (PERILAKU) BINATANG } \\
\text { BUAS/TAWANAN }\end{array}$ & $\begin{array}{l}\mathrm{X} \text { (tak) kontrol/(tidak mampu lagi) mengendalikan/ } \\
\text { mengurai/memburu/diterkam (emosi) ketakutan (dan } \\
\text { cemas, ketegangan) }\end{array}$ & 5 \\
\hline i. & $\begin{array}{l}\text { KETAKUTAN (/MENJADI } \\
\text { TAKUT) ADALAH } \\
\text { SUARA/BUNYI (SOUND) }\end{array}$ & $\begin{array}{l}\text { jerit/(terdengar) teriakan(-teriakan)/ bunyi erang/suara } \\
\text { ketakutan }\end{array}$ & 7 \\
\hline & $\begin{array}{l}\text { KETAKUTAN (/MENJADI } \\
\text { TAKUT) ADALAH } \\
\text { KUATNYA AKIBAT DARI }\end{array}$ & $\begin{array}{l}\text { 1. X terjatuh oleh/ambruk karena ketakutan [2] } \\
\text { 2. ketakutan (yang) dahsyat/luar biasa [4] }\end{array}$ & 6 \\
\hline
\end{tabular}


SUATU TENAGA (FISIK

YANG

MENGHANCURKAN/

DESTRUKTIF)

$\mathrm{k}$. KETAKUTAN (/MENJADI

TAKUT) ADALAH

1. warna X adalah ketakutan,

WARNA

2. ketakutan menjadi warna,

3. rona ketakutan kian jelas (di wajah $\mathrm{X}$ )

1. KETAKUTAN (/MENJADI X berbalur/berlepotan/penuh garis-garis ketakutan

\subsubsection{Metafora KETAKUTAN yang Jarang Digunakan}

Seperti halnya pada metafora AMARAH, penelitian ini juga menemukan sejumlah metafora KETAKUTAN yang munculnya jarang dalam korpus BI yang diteliti. Ditemukan 9 MK yang memotivasi 12 ML. Jumlah tersebut mewakili 3,25 \% metafora KETAKUTAN yang ditemukan dalam BI. Metafora ketakutan yang munculnya jarang didaftar pada tabel 5.3c. Metafora yang dimaksud adalah KETAKUTAN (/MENJADI TAKUT) ADALAH:

(5-74) SANTAPAN

Poh Wangi menikmati ketakutannya.

(5-75) KEDALAMAN

Ada ketakutan teramat dalam kalau-kalau dalam perang itu aku terbunuh.

(5-76) (GAS/ UDARA/) NAFAS

Aku terbangun dengan napas ketakutan.

(5-77) TINGGI

Ketakutan warga memuncak (909).

(5-78) BENDA/ OBJEK TAJAM

Ketakutan yang amat sangat menusuk seperti jarum panjang di dalam dadanya, $[\ldots]$.

(5-79) (OBJEK BER)BAU 
Keheningan menebarkan aroma ketakutan yang menguji keimanan.

(5-80) BENDA PENGHIAS

Suasana di Desa Bojong Sawo [...] dihiasi oleh ketakutan demi ketakutan.

(5-81) OBAT

Ketakutan telah menghilangkan rasa nyeri.

(5-82) GANGGUAN FISIK

Orang-orang tawanan yang akan dibawa ke situ, sudah kejang duluan oleh ketakutan.

Tabel 5.3c

MK dan Pola Metaforis Ketakutan yang Munculnya Jarang

\begin{tabular}{lllc}
\hline No & Metafora Konseptual & Pola Metaforis & Kekerapan \\
\hline a. & $\begin{array}{l}\text { KETAKUTAN (/MENJADI TAKUT) } \\
\text { ADALAH SANTAPAN }\end{array}$ & $\begin{array}{l}\text { X menikmati ketakutan(-ketakutan) (dan } \\
\text { kesedihan[-kesedihan]) }\end{array}$ & 2 \\
\hline b. & $\begin{array}{l}\text { KETAKUTAN (/MENJADI TAKUT) } \\
\text { ADALAH KEDALAMAN }\end{array}$ & (ada) ketakutan teramat dalam & 2 \\
\hline c. & $\begin{array}{l}\text { KETAKUTAN (/MENJADI TAKUT) } \\
\text { ADALAH (GAS/UDARA/) NAFAS }\end{array}$ & nafas ketakutan & 1 \\
\hline d. & $\begin{array}{l}\text { KETAKUTAN (/MENJADI TAKUT) } \\
\text { ADALAH TINGGI }\end{array}$ & ketakutan memuncak \\
\hline e. & $\begin{array}{l}\text { KETAKUTAN (/MENJADI TAKUT) } \\
\text { ADALAH BENDA/OBJEK TAJAM }\end{array}$ & $\begin{array}{l}\text { ketakutan menusuk seperti jarum panjang (di dalam } \\
\text { dadaX) }\end{array}$ & 1 \\
\hline f. & $\begin{array}{l}\text { KETAKUTAN (/MENJADI TAKUT) } \\
\text { ADALAH (OBJEK BER)BAU }\end{array}$ & X menebarkan aroma ketakutan \\
\hline g. & $\begin{array}{l}\text { KETAKUTAN (/MENJADI TAKUT) } \\
\text { ADALAH BENDA PENGHIAS }\end{array}$ & X dihiasi oleh ketakutan \\
\hline h. & $\begin{array}{l}\text { KETAKUTAN (/MENJADI TAKUT) } \\
\text { ADALAH OBAT }\end{array}$ & $\begin{array}{l}\text { ketakutan menghilangkan rasa nyeri } \\
\text { ADALAH GANGGUAN FISIK }\end{array}$ & 1 \\
\hline
\end{tabular}




\subsubsection{Metafora Struktur Peristiwa untuk KETAKUTAN}

MSP untuk konsep KETAKUTAN juga dikelompokkan menjadi dua, yaitu kelompok sistem lokasi dan kelompok sistem objek dan kepemilikan Lakoff (1993:225). Untuk kedua kelompok ini, ditemukan 15 MK yang mendorong 169 ML untuk emosi ketakutan. Metafora jenis ini mewakili 45,80 \% metafora KETAKUTAN yang ditemukan dalam korpus BI. Secara lengkap, metafora ketakutan yang termasuk MSP didaftar pada tabel 5.3d. Metafora KETAKUTAN yang tergolong metafora STRUKTUR PERISTIWA ditemukan cukup variatif. Metafora yang dimaksud adalah KETAKUTAN (/MENJADI TAKUT) ADALAH:

(5-83) LOKASI (TERKUNGKUNG/ WADAH)

a. Mereka itu di dalam ketakutan, takut akan dilihat orang.

b. Semua berada dalam keadaan ketakutan sehingga benda sederhana $[\ldots]$.

(5-84) BERTINDAK/MELAKUKAN SESUATU DI DALAM SUATU LOKASI

a. Orang yang menjerit histeris dalam ketakutan itu tak lain adalah Mak.

b. Linda dkk berbicara dalam ketakutan dan kepanikan!

(5-85) MELAKUKAN SESUATU DISERTAI/ DITEMANI DENGAN OBJEK (INSTRUMEN)

a. Orang-orang di sekitarnya memandang dengan kagum dan ketakutan.

b. Buron pun melompat turun dengan ketakutan dan malu [...].

(5-86) (SECARA POTENSIAL) MEMBERI/MENTRANSFER SUATU OBJEK Ada kekuatan yang sedang bekerja untuk menyebarkan ketakutan.

(5-87) (SECARA POTENSIAL) MENERIMA SUATU OBJEK

Sebaliknya hanya menginginkan ketegangan dan ketakutan hati saja.

(5-88) KEPEMILIKAN

a. Itu sekedar ketakutanmu saja.

b. Aku meneteskan air mata, merasakan ketakutan Chris.

(5-89) OBJEK YANG DIGERAKKAN

a. "Sudahlah, Nyai. Ketakutanku terbawa ke dalam mimpi."

b. Orang-orang yang hendak menangkapnya undur ketakutan. 
(5-90) OBJEK BERGERAK

a. Ketakutannya menerobos keluar dari tidurnya.

b. Akan tetapi ketegangan dan ketakutannya kembali dengan cepat, $[\ldots]$

(5-91) PERGERAKAN TERDORONG SUATU OBJEK (OTHER-PROPELLED MOTION)

a. Wak Katok berkelahi dengan hebat, didorong oleh ketakutannya dan kemarahan hatinya.

b. [...] terdorong ketakutannya menghadapi hari tua, aku tak bisa berbuat lain kecuali iba.

(5-92) HALANGAN (BAGI PERGERAKAN)

a. Maya, istriku, membentengiku dengan pagar-pagar ketakutan dan kesedihan miliknya.

b. [...] hatinya diremas dan terhimpit oleh batu besar ketakutan.

(5-93) PENYEBAB

a. Anda lupa bahwa ketakutan terkadang dapat menimbulkan keajaiban.

b. Ketakutannya atas kemungkinan jawaban tersebut, membuatnya bungkam selama puluhan tahun.

(5-94) UKURAN/ KUANTITAS

a. [...] dan juga melihat banyak ketakutan yang dialami oleh manusia.

b. Sebuah rasa ketakutan yang sempurna.

(5-95) OBJEK DI SUATU LOKASI

a. Sejujurnya, ada ketakutan dalam diriku jika aku harus benar-benar berpisah.

b. Tak ada ketakutan atau cemas sedikit pun di muka wajah Nyai Tanca

(5-96) ADANYA/ KEBERADAAN/ KEHADIRAN FISIK SUATU OBJEK

a. Ada ketakutan universal yang mempersatukan semua umat, [...].

b. Selamanya tiada ketakutan terhadap bahaya.

(5-97) OBJEK FISIK

a. Ketegangan sekaligus berubah jadi ketakutan. Apa kalian takuti?

b. [...] pikiran benar menjadi hilang, bertukar dengan ketakutan dan was-was. 
Tabel 5.3d

\section{MK dan Pola MSP untuk Ketakutan}

\begin{tabular}{|c|c|c|c|}
\hline No & Metafora Konseptual & Pola Metaforis & Kekerapan \\
\hline a. & $\begin{array}{l}\text { KETAKUTAN (/MENJADI } \\
\text { TAKUT) ADALAH } \\
\text { LOKASI } \\
\text { (TERKUNGKUNG/ } \\
\text { WADAH) }\end{array}$ & $\begin{array}{l}\text { 1. X memberi ruang amat luas berupa ketakutan, } \\
\text { 2. ketakutan jadi lahan subur penindasan, } \\
\text { 3. X (berada) (di) dalam (keadaan) ketakutan (dan } \\
\text { kegentaran, gelisah, [ke]cemas[an], khawatir) [9], } \\
\text { 4. X meninggalkan Y dalam (keadaan) ketakutan, } \\
\text { 5. (X) dari ketakutan, } \\
\text { 6. X jauh/terbangun dari/pelarian dari/ berujung ke } \\
\text { ketakutan [4], } \\
\text { 7. } \\
\text { X (mengembalikan } \mathrm{Y} \text { ) pada ketakutan }[2]\end{array}$ & e \\
\hline
\end{tabular}

b. KETAKUTAN (/MENJADI X menyertai Y/menunggu/menjerit/berbicara/berjalan/ 12 TAKUT) ADALAH Berlangsung/duduk/tunduk/hidup/minum dalam

BERTINDAK/MELAKUKA ketakutan (dan kegelisahan/kepanikan)

N SESUATU DI DALAM

SUATU LOKASI

c. KETAKUTAN (/MENJADI

TAKUT) ADALAH

MELAKUKAN SESUATU

DISERTAI/TEMANI

DENGAN OBJEK

(INSTRUMEN)

1. X memandang (ke Y)/menoleh (ke Y)/berpandangpandangan/menjerit-jerit/menjawab/(me)lari(kan) (diri) keluar/melompat turun dengan ketakutan [9],

2. seru/sahut/sentak/jawab X dengan ketakutan (dan kebingungan) [4],

3. X menyambut/membawa/memejamkan/mengangkat/ menarik/ditinggalkan/berkata pada Y dengan (rasa) ketakutan [8],

4. dengan ketakutan X mencoba/menguak/ menyampaikan Y/mengikuti Y/lari/berbisik [6],

5. X V(erba) tanpa ketakutan [2]

d. KETAKUTAN (/MENJADI X menyebarkan ketakutan

TAKUT) ADALAH

(SECARA POTENSIAL)

MEMBERI/MENTRANSFE

R SUATU OBJEK

e. KETAKUTAN (/MENJADI X menginginkan ketakutan

TAKUT) ADALAH

(SECARA POTENSIAL)

MENERIMA SUATU

OBJEK

f. KETAKUTAN (/MENJADI

TAKUT) ADALAH

1. ketakutanku/mu/nya (sendiri) [14],

KEPEMILIKAN

2. ketakutan pronomina/nama diri/(sen)diri) [4],

3. ketakutan milik/jadi bagian X [2],

4. ketakutan (telah) ditebus

2. X undur ketakutan [2] 
h. KETAKUTAN (/MENJADI 1. ketakutan menghampiri Y

TAKUT) ADALAH OBJEK

2. ketakutan sampai/kembali (dengan cepat)/menerobos keluar/melintas/berputar/berakhir [7], BERGERAK

3. gerak/akhir dari ketakutan [2]

i. KETAKUTAN (/MENJADI X didorong oleh/terdorong ketakutan

TAKUT) ADALAH

PERGERAKAN

TERDORONG SUATU

OBJEK (OTHER-

PROPELLED MOTION)

j. $\quad$ KETAKUTAN (/MENJADI TAKUT) ADALAH

1. X menghindari/mengesampingkan/terhimpit oleh batu 7

HALANGAN (BAGI besar/dibelit (rasa) ketakutan [4],

PERGERAKAN)

2. X membentengi Y dengan pagar-pagar ketakutan (dan kesedihan),

3. ketakutan menjadi penghalang bagi X,

4. dera melilit bersama ketakutan

k. KETAKUTAN (/MENJADI TAKUT) ADALAH PENYEBAB
1. ketakutan menimbulkan/menumbuhkan/memberi sumbangsih dalam X [4],

2. ketakutan(-ketakutan) membuat X (menjadi/ kayak) Y(Ajektiva/ Nomina) [4]
1. KETAKUTAN (/MENJADI TAKUT) ADALAH UKURAN/KUANTITAS
1. sebuah/setiap/semua/berbagai macam/banyak/ cukup(kah) ketakutan [6],

2. ketakutan(-ketakutan) (dan ketegangan/kesedihan) besar/ lebih banyak/(yang terlalu) berlebihan/(yang) amat sangat/menjadi-jadi [7],

3. X mengukur/mengurangi ketakutan [2],

4. ketakutan bertambah/melebihi/lebih besar/membesar/ terkikis/susut [6],

5. X membuat ketakutan berkurang sedikit demi sedikit, (yang ada cuma) ketakutan demi/dan ketakutan [2]

\footnotetext{
m. KETAKUTAN (/MENJADI TAKUT) ADALAH OBJEK DI SUATU LOKASI
}

1. ada ketakutan dalam/di X [4],

2. di mana-mana yang ada cuma ketakutan [1],

3. ketakutan pada $\mathrm{Y}$ [4]
n. KETAKUTAN (/MENJADI TAKUT) ADALAH ADANYA/KEBERADAAN/ KEHADIRAN FISIK SUATU OBJEK

1. (yang) (ti)ada ketakutan (dan kebencian) [4],

2. ketakutan hilang/lenyap [6],

3. (kekuatiran dan) ketakutan hilanglah sudah,

4. X melenyapkan/melipurkan/menghilangkan (kegelisahan/kebimbangan dan) ketakutan [3],

5. ketakutan dihilangkan oleh $\mathrm{Y}$,

6. X merasakan ketakutan [2] o. KETAKUTAN (/MENJADI TAKUT) ADALAH OBJEK FISIK
1. X (abstrak) berubah (men)jadi ketakutan [4],

2. X bertukar dengan/memanfaatkan ketakutan (dan waswas) [3] 


\subsection{Metafora KEBAHAGIAAN}

Kövecses (2000:24) telah menetapkan 15 konsep emosi KEBAHAGIAAN BIng. seperti pada (a--o) di bawah ini. Dinyatakan bahwa metafora KEBAHAGIAAN BIng. diungkapkan dengan beberapa RS metaforis yang umum, seperti BINATANG TAWANAN (CAPTIVE ANIMAL), MUSUH (OPPONENT), KEGILAAN (INSANITY) dan lain-lain. Konsep KEBAHAGIAAN juga ditandai dengan sejumlah RS yang lebih terbatas, seperti KE/DI ATAS (UP), CAHAYA (LIGHT), RASA TERPESONA/ TINGGI/ (PUNCAK) (RAPTURE/HIGH). Ada juga yang diklaim sebagai metafora spesifik emosi kebahagiaan, yaitu BINATANG YANG HIDUP BAIK ( $A N$ ANIMAL THAT LIVES WELL), dan SENSASI TUBUH YANG MENYENANGKAN (PLEASURABLE PHYSICAL SENSATION). Metafora KEBAHAGIAAN yang telah diidentifikasi dipaparkan di bawah ini dengan terjemahan BI secara literal.

(a) BAHAGIA ADALAH (DI/ KE) ATAS: Kita harus membahagiakan dia. (HAPPY IS UP: We had to cheer him up.)

(b) KEBAHAGIAAN ADALAH MELAYANG: Saya berada enam kaki di atas tanah. Saya begitu bahagia sehingga kaki saya tidak menyentuh tanah. (HAPPINESS IS BEING OFF THE GROUND: I am six feet off the ground. I was so happy, my feet barely touched the ground.)

(c) KEBAHAGIAAN ADALAH BERADA DI SURGA: Itu adalah surga dunia. (HAPPINESS IS BEING IN HEAVEN: That was heaven on earth.)

(d) BAHAGIA ADALAH CAHAYA: Dia ceria mendengar berita itu. (HAPPY IS LIGHT: She brightened up at the news.)

(e) KEBAHAGIAAN ADALAH VITALITAS/ KEKUATAN HIDUP: Dia hidup dengan sukacita. (HAPPINESS IS VITALITY: He was alive with joy.)

(f) BAHAGIA ADALAH KEHANGATAN: Itu menghangatkan semangat saya. (HAPPY IS WARM: That warmed my spirits.)

(g) KEBAHAGIAAN ADALAH KESEHATAN: Hal itu membuat saya merasa hebat. (HAPPINESS IS HEALTH: It made me feel great.) 
(h) SESEORANG YANG BAHAGIA ADALAH BINATANG YANG HIDUP DENGAN BAIK: Dia senang seperti babi di dalam kotoran. Dia tampak seperti kucing yang mendapat krim. (A HAPPY PERSON IS AN ANIMAL THAT LIVES WELL: He was happy as a pig in shit. He looks like the cat that got the cream.)

(i) KEBAHAGIAAN ADALAH SENSASI TUBUH YANG MENYENANGKAN: Aku tergelitik merah muda. (HAPPINESS IS A PLEASURABLE PHYSICAL SENSATION: I was tickled pink.)

(j) KEBAHAGIAAN ADALAH CAIRAN DALAM WADAH: Dia meluap dengan sukacita. (HAPPINESS IS A FLUID IN A CONTAINER: He was overflowing with joy.)

(k) KEBAHAGIAAN ADALAH BINATANG TAWANAN: Perasaannya yang bahagia melonggar. Dia tidak bisa menahan perasaan bahagianya. (HAPPINESS IS A CAPTIVE ANIMAL: His feelings of happiness broke loose. She couldn't hold back her feelings of happiness.)

(1) KEBAHAGIAAN ADALAH MUSUH DALAM PERJUANGAN: Dia tersingkir! Dia diliputi dengan sukacita. (HAPPINESS IS AN OPPONENT IN A STRUGGLE: He was knocked out! She was overcome by joy.)

(m) KEBAHAGIAAN ADALAH RASA TERPESONA/ TINGGI/ (PUNCAK: Aku mabuk kebahagiaan. (HAPPINESS IS A RAPTURE/HIGH: I was drunk with joy.)

(n) KEBAHAGIAAN ADALAH KEGILAAN: Mereka gila dengan kebahagiaan. (HAPPINESS IS INSANITY: They were crazy with happiness.)

(o) KEBAHAGIAAN ADALAH KEKUATAN ALAM: Kakinya tersapu. (HAPPINESS IS A NATURAL FORCE: He was swept off his feet.) (Kövecses, 2000:24)

\subsubsection{Metafora KEBAHAGIAAN yang Dibicarakan dalam Pustaka}

Penelitian ini berhasil mengidentifikasi 9 metafora KEBAHAGIAAN yang memotivasi 32 ungkapan linguistik yang menyangkut kebahagiaan dalam korpus yang diteliti. Jumlah ini mewakili 5,65 \% dari seluruh metafora kebahagiaan yang ditemukan. Hal ini berarti bahwa penelitian Kövecses (2000) meluputkan 
sebagian besar metafora KEBAHAGIAAN yang potensial dapat ditemukan melalui APM.

Metafora KEBAHAGIAAN yang telah diidentifikasi oleh Kövecses (2000:24) dan juga ditemukan dalam BI dapat dipaparkan pada (5-98 -5-106) disertai masing-masing dengan contoh ML yang merealisasikannya. Sementara itu, pola metaforis dan pemetaannya dipaparkan pada tabel 5.4a. Metafora yang dimaksud adalah KEBAHAGIAAN(/MENJADI BAHAGIA) ADALAH:

(5-98) (BERADA DI) ATAS (UP)

a. Bagi kami, kebahagiaan tertinggi yang dapat kami rasakan adalah apabila [...].

b. [...] karena kehormatan adalah mahkota kebahagiaan kami.

(5-99) BERADA DI ATAS TANAH/ MELAYANG

a. Serasa terayun aku ke langit dalam kebahagiaan ketika aku mendengar ucapan Kartini itu.

b. Seketika itu hati Dewi Ular berdesir indah, jiwanya bagaikan melayang dalam kebahagiaan, [...].

(5-100) BERADA DI SURGA

a. Tujuan kita Bersama tentu! Surga kebahagiaan!

(5-101) CAHAYA

a. Tampak secercah kebahagiaan sebentar memikul beban hidupnya.

b. Anna menatap kedua mata Nafisah memancarkan sinar kebahagiaan.

(5-102) CAIRAN DALAM WADAH

a. Seolah tidak ada cakrawala untuk luapan kegembiraan dan kebahagiaanku.

b. Bahkan, saat ini, aku merasakan kebahagiaan yang lebih meruah dan bergairah.

(5-103) BINATANG TAWANAN

a. Ular berbisa adalah segala lambang segala ilmu obat-obatan dan lambang segala kesehatan dan kebahagiaan.

(5-104) MUSUH/ LAWAN DALAM SUATU PERJUANGAN

a. Kebahagiaan, agaknya, tidak pernah berpihak kepadaku. 
b. Rupanya perempuan yang meneteskan air mata itu terus mengawasi aku dan kebahagiaanku.

(5-105) KEGILAAN

a. Dalam sejarah hanya ada dua yang betul-betul mencapai kemerdekaan ini. Kebahagiaan yang edan ini!

(5-106) KEKUATAN ALAM

a. Hatinya dingin. Ada gelombang kebahagiaan luar biasa yang bagai memusat di ubun ubun kepalanya.

b. Kami pun hanyut dalam tawa kebahagiaan.

Contoh (5-98--5-106) mengindikasikan bahwa metafora KEBAHAGIAAN BIng yang diidentifikasi oleh Kövecses (2000:24) dan tidak muncul dalam korpus BI adalah KEBAHAGIAAN SEBAGAI VITALITAS, KEBAHAGIAAN SEBAGAI KEHANGATAN, KEBAHAGIAAN SEBAGAI BINATANG YANG HIDUP BAIK, KEBAHAGIAAN SEBAGAI SENSASI FISIK YANG MENYENANGKAN, dan KEBAHAGIAAN SEBAGAI MABUK.

Tiga alasan yang telah dibicarakan pada 5.2.1 dipandang relevan sebagai penyebab ketidakmunculan pemetaan pada kasus metafora KEBAHAGIAAN yang dimaksudkan di atas.

\section{Tabel 5.4a}

MK Kebahagiaan dalam Kövecses (2000) dan Realisasi Pola Metaforis BI

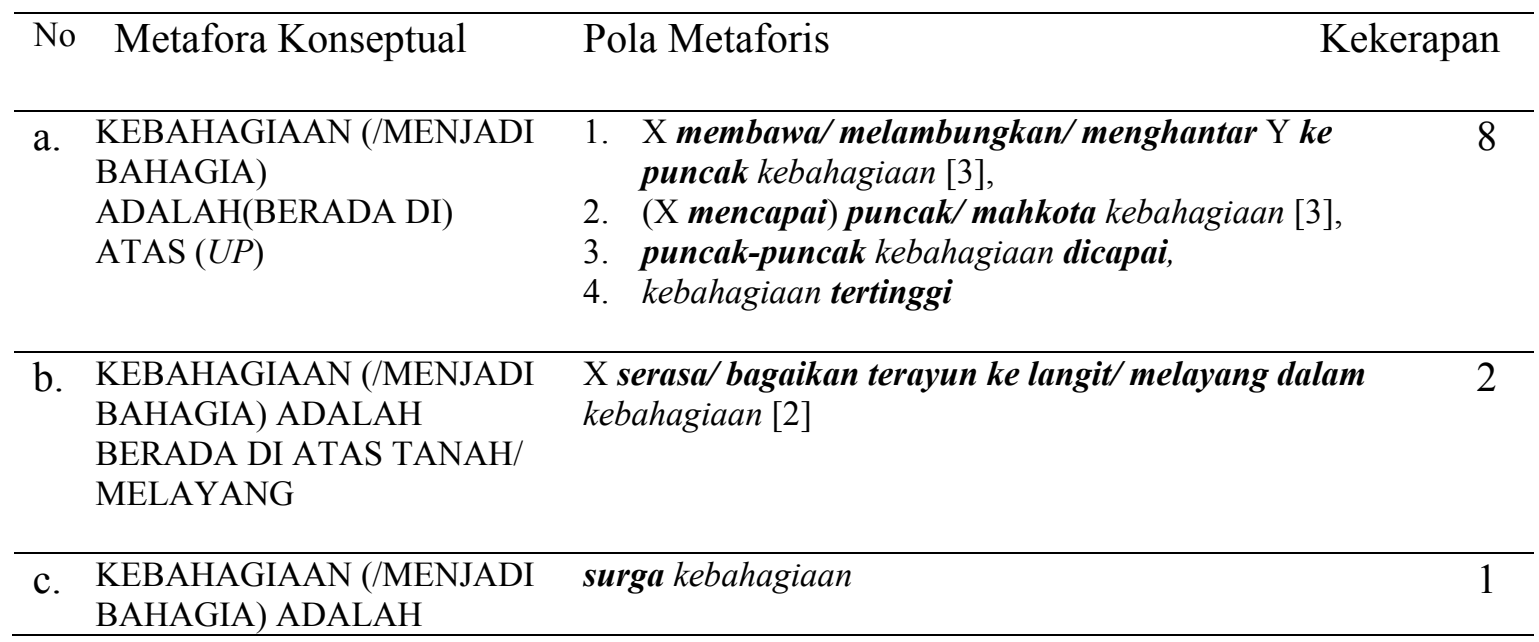


BERADA DI SURGA
d. KEBAHAGIAAN (/MENJADI 1. binar/secercah kebahagiaan [2], BAHAGIA) ADALAH 2. wajah/mata (X) memancarkan (sinar) kebahagiaan CAHAYA
1. binar/secercah kebahagiaan [2], 9 [2],
3. matahari kebahagiaan bersinar terang (di hatiX) [2],
4. pada/di wajah X memancar/terpamcar (sinar) kebahagiaan [3]

e. KEBAHAGIAAN (/MENJADI

BAHAGIA) ADALAH

VITALITAS

f. KEBAHAGIAAN (/MENJADI

BAHAGIA) ADALAH

KEHANGATAN

g. KEBAHAGIAAN (/MENJADI

BAHAGIA) ADALAH

BINATANG YANG HIDUP

BAIK (ANIMALS THAT LIVE

WELL)

h. KEBAHAGIAAN (/MENJADI

BAHAGIA) ADALAH

SENSASI FISIK YANG

MENYENANGKAN

(PLEASURABLE PHYSICAL

SENSATION)

i. KEBAHAGIAAN (/MENJADI BAHAGIA) ADALAH

1. luapan kebahagiaan,

CAIRAN DALAM WADAH

2. kebahagiaan yang lebih meruah,

3. kebahagiaan tumpah (bagai air hujan)

j. KEBAHAGIAAN (/MENJADI ular berbisa adalah lambang kebahagiaan BAHAGIA) ADALAH BINATANG TAWANAN
k. KEBAHAGIAAN (/MENJADI 1. X mati lemas oleh/mengawasi kebahagiaan [2], 3 BAHAGIA) ADALAH
2. kebahagiaan tidak pernah berpihak pada $\mathrm{X}$ MUSUH/LAWAN DALAM SUATU PERJUANGAN
1. KEBAHAGIAAN (/MENJADI BAHAGIA) ADALAH MABUK (RAPTURE/HIGH)
m. KEBAHAGIAAN (/MENJADI kebahagiaan yang edan BAHAGIA) ADALAH KEGILAAN

n. KEBAHAGIAAN (/MENJADI 1. gelombang kebahagiaan [3], BAHAGIA) ADALAH

2. X hanyut dalam (tawa) kebahagiaan KEKUATAN ALAM 


\subsubsection{Metafora KeBAHAgIAAN yang Tidak Dibicarakan dalam Pustaka}

Penelitian ini berhasil menemukan 15 metafora KEBAHAGIAAN yang mendorong munculnya $157 \mathrm{ML}$ tentang kebahagiaan yang sering digunakan dalam BI tetapi tidak dibicarakan dalam pustaka Kövecses (2000:24). Jumlah ini mewakili $27,74 \%$ dari jumlah metafora kebahagiaan yang ditemukan. Metafora kebahagiaan yang termasuk dalam kelompok ini secara lengkap dapat dicermati pada tabel $5.4 \mathrm{~b}$

Berikut ini dipaparkan metafora KEBAHAGIAAN yang tidak dibicarakan dalam pustaka Kövecses disertai dengan masing-masing contoh ML yang merealisasikannya. Metafora yang dimaksud adalah KEBAHAGIAAN (/MENJADI BAHAGIA) ADALAH:

(5-107) UNSUR DALAM WADAH (BERTEKANAN)

a. Marilah kita menuju hidup yang tenang dan penuh kebahagiaan.

b. Meledaklah kebahagiaan Ika mendengar jawaban ayahnya.

(5-108) CAIRAN

a. Namun, terlihat juga bahwa sumber kebahagiaan hidup tidaklah terwujud.

b. Ada kebahagiaan yang mengalir dalam hati perempuan tua itu.

(5-109) UNSUR CAMPURAN

a. Kebahagiaan itu pun membuncah ketika dia mengetahui bakal memiliki seorang kakak.

b. Cerita Sonya telah membuncahkan kebahagiaan di hatinya.

(5-110) (KE)GELAP(AN)

a. Kebahagiaan dan kesibukan sepanjang hari membuat semuanya terbungkus kabut.

b. Kebahagiaan meliputi hati Idayu.

(5-111) OBJEK (TAK)TERSEMBUNYI/ TAMPAK

a. Mengintip kebahagiaan ayahnya dalam rangkulan perempuan jalang itu.

b. Tapi aku melihat kebahagiaan dalam pernikahan keduanya. 
(5-112) MAKHLUK HIDUP/MANUSIA/ORGANISME (TERTIDUR/ TENANG)

a. Jika aku kembali aku hanya mengganggu kedamaian dan kebahagiaan anakku saja.

b. Sejenak saja aku lihat kebahagiaanku berganti rupa, pucat [...].

(5-113) TANAMAN

a. Orang-orang telah mencabut kebahagiaannya di setiap tempat.

b. Kesehatan adalah pangkal kebahagiaan.

(5-114) SANTAPAN (MAKANAN/ MINUMAN)

a. Mari kita duduk dan menikmati kebahagiaan ini.

b. Sebelum saudara-saudaraku senang dan Ibu ikut mengecap kebahagiaan atas jerih payahku nanti, Bu.

(5-115) (MEMBELI SUATU) OBJEK BERHARGA DAN METAFORA KOMERSIL LAINNYA

a. Tetapi uang tak bisa membeli kebahagiaan.

b. Aku telah menggadaikan kebahagiaanku.

(5-116) OBJEK RAPUH/ PECAH BELAH (FRAGILE/DESTROYABLE OBJECT)

a. Kalau mampu, ingin kuhancurkan kebahagiaan kalian.

b. Dadaku benar-benar sesak, seperti dihantam benda keras yang meluluhlantahkan serpihan kebahagiaanku.

(5-117) OBJEK ASLI/PALSU

a. Kebahagiaan yang kau inginkan adalah kebahagiaan semu, Karim.

b. Dyah Menur yang telah memberi arti kebahagiaan sejati.

(5-118) OBJEK DAMBAAN

a. Mereka merindukan kedamaian dan kebahagiaan.

b. Semua orang mengharapkan kebahagiaan mereka.

(5-119) OBJEK (TAK) LENGKAP

a. Kebahagiaan Ibnu Zaidun semakin lengkap.

b. Pokoknya kejutan kita ini akan semakin melengkapi kebahagiaan Pakde sekarang.

(5-120) DURASI

a. Tapi, apalah arti kebahagiaan sesaat yang hanya ber-landaskan nafsu.

b. Telah lalu semua dalam satu kata, seperti satu detik kebahagiaan, tapi terus terang, persetan segalanya.

(5-121) UNGKAPAN VERBAL/KATA-KATA

a. Kebahagiaan tinggalah kata-kata merdu didengar namun sukar diraih.

b. Kakek, wujudmu tetap saja tak nampak dan kebahagiaan yang kau 
janjikan sampai saat ini hanyalah obralan janji-janji semata.

Tabel 5.4b

MK dan Pola Metaforis Kebahagiaan yang tidak Dibicarakan dalam Pustaka

\begin{tabular}{|c|c|c|c|}
\hline & Metafora Konseptual & Pola Metaforis & pan \\
\hline a. & $\begin{array}{l}\text { KEBAHAGIAAN (/MENJADI } \\
\text { BAHAGIA) ADALAH } \\
\text { UNSUR DALAM WADAH } \\
\text { (BERTEKANAN) }\end{array}$ & $\begin{array}{l}\text { 1. X V(erba) (dengan) penuh (debar) kebahagiaan (dan } \\
\text { keyakinan) [8], } \\
\text { 2. denyut kebahagiaan, } \\
\text { 3. X (di)penuh(i) (dengan)/sarat (akan) kebahagiaan } \\
\text { [5], } \\
\text { 4. kebahagiaan penuh mengisi X, } \\
\text { 5. meledaklah kebahagiaan }\end{array}$ & 16 \\
\hline b. & $\begin{array}{l}\text { KEBAHAGIAAN (/MENJADI } \\
\text { BAHAGIA) ADALAH } \\
\text { CAIRAN }\end{array}$ & 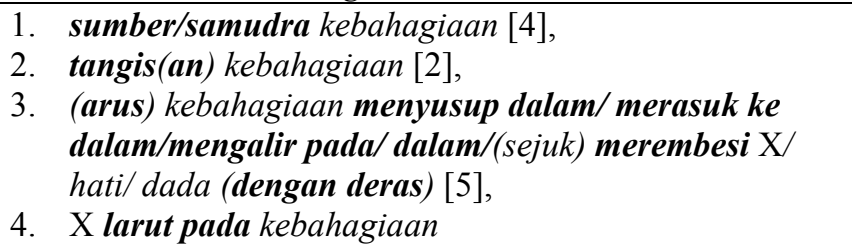 & 13 \\
\hline c. & $\begin{array}{l}\text { KEBAHAGIAAN (/MENJADI } \\
\text { BAHAGIA) ADALAH } \\
\text { UNSUR CAMPURAN }\end{array}$ & $\begin{array}{l}\text { 1. (tangis) kebahagiaan membuncah/berbuncah-buncah } \\
\text { [3], } \\
\text { 2. X membuncahkan/buncah oleh kebahagiaan (dalam } \\
\text { hatiX) [2] }\end{array}$ & 5 \\
\hline $\mathrm{d}$. & $\begin{array}{l}\text { KEBAHAGIAAN (/MENJADI } \\
\text { BAHAGIA) ADALAH } \\
\text { (KE)GELAP(AN) }\end{array}$ & $\begin{array}{l}\text { 1. X diliputi kebahagiaan }[2], \\
\text { 2. kebahagiaan mengelilingi/menyelimuti/meliputi X } \\
{[3],} \\
\text { 3. kebahagiaan membuat X terbungkus kabut }\end{array}$ & 6 \\
\hline e. & $\begin{array}{l}\text { KEBAHAGIAAN (/MENJADI } \\
\text { BAHAGIA) ADALAH OBJEK } \\
\text { (TAK) TERSEMBUNYI/ } \\
\text { TAMPAK }\end{array}$ & 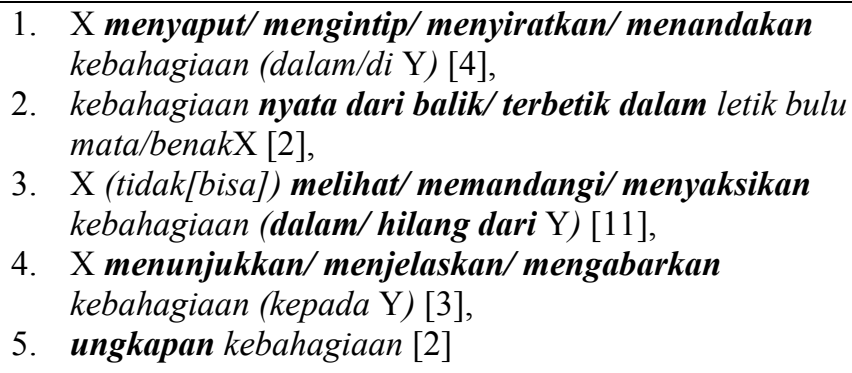 & 22 \\
\hline f. & $\begin{array}{l}\text { KEBAHAGIAAN (/MENJADI } \\
\text { BAHAGIA) ADALAH } \\
\text { MAKHLUK } \\
\text { HIDUP/MANUSIA/ORGANIS } \\
\text { ME (TERTIDUR/ TENANG) }\end{array}$ & $\begin{array}{l}\text { 1. X mengganggu/usik/memuaskan/mengenal/ bicara } \\
\text { pada kebahagiaan [8], } \\
\text { 2. kebahagiaan terganggu [2], } \\
\text { 3. kebahagiaan begitu egoistis, pengganggu kebahagiaan } \\
\text { [2], } \\
\text { 4. kebahagiaan pulih kembali/(ber-/peng-)ganti rupa/ } \\
\text { diam [4], } \\
\text { 5. kebahagiaan adalah saudara kembar X (kepahitan) }\end{array}$ & 18 \\
\hline g. & $\begin{array}{l}\text { KEBAHAGIAAN (/MENJADI } \\
\text { BAHAGIA) ADALAH } \\
\text { TANAMAN }\end{array}$ & $\begin{array}{l}\text { X bertabur bunga/ adalah/sebagai pangkal/mencabut } \\
\text { kebahagiaan }\end{array}$ & 4 \\
\hline
\end{tabular}



h. KEBAHAGIAAN (/MENJADI 1. X menikmati/mengecap/mengenyam/mengolah
BAHAGIA) ADALAH kebahagiaan (dan kedamaian/ ketenangan) [17],
SANTAPAN
2. X merasakan kebahagiaan yang segar seperti apel,
(MAKANAN/MINUMAN)
3. X haus pada kebahagiaan,
4. jamu ibarat kebahagiaan,
5. kebahagiaan X reguk,
6. X (merasa puas) mereguk (sejuta)/menikmati mangkuk kebahagiaan sampai tetes yang terakhir [3],
7. kebahagiaan menghilangkan rasa haus $\mathrm{X}$

\begin{tabular}{|c|c|c|c|}
\hline & $\begin{array}{l}\text { KEBAHAGIAAN (/MENJADI } \\
\text { BAHAGIA) } \\
\text { ADALAH(MEMBELI } \\
\text { SUATU) OBJEK BERHARGA } \\
\text { DAN METAFORA } \\
\text { KOMERSIL LAINNYA }\end{array}$ & $\begin{array}{l}\text { 1. (uang tak bisa) membeli kebahagiaan, } \\
\text { 2. kebahagiaan dibeli dengan wang ringgit, } \\
\text { 3. X menukar kebahagiaan dengan } \mathrm{Y}, \\
\text { 4. X menggadaikan kebahagiaan, } \\
\text { 5. X merelakan kebahagiaan tergadaikan oleh } \mathrm{Y} \text {, } \\
\text { kebahagiaan materi, } \\
\text { 6. kebahagiaan nilainya lebih mahal, } \\
\text { 7. nilai kebahagiaan, } \\
\text { 8. X belum senilai dengan kebahagiaan, } \\
\text { 9. tebusan untuk kebahagiaan }\end{array}$ & 10 \\
\hline & $\begin{array}{l}\text { KEBAHAGIAAN (/MENJADI } \\
\text { BAHAGIA) ADALAH OBJEK } \\
\text { RAPUH/PECAH BELAH } \\
(F R A G I L E / D E S T R O Y A B L E \\
\text { OBJECT) }\end{array}$ & $\begin{array}{l}\text { 1. X menghancurkan/meluluhlantakkan serpihan/ } \\
\text { merobohkan/merusakkan (harapan dan) kebahagiaan } \\
{[7],} \\
\text { 2. kehancuran/perusak kebahagiaan }[2] \text {, } \\
\text { 3. kebahagiaan fana }\end{array}$ & 10 \\
\hline & $\begin{array}{l}\text { KEBAHAGIAAN (/MENJADI } \\
\text { BAHAGIA) ADALAH OBJEK } \\
\text { ASLI/ PALSU }\end{array}$ & kebahagiaan (yang) semu/sejati & 8 \\
\hline & $\begin{array}{l}\text { KEBAHAGIAAN (/MENJADI } \\
\text { BAHAGIA) ADALAH OBJEK } \\
\text { DAMBAAN }\end{array}$ & $\begin{array}{l}\mathrm{X} \text { merindukan/mengharapkan/(me)mohon demi/ } \\
\text { (untuk)/(ber-/puja mantra) doa untuk kebahagiaan (Y) }\end{array}$ & 8 \\
\hline & $\begin{array}{l}\text { KEBAHAGIAAN (/MENJADI } \\
\text { BAHAGIA) ADALAH OBJEK } \\
\text { (TAK) LENGKAP }\end{array}$ & $\begin{array}{l}\text { 1. kebahagiaan (X) (semakin) lengkap }[3] \text {, } \\
\text { 2. kelengkapan kebahagiaan } \mathrm{X}, \\
\text { 3. X melengkapi kebahagiaan } \mathrm{Y}\end{array}$ & 5 \\
\hline & $\begin{array}{l}\text { KEBAHAGIAAN (/MENJADI } \\
\text { BAHAGIA) ADALAH } \\
\text { DURASI }\end{array}$ & $\begin{array}{l}\text { 1. kebahagiaan sesaat/ (tidak) bertahan lama [3], } \\
\text { 2. (satu) detik kebahagiaan [2] }\end{array}$ & 5 \\
\hline & $\begin{array}{l}\text { KEBAHAGIAAN (/MENJADI } \\
\text { BAHAGIA) ADALAH } \\
\text { UNGKAPAN } \\
\text { VERBAL/KATA-KATA }\end{array}$ & $\begin{array}{l}\text { kebahagiaan tinggallah kata-kata merdu didengar/ } \\
\text { hanyalah obralan janji-janji }\end{array}$ & 2 \\
\hline
\end{tabular}




\subsubsection{Metafora KEBAHAGIAAN yang Munculnya Jarang}

Metafora KEBAHAGIAAN dan metafora lingistik yang tidak dibicarakan dalam pustaka Kövecses (2000) dan munculnya ditemukan sangat jarang dalam BI dipaparkan di bawah ini.

Ditemukan 5 metafora KEBAHAGIAAN yang memotivasi 5 ML tentang kebahagiaan atau $0,88 \%$ dari seluruh metafora KEBAHAGIAAN yang ditemukan. Metafora kebahagiaan jenis ini digambarkan pada tabel 5.4c. Masing-masing MK disertai dengan contoh ML yang merealisasikannya. Metafora tersebut adalah KEBAHAGIAAN (/MENJADI BAHAGIA) ADALAH:

(5-122) GELEMBUNG

Mulai saat itu, kebahagiaanku hanya gelembung tanpa warna di mataku.

(5-123) SUARA

Syaikh Utsman membimbing hadirin untuk melantunkan thalaal badru, lagu kebahagiaan yang dinyanyikan kaum Anshar.

(5-124) SIHIR

Ia mencoba menemukan hidup bermakna dalam derita gaib kesedihan dan kebahagiaan.

(5-125) OBJEK/BENDA TAJAM Dilipatnya gurat-gurat kebahagiaan yang selama ini menghiasi tulang pipinya yang merona.

(5-126) KEKUATAN FISIK

Kebahagiaan Zahrana malam itu menghapus semua derita yang dialaminya. 
Tabel 5.4c

MK dan Pola Metaforis Kebahagiaan yang Munculnya Jarang

\begin{tabular}{lllc}
\hline No & Metafora Konseptual & Pola Metaforis & Kekerapan \\
\hline a. & KEBAHAGIAAN (/MENJADI & kebahagiaan hanya gelembung & 1 \\
& $\begin{array}{l}\text { BAHAGIA) ADALAH } \\
\text { GELEMBUNG }\end{array}$ & \\
\hline b. & KEBAHAGIAAN (/MENJADI & lagu kebahagiaan & 1 \\
& BAHAGIA) ADALAH SUARA & & 1 \\
\hline c. & $\begin{array}{l}\text { KEBAHAGIAAN (/MENJADI } \\
\text { BAHAGIA) ADALAH SIHIR }\end{array}$ & gaib (kesedihan dan) kebahagiaan & 1 \\
& & \\
\hline d. & $\begin{array}{l}\text { KEBAHAGIAAN (/MENJADI } \\
\text { BAHAGIA) ADALAH } \\
\text { OBJEK/BENDA TAJAM }\end{array}$ & gurat-gurat kebahagiaan & 1 \\
& & & \\
\hline e. & $\begin{array}{l}\text { KEBAHAGIAAN (/MENJADI } \\
\text { BAHAGIA) ADALAH } \\
\text { KEKUATAN FISIK }\end{array}$ & kebahagiaan menghapus X(derita) & \\
&
\end{tabular}

\section{Jumlah 5}

\subsubsection{Metafora Struktur Peristiwa untuk KEBAHAGIAAN}

Ditemukan 16 metafora KEBAHAGIAAN BI yang dapat diklasifikasikan sebagai MSP. MK tersebut didukung dengan 372 ML yang mengejewantahkan MK yang memotivasinya. Jumlah ini mewakili 65,73 \% dari seluruh metafora kebahagiaan yang ditemukan. Metafora yang termasuk MSP selengkapnya didaftar pada tabel 5.4d. Metafora yang termasuk jenis ini adalah KEBAHAGIAAN (/MENJADI BAHAGIA) ADALAH:

(5-127) LOKASI (TERKUNGKUNG/ WADAH)

a. Rasanya ia jauh dari kebahagiaannya.

b. Aku di sini Karim. Di samping kebahagiaanmu.

(5-128) BERTINDAK/MELAKUKAN SESUATU DI DALAM SUATU LOKASI

a. Zahrana tidur dalam kebahagiaan tiada terkira.

b. Wanita-wanita yang hidup dalam kebahagiaan semu. 
(5-129) MELAKUKAN SESUATU/MENJADI DISERTAI DENGAN/ TANPA OBJEK (INSTRUMEN)

a. Aku ingin kau hidup dengan kebahagiaan abadi, penuh sukacita dan kepuasan pribadi.

b. Lalu aku pergi, pulang dengan kebahagiaanku.

(5-130) (SECARA POTENSIAL) MEMBERIKAN/ MENTRANSFER SUATU OBJEK

a. Aku hanya ingin membagi kebahagiaanku pada Alifa.

b. Kau telah memberikan kebahagiaan ini padaku.

(5-131) (SECARA POTENSIAL) MENERIMA SUATU OBJEK

a. Sebelum Aiex memperoleh kebahagiaannya yang diharapkan.

b. Aku telah mendapatkan semua kebahagiaan.

(5-132) KEPEMILIKAN

a. "Kebahagiaanmu tidak berarti kebahagiaanku, kan?"

b. Kebahagiaanku belum sepenuhnya menjadi milikku.

(5-133) OBJEK BERGERAK

a. Hari-hari kebahagiaan telah datang mengunjungi kita.

b. Setelah beberapa tahun lamanya, kebahagiaan itu akhirnya kembali menghampiri dirinya.

(5-134) PENYEBAB

a. Tembaga hadir sebagai tembaga dan kebahagiaan mendatangkan kebahagiaan.

b. Tetapi, kebahagiaan yang menyungkupnya membuatnya lega menghirup udara.

(5-135) UKURAN/ KUANTITAS

a. Dengan membuat semakin banyak orang bahagia, kebahagiaan saya sendiri menjadi semakin besar.

b. Kebahagiaannya benar-benar bertambah tatkala Wilada siap dijadikan tunangannya.

(5-136) PENGHALANG

a. Kecerdikannya, kelemah-lembutan perangainya, kebahagiaannya, dan kelantangan Ibnu Zaidun benar-benar menjadi kebencian dan penghalang utama baginya.

b. Kebahagiaan yang luar biasa membungkam mulutnya.

(5-137) OBJEK DI SUATU LOKASI

a. Kau ikut andil dalam kebahagiaan di tempat ini.

b. Kedamaian dan kebahagiaan hidup mempunyai beberapa tempat sendiri-sendiri. 
(5-138) MENCARI/MENGEJAR/MEMBURU SUATU OBJEK

a. Apakah sebegini susahnya aku mencari kebahagiaan?

b. Kebahagiaan tahap pertama telah engkau songsong, [...].

(5-139) MENEMUKAN/MERAIH SUATU OBJEK

a. [...] semoga ketika dewasa kelak akan menemukan kebahagiaannya.

b. Tak bisakah kuraih kebahagiaanku?

(5-140) PERJALANAN

a. Barangkali ini adalah titik awal untuk menuju kebahagiaan sejati.

b. Seberapa jarak lagikah kebahagiaan itu bisa kujelang.

(5-141) ADANYA/ KEBERADAAN/KEHADIRAN FISIK SUATU OBJEK

a. Pernahkah kamu rasakan kebahagiaan yang dadakan.

b. Ada kebahagiaan, pasti ada kesedihan.

(5-142) OBJEK FISIK

a. Yang penting ciptakan kebahagiaan dan kesejahteraan keluarga.

b. Sudah saatnya untuk membuat kebahagiaan non sendiri.

Tabel 5.4d

MK dan Pola MSP untuk Kebahagiaan

\begin{tabular}{|c|c|c|c|}
\hline & Metafora Konseptual & \multicolumn{2}{|l|}{ Pola Metaforis } \\
\hline a. & $\begin{array}{l}\text { KEBAHAGIAAN } \\
\text { (/MENJADI BAHAGIA) } \\
\text { ADALAH LOKASI } \\
\text { (TERKUNGKUNG/ } \\
\text { WADAH) }\end{array}$ & $\begin{array}{l}\text { 1. X di (samping)/antara/dalam kebahagiaan [4], } \\
\text { 2. X tertumpah kepada/jauh dari kebahagiaan [2], } \\
\text { 3. X dituliskan Y pada kebahagiaan }\end{array}$ & 7 \\
\hline b. & $\begin{array}{l}\text { KEBAHAGIAAN } \\
\text { (/MENJADI BAHAGIA) } \\
\text { ADALAH BERTINDAK/ } \\
\text { MELAKUKAN SESUATU } \\
\text { DI DALAM SUATU } \\
\text { LOKASI }\end{array}$ & $\begin{array}{l}\text { 1. X berkasih-kasihan/hidup/tidur (di) dalam kebahagiaan } \\
{[4],} \\
\text { 2. X meraih Y dalam kebahagiaan }\end{array}$ & 5 \\
\hline c. & $\begin{array}{l}\text { KEBAHAGIAAN } \\
\text { (/MENJADI BAHAGIA) } \\
\text { ADALAH MELAKUKAN } \\
\text { SESUATU/ MENJADI } \\
\text { DISERTAI } \\
\text { DENGAN/TANPA OBJEK } \\
\text { (INSTRUMEN) }\end{array}$ & $\begin{array}{l}\mathrm{X} \text { (menjalani ke-) hidup(-an)/berbahagia/disambut/duduk } \\
\text { di Y/mendengar Y/menari berputar-putar/pulang dengan } \\
\text { kebahagiaan }\end{array}$ & 10 \\
\hline
\end{tabular}




\begin{tabular}{ll}
\hline d. & KEBAHAGIAAN \\
(/MENJADI BAHAGIA) \\
ADALAH (SECARA \\
POTENSIAL) \\
MEMBERIKAN/MENTRAN \\
SFER SUATU OBJEK
\end{tabular}

1. X ber-/membagi(-kan) kebahagiaan ([ke]pada/dengan/ bersama Y) [7],

2. X membawa kebahagiaan buat/pada $\mathrm{Y}$ [3],

3. X memberi(-kan) kebahagiaan ([ke]pada/buat $\mathrm{Y})$ [14],

4. X memberi Y kebahagiaan [4],

5. X diberi (anugrah)/dikaruniai kebahagiaan [3],

6. X menjamin kebahagiaan [3],

7. kebahagiaan adalah memberi dan berbagi,

8. (X) sampaikan/persembahkan kebahagiaan (pada Y) [2],

9. kebahagiaan dari sedekah pemberian $\mathrm{X}$,

10. hadiah/jatah kecil/iming-iming/jaminan(-jaminan yang dibutuhkan untuk) kebahagiaan [5],

11. X menjanjikan (Y) kebahagiaan (pada/bagi Y) [7],

12. X mendatangkan/menghadirkan kebahagiaan (bagi Y) [4]

\section{e. KEBAHAGIAAN \\ (/MENJADI BAHAGIA) \\ ADALAH (SECARA POTENSIAL) MENERIMA SUATU OBJEK}

1. X memperoleh/beroleh kebahagiaan (dari Y) [5],

2. X mendapat(kan)/menyambut/menerima kebahagiaan [12],

3. X menagih janji tentang/berhak atas/menginginkan/ butuh/meminta/menuntut kebahagiaan [9],

4. tuntutan kebahagiaan, kebahagiaan bagi/patut untuk $\mathrm{X}$ [2]

. kebahagiaanku/mu/nya (sendiri) [26],

f. KEBAHAGIAAN ADALAH KEPEMILIKAN

2. kebahagiaan pronomina/nama diri/nomina umum (sendiri) [53],

3. kebahagiaan menjadi milik X, X memiliki/punya kebahagiaan [4],

4. kebahagiaan X dikorbankan, X mengorbankan/iri terhadap kebahagiaan Y [2],

5. kebahagiaan dari(pada) X [2],

6. X kehilangan/meratapi kebahagiaan [5],

7. X merampas/merenggut kebahagiaan $\mathrm{Y}$ [6],

8. kebahagiaan terrenggut/dirampok (oleh Y) [3]

g. $\begin{aligned} & \text { KEBAHAGIAAN } \\ & \text { (/MENJADI BAHAGIA) }\end{aligned}$ ADALAH OBJEK BERGERAK
1. kebahagiaan pergi/mengundurkan diri [2],

2. datangnya kebahagiaan, kebahagiaan (yang akan) datang/hadir (padaX) [3],

3. kebahagiaan menghampiri/datang mengunjungi [2],

4. X menghalangi kebahagiaan,

5. X menjadi penghalang kebahagiaan $Y$

1. kebahagiaan mendatangkan/menumbuhkan X [2],

2. kebahagiaan membuat X lega/seperti KEJADIAN h. KEBAHAGIAAN (/MENJADI BAHAGIA) ADALAH PENYEBAB
1. kebahagiaan kecil/terbesar/paling besar/ (yang) lebih besar/menjadi semakin besar [7],

2. X lebih besar daripada kebahagiaan, betapa besar kebahagiaan, kebahagiaan bertambah [2],

3. X (hidup) berlimpah(nya) kebahagiaan [3],

4. kebahagiaan (yang) terlalu amat sangat/luar biasa [2],

5. berjuta-juta/ secuil kebahagiaan [2], 
6. s(u)atu(-satunya)/sebuah/seonggok kebahagiaan [7],

7. segala/ seluruh kebahagiaan [2],

8. ukuran/takaran X tentang kebahagiaan [2],

9. kebahagiaan diukur dengan $\mathrm{X}$

j. KEBAHAGIAAN $\quad$ kebahagiaan menjadi penghalang bagi/membungkam X 2

(/MENJADI BAHAGIA)

ADALAH PENGHALANG

k. KEBAHAGIAAN (/MENJADI BAHAGIA)

1. (ada [kah]) kebahagiaan di X [5], ADALAH OBJEK DI

2. (ada) kebahagiaan (di) dalam/di atas/di depan X [6], SUATU LOKASI

3. X merasakan/mengalami kebahagiaan di/pada $\mathrm{Y}$ [2],

4. kebahagiaan ada pada/dekat dengan X [2],

5. kebahagiaan mempunyai tempat,

6. X melepaskan kebahagiaan dari $\mathrm{Y}$,

7. gudangnya/ letak kebahagiaan [2],

8. kebahagiaan duniawi

1. KEBAHAGIAAN (/MENJADI BAHAGIA)

ADALAH

MENCARI/MENGEJAR/ME MBURU SUATU OBJEK
1. X (berjuang) mencari/memperjuangkan/berkorban untuk/mengorbankan Y untuk/mengejar kebahagiaan [13],

2. kebahagiaan menunggu X/menanti [2],

3. X songsong/menjemput kebahagiaan [3],

4. kebahagiaan mesti diperebutkan

m. KEBAHAGIAAN

(/MENJADI BAHAGIA)

X menemukan/nemuin/(me)raih(lah) kebahagiaan ADALAH MENEMUKAN/ MERAIH SUATU OBJEK

n. KEBAHAGIAAN ADALAH PERJALANAN
1. kunci kebahagiaan,

2. X berada di pintu gerbang kebahagiaan,

3. X memimpin/menuntun Y (melalui Z) ke arah kebahagiaan [3],

4. X mendekatkan/membawa Y pada kebahagiaan [2],

5. seberapa jarak kebahagiaan bisa X jelang,

6. X (adalah titik awal untuk) menuju kebahagiaan [2],

7. X lewatkan kebahagiaan,

8. X menemukan taman/mencapai kebahagiaan [6],

9. kebahagiaan tercapai,

10. X memulai kebahagiaan (dengan Y) di tempat lain

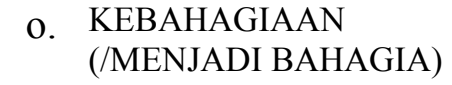

ADALAH ADANYA/

KEBERADAAN/

KEHADIRAN FISIK

SUATU OBJEK
1. X merasakan kebahagiaan [15],

2. yang ada tinggal kebahagiaan, (t[id]ak [pernah]) ada kebahagiaan [7],

3. kebahagiaan hilang [2],

4. X melenyapkan kebahagiaan

p. KEBAHAGIAAN (/MENJADI BAHAGIA) ADALAH OBJEK FISIK

1. X ciptakan/membuat/mengenangkan kebahagiaan [3]

2. penyulap kesedihan menjadi kebahagiaan 


\subsection{Metafora KESEDIHAN}

Metafora KESEDIHAN BIng. telah dibicarakan dalam penelitian metafora emosi dengan perspektif linguistik kognitif. Kövecses (2000:25) telah mengidentifikasi dan mendaftar metafora KESEDIHAN seperti di bawah ini.

(a) SEDIH ADALAH BERADA/MENJADI DI BAWAH: Dia menurunkanku melalui sambutannya. (SAD IS DOWN: He brought me down with his remarks.)

(b) SEDIH ADALAH KEGELAPAN/GELAP: Dia berada dalam suasana hati yang gelap. (SAD IS DARK: He is in a dark mood.)

(c) KESEDIHAN ADALAH KURANGNYA KEHANGATAN: Kehilangan ayahnya telah memadamkan apinya; ia tertekan selama dua tahun. (SADNESS IS A LACK OF HEAT: Losing his father put his fire out; he's been depressed for two years.)

(d) KESEDIHAN ADALAH KURANGNYA VITALITAS: Ini berita yang menyedihkan. (SADNESS IS A LACK OF VITALITY: This was disheartening news.)

(e) KESEDIHAN ADALAH ADALAH CAIRAN DALAM WADAH: Aku dipenuhi dengan kesedihan. (SADNESS IS A FLUID IN A CONTAINER: I am filled with sorrow.)

(f) KESEDIHAN ADALAH KEKUATAN FISIK: Itu merupakan pukulan mengerikan. (SADNESS IS A PHYSICAL FORCE: That was a terrible blow.)

(g) KESEDIHAN ADALAH KEKUATAN ALAM: Gelombang depresi mendatanginya. (SADNESS IS A NATURAL FORCE: Waves of depression came over him.)

(h) KESEDIHAN ADALAH PENYAKIT: Dia sakit hati. Waktu menyembuhkan semua penderitaan. (SADNESS IS AN ILLNESS: She was heart-sick. Time heals all sorrows.)

(i) KESEDIHAN ADALAH KEGILAAN: Dia gila karena kesedihan. (SADNESS IS INSANITY: He was insane with grief.)

(j) KESEDIHAN ADALAH BEBAN: Dia terhuyung-huyung kesakitan. (SADNESS IS A BURDEN: He staggered under the pain.) 
(k) KESEDIHAN ADALAH MAKHLUK HIDUP/ ORGANISME: Dia menenggelamkan kesedihannya dalam minuman. (SADNESS IS A LIVING ORGANISM: He drowned his sorrow in drink.)

(1) KESEDIHAN ADALAH BINATANG TAWANAN/BUAS: Perasaannya yang menderita lepas dari tangan. (SADNESS IS A CAPTIVE ANIMAL: His feelings of misery got out of hand.)

(m)KESEDIHAN ADALAH MUSUH: Dia ditangkap oleh serangan depresi. (SADNESS IS AN OPPONENT: He was seized by a fit of depression.)

(n) KESEDIHAN ADALAH ATASAN SOSIAL: Ia diperintah oleh kesedihan. SADNESS IS A SOCIAL SUPERIOR: She was ruled by sorrow.) (Kövecses, 2000:25)

\subsubsection{Metafora KESEDIHAN yang Dibicarakan dalam Pustaka}

Penjelajahan korpus BI dengan metode APM, berhasil menemukan hampir semua metafora KESEDIHAN yang telah diidentifikasi oleh Kövecses (2000), dengan introspektif atau metode bukan korpus modern, kecuali KESEDIHAN SEBAGAI KEGILAAN.

Ditemukan 12 metafora KESEDIHAN yang memotivasi 122 ML menyangkut emosi kesedihan. Jumlah ini mewakili $24,60 \%$ dari seluruh metafora KESEDIHAN yang ditemukan.

Metafora KESEDIHAN yang telah diidentifikasi oleh Kövecses (2000:25) dan juga ditemukan dalam BI dapat dicermati pada (5-143--5-154) disertai masing-masing dengan contoh ML. Sementara itu, pola metaforis dan pemetaannya dipaparkan pada tabel 5.5a. Metafora yang dimaksud adalah KESEDIHAN (/MENJADI SEDIH ADALAH:

(5-143) (BERADA/MENJADI DI/KE) BAWAH

a. Ia tak mau tenggelam dalam kesedihan.

b. [...], sekian lama aku terpuruk dalam kesedihan derita akibat ulah diriku yang begitu larut akan masa lalu. 
(5-144) KEGELAPAN/ GELAP

a. Bayang-bayang kesedihan mulai membias dan sorot mata sang Dewi Ular.

b. Wajahnya berselimut kesedihan.

(5-145) KURANGNYA KEHANGATAN

a. Ayolah, jangan beku hanya lantaran kesedihan.

(5-146) KURANGNYA VITALITAS/ SAKIT

a. Kesedihan yang tidak mungkin terobati dalam waktu singkat.

b. Beliau sekarang sedang menderita kesedihan.

(5-147) CAIRAN DALAM WADAH

a. Jangan melampiaskan kesedihan dengan datang setiap hari ke sini, Sil.

b. Di kamar Maria aku mencurahkan semua kesedihanku padanya.

(5-148) KEKUATAN FISIK

a. [...] semangatnya yang dirobek-robek kesedihan menunjukkan bahwa tidak ada hidup sejati baginya di luar Musashi.

b. Jangan sampai pagi yang indah ini pecah oleh kesedihan yang aneh," sambungnya.

(5-149) KEKUATAN ALAM

a. Karena redanya kesedihan dan kepanikan itu maka Vinge dapat diajak bicara dengan mudah dan lancar.

b. Kesedihan Tante Riza pun dengan cepat menjadi surut.

(5-150) BEBAN

a. Seluruh negeri sepi dirundung kesedihan .

b. Ketika itu aku ditimpa oleh suatu kesedihan yang rupanya takkan berbeda dengan kesedihan Sri Rama.

(5-151) MAHKLUK HIDUP/ORGANISME

a. Semua kesedihan ini benar-benar tidak mengenal batas.

b. Menghibur kesedihan di hati bungsunya.

(5-152) BINATANG TAWANAN/BUAS

a. Dengan tidak dapat mengontrol kemarahannya dan kesedihannya, Bhima ingin membunuh Aswattama waktu itu juga.

b. Tubuh yang lebih kurus dari biasanya itu terlihat sengsara sekali menyekap kesedihan yang merayap-rayap di dalamnya.

(5-153) MUSUH/LAWAN DALAM SUATU PERJUANGAN

a. Dan ia juga mengalami kesedihan yang nyaris membinasakannya. 
b. Hatinya sudah dicekam kesedihan lebih dulu.

\section{(5-154) ATASAN SOSIAL}

a. Buat apa menuruti kesedihan.

b. Gerak-geriknya dipengaruhi oleh kesedihan.

\section{Tabel 5.5a}

MK Kesedihan dalam Kövecses (2000) dan Realisasi Pola Metaforis BI.

\begin{tabular}{|c|c|c|c|}
\hline & Metafora Konseptual & Pola Metaforis & pan \\
\hline & $\begin{array}{l}\text { KESEDIHAN (/MENJADI } \\
\text { SEDIH) ADALAH } \\
\text { (BERADA/ MENJADI } \\
\text { DI/KE) BAWAH }\end{array}$ & $\begin{array}{l}\text { 1. X tenggelam/terperosok/terpuruk (ke) dalam (jurang)/ } \\
\text { oleh kesedihan [8], } \\
\text { 2. X menghilang ke/jatuh terguling-guling di dasar } \\
\text { kesedihan [2], } \\
\text { 3. X bangkit/bangun dari kesedihan }[3]\end{array}$ & 13 \\
\hline b. & $\begin{array}{l}\text { KESEDIHAN (/MENJADI } \\
\text { SEDIH) ADALAH } \\
\text { KEGELAPAN/ GELAP }\end{array}$ & $\begin{array}{l}\text { 1. (bayang-) bayang(an) kesedihan (dari wajahX) [2], } \\
\text { 2. terpendam dari senja kesedihan, } \\
\text { 3. } \mathrm{X} / \text { mata/ wajah suram oleh/ber[/di] selimut }[\mathbf{i}] / \\
\text { terbungkus/tersaput kesedihan [5], } \\
\text { 4. kesedihan melingkup hati } \mathrm{X}, \\
\text { kesedihan yang membayang/menyaput (di wajah) [2] }\end{array}$ & 11 \\
\hline & $\begin{array}{l}\text { KESEDIHAN (/MENJADI } \\
\text { SEDIH) ADALAH } \\
\text { KURANGNYA } \\
\text { KEHANGATAN }\end{array}$ & beku lantaran kesedihan & 1 \\
\hline d. & $\begin{array}{l}\text { KESEDIHAN (/MENJADI } \\
\text { SEDIH) ADALAH } \\
\text { KURANGNYA } \\
\text { VITALITAS/SAKIT }\end{array}$ & $\begin{array}{l}\text { 1. kesedihan yang tidak terobati/yang menggerogoti } \mathrm{X}[2] \text {, } \\
\text { 2. kesedihan (hati) berobat, } \\
\text { 3. X penyembuh/menderita kesedihan }[2], \\
\text { 4. X memperpedih kesedihan }\end{array}$ & 6 \\
\hline & $\begin{array}{l}\text { KESEDIHAN (/MENJADI } \\
\text { SEDIH) ADALAH CAIRAN } \\
\text { DALAM WADAH }\end{array}$ & 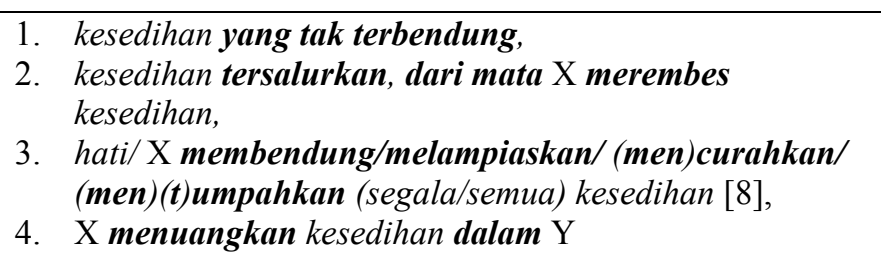 & 12 \\
\hline f. & $\begin{array}{l}\text { KESEDIHAN (/MENJADI } \\
\text { SEDIH) ADALAH } \\
\text { KEKUATAN FISIK }\end{array}$ & $\begin{array}{l}\text { 1. X pecah oleh/dirobek-robek kesedihan [2], } \\
\text { 2. kesedihan yang dahsyat, } \\
\text { 3. kesedihan mencurahkan habis air mata, } \\
\text { 4. kesedihan (hati) menghapus Y (ingatan/ kenangan) [2], } \\
\text { 5. kesedihan menyebabkan meruntuhkan air mata, } \\
\text { 6. X menguatkan kesedihan }\end{array}$ & 8 \\
\hline & $\begin{array}{l}\text { KESEDIHAN (/MENJADI } \\
\text { SEDIH) ADALAH } \\
\text { KEKUATAN ALAM }\end{array}$ & $\begin{array}{l}\text { 1. redanya kesedihan, } \\
\text { 2. X meredakan kesedihan [2], } \\
\text { 3. X digoncangkan oleh angin ribut (kekecewaan dan) } \\
\text { kesedihan, } \\
\text { 4. X hanyut dalam/dilanda/diterpa kesedihan [6], }\end{array}$ & 14 \\
\hline
\end{tabular}


5. kesedihan melanda $\mathrm{X}$

6. kesedihan (hati) menjadi surut/lebih mengombak [2]

h. KESEDIHAN (/MENJADI

SEDIH) ADALAH

KEGILAAN
i. KESEDIHAN (/MENJADI 1. X ditimpa oleh/berat tertimpa oleh (tekanan)/ 16
SEDIH) ADALAH BEBAN $\quad$ dirundung kesedihan [6],
2. timpaan (bingung dan) kesedihan, kesedihan menjadi beban/menimpa X [2],
3. kesedihan yang menimpa,
4. kesedihan sedemikian hebat untuk ditanggung/yang ditanggung [2],
5. X mengurangi beban/menanggung kesedihan [3],
6. X merundung Y dengan kesedihan

j. KESEDIHAN (/MENJADI SEDIH) ADALAH MAHKLUK HIDUP/ ORGANISME
1. (X menghibur/) pembangkit kesedihan [2],

2. kesedihan mengenal X [4],

3. kesedihan yang menggoda $\mathrm{X}$,

4. kesedihan (tak) panjang umur,

5. kesedihan membutuhkan/memerlukan/membuka X [3],

6. X mengantarkan/mengiringi/ diiringi kesedihan (hati) [4],

7. selamat siang kesedihan

k. KESEDIHAN (/MENJADI X mengontrol/menyekap kesedihan

SEDIH) ADALAH

BINATANG TAWANAN/

BUAS

1.
KESEDIHAN (/MENJADI
SEDIH) ADALAH
MUSUH/LAWAN DALAM
SUATU PERJUANGAN

1. kesedihan yang mendera,

2. kesedihan yang membinasakan $\mathrm{X}$,

3. kesedihan mengganggu/menerjang/mendera/ mencekam X [4],

4. X atasi/dicekam/didera/disiksa oleh/dihantam/ tercengkeram/sembunyi dari/menghadapi/melawan/ mengusir/mengenyahkan/mengungguli kesedihan [13],

5. intaian kesedihan

m. KESEDIHAN (/MENJADI SEDIH) ADALAH ATASAN SOSIAL 


\subsubsection{Metafora KESEDIHAN yang Tidak Dibicarakan dalam Pustaka}

Selain menemukan hampir semua metafora KESEDIHAN yang telah diidentifikasi oleh Kövecses (2000: 25), penelitian ini berhasil menemukan 15 metafora KESEDIHAN yang mendorong munculnya 158 ML tentang kesedihan yang digunakan dalam BI tetapi tidak dibicarakan dalam pustaka Kövecses. Jumlah ini mewakili $31,85 \%$ dari jumlah metafora kesedihan yang ditemukan pada korpus yang diteliti. Metafora kesedihan yang termasuk dalam kelompok ini secara lengkap dapat dicermati pada tabel 5.5b. Metafora tersebut adalah KESEDIHAN (/MENJADI SEDIH) ADALAH:

(5-155) UNSUR DALAM WADAH (BERTEKANAN)

a. Wajahnya sayu penuh kesedihan yang tidak tertahan.

b.Janganlah engkau gusar mendengar cerita ini, karena banyak mengandung kesedihan.

(5-156) UNSUR CAMPURAN

a. Kesedihan dan amarah bercampur jadi satu.

b. Kecuali kesedihan, kemurungan, yang bercampur pekat dengan kebingungan.

(5-157) CAIRAN
a. Aku tidur terlarut dalam kesedihan kisah cintaku.
b. Tak terasa ia pun melelehkan air mata kesedihan.

(5-158) OBJEK (TAK)TERSEMBUNYI/ TAMPAK

a. Kumala Dewi buru-buru menyembunyikan kesedihannya.

b. Langit sudah mulai memperlihatkan kesedihannya.

(5-159) SUARA/ NADA

a. Meski mulai ada denting kesedihan di sana.

b. Dan Delisa kaku seketika. Serunai kesedihan mulai terdengar.

(5-160) OBJEK/BENDA TAJAM

a. Kesedihan di hati Kanda semakin terasa begitu menggores jiwa.

b. Wajah yang murung dan mengguratkan kesedihan.

(5-161) KEDALAMAN

a. Ia meninggalkan duka dan kesedihan mendalam. 
b. [...], kesedihan yang dideritanya sungguh sangat dalam.

(5-162) KERAS/LEMBUT

a. Semua yang hadir merasakan kentalnya kesedihan yang sama.

b. Kesedihan yang menggumpal di bukit-bukit Lhok Nga.

(5-163) WARNA

a. Dalam rona kesedihan yang dalam, Hamsad menjelaskan kepada mereka, [...].

b. Pancaksara juga mencatat warna kesedihan yang serupa yang terpancar dari wajah segenap kawula yang [...].

(5-164) NODA/ KOTORAN

a. Sangat mudah bagi Tuhan untuk menghapus duka dan kesedihan hamba-Nya.

b. Ia berusaha menghapus kesedihannya.

(5-165) DURASI

a. Namun, kesedihan itu mungkin hanya sekilas karena [...].

b. Ini persoalan juga sangat runcing dan bisa mengakibatkan kesedihan berlarut-larut.

(5-166) TANAMAN

a. Ia menunduk. Ada kesedihan merambati hatinya.

b. [...], tentang bagaimana kesedihan sewarna menjalar saat dulu Prabu Kertarajasa Jayawardhana mangkat.

(5-167) SANTAPAN

a. Ia perempuan, yang telah kenyang oleh kesedihan, meskipun umurnya belum seberapa.

b. Menikmati kesedihan-kesedihan dan ketakutan-ketakutannya [...].

(5-168) OBJEK BERHARGA

a. Tangisnya benar-benar mewakili harga kesedihan yang dialaminya.

b. Kegembiraan yang sekejap telah ditebus dengan kesedihan yang lebih mencekam.

(5-169) UDARA/NAFAS

a. Lelah menghela kesedihan yang tak kunjung henti setiap kali ia memutuskan untuk kembali ke sini.

b. Napas kesedihan mengapung di atas bunga-bungaan. 
Tabel 5.5b

MK dan Pola Metaforis Kesedihan yang Tidak Dibicarakan dalam Pustaka

\begin{tabular}{|c|c|c|c|}
\hline No & Metafora Konseptual & Pola Metaforis & pan \\
\hline a. & $\begin{array}{l}\text { KESEDIHAN(/MENJADI } \\
\text { SEDIH) ADALAH UNSUR } \\
\text { DALAM WADAH } \\
\text { (BERTEKANAN) }\end{array}$ & $\begin{array}{l}\text { 1. kesedihan yang menyesak dada, } \\
\text { 2. kesedihan menyebabkan isi dada X sesak, } \\
\text { 3. } \mathrm{X} / \text { wajah X/ raut muka X/pandangan (mata) X/air } \\
\text { mataX penuh (dengan) kesedihan }[14], \\
\text { 4. X seperti diisi dengan jumlah segala kesedihan, } \\
\text { 5. X (yang) (banyak) mengandung kesedihan [2], } \\
\text { 6. X/dada X menahan/menekan (lebih) dalam/sesak } \\
\text { menahan/menghamburkan kesedihan (hati) [4], } \\
\text { 7. kesedihan menembus batas }\end{array}$ & 24 \\
\hline b. & $\begin{array}{l}\text { KESEDIHAN(/MENJADI } \\
\text { SEDIH) ADALAH UNSUR } \\
\text { CAMPURAN }\end{array}$ & $\begin{array}{l}\text { 1. X bersatu/menetralisir kesedihan [2], } \\
\text { 2. EMOSI dan kesedihan bercampur (aduk/jadi satu) [3], } \\
\text { 3. kesedihan (, EMOSI) bercampur (pekat [dengan]) } \\
\text { EMOSI [3], } \\
\text { 4. kesedihan mendarah daging, } \\
\text { 5. kesedihan mengharu biru isi dada }\end{array}$ & 10 \\
\hline c. & $\begin{array}{l}\text { KESEDIHAN(/MENJADI } \\
\text { SEDIH) ADALAH CAIRAN }\end{array}$ & $\begin{array}{l}\text { 1. } \mathrm{X}(\text { ter)larut dalam/dengan kesedihan }[12], \\
\text { 2. }([\mathrm{X} \text { mencucurkan/melelehkan]/cucuran) air mata } \\
\text { kesedihan }[7], \\
\text { 3. tangis kesedihan }[3], \\
\text { 4. lautan kesedihan }\end{array}$ & 23 \\
\hline d. & $\begin{array}{l}\text { KESEDIHAN(/MENJADI } \\
\text { SEDIH) ADALAH OBJEK } \\
\text { (TAK)TERSEMBUNYI/TA } \\
\text { MPAK }\end{array}$ & $\begin{array}{l}\text { 1. kesedihan disembunyikan, } \\
\text { 2. kesedihan bersemayam dalam X, } \\
\text { 3. X menyembunyikan/menyimpan/memendam/ } \\
\text { menutup(i)/timbuni kesedihan [12], } \\
\text { 4. X (/wajah) mengungkapkan/memperlihatkan/ } \\
\text { menyiratkan/menunjukkan/menyatakan/mewartakan/ } \\
\text { membuat tengara/menimbulkan/melukiskan/pamer } \\
\text { kesedihan (terpendam) [17], } \\
\text { 5. X melihat/membaca kesedihan (di mata/muka/ wajah } \\
\text { Y) [10], } \\
\text { 6. wajah yang tampak hanya/tampak/terlihat kesedihan } \\
\text { (di wajah X) [3], } \\
\text { 7. kesedihan timbul/muncul, ekspresi/mimik/ungkapan/ } \\
\text { cetak biru kesedihan (di wajah) [4] }\end{array}$ & 50 \\
\hline e. & $\begin{array}{l}\text { KESEDIHAN(/MENJADI } \\
\text { SEDIH) ADALAH } \\
\text { SUARA/NADA }\end{array}$ & $\begin{array}{l}\text { 1. rinai/denting/lagu/sedu sedan/nada/tembang } \\
\text { kesedihan }[6], \\
\text { 2. terdengar senandung kesedihan, } \\
\text { 3. serunai/senandung kesedihan terdengar/makin keras } \\
\text { [2] }\end{array}$ & 9 \\
\hline f. & $\begin{array}{l}\text { KESEDIHAN(/MENJADI } \\
\text { SEDIH) ADALAH } \\
\text { OBJEK/BENDA TAJAM }\end{array}$ & $\begin{array}{l}\text { 1. kesedihan menggores jiwa, } \\
\text { 2. wajah bergurat kesedihan, } \\
\text { 3. gurat(-gurat)/guratan kesedihan (di wajah) [4], } \\
\text { 4. X menggurat(kan) kesedihan [3] }\end{array}$ & 9 \\
\hline g. & $\begin{array}{l}\text { KESEDIHAN(/MENJADI } \\
\text { SEDIH) ADALAH }\end{array}$ & kesedihan (yang) mendalam/(sangat) dalam & 7 \\
\hline
\end{tabular}


KEDALAMAN

h. KESEDIHAN(/MENJADI

1. kentalnya kesedihan,

SEDIH) ADALAH KERAS/

2. kesedihan sangat kental,

LEMBUT

3. kesedihan yang menggumpal/sangat halus,

4. X melunakkan kesedihan

i. KESEDIHAN(/MENJADI 1. rona/ warna kesedihan [3],

SEDIH) ADALAH WARNA 2. kesedihan mewarnai langit

\begin{tabular}{llll}
\hline $\mathrm{j}$. & KESEDIHAN(/MENJADI & 1. & X menghapus (duka dan) kesedihan [3], \\
SEDIH) ADALAH NODA// & 2. & kesedihan(, duka dan nestapa) dihapus
\end{tabular}

4

SEDIH) ADALAH NODA/

KOTORAN

k. KESEDIHAN(/MENJADI kesedihan sekilas/(yang) berlarut(-larut) SEDIH) ADALAH DURASI

1. KESEDIHAN(/MENJADI SEDIH) ADALAH

1. kesedihan merambat/menjalar [2],

TANAMAN

2. kesedihan merambati hati

3

m. KESEDIHAN(/MENJADI X kenyang oleh/menikmati kesedihan(-kesedihan) SEDIH) ADALAH

SANTAPAN

n. KESEDIHAN(/MENJADI SEDIH) ADALAH OBJEK

1. harga kesedihan,

2. X ditebus dengan kesedihan BERHARGA

o. KESEDIHAN(/MENJADI

SEDIH) ADALAH

1. X menghela kesedihan,

2. nafas kesedihan

\subsubsection{Metafora KESEDIHAN yang Munculnya Jarang}

Metafora KESEDIHAN dan metafora lingistik menyangkut kesedihan yang tidak dibicarakan dalam pustaka Kövecses (2000:25) dan munculnya ditemukan sangat jarang dalam BI dipaparkan di bawah ini. Ditemukan 7 metafora KESEDIHAN yang memotivasi 7 ML tentang kesedihan atau 1,41\% dari seluruh metafora KESEDIHAN yang ditemukan. Metafora kesedihan jenis ini selengkapnya 
digambarkan pada tabel 5.4c. Metafora yang dimaksud adalah KESEDIHAN (/MENJADI SEDIH) ADALAH:

(5-170) API

Saat ini, belum apa-apa dirinya sudah terbakar oleh api cemburu, api penyesalan dan kesedihan yang luar biasa panas baranya.

(5-171) CAHAYA

Wajahnya bukan saja memancarkan kesedihan, namun juga memendam kekecewaan.

(5-172) GANGGUAN FISIK

Delisa tergugu oleh kesedihan.

(5-173) TEORI/ ILMU

Hanya Atang dan Raja yang bisa mempraktekkan kesedihan ini dengan baik dan benar.

(5-174) SIHIR

Seperti bayi yang baru dilahirkan, ia mencoba menemukan hidup bermakna dalam derita gaib kesedihan dan kebahagiaan.

(5-175) KEBEBASAN

Kesedihan orang lain lebih merdeka dan lebih puas, ... .

(5-176) CATATAN

Kami sudah terlalu sering membuat catatan kesedihan dan kami tidak bisa menutup-nutupi.

\section{Tabel 5.5c}

MK dan Pola Metaforis Kesedihan yang Munculnya Jarang

\begin{tabular}{|c|c|c|}
\hline No Metafora Konseptual & Pola Metaforis & pan \\
\hline $\begin{array}{ll}\text { a. } & \text { KESEDIHAN (/MENJADI } \\
& \text { SEDIH) ADALAH API }\end{array}$ & $\begin{array}{l}\text { api (penyesalan dan) kesedihan (yang luar biasa panas } \\
\text { baranya) }\end{array}$ & 1 \\
\hline $\begin{array}{ll}\text { b. } & \text { KESEDIHAN (/MENJADI } \\
\text { SEDIH) ADALAH CAHAYA }\end{array}$ & wajah X memancarkan kesedihan & 1 \\
\hline $\begin{array}{ll}\text { c. } & \text { KESEDIHAN (/MENJADI } \\
\text { SEDIH) ADALAH GANGGUAN } \\
\text { FISIK }\end{array}$ & X tergugu oleh kesedihan & 1 \\
\hline
\end{tabular}




\begin{tabular}{|c|c|c|c|}
\hline & $\begin{array}{l}\text { KESEDIHAN (/MENJADI } \\
\text { SEDIH) ADALAH TEORI/ILMU }\end{array}$ & $\mathrm{X}$ mempraktekkan kesedihan & 1 \\
\hline e. & $\begin{array}{l}\text { KESEDIHAN (/MENJADI } \\
\text { SEDIH) ADALAH SIHIR }\end{array}$ & gaib kesedihan & 1 \\
\hline f. & $\begin{array}{l}\text { KESEDIHAN (/MENJADI } \\
\text { SEDIH) ADALAH } \\
\text { KEBEBASAN }\end{array}$ & kesedihan X lebih merdeka & 1 \\
\hline g. & $\begin{array}{l}\text { KESEDIHAN (/MENJADI } \\
\text { SEDIH) ADALAH CATATAN }\end{array}$ & catatan kesedihan & 1 \\
\hline & & & 7 \\
\hline
\end{tabular}

\subsubsection{Metafora Struktur Peristiwa untuk KESEDIHAN}

Ditemukan 17 metafora KESEDIHAN yang dapat diklasifikasikan sebagai MSP. MK tersebut didukung dengan 209 ML yang mengejewantahkan MK yang memotivasinya. Jumlah ini mewakili $42,14 \%$ dari seluruh metafora kesedihan yang ditemukan. Metafora yang termasuk MSP selengkapnya didaftar pada tabel 5.5d. MK serta masing-masing contoh ML tersebut dapat dicermati pada contoh (5-177 -- 5-193). Metafora tersebut adalah KESEDIHAN (/MENJADI SEDIH) ADALAH:

(5-177) LOKASI (TERKUNGKUNG/ WADAH)

a. Putri itu benar-benar terhibur dalam kesedihannya.

b. Syahna iba meninggalkanku sendiri di tengah-tengah kesedihanku.

(5-178) BERTINDAK/MELAKUKAN SESUATU DI DALAM SUATU LOKASI

a. Ketika kaulahir, nenekmu mengatupkan bibirnya dalam kesedihan dan berkata: Ah, seorang anak perempuan dan jelek lagi!.

b. Kita tidak boleh berkubang terus-menerus dalam kesedihan, Layla. 
a. Semuanya dengan kesedihan dan kemarahan yang tidak kepalang.

b. Mereka menghibur lelaki dengan kesedihan hidup mereka.

(5-180) KEPEMILIKAN

a. "Jangan disimpan sendiri. Beginilah kesedihanmu denganku. Ya?"

b. Aku punya kesedihan sendiri.

(5-181) UKURAN/ KUANTITAS

a. Mengingat itu bertambah-tambahlah kesedihannya.

b. Yang banyak di sini hanyalah kesedihan.

(5-182) OBJEK YANG DIGERAKKAN

a. Untuk mengalihkan kesedihan aku mengambil buku [...].

b. Rency mencoba membuang kesedihannya dengan mengunjungi Opa Hans.

(5-183) OBJEK BERGERAK

a. Tapi kesedihan sedikit menyinggahi hatiku.

b. Bersabarlah! Tidak lama lagi semua kesedihan dan kerinduanmu akan berlalu.

(5-184) KONTROL OBJEK BERGERAK

a. Antawis Maekani, nampak menahan kesedihan dan perasaan kehilangan, [...].

b. Halimah pun lebih-lebih lagi, sekuat-kuatnya ditahannya kesedihan hatinya, [...].

(5-185) HALANGAN (BAGI PERGERAKAN)

a. Semuanya menunaskan bara di dalam bilik-bilik hati kami yang kian sempit dihimpit kesedihan.

b. Belajar dengan hati yang masih terbelenggu kesedihan.

(5-186) PERGERAKAN TERDORONG SUATU OBJEK

a. Jerit tangis dan orang pinsan ada di mana-mana, yang umumnya didorong oleh rasa kehilangan dan kesedihan yang luar biasa.

(5-187) PENYEBAB

a. GERONTE Ah, kesedihan sudah membuat aku jadi pikun.

b. Kesedihannya ini hampir menghilangkan putih rambut di kepalanya.

(5-188) OBJEK DI SUATU LOKASI

a. Di sana tidaklah ada kesedihan dan kedukaan.

b. Cerita kematian selalu meninggalkan kesedihan, tetapi [...].

(5-189) (SECARA POTENSIAL) MEMBERIKAN SUATU OBJEK 
a. [...], kamu ikut membagi kesedihanku.

b. Cowok itu sama sekali tidak suka cuaca hujan, cuma bisa memberi kesedihan kepada setiap orang.

(5-190) (SECARA POTENSIAL) MENERIMA/MENDAPAT SUATU OBJEK

a. Dan engkau pun yang berasa miskin dan hina, yang selalu mendapat bahaya, kesengsaraan, dan kesedihan, janganlah [...].

b. [...] karena takut beroleh kesakitan dan kesedihan pula, tiada hendak kawin lagi.

(5-191) MENEMUKAN/ MERAIH SUATU OBJEK

a. Laili yang menangkap kesedihanku menatapku lekat.

(5-192) ADANYA/KEBERADAAN/ KEHADIRAN FISIK SUATU OBJEK

a. Ada kebahagiaan, pasti ada kesedihan.

b. Apakah ia sudah mampu menghilangkan kesedihannya, atau [...].

(5-193) OBJEK FISIK

a. Tetapi raut dan bentuk kesedihan sama di seluruh dunia.

b. [...] itu saja cukup sudah untuk membuat kesedihan sepanjang tahun.

Tabel 5.5d

MK dan Pola MSP untuk Kesedihan

\begin{tabular}{|c|c|c|c|}
\hline & Metafora Konseptual & Pola Metaforis & pan \\
\hline a. & $\begin{array}{l}\text { KESEDIHAN(/MENJADI } \\
\text { SEDIH) ADALAH LOKASI } \\
\text { (TERKUNGKUNG/WADAH) }\end{array}$ & $\begin{array}{l}\text { 1. X dalam kesedihan [6], } \\
\text { 2. X menemui ajal/ meninggalkan Y dalam/di tengah- } \\
\text { tengah kesedihan [3], } \\
\text { 3. X berujung pada/lari dari/melewati kesedihan [3], } \\
\text { 4. kubur/telaga kesedihan [2], } \\
\text { 5. lubang kesedihan (menganga semakin lebar) }\end{array}$ & 15 \\
\hline b. & $\begin{array}{l}\text { KESEDIHAN(/MENJADI } \\
\text { SEDIH) ADALAH } \\
\text { BERTINDAK/MELAKUKAN } \\
\text { SESUATU DI DALAM } \\
\text { SUATU LOKASI }\end{array}$ & $\begin{array}{l}\text { 1. X berkial-kial/berkubang dalam kesedihan }[2], \\
\text { 2. X mengangguk/mengatupkan bibir/mengadukan } \mathrm{Y} \\
\text { dalam kesedihan }[3]\end{array}$ & 5 \\
\hline c. & $\begin{array}{l}\text { KESEDIHAN(/MENJADI } \\
\text { SEDIH) ADALAH } \\
\text { MELAKUKAN SESUATU/ } \\
\text { MENJADI DISERTAI } \\
\text { DENGAN/TANPA OBJEK } \\
\text { (INSTRUMEN) }\end{array}$ & $\begin{array}{l}\text { 1. X dengan kesedihan [2], } \\
\text { 2. X masuk/mencoba dengan kesedihan [2], } \\
\text { 3. X menghibur/habiskan/meledakkan/meresapi Y } \\
\text { dengan kesedihan }[4], \\
\text { 4. jawab X dengan kesedihan, } \\
\text { 5. X didengar oleh Y dengan kesedihan }\end{array}$ & 10 \\
\hline & KESEDIHAN(/MENJADI & 1. X punya kesedihan, kesedihanku/mu/nya (sendiri) & 39 \\
\hline
\end{tabular}




\begin{tabular}{|c|c|c|c|}
\hline & $\begin{array}{l}\text { SEDIH) ADALAH } \\
\text { KEPEMILIKAN }\end{array}$ & $\begin{array}{l}{[15],} \\
\text { 2. kesedihan pronomina/nama diri/ nomina umum [23] }\end{array}$ & \\
\hline e. & $\begin{array}{l}\text { KESEDIHAN(/MENJADI } \\
\text { SEDIH) ADALAH UKURAN/ } \\
\text { KUANTITAS }\end{array}$ & 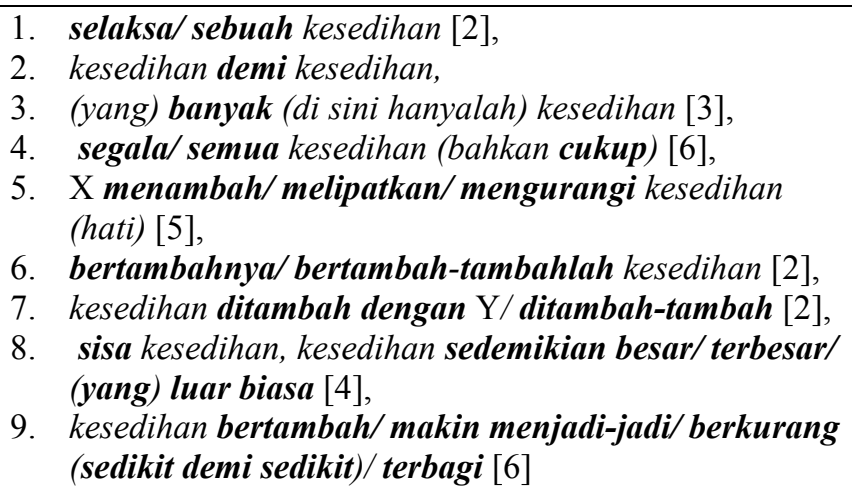 & 32 \\
\hline f. & $\begin{array}{l}\text { KESEDIHAN(/MENJADI } \\
\text { SEDIH) ADALAH OBJEK } \\
\text { YANG DIGERAKKAN }\end{array}$ & X mengalihkan/membuang(lah jauh) kesedihan & 3 \\
\hline & $\begin{array}{l}\text { KESEDIHAN(/MENJADI } \\
\text { SEDIH) ADALAH OBJEK } \\
\text { BERGERAK }\end{array}$ & $\begin{array}{l}\text { 1. jejak kesedihan }[2], \\
\text { 2. kesedihan pindah } \text { ke/ menyinggahi } \mathrm{X} / \text { berlalu }\end{array}$ & 5 \\
\hline h. & $\begin{array}{l}\text { KESEDIHAN(/MENJADI } \\
\text { SEDIH) ADALAH KONTROL } \\
\text { OBJEK BERGERAK }\end{array}$ & $\begin{array}{l}\text { 1. X (t[id]ak kuasa/ mampu/ sanggup) menahan } \\
\text { kesedihan [11], } \\
\text { 2. kesedihan hati sekuat-kuatnya ditahannya, } \\
\text { 3. jangan teruskan kesedihan, } \\
\text { 4. kesedihan terhenti [2] }\end{array}$ & 15 \\
\hline & $\begin{array}{l}\text { KESEDIHAN(/MENJADI } \\
\text { SEDIH) ADALAH } \\
\text { HALANGAN (BAGI } \\
\text { PERGERAKAN) }\end{array}$ & $\begin{array}{l}\text { 1. X digelut/dihimpit/dililit/terbelenggu/terjerat/ } \\
\text { menghindar dari kesedihan [6], } \\
\text { 2. X membentengi Y dengan pagar-pagar (ketakutan } \\
\text { dan) kesedihan }\end{array}$ & 7 \\
\hline $\mathrm{j}$. & $\begin{array}{l}\text { KESEDIHAN(/MENJADI } \\
\text { SEDIH) ADALAH } \\
\text { PERGERAKAN } \\
\text { TERDORONG SUATU } \\
\text { OBJEK }\end{array}$ & $\mathrm{X}$ didorong oleh rasa (kehilangan dan) kesedihan & 1 \\
\hline $\mathrm{k}$. & $\begin{array}{l}\text { KESEDIHAN(/MENJADI } \\
\text { SEDIH) ADALAH } \\
\text { PENYEBAB }\end{array}$ & $\begin{array}{l}\text { 1. kesedihan membuat X (jadi) cemas/nekat/pikun [3], } \\
\text { 2. kesedihan menghilangkan X/meringankan }[2]\end{array}$ & 5 \\
\hline 1. & $\begin{array}{l}\text { KESEDIHAN(/MENJADI } \\
\text { SEDIH) ADALAH OBJEK DI } \\
\text { SUATU LOKASI }\end{array}$ & $\begin{array}{l}\text { 1. ada kesedihan (mengeram) di sana/sudut dada [2], } \\
\text { 2. kesedihan (ber)ada di (per)muka(an) [2], } \\
\text { 3. mata kesedihan, } \\
\text { 4. X meninggalkan kesedihan (di hati) [3], } \\
\text { 5. kesedihan (di) hati }[3], \\
\text { 6. kesedihan dalam/pada X [3], } \\
\text { 7. di sana sini kesedihan }\end{array}$ & 15 \\
\hline $\mathrm{m}$. & $\begin{array}{l}\text { KESEDIHAN(/MENJADI } \\
\text { SEDIH) ADALAH(SECARA } \\
\text { POTENSIAL) MEMBERIKAN }\end{array}$ & $\begin{array}{l}\text { 1. X mendatangkan kesedihan, } \\
\text { 2. X membawa (pergi)/membagi/ berbagi/ memberi } \\
\text { kesedihan (kepada/dengan Y) [6], }\end{array}$ & 8 \\
\hline
\end{tabular}




\begin{tabular}{|c|c|c|c|}
\hline & $\begin{array}{l}\text { KESEDIHAN(/MENJADI } \\
\text { SEDIH) ADALAH(SECARA } \\
\text { POTENSIAL) MENERIMA/ } \\
\text { MENDAPAT SUATU OBJEK }\end{array}$ & $\begin{array}{l}\mathrm{X} \text { meminta/mendapat/beroleh (kesengsaraan/kesakitan } \\
\text { dan) kesedihan }\end{array}$ & 3 \\
\hline o. & $\begin{array}{l}\text { KESEDIHAN(/MENJADI } \\
\text { SEDIH) ADALAH } \\
\text { MENEMUKAN/MERAIH } \\
\text { SUATU OBJEK }\end{array}$ & $\mathrm{X}$ menangkap kesedihan & 1 \\
\hline p. & $\begin{array}{l}\text { KESEDIHAN(/MENJADI } \\
\text { SEDIH) ADALAH } \\
\text { ADANYA/KEBERADAAN/K } \\
\text { EHADIRAN FISIK SUATU } \\
\text { OBJEK }\end{array}$ & $\begin{array}{ll}\text { 1. } & \text { ada kesedihan }[5], \\
\text { 2. } & \text { X merasakan kesedihan }[11], \\
\text { 3. } & \text { kesedihan sirna/melenyap/(terasa) hilang [4], } \\
\text { 4. } & \text { tanda hilang kesedihan, } \\
5 . & \text { dilipurX kesedihan, } \\
\text { 6. } & \text { X menghilangkan/melipur(kan) kesedihan [9] }\end{array}$ & 31 \\
\hline $\mathrm{q}$. & $\begin{array}{l}\text { KESEDIHAN(/MENJADI } \\
\text { SEDIH) ADALAH OBJEK } \\
\text { FISIK }\end{array}$ & $\begin{array}{l}\text { 1. } \text { bentuk kesedihan, } \\
\text { 2. kesedihan dibuat/ditukar [2], } \\
\text { 3. X membuat kesedihan, } \\
\text { 4. penyulap kesedihan menjadi EMOSI, } \\
\text { 5. X berubah menjadi kesedihan, } \\
\text { 6. (X hanya) kesedihan (yang) menggantung [2], } \\
\text { 7. X (me)lupakan(lah)/lupa pada kesedihan [4], } \\
\text { 8. X mengenang kesedihan, teringat oleh X kesedihan }\end{array}$ & 14 \\
\hline
\end{tabular}

Jumlah 209

\subsection{Metafora CINTA}

Konsep cinta mungkin merupakan konsep emosi yang paling banyak digunakan secara metaforis (Kövecses, 2000:.26). Kövecses menduga, keadaan ini mungkin disebabkan oleh fakta bahwa cinta tidak hanya digunakan untuk membicarakan emosi, tetapi juga digunakan untuk membicarakan sebuah hubungan. Dengan demikian, konsep cinta mengambil bagian dalam RS yang mencirikan hubungan kemanusiaan. Sehubungan dengan metafora CINTA, Kövecses (2000:26-27) telah mengidentifikasi 23 metafora CINTA BIng. seperti di bawah ini. 
(a) CINTA ADALAH GIZI (MAKANAN/MINUMAN: Saya kelaparan akan cinta. (LOVE IS A NUTRIENT: I am starved for love.)

(b) CINTA ADALAH PERJALANAN: Ini jalan yang panjang dan bergelombang. (LOVE IS A JOURNEY: It's been a long, bumpy road.)

(c) CINTA ADALAH KESATUAN (DARI BAGIAN-BAGIAN): Kami seperti satu. Mereka putus. Kami tak terpisahkan. Kami digabungkan bersama. (LOVE IS A UNITY OF PARTS: We're as one. They're breaking up. We're inseparable. We fused together.)

(d) CINTA ADALAH KEDEKATAN: Mereka sangat dekat. (LOVE IS CLOSENESS: They're very close.)

(e) CINTA ADALAH IKATAN: Ada ikatan erat antara mereka. (LOVE IS A BOND: There is a close tie between them.)

(f) CINTA ADALAH CAIRAN DALAM WADAH: Dia dipenuhi dengan cinta. (LOVE IS A FLUID IN A CONTAINER: She was overflowing with love.)

(g) CINTA ADALAH API: Aku terbakar oleh cinta. (LOVE IS FIRE: I am burning with love.)

(h) CINTA ADALAH ADALAH PERTUKARAN EKONOMI: Aku menaruh lebih banyak ke ini daripada kamu. (LOVE IS AN ECONOMIC EXCHANGE: I'm putting more into this than you are.)

(i) CINTA ADALAH KEKUATAN ALAM: Dia menyapuku dari kakiku. (LOVE IS A NATURAL FORCE: She swept me off my feet.)

(j) CINTA ADALAH KEKUATAN FISIK: Aku tertarik pada perempuan itu secara magnetis. (LOVE IS A PHYSICAL FORCE: I was magnetically drawn to her.)

(k) CINTA ADALAH MUSUH/LAWAN: Dia berusaha melawan perasaan cintanya. (LOVE IS AN OPPONENT: She tried to fight her feelings of love.)

(1) CINTA ADALAH BINATANG TAWANAN/BUAS: Dia melepaskan perasaannya. (LOVE IS A CAPTIVE ANIMAL: She let go of her feelings.)

(m) CINTA ADALAH PERANG: Dia menaklukkan laki-laki itu. (LOVE IS WAR: She conquered him.)

(n) CINTA ADALAH OLAHRAGA/ PERMAINAN: Dia mempermainkan perempuan itu. (LOVE IS SPORT/A GAME: He made a play for her.) 
(o) CINTA ADALAH PENYAKIT/SAKIT: Aku sakit hati. (LOVE IS A DISEASE/AN ILLNESS: I am heart-sick.)

(p) CINTA ADALAH SIHIR: Dia terpesona. (LOVE IS MAGIC: He was enchanted.)

(q) CINTA ADALAH KEGILAAN: Aku tergila-gila kepadamu. (LOVE IS INSANITY: I am crazy about you.)

(r) CINTA ADALAH ATASAN SOSIAL: Dia sepenuhnya diperintah oleh cinta. (LOVE IS A SOCIAL SUPERIOR: She is completely ruled by love.)

(s) CINTA ADALAH MABUK: Aku telah mabuk cinta selama bermingguminggu. (LOVE IS RAPTURE/A HIGH: I have been high on love for weeks.)

(t) OBJEK CINTA ADALAH MAKANAN PERANGSANG SELERA: He, pasta manis. (THE OBJECT OF LOVE IS APPETIZING FOOD: Hi, sweetie-pie.)

(u) OBJEK CINTA ADALAH ANAK KECIL: Yah, bayi, apa yang akan kita lakukan?(THE OBJECT OF LOVE IS A SMALL CHILD: Well, baby, what are we gonna do?)

(v) OBJEK CINTA ADALAH DEWA/ DEWI: Jangan taruh gadis itu di alas. Dia memujanya. (THE OBJECT OF LOVE IS A DEITY: Don't put her on a pedestal. He worships her.)

(w) OBJEK CINTA ADALAH OBJEK BERHARGA: Engkau hartaku! (THE OBJECT OF LOVE IS A VALUABLE OBJECT: You're my treasure!) (Kövecses, 2000:26-27)

\subsubsection{Metafora CINTA yang Dibicarakan dalam Pustaka}

Hasil penjelajahan korpus menunjukkan bahwa 16 metafora CINTA yang memotivasi 114 ML yang berhubungan dengan cinta dapat diidentifikasi. Jumlah tersebut mewakili $16,43 \%$ dari semua metafora cinta yang ditemukan. Tujuh dari 23 metafora CINTA yang telah diidentifikasi oleh Kövecses (2000:26) tidak ditemukan dalam korpus BI yang diteliti. MK yang tidak ditemukan adalah CINTA SEBAGAI KEDEKATAN, CINTA SEBAGAI PERTUKARAN EKONOMI, CINTA 
SEBAGAI BINATANG TAWANAN/BUAS, CINTA SEBAGAI OBJEK CINTA ADALAH ANAK KECIL, OBJEK CINTA SEBAGAI DEWA-DEWI, OBJEK CINTA SEBAGAI MAKANAN PERANGSANG SELERA, dan OBJEK CINTA SEBAGAI BENDA BERHARGA. Ketidakmunculan metafora tersebut dapat disebabkan oleh alasan yang telah diuraikan pada sub-bab sebelumnya (5.2.1).

Metafora CINTA yang telah diidentifikasi oleh Kövecses (2000) dan juga ditemukan dalam BI dapat dipaparkan di bawah ini disertai masing-masing dengan contoh ML. Sementara itu, pola metaforis dan pemetaan selengkapnya dipaparkan pada tabel 5.6a. Metafora yang dimaksud adalah CINTA/(MENJADI CINTA) ADALAH

(5-194) GIZI (NUTRIENT) (MAKANAN/MINUMAN)

a. Bukankah kita tidak makan cinta?

b. Sepimu, Widuri, adalah sepi perempuan yang beranjak tua tanpa pernah menikmati manisnya cinta.

(5-195) PERJALANAN

a. Ternyata perjalanan cintanya cukup rumit dengan Pandu.

b. Dengan siapa cinta itu harus berlabuh.

(5-196) KESATUAN (DARI BAGIAN-BAGIAN)

a. Menyatukan cinta yang terpisah lama dalam rentangan dua kejadian.

b. Di situ ada penginapan Garden, tempat orang-orang memadu cinta gelap.

(5-197) IKATAN

a. Sewindu ini, kita jalin cinta dengan jarak yang jauh.

b. "Kenapa kamu, abis putus cinta ya, atau lagi sakit gigi?"

(5-198) CAIRAN DALAM WADAH

a. Mereka menumpahkan seluruh cinta untuknya.

(5-199) API

a. Murtini membakar dirinya dengan api cinta.

b. Cinta membara seperti yang sedang dialami Wingky dan Mandy.

(5-200) KEKUATAN ALAM 
a. Sudah sebulan diriku dilanda cinta olehnya.

b. Gelombang cinta akan terus-menerus menggerus, mengaliri seluruh urat nadi tubuh saya.

(5-201) KEKUATAN FISIK

a. Belum ada getar-getar cinta kala itu.

b. Toh cinta di situ cuma kekuatan yang mendorong ke arah perkawinan.

(5-202) MUSUH/ LAWAN

a. Ia tahu kalau kadang apa yang aku lakukan di luar nalar manusia biasa namun rasa cinta mengalahkan semuanya.

b. Apa yang mampu mengalahkan kekuatan cinta?

(5-203) PERANG

a. Ini dia pahlawan cinta kita!

b. Dia hanya tersenyum," makasih buat kejujurannya, saran saya cinta itu harus diperjuangkan.

(5-204) PERMAINAN

a. Agaknya cinta hanya menjadi permainan mulut saja sebelum bibir saling mengecup.

b. Rah tentunya lebih gandrung bermain cinta daripada [...].

(5-205) PENYAKIT/ SAKIT

a. "Demam cinta kali. Apa jangan-jangan terlalu banyak mikirin aku?"

b. Luar biasa hebatnya virus cinta itu [...].

(5-206) SIHIR (MAGIC)

a. Gelang ini belinya di Bali kata yang jualnya sih bisa jadi jimat cinta tapi kayaknya itu cuma akal-akalan yang dagang [...].

b. [...] tapi yang paling berbahaya adalah pesona cinta itu sendiri.

(5-207) KEGILAAN

a. Cinta membuatku bodoh.

b. Cinta telah menyeretku menjadi gila.

(5-208) ATASAN SOSIAL

a. Adhistia melakukan ini dan menganggap pengorbanannya ini sebagai pengabdiannya pada cinta sejati.

b. Ia akhirnya mengadu pada sang Cinta.

(5-209) MABUK (HIGH/RAPTURE)

a. Galib rupanya tengah dimabuk cinta.

b. Sesaat kemudia sepasang remaja yang dimabuk cinta itu beranjak 
pergi [...].

Tabel 5.6a

MK Cinta dalam Kövecses (2000) dan Realisasi Pola Metaforis BI.

\begin{tabular}{|c|c|c|c|}
\hline & Metafora Konseptual & Pola Metaforis & pan \\
\hline a. & $\begin{array}{l}\text { CINTA/ (MENJADI CINTA) } \\
\text { ADALAH GIZI } \\
\text { (NUTRIENT) (MAKANAN/ } \\
\text { MINUMAN) }\end{array}$ & 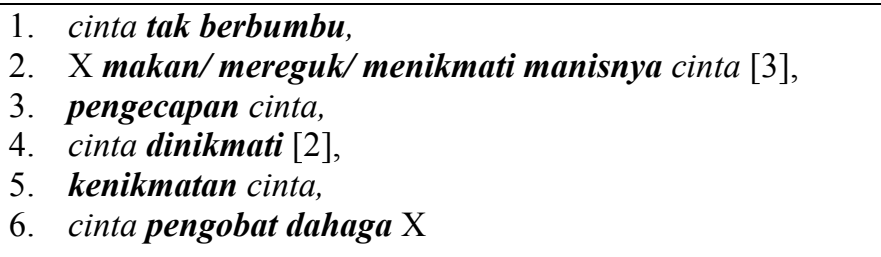 & 9 \\
\hline b. & $\begin{array}{l}\text { CINTA/ (MENJADI CINTA) } \\
\text { ADALAH PERJALANAN }\end{array}$ & $\begin{array}{ll}\text { 1. } & \text { (per)jalan (an)/ pengembara cinta }[3], \\
2 . & \text { cinta berlanjut/ berakhir/ diakhiri }[3], \\
3 . & \text { (rasa) cinta berlabuh (pada X) }[2], \\
\text { 4. } & \text { (X membawa Y ke) kaki langit cinta }[2], \\
5 . & \mathrm{X}(\text { terbang) menuju rumah cinta (bersama kekasih) }[2], \\
6 . & \text { terminal cinta terakhir }[4]\end{array}$ & 16 \\
\hline c. & $\begin{array}{l}\text { CINTA/ (MENJADI CINTA) } \\
\text { ADALAH KESATUAN } \\
\text { (DARI BAGIAN-BAGIAN) }\end{array}$ & $\begin{array}{l}\text { 1. X memadu/menyatukan cinta (yang terpisah) [3], } \\
\text { 2. cinta dipenggal }\end{array}$ & 4 \\
\hline & $\begin{array}{l}\text { CINTA/ (MENJADI CINTA) } \\
\text { ADALAH KEDEKATAN }\end{array}$ & - & 0 \\
\hline & $\begin{array}{l}\text { CINTA/ (MENJADI CINTA) } \\
\text { ADALAH IKATAN }\end{array}$ & $\begin{array}{l}\text { 1. X berjalin/dilibat/(me-)putus cinta }[5], \\
\text { 2. X (men-)jalin/memutuskan (hubungan) cinta (dengan) } \\
\text { Y }[4], \\
\text { 3. terjalin sebuah hubungan cinta, hubungan/jalinan/ } \\
\text { tali/pengikat (kasih) cinta }[7], \\
\text { 4. cinta mempersatukan jiwa, } \\
\text { 5. X diikat oleh tali cinta, } \\
\text { 6. kasih dan cinta terjalin }\end{array}$ & 20 \\
\hline f. & $\begin{array}{l}\text { CINTA/ (MENJADI CINTA) } \\
\text { ADALAH CAIRAN } \\
\text { DALAM WADAH }\end{array}$ & $\mathrm{X}$ menumpahkan cinta & 1 \\
\hline & $\begin{array}{l}\text { CINTA/ (MENJADI CINTA) } \\
\text { ADALAH API }\end{array}$ & $\begin{array}{l}\text { 1. X membakar diri dengan/terbakar oleh panasnya api } \\
\text { cinta }[2], \\
\text { 2. X memadamkan/meredakan gelora (rasa) cinta }[2], \\
\text { 3. bara cinta, } \\
\text { 4. cinta membara }\end{array}$ & 6 \\
\hline & $\begin{array}{l}\text { CINTA/ (MENJADI CINTA) } \\
\text { ADALAH PERTUKARAN } \\
\text { EKONOMI }\end{array}$ & & 0 \\
\hline & $\begin{array}{l}\text { CINTA/ (MENJADI CINTA) } \\
\text { ADALAH KEKUATAN }\end{array}$ & $\begin{array}{l}\text { 1. tiupan angin cinta, } \\
\text { 2. cinta badai, }\end{array}$ & 6 \\
\hline
\end{tabular}




\begin{tabular}{|c|c|c|c|}
\hline & ALAM & $\begin{array}{l}\text { 3. X dibadai/ dilanda cinta }[3] \\
\text { gelombang cinta menggerus } \mathrm{X}\end{array}$ & \\
\hline $\mathrm{j}$. & $\begin{array}{l}\text { CINTA/ (MENJADI CINTA) } \\
\text { ADALAH KEKUATAN } \\
\text { FISIK }\end{array}$ & $\begin{array}{l}\text { 1. } \text { getaran/getar-getar cinta }[2], \\
\text { 2. kekuatan/ kuatnya/ energi cinta }[3], \\
\text { 3. X tersiksa karena cinta, cinta yang dahsyat/adalah } \\
\text { siksaan/ cuma kekuatan (yang mendorong) [3] }\end{array}$ & 9 \\
\hline $\mathrm{k}$. & $\begin{array}{l}\text { CINTA/(MENJADI CINTA) } \\
\text { ADALAH MUSUH/ } \\
\text { LAWAN }\end{array}$ & $\begin{array}{l}\text { 1. (rasa) cinta mengalahkan/mengatasi } \mathrm{X}, \\
\text { 2. cinta mempunyai dendam, } \\
\text { 3. cinta melepaskan detak kasih sayang, } \\
\text { 4. cinta (bisa) diuji (oleh cinta) [2], } \\
\text { 5. X menghadapi/ menguji/tahan uji terhadap/diamuk/ } \\
\text { didera/mengalahkan kekuatan (perasaan) cinta [6], }\end{array}$ & 12 \\
\hline 1. & $\begin{array}{l}\text { CINTA/ (MENJADI CINTA) } \\
\text { ADALAH BINATANG } \\
\text { TAWANAN/BUAS }\end{array}$ & - & 0 \\
\hline $\mathrm{m}$ & $\begin{array}{l}\text { CINTA/ (MENJADI CINTA) } \\
\text { ADALAH PERANG }\end{array}$ & $\begin{array}{l}\text { 1. pahlawan cinta, } \\
\text { 2. X menyerahkan jiwa sebagai pengorbanan cinta, } \\
\text { 3. cinta (harus) diperjuangkan, } \\
\text { 4. cinta memang tidak mudah }\end{array}$ & 4 \\
\hline $\mathrm{n}$. & $\begin{array}{l}\text { CINTA/ (MENJADI CINTA) } \\
\text { ADALAH PERMAINAN }\end{array}$ & $\begin{array}{l}\text { 1. cinta menjadi permainan mulut, } \\
\text { 2. X bermain cinta }\end{array}$ & 2 \\
\hline O. & $\begin{array}{l}\text { CINTA/ (MENJADI CINTA) } \\
\text { ADALAH PENYAKIT/ } \\
\text { SAKIT }\end{array}$ & luka-luka/demam/virus/dokter cinta & 5 \\
\hline & $\begin{array}{l}\text { CINTA/ (MENJADI CINTA) } \\
\text { ADALAH SIHIR (MAGIC) }\end{array}$ & jimat/pesona cinta & 4 \\
\hline & $\begin{array}{l}\text { CINTA/ (MENJADI CINTA) } \\
\text { ADALAH KEGILAAN }\end{array}$ & $\begin{array}{l}\text { 1. cinta membuat/menyeret X menjadi bodoh/gila [2], } \\
\text { 2. cinta mati }\end{array}$ & 3 \\
\hline r. & $\begin{array}{l}\text { CINTA/ (MENJADI CINTA) } \\
\text { ADALAH ATASAN } \\
\text { SOSIAL }\end{array}$ & $\begin{array}{l}\text { 1. pengabdian (X) pada cinta }[2], \\
\text { 2. X mengadu pada sang cinta, } \\
\text { 3. sang cinta kejam dan sadis, } \\
\text { 4. X ngga bisa mengatur cinta }\end{array}$ & 5 \\
\hline S. & $\begin{array}{l}\text { CINTA/ (MENJADI CINTA) } \\
\text { ADALAH MABUK } \\
(H I G H / R A P T U R E)\end{array}$ & $\mathrm{X}(\boldsymbol{d i})$ mabuk cinta & 8 \\
\hline t. & $\begin{array}{l}\text { CINTA/ (MENJADI CINTA) } \\
\text { ADALAH OBJEK CINTA } \\
\text { ADALAH ANAK KECIL }\end{array}$ & - & 0 \\
\hline u. & $\begin{array}{l}\text { CINTA/ (MENJADI CINTA) } \\
\text { ADALAH OBJEK CINTA } \\
\text { ADALAH DEWA (DEITY) }\end{array}$ & - & 0 \\
\hline
\end{tabular}




\begin{tabular}{llc}
\hline v. & CINTA/ (MENJADI CINTA) & 0 \\
ADALAH OBJEK CINTA & & \\
ADALAH MAKANAN & - & \\
BERSELERA (APPETIZING & & 0 \\
& $F O O D)$ \\
& & \\
\hline w. & CINTA/ (MENJADI CINTA) \\
& ADALAH OBJEK CINTA \\
& ADALAH BENDA \\
BERHARGA & - &
\end{tabular}

\subsubsection{Metafora CINTA yang Tidak Dibicarakan dalam Pustaka}

Ditemukan 16 metafora CINTA yang memotivasi 240 ML tentang cinta yang digunakan dalam BI tetapi tidak dibicarakan dalam pustaka. Jumlah ini mewakili 34,58 \% dari jumlah metafora cinta yang ditemukan pada korpus yang diteliti. Metafora cinta yang termasuk dalam kelompok ini secara lengkap dapat dicermati pada tabel $5.6 \mathrm{~b}$

Berikut ini dipaparkan metafora CINTA yang tidak dibicarakan dalam pustaka Kövecses (2000) disertai dengan masing-masing contoh ML yang merealisasikannya. Metafora yang dimaksud adalah CINTA (/MENJADI CINTA) ADALAH:

(5-210) UNSUR DALAM WADAH (BERTEKANAN)

a. Saya dan Panji Semirang dengan penuh cinta melewati malammalam.

b. Dari matanya aku tahu begitu banyak cinta di dalamnya.

(5-211) UNSUR CAMPURAN/ MURNI

a. Kenapa cinta murni susut sucinya jika tidak memperoleh darinya pamrih?

b. Aku merasakan cinta yang berbuncah-buncah. 
(5-212) CAHAYA

a. [...] tapi kulihat di bola matanya ada cinta menyala disana?

b. Dia seorang gadis yang punya sinar cinta di matanya.

(5-213) (KE)GELAP(AN)

a. Cinta itu buta, wahai Abu Walid.

b. Cinta sejati bukanlah cinta yang membutakan mata hati, tapi [...].

(5-214) OBJEK BERWARNA/WARNA

a. Cinta diberi warna oleh dua orang yang menjalaninya.

b. Pertemanan, yang tak mungkin dipisahkan karena ungkitan pemuasan atau memudarnya cinta.

(5-215) OBJEK (TAK)TERSEMBUNYI/TAMPAK

a. Cinta dan batuk tidak dapat disembunyikan!

b. Waduh ternyata memendam rasa cinta itu susah banget yach [...].

(5-216) UNGKAPAN VERBAL/BAHASA

a. Baginda Nabi sejatinya telah mengajarkan idiom cinta yang begitu indah.

b. Dia melantunkan syair cinta di kota 'Nora' Spanyol.

(5-217) MAKHLUK HIDUP/ MANUSIA/ ORGANISME (TERTIDUR/TENANG)

a. Begitulah cinta menemukan menentukan warnanya sendiri.

b. Jika cinta sudah memanggilmu, pasrahlah dan menyerahlah, [...].

(5-218) TANAMAN

a. Akhirnya, benih-benih cinta mulai tumbuh di antara aku dan Widi.

b. Baru mulai jatuh sayang, baru mulai bersemi bunga bunga cinta, orang itu sudah berani memakinya.

(5-219) CERITA

a. Aku butuh cerita cinta.

b. Ini adalah awal kisah cinta kami yang begitu mengagetkan.

(5-220) OBJEK BERSIFAT ILAHI/ KEILAHIAN

a. Barangkali itulah yang disebut dengan cinta abadi.

b. Wingky memilih tato bergambar dewa cinta di lengan.

(5-221) KESALAHAN (WRONGDOING)

a. Cintanya pada Gilang bukanlah cinta terlarang.

b. Sama orang lain yang bukan cinta terlarang.

(5-222) SUARA/ BUNYI/ NADA

a. Kami lalu memainkan melodi cinta paling indah. 
b. Tak akan kunyanyikan senandung cinta sebelum kau datang [...].

(5-223) OBJEK/ BENDA PENGHIAS

a. Seorang penyayang yang menghiasimu dengan cinta?

b. Cinta pink itu ya cinta yang selalu indah, malu-malu.

(5-224) OBJEK ASLI/ PALSU

a. Yang menyita waktu dari kepemudaannya hanya demi cinta palsu.

b. Cinta sejati itu Doni.

(5-225) KEBEBASAN

a. Sementara cinta itu sendiri adalah kebebasan.

b. Cinta merdeka! Rusli dan Kartini, cinta merdeka! Berzinah itu!

(5-226) OBJEK DAMBAAN

a. [...] hati dosen yang kering mendambakan cinta.

b. Selah tersaruk-saruk merindukan cinta, maka inilah hasilnya.

(5-227) LOGAM/ BESI

a. Bagaimana cinta akan berkarat hanya karena jarak [...].

b. Jika cinta ini belum juga berkarat setelah mengarungi berabadabad jarak, $[\ldots]$.

(5-228) TEORI/ ILMU

a. Terima kasih telah mengajariku cinta.

b. Dalam dunia maya yang penuh ragam ini, berbagai konsep cinta bermunculan.

(5-229) KEHANGATAN

a. Buku, cinta, dan pesta adalah kehangatan.

b. Pelukan cinta yang akan aku bawa bersama rohku terbang ke awang-awang yang tinggi.

(5-230) MISTERI

a. Cinta memang ngga bisa ditebak.

b. Itu semua rahasia cinta.

Tabel 5.6b

MK dan Pola Metaforis Cinta yang Tidak Dibicarakan dalam Pustaka

\begin{tabular}{lllll}
\hline No & Metafora Konseptual & Pola Metaforis & Kekerapan \\
& & & & \\
\hline a. & CINTA (/MENJADI CINTA) & 1. X V(erba) (Y) (dengan) penuh (rasa) cinta (dan [kasih] & 21 \\
ADALAH UNSUR DALAM & & sayang/hormat/kelembutan) [10], \\
& WADAH (BERTEKANAN) & 2. X penuh (dengan) (perasaan) cinta [5], & \\
& 3. pandangan (mata)/hati penuh (dengan)/sepenuhnya & \\
\hline
\end{tabular}


dipenuhi (rasa) cinta [3]

4. X mengisi Y penuh dengan cinta,

5. penuhilah hati dengan cinta dan kasih sayang,

6. begitu banyak cinta di dalam $\mathrm{X}$

\begin{tabular}{|c|c|c|}
\hline & $\begin{array}{l}\text { CINTA (/MENJADI CINTA) } \\
\text { ADALAH UNSUR } \\
\text { CAMPURAN/ MURNI }\end{array}$ & $\begin{array}{l}\text { 1. } \text { cinta murni }[2], \\
\text { 2. rasa cinta (X pada } \mathrm{Y}) \text { membuncah, } \\
\text { 3. cinta berbuncah-buncah, } \\
\text { 4. X terkurangi dari (rasa) cinta }\end{array}$ \\
\hline & $\begin{array}{l}\text { CINTA (/MENJADI CINTA) } \\
\text { ADALAH CAHAYA }\end{array}$ & $\begin{array}{l}\text { 1. cinta menyala, } \\
\text { 2. cahaya/sinar cinta (di mata } X)\end{array}$ \\
\hline d. & $\begin{array}{l}\text { CINTA (/MENJADI CINTA) } \\
\text { ADALAH (KE)GELAP(AN) }\end{array}$ & $\begin{array}{l}\text { 1. } \text { cinta (itu) buta }[4], \\
\text { 2. } \quad \text { cinta (itu) gak punya mata }[3], \\
\text { 3. cinta membutakan mata hati, } \\
\text { 4. X dibutakan oleh/menyelimuti Y dengan cinta [2] }\end{array}$ \\
\hline
\end{tabular}
e. CINTA (/MENJADI CINTA) 1. cinta diberi warna oleh X,
ADALAH OBJEK 2. cinta hanyalah pemulas,
BERWARNA/ WARNA 3. cinta yang polos/(tiada pernah) pudar [2],
4. memudarnya cinta,
5. (rasa) cinta memudar/pudar [2],
6. cinta ([dengan/ber-]warna) merah/pink/hijau/kuning/ pastel [10],
7. cinta (serupa) warna X [2]

f. CINTA (/MENJADI CINTA) ADALAH OBJEK (TAK)

1. X memendam (ketulusan) ([pe]rasa[an]) cinta [3], TERSEMBUNYI/ TAMPAK

2. cinta (yang) terpendam di hati/timbul/tersekap [3],

3. cinta (perlu) diungkapkan,

4. cinta (tidak dapat) disembunyikan,

5. gambaran cinta,

6. X melihat cinta (, kesedihan, kebencian) di mata $\mathrm{Y}$,

7. pernyataan/ungkapan cinta [3],

8. X menyatakan/nyatain/nampakkan/mengungkapkan/ ungkapkan/mengutarakan ([pe]rasa[an]) cinta ([ke]pada/ ke/ama Y) [21],

9. $\mathrm{X} /$ mata menyimpan cinta [3],

10. X mengubur (perasaan) cinta
g. CINTA (/MENJADI CINTA) 1. bahasa/ idiom/kalimat/kata(-kata)/sajak/penyair/ (melantunkan) (bait-bait) syair cinta [13],
VERBAL/ BAHASA 2. X mengucapkan cinta,
3. cinta hanya sekedar ucapan/adalah kata sakral [2],
4. sapa cinta menjadi seribu gagu
h. CINTA (/MENJADI CINTA) ADALAH MAKHLUK HIDUP/ MANUSIA/ ORGANISME (TERTIDUR/ TENANG)
1. X memanggil(-manggil) $\mathrm{Y}$ [2],
2. cinta (tak) kasih tau,
3. cinta memiliki hati,
4. cinta butuh pengakuan,
5. cinta (lebih) memilih X/(tidak pernah) meminta [2],
6. cinta (tiada/tidak) memandang/mengenal X [3],
7. cinta itu pelit dan dengki,
8. cinta kehilangan $\mathrm{X}$,
9. X memfitnah/mengenal/disentuh oleh/diperkenalkan cinta [4],




\begin{tabular}{|c|c|c|}
\hline & $\begin{array}{l}\text { 10. X mengenalkan cinta buat } \mathrm{Y}, \\
\text { 11. X (ga/tidak) percaya pada cinta }[2], \\
\text { 12. maut dan cinta segolongan, } \\
\text { 13. pacaran serupa dengan cinta, } \\
\text { 14. X lebih kaya daripada cinta, } \\
\text { 15. cinta monyet }[4], \\
\text { 16. sayap cinta }[2], \\
\text { 17. cinta hanya pengantar penghilang kecanggungan, } \\
\text { keinginan cinta, } \\
\text { 18. atas nama cinta (dan sayang) }[3], \\
\text { 19. cinta kehilangan hakikat }\end{array}$ & \\
\hline $\begin{array}{l}\text { i. } \text { CINTA (/MENJADI CINTA) } \\
\text { ADALAH TANAMAN }\end{array}$ & $\begin{array}{l}\text { 1. benih-benih cinta mulai tumbuh di hati/ antara } \mathrm{X} \text { dan } \mathrm{Y} \\
\text { [3], } \\
\text { 2. cinta di hati } \mathrm{X} \text { makin bersemi, } \\
\text { 3. X menanamkan benih cinta di hati } \mathrm{Y}, \\
\text { 4. X menumbuhkan cinta }[2], \\
\text { 5. cinta bersemi pada } \mathrm{X}, \\
\text { 6. (bersemi) bunga-bunga cinta }[2], \\
\text { 7. tumbuhnya cinta }[2], \\
\text { 8. bunga perlambang cinta, semak cinta }[2]\end{array}$ & 16 \\
\hline $\begin{array}{ll}\text { j. } & \text { CINTA (/MENJADI CINTA) } \\
& \text { ADALAH CERITA }\end{array}$ & cerita/ kisah cinta & 13 \\
\hline $\begin{array}{ll}\mathrm{k} . & \text { CINTA (/MENJADI CINTA) } \\
& \text { ADALAH OBJEK } \\
\text { BERSIFAT } \\
\text { ILAHI/KEILAHIAN }\end{array}$ & $\begin{array}{l}\text { 1. cinta (yang) abadi/sempurna }[7], \\
\text { 2. dewa cinta, } \\
\text { 3. Tuhan adalah sumber cinta, } \\
\text { 4. cinta dapat mengubah segala-galanya, } \\
\text { 5. cinta tidak egois/tidak pernah salah }\end{array}$ & 12 \\
\hline $\begin{array}{l}\text { 1. CINTA (/MENJADI CINTA) } \\
\text { ADALAH KESALAHAN } \\
(\text { WRONGDOING) }\end{array}$ & $\begin{array}{l}\text { 1. cinta terlarang }[6], \\
\text { 2. X (Allah) melaknat cinta }\end{array}$ & 7 \\
\hline $\begin{array}{l}\text { m. CINTA (/MENJADI CINTA) } \\
\text { ADALAH SUARA/BUNYI/ } \\
\text { NADA }\end{array}$ & $\begin{array}{l}\text { melodi/(alunan) nada/senandung(-senandung)/ simfoni } \\
\text { cinta }\end{array}$ & 6 \\
\hline $\begin{array}{l}\text { n. } \text { CINTA (/MENJADI CINTA) } \\
\text { ADALAH OBJEK/BENDA } \\
\text { PENGHIAS }\end{array}$ & $\begin{array}{l}\text { 1. X menghiasi Y dengan cinta, } \\
\text { 2. cinta (memang [tidak semuanya]/ selalu) indah [4], } \\
\text { 3. indahnya cinta }\end{array}$ & 6 \\
\hline $\begin{array}{l}\text { o. } \text { CINTA (/MENJADI CINTA) } \\
\text { ADALAH OBJEK ASLI/ } \\
\text { PALSU }\end{array}$ & cinta palsu/sejati & 8 \\
\hline $\begin{array}{ll}\text { p. } & \text { CINTA (/MENJADI CINTA) } \\
& \text { ADALAH KEBEBASAN }\end{array}$ & $\begin{array}{l}\text { 1. cinta adalah kebebasan, } \\
\text { 2. kebebasan cinta, } \\
\text { 3. cinta merdeka }\end{array}$ & 5 \\
\hline $\begin{array}{l}\text { q. } \\
\text { ADANTA (/MENJADI CINTA) } \\
\text { DAMBAH OBJEK } \\
\text { DAN }\end{array}$ & $\mathrm{X}$ merindukan/mengharapkan/mendambakan cinta & 4 \\
\hline
\end{tabular}




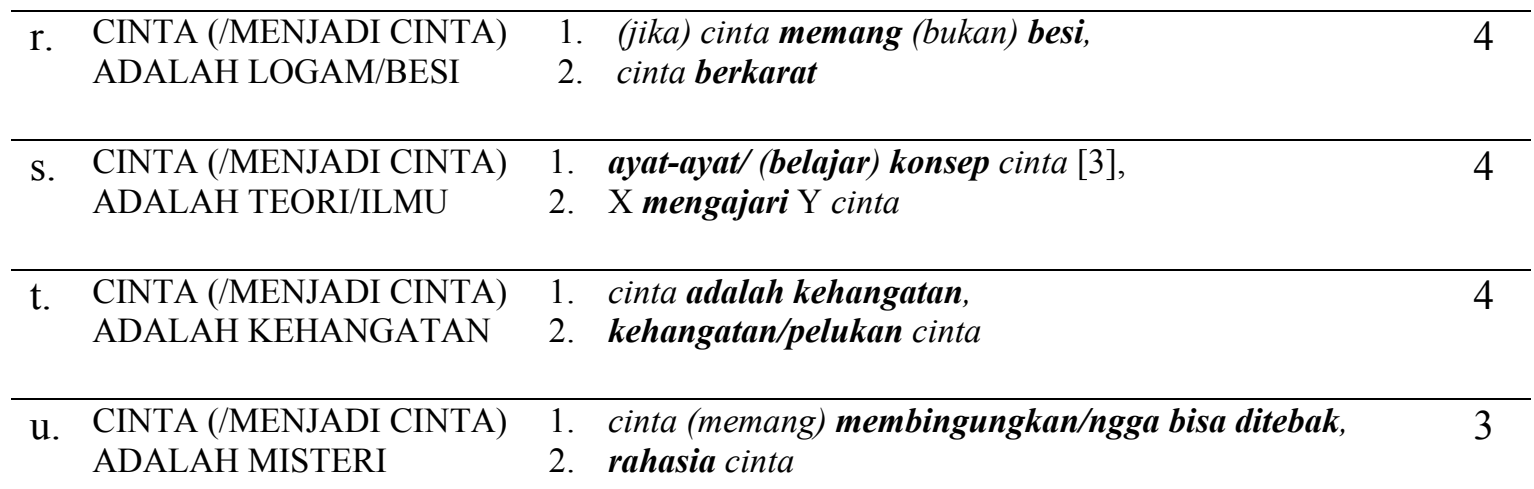

\subsubsection{Metafora CINTA yang Munculnya Jarang}

Metafora CINTA dan metafora lingistik yang tidak dibicarakan dalam pustaka Kövecses (2000:26) dan munculnya ditemukan sangat jarang dalam BI dipaparkan di bawah ini. Ditemukan 10 metafora CINTA yang memotivasi $12 \mathrm{ML}$ tentang cinta atau $1,73 \%$ dari seluruh metafora CINTA yang ditemukan. Pola metaforis cinta jenis ini digambarkan pada tabel 5.6c. Metafora yang dimaksud adalah CINTA (/MENJADI CINTA) ADALAH:

(5-231) BANGUNAN

Oh, ya. Memang perlu strategi pembangunan cinta.

(5-232) OBJEK RAPUH/PECAH BELAH (FRAGILE)

[...] kepadaku diperkenalkan hasrat saling ingin membunuh yang akanmenghancurkan cinta itu.

(5-233) OBJEK/BENDA TAJAM

Gadis itu telah melepaskan jarum-jarum cinta lewat matanya.

(5-234) GARIS

Garis ini adalah garis cinta.

(5-235) PASIR

Wingky, menurutku cinta itu seperti butiran pasir. 
(5-236) ROH/MAKHLUK SPIRITUAL

Aku seperti kerasukan setan cinta.

(5-237) KEDALAMAN

Tapi, kamu harus tahu, masih lebih dalam lagi cinta yang telah melahirkanmu.

(5-238) OBAT/PENYEMBUH

Terapinya adalah cinta.

(5-239) MEMBELI SUATU OBJEK BERHARGA

Cinta bisa dibeli di zaman ini.

(5-240) CAIRAN

Ia terlarut dalam cinta.

Tabel 5.6c

MK dan Pola Metaforis Cinta yang Munculnya Jarang

\begin{tabular}{|c|c|c|c|}
\hline & Metafora Konseptual & Pola Metaforis & Kekerapan \\
\hline a. & $\begin{array}{l}\text { CINTA (/MENJADI CINTA) } \\
\text { ADALAH BANGUNAN }\end{array}$ & pembangunan cinta & 2 \\
\hline b. & $\begin{array}{l}\text { CINTA (/MENJADI CINTA) } \\
\text { ADALAH OBJEK } \\
\text { RAPUH/PECAH BELAH } \\
(F R A G I L E)\end{array}$ & $\begin{array}{l}\text { 1. perusak cinta, } \\
\text { 2. X menghancurkan cinta }\end{array}$ & 2 \\
\hline c. & $\begin{array}{l}\text { CINTA (/MENJADI CINTA) } \\
\text { ADALAH OBJEK/BENDA } \\
\text { TAJAM }\end{array}$ & jarum-jarum cinta & 1 \\
\hline $\mathrm{d}$. & $\begin{array}{l}\text { CINTA (/MENJADI CINTA) } \\
\text { ADALAH GARIS }\end{array}$ & garis ini adalah garis cinta & 1 \\
\hline e. & $\begin{array}{l}\text { CINTA (/MENJADI CINTA) } \\
\text { ADALAH PASIR }\end{array}$ & cinta seperti butiran pasir & 1 \\
\hline f. & $\begin{array}{l}\text { CINTA (/MENJADI CINTA) } \\
\text { ADALAH ROH/MAKHLUK } \\
\text { SPIRITUAL }\end{array}$ & X seperti kerasukan setan cinta & 1 \\
\hline g. & $\begin{array}{l}\text { CINTA (/MENJADI CINTA) } \\
\text { ADALAH KEDALAMAN }\end{array}$ & cinta masih lebih dalam lagi & 1 \\
\hline
\end{tabular}


h. CINTA (/MENJADI CINTA) $\quad$ terapinya adalah cinta 1 ADALAH OBAT/ PENYEMBUH

\begin{tabular}{llll}
\hline i. & CINTA (/MENJADI CINTA) & cinta (bisa) dibeli & 1
\end{tabular} ADALAH MEMBELI SUATU

OBJEK BERHARGA

j. $\quad$ CINTA (/MENJADI CINTA) X terlarut dalam cinto 1 ADALAH CAIRAN

\subsubsection{Metafora Struktur Peristiwa untuk CINTA}

Ditemukan 19 metafora CINTA yang dapat diklasifikasikan sebagai MSP. Metafora tersebut didukung dengan 328 ML yang mengejewantahkan MK yang memotivasinya. Jumlah ini mewakili $47,26 \%$ dari seluruh metafora cinta yang detemukan. Pola metaforis CINTA yang termasuk MSP selengkapnya didaftar pada tabel 5.6d. Metafora yang dimaksud adalah CINTA (/MENJADI CINTA) ADALAH:

(5-241) LOKASI (TERKUNGKUNG/WADAH)

a. Cinta yang penuh kehati-hatian, malu-malu.

b.Dia memasuki segala celah cinta dalam hatiku.

(5-242) BERTINDAK/ MELAKUKAN SESUATU DI DALAM SUATU LOKASI a. Aku memeluk ibuku, memeluknya dalam cinta dan kasih sayang.

b. Dengan kebutaan yang aku miliki aku terlena dalam cinta yang indah sesaat $[\ldots]$.

(5-243) PERGERAKAN AKSIDENTAL

a. Sebenarnya aku jatuh cinta pada kunjungan pertama [...].

b. Untuk pertama kalinya aku jatuh cinta kepada Kartini.

(5-244) LANDASAN/ DASAR

a. Katamu dasar hidup adalah cinta, [...].

b. Pernikahan yang tidak didasari oleh cinta yang tulus tampaknya akan susah untuk langgeng.

(5-245) MELAKUKAN SESUATU DISERTAI/ TEMANI DENGAN OBJEK (INSTRUMEN) 
a. Ali Topan yang ia asuh dengan cinta.

b. Sudah kubilang. Tidak usah pake cinta. Itu aturannya.

(5-246) SECARA POTENSIAL MEMBERIKAN/MENTRANSFER SUATU OBJEK

a. "Cinta Kasih hanya untukmu Ko aku selalu tahu itu [...].

b. [...] aku bertemu dengan orang yang dapat memberikan aku cinta yang tulus.

(5-247) SECARA POTENSIAL MENERIMA/MEMPEROLEH SUATU OBJEK

a. Seorang penulis, katanya mana ada disukai apalagi mendapatkan cinta dari seorang wanita.

b. Aku berhak dong, nolak atau (me)nerima cinta siapapun.

(5-248) KEPEMILIKAN

a. Padahal, bola adalah cinta ketiga gue.

b. Aku merasa memiliki cinta untukmu.

(5-249) OBJEK BERGERAK

a. Dari mana cinta itu datang.

b. "Bisakah cinta singgah lagi di hati saya?"

(5-250) OBJEK YANG DIGERAKKAN

a. Jangan-jangan ada yang mengira aku memaksakan cinta.

b. [...] sebab-sebab inilah yang mendorong rasa cinta pada mereka, $[\ldots]$.

(5-251) HALANGAN

a. [...] Topan anak jalanan: kesandung cinta.

b. [...], disamping aku takut terjebak cinta, ada satu lagi ketakutan $[\ldots]$.

(5-252) BEBAN

a. Tekadku untuk memikul cinta yang terpasung.

(5-253) PENYEBAB

a. Harus kucatat bahwa cinta telah membuat aku menjadi manusia kreatif menurut versiku.

b. [...] cinta membawa penderitaan, tetapi tidak pernah mendendam.

(5-254) UKURAN/ KUANTITAS

a. Bertambahlah perasaan cinta dalam dirinya.

b. Menebar kasih sayang pada sahabat-sahabatnya dan tidak mengurangi rasa cinta dalam dendam pada musuh-musuhnya.

(5-255) OBJEK DI SUATU LOKASI

a. Mengapa ada cinta yang buta di antara pengabdianmu pada kami? 
b. Cinta hanya ada pada dua kutub yang setaraf.

(5-256) MENCARI/ MENGEJAR/ MEMBURU SUATU OBJEK

a. "Kau mau mencari cinta yang sejati, sekali nemplok, lansung pada kau.

b. "Ya, dalam memburu cinta Wilada.".

(5-257) MENEMUKAN/MERAIH SUATU OBJEK

a. Karena kabar bumi senantiasa damai selama kau menemukan cinta yang tulus dan kecantikan yang penuh kasih sayang.

(5-258) ADANYA/KEBERADAAN/ KEHADIRAN FISIK SUATU OBJEK

a. "Bah!" "Hari ini tiada cinta," kata lelaki itu.

b. [...] hilangnya cinta yang di bangga-banggakannnya selama ini.

(5-259) OBJEK FISIK

a. Aku mencintaimu, tetapi dalam bentuk cinta yang platonis.

b. Dia lalu menciptakan cinta dalam diri manusia.

\section{Tabel 5.6d}

MK dan Pola MSP untuk Cinta

\begin{tabular}{|c|c|c|c|}
\hline & Metafora Konseptual & Pola Metaforis & Kekerapan \\
\hline a. & $\begin{array}{l}\text { CINTA (/MENJADI CINTA) } \\
\text { ADALAH LOKASI } \\
\text { (TERKUNGKUNG/ } \\
\text { WADAH) }\end{array}$ & $\begin{array}{l}\text { 1. X antara/dalam cinta [4], } \\
\text { 2. cinta diisi dengan/yang penuh X [2], } \\
\text { 3. X sampai pada batas cinta, } \\
\text { 4. X memasuki celah/mengaliri pori-pori cinta [2], } \\
\text { 5. jarak benci dan cinta, } \\
\text { 6. X bertolak dari/terjebak dalam cinta [2] }\end{array}$ & 12 \\
\hline b. & $\begin{array}{l}\text { CINTA (/MENJADI CINTA) } \\
\text { ADALAH BERTINDAK/ } \\
\text { MELAKUKAN SESUATU } \\
\text { DI DALAM SUATU } \\
\text { LOKASI }\end{array}$ & $\mathrm{X}$ memeluk Y/terlena dalam cinta $[2]$ & 2 \\
\hline & $\begin{array}{l}\text { CINTA (/MENJADI CINTA) } \\
\text { ADALAH PERGERAKAN } \\
\text { AKSIDENTAL }\end{array}$ & $\mathrm{X}$ jatuh cinta (ke/[ke]pada/[s]ama Y) & 91 \\
\hline & $\begin{array}{l}\text { CINTA (/MENJADI CINTA) } \\
\text { ADALAH LANDASAN/ } \\
\text { DASAR }\end{array}$ & $\begin{array}{l}\text { 1. dasar hidup adalah cinta, } \\
\text { 2. cinta kokoh, } \\
\text { 3. X didasari (oleh) cinta [2] }\end{array}$ & 4 \\
\hline e. & $\begin{array}{l}\text { CINTA (/MENJADI CINTA) } \\
\text { ADALAH MELAKUKAN } \\
\text { SESUATU }\end{array}$ & $\begin{array}{l}\text { 1. X asuh } \mathrm{Y} / \text { tertinggal di } \mathrm{Y} \text { dengan (perasaan) cinta [2], } \\
\text { 2. } \mathrm{X}(\text { V }[\text { erba]) tanpa/ pakai cinta [11], } \\
\text { 3. cinta hanya sarana untuk } \text { V(erba) }\end{array}$ & 14 \\
\hline
\end{tabular}


DISERTAI/TEMANI

DENGAN OBJEK

(INSTRUMEN)

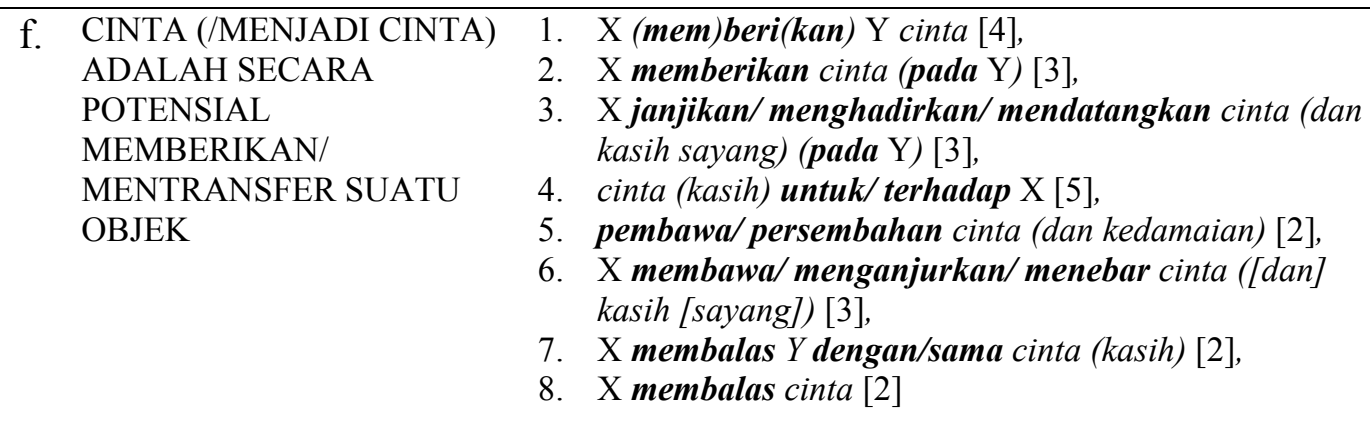

3. X janjikan/menghadirkan/mendatangkan cinta (dan kasih sayang) (pada Y) [3],

4. cinta (kasih) untuk/terhadap X [5],

5. pembawa/ persembahan cinta (dan kedamaian) [2],

6. X membawa/ menganjurkan/menebar cinta ([dan] kasih [sayang]) [3],

7. X membalas $Y$ dengan/sama cinta (kasih) [2],

8. X membalas cinta [2]

\begin{tabular}{|c|c|c|c|}
\hline & $\begin{array}{l}\text { CINTA (/MENJADI CINTA) } \\
\text { ADALAH SECARA } \\
\text { POTENSIAL MENERIMA/ } \\
\text { MEMPEROLEH SUATU } \\
\text { OBJEK }\end{array}$ & 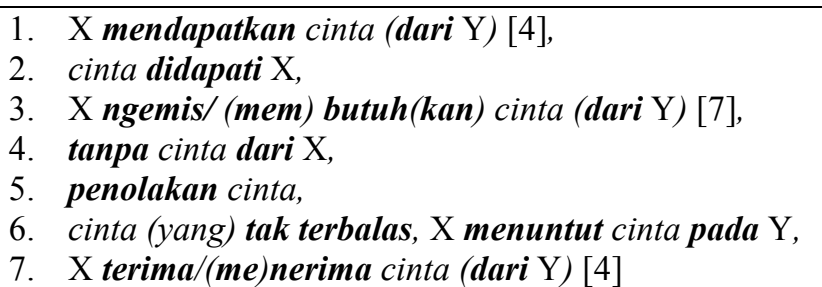 & 20 \\
\hline h. & $\begin{array}{l}\text { CINTA (/MENJADI CINTA) } \\
\text { ADALAH KEPEMILIKAN }\end{array}$ & $\begin{array}{l}\text { 1. } \text { cintaku/mu/nya [13], } \\
\text { 2. cinta pronomina/(si) nama diri/nomina umum [25], } \\
\text { 3. cinta tidak harus memiliki, } \\
\text { 4. X mengembalikan cinta, } \\
\text { 5. X punya/memiliki (sejuta) (rasa) cinta }[10], \\
\text { 6. X mempertahankan/ kehilangan (rasa) cinta [5], } \\
\text { 7. X kaya cinta }\end{array}$ & 56 \\
\hline i. & $\begin{array}{l}\text { CINTA (/MENJADI CINTA) } \\
\text { ADALAH OBJEK } \\
\text { BERGERAK }\end{array}$ & 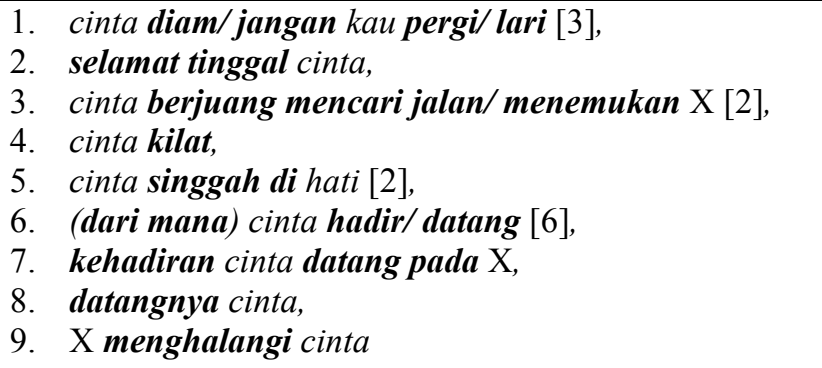 & 18 \\
\hline & $\begin{array}{l}\text { CINTA (/MENJADI CINTA) } \\
\text { ADALAH OBJEK YANG } \\
\text { DIGERAKKAN }\end{array}$ & $\begin{array}{l}\text { 1. X memaksakan/mendorong (rasa) cinta pada } \mathrm{Y} \text { [2], } \\
\text { 2. (rasa) cinta } \mathrm{X} \text { ke } \mathrm{Y} \text { [3] }\end{array}$ & 5 \\
\hline & $\begin{array}{l}\text { CINTA (/MENJADI CINTA) } \\
\text { ADALAH HALANGAN }\end{array}$ & $\mathrm{X}$ kesandung/terjebak cinta & 2 \\
\hline & $\begin{array}{l}\text { CINTA (/MENJADI CINTA) } \\
\text { ADALAH BEBAN }\end{array}$ & $\mathrm{X}$ memikul cinta & 1 \\
\hline & $\begin{array}{l}\text { CINTA (/MENJADI CINTA) } \\
\text { ADALAH PENYEBAB }\end{array}$ & 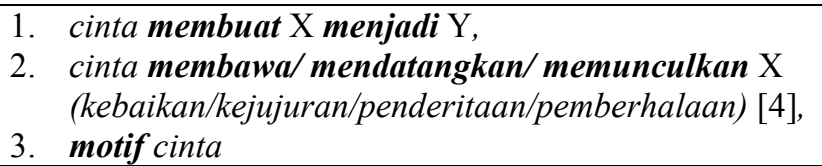 & 6 \\
\hline
\end{tabular}




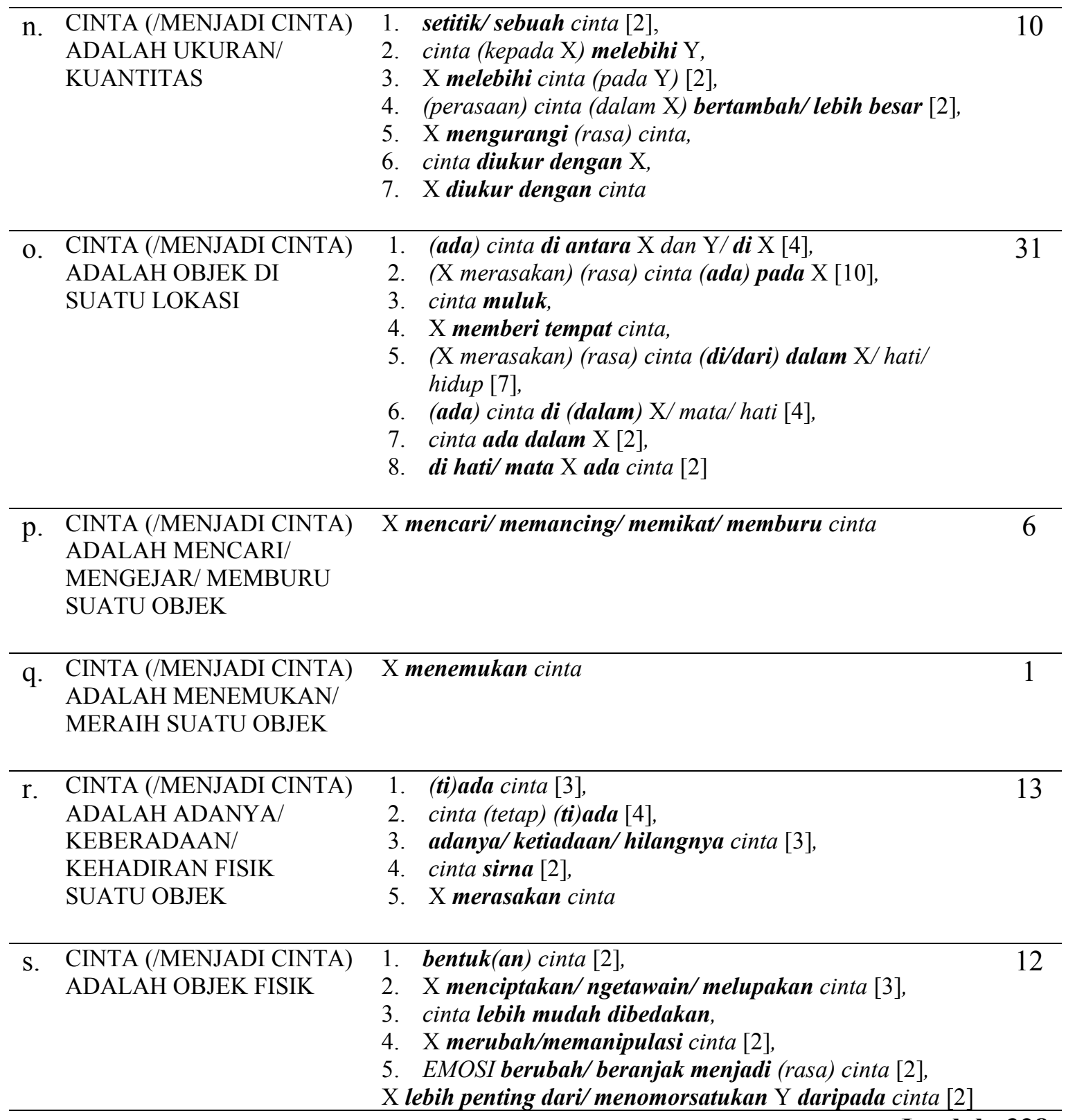

Jumlah..328

\subsection{Rekapitulasi MK dan ML menyangkut Emosi}

Di bawah ini disajikan rekapitulasi temuan MK dan ML yang menyangkut emosi amarah/kemarahan, ketakutan, kebahagiaan, kesedihan, dan cinta. 
Tabel 5.7

Rekapitulasi MK dan ML Menyangkut Emosi Amarah/Kemarahan, Ketakutan, Kebahagiaan, Ketakutan, dan Cinta

\begin{tabular}{|c|c|c|c|c|}
\hline EMOSI & Metafora & M K & M L & Persen \\
\hline \multirow[t]{5}{*}{$\begin{array}{l}\text { Amarah/ } \\
\text { Kemarahan }\end{array}$} & Yang telah dibicarakan dalam Pustaka & 10 & 248 & 26,56 \\
\hline & Yang belum dibicarakan dalam Pustaka & 19 & 397 & 42,51 \\
\hline & Yang munculnya jarang & 8 & 11 & 1,17 \\
\hline & Struktur Peristiwa & 17 & 278 & 29,76 \\
\hline & Jumlah & 54 & 934 & 100 \\
\hline \multirow[t]{5}{*}{ Ketakutan } & Yang telah dibicarakan dalam Pustaka & 7 & 73 & 19,78 \\
\hline & Yang belum dibicarakan dalam Pustaka & 12 & 115 & 31,17 \\
\hline & Yang munculnya jarang & 9 & 12 & 3,25 \\
\hline & Struktur Peristiwa & 15 & 169 & 45,80 \\
\hline & Jumlah & 43 & 369 & 100 \\
\hline \multirow[t]{5}{*}{ Kebahagiaan } & Yang telah dibicarakan dalam Pustaka & 9 & 32 & 5,65 \\
\hline & Yang belum dibicarakan dalam Pustaka & 15 & 157 & 27,74 \\
\hline & Yang munculnya jarang & 5 & 5 & 0,88 \\
\hline & Struktur Peristiwa & 16 & 372 & 65,73 \\
\hline & Jumlah & 45 & 566 & 100 \\
\hline \multirow[t]{5}{*}{ Kesedihan } & Yang telah dibicarakan dalam Pustaka & 12 & 122 & 24,60 \\
\hline & Yang belum dibicarakan dalam Pustaka & 15 & 158 & 31,85 \\
\hline & Yang munculnya jarang & 7 & 7 & 1,41 \\
\hline & Struktur Peristiwa & 17 & 209 & 42,14 \\
\hline & Jumlah & 51 & 496 & 100 \\
\hline \multirow[t]{5}{*}{ Cinta } & Yang telah dibicarakan dalam Pustaka & 16 & 114 & 16,43 \\
\hline & Yang belum dibicarakan dalam Pustaka & 21 & 240 & 34,58 \\
\hline & Yang munculnya jarang & 10 & 12 & 1,73 \\
\hline & Struktur Peristiwa & 19 & 328 & 47,26 \\
\hline & Jumlah & 66 & 694 & 100 \\
\hline
\end{tabular}




\section{BAB VI}

\section{METAFORA KHAS EMOSI BAHASA INDONESIA}

\subsection{Pengantar}

Kövecses (2000:35) mengangkat isu teoretis terkait dengan RS metaforis khas bagi RT EMOSI. Isu ini menurut Kövecses (2000:35) berkaitan secara lebih luas dengan cakupan dari suatu RS metaforis, yaitu rentangan RT yang dapat dikonseptualisasikan dengan suatu RS metaforis (Kövecses, 2010:136). Pada kasus metafora emosi, salah satu pertanyaannya ialah "apakah RS bagi metafora emosi hanya digunakan dalam lingkup RT EMOSI secara khusus atau dapat digunakan di luar RT EMOSI?” (Kövecses, 2000:35). Jawaban Kövecses (2000:36) ialah cakupan RS metafora emosi, seperti yang ditampilkan pada bab sebelumnya, tidak khas bagi emosi saja, tetapi dapat digunakan secara lebih luas di luar konsep EMOSI.

Salah satu contohnya adalah RS API/ PANAS. Kövecses (2010:140--141) menilai bahwa orang kebanyakan akan cenderung mengaitkan RS ini dengan pemahaman metaforis RT EMOSI seperti AMARAH, CINTA, HASRAT, dan yang lainnya, yang dipayungi oleh MK umum EMOSI ADALAH PANAS (DARI API). Sebagian kecil contoh ekspresi linguistiknya adalah "the fire of ambition burned" untuk HASRAT/AMBISI, “burning anger" untuk AMARAH, dan "keeping the flames of love alive” untuk CINTA (Kövecses, 2002:141). 
Akan tetapi, RS API/PANAS juga dapat diperluas pemakaiannya ke luar RT EMOSI, seperti RT ARGUMEN, KONFLIK, SKANDAL, AKTIVITAS EKONOMI, dan sejenisnya, yang secara skematis digolongkan ke dalam SITUASI (AKSI, PERISTIWA, KEADAAN) yang intens (Kövecses, 2002:114--115). Beberapa contoh perwujudan linguistik RS API di luar RT EMOSI BI dapat dilihat pada tiga dari 175 sitiran konkordansi pola [menyulut $*$ ] berikut yang diperoleh dari internet melalui mesin pencari Google pada situs Webcorp:

(6-1) Kelahirannya menyulut perdebatan sengit tentang etika dan akibat kloning. ${ }^{1}$ [KONFLIK]

Asing bisa menyulut IHSG hingga $5.000 .^{2}$ [AKTIVITAS EKONOMI]

(6-2) Hal tersebut telah menimbulkan konflik yang $\underline{\text { menyulut aksi }}$ kekerasan pada tahun 1991 sampai 1996. ${ }^{3}$ [AKSI]

Topik pembahasan pada disertasi ini tidaklah mengenai penggunaan RS metaforis bagi RT EMOSI yang telah didaftar pada bab sebelumnya terhadap RT selain EMOSI. Akan tetapi, bab ini akan menitikberatkan perhatian pada keutamaan suatu RS metaforis terhadap RT EMOSI tertentu secara internal, yaitu hanya pada lingkup kelima RT EMOSI yang dikaji. Pembatasan ini dimotivasi oleh sebuah implikasi teoretis: keutamaan suatu metafora bagi suatu emosi diharapkan dapat memperlihatkan perbedaan emosi yang dimaksud dengan emosi lainnya (Stefanowitsch, 2004a, 2006a).

Jadi, RS metaforis khas emosi dalam cakupan ini dapat dibatasi sebagai "RS yang digunakan dalam konseptualisasi metaforis sebagian RT EMOSI" (Stefanowitsch, 2006a:90). Keintian internal suatu RS metaforis bagi sebagian RT EMOSI juga sebenarnya menjadi salah satu pertanyaan teoretis yang diajukan 
oleh Kövecses (2000:35):“[...] apakah mereka (RS metaforis) bersifat khas bagi sekelompok (a subset of) emosi [...]?”. Atas dasar data metafora BIng. yang didaftar oleh Kövecses dalam karyanya (2000:20-33), generalisasi terkait pemakaian secara khas RS metaforis tertentu terhadap RT EMOSI (sembilan jenis emosi) kemudian dibuatnya (Kövecses, 2000:36--40). Generalisasi ini dibagi menjadi empat subkelompok seperti terangkum pada Tabel 6.1 berikut.

Tabel 6.1

Aplikasi RS metaforis terhadap RT EMOSI (Kövecses, 2000:36--40)

\begin{tabular}{|c|c|}
\hline \multicolumn{2}{|l|}{ RANAH SUMBER YANG BERLAKU UNTUK SEMUA EMOSI } \\
\hline RANAH SUMBER/METAFORA & EMOSI \\
\hline $\begin{array}{l}\text { KEBERADAAN EMOSI ADALAH } \\
\text { ADANYA/KEBERADAAN/KEHADIRAN FISIK SUATU OBJEK, } \\
\text { MENJADI BERADA DI LOKASI TERKUNGKUNG, dan } \\
\text { KEPEMILIKAN (TERHADAP SUATU OBJEK); EMOSI ADALAH } \\
\text { ORGANISME HIDUP (LIVING ORGANISM) }\end{array}$ & Semua \\
\hline \multicolumn{2}{|c|}{ RANAH SUMBER YANG BERLAKU UNTUK KEBANYAKAN EMOSI } \\
\hline RANAH SUMBER/METAFORA & EMOSI \\
\hline EMOSI ADALAH UNSUR (CAIRAN, GAS) DALAM WADAH & Semua \\
\hline EMOSI ADALAH KEKUATAN ALAM & $\begin{array}{l}\text { Kebanyakan (utamanya } \\
\text { emosi yang "kuat") }\end{array}$ \\
\hline EMOSI ADALAH KEKUATAN FISIK & $\begin{array}{l}\text { Kebanyakan; } \\
\text { pengecualiannya hanya } \\
\text { KEBANGAAN (pride) } \\
\text { dan MALU (shame) }\end{array}$ \\
\hline \multirow[t]{2}{*}{ EMOSI ADALAH ATASAN SOSIAL } & $\begin{array}{l}\text { Pasti: AMARAH, } \\
\text { KETAKUTAN, CINTA, } \\
\text { dan KEBANGGAN }\end{array}$ \\
\hline & $\begin{array}{l}\text { Dengan mudah dapat } \\
\text { dibayangkan muncul: } \\
\text { KEBAHAGIAAN, } \\
\text { KESEDIHAN, MALU, } \\
\text { dan NAFSU (tapi tidak } \\
\text { ditemukan dari survei }\end{array}$ \\
\hline
\end{tabular}


Kövecses sendiri).

Tidak mungkin (unlikely):

KETERKEJUTAN

(surprise)

EMOSI ADALAH LAWAN, BINATANG TAWANAN (CAPTIVE

ANIMAL), dan KEGILAAN

Pengecualiannya hanya

KEBANGGAN, MALU, dan KETERKEJUTAN.

EMOSI ADALAH BEBAN

Muncul terang-terangan:

AMARAH,

KETAKUTAN,

KESEDIHAN, dan

MALU

Yang tampaknya tidak:

KEBAHAGIAAN,

KEBANGGAN, dan

KETERKEJUTAN

Yang dapat dibayangkan memakai RS ini: CINTA dan NAFSU

EMOSI ADALAH PENYAKIT (Illness)

Untuk emosi "negatif":

KETAKUTAN,

KESEDIHAN, MALU, dan CINTA (yang tak terbalas)

\section{RANAH SUMBER YANG BERLAKU UNTUK BEBERAPA (Min. 2) EMOSI}

RANAH SUMBER/METAFORA

EMOSI

EMOSI ADALAH PANAS/API

AMARAH, CINTA

(romantis), NAFSU.

Mungkin dapat berlaku

untuk MALU

Tampaknya tidak muncul

dengan

KEBAHAGIAAN,

KESEDIHAN,

KEBANGGAAN, dan

KETERKEJUTAN

EMOSI ADALAH HANGAT-DINGIN, TERANG-GELAP, ATAS-

BAWAH, VITALITAS-KURANGNYA VITALITAS
Berlaku untuk

KEBAHAGIAAN dan

KESEDIHAN semata 
MALU

\begin{tabular}{ll}
\hline EMOSI ADALAH SANTAPAN (MAKANAN/NUTRISI/GIZI), & Tampaknya terbatas untuk \\
PERANG, dan PERMAINAN & CINTA dan NAFSU \\
\hline EMOSI ADALAH MESIN, PERILAKU AGRESIF BINATANG, dan & AMARAH dan NAFSU \\
RASA LAPAR & \\
\hline EMOSI ADALAH MABUK $($ RAPTURE/HIGH) dan OBJEK & KEBAHAGIAAN dan \\
TERSEMBUNYI & CINTA \\
\hline EMOSI ADALAH SIHIR $(M A G I C)$, KESATUAN, dan PERJALANAN & CINTA dan NAFSU \\
& (yang marjinal untuk \\
& PERJALANAN) \\
\hline EMOSI ADALAH KERUSAKAN FISIK $(P H Y S I C A L ~ D A M A G E)$ & KEBANGGAAN dan \\
& MALU
\end{tabular}

\begin{tabular}{ll}
\hline \multicolumn{2}{l}{ RANAH SUMBER YANG BERLAKU HANYA UNTUK SATU EMOSI } \\
RANAH SUMBER/METAFORA & EMOSI \\
\hline EMOSI ADALAH PELANGGARAN DOSA, GANGGUAN FISIK & AMARAH \\
\hline EMOSI ADALAH MUSUH TERSEMBUNYI, MAHKLUK SPIRITUAL & KETAKUTAN \\
\hline $\begin{array}{l}\text { EMOSI ADALAH MENJADI MELAYANG, DI SURGA, BINATANG } \\
\text { YANG HIDUP BAIK, SENSASI FISIK YANG MENYENANGKAN }\end{array}$ \\
$\begin{array}{l}\text { TIDAK BERPAKAIAN, MENGECILNYA UKURAN, MENGHALANGI } \\
\text { DUNIA (BLOCK OUT THE WORLD) }\end{array}$ \\
\hline
\end{tabular}

Rampatan pada Tabel 6.1 menuntun Kövecses (2000:40) untuk mengusulkan bahwa kebanyakan RS metaforis dapat digunakan bersama oleh beberapa RT EMOSI dan terdapat beberapa RS yang tampaknya hanya khas bagi satu emosi.

Akan tetapi, jika melihat kembali batasan dari RS khas emosi di atas, maka isu kekhasan dari keberlakuan suatu RS untuk RT EMOSI tertentu secara fundamental berkaitan dengan isu mengenai pemakaian bahasa, yaitu apa yang “sering” muncul, digunakan, atau khas (tipikal); bukan mengenai sistem linguistik itu sendiri, yaitu apa yang "mungkin" atau "bisa" digunakan (Stefanowitsch, 
2006a:90, 2006b:70). Dengan kata lain, dalam kaitannya dengan penelitian berbasis korpus ini, validasi dari generalisasi yang diajukan oleh Kövecses (2000:36--40) pada Tabel 6.1 di atas mestinya dapat tercermin secara nyata melalui kekerapan pemakaian pola linguistik metaforisnya pada data korpus, walaupun hasil serupa tidak dapat terlalu diharapkan karena perbedaan objek bahasa yang dikaji kali ini.

Dalam APM, pola-pola metaforis yang ditemukan dari data pemakaian bahasa aktual berperan penting karena pola-pola tersebut menjadi "bingkai gramatikal dengan satu atau lebih celah (slot) kosong untuk unsur leksikal RT, dan di dalam sistem linguistik tidak ada yang dapat menghalangi penutur untuk 'memasukkan unsur leksikal RT manapun ke dalam slot kosong tersebut." (Stefanowitsch, 2006a:90). Misalnya, munculnya pola api $X$ dalam RT EMOSI BI secara intuitif bisa lebih condong dihubung-hubungkan dengan AMARAH (api amarah/kemarahan) dan CINTA (api cinta), yang memang pada penelitian ini munculnya ditemukan pada sampel. Meskipun hanya sekali, pola api kesedihan juga ditemukan muncul pada sampel. Ini berarti celah $\mathrm{X}$ pada pola api $\mathrm{X}$ juga berpeluang diperinci secara bebas oleh penutur dengan unsur leksikal dari RT EMOSI lainnya semisal api kebahagiaan/ketakutan, yang meskipun bisa berasa agak janggal, setidaknya dapat dipahami maksudnya.

Sayangnya, pola api kebahagiaan atau api ketakutan tidak ditemukan pada sampel. Keingintahuan untuk membuktikan asumsi terkait pemakaian unsur leksikal emosi selain amarah/kemarahan, cinta, dan kesedihan pada pola api $X$ diakhiri dengan pencarian langsung lewat pola kunci khusus [api kebahagiaan] 
dan [api ketakutan] melalui situs Webcorp dengan mesin pencari Google dan batasan ranah situs $<. i d>$ dan $<. c o m>$. Hasilnya, pola api kebahagiaan dan api ketakutan muncul meskipun pola yang disebut pertama lebih jarang daripada yang disebut terakhir. Jadi, meskipun RS API terlihat agak jarang untuk RT KEBAHAGIAAN, bukan berarti konfigurasi keduanya tidak mungkin:

(6-3) “[...] dan terus membuat api kebahagiaan pernikahan kami selalu terjaga dan bertumbuh!"”

(6-4) Setelah bumiku dilanda api ketakutan. ${ }^{2}$

Contoh nyata pada (6-4) dan (6-5) dapat menunjukkan dua hal. Pertama, generalisasi teoretis oleh Kövecses $(2000: 38)^{3}$ seperti pada Tabel 6.1 jika "RS PANAS/API tampaknya tidak muncul" sebagai RS metaforis utamanya bagi RT KETAKUTAN, KEBAHAGIAAN, dan KESEDIHAN terbukti bisa digugurkan jika dihadapkan pada realitas pemakaian bahasa dalam korpus, setidaknya dalam kasus BI dan juga BIng. (Stefanowitsch, 2006a:81, 84, dan 88). Lebih lanjut, kedua contoh sitiran tadi juga secara metodologis memperlihatkan bahwa "korpus sebagai salah satu sumber contoh berlawanan (counterexample) seharusnya mendapat satu tempat utama dalam kotak peralatan metodologis dari seorang peneliti bahasa." (Stefanowitsch, 2011:268; ulasan terkait contoh berlawanan yang lebih padu bisa dilihat pada Stefanowitsch, 2006b).

Kedua, penilaian intuitif-subjektif terhadap suatu pola linguistik metaforis yang mencerminkan suatu MK, seperti api $X$, hanyalah sebatas intuisi kemungkinan munculnya pola tersebut dengan unsur leksikal RT tertentu seperti EMOSI. Ini juga mengindikasikan bahwa intuisi kebahasaan penutur asli suatu bahasa belumlah dapat dijadikan suatu metode yang patut guna memberikan 
jawaban bermakna terhadap keutamaan dan kekhasan suatu RS metaforis melalui pernyataan "RS X 'dapat' muncul dengan konsep emosi tertentu", yang semestinya dijawab dengan pernyataan "RS X 'benar-benar' muncul dengan konsep emosi tertentu pada pemakaian sesungguhnya dalam tuturan." (Stefanowitsch, 2006a:91). Pernyataan ini sesuai dengan salah satu asas inti dari Linguistik Kognitif, yaitu Model Bahasa Berdasarkan Penggunaan (Usage-based Thesis) (Evans \& Green, 2006:108; Langacker, 2008:220--221).

Selanjutnya, hasil pencarian dengan situs Webcorp terhadap pola api $X$ mengindikasikan jika korpus penelitian ini diperluas dan diperbesar, maka tidaklah mustahil bagi RS metaforis API, yang dapat diwakili oleh pola api $X$, untuk muncul dengan semua RT EMOSI yang dianalisis pada penelitian ini. Karenanya, metafora mana yang muncul dengan suatu RT dalam pemakaian sesungguhnya tetap tidak terjawab secara subjektif (Stefanowitsch, 2006a:91). Meskipun telah dinyatakan juga bahwa kemampuan penggunaan bersama suatu RS metaforis, misalnya PANAS/API, oleh beberapa RT EMOSI, misalnya AMARAH, CINTA (Kövecses, 2000:38) dan KEBAHAGIAAN, KESEDIHAN, serta KETAKUTAN seperti ditunjukkan dalam BI, dimotivasi oleh kesamaan unsur, misalnya INTENSITAS, yang dapat dimiliki oleh RT yang dimaksud dan yang difokuskan oleh RS yang dibagi (Kövecses, 2000:40--46), realitas praktis dari pernyataan ini bisa jadi berbeda. Artinya, dari perspektif LKorp, kemunculan bersama suatu RS metaforis yang menonjolkan suatu unsur semantis terhadap sejumlah RT EMOSI melalui pola linguistik metaforisnya dalam korpus dapat diasumsikan berada tidak pada kekerapan yang sama bagi setiap emosi, terlebih lagi jika dihadapkan dengan 
data dari bahasa yang berbeda. Hal ini telah ditunjukkan secara tidak terlalu gamblang oleh informasi kekerapan pola linguistik metaforis dari masing-masing RT EMOSI pada bab sebelumnya dan juga dari perbedaan hasil sitiran api kesedihan dan api kebahagiaan melalui Webcorp.

Jadi, untuk mencari jawaban dari situasi kompleks, yaitu dicontohkannya suatu RS metaforis secara linguistik oleh semua RT EMOSI yang kemungkinannya memiliki kekerapan berbeda dalam penggunaan sesungguhnya pada data korpus (ditampilkan pada Tabel 6.2), maka penilaian intuitif-subjektif, secara kasat mata tidak akan dapat memberikan jawaban berarti terkait kecondongan suatu RS metaforis tertentu terhadap RT EMOSI tertentu. Suatu metode yang diakui secara seragam paling tepat untuk mengevaluasi data distribusional kuantitatif seperti yang dihasilkan dari kajian korpus ialah ilmu statistik, utamanya untuk kasus ini yang bersifat inferensial/analitik (Gries, 2009b:148).

Dengan metode LKorp yang digunakan dalam penelitian ini, kekerapan pola metaforis yang mencontohkan $\mathrm{MK}$ emosi berperan sangat penting (Stefanowitsch, 2006a:65). Apabila pola metaforis linguistik yang secara berlimpah didaftar pada bab sebelumnya memang sungguh dipandang sebagai cerminan dari suatu $\mathrm{MK}$, maka penilaian statistik terkait pentingnya metafora tersebut akan dapat menunjukkan keterpatrian (Evans \& Green, 2006:114; Langacker, 2008:220) relatifnya dalam suatu guyub tutur (Stefanowitsch, 2006a:69, periksa juga Stefanowitsch, 2004a). Kelebihbaikan dari kebertautan secara statistik daripada pemaparan kekerapan kemunculan mentah dalam 
memodelkan keterpatrian telah ditunjukkan oleh sejumlah kajian LKorp (Stefanowitsch \& Gries, 2005; Gries dkk., 2005; Stefanowitsch, 2005, 2006a\&b).

Berdasarkan sejumlah pustaka yang telah ditelusuri dalam rangka penelitian disertasi ini, kajian yang berkaitan dengan (i) metafora emosi BI berbasis metode LKorp dan (ii) penelusuran RS metaforis khas bagi RT EMOSI BI belum pernah ditemukan sejauh ini. Jadi, hasil analisis statistik terhadap data kekerapan pemetaan metafora emosi yang ditemukan dalam korpus dapat dipandang sebagai kajian pertama yang akan mengungkap keintian suatu RS metaforis bagi RT EMOSI tertentu dalam BI.

Pengungkapan ini pada akhirnya mengikutkan sebuah perihal menarik terkait keberagaman dan kesemestaan metafora (Kövecses, 2000, 2002, 2005, 2010). Penelitian-penelitian metafora emosi yang sebelumnya telah dilakukan terutama oleh Kövecses (2000, 2002, 2005, 2008) dan juga penelitian dengan metode LKorp oleh Stefanowitsch (2004a, 2006a) menggunakan data BIng. Sedangkan, data penelitian pada disertasi ini berasal dari BI, salah satu rumpun bahasa yang bukan Indo-Eropa. Jadi, bisa diasumsikan bahwa akan muncul keberagaman, atau bahkan mungkin kesemestaan, terkait RS metaforis spesifik emosi tertentu yang dimiliki oleh guyub tutur BI jika dibandingkan dengan BIng.

\subsection{Metodologi Analisis Ketertarikan antara RT Emosi dan RS Metaforis}

Kajian empiris kuantitatif seperti LKorp pada dasarnya menuntut penerjemahan rumusan masalah penelitian, yang diformulasikan dalam suatu lingkup teori linguistik, ke dalam bahasa kuantitatif dan melibatkan perumusan 
asumsi serta pengoperasionalan variabel yang terlibat dalam asumsi tersebut (Gries, 2009a:176-178, 2009b:10-18; Stefanowitsch, 2011:259--260).

Kontekstualisasi teoretis yang diulas pada subbab sebelumnya terkait dengan klaim Kövecses (2000) tentang adanya RS metaforis yang secara khusus berasosiasi dengan RT EMOSI tertentu dan pembuktian empiris secara metodologis klaim Kövecses ini oleh Stefanowitsch (2006a) terhadap data BIng. dapat melandasi asumsi bahwa RS metaforis khas RT EMOSI tertentu dapat berperan sebagai pembeda bagi RT EMOSI tersebut dibandingkan dengan emosi lain secara lebih jelas. Ini menjadi mungkin karena melalui prinsip internal TMK secara jelas disebutkan bahwa suatu konsep, dalam hal ini RT, secara umum dicirikan oleh sejumlah unsur dan RS metaforis berbeda akan menyoroti unsur yang berbeda dari RT yang sama (Kövecses, 2010:91--93).

Asumsi lanjutannya ialah pemahaman metaforis berbeda melalui penyorotan unsur yang berbeda dari RT EMOSI jika dibandingkan dengan RT EMOSI yang lain dapat memicu perbedaan kecondongan penggunaan RS metaforis di antara RT EMOSI tersebut. Dengan kata lain, pemakaian RS metaforis tertentu yang tercermin dalam pemakaian bahasa asli (authentic) akan bervariasi dalam kaitannya dengan kelima RT EMOSI. Asumsi ikutannya, jika memang terdapat perbedaan kekerapan munculnya suatu RS metaforis M1 terhadap kelima RT EMOSI tersebut, maka lebih besarnya rasio kemunculan, misalnya RS M1 terhadap RT E1 dibandingkan dengan RT E2, E3, hingga E5 secara keseluruhan menandakan lebih besarnya ketertarikan RS M1 terhadap RT E1 dibandingkan dengan RT lainnya. 
Asumsi yang telah dibangun oleh peneliti sendiri sebelumnya berdasarkan suatu fenomena teoretis disebut dengan "asumsi alternatif" (disingkat A1). Jika melibatkan variabel terikat dan bebas, A1 umumnya akan menyatakan adanya efek dan korelasi antara dua atau lebih variabel (Gries, 2009a:177, 2009b:13): yaitu dengan kata lain, distribusi dari satu variabel tergantung pada variabel yang lain (Gries, 2009b:165). Sedikit catatan, variabel terikat (dependent) adalah variabel yang nilai, variasi, atau distribusinya akan dijelaskan, dan variabel bebas (independent) adalah variabel yang sering kali, namun tidak harus, menjadi penyebab dari perubahan atau efek pada variabel terikat (Gries, 2009b:12). Berikut ini adalah dua variabel utama yang terlibat dalam analisis:

a) Variabel kategorial terikat yang akan dinamai METAFORA, dengan tingkatan yang terdiri atas 88 tipe RS metaforis yang berhasil diidentifikasi dan didaftar pada bab sebelumnya.

b) Variabel kategorial bebas yang akan dinamai EMOSI dengan lima tingkatan, yaitu AMARAH/KEMARAHAN, KETAKUTAN, KEBAHAGIAAN, KESEDIHAN, dan CINTA.

Variabel kategorial atau nominal adalah salah satu dari tiga tipe variabel yang dapat dicirikan atas dasar tingkatan pengukurannya (level of measurement) (Gries, 2009b:15). Dua variabel lainnya adalah variabel ordinal dan variabel rasio. Gries menyatakan bahwa variabel kategorial atau nominal memiliki nilai informasi yang paling rendah: perbedaan nilai atau tingkatan dari variabel ini hanya menyatakan bahwa objek dari tingkatan berbeda tersebut menampilkan karakteristik berbeda (2009b:15). Suatu variabel dinamakan "nominal” jika 
memiliki hanya dua tingkatan, yang sering disebut juga binary variable; dan "kategorial” jika dapat memiliki tiga atau lebih tingkatan.

Selain A1, satu asumsi yang mesti dirumuskan adalah "asumsi kosong" (A0) yang merupakan lawan logis dari asumsi alternatif. A0 pada dasarnya dan kebanyakan kasus akan menyatakan bahwa variabel terikat tersebar secara acak, atau bahwa sama sekali tidak ada perbedaan, efek, dan korelasi di antara variabelvariabel yang diujikan; kalaupun ada ditemukan perbedaan, efek, dan korelasi dalam sampel data, A0 menganggap hal itu hanya sebagai suatu kebetulan semata (Gries, 2009b:13--14). A0 global untuk penelitian ini tidak ada korelasi antara pemakaian suatu RS metaforis sehubungan dengan konseptualisasi metaforis RT EMOSI tertentu, atau dengan kata lain, kedua variabel tersebut tidak saling terikat antara yang satu dengan yang lainnya. Gries menegaskan bahwa hal yang paling mendasar dalam mengevaluasi asumsi secara statistik terkait data yang didapat ialah tidak mencoba membuktikan kebenaran A1, melainkan menunjukkan bahwa A0 kemungkinan besar salah dan tidak dapat menjelaskan data (2009a:183, 2009b:30). Karena A0 adalah lawan logis dari A1, maka gugurnya A0 dapat membangun suatu keyakinan bagi peneliti untuk selanjutnya beralih ke A1 (Gries, 2009a:184, 2009b:30).

Berikutnya, variabel yang diikutkan dalam asumsi yang dibangun mesti dioperasionalkan sedemikian rupa sehingga memudahkan penelusurannya. Operasionalisasi berarti "menentukan apa yang mesti diamati, dihitung, diukur, dan sebagainya ketika menyelidiki variabel-variabel tersebut" (Gries, 2009b:14). Pengukuran variabel METAFORA dengan tingkatan RS-nya dan EMOSI cukup jelas 
jika mengadopsi metode APM. Caranya ialah dengan melihat semua sitiran konkordansi dari masing-masing unsur leksikal RT EMOSI sebagai kata kunci yang terlibat dalam pola metaforis, yaitu mengisi salah satu celah (slot) kosong pada ekspresi dari RS. Setelah itu, pada setiap pola metaforis yang ditemukan dihitung berapa kali, misalnya pola metaforis linguistik dari RS metaforis M1, M2, Mn muncul dengan unsur leksikal yang mewakili RT EMOSI E1, E2, E5. Misalnya, nomina api dan verba terbakar pada frase nomina api amarah dan klausa $X$ terbakar oleh amarah/kemarahan terhitung sebagai dua kemunculan pola metaforis linguistik dari metafora AMARAH/KEMARAHAN ADALAH API atau dengan kata lain, ditandai sebagai dua kemunculan linguistik dari RS API dalam konfigurasi metaforisnya dengan RT AMARAH/KEMARAHAN. Ini berarti pada dasarnya analisis statistik kali ini sepenuhnya dilandasi atas bukti kekerapan.

Ditemukan 3.059 pola metaforis yang mencerminkan $88 \mathrm{RS}$ dari analisis konkordansi kelima unsur leksikal cerminan RT EMOSI. Tabel 6.2 berikut menukilkan hanya 20 baris teratas dari keseluruhan tabulasi persebaran tingkatan variabel METAFORA dan variabel EMOSI.

Setidaknya, A0 dapat digugurkan jika melihat secara kasat mata Tabel 6.2. Salah satu bukti misalnya perbedaan persebaran metafora BEBAN terhadap kelima RT EMOSI. Tampak bahwa RS BEBAN paling sering muncul dengan RT KESEDIHAN dibandingkan dengan RT yang lain yang mungkin secara deskriptif akan menuntun suatu simpulan adanya korelasi dengan RT KESEDIHAN. 
Tabel 6.2

Nukilan Tabulasi Tingkatan Variabel METAFORA X EMOSI

\begin{tabular}{|c|c|c|c|c|c|c|}
\hline \multirow[b]{2}{*}{ METAFORA } & \multicolumn{5}{|c|}{ EMOSI } & \multirow[t]{2}{*}{ Total } \\
\hline & AMARAH & KETAKUTAN & KEBAHAGIAAN & KESEDIHAN & CINTA & \\
\hline $\begin{array}{l}\text { KUATNYA AKIBAT DARI SUATU) } \\
\text { KEKUATAN FISIK } \\
\text { (MENGHANCURKAN/DESTRUKTIF) }\end{array}$ & 15 & 6 & 1 & 8 & 9 & 39 \\
\hline $\begin{array}{l}\text { (MENJADI) BERADA DI ATAS } \\
\text { (MELAYANG) (UP/OFF THE } \\
\text { GROUND) }\end{array}$ & 0 & 0 & 10 & 0 & 0 & 10 \\
\hline (MENJADI) BERADA DI SURGA & 0 & 0 & 1 & 0 & 0 & 1 \\
\hline (MENJADI) BERADA DI BAWAH & 0 & 0 & 0 & 13 & 0 & 13 \\
\hline (OBJEK BER)BAU & 2 & 1 & 0 & 0 & 0 & 3 \\
\hline (OBJEK BER)WARNA & 2 & 3 & 0 & 4 & 20 & 29 \\
\hline $\begin{array}{l}\text { (SECARA POTENSIAL) } \\
\text { MEMBERIKAN/MENTRANSFER } \\
\text { SUATU OBJEK }\end{array}$ & 8 & 1 & 54 & 8 & 24 & 95 \\
\hline $\begin{array}{l}\text { (SECARA POTENSIAL) } \\
\text { MENERIMA/MENDAPAT SUATU } \\
\text { OBJEK }\end{array}$ & 4 & 1 & 29 & 3 & 20 & 57 \\
\hline $\begin{array}{l}\text { ADANYA/KEBERADAAN/KEHADIR } \\
\text { AN FISIK SUATU OBJEK }\end{array}$ & 15 & 17 & 26 & 31 & 13 & 102 \\
\hline API & 50 & 0 & 0 & 1 & 6 & 57 \\
\hline $\begin{array}{l}\text { ATASAN SOSIAL (SOCIAL } \\
\text { SUPERIOR) }\end{array}$ & 8 & 4 & 0 & 3 & 5 & 20 \\
\hline BANGUNAN & 0 & 0 & 0 & 0 & 2 & 2 \\
\hline BEBAN & 5 & 3 & 0 & 16 & 1 & 25 \\
\hline $\begin{array}{l}\text { BERTINDAK/MELAKUKAN } \\
\text { SESUATU DI DALAM SUATU } \\
\text { LOKASI }\end{array}$ & 4 & 12 & 5 & 5 & 2 & 28 \\
\hline $\begin{array}{l}\text { BINATANG TAWANAN/BUAS } \\
(C A P T I V E \text { ANIMALS })\end{array}$ & 17 & 5 & 1 & 2 & 0 & 25 \\
\hline CAHAYA & 28 & 8 & 9 & 1 & 3 & 49 \\
\hline CAIRAN & 0 & 14 & 13 & 23 & 1 & 51 \\
\hline CAIRAN DALAM WADAH & 42 & 1 & 3 & 12 & 1 & 59 \\
\hline CAIRAN PANAS DALAM WADAH & 30 & 0 & 0 & 0 & 0 & 30 \\
\hline CATATAN & 0 & 0 & 0 & 1 & 0 & 1 \\
\hline$\cdots$ & $\ldots$ & $\ldots$ & $\ldots$ & $\ldots$ & $\ldots$ & $\ldots$ \\
\hline Total & 934 & 369 & 566 & 496 & 694 & 3.059 \\
\hline
\end{tabular}


Akan tetapi, dalam ilmu humaniora, untuk menyangkal kebenaran A0 tidaklah cukup, pada umumnya, hanya dengan satu contoh berlawanan. Keseluruhan data dalam sampel mesti dievaluasi untuk "menentukan apakah A0 dan hasil empiris yang diperoleh memang tidak cocok secara memadai untuk menolak A0 dan akhirnya mengadopsi A1" (Gries, 2009b:30). Gries menegaskan:

“[...] anggaplah A0 benar, dan hitung probabilitas $p$ untuk mendapatkan hasil nyata yang diperoleh (observed result) atau hasil lainnya yang bahkan melenceng (deviate) secara lebih kuat dari A0. Ketika $p$ sebesar atau lebih besar dari 5\%, A0 harus tetap dipegang karena dapat dikatakan hasil yang diperoleh masih terlalu cocok dengan A0 untuk beralih ke A1. Sedangkan jika $p$ lebih kecil dari 5\%, maka A0 dapat ditolak untuk mengadopsi A1" (2009:30).

Sedikit catatan penting. Pertama, terkait pemakaian kata "signifikan" dalam tradisi statistik. Fakta bahwa suatu efek dikatakan signifikan secara statistik tidak berarti bahwa efek tersebut juga "penting", mengingat bersinoniminya kata "signifikan" dan "penting". Juga, pertanyaan tentang signifikansi dari suatu distribusi atau efek tidaklah sama dengan pertanyaan tentang adanya suatu hal menarik dari distribusi atau efek tersebut (Stefanowitsch, 2004b). Secara teknis, kata "signifikan" digunakan dalam arti "efek yang ditemukan cukup besar untuk dapat berasumsi bahwa, mengingat besarnya sampel, efek tersebut tidaklah suatu kebetulan" (Gries, 2009b:31; juga Stefanowitsch, 2004b). Jika dibawa ke ranah linguistik, pernyataan dari Stefanowitsch (2004b) berikut sangatlah krusial:

"[...] signifikansi statistik yang ditemukan sama sekali tidak menyatakan adanya signifikansi secara linguistik, yaitu, mengungkap sesuatu terkait cara kerja bahasa yang dimaksud. Akan tetapi jika suatu distribusi tidak signifikan secara statistik, maka isu mengenai kepentingan linguistik (linguistic interest) utamanya tidak akan muncul. Oleh sebab itu, signifikansi statistik 
merupakan prasyarat adanya signifikansi secara linguistik, tetapi bukanlah suatu jaminan." (penekanan cetak miring sesuai aslinya).

Kedua, "diterimanya A1 mengingat hasil signifikan yang diperoleh bukan berarti bahwa seorang peneliti telah berhasil membuktikan A1" (Gries, 2009b:31). Ini dikarenakan masih adanya probabilitas $p$ untuk berbuat salah, yang disebut “probabilitas kesalahan" (probability of error), ketika menerima A1 atas dasar data yang diperoleh: "nilai $p$ cukup kecil untuk menjamin seseorang menerima A1, tetapi tidak untuk membuktikannya A1" (Gries, 2009:31). Sedangkan, disebutkan juga pada satu sitiran sebelumnya terkait "probabilitas 5\%". Ini disebut "taraf signifikansi": taraf yang tidak boleh dilewati probabilitas kesalahan dan dalam statistik secara lazim ditetapkan sebesar 5\% (Gries, 2009b:32).

Tahapan analisis yang hanya sampai pada tabulasi seperti pada Tabel 6.2 masih bersifat deskriptif dan belum ada analisis lanjutan yang dapat mendukung secara pasti terkait seberapa signifikan secara statistik, jika memang ada, keterkaitan di antara variabel METAFORA dan EMOSI, dan distribusi data yang diperoleh secara menyeluruh. Singkat kata, pemaparan tabulatif seperti pada Tabel 6.2 hanya akan memberikan wawasan yang sangat terbatas terhadap distribusi pemakaian RS metaforis dalam hubungannya dengan suatu RT EMOSI.

Menjadi menarik untuk melihat apakah terdapat sejumlah kebertautan di antara kedua variabel tersebut. Apakah ada tipe-tipe RS metaforis tertentu, dari sekian banyak RS yang berhasil diidentifikasi, yang secara lebih kuat daripada yang diharapkan atas dasar kebetulan (based on chance) memiliki ketertarikan dengan suatu RT EMOSI? Selain itu, apakah utamanya seluruh distribusi RS 
metaforis terhadap RT EMOSI secara statistik signifikan? Artinya, apakah persebaran data yang dihadapi hanyalah suatu kemunculan yang bersifat kebetulan?

Metode analitik yang dapat menjawab semua pertanyaan di atas ialah metode statistik yang dikenal dengan nama Configural Frequency Analisis (CFA) (von Eye, 2002; von Eye dkk., 2010; Stefanowitsch, naskah; Gries, 2009b:240-252). CFA adalah suatu metode statistik multivariasi yang digunakan untuk menganalisis tabel kekerapan multidimensi. Secara konseptual CFA merupakan perluasan multidimensi dari tes chi-square (untuk penjelasan tes chi-square dasar dan penerapannya dengan data linguistik dapat dilihat pada Stefanowitsch, 2004b; Gries, 2009a \& b; untuk penerapan CFA dengan data linguistik, Stefanowitsch \& Gries, 2005; Stefanowitsch, naskah, 2006a; Hilpert, 2008; Berez \& Gries, 2010; Hoffmann, 2011). CFA pada umumnya diterapkan sebagai piranti pengungkapan pola kompleks di antara sejumlah variabel yang sering terlewatkan oleh intuisi manusia. Misalnya, seseorang mungkin ingin mengetahui keterkaitan antara JENDER dan TINGKAT PENDIDIKAN dalam memengaruhi pemakaian "ekspresi berpagar" (HEDGE) (Stefanowitsch, naskah). CFA juga dapat diartikan sebagai suatu metode penjelajah dan penguji asumsi (Gries, 2009b:240).

Pertama, CFA dikatakan penjelajah karena semua kombinasi dari tingkatan variabel, yang disebut "konfigurasi", diujikan terkait dengan ada atau tidaknya efek: menguji konfigurasi yang secara statistik "istimewa", yaitu diartikan sebagai konfigurasi yang secara statistik muncul lebih sering atau lebih jarang daripada yang diharapkan atas dasar kebetulan (expected by chance) atau 
atas dasar A0? Jika kita kembali pada contoh HEDGE sebelumnya, CFA akan menentukan apakah wanita dan pria berpendidikan menggunakan ekspresi berpagar lebih sering atau lebih jarang daripada yang diharapkan dan ataukah efek tersebut tidak lebih dari sekedar kebetulan? Konfigurasi inilah yang menjadi perhatian utama dari CFA.

Kedua, CFA dikatakan sebagai metode penguji asumsi karena uji signifikansi dilakukan untuk setiap konfigurasi selain juga dapat dilakukan untuk tabel secara global. Secara teknis, pengujian untuk menghasilkan nilai $p$ ini dilakukan dengan "tes binomial tepat" (exact binomial test) yang tingkat nilai signifikansinya disesuaikan (adjusted) dengan metode koreksi Bonferroni atau Holm-Bonferroni atas dasar pengujian berulang pada semua A0 lokal, yaitu A0 dari setiap konfigurasi, terhadap perangkat data yang sama (Gries, 2009b:242). Kembali ke contoh HEDGE, keluaran CFA salah satunya menunjukkan ekspresi berpagar secara signifikan lebih banyak digunakan oleh wanita yang tidak berpendidikan dibandingkan dengan pria yang berpendidikan (Stefanowitsch, naskah).

Kombinasi dari tingkatan variabel yang muncul lebih sering daripada yang diharapkan disebut type. Untuk kepentingan penelitian ini, type dialihbahasakan menjadi "tipe"; Sebaliknya, konfigurasi yang muncul lebih jarang daripada yang diharapkan disebut antitype, yang akan disebut "antitipe" (Gries, 2009b:244). Oleh karena itu, terkait dengan penelitian ini, metode CFA akan digunakan untuk menentukan tipe dari metafora emosi yang dapat dianggap mencerminkan metafora yang utama (sentral) atau khas berasosiasi dengan suatu emosi. 
Perlu diketahui bahwa terdapat dua versi CFA, yaitu CFA itu sendiri dan yang berjenjang, disebut dengan H(ierarchical)-CFA (Gries, 2009b). HCFA, sesuai dengan namanya, bekerja dengan meniadakan secara sistematis variabelvariabel yang berkontribusi minimal dalam menentukan munculnya tipe dan antitipe. Sedangkan, CFA mengikutkan semua variabel. Karena penelitian ini terpusat pada interaksi hanya dua variabel, yaitu RS metaforis tertentu dalam kaitannya dengan RT EMOSI, maka kedua variabel tetap terlibat dalam analisis.

Penghitungan statistik pada disertasi ini menggunakan paket piranti lunak statistik dan bahasa pemrograman (progamming language) yang dinamakan $R$, utamanya versi 2.13.1, dan dapat diunduh secara cuma-cuma dari situs http://www.R-project.org/ (R Development Core Team, 2011). Secara khusus, penghitungan bagi analisis CFA dilakukan dengan $H C F A$ 3.2, sebuah naskah (script) pemrograman yang disusun oleh Gries (2004) bagi piranti lunak $R$.

\subsection{Hasil Analisis CFA dan Pembahasan}

Penghitungan CFA menunjukkan bahwa A0 yang diajukan sebelumnya dapat digugurkan: secara umum terdapat keterkaitan antara konseptualisasi RT EMOSI dengan sejumlah RS metaforis tertentu dalam BI dan keterkaitan ini secara statistik sangat signifikan $\left(\chi^{2}=2813.84, d f=348, p=0\right)$. Dengan kata lain, kelima RT EMOSI BI berbeda secara signifikan dalam hubungannya dengan RS metaforis tertentu. Untuk hubungan yang lebih rinci, analisis CFA menetapkan 46 konfigurasi signifikan, baik yang berlabel tipe maupun antitipe. Tabel 6.3 berikut 
menukilkan enam konfigurasi signifikan teratas dari hasil keluaran HCFA 3.2 terhadap data. Hasil lengkapnya dapat dilihat pada lampiran 1.

Tabel 6.3

Nukilan Enam Konfigurasi Signifikan Teratas Variabel METAFORA X EMOSI

\begin{tabular}{|c|c|c|c|c|c|c|c|}
\hline METAFORA & EMOSI & Frek & Har & $\chi^{2}$ & P.adj.Holm & Put & $\mathbf{K}$ \\
\hline $\begin{array}{l}\text { PERGERAKAN } \\
\text { AKSIDENTAL }\end{array}$ & CINTA & 91 & 20.6 & 239.75 & $8.96 \mathrm{E}-28$ & $* * *$ & 0.023 \\
\hline KEPEMILIKAN & KEBAHAGIAAN & 103 & 44.8 & 75.71 & $1.81 \mathrm{E}-11$ & $* * *$ & 0.019 \\
\hline KEPEMILIKAN & AMARAH & 23 & 73.9 & 35.05 & $1.21 \mathrm{E}-09$ & $* * *$ & 0.017 \\
\hline $\begin{array}{l}\text { KONTROL OBJEK } \\
\text { BERGERAK }\end{array}$ & AMARAH & 75 & 27.5 & 82.18 & $1.86 \mathrm{E}-11$ & $* * *$ & 0.016 \\
\hline $\begin{array}{l}\text { UNSUR DALAM WADAH } \\
\text { (BERTEKANAN) }\end{array}$ & AMARAH & 94 & 51.6 & 34.84 & $2.38 \mathrm{E}-05$ & $* * *$ & 0.014 \\
\hline $\begin{array}{l}\text { (SECARA POTENSIAL) } \\
\text { MEMBERIKAN SUATU } \\
\text { OBJEK }\end{array}$ & KEBAHAGIAAN & 54 & 17.6 & 75.47 & $8.75 \mathrm{E}-10$ & $* * *$ & 0.012 \\
\hline
\end{tabular}

Cara mengartikan hasil pada Tabel 6.3 ialah dengan membandingkan kekerapan aktual (observed frequency) ( $\mathrm{Fa}$ ) pada kolom "Frek", dengan kekerapan harapan (expected frequency) (Fh) pada kolom "Har". Perbandingan ini menunjukkan arah asosiasi dari suatu konfigurasi: ketertarikan (attraction) terjadi ketika $\mathrm{Fa}>\mathrm{Fh}$, dan disebut tipe; sedangkan ketertolakan (repulsion) adalah situasi ketika $\mathrm{Fa}<\mathrm{Fh}$, disebut antitipe. Istilah "ketertarikan/ketertolakan" diadopsi dari Stefanowitsch \& Gries (2003) dan Stefanowitsch (2006a).

Kolom dengan label "K", disebut dengan "koefisien kelantangan" (coefficient of pronouncedness), menunjukkan ukuran efek (size of the effect) dari sebuah konfigurasi: semakin tinggi nilainya, semakin kuat atau dominan keterpatriannya (Gries, 2009b:251). Nilai K terentang dari 0, yang berarti tidak 
ada korelasi, sampai 1, yang berarti korelasi sempurna. Untuk memperoleh nilai K yang tinggi diperlukan kekerapan token yang relatif tinggi karena hanya konfigurasi-konfigurasi yang berkontribusi cukup tinggi bagi nilai chi-kwadrat tabel-lah yang akan menghasilkan nilai K yang tinggi (Wiechmann, 2010:226).

Tiga kolom tersisa secara berurutan ialah (i) kolom " $\chi^{2}$ " yang menunjukkan nilai kontribusi sel tersebut bagi nilai chi-kwadrat keseluruhan tabel, (ii) kolom "P.adj.Holm" yang mengandung hasil penyesuaian nilai probabilitas $p$ ( $p$-value) dengan metode Holm, dan (iii) kolom putusan (decision) "Put" yang mengindikasikan signifikansi dari suatu konfigurasi. Cara penyajian nilai $p$ pada kolom "P.adj.Holm" mungkin tidak begitu akrab di mata kebanyakan ahli bahasa.

Dalam istilah "notasi eksponensial”, angka setelah tanda E- menunjukkan jumlah titik desimal, yaitu berapa angka di belakang koma yang mesti ditransposisi dari angka sebelum tanda E-. Misalnya, 2.38E-05 mesti dibaca 0.0000238, 6.32E-07 mesti dibaca 0.000000632 , dan seterusnya. Notasi ini akan sangat membantu ketika menemui nilai $p$ yang sangat kecil dengan nilai desimal, misalnya, mencapai 15, 30, 45 angka atau lebih di belakang koma (Stefanowitsch, 2005:194, catatan akhir 7).

Berikutnya, pada kolom "Put", tanda “***” menandakan $p<0.001$ dan efeknya dinyatakan "sangat (highly) signifikan"; tanda "**" berarti $0.001 \leq p<0.01$ dan efeknya dinyatakan "begitu (very) signifikan"; “*” menandakan $0.01 \leq p<0.05$ dan efeknya dinyatakan "signifikan” (Gries, 2009b:32). Anak-anak subbab berikut memaparkan hasil analisis CFA untuk masing-masing RT EMOSI. 


\subsubsection{Metafora yang Signifikan Tertarik pada RT AMARAH}

Secara keseluruhan, terdapat 14 konfigurasi signifikan yang terbagi atas delapan tipe metafora spesifik, yaitu metafora yang signifikan ditarik, dan enam antitipe, yaitu metafora yang signifikan ditolak, bagi RT AMARAH. Konfigurasi metaforis yang memiliki ketertarikan dan keterpatrian paling kuat dengan AMARAH BI ialah metafora skematis bagian dari MSP, yaitu KONTROL EMOSI ADALAH KONTROL OBJEK BERGERAK (Kövecses, 2000:56-58) $\left(\mathrm{F}_{\mathrm{o}}=75, \mathrm{Fe}=\right.$ 27.5, $\left.\chi^{2}=82.18, * * *, Q=0.016\right)$. Metafora ini adalah pengikutan gabungan dari dua subtipe MSP, yaitu AKSI ADALAH PERGERAKAN dan PENYEBAB ADALAH DAYA (CAUSES ARE FORCES) (Kövecses, 2000:56-57). Beberapa pola metaforis yang acap ditemui misalnya amarah/kemarahan tertahan/ditahan-tahan, X menahan amarah/kemarahan, X menghentikan/mengakhiri/mencegah amarah/ kemarahan. Secara eksplisit, dalam literatur (Kövecses, 2000:57), RS KONTROL OBJEK BERGERAK tidak pernah dinyatakan menjadi pilihan kuat dan signifikan dalam konseptualisasi metaforis yang secara khas berasosiasi dengan RT AMARAH, tetapi lebih banyak dipandang muncul secara umum dengan konsep EMOSI.

Metafora berikutnya yang juga signifikan berasosiasi dengan AMARAH berada pada satu kesatuan yang padu tetapi berbeda dalam kerinciannya: (i) EMOSI ADALAH UNSUR DALAM WADAH BERTEKANAN (PRESSURISED CONTAINER) $\left(\mathrm{F}_{\mathrm{o}}=95, \mathrm{Fe}=51.9, \chi^{2}=35.78, * * *, Q=0.014\right)$ seperti pada ekspresi X penuh (dengan) (muatan) amarah/kemarahan, (ii) EMOSI ADALAH CAIRAN DALAM WADAH $\left(\mathrm{F}_{\mathrm{o}}=42, \mathrm{Fe}=18, \chi^{2}=31.94, * * *, Q=0.008\right)$ seperti pada ekspresi $\mathrm{X}$ 
menumpahkan/melampiaskan amarah/ kemarahan, dan penciriannya yang lebih spesifik (iii) EMOSI ADALAH CAIRAN PANAS DALAM WADAH $\left(\mathrm{F}_{\mathrm{o}}=30, \mathrm{Fe}=9.2, \chi^{2}\right.$ $=47.41, * * *, Q=0.007)$ seperti pada ekspresi amarah/kemarahan menggelegak/ mendidih. Dua metafora yang masih dipandang terkait juga berhasil diidentifikasi melalui analisis CFA, yaitu EMOSI ADALAH API $\left(\mathrm{F}_{\mathrm{o}}=50, \mathrm{Fe}=17.4, \chi^{2}=61.05\right.$, ***, $Q=0.011$ ) seperti pada ekspresi X terbakar oleh amarah, (emosi) kemarahan berkobar/bergelora, dan metafora yang lebih skematis EMOSI ADALAH PANAS/DINGIN SUATU OBJEK $\left(\mathrm{F}_{\mathrm{o}}=16, \mathrm{Fe}=4.9, \chi^{2}=25.23, *, Q=\right.$ 0.004) seperti pada ekspresi X menyejukkan panas amarah dan hawa panas kemarahan. Hasil analisis data BI ini setidaknya mendukung argumentasi Kövecses (2000, 2002, 2005, \& 2008) terkait dengan keintian dan kekhasan RS dari metafora-metafora tersebut, utamanya UNSUR DALAM WADAH BERTEKANAN, CAIRAN PANAS DALAM WADAH, dan API, untuk RT AMARAH.

Selanjutnya, satu lagi metafora skematis yang juga sangat signifikan bertautan dengan AMARAH ialah EMOSI ADALAH TINGGI/RENDAH $\left(\mathrm{F}_{\mathrm{o}}=27, \mathrm{Fe}=\right.$ $\left.8.5, \chi^{2}=39.82, * * *, Q=0.006\right)$ seperti pada pola amarah/kemarahan memuncak, X mengubunkan amarah. Menariknya, meskipun sama-sama ditemukan sebagai tipe metafora khas untuk emosi AMARAH, hasil statistik menunjukkan bahwa preferensi penggunaan RS TINGGI/RENDAH dengan AMARAH lebih signifikan dan sedikit lebih kuat dibandingkan dengan RS PANAS/DINGIN. Di luar perbedaan ini, satu hal menarik yang dapat diungkap ialah koherensi antara RS-RS yang sudah teridentifikasi sebelumnya. RS TINGGI/RENDAH berkaitan secara runtut dengan RS UNSUR/CAIRAN (PANAS) DALAM WADAH (BERTEKANAN): ketika taraf 
kekuatan dari UNSUR/CAIRAN (PANAS) DALAM WADAH bertambah, maka taraf UNSUR/CAIRAN (PANAS) di dalamnya akan meningkat (Kövecses, 2010:124). Lalu, RS PANAS/DINGIN selingkup dengan RS API (Kövecses, 2010:144).

Metafora terakhir yang juga sangat signifikan muncul lebih sering daripada yang diharapkan dengan RT AMARAH ialah EMOSI ADALAH KEKUATAN $\operatorname{ALAM}\left(\mathrm{F}_{\mathrm{o}}=60, \mathrm{~F}_{\mathrm{e}}=27.5, \chi^{2}=38.49, * * *, Q=0.011\right)$ seperti pada ekspresi badai kemarahan, X tersesat dalam pusaran/dibawa/larut dalam arus kemarahan, X meredakan kemarahan/amarah. Perlu dicatat bahwa RS KEKUATAN ALAM, demikian juga RS UNSUR DALAM WADAH BERTEKANAN dan CAIRAN DALAM WADAH sebelumnya, muncul juga dengan semua RT EMOSI tersisa, tetapi tidak sering secara signifikan. Status anak emas RS-RS tersebut yang tersemat pada RT AMARAH hanya akan secara jelas ditemukenali melalui penilaian statistik distribusinya terhadap konsep emosi lainnya. Hasil ini sedikitnya mengabsahkan pentingnya penyertaan analisis statistik analitis untuk mengevaluasi seperangkat data kuantitatif yang bersifat kompleks.

Adanya ketertarikan mengikutkan ketertolakan. Terdapat enam antitipe signifikan bagi RT AMARAH. Dua dari enam metafora yang signifikan muncul lebih sedikit dari yang diharapkan melibatkan metafora model OBJEK dari MSP (Lakoff, 2006:204). Salah satunya yang paling kuat ditolak adalah EMOSI ADALAH KEPEMILIKAN $\left(\mathrm{F}_{\mathrm{o}}=23, \mathrm{Fe}=73.9, \chi^{2}=35.05, * * *, Q=0.017\right)$ seperti pada ekspresi X kehilangan amarah. Metafora model OBJEK kedua ialah MENYEBABKAN SESEORANG EMOSI ADALAH (SECARA POTENSIAL) MEMBERIKAN SUATU OBJEK $\left(\mathrm{F}_{\mathrm{o}}=8, \mathrm{Fe}_{\mathrm{e}}=29, \chi^{2}=15.21, * *, Q=0.007\right)$ seperti dicontohkan 
pada kemarahan adalah untuk/dialamatkan (ke)pada X. Hasil ini berarti bahwa RT AMARAH memang dapat muncul dengan RS KEPEMILIKAN dan MEMBERIKAN SUATU OBJEK tetapi pemakaiannya sangatlah tidak tipikal.

Tiga antitipe berikutnya secara umum masih tergolong MSP yang secara lebih rinci berada pada lingkup model PERGERAKAN-LOKASI dari MSP, yaitu MENJADI EMOSI ADALAH PERGERAKAN AKSIDENTAL $\left(\mathrm{F}_{\mathrm{o}}=0, \mathrm{Fe}_{\mathrm{e}}=27.8, \chi^{2}=\right.$ $27.78, * * *, Q=0.009)$, MENJADI EMOSI ADALAH PERJALANAN $\left(\mathrm{F}_{\mathrm{o}}=0, \mathrm{Fe}=10.7\right.$, $\left.\chi^{2}=10.69, * *, Q=0.004\right)$, dan MENJADI EMOSI ADALAH MENEMUKAN/MERAIH SUATU OBJEK $\left(\mathrm{F}_{\mathrm{o}}=0, \mathrm{Fe}=9.5, \chi^{2}=9.47,{ }^{*}, Q=0.003\right)$. Dua metafora terakhir secara khusus membentuk model PENCARIAN (QUEST model) (Stefanowitsch, 2004a:143). Metafora terakhir yang juga adalah antitipe RT AMARAH adalah EMOSI ADALAH CAIRAN $\left(\mathrm{F}_{\mathrm{o}}=0, \mathrm{Fe}=15.6, \chi^{2}=15.57, * * *, Q=0.005\right)$.

Penolakan terhadap RS CAIRAN tampaknya didasari atas kuatnya ketertarikan RT AMARAH akan adanya unsur tekanan dan kuantitas dari keberadaan cairan atau unsur dalam suatu wadah yang tidak terdapat pada RS CAIRAN saja. Contoh ekspresi linguistik dari RS CAIRAN, yang muncul dengan emosi selain AMARAH, misalnya X dialiri oleh/larut dalam E(mosi), sumber E. Di sisi lain, metafora model OBJEK, khususnya SERAH-TERIMA, dan PERGERAKAN-LOKASI, dapat mencirikan secara potensial pemahaman guyub tutur BI terhadap konsep AMARAH, bahwa tidak umumnya seseorang mencari, menjadi, dan memiliki keadaan emosional yang dimaksud. 


\subsubsection{Metafora yang Signifikan Tertarik pada RT KETAKUTAN}

Hanya empat konfigurasi metaforis yang berhasil mencapai tingkat signifikansi terkoreksi. Dua berupa tipe dan dua yang lain berupa antitipe. Metafora yang secara sangat signifikan kuat bertautan dengan RT KETAKUTAN ialah EMOSI ADALAH MUSUH/LAWAN $\left(\mathrm{F}_{\mathrm{o}}=47, \mathrm{Fe}=17.0, \chi^{2}=52.88, * * *, Q=\right.$ 0.01) seperti pada ekspresi metaforis perlawanan/(ke)menang(an) atas/ancaman ketakutan. Jika dilihat kembali bagian akhir dari Tabel 6.1 terkait aplikasi RS-RS metaforis terhadap RT EMOSI, RS metaforis MUSUH TERSEMBUNYI dipandang bersifat khas hanya bagi RT KETAKUTAN.

Permasalahannya ialah ketidakjelasan kenapa RS tersebut dipisahkan dari atau tidak diikutkan ke dalam tingkatan pemetaan yang lebih tinggi, seperti RS MUSUH/LAWAN. Karena ketidakjelasan ini, maka RS MUSUH TERSEMBUNYI ini diikutkan ke dalam RS MUSUH/LAWAN (Stefanowitsch, 2006:78-79). Jika dilihat dari tataran yang lebih umum, hasil statistik terhadap keintian signifikan RS MUSUH/LAWAN yang ditemukan pada data BI terhadap RT KETAKUTAN mendukung asumsi Kövecses (2000:48). Satu metafora terakhir yang juga begitu signifikan dipikat oleh KETAKUTAN BI ialah metafora MSP model OBJEK, yaitu (BERTINDAK) EMOSI(ONAL) ADALAH MELAKUKAN SESUATU/DISERTAI/TEMANI OBJEK PENYERTA $\left(\mathrm{F}_{\mathrm{o}}=29, \mathrm{Fe}=11.6, \chi^{2}=26.20, * *, Q=0.006\right)$. Pola metaforis yang sering muncul bagi metafora ini ialah X V(erba) dengan/tanpa ketakutan.

Berikutnya, antitipe bagi RT KETAKUTAN yang memenuhi nilai standar tingkat signifikansi terkoreksi ialah MENJADI EMOSI ADALAH PERGERAKAN AKSIDENTAL $\left(\mathrm{F}_{\mathrm{o}}=0, \mathrm{Fe}=11.0, \chi^{2}=10.98, * *, Q=0.004\right)$ dan KONTROL EMOSI 
ADALAH KONTROL OBJEK BERGERAK $\left(\mathrm{F}_{\mathrm{o}}=0, \mathrm{Fe}_{\mathrm{e}}=10.9, \chi^{2}=10.86, * *, Q=\right.$ $0.004)$.

\subsubsection{Metafora yang Signifikan Tertarik pada RT KEBAHAGIAAN}

Terdapat 13 konfigurasi metaforis signifikan bagi KEBAHAGIAAN. Sembilan di antaranya signifikan dipikat oleh KEBAHAGIAAN yang 78\%-nya merupakan tipe metafora skematis MSP. Berkebalikan dengan AMARAH, metafora yang sangat signifikan dikaitkan dengan KEBAHAGIAAN ialah EMOSI ADALAH KEPEMILIKAN $\left(\mathrm{F}_{\mathrm{o}}=103, \mathrm{Fe}=44.8, \chi^{2}=75.71, * * *, Q=0.019\right)$, yang merupakan metafora MSP model OBJEK, seperti dicontohkan oleh pola X memiliki/punya/merampas/merenggut/kehilangan kebahagiaan.

Seperti yang diprediksi oleh Kövecses (2000:36) bahwa KEPEMILIKAN adalah RS yang dapat dipakai oleh semua RT EMOSI, demikian juga dalam sampel RS ini muncul dengan kelima RT EMOSI. Akan tetapi, RS KEPEMILIKAN tidak bersifat inti bagi dan ditarik oleh RT EMOSI selain KEBAHAGIAAN secara signifikan. Keutamaan RS ini khususnya untuk KEBAHAGIAAN BI juga tidak pernah diperkirakan jika hanya dilandasi acuan terhadap literatur terkait (Kövecses, 2000). Ketertarikan ini bisa diperkuat dengan adanya keterkaitan signifikan dari dua pengembangan terkait RS KEPEMILIKAN dengan RT KEBAHAGIAAN.

Kedua pengembangan tersebut tergolong metafora umum dari MSP, yaitu (i) MENYEBABKAN EMOSI ADALAH (SECARA POTENSIAL) MEMBERIKAN SUATU OBJEK $\left(\mathrm{F}_{\mathrm{o}}=54, \mathrm{Fe}=17.6, \chi^{2}=75.47, * * *, Q=0.012\right)$ seperti pada pola $\mathrm{X}$ 
memberi(kan) kebahagiaan ([ke]pada/buat Y), X ber-/membagi(kan) kebahagiaan ([ke]pada/dengan/bersama Y), dan (ii) MENJADI EMOSI ADALAH (SECARA POTENSIAL) MENDAPAT/MENERIMA SUATU OBJEK $\left(\mathrm{F}_{\mathrm{o}}=29, \mathrm{Fe}=10.5, \chi^{2}\right.$ $=32.29, * * *, Q=0.006)$ seperti pada X mendapat(kan)/menyambut/menerima kebahagiaan.

Kedua RS metaforis tersebut beserta RS KEPEMILIKAN secara terpadu membentuk model yang khususnya berciri SERAH-TERIMA (TRANSFER) dan yang ditemukan oleh Stefanowitsch sangat signifikan berasosiasi dengan KEBAHAGIAAN BIng. (2004a:143, 2006a:93, 99). Model SERAH-TERIMA metaforis ini juga nyatanya terbukti sangat terpatri dalam guyub tutur BI, khususnya sebagai salah satu kerangka inti bagi konseptualisasi metaforis RT KEBAHAGIAAN.

Selanjutnya, RT KEBAHAGIAAN BI juga secara signifikan memiliki ketertarikan dengan tiga metafora berkelas MSP. Gabungan ketiganya memiliki model yang berbeda dengan model SERAH-TERIMA sebelumnya. Secara skematis, tiga metafora berikutnya membentuk apa yang disebut oleh Stefanowitsch sebagai model PENCARIAN (QUEST) (2004a) KEBAHAGIAAN. Ketiga metafora tersebut ialah (i) MENCOBA MENJADI EMOSI ADALAH MENCARI/MENGEJAR/MEMBURU SUATU OBJEK $\left(\mathrm{F}_{\mathrm{o}}=19, \mathrm{Fe}=4.6, \chi^{2}=44.67, * * *, Q=0.005\right)$ seperti ditunjukkan oleh pola X (berjuang) mencari/mengejar/memperjuangkan/songsong kebahagiaan, (ii) MENJADI EMOSI ADALAH MENEMUKAN/MERAIH SUATU OBJEK ( $\mathrm{F}_{\mathrm{o}}=29, \mathrm{Fe}=$ 5.7, $\left.\chi^{2}=94.36, * * *, Q=0.008\right)$ seperti dicontohkan oleh X menemukan/ nemuin/(me)raih(lah) kebahagiaan, dan (iii) PROSES MENJADI EMOSI ADALAH 
PERJALANAN $\left(\mathrm{F}_{\mathrm{o}}=19, \mathrm{Fe}=6.5, \chi^{2}=24.22,{ }^{*}, Q=0.004\right)$ seperti pada $\mathrm{X}$ menemukan taman/mencapai kebahagiaan. Ketertarikan RT KEBAHAGIAAN BI dengan model SERAH-TERIMA dan PENCARIAN menunjukkan secara teoretis pentingnya untuk tidak hanya menganalisis metafora yang rinci secara semantis tetapi juga yang bersifat skematis seperti MSP. Lebih lanjut, sekali lagi, atas dasar literatur, keterpatrian dua model metaforis ini terhadap RT KEBAHAGIAAN tidak akan pernah diharapkan muncul.

Satu lagi metafora model OBJEK dari MSP yang signifikan ditarik oleh KEBAHAGIAAN ialah EMOSI ADALAH OBJEK RAPUH/PECAH BELAH (FRAGILE OBJECT $)\left(\mathrm{Fo}_{\mathrm{o}}=10, \mathrm{Fe}=2.2, \chi^{2}=27.26,{ }^{*}, Q=0.003\right)$ seperti dicontohkan dalam pola X menghancurkan kebahagiaan.

Berikutnya, metafora yang memang diajukan dalam literatur bersifat khas hanya untuk KEBAHAGIAAN juga berhasil diidentifikasi muncul lebih sering secara begitu signifikan dengan RT KEBAHAGIAAN BI, yaitu MENJADI EMOSI ADALAH (MENJADI) BERADA DI ATAS/MELAYANG (UP/OFF THE GROUND) $\left(\mathrm{F}_{\mathrm{o}}=10\right.$, $\left.\mathrm{Fe}=1.9, \chi^{2}=35.90, * *, Q=0.003\right)$. Pola metaforisnya ialah $\mathrm{X}$ membawa/melambungkan/menghantar Y ke puncak kebahagiaan. Menariknya, metafora spasial ini juga signifikan ditarik oleh RT KEBAHAGIAAN BIng. (Stefanowitsch, 2006a:93). Metafora terakhir yang sangat signifikan bersifat sentral bagi RT KEBAHAGIAAN BI ialah EMOSI ADALAH SANTAPAN $\left(\right.$ MAKANAN/MINUMAN) $\left(\mathrm{F}_{\mathrm{o}}=25, \mathrm{Fe}=8.3, \chi^{2}=33.39, * * *, Q=0.005\right)$ seperti $\mathrm{X}$ haus pada/menikmati kebahagiaan. 
Metafora-metafora yang merupakan antitipe signifikan bagi RT KEBAHAGIAAN ialah EMOSI ADALAH MUSUH/LAWAN $\left(\mathrm{F}_{\mathrm{o}}=3, \mathrm{Fe}=26.1, \chi^{2}=\right.$ 20.43, ***, $Q=0.008)$ seperti X mati lemas oleh/mengawasi kebahagiaan, MENJADI EMOSI ADALAH PERGERAKAN AKSIDENTAL $\left(\mathrm{F}_{\mathrm{o}}=0, \mathrm{Fe}=16.8, \chi^{2}=\right.$ $16.84, * * *, Q=0.006)$, KONTROL EMOSI ADALAH KONTROL OBJEK BERGERAK $\left(\mathrm{F}_{\mathrm{o}}=0, \mathrm{Fe}=16.7, \chi^{2}=16.65, * * *, Q=0.005\right)$, dan EMOSI ADALAH API $\left(\mathrm{F}_{\mathrm{o}}=0, \mathrm{Fe}\right.$ $\left.=10.5, \chi^{2}=10.55, *, Q=0.003\right)$.

\subsubsection{Metafora yang Signifikan Tertarik pada RT KESEDIHAN}

Hanya empat konfigurasi metaforis bagi RT KESEDIHAN yang mencapai tingkat signifikansi terkoreksi, tiga di antaranya signifikan dipikat oleh KESEDIHAN dan sisanya signifikan ditolak. Seperti yang sering dibicarakan dalam literatur terkait (Lakoff \& Johnson, 1980:15; Kövecses, 2000:25) bahwa KESEDIHAN cenderung diasosiasikan dengan RS (MENJADI) BERADA DI BAWAH, hasil analisis statistik menemukenali RS ini juga ternyata sangat signifikan muncul lebih sering dengan RT KESEDIHAN $\left(\mathrm{F}_{\mathrm{o}}=13, \mathrm{Fe}=2.1, \chi^{2}=56.28, * * *, Q\right.$ $=0.004$ ). Ekspresi linguistik RS (MENJADI) BERADA DI BAWAH) yang berhasil ditemukan di dalam sampel di antaranya $\mathrm{X}$ tenggelam dalam/oleh/terperosok/terpuruk (ke) dalam (jurang) kesedihan.

Dua metafora khas lainnya yang juga begitu signifikan diasosiasikan dengan RT KESEDIHAN BI adalah EMOSI ADALAH BEBAN $\left(\mathrm{F}_{\mathrm{o}}=16, \mathrm{Fe}=4.1, \chi^{2}=\right.$ 35.21, **, $Q=0.004)$ seperti dicontohkan oleh kesedihan menjadi beban/menimpa $X$, X mengurangi beban/menanggung kesedihan, dan EMOSI 
ADALAH CAIRAN $\left(\mathrm{F}_{\mathrm{o}}=23, \mathrm{Fe}=8.3, \chi^{2}=26.24, * *, Q=0.005\right)$ seperti pada pola X (ter)larut dalam/dengan kesedihan, lautan kesedihan. Satu-satunya metafora yang sangat signifikan ditolak oleh RT KESEDIHAN ialah metafora MSP MENJADI EMOSI ADALAH PERGERAKAN AKSIDENTAL $\left(\mathrm{F}_{\mathrm{o}}=0, \mathrm{Fe}=14.8, \chi^{2}=\right.$ $14.76, * * *, Q=0.005)$.

\subsubsection{Metafora yang Signifikan Tertarik pada RT CINTA}

Terdapat enam metafora, dari total sebelas, yang signifikan diasosiasikan dengan RT CINTA BI, lima sisanya signifikan ditolak. Metafora yang sangat signifikan muncul lebih sering dari yang diharapkan dengan CINTA ialah MENJADI EMOSI ADALAH PERGERAKAN AKSIDENTAL $\left(\mathrm{F}_{0}=91, \mathrm{Fe}=20.6, \chi^{2}=239.75\right.$, ***, $Q=0.023$ ). Metafora ini merupakan turunan dari metafora PERUBAHAN ADALAH PERGERAKAN (Kövecses, 2010:164). Cerminan linguistik tunggal yang mencontohkannya ialah ekspresi yang sangat lazim dalam BI, yaitu X jatuh cinta (ke/[ke]pada/[s]ama Y).

Jika mengacu pada daftar metafora yang dapat muncul dengan RT CINTA (Kövecses, 2000:26-27), RS PERGERAKAN AKSIDENTAL ini tidak tercantum di dalamnya meskipun RS inilah yang menjadi pemicu kognitif keberadaan ekspresi jatuh cinta/hati dalam BI dan fall in love dalam BIng. (Kövecses, 2010:164). Metode APM yang diadopsi pada penelitian ini akhirnya tidak hanya menunjukkan bahwa RS PERGERAKAN AKSIDENTAL juga memang ada, tercermin secara linguistik, dan muncul dalam sampel BI tetapi juga secara statistik 
menunjukkan perannya sebagai salah satu RS metaforis protagonis yang sangat signifikan bagi guyub tutur BI dalam memahami RT CINTA.

Berikutnya, metafora yang secara khas berasosiasi dengan CINTA, yang salah satunya memang nyata diharapkan munculnya, dari hasil penelitian nonkorpus kuantitatif oleh Kövecses (2000:27) dalam BIng. dan yang juga secara statistik sangat signifikan muncul lebih sering dengan CINTA BI ialah EMOSI ADALAH IKATAN $\left(\mathrm{F}_{\mathrm{o}}=20, \mathrm{Fe}=4.8, \chi^{2}=48.72, * * *, Q=0.005\right)$. Beberapa pola metaforis yang mencontohkan metafora yang dimaksud di antaranya $\mathrm{X}$ berjalin/dilibat/(me-) putus cinta, hubungan/jalinan/tali/pengikat (kasih) cinta. Seperti halnya pada hasil analisis statistik untuk RT AMARAH, KETAKUTAN, KEBAHAGIAAN, dan KESEDIHAN sebelumnya, analisis kali ini juga telah menemukenali RS metaforis IKATAN yang dipandang secara teoretis paling tipikal berkorelasi dengan RT CINTA.

Empat metafora tersisa yang signifikan ditarik oleh RT CINTA ialah (i) EMOSI ADALAH CERITA $\left(\mathrm{Fo}_{\mathrm{o}}=13, \mathrm{Fe}=2.9, \chi^{2}=34.25, * *, Q=0.003\right)$ seperti pada cerita/kisah cinta, (ii) EMOSI ADALAH UNGKAPAN VERBAL ( $\mathrm{F}_{\mathrm{o}}=17, \mathrm{Fe}=5.2, \chi^{2}$ $\left.=26.60,{ }^{*}, Q=0.004\right)$ seperti bahasa/idiom/kalimat/kata(-kata)/sajak cinta, cinta hanya sekedar ucapan, (iii) EMOSI ADALAH (OBJEK BER)WARNA (Fo $=20, \mathrm{Fe}=$ $\left.6.6, \chi^{2}=27.38, * *, Q=0.004\right)$, contohnya memudarnya cinta, cinta hanyalah pemulas, dan (iv) EMOSI ADALAH OBJEK BERKEILAHIAN $\left(\mathrm{F}_{\mathrm{o}}=12, \mathrm{Fe}=2.7, \chi^{2}=\right.$ 31.62, * $Q=0.003$ ) seperti pada cinta (yang) abadi/sempurna, Tuhan adalah sumber cinta, dewa cinta. Tidak satupun dari keempat RS metaforis tersebut diharapkan untuk berperan penting bagi RT CINTA jika melihat literatur, yang kali 
ini dapat sangat dipahami karena perbedaan objek bahasa yang dikaji. Akan tetapi, perbedaan ini sedikitnya mengindikasikan menariknya meneliti konseptualisasi metaforis suatu RT yang sama dari sudut pandang lintas-bahasa dengan metode yang lebih empiris.

Lima metafora yang signifikan berkorelasi negatif dengan RT CINTA BI ialah (i) KONTROL EMOSI ADALAH KONTROL OBJEK BERGERAK ( $\mathrm{F}_{\mathrm{o}}=0, \mathrm{Fe}=$ 20.4, $\chi^{2}=20.42, * * *, Q=0.007$ ), kemudian (ii) EMOSI ADALAH MUSUH/LAWAN $\left(\mathrm{F}_{\mathrm{o}}=12, \mathrm{Fe}=32.0, \chi^{2}=12.49, *, Q=0.007\right)$ seperti pada $\mathrm{X}$ menghadapi/diamuk/didera/mengalahkan kekuatan (perasaan) cinta, (iii) EMOSI ADALAH CAIRAN DALAM WADAH $\left(\mathrm{F}_{\mathrm{o}}=1, \mathrm{Fe}_{\mathrm{e}}=13.4, \chi^{2}=11.46, * *, Q=\right.$ 0.004) yang hanya muncul sekali pada pola $X$ menumpahkan cinta, dan juga (iv) EMOSI ADALAH CAIRAN $\left(\mathrm{F}_{\mathrm{o}}=1, \mathrm{Fe}=11.6, \chi^{2}=9.66, *, Q=0.003\right)$ yang direalisasikan tunggal oleh X terlarut dalam cinta, dan terakhir metafora skematis (v) INTENSITAS EMOSI ADALAH UKURAN/KUANTITAS $\left(\mathrm{F}_{\mathrm{o}}=10, \mathrm{Fe}=28.1, \chi^{2}=\right.$ $11.69, *, Q=0.006$ ) yang misalnya tercermin pada X mengurangi (rasa) cinta, cinta diukur dengan $\mathrm{X}$

\subsubsection{Metafora WADAH Khas BI}

Penelitian ini berhasil menemukan metafora WADAH khas BI melalui kajian lintas bahasa yang telah didiskusikan dalam Kövecses (2000) terhadap BIng., bahasa Hungaria, bahasa Cina, dan bahasa Jepang. Kekhasan metafora WADAH ditemukan pada tingkat yang lebih terperinci secara semantis, yaitu WADAH metaforis dari leksikon "anggota tubuh". Setelah memeriksa seluruh 
sitiran metaforis emosi dengan berfokus pada beberapa leksikon dari ranah “anggota tubuh", ditemukan bahwa kekerapan munculnya leksikon "anggota tubuh" seperti ditunjukkan pada Tabel 6.4 berikut.

\section{Tabel 6.4}

\section{Kekerapan Leksikon “Anggota Tubuh” sebagai WADAH EMOSI}

\begin{tabular}{cccccc}
\hline hati & dada & Mata & jantung & kepala & total \\
$95(28,4)$ & $29(28,4)$ & $12(28,4)$ & $2(28,4)$ & $4(28,4)$ & $\mathbf{1 4 2}$
\end{tabular}

Tabel 6.4 menunjukkan bahwa leksikon hati dan dada lebih sering digunakan secara sangat signifikan pada pola metaforis RT EMOSI BI. Temuan ini menjadi dasar untuk mengusulkan kekhasan hati dan juga dada lebih sering digunakan secara metaforis, khususnya kali ini sebagai WADAH pada ranah EMOSI. MK yang termotivasi oleh latarbelakang budaya Indonesia ialah EMOSI ADALAH UNSUR DI DALAM WADAH (HATI/ DADA). Terkait dengan lebih seringnya penggunaan leksikon hati secara metaforis dibandingkan dengan penggunaannya secara harafiah dalam BI juga ditemukan pada studi sebelumnya yang dilakukan oleh Siahaan (2008). Sedangkan wadah emosi berupa perut yang dikatakan WADAH EMOSI khas budaya Jepang, tidak ditemukan sama sekali dalam pemakaian BI.

Temuan yang kali ini menarik untuk dipaparkan adalah persebaran keempat leksikon "anggota tubuh" pada Tabel 6.4 dalam kaitannya dengan kelima RT EMOSI. Secara menyeluruh, terdapat interaksi antara variabel leksikon “anggota tubuh" dengan variabel RT EMOSI dan leksikon "anggota tubuh" tertentu lebih memiliki ketertarikan khas atau tipikal dengan RT EMOSI tertentu. Tabel 6.5 
berikut menunjukkan persebaran leksikon "anggota tubuh" berdasarkan RT EMOSI.

\section{Tabel 6.5}

Persebaran Leksikon “Anggota Tubuh” berdasarkan RT EMOSI

\begin{tabular}{ccccccc}
\hline Emosi & hati & Dada & jantung & mata & kepala & total \\
\hline KESEDIHAN & $32(28.9)$ & $9(8.8)$ & $0(0.6)$ & $1(3.5)$ & $0(1.2)$ & $\mathbf{4 2}$ \\
AMARAH & $25(32.4)$ & $16(9.9)$ & $1(0.7)$ & $5(4.3)$ & $4(1.4)$ & $\mathbf{5 1}$ \\
CINTA & $22(17.9)$ & $0(5.5)$ & $1(0.4)$ & $3(2.2)$ & $0(0.7)$ & $\mathbf{2 6}$ \\
KEBAHAGIAAN & $10(8.9)$ & $2(2.7)$ & $0(0.2)$ & $1(1.1)$ & $0(0.4)$ & $\mathbf{1 3}$ \\
KETAKUTAN & $6(6.9)$ & $2(2.1)$ & $0(0.1)$ & $2(0.8)$ & $0(0.3)$ & $\mathbf{1 0}$ \\
total & $\mathbf{9 5}$ & $\mathbf{2 9}$ & $\mathbf{2}$ & $\mathbf{1 2}$ & $\mathbf{4}$ & $\mathbf{1 4 2}$ \\
\hline
\end{tabular}

Data pada Tabel 6.5 dianalisis menggunakan HCFA dan hasilnya menunjukkan bahwa secara keseluruhan keterkaitan di antara pemakaian leksikon "anggota tubuh" tertentu terhadap RT EMOSI tertentu hanya menunjukkan signifikansi marjinal $\left(\chi^{2}=26.03, d f=16, p=0.0535\right)$. Interaksi individu masingmasing leksikon dengan RT EMOSI juga seluruhnya tidak signifikan. Hal ini menunjukkan bahwa belum adanya cukup bukti pada data guna menunjukkan adanya ketertarikan khusus antara leksikon "anggota tubuh" tertentu dalam penggunaan metaforisnya dengan RT EMOSI tertentu. Hasil analisis HCFA untuk bagian ini dapat dilihat selengkapnya pada lampiran 6 


\section{Catatan Akhir}

1. (http://metropop-lover.blogspot.com/2009_07_01_archive.html. Keluaran situs Webcorp pada hari Senin, 13 Feb 2012, 13.20.05 GMT)

2. (http://www.kabarindonesia.com/beritaprint.php?id=20090130211843. Keluaran situs Webcorp pada hari Senin, 13 Feb 2012, 13.29.45 GMT)

3. Menariknya, kesan introspektif terkait kemungkinan munculnya dan kelaziman suatu RS metaforis terhadap RT EMOSI tertentu seperti yang terangkum pada Tabel 5.1 tercermin secara implisit dari gaya pemaparan Kövecses (2000) seperti pada beberapa kutipan langsung berikut ini: "[...] ini (RS ATASAN SOSIAL) tidak mungkin muncul dengan KETERKEJUTAN (surprise) [....]" (Kövecses, 2000:37); "Dapat dibayangkan bahwa CINTA dan NAFSU bisa memakai ini (RS BEBAN) [....]” (Kövecses, 2000:38); dan “Aplikasi mereka (RS SANTAPAN, PERANG, dan PERMAINAN) tampaknya terbatas pada CINTA dan NAFSU." (Kövecses, 2000:39). 


\section{BAB VII \\ MAKNA METAFORA EMOSI BAHASA INDONESIA}

\subsection{Pengantar}

Semantik Kognitif dan Linguistik Kognitif secara teoretis tidak sejalan dengan pandangan semantik formal yang berdasar pada "Truth-conditional semantics". Pandangan ini melihat bahwa makna linguistik diperoleh dari "dunia yang dibatasi secara objektif” (“[...] an objectively defined 'world”) (Evans \& Green, 2006:457). Dengan kata lain, “makna kata muncul dari hubungan langsung antara kata dan objek yang diacunya di dunia" (Evans \& Green, 2006:209; Langacker, 2008:28). Implikasinya adalah pengadopsian semantik formal terhadap "model kamus" (dictionary view) bagi makna linguistik yang sekaligus menunjukkan pemisahan antara pengetahuan linguistik dan pengetahuan dunia (Evans \& Green, 2006:171, 208; Langacker, 2008:38). Pendekatan "model kamus" semantik formal mencirikan penguraian makna dengan definisi yang ketat dalam bentuk fitur semantik atau primitif yang sepenuhnya terpisah dari konteks (Evans \& Green, 2006:171, 208, 458; Langacker, 2008:38). Sebagai contoh, makna dasar bull 'banteng' sering disajikan dalam bentuk fitur semantik primitif [MALE], [ADULT], dan [BOVINE], yang sekaligus meminggirkan segala pengetahuan lain yang diketahui terkait hewan ini dan dianggap sebagai pengetahuan non-linguistik, misalnya perannya dalam tarung banteng dan rodeo (Langacker, 2008:38). Ikutan lain dari komposisionalitas makna seperti ini adalah pemisahan antara semantik (makna yang tetap secara komposisional) dan pragmatik (interpretasi kontekstual) yang dalam Semantik dan Linguistik 
Kognitif, pembedaan ini dianggap tidak relevan namun dipandang membentuk suatu gradasi (Langacker, 2008:40; Evans \& Green, 2006:171, 220-221). Komposisionalitas juga terbawa ke ranah makna kalimat yang dibentuk dari makna kata. Pendekatan seperti ini mungkin bisa diterapkan pada sejumlah kalimat. Akan tetapi, bagaimana cara memaknai kalimat atau ekspresi linguistik yang maknanya tidak sepenuhnya dapat diterka dari makna unsur pembentuknya seperti idiom dan metafora? (Evans \& Green, 2006:171). Pertanyaan yang sering muncul bagi kasus seperti ini biasanya "segi yang mana dari ekspresi tersebut yang masuk ke dalam semantik (yang sekadar mencerminkan bahasa) dan segi yang mana sebaiknya diserahkan kepada pragmatik?” (Langacker, 2008:39). Akibatnya, ekspresi non-komposisional cenderung dipandang sebagai pengecualian, bukannya malah sebagai suatu kelaziman oleh pendekatan semantik formal, yang sebaliknya oleh Linguistik dan Semantik Kognitif, "bahasa figuratif kenyataannya bersifat sentral terhadap cara kita berpikir dan juga terhadap cara kerja bahasa." (Evans \& Green, 2006:171).

Salah satu prinsip teoretis mendasar dari Semantik Kognitif, khususnya, dan Linguistik Kognitif, secara luas, adalah "Meaning construction is conceptualisation" atau "Pembangunan makna adalah konseptualisasi" yang berhubungan dengan ekspresi linguistik (Evans \& Green, 2006:162; Langacker, 2008:4). Dengan kata lain, Semantik Kognitif memandang bahwa unit linguistik, seperti kata, frasa, kalimat, dan sebagainya berperan sebagai batu loncatan menuju ke banyak pengetahuan, yang berkaitan dengan konsep tertentu, dan seperangkat mekanisme konseptual sebagai bahan yang berpotensi untuk diakses dalam 
pemaknaan linguistik (Evans \& Green, 2006:160, 162, 215; Langacker, 2008:39, 42). Adanya banyak pengetahuan bagi representasi makna linguistik mencirikan pengadopsian pandangan "makna ensiklopedis" dari Semantik dan Linguistik Kognitif (Evans \& Green, 2006:173). Artinya, dibandingkan dengan pendekatan semantik formal sebelumnya, makna unsur linguistik tidaklah dibatasi oleh fiturfitur semantis yang 'dikemas' secara rapi (Evans \& Green, 2006:160). Secara tidak langsung, pandangan makna ensiklopedis yang dianut oleh Semantik dan Linguistik Kognitif bersamaan dengan pandangan makna yang terbentuk oleh konteks secara dinamis ("a dynamic context-driven view of meaning") mengikutkan tidak adanya pemisahan yang prinsip terhadap semantik dan pragmatik (Evans \& Green, 2006:460). Selanjutnya, sejumlah mekanisme mendasar yang berperan dalam pembangunan makna linguistik adalah "proyeksi konseptual" atau yang juga dikenal dengan "pemetaan" atau mapping, seperti metafora dan metonimi, "pemaduan" atau blending, dan "ruang mental" atau mental spaces (Evans \& Green, 2006:167, 364, 367; Langacker, 2008:35-36). Dalam hal ini dan untuk kepentingan analisis makna metafora pada Bab ini, pendekatan Semantik Kognitif dapat memfasilitasinya secara teoretis terpadu. Lebih jelasnya, "pemetaan" atau proyeksi konseptual adalah salah satu mekanisme pembangunan makna yang diusung oleh Semantik Kognitif dan ekspresi metaforis adalah cerminan dari adanya "pemetaan" konseptual ranah sumber guna memahami ranah target. Jadi, pendekatan Semantik Kognitif umumnya, dan Metafora Konseptual khususnya, adalah pasangan yang tepat secara teoretis bagi analisis makna metafora emosi. 
Selanjutnya, analisis Sorot Makna Utama (main meaning focus) metafora pada bab ini mencerminkan salah satu unsur dari pendekatan makna ensiklopedis. Unsur ini adalah 'keintian' unsur tertentu dari rentangan sejumlah pengetahuan yang dimiliki oleh suatu ranah. Langacker (2008:39) menyatakan bahwa "pencirian tertentu dari makna suatu ekspresi menjadi begitu inti sehingga pencirian tersebut selalu diaktifkan setiap kali ekspresi tersebut digunakan, sedangkan yang lain diaktifkan secara kurang konsisten dan sisanya bersifat pinggiran saja sehingga hanya diakses pada konteks-konteks tertentu." "Keintian adalah peluang (likelihood) ranah tertentu untuk diaktifkan ketika suatu ekspresi digunakan pada suatu kesempatan.” (Langacker, 2008:48). Konsep keintian ini terkait dengan penonjolan atau pengedepanan unsur tertentu dari ranah sumber yang diproyeksikan kepada ranah target secara metaforis (Langacker, 2008:58).

Pada analisis berikutnya, akan dapat dilihat bahwa dari sekian banyak unsur-unsur ranah sumber metaforis yang dicerminkan oleh pola metaforis ranah sumber tersebut, akan terdapat perbedaan tingkat keintian/keutamaan dari unsurunsur tersebut. Tingkat keintian ini dapat dilihat dari peluang atau probabilitas unsur-unsur tersebut untuk lebih sering diaktifkan dalam penggunaannya di luar unsur kebetulan dibandingkan dengan unsur lain dari suatu ranah sumber (periksa Langacker, 2008:49). Tentunya, probabilitas tersebut dapat diukur signifikansinya secara statistik mengingat metode Linguistik Korpus yang digunakan pada disertasi ini. Oleh karena itu, penggabungan metode Linguistik Korpus dan pendekatan teoretis Semantik Kognitif dalam lingkup permasalahan yang dikaji dalam disertasi ini telah terbukti. 
RS metaforis khas emosi yang dipaparkan sebelumnya berkaitan erat dengan penonjolan unsur terpenting dari kelima konsep emosi oleh RS metaforis tersebut. Ini disebabkan oleh masing-masing RS metaforis, dalam kombinasinya dengan RT sebagai MK, memiliki tema atau makna utama (Kovecses, 2002; 2005) yang dipetakan ke RT, dalam hal ini EMOSI. Jadi, dengan mengetahui unsur semantis utama dari RS metaforis yang signifikan dipikat oleh emosi tertentu, maka unsur utama yang ditonjolkan dari konsep emosi yang dimaksud akan dapat dipahami.

Bab ini memaparkan hasil analisis terhadap "Sorot Makna Utama" (main meaning focus) serta "Pemetaan Utama" (central mapping) dari masing-masing RS metaforis khas EMOSI BI. Pada dua anak bab berikut nosi SMU dan PU akan dijabarkan secara ringkas sebelum menuju hasil analisis.

\subsection{Sorot Makna Utama}

Sorot Makna Utama (SMU) dan Pemetaan Utama (PU) adalah dua konsep teoretis dari TMK (Kovecses, 2002). Untuk perihal SMU, masing-masing RS metaforis dikaitkan dengan suatu tema makna utama tertentu yang (i) secara alamiah telah ditentukan (predetermined), (ii) lazimnya tetap, (iii) menggambarkan sejumlah pengetahuan mendasar mengenai suatu RS yang telah secara luas diterima bersama dalam suatu guyub tutur dan (iv) yang dapat ditemukan pada kebanyakan pencontohan dari RS yang dimaksud, dan 
(v) yang secara khas mencirikan RS tersebut (Kovecses, 2002:110; 2005:11).

Dilihat dari sisi linguistik, Lakoff juga telah lebih dahulu menyatakan bahwa "unsur leksikal dan ekspresi tetap (fixed expressions) suatu bahasa dapat menyatakan atau digunakan untuk mengungkapkan unsur dari suatu MK pada tingkat yang besar atau kecil.” (1987:384). Contohnya metafora SISTEM KOMPLEKS (misalnya ARGUMEN) ADALAH BANGUNAN (Lakoff \& Johnson, 2003), SMUnya ialah "pembentukan struktur yang stabil dari suatu sistem kompleks" (Kovecses, 2002:110).

Sejumlah ML cerminannya ialah seperti we've got the framework for a solid argument; If you don't support your argument with solid facts, the whole thing will colapse; He is trying to buttress his argument with a lot of irrelevant facts, but it is still so shaky that it will easily fall apart under criticism; With the groundwork you've got, you can construct a pretty strong argument (Kovecses, 2002:110). Ekspresi linguistik metaforis di atas kebanyakan menitikberatkan unsur 'kekuatan', 'struktur' serta 'pembentukan' argumen (Kovecses, 2002:110). Contoh lainnya RS PERJALANAN bagi RT CINTA dan RT KEHIDUPAN menyoroti unsur ‘kemajuan’ (progress) (Kovecses, 2005:11).

\subsection{Pemetaan Utama}

Konsep "Pemetaan Utama" (PU) muncul sebagai bagian dari salah satu pandangan mendasar TMK bahwa suatu MK dengan pola A ADALAH B terdiri atas seperangkat konstituen pemetaan antara beberapa unsur RS terhadap RT (Kovecses, 2002:93). Mengacu pada contoh metafora ARGUMEN ADALAH 
BANGUNAN, pengetahuan mendasar terkait RS BANGUNAN dapat dimodelkan ke dalam suatu pemetaan yang mencirikan metafora ARGUMEN ADALAH BANGUNAN atas dasar realisasi linguistiknya (Kovecses, 2002:110): RGUMEN ADALAH BANGUNAN

(a) fondasi $\rightarrow$ dasar/basis yang menyokong argumen

(b) kerangka $\rightarrow$ struktur elemen menyeluruh yang menyusun argumen

(c) elemen tambahan guna menyokong kerangka $\rightarrow$ elemen tambahan guna mendukung struktur argumen

(d) rancangan $\rightarrow$ sturktur logis argumen

(e) arsitek $\rightarrow$ pembuat/pembangun argumen

(f) pembangunan $\rightarrow$ penyusunan argumen

$(\mathrm{g})$ kekuatan $\rightarrow$ kekekalan/kestabilan argumen

(h) kerobohan $\rightarrow$ kegagalan argumen

Seluruh konstituen pemetaan di atas dapat disederhanakan menjadi pemetaan yang lebih umum tanpa kehilangan informasi terkait SMU dari metafora ARGUMEN ADALAH BANGUNAN (Kovecses, 2002:111):

(1) pembangunan $\rightarrow$ penyusunan argumen (pemetaan "e" dan "fo")

(2) struktur fisik $\rightarrow$ struktur abstrak (pemetaan "a" sampai "d")

(3) kekuatan fisik $\rightarrow$ kekekalan abstrak (pemetaan "g" dan "h")

Ketiga pemetaan tersebut tentunya dapat juga diperankan sebagai submetafora dari metafora ARGUMEN ADALAH BANGUNAN: PENYUSUNAN ARGUMEN ADALAH PEMBANGUNAN, STRUKTUR ABSTRAK ARGUMEN ADALAH STRUKTUR FISIK, dan KEKEKALAN ABSTRAK ARGUMEN ADALAH KEKUATAN FISIK (Kovecses, 2002:111). Ketiga PU (generalised mapping) (pemetaan "1" sampai “3"), yang menjadi asal dari pemetaan lainnya (yaitu pemetaan "a" sampai "h"), inilah yang dinamakan dengan "Pemetaan Utama" (Kovecses, 2002:112). 
Jadi, SMU dari RS BANGUNAN yang berupa 'pembuatan struktur yang kuat' dipetakan ke RT ARGUMEN oleh ketiga pemetaan utama tadi yang juga dapat menurunkan pemetaan lainnya.

Kövecses (2002:112) menyatakan bahwa PU memiliki ciri-ciri sebagai berikut:

“(a) secara konseptual, PU menuntun kemunculan pemetaan lain, entah itu konstituen pemetaan dasar atau pengikutan metaforis (metaphorical entailment), (b) secara budaya, PU mencerminkan perhatian utama manusia dalam kaitannya dengan RS yang dimaksud, (c) secara motivasi, PU adalah pemetaan yang paling termotivasi atas dasar pengalaman (most motivated experientially) — entah secara budaya atau fisik, (d) secara linguistik, PU memunculkan ekspresi metaforis yang mendominasi suatu metafora."

Garis besarnya ialah pertama, masing-masing RS metaforis dicirikan oleh suatu tema makna utama tertentu yang berupa khasanah tertetapkan (predetermined) dari kebanyakan RS, misalnya BANGUNAN. Kedua, SMU dan PU yang dikaitkan dengan suatu RS dapat diamati dari realisasi linguistik yang mendominasi suatu metafora. Ketiga, khasanah makna tertetapkan yang melekat pada RS tersebutlah yang diusung dan dipetakan oleh PU ke RT (Kovecses, 2002:112).

\subsection{Sorot Makna Utama, Pemetaan Utama, dan Metode Analisis Pola Metaforis \& Linguistik Korpus}

Penggunaan metode Analisis Pola Metaforis (APM) (Stefanowitsch, 2004a \& 2006a) yang berciri kuantitatif, khususnya dalam kaitannya dengan analisis SMU dan PU yang berunsur kualitatif pada bab ini, dipertemukan pada ciri keempat dari pemaparan SMU dan PU sebelumnya. Benang merah yang 
dimaksud ialah "SMU yang diasosiasikan dengan suatu RS dapat dilihat dari ekspresi linguistik metaforis yang mendominasi suatu metafora" (Kovecses, 2002:112) secara implisit dapat dioperasionalkan secara kuantitatif.

Artinya, terkait dengan metode LKorp seperti APM, konsep teoretis SMU dan PU suatu RS metaforis dapat dioperasionalkan berdasarkan "kekerapan" munculnya pola metaforis yang digunakan untuk mengungkapkan unsur suatu RS pada tingkatan tertentu (Lakoff, 1987:384). Dengan mengoperasionalkan SMU dan PU menggunakan pengukuran "kekerapan" seperti tersebut, akan ada kemudahan untuk menentukan apa yang perlu diamati pada korpus dan menentukan nilai ukurnya secara kuantitatif.

SMU dan PU yang diusung oleh RS khas emosi dan yang ditemukan pada sampel data BI kali ini telah dibahas sebelumnya dan diajukan utamanya oleh Kövecses (2000, 2002, 2005) ataupun oleh literatur lain, semisal Stefanowitsch (2004a \& 2006a) melalui data dari BIng. Penelitian ini, utamanya mendasari penyematan kecenderungan suatu unsur makna RS tertentu sebagai SMU dan PU atas dasar data kuantitatif BI yang diperoleh dan yang tentunya dilandasi oleh teori bahwa SMU dan PU dapat diamati dari realisasi pola metaforis yang dominan bagi metaforanya. Mekanisme ini dilandasi oleh salah satu asas Linguistik Kognitif, yaitu "Model Bahasa Berdasarkan Penggunaan” (Evans \& Green, 2006). Linguistik Kognitif memandang "unit linguistik yang ditemukan lebih sering akan menjadi lebih terpatri (yaitu, tertetapkan sebagai pola atau rutinitas kognitif)" (Evans \& Green, 2006:114). 
Diasumsikan (A1) bahwa kekerapan pola metaforis yang mengacu pada unsur makna tertentu dari suatu RS metaforis tidak akan sama seringnya (inequally often). Arah dari efek perbedaan tersebut ditentukan dengan cara membandingkan kekerapan aktual (observed frequency) dengan kekerapan harapan (expected frequency) dari unsur makna yang dinyatakan oleh pola metaforis suatu metafora. Unsur yang signifikan lebih sering dicontohkan oleh pola metaforisnya dari yang diharapkan berdasarkan data dapat dipandang secara teoretis lebih berkemungkinan besar mencerminkan SMU dan PU dari RS tersebut dibandingkan dengan unsur lain yang juga direalisasikan. Asumsi kosongnya (A0) ialah kekerapan pola metaforis yang mengacu pada unsur makna tertentu, entah itu yang mencirikan SMU dan PU ataupun tidak, suatu RS metaforis akan sama seringnya.

Jika memang SMU dan PU yang sudah dibahas dalam karya Kövecses (2000, 2002, 2005) sebelumnya pada akhirnya juga dicerminkan oleh pola metaforis yang kekerapannya lebih mendominasi realisasi MKnya dari yang diharapkan secara signifikan dibandingkan dengan unsur lain, ini memberikan dukungan secara empiris dan lintas bahasa terkait SMU dan PU yang telah diajukan tersebut.

Uji signifikansi dilakukan dengan menggunakan "Tes Binomial (Binomial Test)" (Gries, 2009b:33--43). Tes ini digunakan jika sejumlah percobaan $n$ dari satu variabel menghasilkan dua keluaran atau tingkatan, yaitu unsur makna RS metaforis. (keluarannya secara umum dikelompokkan sebagai "sukses" atau “gagal”) (Baayen, 2008:46; Crawley, 2007:300). Percobaan $n$ kali ini dapat 
diartikan sebagai jumlah pola metaforis suatu metafora. Akan tetapi, jika total pola metaforis $n$ menghasilkan lebih dari dua keluaran, yaitu mengacu pada lebih dari dua unsur, maka "Tes Multinomial (Multinomial Test)" yang digunakan (Gries, 2009b:158; akan terbit:9). Tes Binomial adalah Tes Multinomial yang berkeluaran dua tingkat. Penghitungan statistik ini menggunakan piranti lunak $R$.

Kamus Bahasa Indonesia (2008) digunakan dalam analisis bab ini untuk mengetahui makna dasar dari unsur leksikal RS pada pola metaforisnya. Kemudian, kaitan antara makna literal unsur leksikal tersebut pada RS dengan sorot makna metaforis utamanya yang dipetakan ke RT dimaknai dengan menggunakan interpretasi peneliti (Stefanowitsch, 2006b), selain juga memeriksa literatur-literatur utama terkait kaijan ini, seperti Kövecses (2000, 2002, 2005).

\subsection{Sorot Makna Utama dan Pemetaan Utama Metafora AMARAH}

Terdapat delapan metafora yang signifikan khas AMARAH BI. Subbab ini akan membahas penekanan unsur semantis yang diungkapkan oleh pola metaforis dari metafora khas AMARAH.

\subsubsection{Metafora KONTROL AMARAH ADALAH KONTROL OBJEK BERGERAK}

Metafora ini bersifat skematis terkait spesifikasi objek yang dikontrol. Metafora KONTROL OBJEK BERGERAK ini dilandasi dengan pengikutan dari penggabungan dua metafora tipe MSP (Event Structure Metaphors) AKSI ADALAH PERGERAKAN dan PENYEBAB ADALAH DAYA (Kövecses, 2000:56): jika aksi adalah pergerakan maka kendali terhadap aksi emosional adalah kendali terhadap 
pergerakan objek, yang dikonseptualisasikan sebagai aksi emosional. Salah satu contohnya dalam BIng. ialah "he held back his anger" (Kövecses, 2000:57). Metafora ini dapat dipandang berkaitan dengan metafora KENDALI DIRI ADALAH KENDALI OBJEK (Kovecses, 2005:59) yang dimotivasi oleh dasar pengalaman, yaitu hubungan antara memanipulasi objek dan mengendalikannya.

Dilihat dari 934 sitiran metaforis yang ditemukan untuk RT AMARAH, 75 sitiran mencerminkan metafora KONTROL AMARAH ADALAH KONTROL OBJEK BERGERAK. Pengamatan terhadap ke-75 pola metaforis dari RS KONTROL OBJEK BERGERAK menunjukkan bahwa unsur makna yang tercermin dapat dikelompokkan menjadi dua: pola yang pada RT menyoroti unsur 'pengendalian emosi' dan unsur 'tindakan emosional'. Konstituen pemetaan metafora KONTROL AMARAH ADALAH KONTROL OBJEK BERGERAK yang dapat dibangun adalah sebagai berikut:

Ranah Sumber

a. Mengontrol objek bergerak $\rightarrow$ Mengontrol diri bertindak emosional

b. Membiarkan objek bergerak $\rightarrow$ Membiarkan diri bertindak emosional

Tabel 7.5.1 mendaftar semua pola metaforis yang ditemukan pada sampel. Angka di dalam tanda kurung “(...)” berarti kekerapan harapan (Fe). 
Tabel 7.5.1

\section{PM untuK MK KONTROL AMARAH ADALAH KONTROL OBJEK BERGERAK}

\begin{tabular}{|c|c|c|c|}
\hline \multirow[b]{2}{*}{ Pola Metaforis } & \multicolumn{2}{|c|}{ Unsur Ranah Target } & \multirow[b]{2}{*}{ Tota } \\
\hline & $\begin{array}{l}\text { tindakan } \\
\text { emosional }\end{array}$ & pengendalian emosi & \\
\hline X (me)nahan NP_emo & & 60 & 60 \\
\hline NP_emo (yang) tertahan & & 3 & 3 \\
\hline Tahan(lah) NP_emo & & 2 & 2 \\
\hline NP_emo ditahan(-tahan) & & 2 & 2 \\
\hline NP_emo X tahan & & 1 & 1 \\
\hline X mengakhiri NP_emo & & 1 & 1 \\
\hline X mencegah NP_emo & & 1 & 1 \\
\hline X mengurungkan NP_emo & & 1 & 1 \\
\hline X menghentikan NP_emo & & 1 & 1 \\
\hline NP_emo ditunda & & 1 & 1 \\
\hline X melanjutkan NP_emo & 1 & & 1 \\
\hline Teruskan NP_emo & 1 & & 1 \\
\hline Total & $2(37.5)$ & $73(37.5)$ & 75 \\
\hline
\end{tabular}

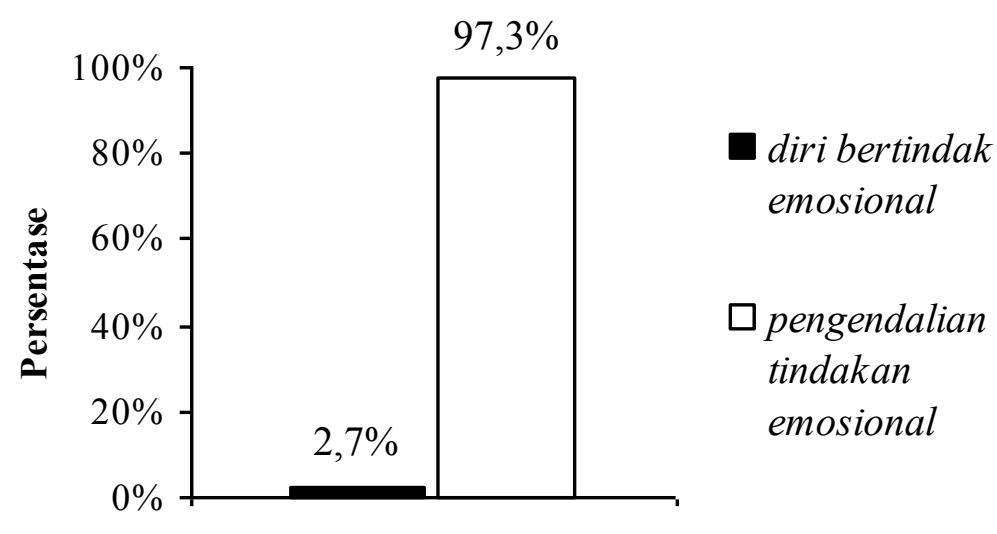

Bagan 7.5.1

Distribusi Unsur Makna MK KONTROL AMARAH ADALAH KONTROL OBJEK BERGERAK 
Seperti dapat dilihat pada Tabel 7.5.1, pola metaforis metafora KONTROL AMARAH ADALAH KONTROL OBJEK BERGERAK yang mengacu pada 'pengendalian emosi' diri (pemetaan [a]) diamati jauh lebih sering daripada yang diharapkan $(73>37.5)$ dibandingkan dengan 'tindakan emosional' $(2<37.5)$ (pemetaan [b]). Tes Binomial menunjukkan bahwa hal ini adalah penyimpangan yang sangat signifikan dari kekerapan yang diharapkan muncul atas dasar kebetulan $\left(P_{\text {binomial }}=1.51 \mathrm{E}-19\right)$.

Jika mengacu pada utamanya pernyataan Kövecses $(2002: 110,112)$ bahwa SMU merepresentasikan pengetahuan mendasar dari RS yang ditemukan pada kebanyakan pencontohan RS secara linguistik, maka unsur 'pengendalian tindakan emosional' dipandang lebih cenderung mencirikan SMU dari RS KONTROL OBJEK BERGERAK. Lebih lanjut, mengingat bahwa sorot makna ini mencirikan pemetaan (a) di atas yang memiliki pola metaforis yang jauh lebih dominan, maka pemetaan (a) juga mencerminkan pemetaan sentral bagi metafora KONTROL AMARAH ADALAH KONTROL OBJEK BERGERAK.

\subsubsection{Metafora AMARAH ADALAH UNSUR DALAM WADAH (BERTEKANAN)}

Metafora AMARAH ADALAH UNSUR DALAM WADAH (BERTEKANAN) bersifat lebih skematis terkait pencirian UNSUR yang mengisi wadah daripada pencontohan khusus metafora ini, yaitu AMARAH ADALAH CAIRAN (PANAS) DALAM WADAH yang juga signifikan ditarik oleh RT AMARAH BI dan akan dibahas pada anak subbab selanjutnya. Lebih lanjut, persamaan dari kedua 
metafora WADAH tersebut adalah wadahnya berupa wadah bertekanan, baik dengan atau tanpa panas (Kövecses, 2002:170).

Pada data korpus, ditemukan 95 sitiran metaforis yang mencerminkan metafora AMARAH ADALAH UNSUR DALAM WADAH (BERTEKANAN). Hasil analisis menunjukkan bahwa ke-95 pola metaforis tersebut secara umum dapat dikelompokkan ke dalam pola yang menggunakan unsur 'penuh, bertekanan, ledakan/keluaran' dan 'pengandungan' dari RS UNSUR DALAM WADAH (BERTEKANAN) (periksa Stefanowitsch (2006a:99) untuk data BIng. terkait RS CAIRAN DALAM WADAH).

Pola yang menyatakan 'pengandungan' unsur dalam wadah dalam RT dapat diartikan sebagai 'diri yang sedang marah' yang pada pemetaan dasar di bawah ini dipayungi oleh pemetaan (a) dan (b) di bawah ini. Sedangkan, pola yang mengacu pada unsur 'penuh, bertekanan, ledakan/keluaran' dapat diartikan sebagai unsur yang mengacu pada 'intensitas emosi' dalam diri (pemetaan [c]). Pemetaan dasar AMARAH ADALAH UNSUR DALAM WADAH (BERTEKANAN) ialah sebagai berikut (Kövecses, 2000:66, 2002:96):

Ranah Sumber

a. Wadah berunsur

b. Unsur dalam wadah

c. Kuantitas unsur dalam wadah

d. Penyebab meningkatnya tekanan unsure

\section{Ranah Target}

$\rightarrow \quad$ Tubuh seseorang yang marah

$\rightarrow$ Amarah dalam diri

$\rightarrow$ Daya atau intensitas amarah

$\rightarrow \quad$ Penyebab dari amarah 
Pemetaan di atas menunjukkan bahwa keberadaan unsur dalam wadah menyatakan adanya emosi dalam diri atau diri emosional; sedikitnya jumlah unsur dalam wadah menandakan kecilnya tekanan yang berarti rendahnya intensitas emosi, sedangkan meningkatnya kuantitas unsur menandakan meningkatnya intensitas emosi; tekanannya yang dibawa bersamaan dengan meningkatnya

Tabel 7.5.2a

PM untuk MK AMARAH ADALAH UNSUR DALAM WADAH (BERTEKANAN)

\begin{tabular}{|c|c|c|c|}
\hline \multirow[b]{2}{*}{ Pola Metaforis } & \multicolumn{3}{|c|}{ Unsur Ranah Target } \\
\hline & intensitas emosi & subjek emosional & Total \\
\hline X penuh (dengan) (muatan) NP_emo & 21 & & 21 \\
\hline $\begin{array}{l}\text { NP_emo (yang) meledak(-ledak [di } \\
\text { [dalam] hati]) }\end{array}$ & 13 & & 13 \\
\hline X VP penuh (dengan) NP_emo & 13 & & 13 \\
\hline $\begin{array}{l}\text { X meledakkan/meletupkan/ } \\
\text { menyemburkan/semburkan/memuntahk } \\
\text { an/membuang/mengeluarkan NP_emo } \\
\text { (dalam hati) }\end{array}$ & 10 & & 10 \\
\hline X VP dengan penuh NP_emo & 6 & & 6 \\
\hline ledakan/letusan/letupan NP_emo & 6 & & 6 \\
\hline $\begin{array}{l}\text { X diisi dengan/dipenuhi/disesaki } \\
\text { NP_emo }\end{array}$ & 4 & & 4 \\
\hline X menekan NP_emo & 3 & & 3 \\
\hline VPX (dengan) penuh NP_emo & 3 & & 3 \\
\hline NP_emo meletus/meletup-letup & 3 & & 3 \\
\hline meledaklah NP_emo & 2 & & 2 \\
\hline NP_emo kelewat batas/terlontar & 2 & & 2 \\
\hline $\begin{array}{l}\mathrm{NP} \text { _emo mendesak/menyodok ke } \\
\text { jantung hati }\end{array}$ & 2 & & 2 \\
\hline NP_emo dipaksakan & 1 & & 1 \\
\hline NP_emo dimasukkanX ke dalam hati & & 1 & 1 \\
\hline $\mathrm{X}$ mengandung NP_emo & & 5 & 5 \\
\hline Total & $89(47.5)$ & $6(47.5)$ & 95 \\
\hline
\end{tabular}


kuantitas unsur dalam wadah mengindikasikan emosi yang menyebabkan diri menanggapi atau bertindak (emosional) (Kövecses, 2000:66). Tabel 7.5.2a mendaftar semua pola metaforis yang ditemukan.

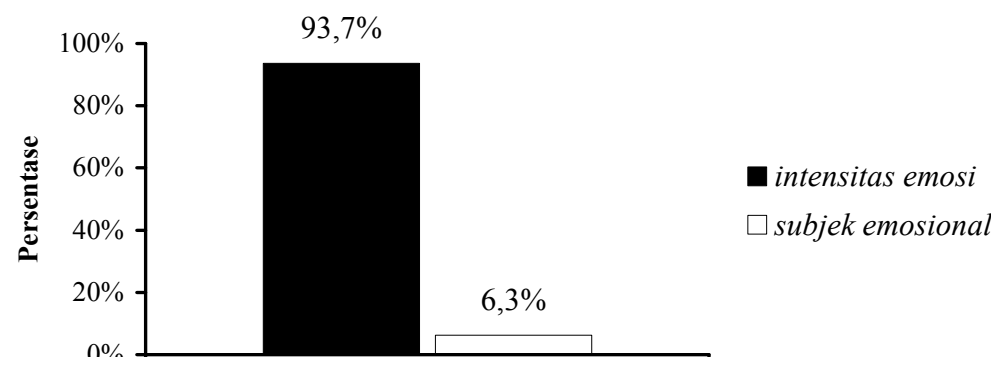

Bagan 7.5.2a

\section{Distribusi Unsur Makna MK AMARAH ADALAH UNSUR DALAM WADAH (BERTEKANAN)}

Dapat dilihat pada Tabel 7.5.2a dan Bagan 7.5.2a, bahwa terdapat ketimpangan kekerapan dari yang diharapkan jika menganggap A0 memang benar: dari total 95 sitiran metafora AMARAH ADALAH UNSUR DALAM WADAH (BERTEKANAN), 89 pola metaforis mengacu pada unsur makna 'intensitas emosi' dan enam pola mengacu pada unsur 'subjek emosional'. Ketimpangan ini sangat signifikan $\left(P_{\text {binomial }}=4.7 \mathrm{E}-20\right)$. Dengan kata lain, kecilnya nilai probabilitas menunjukkan lebih seringnya unsur 'intensitas' dicontohkan dari RS UNSUR DALAM WADAH (BERTEKANAN) sangat tidak mungkin terjadi jika perbedaan fokus terhadap kedua unsur makna tersebut memang benar tidak ada.

Implikasinya, lanjutan dari hasil ini ialah dukungan terhadap pernyataan bahwa unsur 'intensitas emosi' dari RS yang berciri WADAH seperti UNSUR DALAM WADAH (BERTEKANAN) cenderung lebih disoroti oleh kebanyakan pola 
metaforisnya (Kövecses, 2000:65), utamanya yang kali ini diamati melalui data BI. RS ini juga ditemukan pada sejumlah bahasa berbeda seperti Jepang, Hungaria, Polandia, Cina, Wolof, dan Zulu (Kövecses, 2005:39).

Hasil penilaian secara statistik sebelumnya dapat secara lebih rinci diketahui dengan melihat realisasi linguistik terkait identifikasi PU dari RS UNSUR DALAM WADAH (BERTEKANAN). Selain ciri yang berhubungan dengan pola metaforis yang mendominasi suatu metafora, Kövecses menyatakan bahwa salah satu ciri PU suatu metafora adalah "secara konseptual menuntun munculnya pemetaan lain, entah itu konstituen pemetaan dasar atau pengikutan metaforis (metaphorical entailment)" (2002:112). Metafora AMARAH ADALAH UNSUR DALAM WADAH (BERTEKANAN) menunjukkan adanya pengikutan metaforis tersebut atas bukti pola metaforis yang merealisasikannya (Kövecses, 2002:96; Lakoff, 1987:384).

Pengikutan metaforis merupakan khasanah pengetahuan tambahan yang dipetakan ke RT, selain unsur pemetaan dasarnya (Kövecses, 2002:94). Khusus untuk RS UNSUR DALAM WADAH (BERTEKANAN), pengikutan metaforisnya telah sebelumnya dibahas oleh Kövecses (2002:96--98; 2005:40) dan juga Lakoff (1987:384--386). Jadi, pemaparan kali ini akan mengacu pada hasil kajian kedua peneliti tersebut. Pengikutan metaforis RS UNSUR DALAM WADAH (BERTEKANAN) berikut ini dibangun atas dasar pola metaforis BI yang khusus mengacu pada unsur 'intensitas' emosi dan atas dasar adaptasi dari pengikutan metaforis yang diajukan oleh Kövecses (2002:96--98; 2005:40). 
Tabel 7.5.2b

\section{PM dan Pengikutan Metaforis Unsur Makna 'intensitas' dari MK AMARAH ADALAH CAIRAN DALAM WADAH}

\begin{tabular}{|c|c|c|c|c|c|c|}
\hline \multirow[b]{2}{*}{ Pola Metaforis } & \multicolumn{6}{|c|}{$\begin{array}{c}\text { Pengikutan Metaforis Unsur Makna ‘intensitas’ dari RS } \\
\text { UNSUR DALAM WADAH (BERTEKANAN) }\end{array}$} \\
\hline & $\begin{array}{l}\text { menahan } \\
\text { tekanan }\end{array}$ & $\begin{array}{c}\text { unsur } \\
\text { bertambah }\end{array}$ & $\begin{array}{l}\text { tekanan } \\
\text { pada } \\
\text { wadah }\end{array}$ & $\begin{array}{l}\text { timbul } \\
\text { ledakan }\end{array}$ & $\begin{array}{l}\text { keluarny } \\
\text { a unsur }\end{array}$ & Total \\
\hline $\begin{array}{l}\text { ledakan/letusan/letupan } \\
\text { NP_emo }\end{array}$ & & & & 6 & & 6 \\
\hline meledaklah NP_emo & & & & 2 & & 2 \\
\hline $\begin{array}{l}\text { NP_emo (yang) meledak(- } \\
\text { ledak [di [dalam] hati]) }\end{array}$ & & & & 13 & & 13 \\
\hline NP_emo dipaksakan & 1 & & & & & 1 \\
\hline $\begin{array}{l}\text { NP_emo kelewat } \\
\text { batas/terlontar }\end{array}$ & & & & & 2 & 2 \\
\hline $\begin{array}{l}\text { NP_emo meletus/meletup- } \\
\text { letup }\end{array}$ & & & & 3 & & 3 \\
\hline $\begin{array}{l}\mathrm{NP} \text { _emo } \\
\text { mendesak/menyodok ke } \\
\text { jantung hati }\end{array}$ & & & 2 & & & 2 \\
\hline $\begin{array}{l}\text { VPX (dengan) penuh } \\
\text { NP_emo }\end{array}$ & & 3 & & & & 3 \\
\hline $\begin{array}{l}\mathrm{X} \text { diisi } \\
\text { dengan/dipenuhi/disesaki } \\
\text { NP_emo }\end{array}$ & & 3 & 1 & & & 4 \\
\hline X menekan NP_emo & 3 & & & & & 3 \\
\hline $\begin{array}{l}\text { X penuh (dengan) (muatan) } \\
\text { NP_emo }\end{array}$ & & 21 & & & & 21 \\
\hline X VP dengan penuh NP_emo & & 6 & & & & 6 \\
\hline $\begin{array}{l}\text { X VP penuh (dengan) } \\
\text { NP_emo }\end{array}$ & & 13 & & & & 13 \\
\hline X meledakkan NP_emo & & & & 2 & & 2 \\
\hline X meletupkan NP_emo & & & & 2 & & 2 \\
\hline $\begin{array}{l}\text { X menyemburkan/semburkan } \\
\text { NP_emo }\end{array}$ & & & & & 2 & 2 \\
\hline X memuntahkan NP_emo & & & & & 2 & 2 \\
\hline $\begin{array}{l}\text { X membuang NP_emo dalam } \\
\text { hati }\end{array}$ & & & & & 1 & 1 \\
\hline X mengeluarkan NP_emo & & & & & 1 & 1 \\
\hline Total & $4(17.8)$ & $46(17.8)$ & $3(17.8)$ & $28(17.8)$ & $8(17.8)$ & 89 \\
\hline
\end{tabular}






Bagan 7.5.2b

\section{Distribusi Pengikutan Metaforis Unsur Makna 'kekerapan' dari MK}

Kövecses menyatakan bahwa jika ditemukan pola metaforis lazim yang menunjukkan salah satu dari sejumlah pengikutan metaforis, dalam hal ini kelima pengikutan metaforis yang ditemukan di atas dalam kasus BI, ketika berbicara tentang AMARAH, maka diperkirakan bahwa penutur bahasa tersebut "benar-benar sering berpikir dari segi pengikutan metaforis itu." (2002:96).

Pernyataan Kövecses tersebut dapat digunakan sebagai pertimbangan secara teoretis bahwa pengikutan metaforis yang direalisasikan oleh pola metaforisnya lebih sering daripada yang diharapkan cenderung bersifat lebih inti dalam kaitannya dengan pola pikir seseorang ketika berbicara tentang RT tertentu. Bukti kuantitatif pola metaforis yang mencontohkan kelima pengikutan metaforis di atas menunjukkan bukan suatu kebetulan bahwa, dibandingkan dengan pengikutan lainnya, pengikutan 'unsur bertambah' dan 'timbul ledakan' lebih sering digunakan dalam BI ketika mengungkapkan unsur 'intensitas' AMARAH $(P$ multinomial $=1.05 \mathrm{E}-20)$.

Pemaparan dan hasil statistik sebelumnya menunjukkan bahwa pengikutan metaforis metafora AMARAH ADALAH UNSUR DALAM WADAH (BERTEKANAN) BI 
berpusat pada dan didasari dengan pemetaan yang mengacu pada unsur 'intensitas emosi', khususnya pemetaan 'kuantitas unsur dalam wadah $\rightarrow$ daya atau intensitas amarah" yang karenanya dapat dipandang lebih condong menjadi pemetaan utamanya. Jika melihat pengikutan metaforisnya, pengikutan yang menyatakan meningkatnya intensitas unsur/emosi dan intensitas unsur/emosi yang tidak tertahan hingga timbul ledakan/tanggapan emosional lebih sering disoroti.

\subsubsection{Metafora AMARAH ADALAH CAIRAN DALAM WADAH}

RS ini merupakan pencirian yang lebih spesifik dari UNSUR DALAM WADAH (BERTEKANAN) terkait jenis UNSURnya. Hal ini ditunjukkan secara linguistik dari pencirian semantis unsur leksikal RS pola metaforisnya yang dapat dipandang berasal dari RS CAIRAN DALAM WADAH. Konstituen pemetaan metafora AMARAH ADALAH CAIRAN DALAM WADAH seperti yang diadaptasi dari Kövecses (2002:96) ialah sebagai berikut:

Ranah Sumber

a. Wadah bercairan

b. Cairan dalam wadah

c. Kuantitas cairan dalam wadah $\rightarrow$ Daya atau intensitas amarah

d. Penyebab meningkatnya tekanan cairan

\section{Ranah Target}

$\rightarrow$ Tubuh seseorang yang marah

$\rightarrow$ Amarah dalam diri

$\rightarrow$ Penyebab dari amarah

Ditemukan 42 pola metaforis pada sitiran RT AMARAH yang merealisasikan metafora AMARAH ADALAH CAIRAN DALAM WADAH. Semua pola tersebut secara umum menyoroti unsur 'intensitas' cairan dalam wadah atau emosi dalam diri seperti yang dinyatakan oleh utamanya pemetaan (c) di atas. 
Secara lebih rinci, unsur makna 'intensitas' pada RT AMARAH yang disoroti oleh pola metaforis dari RS CAIRAN DALAM WADAH dapat dipecah menjadi sejumlah submetafora yang merupakan pengikutan metaforis dari metafora AMARAH ADALAH CAIRAN DALAM WADAH. Secara umum, pengikutan metaforis untuk RS berciri WADAH sama seperti pada pengikutan metaforis untuk RS UNSUR DALAM WADAH (BERTEKANAN) sebelumnya. Yang membedakan hanyalah jenis unsur yang dicirikan dan penggunaan aktualnya dalam sampel.

Untuk RS CAIRAN DALAM WADAH, pengikutan metaforis yang dapat ditafsirkan atas dasar pengamatan pola metaforis yang ditemukan, di antaranya (i) kuantitas cairan dalam wadah yang dapat bertambah ataupun berkurang; (ii) usaha diri menahan cairan agar tidak keluar dari wadah; dan (iii) ketidakmampuan menahan kuantitas berlimpah cairan dalam wadah sehingga cairan keluar wadah. Kajian Kövecses $(2000,2002)$ terkait metafora emosi khususnya pengikutan metaforis RS CAIRAN DALAM WADAH belum menunjukkan pengikutan mana yang lebih lazim atau lebih sering digunakan. Memang penelitian terhadap bagian ini belum pernah ditemukan dan dilakukan sebelumnya. Jadi, kecondongan distribusi dari pengikutan-pengikutan metaforis tersebut tidak dapat diketahui.

Akan tetapi, dengan pernyataan Kövecses (2002:96) bahwa lebih lazimnnya penyorotan pengikutan metaforis potensial tertentu daripada pengikutan yang lain ketika, dalam hal ini, berbicara tentang AMARAH dapat menyiratkan keterpatrian pola pikir orang terkait dengan pengikutan metaforis potensial tersebut, maka bisa diasumsikan bahwa pola metaforis dari ketiga pengikutan RS CAIRAN DALAM WADAH tadi yang muncul lebih sering daripada 
yang diharapkan berkecenderungan kuat mencerminkan konsep yang digunakan ketika berbicara tentang AMARAH BI.

Tabel 7.5.3

PM dan Pengikutan Metaforis Unsur Makna 'intensitas' dari MK AMARAH ADALAH CAIRAN DALAM WADAH

\begin{tabular}{|c|c|c|c|c|}
\hline \multirow[b]{2}{*}{ Pola Metaforis } & \multicolumn{4}{|c|}{$\begin{array}{c}\text { Pengikutan Metaforis Unsur Makna } \\
\text { 'intensitas' dari RS CAIRAN DALAM WADAH }\end{array}$} \\
\hline & $\begin{array}{l}\text { keluarnya } \\
\text { cairan }\end{array}$ & $\begin{array}{c}\text { tingkat } \\
\text { kuantitas } \\
\text { cairan }\end{array}$ & $\begin{array}{c}\text { menahan } \\
\text { cairan di } \\
\text { wadah }\end{array}$ & Total \\
\hline $\begin{array}{l}\text { X (me)lampiaskan/ } \\
\text { ngelampiasin/menuntaskan } \\
\text { NP_emo (pada/ke Y) }\end{array}$ & 19 & & & 19 \\
\hline $\begin{array}{l}\text { X menumpahkan/ menuangkan } \\
\text { NP_emo (kepada/dalam Y) }\end{array}$ & 6 & & & 6 \\
\hline X menyalurkan NP_emo & 4 & & & 4 \\
\hline $\begin{array}{l}\mathrm{X} \text { menahan/membendung air mata } \\
\text { NP_emo (yang mengubun) }\end{array}$ & & & 3 & 3 \\
\hline $\begin{array}{l}\text { NP_emo ditumpahkan/ } \\
\text { dilimpahkan kepada Y }\end{array}$ & 2 & & & 2 \\
\hline pelampiasan NP_emo (kepada Y) & 2 & & & 2 \\
\hline jebolnya tanggul NP_emo & 1 & & & 1 \\
\hline NP_emo menguap & & 1 & & 1 \\
\hline NP_emo meruah & 1 & & & 1 \\
\hline NP_emo butuh penyaluran & 1 & & & 1 \\
\hline $\mathrm{NP}$ _emo terbendung & & & 1 & 1 \\
\hline NP_emo tumpah & 1 & & & 1 \\
\hline Total & $37(14)$ & $1(14)$ & $4(14)$ & 42 \\
\hline
\end{tabular}

Tabel 7.5.3 dan Bagan 7.5.3 menunjukkan intensitas pengikutan metaforis potensial unsur makna 'intensitas' RS CAIRAN DALAM WADAH dan pola metaforisnya yang ditemukan dalam sampel data. 


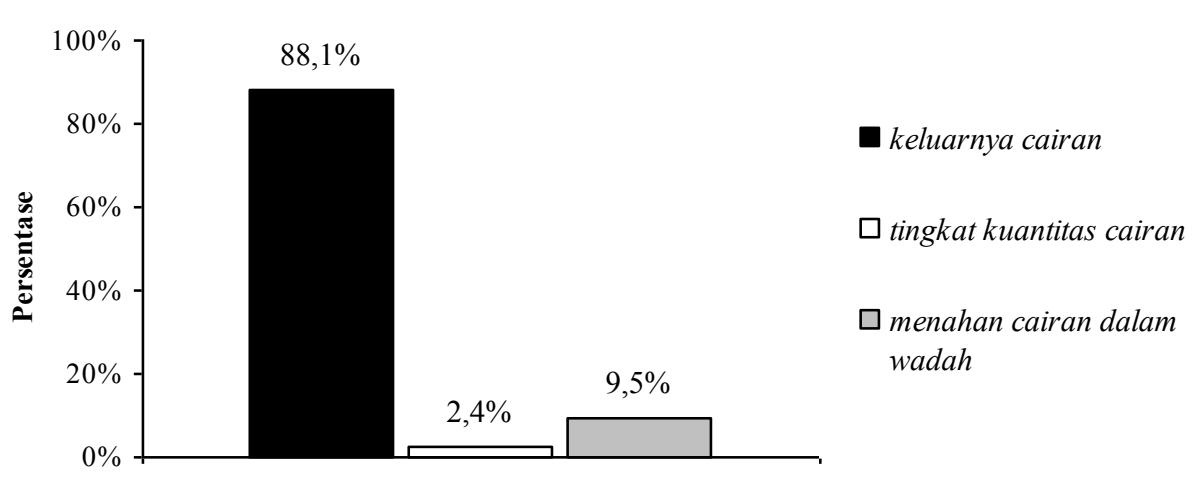

\section{Bagan 7.5.3}

\section{Distribusi Pengikutan Metaforis Unsur Makna 'kekerapan' dari MK AMARAH ADALAH CAIRAN DALAM WADAH}

Jika mengacu pada tabulasi data pada Tabel 7.5.3 serta ilustrasi grafis Bagan 7.5.3, secara jelas terlihat bahwa terdapat kejomplangan kekerapan di antara ketiga pengikutan metaforis tersebut daripada yang diharapkan. Perbedaan yang dimaksudkan ialah kecenderungan mencolok penyorotan pengikutan metaforis 'cairan keluar wadah' oleh $88.1 \%$ pola metaforis RS CAIRAN DALAM WADAH, yang merupakan akibat dari ketidakmampuan mengendalikan besarnya kuantitas cairan dalam wadah, daripada dua unsur lainnya.

Pertanyaan yang muncul tentunya apakah hasil ini adalah situasi yang diharapkan muncul secara kebetulan atau tidak sehingga mungkin mencerminkan keteraturan yang ingin diungkap. Tes Multinomial menunjukkan bahwa terdapat bukti yang kuat pada sampel guna mengajukan pengikutan 'cairan keluar wadah' secara sangat signifikan lebih lazim diungkapkan ketika mengkonseptualisasikan unsur 'intensitas' dari RT AMARAH BI $\left(P_{\text {multinomial }}=3.89 \mathrm{E}-14\right)$.

Pengikutan metaforis 'cairan keluar wadah' yang dipetakan ke RT dapat disandingkan dengan ketidakmampuan diri menahan amarah yang intens sehingga 
mengakibatkan diri menanggapi/bertindak emosional. Sedangkan dua pengikutan lainnya 'kuantitas cairan berkurang' dan 'menahan cairan dalam wadah' secara berurutan dapat diartikan pada RT sebagai berkurangnya intensitas amarah dan kemampuan mengendalikan amarah. Pengikutan-pengikutan metaforis yang berasal dari pemetaan "kuantitas cairan dalam wadah $\rightarrow$ daya/intensitas amarah" tersebut secara empiris mendukung potensi pemetaan tadi sebagai pemetaan utama metafora AMARAH ADALAH CAIRAN DALAM WADAH.

\subsubsection{Metafora AMARAH ADALAH CAIRAN PANAS DALAM WADAH}

Salah satu metafora yang paling banyak mendapat perhatian terkait RT AMARAH dalam kajian-kajian metafora emosi lintas bahasa ialah AMARAH ADALAH CAIRAN PANAS DALAM WADAH (Lakoff, 1987, Kövecses, 2002). Kövecses (2000:22) menganggap bahwa metafora ini bersifat sentral bagi AMARAH. Anggapan ini dapat diterima khususnya berdasarkan hasil analisis CFA pada data korpus BI pada bab sebelumnya yang menunjukkan signifikansi ketertarikan RS CAIRAN PANAS DALAM WADAH dengan RT AMARAH.

Kövecses menyatakan bahwa unsur RT EMOSI yang diasosiasikan oleh RS PANAS dalam kombinasinya dengan (CAIRAN DALAM) WADAH adalah utamanya 'intensitas' emosi dengan kecenderungan ketidakmampuan diri mengendalikan intensnya emosi (2000:41, 2002:95--98). Menarik untuk diketahui apakah data yang berasal dari korpus BI kali ini menegaskan hasil serupa atau tidak. Berikut ini adalah unsur pemetaan metafora tersebut (Kövecses, 2002:96): 
Ranah Sumber

a. Wadah fisik bercairan panas

b. Cairan panas dalam wadah

c. Tingkat panas cairan dalam wadah

d. Penyebab meningkatnya panas cairan
Ranah Target

$\rightarrow \quad$ Tubuh seseorang yang marah

$\rightarrow \quad$ Amarah dalam diri

$\rightarrow \quad$ Daya atau intensitas amarah

$\rightarrow \quad$ Penyebab dari amarah

Ditemukan 30 sitiran pola metaforis yang mendasari metafora AMARAH ADALAH CAIRAN PANAS DALAM WADAH. Ke-30 pola metaforis ini secara luas mengacu pada 'kadar panas cairan dalam wadah' (pemetaan [c]), atau yang pada RT menyatakan 'intensitas amarah'. Ini artinya, ditemukan lagi bukti, yang kali ini melalui data BI, bahwa unsur 'kadar panas cairan dalam wadah' dari RS CAIRAN PANAS DALAM WADAH memang cenderung disoroti secara linguistik seperti yang dinyatakan oleh Kövecses (2000:41, 2002:95—98).

Jika dilihat dari konstituen dasar pemetaan metaforisnya, unsur 'intensitas' ditunjukkan oleh pemetaan "tingkat panas cairan dalam wadah $\rightarrow$ daya/intensitas amarah" (pemetaan [c]). Karena berdasarkan data yang diperoleh metafora AMARAH ADALAH CAIRAN PANAS DALAM WADAH cenderung diwujudkan oleh pola metaforis dengan unsur 'intensitas' seperti ditunjukkan oleh pemetaan (c), maka pemetaan (c) mencirikan pemetaan utama metafora AMARAH ADALAH CAIRAN PANAS DALAM WADAH.

Berikutnya, keutamaan pemetaan (c) tersebut juga dapat dilihat dari elaborasi rinci terkait pengetahun yang dimiliki oleh RS CAIRAN PANAS DALAM WADAH, yaitu pengikutan metaforisnya, yang dicirikan oleh pola metaforisnya 
(Lakoff, 1987:384; Kövecses, 2002:96). Berikut ini ialah sejumlah pengetahuan terkait perilaku cairan panas dalam wadah (Kovecses, 2002:96):

"begitu panas cairan meningkat, cairan pun meningkat; diketahui juga jika panas menghasilkan uap; diketahui pula bahwa cairan dan panas tersebut memberikan tekanan pada dinding wadah; diketahui juga bahwa setelah batas tertentu, dinding tersebut akan meledak (pecah) akibat tekanan yang begitu kuat; diketahui pula cairan akan keluar wadah akibat ledakan tersebut; diketahui juga jika bagian-bagian dari wadah yang meledak akan beterbangan ke semua tempat; dan hal itu bisa berbahaya bagi orang-orang di sekitarnya, dll.”

Secara khusus, berikut ini adalah pengikutan yang dimaksud dari penjelasan sebelumnya (Kövecses, 2002:96--97): (i) KETIKA PANAS CAIRAN/INTENSITAS AMARAH MENINGKAT, CAIRAN MENINGKAT, (ii) AMARAH INTENS MENGHASILKAN UAP, (iii) AMARAH INTENS MEMBERIKAN TEKANAN PADA WADAH, (iv) DIRI YANG MARAH MENCOBA MENAHAN TEKANAN, (v) KETIKA AMARAH MENJADI BEGITU INTENS, TIMBUL LEDAKAN, (vi) KETIKA DIRI YANG MARAH MELEDAK, SEBAGIAN DARINYA BERTABURAN KE UDARA, dan (vii) KETIKA DIRI YANG MARAH MELEDAK, APA YANG ADA DI DALAMNYA KELUAR.

Pemaparan di atas merupakan pengikutan metaforis potensial yang dapat dipetakan secara koheren ke RT AMARAH (Kövecses, 2002). Yang perlu diamati kali ini ialah pengikutan potensial mana yang benar-benar dipetakan dari RS ke RT AMARAH atas dasar bukti pola metaforis BI. Jadi, pengamatan ini dipusatkan pada ke-30 pola metaforis yang mencerminkan unsur makna 'intensitas' untuk melihat pengikutan mana saja yang disoroti dan bagaimana distribusi pengikutan tersebut. Tabel 7.5.4 berikut menunjukkan empat pengikutan metaforis unsur 
'intensitas' dari RS CAIRAN PANAS DALAM WADAH yang dicontohkan oleh pola metaforisnya dalam BI.

Tabel 7.5.4

PM dan Pengikutan Metaforis Unsur Makna 'intensitas' dari MK AMARAH ADALAH CAIRAN PANAS DALAM WADAH

\begin{tabular}{|c|c|c|c|c|c|}
\hline \multirow[b]{2}{*}{ Pola Metaforis } & \multicolumn{5}{|c|}{$\begin{array}{c}\text { Pengikutan Metaforis Unsur Makna 'intensitas' dari RS } \\
\text { CAIRAN PANAS DALAM WADAH }\end{array}$} \\
\hline & $\begin{array}{l}\text { amarah } \\
\text { intens } \\
\text { memberi } \\
\text { tekanan }\end{array}$ & $\begin{array}{l}\text { cairan } \\
\text { panas } \\
\text { keluar }\end{array}$ & $\begin{array}{l}\text { panas meningkat, } \\
\text { cairan meningkat }\end{array}$ & $\begin{array}{l}\text { timbul } \\
\text { ledakan }\end{array}$ & Total \\
\hline $\begin{array}{l}\text { (X berisi) NP_emo yang } \\
\text { meluap-luap }\end{array}$ & & 2 & & & 2 \\
\hline luapan NP_emo & & 5 & & & 5 \\
\hline $\begin{array}{l}\text { NP_emo bagaikan } \\
\text { kepundan gunung }\end{array}$ & 1 & & & & 1 \\
\hline NP_emo meluap & & 8 & & & 8 \\
\hline NP_emo membludak & & & & 2 & 2 \\
\hline $\begin{array}{l}\text { NP_emo mendidih di } \\
\text { dalam dada }\end{array}$ & & & 1 & & 1 \\
\hline NP_emo menggelegak & & & 3 & & 3 \\
\hline NP_emo seperti lahar & 1 & & & & 1 \\
\hline NP_emo yang mendidih & & & 1 & & 1 \\
\hline NP_emo yang meruap & & & 1 & & 1 \\
\hline X (me)luapkan NP_emo & & 3 & & & 3 \\
\hline $\begin{array}{l}\text { X memuntahkan lahar } \\
\text { NP_emo }\end{array}$ & & 1 & & & 1 \\
\hline $\begin{array}{l}\text { X menggelegak oleh } \\
\text { NP_emo }\end{array}$ & & & 1 & & 1 \\
\hline Total & $2(7.5)$ & $19(7.5)$ & $7(7.5)$ & $2(7.5)$ & 30 \\
\hline
\end{tabular}




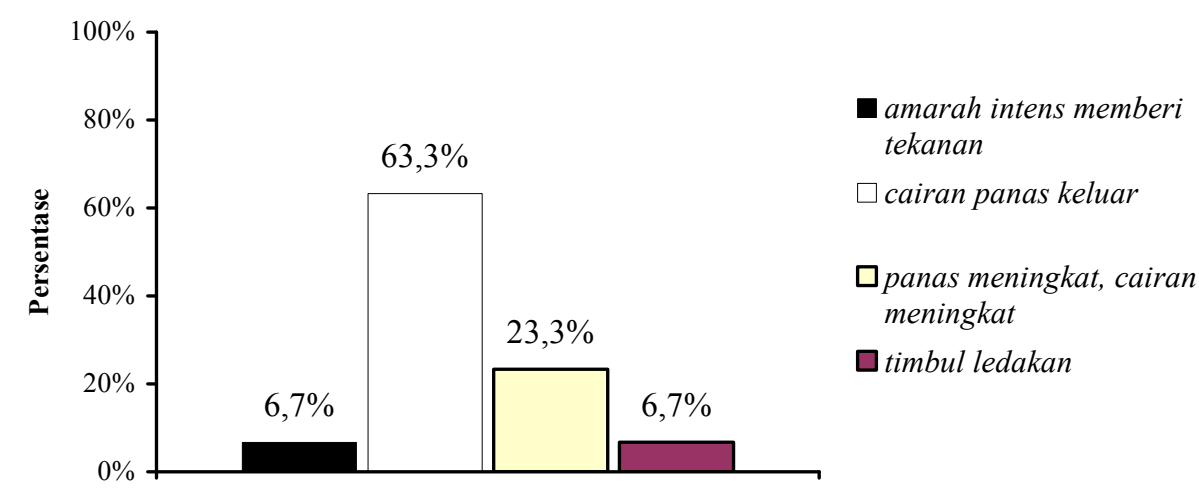

\section{Bagan 7.5.4}

\section{Distribusi Pengikutan Metaforis Unsur Makna 'intensitas' dari MK AMARAH ADALAH CAIRAN PANAS DALAM WADAH}

Seperti terlihat pada Tabel dan Bagan 7.5.4, persebaran keempat pengikutan metaforis tersebut menyimpang secara sangat signifikan dari yang diharapkan $(P$ multinomial $=9.38 \mathrm{E}-08)$. Efek utama yang dapat dilihat dari data, yaitu pengikutan KETIKA DIRI YANG MARAH MELEDAK, APA YANG ADA DI DALAMNYA KELUAR ditonjolkan lebih sering dari yang diharapkan. Dapat ditafsirkan dari hasil ini bahwa unsur intensitas amarah yang pada akhirnya tidak tertahan hingga diri mengekspresikan amarahnya/berespon emosional lebih cenderung disoroti. Pengikutan metaforis ini juga lebih sering tersorot pada RS CAIRAN DALAM WADAH bagi RT AMARAH sebelumnya.

\subsubsection{Metafora AMARAH ADALAH PANAS/DINGIN}

Metafora jenis ini merupakan metafora generik atau skematis yang mencirikan konsep AMARAH (Lakoff, 1987:383). Menurut Lakoff (1987:383), pencirian spesifik RS PANAS ini menghasilkan dua metafora yang berkaitan atas dasar jenis entitas ke mana panas ini diaplikasikan: jika panas diterapkan pada 
benda padat, menghasilkan AMARAH ADALAH API dan jika diterapkan pada zat cair, menghasilkan AMARAH ADALAH CAIRAN DALAM WADAH.

Kövecses (2000:41,76) menyatakan bahwa RS PANAS ini juga memfokuskan unsur 'intensitas emosi', dalam hal ini AMARAH. Hubungan antara unsur 'intensitas' amarah dan PANAS pada metafora AMARAH ADALAH PANAS dilandasi dengan pengalaman jasmaniah manusia: meningkatnya panas tubuh ketika seseorang terlibat dengan situasi yang intens, misalnya marah (Lakoff, 1987:382, Kövecses, 2000:156). Terdapat 16 pola metaforis yang mencontohkan metafora AMARAH ADALAH PANAS/DINGIN. Dari total 16 pola, semuanya mencirikan beragam 'intensitas' AMARAH.

Kövecses (2000:76) lebih lanjut menyatakan bahwa keragaman kadar panas berhubungan dengan keragaman kadar intensitas emosi secara umum, dan kurangnya panas mengindikasikan rendah/kurangnya emosi. Keragaman tingkat panas ini dapat dipandang sebagai pengikutan metaforis metafora AMARAH ADALAH PANAS/DINGIN (ban Stefanowitch, 2006) dan dioperasionalkan menjadi kekerapan pola yang mengacu pada unsur PANAS, HANGAT, serta DINGIN. Ketiga tingkatan unsur ini setidaknya tercermin pada pola metaforis yang merealisasikan metafora AMARAH ADALAH PANAS/DINGIN dalam BI. Yang menarik untuk diamati dari data kali ini yakni apakah terdapat perbedaan kekerapan dari ketiga tingkatan unsur pengikutan unsur 'intensitas' dan jika ada, pengikutan manakah yang signifikan lebih sering: intensitas tertinggi (PANAS), intensitas menengah (HANGAT) atau berkurangnya intensitas (DINGIN), yang berarti berkurangnya AMARAH? 
Tabel 7.5.5

PM dan Pengikutan Metaforis Unsur Makna 'intensitas' dari MK AMARAH ADALAH PANAS/DINGIN

\begin{tabular}{lcccc}
\hline & $\begin{array}{r}\text { Pengikutan Metaforis Unsur Makna 'intensitas' } \\
\text { dari RS PANAS/DINGIN }\end{array}$ \\
\hline Pola Metaforis & panas & hangat & dingin & Total \\
bahang NP_emo & 1 & 1 & 1 \\
hawa NP_emo yang hangat & & & 1 & 1 \\
hawa panas NP_emo & 1 & & 1 \\
merona NP_emo & & & 1 \\
NP_emo mendingin & & & 1 \\
rona NP_emo & 1 & & 1 \\
X membahangkan NP_emo & 4 & & 4 \\
X membakar(-bakar) NP_emo & 1 & & 1 \\
X mendidih oleh NP_emo & & & 2 & 2 \\
$\begin{array}{l}\text { X mendinginkan/menyejukkan } \\
\text { panas NP_emo }\end{array}$ & & & & 1 \\
X merah (padam) oleh NP_emo & 2 & & 2 \\
Total & $10(5.3)$ & $3(5.3)$ & $3(5.3)$ & 16 \\
\hline
\end{tabular}



Bagan 7.5.5

Distribusi Pengikutan Metaforis Unsur Makna 'kekerapan' dari MK AMARAH ADALAH PANAS/DINGIN

Tabel 7.5.5 menampilkan distribusi pola metaforis yang dikelompokkan ke dalam pola yang mengacu pada tiga kadar berbeda dari konsep emosi AMARAH, yaitu PANAS, HANGAT, dan DINGIN (bandingkan Stefanowitsch, 2006: 76). 
Hasil analisis menunjukkan bahwa terdapat perbedaan yang begitu signifikan dari munculnya ketiga pengikutan tersebut dari yang diharapkan $\left(P_{\text {multinomial }}=0.004\right)$. Pengikutan metaforis unsur 'intensitas' $R$ S PANAS/DINGIN yang menyatakan kadar panas tertinggi, yaitu PANAS, diungkapkan oleh sekitar $62.5 \%$ pola metaforisnya jauh lebih sering daripada yang diharapkan. Maka dari itu, dapat ditafsirkan suatu pemetaan, yaitu "panas tertinggi $\rightarrow$ intensitas tertinggi amarah" yang lebih condong untuk ditempatkan sebagai pemetaan utama bagi metafora AMARAH ADALAH PANAS/DINGIN dalam BI.

\subsubsection{Metafora AMARAH ADALAH API}

Metafora ini adalah kasus khusus dari metafora AMARAH ADALAH PANAS/DINGIN (Lakoff, 1987) karena konsep PANAS dan API saling berkaitan (Kövecses, 2002:112). Kövecses (2000:41, 2002:116) menegaskan bahwa pemetaan RS API ke RT AMARAH atau RT EMOSI secara umum juga diasosiasikan dengan penonjolan unsur 'intensitas' dari RT yang dimaksud. Hasil ini diperoleh melalui analisis Kövecses (2002:112--116) terhadap data B.Ing. Akan tetapi, tidak ada pemaparan kuantitatif, yaitu kekerapan munculnya pola metaforis terkait penetapan unsur 'intensitas' dari RS API melalui bukti ekspresi linguistik. Jika memang 'intensitas' menjadi perhatian dominan dari RS API, maka pola metaforis yang mencontohkannya semestinya juga lebih dominan.

Berikut ini ditampilkan unsur pemetaan metafora AMARAH ADALAH API yang diajukan oleh Kövecses (2002:116). 
Ranah Sumber
a. Benda yang terbakar
b. Api
c. Panas api
d. Penyebab api

Ranah Target

$\rightarrow$ Diri yang emosional

$\rightarrow$ Amarah

$\rightarrow$ Daya atau intensitas amarah

$\rightarrow$ Penyebab dari amarah

Tabel 7.5.6a

\section{PM untuk MK AMARAH ADALAH API}

\begin{tabular}{|c|c|c|c|c|c|}
\hline \multirow[b]{2}{*}{ Pola Metaforis } & \multicolumn{5}{|c|}{ Unsur Ranah Target } \\
\hline & emosi & $\begin{array}{l}\text { intensitas } \\
\text { emosi }\end{array}$ & $\begin{array}{l}\text { menyebabkan } \\
\text { emosi }\end{array}$ & $\begin{array}{c}\text { subjek } \\
\text { emosional }\end{array}$ & Total \\
\hline $\begin{array}{l}\text { (Api) NP_emo berkobar(- } \\
\text { kobar)/membakar/bergelora/membar } \\
\text { a/seperti kobaran api membakar }\end{array}$ & & 8 & & & 8 \\
\hline api NP_emo & & 4 & & & 4 \\
\hline bara NP_emo & & 1 & & & 1 \\
\hline $\begin{array}{l}\text { ledakan/kobaran/gejolak (api) } \\
\text { NP_emo }\end{array}$ & & 3 & & & 3 \\
\hline NP_emo (yang) membakar X & & & & 3 & 3 \\
\hline NP_emo menggejolak/bergejolak & & 2 & & & 2 \\
\hline NP_emo padam & & 1 & & & 1 \\
\hline NP_emo tersulut & & & 2 & & 2 \\
\hline obor adalah penanda NP_emo & 1 & & & & 1 \\
\hline $\begin{array}{l}\text { X (me)redakan } \\
\text { (gejolak)/padamkan/menyiram (api) } \\
\text { NP_emo }\end{array}$ & & 4 & & & 4 \\
\hline X menahan gejolak NP_emo & & 1 & & & 1 \\
\hline $\begin{array}{l}\text { X mengobarkan/mengibaskan } \\
\text { NP_emo }\end{array}$ & & 2 & & & 2 \\
\hline $\begin{array}{l}\text { X menyemburkan/memancarkan api } \\
\text { NP_emo }\end{array}$ & & 2 & & & 2 \\
\hline X menyulut/tersulut (oleh) NP_emo & & & 8 & & 8 \\
\hline $\begin{array}{l}\text { X terbakar/dibakar (oleh) (api) } \\
\text { NP_emo }\end{array}$ & & & & 8 & 8 \\
\hline Total & $1(12.5)$ & $28(12.5)$ & $10(12.5)$ & $11(12.5)$ & 50 \\
\hline
\end{tabular}


Terdapat 50 sitiran pola metaforis yang mencerminkan metafora AMARAH ADALAH API. Daftarnya dapat dilihat pada Tabel 7.5.6a di atas.

Tabel 7.5.6a menunjukkan bahwa ke-50 pola metaforis dari metafora AMARAH ADALAH API merealisasikan keempat konstituen pemetaannya secara berbeda daripada yang diharapkan. Perbedaan antara kekerapan aktual dan kekerapan harapan masing-masing konstituen pemetaan tersebut secara statistik sangat signifikan $(P$ multinomial $=5.43 \mathrm{E}-10)$. Dapat dilihat bahwa di antara keempat unsur pemetaan tersebut, unsur 'intensitas emosi' dicontohkan secara sangat signifikan lebih sering daripada yang diharapkan. Unsur 'intensitas emosi' dipetakan ke RT AMARAH melalui pemetaan (c): "panas api $\rightarrow$ daya atau intensitas amarah".

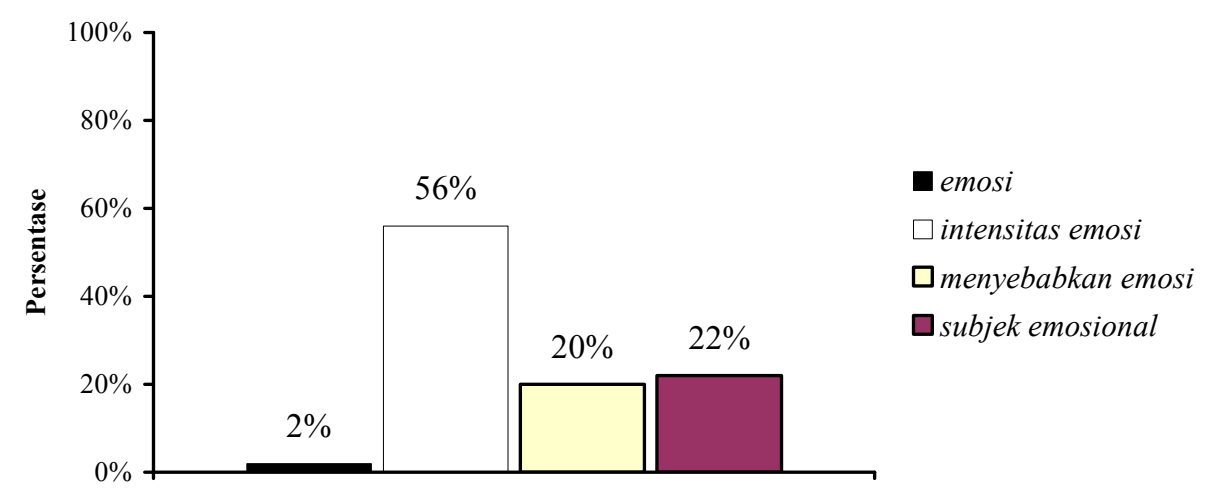

\section{Bagan 7.5.6a}

\section{Distribusi Unsur Makna MK AMARAH ADALAH API}

Hasil ini dapat menunjang teori yang diajukan Kövecses (2002) bahwa dari sudut pandang linguistik, unsur yang menjadi SMU yang dipetakan melalui PU memiliki realisasi pola metaforis yang mendominasi suatu MK. Karena proporsi pola metaforis yang mencirikan metafora AMARAH ADALAH API pada 
data korpus BI kali ini lebih banyak mencerminkan unsur 'intensitas panas api', maka hasil ini juga dapat mendukung secara lebih kuat pernyataan Kövecses (2000:41, 2002:116) bahwa yang menjadi SMU dari RS API adalah 'intensitas emosi' dan yang berarti mengindikasikan pemetaan (c)-lah yang bersifat sentral.

Kesentralan pemetaan "panas api $\rightarrow$ daya atau intensitas amarah" juga ditunjukkan oleh pengikutan metaforis yang sebagian besar terfokus pada unsur 'intensitas'. Berikut ini adalah pengikutan metaforis RS API yang ditemukan pada data atas dasar penyesuaian dan adaptasi dari Kövecses (2002:113--114).

Tabel 7.5.6b

\section{PM dan Pengikutan Metaforis Unsur Makna 'intensitas' dari MK AMARAH ADALAH API}

Pengikutan Metaforis Unsur Makna 'intensitas' dari RS API

\begin{tabular}{|c|c|c|c|c|c|c|}
\hline Pola Metaforis & $\begin{array}{l}\text { intensitas } \\
\text { laten }\end{array}$ & $\begin{array}{l}\text { intensitas } \\
\text { tertinggi }\end{array}$ & $\begin{array}{l}\text { intensitas } \\
\text { mengecil }\end{array}$ & $\begin{array}{l}\text { kendalikan } \\
\text { intensitas }\end{array}$ & $\begin{array}{l}\text { menjaga } \\
\text { intensitas }\end{array}$ & Total \\
\hline $\begin{array}{l}\text { (Api) NP_emo berkobar(- } \\
\text { kobar)/membakar/bergelora/ } \\
\text { membara/seperti kobaran api } \\
\text { membakar }\end{array}$ & & 8 & & & & 8 \\
\hline api NP_emo & & 4 & & & & 4 \\
\hline bara NP_emo & 1 & & & & & 1 \\
\hline $\begin{array}{l}\text { ledakan/kobaran/gejolak (api) } \\
\text { NP_emo }\end{array}$ & & 3 & & & & 3 \\
\hline $\begin{array}{l}\mathrm{NP} \text { _emo } \\
\text { menggejolak/bergejolak }\end{array}$ & & 2 & & & & 2 \\
\hline NP_emo padam & & & 1 & & & 1 \\
\hline $\begin{array}{l}\mathrm{X}(\text { me)redakan } \\
\text { (gejolak)/padamkan/ } \\
\text { menyiram (api) NP_emo }\end{array}$ & & & 4 & & & 4 \\
\hline X menahan gejolak NP_emo & & & & 1 & & 1 \\
\hline $\begin{array}{l}\text { X mengobarkan/mengibaskan } \\
\text { NP_emo }\end{array}$ & & & & & 2 & 2 \\
\hline $\begin{array}{l}\text { X menyemburkan/ } \\
\text { memancarkan api NP_emo }\end{array}$ & & 2 & & & & 2 \\
\hline Total & $1(5.6)$ & $19(5.6)$ & $5(5.6)$ & $1(5.6)$ & $2(5.6)$ & 28 \\
\hline
\end{tabular}




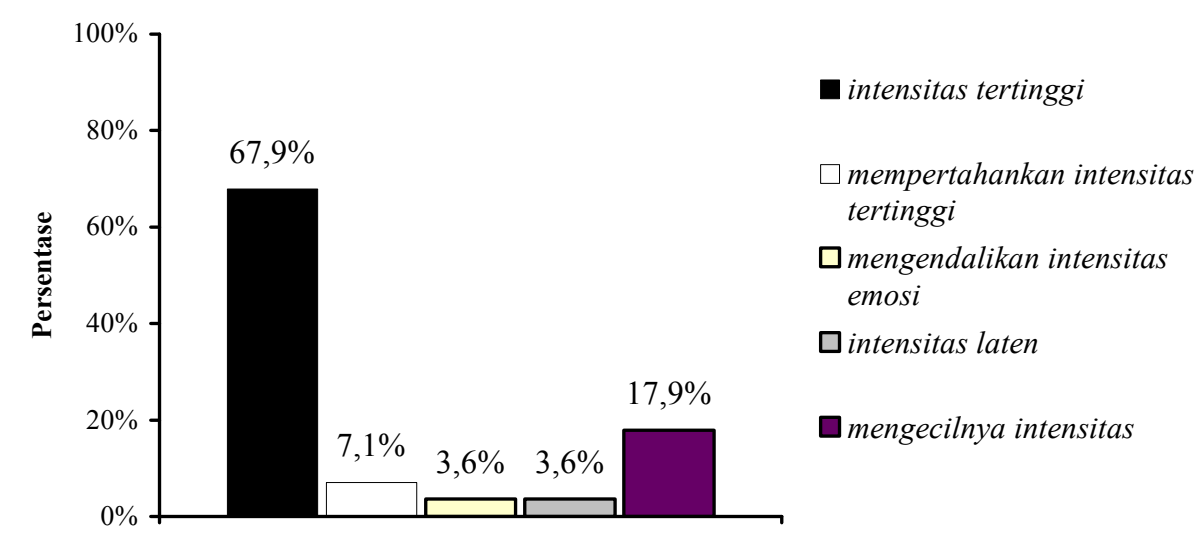

\section{Bagan 7.5.6b \\ Distribusi Pengikutan Metaforis Unsur Makna 'kekerapan' dari MK AMARAH ADALAH API}

Dilihat dari data distribusi pengikutan metaforis yang ditampilkan sebelumnya, dapat ditemukan bahwa kelima pengikutan metaforis dari unsur ‘intensitas' RS API direalisasikan secara berbeda daripada yang diharapkan dan perbedaan ini sangat tidak mungkin jika hanya didasari dengan hal kebetulan $(P$ multinomial $=2.80 \mathrm{E}-10)$. Terlihat bahwa pengikutan SMU 'intensitas' RS API yang sangat signifikan lebih cenderung direalisasikan oleh pola metaforisnya dalam BI yakni TINGKAT INTENSITAS TERTINGGI EMOSI ADALAH TINGKAT TERTINGGI PANAS API.

\subsubsection{Metafora AMARAH ADALAH TINGGI/RENDAH}

RS TINGGI/RENDAH ini adalah salah satu jenis dari Metafora Orientasional (Lakoff \& Johnson, 2003:15; Kövecses, 2002:35). Metafora jenis ini menyediakan sangat sedikit struktur konseptual bagi konsep RT dibandingkan dengan Metafora Struktural dan Ontologikal seperti AMARAH ADALAH CAIRAN PANAS DALAM WADAH (Lakoff \& Johnson, 2003:15; Kövecses, 2002:35). 
Tugas kognitif dari Metafora Orientasional ialah untuk menciptakan pertalian logis (coherence) terhadap konseptualisasi sejumlah konsep RT (Kövecses, 2002:36). Contohnya konsep LEBIH, KEBAHAGIAAN, dan SEHAT semuanya dicirikan oleh orientasi “(KE) ATAS” dan lawannya, KURANG, SEDIH, dan SAKIT dicirikan oleh orientasi “(KE) BAWAH” (Kövecses, 2002:36). Kövecses (2002:36) lebih lanjut menyebutkan bahwa orientasi “(KE) ATAS” cenderung berjalan berbarengan dengan penilaian positif dan sebaliknya.

Dalam lingkup RT AMARAH kali ini, RS TINGGI/RENDAH dapat dipandang lekat secara orientasional dengan konsep ATAS/BAWAH. Jadi, AMARAH ADALAH TINGGI/RENDAH bertipe Metafora Orientasional. Akan tetapi, konseptualisasi RT AMARAH melalui RS orientasional seperti TINGGI/RENDAH tampaknya tidak menyoroti penilaian positif atau negatif amarah yang umumnya dibawa oleh RS seperti ATAS/BAWAH. Sebaliknya, metafora AMARAH ADALAH TINGGI/RENDAH ini dapat dipandang sebagai pencontohan khusus dari metafora LEBIH ADALAH ATAS dan KURANG ADALAH BAWAH (Stefanowitsch, 2006b:77).

Hal ini berarti bahwa dimensi yang disoroti ialah 'lebih/kurangnya' amarah atau yang dengan kata lain 'tinggi/rendahnya intensitas' amarah. Kövecses (2002:69--70) menegaskan bahwa keberpasangan elemen dalam metafora LEBIH/KURANG ADALAH ATAS/BAWAH dilandasi secara eksperiensial oleh pertalian konsep kuantitas dan vertikalitas. Salah satu contoh spesifiknya adalah "ketika kuantitas atau jumlah unsur bertambah (LEBIH), tingkat atau level dari unsur naik (ATAS) dan ketika jumlah unsur berkurang (KURANG) tingkat dari unsur menurun (BAWAH).” (Kövecses, 2002:70). Oleh sebab itu, menjadi masuk 
akal bila (i) metafora AMARAH ADALAH TINGGI/RENDAH konsisten dengan AMARAH ADALAH UNSUR/CAIRAN (PANAS) DALAM WADAH dan (ii) kedua metafora tersebut menyoroti unsur 'intensitas' amarah atas dasar motivasi pengalaman kuantitas dan vertikalitas.

Tabel 7.5.7

\section{PM dan Pengikutan Metaforis Unsur Makna 'intensitas' dari MK AMARAH} ADALAH TINGGI/RENDAH

\begin{tabular}{|c|c|c|c|}
\hline \multirow[b]{2}{*}{ Pola Metaforis } & \multicolumn{3}{|c|}{$\begin{array}{c}\text { Pengikutan Metaforis Unsur Makna 'intensitas' } \\
\text { dari RS TINGGI/RENDAH }\end{array}$} \\
\hline & intensitas rendah & intensitas tinggi & Total \\
\hline NP_emo di puncak & & 1 & 1 \\
\hline NP_emo memuncak & & 9 & 9 \\
\hline $\begin{array}{l}\text { NP_emo menanjak menggapai } \\
\text { puncak }\end{array}$ & & 1 & 1 \\
\hline NP_emo mengubun & & 2 & 2 \\
\hline NP_emo menjulang & & 1 & 1 \\
\hline NP_emo naik & & 1 & 1 \\
\hline NP_emo naik ke kepala & & 1 & 1 \\
\hline NP_emo sampai di ubun-ubun & & 1 & 1 \\
\hline $\mathrm{NP}$ _emo setinggi langit & & 1 & 1 \\
\hline NP_emo turun & 1 & & 1 \\
\hline NP_emo yang memuncak & & 1 & 1 \\
\hline puncak NP_emo & & 5 & 5 \\
\hline X mengubunkan NP_emo & & 1 & 1 \\
\hline $\mathrm{X}$ menurunkan NP_emo & 1 & & 1 \\
\hline Total & $2(13.5)$ & $25(13.5)$ & 27 \\
\hline
\end{tabular}

Pada data sitiran metaforis RT AMARAH, ditemukan sebanyak total 27 pola metaforis yang merealisasikan metafora AMARAH ADALAH TINGGI/RENDAH. Semua pola itu memusatkan unsur makna 'intensitas' amarah. Yang lebih menarik 
untuk diamati yakni apakah distribusi pengikutan metaforis unsur 'intensitas' yang dipetakan melalui RS TINGGI/RENDAH berbeda secara signifikan. Pengikutan yang tercermin dari pola metaforisnya ialah KETIKA AMARAH SANGAT INTENS, TINGKATANNYA TINGGI, dan KETIKA AMARAH TIDAK INTENS, TINGKATANNYA RENDAH. Tabel 7.5.7 di atas menunjukkan persebarannya.

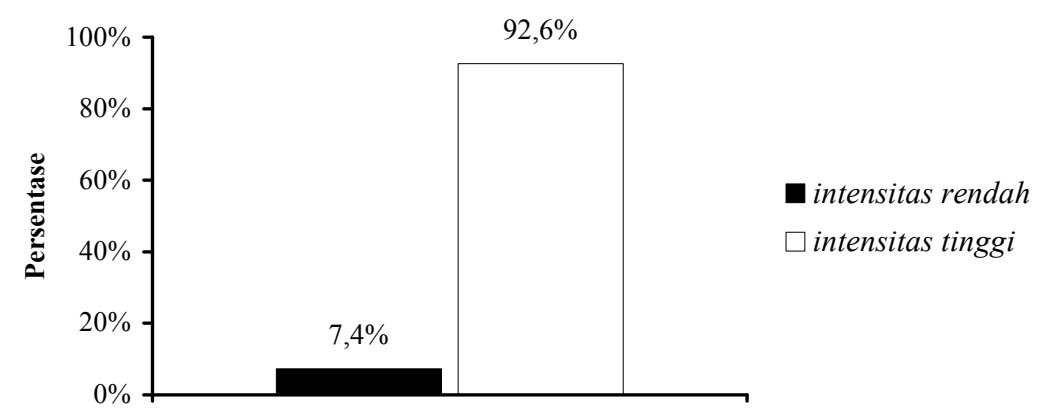

\section{Bagan 7.5.7}

\section{Distribusi Pengikutan Metaforis Unsur Makna 'kekerapan’ dari MK AMARAH ADALAH TINGGI/RENDAH}

Seperti yang ditunjukkan pada perbandingan kekerapan aktual dan harapan, kedua pengikutan metaforis tersebut disoroti tidak sama seringnya secara sangat signifikan $\left(P_{\text {binomial }}=5.65 \mathrm{E}-06\right)$ : pola metaforis yang mengacu pada unsur 'kekerapan tinggi' muncul 25 kali meskipun hanya diharapkan sebanyak 13.5 kali, dan pengikutan terkait unsur 'kekerapan rendah' hanya muncul dua kali walaupun diharapkan muncul sebanyak 13.5 kali. Hal ini kiranya dapat diartikan bahwa melalui data BI amarah seseorang seringnya dicirikan dan dipandang berada pada tingkatan yang sangat intens. 


\subsubsection{Metafora AMARAH ADALAH KEKUATAN ALAM}

RS KEKUATAN ALAM adalah RS khas terakhir yang sangat signifikan ditarik oleh RT AMARAH atas dasar data BI. Kekuatan alam seperti misalnya topan, badai, banjir dan sejenisnya dipandang berdaya sangat kuat dan dapat membawa dampak yang besar bagi suatu objek ketika dipengaruhinya (Kövecses, 2000:71). Dari pencirian eksperiensial tersebut, unsur 'intensitas' juga dapat disoroti oleh RS KEKUATAN ALAM lewat elemen 'daya atau kuatnya akibat' yang dapat ditimbulkan oleh suatu kekuatan alam (Kövecses, 2000:41).

Akan tetapi, Kövecses (2000:42) lebih lanjut menyatakan bahwa “meskipun RS KEKUATAN ALAM juga turut menjaring unsur 'intensitas', fokus utamanya adalah pada nosi 'ketidakberdayaan' (passivity)”. Hal ini berarti bahwa menurut Kövecses (2000:42) sorotan makna yang paling utama dari RS KEKUATAN ALAM ialah 'ketidakberdayaan' diri terhadap keadaan emosi yang dialaminya (Periksa juga Kövecses, 2002:87). Keintian unsur 'ketidakberdayaan’ ini dilandasi oleh pengetahuan bahwa jika objek dipengaruhi oleh dahsyatnya kekuatan alam, objek tersebut tidak dapat mengendalikannya tetapi mengalami imbas kekuatan alam tersebut secara pasif atau tidak berdaya (Kövecses, 2000:72, 2002:87).

Terdapat tiga pernyataan teoretis yang dapat disarikan dan yang kemudian dihadapkan pada data dari BI kali ini terkait SMU dari RS KEKUATAN ALAM yang dipetakan ke RT AMARAH. Yang pertama ialah RS KEKUATAN ALAM dapat menangkap unsur 'intensitas' dan 'ketidakberdayaan' terkait suatu pengalaman emosi, dalam hal ini amarah. Kedua, unsur 'ketidakberdayaan'-lah yang menjadi 
fokus paling utama dari RS KEKUATAN ALAM. Terakhir, keutamaan unsur makna 'ketidakberdayaan' berarti kebanyakan pencontohan linguistik RS KEKUATAN ALAM ini secara teoretis adalah pola metaforis yang mengacu pada unsur 'ketidakberdayaan'.

Ditemukan 60 sitiran metaforis pada korpus yang mencerminkan metafora AMARAH ADALAH KEKUATAN ALAM dari total 934 sitiran metaforis bagi RT AMARAH. Seperti telah ditunjukkan oleh pernyataan pertama sebelumnya, ke-60 pola metaforis tersebut ternyata dapat dikelompokkan menjadi dua: pola yang mengungkapkan unsur 'intensitas' dan unsur 'ketidakberdayaan' dari pengalaman emosional. Keterpilahan ini dapat mendukung pernyataan (Kövecses, 2000:42) bahwa RS KEKUATAN ALAM bisa menangkap kedua unsur dari RT EMOSI tersebut. Pertanyaan selanjutnya adalah apakah ada perbedaan signifikan dari kekerapan kedua unsur makna tersebut untuk dapat menyatakan bahwa salah satu dari kedua unsur tersebut mencirikan makna yang lebih disoroti dari RS KEKUATAN ALAM atas dasar data BI? Berikut ini ditampilkan terlebih dahulu unsur pemetaan metaforis umum metafora AMARAH ADALAH KEKUATAN ALAM (Kovecses, 2000:72).

\section{Ranah Sumber}

a. Kekuatan alam

b. Potensi daya kekuatan alam $\rightarrow$ Intensitas amarah

c. Objek yang tak berdaya $\rightarrow$ Diri yang tak berdaya menanggapi akibat efek kekuatan alam

\section{Ranah Target}

$\rightarrow$ Amarah secara emosional/menjadi emosional 
Tabel 7.5.8a

PM untuK MK AMARAH ADALAH KEKUATAN ALAM

\begin{tabular}{lccc}
\hline & \multicolumn{3}{c}{ Unsur Ranah Target } \\
\hline Pola Metaforis & intensitas & ketidakberdayaan & Total \\
$\begin{array}{l}\text { angin/badai/guntur/taufan/topan/gemuruh/ } \\
\text { gelombang/banjir NP_emo }\end{array}$ & 13 & & 13 \\
$\begin{array}{l}\text { NP_emo diredakan/(me)reda/menjadi } \\
\text { reda/surut }\end{array}$ & 25 & & 25 \\
NP_emo melanda X & & 1 & 1 \\
reda(nya) NP_emo & 2 & & 2 \\
X dibawa/larut dalam arus NP_emo & & 2 & 2 \\
X dilanda NP_emo & & 2 & 2 \\
X mengombak oleh NP_emo & & 2 & 2 \\
X meredakan NP_emo & 12 & & 12 \\
X tersesat dalam pusaran NP_emo & & $8(30)$ & 60 \\
Total & $52(30)$ & & 1 \\
\hline
\end{tabular}

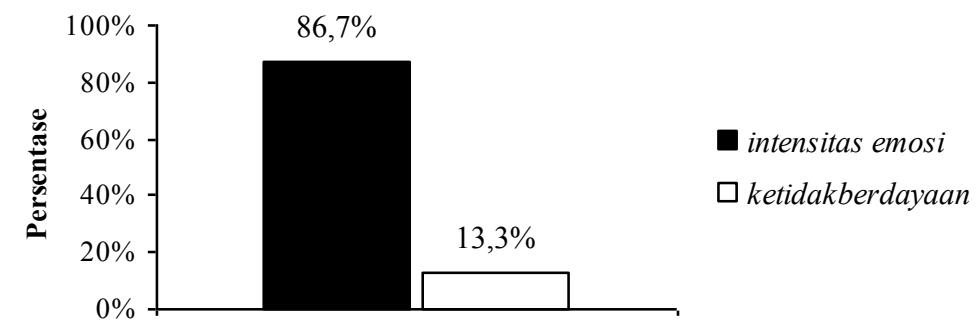

Bagan 7.5.8a

Distribusi Unsur Makna MK AMARAH ADALAH KEKUATAN ALAM

Tampilan grafis dari Bagan 7.5.8a dan juga tabulasi pada Tabel 7.5.8a dengan jelas menunjukkan bahwa terdapat perbedaan kekerapan di antara kedua unsur makna tersebut dari yang diharapkan dan perbedaan ini sangat signifikan $(P$ binomial $=5.21 \mathrm{E}-09)$. Perbedaan ini ialah dominasi yang sangat signifikan dari 
pola metaforis berunsur 'intensitas' yang mencerminkan RS KEKUATAN ALAM daripada yang diharapkan dibandingkan dengan unsur 'ketidakberdayaan' yang dinyatakan oleh Kövecses (2000:42) sebagai fokus utama RS ini.

Temuan ini lebih jauh mengindikasikan bahwa meskipun metafora AMARAH ADALAH KEKUATAN ALAM juga ditemukan dalam BI, unsur makna yang menjadi sorotan utama metafora tersebut dalam bahasa yang berbeda bisa jadi tidak sama dengan yang dinyatakan secara teoretis jika dilihat dari bukti realisasi linguistik aktual metafora tersebut. Pertanyaan mengenai variabel apa yang berkorelasi terhadap perbedaan penekanan ini bukan cakupan disertasi ini.

Pengamatan lebih jauh dari pola metaforis RS KEKUATAN ALAM yang mengacu pada unsur 'intensitas' juga menunjukkan adanya pengikutan metaforis yang lebih rinci yang dipetakan ke RT AMARAH. Pengikutan metaforis untuk RS KEKUATAN ALAM belum pernah diajukan, dibahas, dan ditemukan sebelumnya dalam literatur-literatur terkait, utamanya dalam karya Kövecses $(2000,2002$, \& 2005). Jadi, pengikutan yang diajukan kali ini didasari dan dibangun atas data penggunaan pola metaforis yang mencerminkannya.

Terlihat jelas dalam tabel 7.5.8b bahwa terdapat perbedaan kekerapan di antara kedua pengikutan metaforis RS KEKUATAN ALAM di atas: pengikutan DAYA KEKUATAN ALAM BERKURANG dicontohkan sebanyak 39 kali, lebih sering daripada yang diharapkan dibandingkan dengan pengikutan KEKUATAN ALAM DENGAN DAYA AKIBAT TERTINGGI yang hanya dicontohkan 13 kali ketika diharapkan muncul 26 kali. Ketimpangan kekerapan ini sangat signifikan ( $P$ binomial $=0.0004)$. 
Tabel 7.5.8b

PM dan Pengikutan Metaforis Unsur Makna 'intensitas' dari MK AMARAH ADALAH KEKUATAN ALAM

Pengikutan Metaforis Unsur Makna ‘intensitas’ dari RS KEKUATAN ALAM

\begin{tabular}{lccc}
\hline Pola Metaforis & $\begin{array}{c}\text { daya kekuatan alam } \\
\text { berkurang, intensitas } \\
\text { emosi berkurang }\end{array}$ & $\begin{array}{c}\text { kekuatan alam dengan } \\
\text { daya akibat tertinggi, } \\
\text { intensitas tertinggi } \\
\text { emosi }\end{array}$ & Total \\
$\begin{array}{l}\text { angin/badai/guntur/taufan/ } \\
\text { topan/gemuruh/gelomban } \\
\text { g/banjir NP_emo }\end{array}$ & 13 & 13 \\
$\begin{array}{l}\text { NP_emo } \\
\text { diredakan/(me)reda/menja } \\
\text { di reda/surut }\end{array}$ & 25 & 25 \\
reda(nya) NP_emo & 2 & & \\
X meredakan NP_emo & 12 & $13(26)$ & 2 \\
Total & $39(26)$ & 52 \\
\hline
\end{tabular}

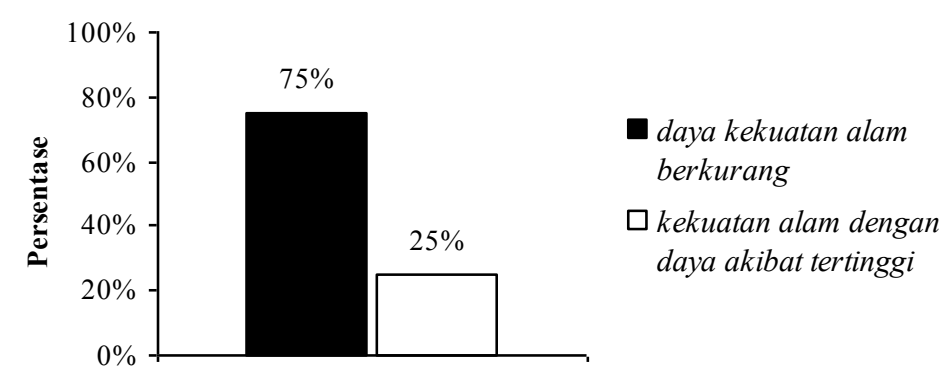

Bagan 7.5.8b

Distribusi Pengikutan Metaforis Unsur Makna 'kekerapan' dari MK AMARAH ADALAH KEKUATAN ALAM 


\subsection{Sorot Makna Utama dan Pemetaan Utama Metafora KETAKUTAN}

Hanya dua metafora yang memenuhi tingkat signifikansi terkoreksi dan yang signifikan tertarik kepada RT KETAKUTAN. Sorotan makna kedua metafora spesifik tersebut akan dibahas pada dua anak subbab berikut ini.

\subsubsection{Metafora KETAKUTAN ADALAH MELAKUKAN SESUATU DISERTAI OBJEK PENYERTA}

Keberadaan RS OBJEK PENYERTA bagi konseptualisasi RT KETAKUTAN secara umum mencerminkan MSP, khususnya metafora model OBJEK (Lakoff, 2006:204; Lakoff \& Johnson, 2003:135; Stefanowitsch, 2006a; Ogarkova, 2007:120). RS OBJEK PENYERTA ini dapat ditafsirkan sebagai RS yang mengindikasikan keadaan seseorang yang sedang emosional, dalam hal ini takut. Hal ini bisa dimotivasi oleh pengetahuan bahwa ketika seseorang melakukan sesuatu disertai oleh suatu objek, objek tersebut menjadi dekat dengan orang yang dimaksud dan potensial dapat memengaruhi orang yang melakukan tindakan yang dimaksud.

Terdapat 29 pola metaforis yang mencerminkan RS OBJEK PENYERTA. Secara struktural, RS ini direalisasikan sebagai adverbial preposisional bagi inti verba kalimatnya. Leksikal RT ketakutan mengelaborasi slot objek preposisinya seperti pada sitiran Sementara di belakang panggung dua orang membawa keranjang (upeti) lewat begitu saja dengan rasa ketakutan. Pada taraf yang lebih umum, unsur makna RS yang dipetakan ke RT KETAKUTAN dapat dibelah dua: pola yang mengacu pada 'adanya objek penyerta', yang dapat diartikan 'subjek 
emosi/takut' dan 'ketiadaan objek penyerta' yang dapat diartikan 'subjek tidak emosi/takut. Dalam hal tipe polanya, unsur makna RS OBJEK PENYERTA tersebut hanya dicirikan oleh dua tipe pola metaforis dengan kekerapan seperti ditunjukkan pada Tabel 7.6.1 berikut.

Tabel 7.6.1

PM untuk MK KETAKUTAN ADALAH MELAKUKAN SESUATU DISERTAI OBJEK PENYERTA

\begin{tabular}{lccc}
\hline \multicolumn{3}{c}{ Unsur Ranah Target } \\
\hline Pola Metaforis & Subjek takut & Subjek tidak takut & Total \\
X FV dengan NP_emo & 27 & & 27 \\
X FV tanpa NP_emo & & 2 & 2 \\
Total & $27(14.5)$ & $2(14.5)$ & 29 \\
\hline
\end{tabular}

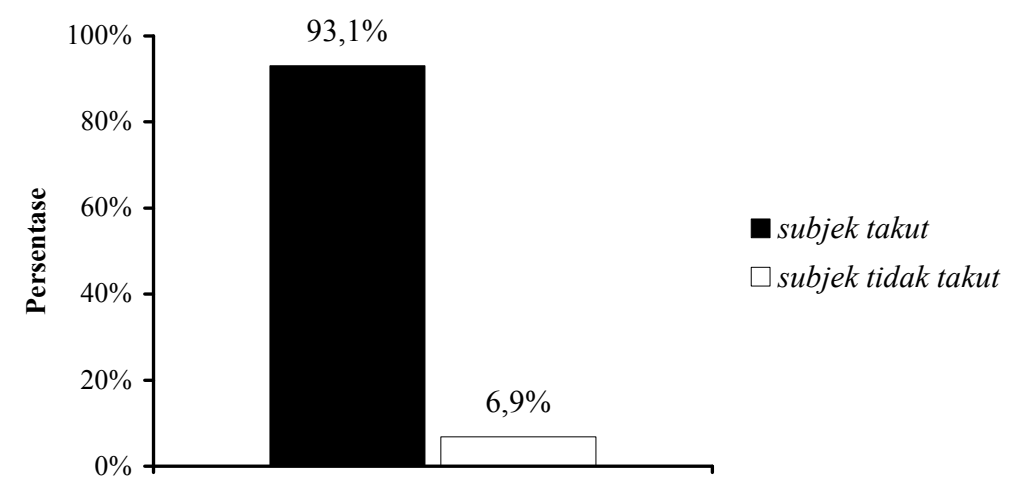

Bagan 7.6.1

Distribusi Unsur Makna MK KETAKUTAN ADALAH MELAKUKAN SESUATU DISERTAI OBJEK PENYERTA

Unsur 'subjek takut' mendapat lebih banyak sorotan dibandingkan dengan unsur 'subjek tidak takut', yaitu 93.1\%. Peluang untuk memperoleh hasil aktual pada sampel data ini atas dasar benarnya asumsi terhadap keseimbangan kekerapan di 
antara kedua unsur makna tersebut $(\mathrm{A} 0)$ sangat kecil $(P$ binomial $=1.62 \mathrm{E}-06)$. Hasil ini menguatkan kecenderungan unsur 'subjek takut' sebagai SMU dari RS OBJEK PENYERTA yang dipetakan melalui pemetaan sentral "adanya objek penyerta ketika subjek bertindak $\rightarrow$ adanya perasaan takut ketika subjek bertindak".

\subsubsection{Metafora KETAKUTAN ADALAH MUSUH/LAWAN}

Suatu emosi dapat bersifat kuat dan intens sehingga pada tingkat tertentu dipandang dapat mengambil kendali atas diri seseorang. RS metaforis MUSUH/LAWAN mengindikasikan adanya dua pelibat di dalamnya. Mereka adalah emosi sebagai musuh dan diri. Pergumulan, pertarungan, dan perjuangan terjadi di antara emosi dan diri. Pertarungan keduanya mencirikan usaha terhadap kendali atau kontrol emosional (Kövecses, 2000:69, 2002:86). Tabel 7.6.2a berikut mendaftar pola metaforis bagi RS MUSUH/LAWAN yang ditemukan dalam sampel beserta unsur makna yang diungkapkannya.

Seperti dapat dilihat pada Tabel 7.6.2a, kekerapan munculnya ketiga cerminan unsur makna tersebut memiliki perbedaan dari kekerapan yang diharapkan. RS MUSUH/LAWAN didominasi oleh pola yang mengacu pada unsur 'pergumulan diri dan emosi' (87.2\%), muncul lebih sering daripada yang diharapkan dibandingkan dengan dua unsur makna tersisa yang kekerapannya berada di bawah batas kekerapan harapan. Tes Multinomial terhadap distribusi tersebut menunjukkan bahwa ada perbedaan signifikan di antara ketiga unsur makna RS MUSUH/LAWAN tersebut $(P$ multinomial $=8.08 \mathrm{E}-15)$, yaitu memberikan bukti awal bahwa unsur 'pergumulan diri dan emosi' lebih banyak disoroti. 
Tabel 7.6.2a

\section{PM untuk MK KETAKUTAN ADALAH MUSUH/LAWAN}

\section{Unsur Ranah Target}

\begin{tabular}{|c|c|c|c|c|}
\hline Pola Metaforis & emosi & $\begin{array}{l}\text { pergumulan } \\
\text { diri dan emosi }\end{array}$ & $\begin{array}{l}\text { potensi bahaya } \\
\text { dari emosi }\end{array}$ & Total \\
\hline ancaman NP_emo & & 1 & & 1 \\
\hline Musuh berupa NP_emo & 1 & & & 1 \\
\hline NP_emo bersembunyi di balik $X$ & & & 1 & 1 \\
\hline NP_emo bertentangan dengan $\mathrm{X}$ & 1 & & & 1 \\
\hline NP_emo mencekam & & 2 & & 2 \\
\hline $\begin{array}{l}\text { NP_emo menyerang/menahan/menguasai/ } \\
\text { meremas-remas/menindas X }\end{array}$ & & 5 & & 5 \\
\hline NP_emo merejang & & 1 & & 1 \\
\hline NP_emo sehebat X & & & 1 & 1 \\
\hline perlawanan/kemenangan atas NP_emo & & 2 & & 2 \\
\hline X bertempur menaklukkan NP_emo & & 1 & & 1 \\
\hline X diburu NP_emo & & 1 & & 1 \\
\hline X dicekam (oleh) NP_emo & & 14 & & 14 \\
\hline X dicekik NP_emo & & 1 & & 1 \\
\hline $\mathrm{X}$ didera NP_emo & & 2 & & 2 \\
\hline $\mathrm{X}$ diremas NP_emo & & 1 & & 1 \\
\hline $\mathrm{X}$ disergap NP_emo & & 1 & & 1 \\
\hline X disiksa oleh NP_emo & & 1 & & 1 \\
\hline X gelisah oleh NP_emo & & & 1 & 1 \\
\hline X melumpuhkan NP_emo & & 1 & & 1 \\
\hline $\mathrm{X}$ menang atas NP_emo & & 1 & & 1 \\
\hline X menguasai diri dari NP_emo & & 1 & & 1 \\
\hline X menolong/melindungi Y dari NP_emo & & 2 & & 2 \\
\hline X meremehkan NP_emo & 1 & & & 1 \\
\hline $\mathrm{X}$ tercekam NP_emo & & 2 & & 2 \\
\hline $\mathrm{X}$ terlindung dari NP_emo & & 1 & & 1 \\
\hline Total & $3(15.7)$ & $41(15.7)$ & $3(15.7)$ & 47 \\
\hline
\end{tabular}




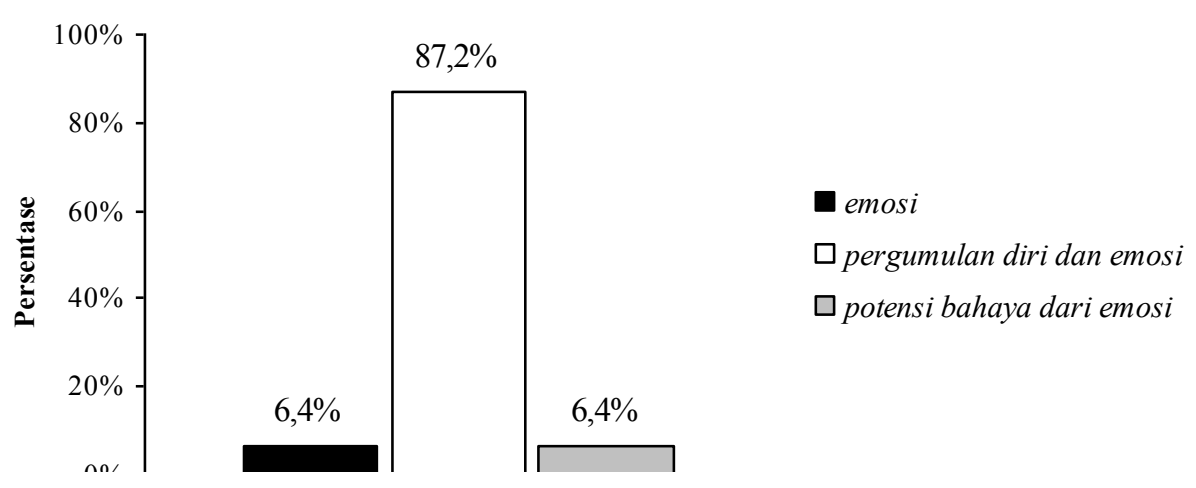

Bagan 7.6.2a

\section{Distribusi Unsur Makna MK KETAKUTAN ADALAH MUSUH/LAWAN}

Di dalam unsur 'pergumulan diri dan emosi' itu sendiri, terdapat sejumlah pengikutan yang dibawa oleh pelibat. Pertama ialah USAHA DIRI UNTUK TIDAK TAKLUK DARI EMOSI atau untuk mengendalikan diri. Kedua, USAHA EMOSI UNTUK MENGEMOSIONALKAN DIRI (Kövecses, 2000:69). Ikutan yang dapat muncul berikutnya ialah hasil akhir dari pergumulan: kemenangan lawan atau diri. Kemenangan lawan berarti EMOSI MEMEGANG KENDALI atau diri kehilangan kendali terhadap emosi. Kemenangan diri berarti DIRI BERHASIL MEMPERTAHANKAN KENDALI TERHADAP EMOSI (Kövecses, 2000:69).

Keempat pengikutan metaforis dari SMU 'pergumulan diri dan emosi' tadi juga ditemukan dipetakan secara rinci ke RT KETAKUTAN. Adanya pengikutan ini secara teoretis memberi dukungan tambahan bagi dan mencirikan keutamaan unsur makna 'pergumulan diri dan emosi' bagi RS MUSUH/LAWAN. Tabel 7.6.2b berikut menunjukkan realisasi semua pengikutan yang telah dibahas sebelumnya dalam konteks pola metaforisnya. 
Tabel 7.6.2b

\section{PM dan Pengikutan Metaforis Unsur Makna 'pergumulan diri dan emosi' dari MK KETAKUTAN ADALAH MUSUH/LAWAN}

\begin{tabular}{|c|c|c|c|c|c|}
\hline \multirow[b]{2}{*}{ Pola Metaforis } & \multicolumn{5}{|c|}{$\begin{array}{c}\text { Pengikutan Metaforis Unsur Makna 'pergumulan diri dan } \\
\text { emosi' dari RS MUSUH/LAWAN }\end{array}$} \\
\hline & $\begin{array}{c}\text { usaha } \\
\text { mengemosion } \\
\text { alkan subjek }\end{array}$ & $\begin{array}{l}\text { emosi } \\
\text { menang }\end{array}$ & $\begin{array}{l}\text { usaha tidak } \\
\text { takluk } \\
\text { terhadap } \\
\text { emosi }\end{array}$ & $\begin{array}{c}\text { berhasil } \\
\text { mengendali } \\
\text { kan emosi }\end{array}$ & Total \\
\hline ancaman NP_emo & 1 & & & & 1 \\
\hline kemenangan atas NP_emo & & & & 1 & 1 \\
\hline $\begin{array}{l}\text { NP_emo menahan/ } \\
\text { menguasai/meremas- } \\
\text { remas/menindas X }\end{array}$ & & 4 & & & 4 \\
\hline NP_emo mencekam & 2 & & & & 2 \\
\hline NP_emo menyerang $X$ & 1 & & & & 1 \\
\hline NP_emo merejang & 1 & & & & 1 \\
\hline perlawanan atas NP_emo & & & 1 & & 1 \\
\hline $\begin{array}{l}\text { X bertempur menaklukkan } \\
\text { NP_emo }\end{array}$ & & & & 1 & 1 \\
\hline X diburu NP_emo & 1 & & & & 1 \\
\hline X dicekam (oleh) NP_emo & & 14 & & & 14 \\
\hline X dicekik NP_emo & & 1 & & & 1 \\
\hline $\mathrm{X}$ didera NP_emo & & 2 & & & 2 \\
\hline $\mathrm{X}$ diremas NP_emo & & 1 & & & 1 \\
\hline $\mathrm{X}$ disergap NP_emo & & 1 & & & 1 \\
\hline $\mathrm{X}$ disiksa oleh NP_emo & & 1 & & & 1 \\
\hline X melumpuhkan NP_emo & & & & 1 & 1 \\
\hline $\mathrm{X}$ menang atas NP_emo & & & & 1 & 1 \\
\hline $\begin{array}{l}\text { X menguasai diri dari } \\
\text { NP_emo }\end{array}$ & & & & 1 & 1 \\
\hline $\begin{array}{l}\mathrm{X} \text { menolong/melindungi } \mathrm{Y} \\
\text { dari NP_emo }\end{array}$ & & & 2 & & 2 \\
\hline X tercekam NP_emo & & 2 & & & 2 \\
\hline $\mathrm{X}$ terlindung dari NP_emo & & & & 1 & 1 \\
\hline Total & $6(10.25)$ & $26(10.25)$ & $3(10.25)$ & $6(10.25)$ & 41 \\
\hline
\end{tabular}


Menarik untuk melihat pengikutan RS MUSUH/LAWAN mana yang signifikan lebih terpatri ketika berbicara tentang usaha diri dalam mengendalikan rasa takutnya dalam $\mathrm{BI}$.

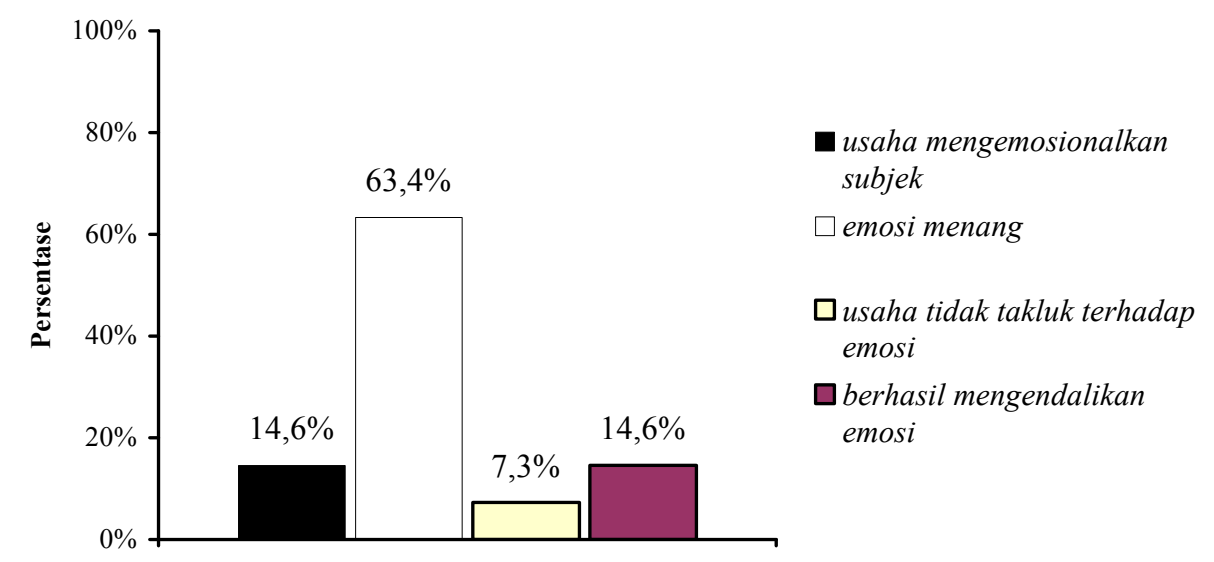

Bagan 7.6.2b

\section{Distribusi Pengikutan Metaforis Unsur Makna 'pergumulan diri dan emosi' dari MK KETAKUTAN ADALAH MUSUH/LAWAN}

Terdapat perbedaan kekerapan yang sangat signifikan terhadap kekerapan yang diharapkan di antara keempat pengikutan metaforis sorotan makna 'pergumulan diri dan emosi' tersebut $(P$ multinomial $=5.51 \mathrm{E}-09)$. Efek perbedaan yang jelas terlihat adalah pengikutan metaforis 'emosi menang' lebih sering diungkapkan sebagai hasil akhir dari 'pergumulan diri dan emosi' bagi RT KETAKUTAN. Hasil pengamatan pada sampel ini setidaknya memberikan gambaran bahwa rasa takut yang pada akhirnya berkecenderungan berhasil menguasai diri seseorang. 


\subsection{Sorot Makna Utama dan Pemetaan Utama Metafora KEBAHAGIAAN}

Terdapat sembilan RS metaforis yang signifikan khas bagi RT KEBAHAGIAAN BI. Subbab ini memaparkan hasil analisis terhadap SMU dan PU bagi kesembilan RS metaforis tersebut.

\subsubsection{Metafora KEBAHAGIAAN ADALAH (SECARA POTENSIAL) MEMBERIKAN SUATU OBJEK}

Pada tingkat yang lebih skematis, RS MEMBERIKAN atau MENTRANSFER SUATU OBJEK dipetakan untuk memahami RT HAL MENYEBABKAN (CAUSATION) lewat metafora "HAL MENYEBABKAN (CAUSATION) ADALAH MEMBERIKAN (SUATU OBJEK)" (Kovecses, 2002:102; Lakoff, 2006:210). Salah satu contohnya ialah kalimat "She gave him a book" pada RS dan "She gave him a headache" pada RT (Kovecses, 2002:102).

RS (SECARA POTENSIAL) MEMBERIKAN SUATU OBJEK merupakan salah satu metafora khas yang berupa model TRANSFER yang juga ditemukan signifikan berasosiasi dengan KEBAHAGIAAN BIng. oleh Stefanowitsch (2004a \& 2006a). RS ini dipandang dari sudut PEMBERI objek. Jika mengacu pada metafora generik HAL MENYEBABKAN (CAUSATION) ADALAH MEMBERIKAN (SUATU OBJEK), maka makna yang terutama disoroti oleh RS MEMBERIKAN SUATU OBJEK secara skematis ialah 'menyebabkan' penerima menerima/mengalami objek, yaitu objek 'keadaan bahagia'. Makna ini dilandasi oleh salah satu pemetaan bawahan MSP yaitu PENYEBAB ADALAH DAYA, yang dalam hal ini DAYA untuk memegang 
kendali atas pergerakan objek, yaitu memberi atau ditarik untuk diberi (Lakoff, 2006:211).

Tabel 7.7.1

\section{PM dan Pengikutan Metaforis Unsur Makna 'potensi menyebabkan' dari MK KEBAHAGIAAN ADALAH MEMBERIKAN SUATU OBJEK}

\begin{tabular}{|c|c|c|c|}
\hline \multirow[b]{2}{*}{ Pola Metaforis } & \multicolumn{3}{|c|}{$\begin{array}{l}\text { Pengikutan Metaforis Unsur Makna 'potensi } \\
\text { menyebabkan' dari RS MEMBERIKAN SUATU OBJEK }\end{array}$} \\
\hline & $\begin{array}{l}\text { Membahagiakan } \\
\text { seseorang }\end{array}$ & $\begin{array}{c}\text { kondisi kepuasan } \\
\text { mengisyaratkan agen } \\
\text { membahagiakan seseorang }\end{array}$ & Total \\
\hline hadiah/jatah kecil NP_emo & 2 & & 2 \\
\hline iming-iming/jaminan-jaminan NP_emo & & 2 & 2 \\
\hline $\begin{array}{l}\text { jaminan yang dibutuhkan untuk } \\
\text { NP_emo }\end{array}$ & & 1 & 1 \\
\hline NP_emo adalah memberi dan berbagi & 1 & & 1 \\
\hline NP_emo dari sedekah pemberian $X$ & 1 & & 1 \\
\hline NP_emo yang Xjanjikan & & 1 & 1 \\
\hline persembahkan NP_emo Y & 1 & & 1 \\
\hline sampaikan NP_emo pada Y & 1 & & 1 \\
\hline X berbagi NP_emo & 2 & & 2 \\
\hline $\mathrm{X}$ datang membawa NP_emo & 1 & & 1 \\
\hline $\mathrm{X}$ diberi (anugrah)/dikaruniai NP_emo & 3 & & 3 \\
\hline $\begin{array}{l}\text { X membagi(kan) NP_emo } \\
\text { (ke)pada/dengan/bersama Y }\end{array}$ & 5 & & 5 \\
\hline X membawa NP_emo buat/pada Y & 2 & & 2 \\
\hline X memberi Y NP_emo & 4 & & 4 \\
\hline X memberi(kan) NP_emo & 6 & & 6 \\
\hline $\begin{array}{l}\text { X memberikan NP_emo buat/(ke)pada } \\
\text { Y }\end{array}$ & 8 & & 8 \\
\hline $\begin{array}{l}\text { X mendatangkan/menghadirkan } \\
\text { NP_emo (bagi Y) }\end{array}$ & 4 & & 4 \\
\hline $\mathrm{X}$ menjamin NP_emo & & 3 & 3 \\
\hline X menjanjikan NP_emo (bagi/pada Y) & & 5 & 5 \\
\hline $\mathrm{X}$ menjanjikan Y NP_emo & & 1 & 1 \\
\hline Total & $41(27)$ & $13(27)$ & 54 \\
\hline
\end{tabular}


Dilihat dari 54 pola metaforis yang merealisasikan metafora KEBAHAGIAAN ADALAH (SECARA POTENSIAL) MEMBERIKAN SUATU OBJEK, unsur makna utama yang pada dasarnya diungkapkan ialah 'potensi untuk menyebabkan' penerima merasakan objek, yaitu kebahagiaan. Akan tetapi, dari unsur makna sentral tadi, terdapat dua pengikutan yang diungkapkan oleh pola metaforisnya. Pertama ialah adanya 'kondisi kepuasan' yang dari sudut pandang agen mengisyaratkan bahwa agen akan membahagiakan penerima (Stefanowitsch \& Gries, 2003:228) dan yang kedua ialah indikasi bahwa agen langsung 'membahagiakan seseorang', dalam arti tidak ada kondisi kepuasan.

Penetapan label bagi kedua pengikutan itu mengacu pada penelitian korpus yang dilakukan oleh Stefanowitsch \& Gries (2003:227) pada unsur semantis konstruksi dwitransitif yang skemanya sendiri, yaitu [Sagen V Openerima Otema], sudah memiliki makna 'X menyebabkan Y memiliki/menerima Z' seperti pada contoh "She gave him a book". Salah satu contoh perluasan makna dasarnya adalah pada kalimat "Chris promised Pat a Car". Kalimat tersebut berkaitan karena kondisi kepuasan yang dinyatakan oleh verba promise mengisyaratkan pemberian atau transfer (Stefanowitsch \& Gries, 2003:227).

Akan tetapi, penelitian ini tidak mengkaji unsur konstruksional metafora MEMBERIKAN SUATU OBJEK. Unsur makna konstruksi dwitransitif seperti yang dipaparkan sebelumnya digunakan sebagai acuan untuk mendukung analisis pengikutan metaforis RS MEMBERIKAN SUATU OBJEK yang secara tidak mengagetkan berkaitan dengan makna skematis konstruksi dwitransitif. 
Tampak bahwa terdapat kecenderungan kuat pengikutan 'membahagiakan seseorang' lebih sering dinyatakan oleh pola metaforis dari metafora KEBAHAGIAAN ADALAH (SECARA POTENSIAL) MEMBERIKAN SUATU OBJEK (75.9\%) dibandingkan dengan yang menyatakan 'kondisi kepuasan mengisyaratkan bahwa agen membahagiakan seseorang' (24.1\%).

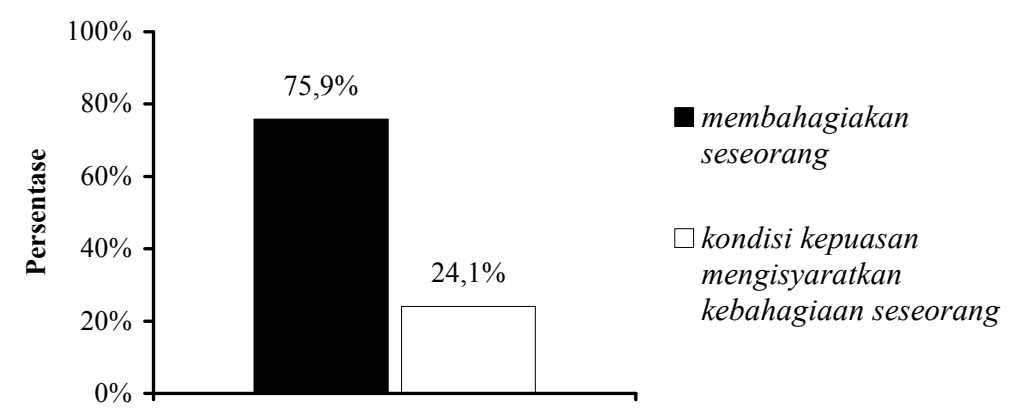

\section{Bagan 7.7.1}

Distribusi Pengikutan Metaforis Unsur Makna 'potensi menyebabkan' dari MK KEBAHAGIAAN ADALAH MEMBERIKAN SUATU OBJEK

Tes Binomial menunjukkan kecilnya peluang untuk mengamati hasil aktual ini jika asumsi terhadap kesetaraan distribusi kedua pengikutan itu benar $(P$ binomial $=0.0001751)$. Hasil ini dapat menyarankan penonjolan 'membahagiakan seseorang' sebagai pengikutan RS MEMBERIKAN SUATU OBJEK yang juga dapat mencirikan PU "memberikan objek kepada seseorang $\rightarrow$ membahagiakan seseorang”. 


\subsubsection{Metafora KEBAHAGIAAN ADALAH (SECARA POTENSIAL) MENERIMA SUATU OBJEK}

RS yang melengkapi RS MEMBERIKAN SUATU OBJEK ialah RS MENERIMA SUATU OBJEK, yang mengambil sudut pandang PENERIMA. Stefanowitsch memandang bahwa kedua RS tersebut dapat menjadi cermin bagaimana penutur memahami hubungan konsep MENJADI dan EMOSI itu sendiri (2004a:142). Khususnya, pada model SERAH-TERIMA yang memayungi RS MEMBERIKAN dan MENERIMA SUATU OBJEK, ketika seseorang merasakan kebahagiaan diibaratkan layaknya penerima emosi.

Interpretasi ini dilandasi dengan salah satu tipe MSP yang memandang RT KEADAAN sebagai OBJEK dan PERUBAHAN KEADAAN sebagai PERGERAKAN dari OBJEK yang dimaksud relatif terhadap PARTISIPAN-nya, dalam hal ini PERGERAKAN MENUJU PARTISIPAN yang artinya PARTISIPAN MEMPEROLEH OBJEK (Stefanowitsch, 2004a:143; Lakoff, 2006:210). Ide inilah yang secara koheren dijaring oleh RS MEMBERIKAN, MENERIMA, dan MEMILIKI SUATU OBJEK (lihat anak subbab 7.7.3 berikut) untuk memahami RT KEBAHAGIAAN.

Hanya terdapat 29 pola metaforis yang mencontohkan RS (SECARA POTENSIAL) MENERIMA SUATU OBJEK. Unsur makna yang diungkapkan seluruhnya ialah 'potensi perubahan keadaan' pada sisi penerima. Dari makna inti ini, terdapat tiga pengikutan yang muncul. Pengikutan ini mencirikan tiga hal: hasrat penerima untuk menjadi bahagia, kepatutan bagi penerima untuk menjadi bahagia dan penerima telah menjadi bahagia.

Data pada Tabel 7.7.2 menunjukkan bahwa terdapat perbedaan intensitas di antara ketiga pengikutan tersebut. Efek utamanya ialah pengikutan 'penerima 
menjadi bahagia' diungkapkan lebih sering secara sangat signifikan daripada yang diharapkan dibandingkan dengan dua pengikutan lainnya $\left(P_{\text {multinomial }}=8.32 \mathrm{E}-05\right)$.

Tabel 7.7.2

PM dan Pengikutan Metaforis Unsur Makna 'potensi perubahan keadaan'
dari MK KEBAHAGIAAN ADALAH MENERIMA SUATU OBJEK

Pengikutan Metaforis Unsur Makna 'potensi perubahan keadaan' dari RS MENERIMA SUATU OBJEK

\begin{tabular}{|c|c|c|c|c|}
\hline Pola Metaforis & $\begin{array}{c}\text { hasrat } \\
\text { penerima } \\
\text { untuk menjadi } \\
\text { bahagia }\end{array}$ & $\begin{array}{c}\text { kondisi kepatutan bagi } \\
\text { penerima menjadi } \\
\text { bahagia }\end{array}$ & $\begin{array}{l}\text { penerima } \\
\text { menjadi } \\
\text { bahagia }\end{array}$ & Total \\
\hline $\begin{array}{l}\text { X mendapat(kan) } \\
\text { NP_emo }\end{array}$ & & & 9 & 9 \\
\hline $\begin{array}{l}\text { X memperoleh } \\
\text { NP_emo }\end{array}$ & & & 3 & 3 \\
\hline $\begin{array}{l}\text { NP_emo X } \\
\text { dapat/terima }\end{array}$ & & & 2 & 2 \\
\hline NP_emo bagi $X$ & & & 1 & 1 \\
\hline $\begin{array}{l}\text { X menyambut } \\
\text { NP_emo }\end{array}$ & & & 1 & 1 \\
\hline $\begin{array}{l}\text { NP_emo yang } \mathrm{X} \\
\text { peroleh dari } \mathrm{Y}\end{array}$ & & & 1 & 1 \\
\hline X beroleh NP_emo & & & 1 & 1 \\
\hline $\begin{array}{l}\text { yang Xinginkan adalah } \\
\text { NP_emo }\end{array}$ & 1 & & & 1 \\
\hline $\begin{array}{l}\text { X menuntut/meminta } \\
\text { NP_emo }\end{array}$ & 2 & & & 2 \\
\hline $\begin{array}{l}\mathrm{X} \text { (meng)inginkan } \\
\text { NP_emo }\end{array}$ & 2 & & & 2 \\
\hline $\mathrm{X}$ butuh NP_emo & 2 & & & 2 \\
\hline $\mathrm{X}$ berhak atas NP_emo & & 1 & & 1 \\
\hline Tuntutan NP_emo & 1 & & & 1 \\
\hline $\begin{array}{l}\text { NP_emo yang patut } \\
\text { untuk X }\end{array}$ & & 1 & & 1 \\
\hline $\begin{array}{l}\text { X menagih janji } \\
\text { tentang NP_emo }\end{array}$ & & 1 & & 1 \\
\hline Total & $8(9.7)$ & $3(9.7)$ & $18(9.7)$ & 29 \\
\hline
\end{tabular}


Hasil ini bisa menunjukkan adanya kecenderungan untuk lebih menyoroti pengikutan 'penerima menjadi bahagia' dari sorot makna utama KEBAHAGIAAN ADALAH (SECARA POTENSIAL) MENERIMA SUATU OBJEK.

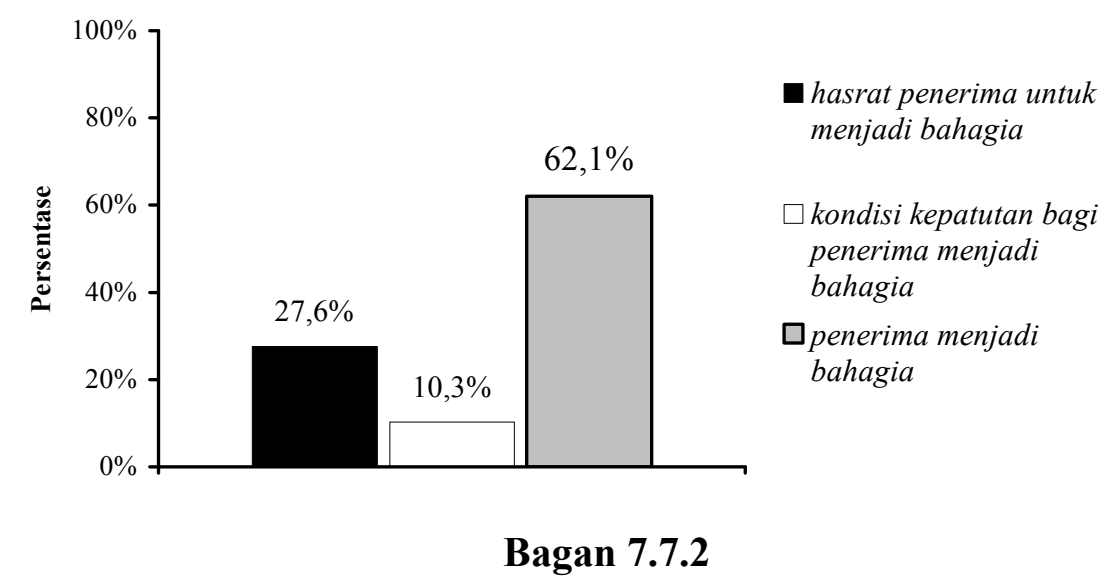

Distribusi Pengikutan Metaforis Unsur Makna 'potensi perubahan keadaan' dari MK KEBAHAGIAAN ADALAH MENERIMA SUATU OBJEK

\subsubsection{Metafora KEBAHAGIAAN ADALAH KEPEMILIKAN}

RS KEPEMILIKAN adalah mata rantai terakhir terkait kebertautannya dengan dua metafora sebelumnya dalam model SERAH-TERIMA bagi konseptualisasi RT KEBAHAGIAAN. Terdapat 103 sitiran metaforis yang mencerminkan metafora KEBAHAGIAAN ADALAH KEPEMILIKAN. Seluruh pola metaforis tersebut menuansakan 'keberadaan emosi' sebagai sorot makna utamanya (Kovecses, 2000:41). SMU ini, memunculkan dua pengikutan metaforis yang tercermin dari pola metaforisnya: KETIKA SESEORANG MEMILIKI SUATU OBJEK, DIA BAHAGIA, dan KETIKA SESEORANG KEHILANGAN SUATU OBJEK, DIA TIDAK BAHAGIA. 
Tabel 7.7.3

PM dan Pengikutan Metaforis Unsur Makna 'keberadaan emosi' dari MK KEBAHAGIAAN ADALAH KEPEMILIKAN

\begin{tabular}{|c|c|c|c|}
\hline \multirow[b]{2}{*}{ Pola Metaforis } & \multicolumn{3}{|c|}{$\begin{array}{c}\text { Pengikutan Metaforis Unsur Makna 'keberadaan } \\
\text { emosi' dari RS KEPEMILIKAN }\end{array}$} \\
\hline & bahagia & tidak bahagia & Total \\
\hline $\begin{array}{l}\mathrm{NP} \text { _emo daripada nomina } \\
\text { umum }\end{array}$ & 1 & & 1 \\
\hline NP_emo dikorbankan & & 1 & 1 \\
\hline NP_emo menjadi milikX & 1 & & 1 \\
\hline NP_emo pronomina_kita & 5 & & 5 \\
\hline NP_emo pronomina_mereka & 2 & & 2 \\
\hline $\begin{array}{l}\mathrm{NP} \text { emo terenggut (oleh } \\
\mathrm{X} \text { )/dirampok }\end{array}$ & & 3 & 3 \\
\hline NP_emo-ku & 13 & & 13 \\
\hline NP_emo-mu & 10 & & 10 \\
\hline NP_emo-nya & 3 & & 3 \\
\hline X kehilangan NP_emo & & 4 & 4 \\
\hline $\mathrm{X}$ memiliki/punya NP_emo & 4 & & 4 \\
\hline $\mathrm{X}$ mengorbankan NP_emo & & 1 & 1 \\
\hline $\begin{array}{l}\text { X merampas/merenggut } \\
\text { NP_emo }\end{array}$ & & 6 & 6 \\
\hline $\mathrm{X}$ meratapi NP_emo & & 1 & 1 \\
\hline $\begin{array}{l}\text { NP_emo pronomina_saya } \\
\text { (sendiri)/aku }\end{array}$ & 8 & & 8 \\
\hline $\begin{array}{l}\text { NP_emo pronomina_kamu } \\
\text { dan Shancai/kalian }\end{array}$ & 3 & & 3 \\
\hline $\begin{array}{l}\text { NP_emo nomina } \\
\text { khusus_nama diri }\end{array}$ & 11 & & 11 \\
\hline $\begin{array}{l}\text { NP_emo dari nomina } \\
\text { khusus_nama diri }\end{array}$ & 1 & & 1 \\
\hline NP_emo nomina umum & 25 & & 25 \\
\hline Total & $87(51,5)$ & $16(51,5)$ & 103 \\
\hline
\end{tabular}

Terdapat perbedaan yang sangat bermakna dari bukti kekerapan munculnya kedua pengikutan metaforis RS KEPEMILIKAN tersebut $\left(P_{\text {binomial }}=\right.$ 
5.39E-13). Pola yang mengacu pada unsur 'bahagia' pada diri direalisasikan lebih sering daripada yang diharapkan dibandingkan dengan unsur diri 'tidak bahagia'.

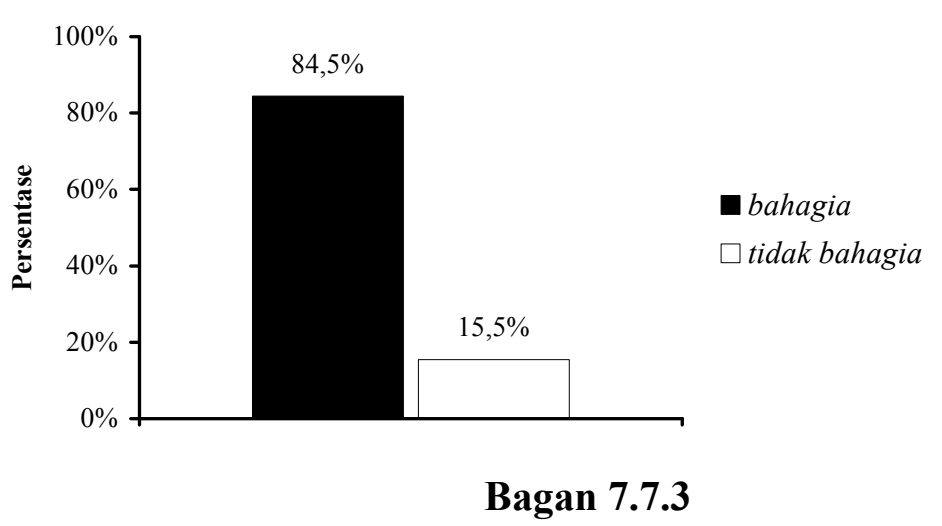

\section{Distribusi Pengikutan Metaforis Unsur Makna 'keberadaan emosi' dari MK KEBAHAGIAAN ADALAH KEPEMILIKAN}

Ketidakbahagiaan ini seringnya dicerminkan oleh pola yang mengacu pada 'kehilangan' objek, misalnya dirampok, dirampas, dan sejenisnya. Sedangkan, unsur 'bahagia' yang lebih menonjol dicerminkan secara dominan oleh konstruksi posesif nominal seperti kebahagiaanku/mu. Dapat disarankan bahwa pengikutan 'bahagia' lebih cenderung mendapat sorotan utama melalui pemetaan 'keadaan bahagia $\rightarrow$ memiliki suatu objek'.

\subsubsection{Metafora KEBAHAGIAAN ADALAH MENCARI/MEMBURU SUATU OBJEK}

Tiga metafora KEBAHAGIAAN sebelumnya dapat dipandang sebagai cerminan keterpilahan sistem LOKASI dari MSP yang dikembangkan ke sistem OBJEK (Lakoff, 2006:210-211) guna membentuk model SERAH-TERIMA metaforis. Keterpilahan pertama ialah KEADAAN ADALAH LOKASI dengan ATRIBUT ADALAH KEPEMILIKAN atas dasar kesamaan lokasi (co-location): diri berada di lokasi- 
keadaan dan diri memiliki objek-atribut (Lakoff, 2006:210). Keterpilahan kedua ialah PERUBAHAN ADALAH PERGERAKAN (DARI atau KE LOKASI) dengan PERUBAHAN ADALAH PERGERAKAN (OBJEK, yaitu MENDAPAT atau TIDAK). Keterpilahan ketiga ialah PENYEBAB ADALAH DAYA (yang MENGENDALIKAN PERGERAKAN KE atau DARI LOKASI) dengan PENYEBAB ADALAH DAYA (yang MENGENDALIKAN PERGERAKAN OBJEK, yaitu MEMBERI atau MENARIK OBJEK).

Sebaliknya, RS MENCARI/MEMBURU SUATU OBJEK dan RS yang akan dibahas pada anak subbab berikutnya, yaitu RS MENEMUKAN/MERAIH SUATU OBJEK mencirikan dualitas dan elaborasi dari salah satu pemetaan MSP, yaitu CITA-CITA ADALAH DESTINASI IDAMAN (DESIRED DESTINATIONS). Dengan mengganti DESTINASI dengan OBJEK, maka didapat metafora CITA-CITA ADALAH OBJEK IDAMAN (Lakoff, 2006:211). Jika dikaitkan dengan metafora KEBAHAGIAAN ADALAH MENCARI/MEMBURU SUATU OBJEK, dapat disarankan bahwa metafora ini merujuk pada unsur makna 'usaha/upaya' untuk tercapainya cita-cita OBJEK IDAMAN, yaitu KEBAHAGIAAN. Unsur makna ini sepenuhnya dicerminkan oleh ke-19 pola metaforisnya.

Terdapat juga pengetahuan tambahan dari sorot makna utama 'usaha/upaya' RS MENCARI/MEMBURU SUATU OBJEK yang dipetakan ke RT melalui pengikutan metaforisnya. Sejumlah pengetahuan tambahan yang masih berkaitan dengan unsur makna utama 'usaha/upaya' mencapai tujuan atau cita-cita yang tercermin dalam pola metaforisnya ialah (i) usaha PENCARIAN itu sendiri, (ii) SIKAP KEGIGIHAN yang ditunjukkan oleh diri demi mencapai tujuan idamannya, dan (iii) OBJEK YANG DIIDAMKAN/DICARI. 
Tabel 7.7.4

\section{PM dan Pengikutan Metaforis Unsur Makna 'usaha/upaya' dari MK KEBAHAGIAAN ADALAH MENCARI/MEMBURU SUATU OBJEK}

\begin{tabular}{|c|c|c|c|c|}
\hline \multirow[b]{2}{*}{ Pola Metaforis } & \multicolumn{4}{|c|}{$\begin{array}{c}\text { Pengikutan Metaforis Unsur Makna } \\
\text { 'usaha/upaya' dari RS MENCARI/MEMBURU } \\
\text { SUATU OBJEK }\end{array}$} \\
\hline & $\begin{array}{l}\text { objek yang } \\
\text { dicari }\end{array}$ & pencarian & $\begin{array}{c}\text { sikap } \\
\text { kegigihan }\end{array}$ & Tota \\
\hline NP_emo diperebutkan & & & 1 & 1 \\
\hline NP_emo menanti & 1 & & & 1 \\
\hline NP_emo menunggu $X$ & 1 & & & 1 \\
\hline NP_emo $\mathrm{X}$ songsong & & 1 & & 1 \\
\hline $\mathrm{X}$ berjuang mencari NP_emo & & & 1 & 1 \\
\hline $\mathrm{X}$ berkorban untuk NP_emo & & & 1 & 1 \\
\hline $\begin{array}{l}\text { X berusaha memperjuangkan } \\
\text { NP_emo }\end{array}$ & & & 1 & 1 \\
\hline $\mathrm{X}$ mencari NP_emo & & 8 & & 8 \\
\hline $\mathrm{X}$ mengejar NP_emo & & 1 & & 1 \\
\hline $\begin{array}{l}\text { X mengorbankan Y untuk } \\
\text { NP_emo }\end{array}$ & & & 1 & 1 \\
\hline X menjemput NP_emo & & 1 & & 1 \\
\hline $\mathrm{X}$ songsong NP_emo & & 1 & & 1 \\
\hline Total & $2(6.3)$ & $12(6.3)$ & $5(6.3)$ & 19 \\
\hline
\end{tabular}

Telah dilihat dari tabel bahwa realisasi dari pengikutan PENCARIAN muncul lebih sering secara berbeda dibandingkan dengan pengikutan lainnya $(P$ multinomial $=$ 0.0009104). Hasil ini tampaknya dapat menyarankan bahwa saat-saat pencarian untuk mencapai kebahagiaanlah yang lebih mendapat penekanan (bandingkan Stefanowitsch (2006a:97--98) untuk analisis BIng.). 


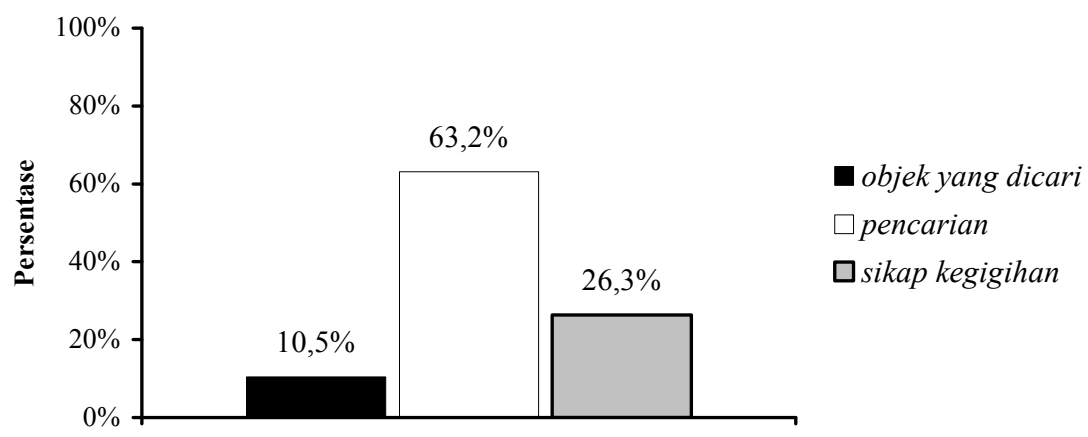

Bagan 7.7.4

Distribusi Pengikutan Metaforis Unsur Makna 'usaha/upaya' dari MK KEBAHAGIAAN ADALAH MENCARI/MEMBURU SUATU OBJEK

\subsubsection{Metafora KEBAHAGIAAN ADALAH MENEMUKAN/MERAIH SUATU}

\section{OBJEK}

Ketika usaha mencari atau mengejar cita-cita tercapai, maka RS MENEMUKAN/MERAIH SUATU OBJEK ini mengindikasikan saat pencapaian akhir yang aktual itu. Dengan kata lain, MENCAPAI CITA-CITA ADALAH MENEMUKAN/MERAIH OBJEK IDAMAN (Lakoff, 2006:211).

Tabel 7.7.5

PM untuk MK KEBAHAGIAAN ADALAH MENEMUKAN/MERAIH SUATU OBJEK

\begin{tabular}{lcc}
\hline & Unsur Ranah Target & \\
\hline Pola Metaforis & menjadi bahagia & Total \\
X (me)raih NP_emo & 7 & 7 \\
X menemu(i/kan) NP_emo & 20 & 20 \\
X nemuin NP_emo & 1 & 1 \\
X temukan NP_emo & 1 & 1 \\
Total & 29 & 29 \\
\hline
\end{tabular}


Jadi, atas dasar metafora MSP itu, pemetaan RS MENEMUKAN/MERAIH SUATU OBJEK ke RT KEBAHAGIAAN dapat ditafsirkan sebagai penyorotan unsur makna utama 'menjadi bahagia' yang secara metaforis dipahami dengan 'menemukan/meraih suatu objek', yaitu objek kebahagiaan (Stefanowitsch (2004a)).

\subsubsection{Metafora KEBAHAGIAAN ADALAH PERJALANAN}

RS PERJALANAN adalah kepingan terakhir yang melengkapi model metaforis PENCARIAN (QUEST model) (Stefanowitsch, 2004a, 2006a) bagi konseptualisasi KEBAHAGIAAN bersamaan dengan dua RS metaforis sebelumnya. RS PERJALANAN ini merupakan lingkup MSP (Lakoff, 2006:207:210). Jika mengacu pada MSP, maka KEBAHAGIAAN dapat dipandang sebagai salah satu KEJADIAN DALAM HIDUP (seperti halnya CINTA (Lakoff, 2006:208)).

Di dalam MSP, HIDUP BERTUJUAN (PURPOSEFUL LIFE) secara umum dikonseptualisasikan sebagai PERJALANAN (Lakoff, 2006:208). Pada umumnya, kehidupan seseorang pada dasarnya bertujuan untuk mencapai suatu cita-cita. Konseptualisasi ini dimodelkan dengan menggabungkan sejumlah metafora tipe MSP. Penggabungan sejumlah metafora MSP bagi konseptualisasi RT HIDUP BERTUJUAN di antaranya CITA-CITA ADALAH DESTINASI, TINDAKAN BERTUJUAN ADALAH PERGERAKAN DIRI KE SUATU LOKASI, dan karenanya "HIDUP BERTUJUAN ADALAH KEGIATAN BERTUJUAN JANGKA PANJANG, yaitu PERJALANAN” (Lakoff, 2006:208). 
Tabel 7.7.6

PM untuk MK KEBAHAGIAAN ADALAH PERJALANAN

\begin{tabular}{|c|c|c|c|c|c|}
\hline \multirow[b]{2}{*}{ Pola Metaforis } & \multicolumn{5}{|c|}{ Unsur Ranah Target } \\
\hline & $\begin{array}{c}\text { tidak } \\
\text { berbahagia }\end{array}$ & $\begin{array}{l}\text { menjadi } \\
\text { bahagia }\end{array}$ & $\begin{array}{l}\text { tindakan } \\
\text { untuk } \\
\text { menjadi } \\
\text { bahagia }\end{array}$ & $\begin{array}{l}\text { alat untuk } \\
\text { menjadi } \\
\text { bahagia }\end{array}$ & Total \\
\hline $\begin{array}{l}\mathrm{X} \text { menuntun } \mathrm{Y} \text { melalui } \mathrm{Z} \\
\text { ke arah } \mathrm{NP} \text { _emo }\end{array}$ & & & 1 & & 1 \\
\hline X menuju NP_emo & & & 1 & & 1 \\
\hline $\begin{array}{l}\text { X menemukan } \\
\text { taman/mencapai } \\
\text { NP_emo }\end{array}$ & & 6 & & & 6 \\
\hline $\begin{array}{l}\text { X memulai NP_emo di } \\
\text { tempat lain }\end{array}$ & & 1 & & & 1 \\
\hline $\begin{array}{l}\mathrm{X} \text { memimpin/menuntun } \\
\text { /membawa/mendekatkan } \\
\mathrm{Y} \text { ke arah/pada NP_emo }\end{array}$ & & & 4 & & 4 \\
\hline X lewatkan NP_emo & 1 & & & & 1 \\
\hline $\begin{array}{l}\text { X berada di pintu } \\
\text { gerbang NP_emo }\end{array}$ & & 1 & & & 1 \\
\hline $\begin{array}{l}\text { titik awal untuk menuju } \\
\text { NP_emo }\end{array}$ & & & 1 & & 1 \\
\hline $\begin{array}{l}\text { Seberapa jarak NP_emo } \\
\text { X jelang }\end{array}$ & & & 1 & & 1 \\
\hline NP_emo tercapai & & 1 & & & 1 \\
\hline kunci NP_emo & & & & 1 & 1 \\
\hline Total & $1(4.8)$ & $9(4.8)$ & $8(4.8)$ & $1(4.8)$ & 19 \\
\hline
\end{tabular}

Penggabungan struktur metaforis di atas dapat diwariskan kepada kasus khusus seperti metafora KEBAHAGIAAN ADALAH PERJALANAN kali ini. Jadi, unsur pemetaan metaforisnya adalah sebagai berikut:

Ranah Sumber

a. Tujuan akhir/destinasi

b. Pergerakan menuju tujuan $\rightarrow$ Tindakan/tahapan untuk menjadi
Ranah Target

$\rightarrow$ Keadaan bahagia 

akhir/perjalanan
bahagia
c. Mencapai tujuan akhir
$\rightarrow$ Berbahagia

Pengetahuan tersebutlah yang menjadi kerangka pemetaan metaforis konsep PERJALANAN ke RT KEBAHAGIAAN.

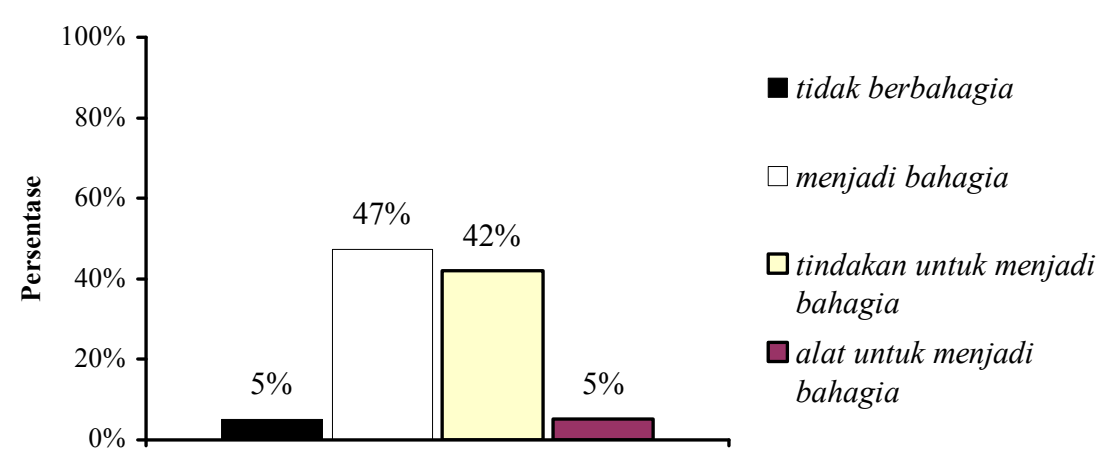

Bagan 7.7.5

\section{Distribusi Unsur Makna MK KEBAHAgIAAN ADALAH PERJALANAN}

Terlihat bahwa terdapat ketimpangan penekanan di antara keempat unsur makna tersebut. Hal ini tercermin dari kekerapan munculnya. Perbedaan itu ialah pola yang merefleksikan saat-saat diri telah mencapai tujuan akhir, atau 'menjadi bahagia' dan pergerakan diri ke arah tujuan akhir, atau 'tindakan untuk menjadi bahagia' muncul lebih sering secara sangat signifikan daripada yang diharapkan dibandingkan dengan dua unsur lainnya $(P$ multinomial $=3.02 \mathrm{E}-5)$.

Hasil ini dapat memberikan bukti awal bahwa unsur RS 'pergerakan diri ke arah tujuan akhir' dan 'diri mencapai tujuan akhir' menjadi penekanan semantis sekaligus unsur PU yang dipetakan ke RT KEBAHAGIAAN. Kedua SMU dari RS PERJALANAN tersebut dapat menyarankan bahwa yang mendapat lebih banyak penekanan atas dasar sampel data BI pada tataran yang lebih skematis 
adalah unsur 'tahapan' (seperti awal mula pergerakan, pergerakan itu sendiri, alur yang dilalui, sampai pada akhirnya tiba di tujuan akhir) untuk mencapai kebahagiaan (bandingkan Stefanowitsch (2004a)).

\subsubsection{Metafora KEBAHAGIAAN ADALAH SANTAPAN}

Yang termasuk SANTAPAN pada kasus ini atas dasar bukti pola metaforisnya ialah MAKANAN dan MINUMAN.

Tabel 7.7.7

PM untuk MK KEBAHAGIAAN ADALAH SANTAPAN

\begin{tabular}{|c|c|c|c|c|c|}
\hline \multirow[b]{2}{*}{ Pola Metaforis } & \multicolumn{5}{|c|}{ Unsur Ranah Target } \\
\hline & $\begin{array}{c}\text { hasrat } \\
\text { untuk } \\
\text { menjadi } \\
\text { bahagia }\end{array}$ & $\begin{array}{l}\text { menciptakan } \\
\text { kebahagiaan }\end{array}$ & $\begin{array}{l}\text { merasakan } \\
\text { kebahagiaan }\end{array}$ & $\begin{array}{c}\text { efek dari } \\
\text { kebahagiaan }\end{array}$ & Total \\
\hline Jamu ibarat NP emo & & & & 1 & 1 \\
\hline $\begin{array}{l}\text { NP_emo menghilangkan rasa } \\
\text { haus }\end{array}$ & & & & 1 & 1 \\
\hline NP_emo X reguk & & & 1 & & 1 \\
\hline $\begin{array}{l}\mathrm{NP} \text { _emo yang segar seperti } \\
\text { apel }\end{array}$ & & & & 1 & 1 \\
\hline $\mathrm{X}$ haus pada NP_emo & 1 & & & & 1 \\
\hline $\begin{array}{l}\mathrm{X} \text { mengecap/mengenyam/ } \\
\text { mereguk NP emo }\end{array}$ & & & 3 & & 3 \\
\hline X mengolah NP_emo & & 1 & & & 1 \\
\hline $\begin{array}{l}\text { X menikmati mangkuk } \\
\text { NP_emo sampai tetes yang } \\
\text { terakhir }\end{array}$ & & & 1 & & 1 \\
\hline X menikmati NP_emo & & & 14 & & 14 \\
\hline $\begin{array}{l}\mathrm{X} \text { merasa puas mereguk } \\
\mathrm{NP} \text { _emo }\end{array}$ & & & & 1 & 1 \\
\hline Total & $1(6.2)$ & $1(6.2)$ & $19(6.2)$ & $4(6.2)$ & 25 \\
\hline
\end{tabular}


Terdapat 25 pola metaforis yang mencerminkan metafora KEBAHAGIAAN ADALAH SANTAPAN. Kövecses (2002:82) mengungkapkan bahwa metafora dengan RS SANTAPAN (NUTRIENT) menekankan unsur 'hasrat' terhadap dan 'efek/konsekuensi' dari emosi. Dihadapkan pada data yang ditemukan bagi RT KEBAHAGIAAN, unsur semantik yang tercermin oleh pola metaforisnya terlihat seperti pada tabel 7.7.7.

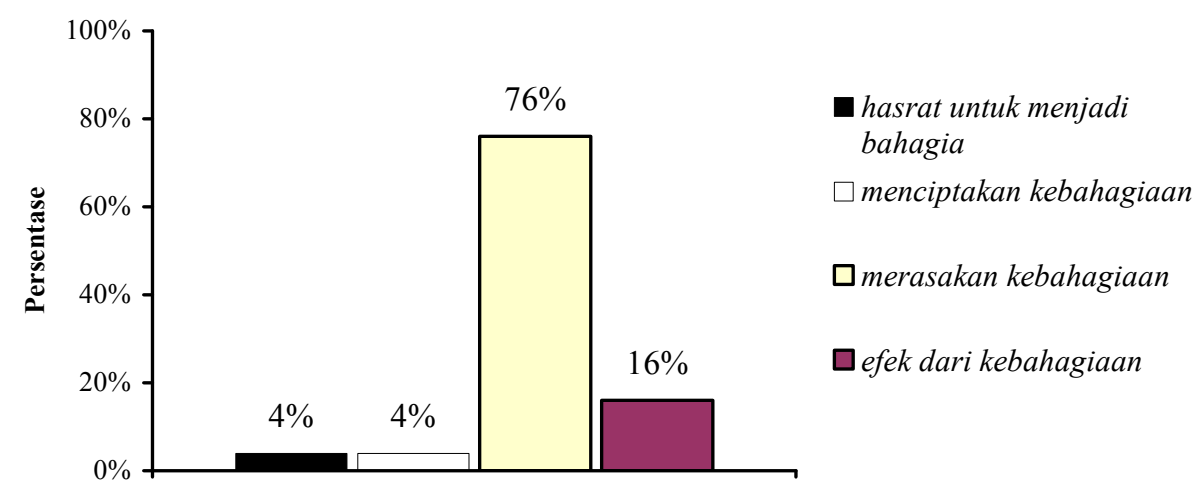

Bagan 7.7.6

\section{Distribusi Unsur Makna MK KEBAHAGIAAN ADALAH SANTAPAN}

Dilihat dari keempat unsur makna yang dirujuk oleh pola metaforisnya, unsur 'merasakan kebahagiaan' pada RT secara signifikan paling disoroti $(P$ multinomial $=4.72 \mathrm{E}-09)$ meskipun unsur 'hasrat' dan 'efek' juga diacu. Unsur RS SANTAPAN yang berkorespondensi dengan unsur makna 'merasakan kebahagiaan' dalam pemetaannya adalah unsur 'pengasupan secara fisik'.

Unsur makna yang tercermin pada Tabel 7.7.7 di atas merupakan elemen pemetaan dari metafora KEBAHAGIAAN ADALAH SANTAPAN. Pemetaan untuk RS SANTAPAN telah ditampilkan oleh Kövecses (2002:83) dalam contohnya dengan RT CINTA. Pemetaan itu yang dijadikan landasan untuk diadaptasi dan 
disesuaikan berdasarkan data yang diperoleh. Hanya satu elemen pemetaan yang berbeda dari pemetaan yang diajukan oleh Kövecses (2002:83), yaitu 'menciptakan kebahagiaan'. Berikut ini ialah pemetaan metafora KEBAHAGIAAN ADALAH SANTAPAN (bandingkan Kövecses (2002:83).
Ranah Sumber
Ranah Target
a. Rasa lapar/haus
$\rightarrow$ Hasrat terhadap kebahagiaan
b. Mengolah santapan
$\rightarrow$ Menciptakan kebahagiaan
c. Pengasupan secara fisik
$\rightarrow$ Merasakan kebahagiaan
d. Efek dari asupan
$\rightarrow$ Efek dari kebahagiaan

Data menunjukkan bahwa pemetaan (c) mencirikan PU dari metafora KEBAHAGIAAN ADALAH SANTAPAN yang memetakan SMU 'merasakan kebahagiaan'.

\subsubsection{Metafora KEBAHAGIAAN ADALAH OBJEK RAPUH/PECAH BELAH}

RS OBJEK RAPUH/PECAH BELAH tidak pernah dibicarakan dalam kaitannya dengan pembahasan metafora EMOSI kecuali oleh Stefanowitsch (2006a:101). Melalui analisis data korpus BIng., Stefanowitsch (2006a:101) juga menemukan bahwa RS ini signifikan diasosiasikan dengan RT KEBAHAGIAAN.

RS OBJEK RAPUH untuk RT KEBAHAGIAAN dapat menunjukkan hubungan dengan model metafora SERAH-TERIMA dan PENCARIAN sebelumnya. Kebahagiaan adalah suatu keadaan yang pastinya selalu ingin dirasakan, dicapai, atau diraih oleh setiap orang. Tepat ketika mereka telah mendapatkan atau merasakannya, mereka berusaha untuk selalu menjaga keadaan bahagia tersebut 
dari situasi ketidakbahagiaan (Stefanowitsch, 2006a:101). Situasi inilah yang menunjukkan kerentanan keadaan bahagia itu yang sewaktu-waktu dapat berakhir.

Hanya sepuluh pola metaforis yang mencerminkan KEBAHAGIAAN ADALAH OBJEK RAPUH/PECAH BELAH. Sorot makna yang paling utama diacu oleh pola metaforis RS OBJEK RAPUH/PECAH BELAH adalah kualitas 'ketahanan objek' atau 'ketahanan keadaan bahagia'. Keterpusatan unsur makna tersebut ditunjukkan juga dari pengikutan metaforisnya: KETAHANAN SESAAT OBJEK MENANDAKAN KETIDAKKEKALANNYA KEBAHAGIAAN, dan HANCUR/ RUSAKNYA OBJEK MENANDAKAN BERAKHIRNYA/TIDAK BERTAHANNYA KEBAHAGIAAN. Perhatikan Tabel 7.7.8 berikut ini.

Tabel 7.7.8

PM dan Pengikutan Metaforis Unsur Makna 'ketahanan keadaan bahagia' dari MK KEBAHAGIAAN ADALAH OBJEK RAPUH/PECAH BELAH

\begin{tabular}{|c|c|c|c|}
\hline \multirow[b]{2}{*}{ Pola Metaforis } & \multicolumn{3}{|c|}{$\begin{array}{c}\text { Pengikutan Metaforis Unsur Makna 'ketahanan keadaan } \\
\text { bahagia' dari RS OBJEK RAPUH/PECAH BELAH }\end{array}$} \\
\hline & akhir dari kebahagiaan & ketidakkekalan kebahagiaan & Total \\
\hline kehancuran NP_emo & 1 & & 1 \\
\hline NP_emo fana & & 1 & 1 \\
\hline perusak NP_emo & 1 & & 1 \\
\hline $\begin{array}{l}\text { X hancurkan } \\
\text { NP_emo }\end{array}$ & 1 & & 1 \\
\hline $\begin{array}{l}\text { X meluluhlantahkan } \\
\text { serpihan NP_emo }\end{array}$ & 1 & & 1 \\
\hline $\begin{array}{l}\text { X menghancurkan } \\
\text { NP_emo }\end{array}$ & 3 & & 3 \\
\hline $\begin{array}{l}\text { X merobohkan } \\
\text { NP_emo }\end{array}$ & 1 & & 1 \\
\hline $\begin{array}{l}\text { X merusakkan } \\
\text { NP_emo }\end{array}$ & 1 & & 1 \\
\hline Total & $9(5)$ & $1(5)$ & 10 \\
\hline
\end{tabular}




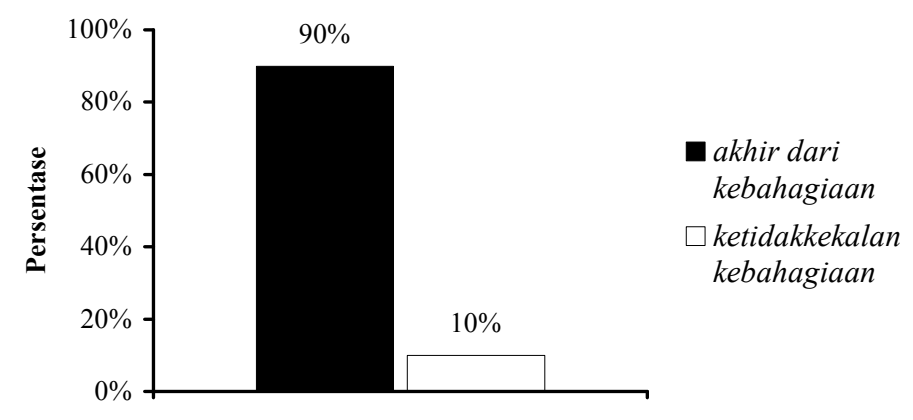

\section{Bagan 7.7.7}

\section{Distribusi Pengikutan Metaforis Unsur Makna 'ketahanan keadaan bahagia' dari MK KEBAHAGIAAN ADALAH OBJEK RAPUH/PECAH BELAH}

Pengikutan HANCUR/RUSAKNYA OBJEK atau AKHIR DARI KEBAHAGIAAN mendapat penonjolan signifikan dibandingkan dengan KETAHANAN SESAAT OBJEK atau KETIDAKKEKALAN KEBAHAGIAAN $\left(P_{\text {binomial }}=0.02148\right)$. Hasil ini dapat menyarankan bahwa kebahagiaan cenderung tidak bertahan lama, yang dikonseptualisasikan secara metaforis oleh hancurnya objek. Korelasi metafora ini terhadap KEBAHAGIAAN dapat dihubungkan dengan dua model metafora sebelumnya: kebahagiaan adalah sesuatu yang diingini dan dicari oleh seseorang dan setelah diperoleh akan berusaha untuk dilindungi dari penyebab potensial bagi ketidakbahagiaan yang salah satunya dipahami dengan kehancuran suatu objek.

\subsubsection{Metafora KEBAHAGIAAN ADALAH BERADA DI ATAS/ MELAYANG}

Metafora ini dalam literatur dipandang khas bagi RT KEBAHAGIAAN (Lakoff \& Johnson, 2003; Kövecses, 2000). Kekhasan metafora tersebut berhasil diidentifikasi pada data korpus BI kali ini dan juga BIng. (Stefanowitsch, 2006a). Sorot makna dari RS BERADA DI ATAS/MELAYANG berbeda dengan RS 
TINGGI/RENDAH yang melekat pada RT AMARAH (anak subbab 7.4.7). Melalui metafora orientasional, khususnya melalui RS berorientasi ATAS, makna yang dicoba untuk disemati ke RT KEBAHAGIAAN secara umum ialah 'kepositifan' dari keadaan bahagia (Kövecses, 2000:44, 2002:84-85). Seluruh pola metaforisnya menunjukkan makna orientasi ATAS.

Tabel 7.7.9

PM untuk MK KEBAHAGIAAN ADALAH BERADA DI ATAS/ MELAYANG

\begin{tabular}{lcc}
\hline & Unsur Ranah Target & \\
\hline Pola Metaforis & nilai positif dari kebahagiaan & Total \\
X mengantar Y ke puncak NP_emo & 1 & 1 \\
X mencapai puncak NP_emo & 1 & 1 \\
X membawa Y ke puncak NP_emo & 1 & 1 \\
X melambungkan Y ke puncak NP_emo & 1 & 1 \\
X bagaikan melayang dalam NP_emo & 1 & 1 \\
Terayun X ke langit dalam NP_emo & 1 & 1 \\
Puncak-puncak NP_emo dicapai & 1 & 1 \\
puncak NP_emo & 1 & 1 \\
NP_emo tertinggi & 1 & 1 \\
mahkota NP_emo & 1 & 1 \\
Total & 10 & 10 \\
\hline
\end{tabular}

\subsection{Sorot Makna Utama dan Pemetaan Utama Metafora KESEDIHAN}

Terdapat tiga metafora yang signifikan ditujukan bagi konseptualisasi RT KESEDIHAN BI. SMU ketiga metafora tersebut akan dibahas pada anak subbab berikut. 


\subsubsection{Metafora KESEDIHAN ADALAH BERADA DI BAWAH}

RS BERADA DI BAWAH bagi RT KESEDIHAN ialah kebalikan dari RS BERADA DI ATAS bagi RT KEBAHAGIAAN (Lakoff \& Johnson, 2003:15). Kovecses $(2000: 25,44)$ menyatakan bahwa RT EMOSI, seperti KESEDIHAN, dapat disoroti dari sisi nilai yang dimilikinya bagi seseorang yang mengalaminya. Sebagai lawan dari metafora KEBAHAGIAAN ADALAH BERADA DI ATAS, maka secara koheren makna utama metafora KESEDIHAN ADALAH BERADA DI BAWAH adalah 'kenegatifan' dari KESEDIHAN (Kovecses, 2000:44). Metafora ini dicontohkan oleh 13 pola metaforis saja.

Yang juga ditemukan pada data pola metaforis BI terkait RS BERADA DI BAWAH ialah dua pengikutan metaforis. Pengikutan pertama ialah KETIKA KESEDIHAN BERDAMPAK NEGATIF PADA DIRI, DIRI BERGERAK KE POSISI BAWAH, dan yang kedua ialah KETIKA DIRI MENCOBA KEMBALI KE KEADAAN POSITIF, DIRI BERGERAK KE POSISI ATAS. Tabel 7.8 .1 berikut menampilkan distribusi kedua pengikutan tersebut.

\section{Tabel 7.8.1}

PM dan Pengikutan Metaforis Unsur Makna 'kenegatifan' dari MK KESEDIHAN ADALAH BERADA DI BAWAH

\begin{tabular}{|c|c|c|c|}
\hline \multirow[b]{2}{*}{ Pola Metaforis } & \multicolumn{3}{|c|}{$\begin{array}{c}\text { Pengikutan Metaforis Unsur Makna 'kenegatifan' } \\
\text { dari RS BERADA DI BAWAH }\end{array}$} \\
\hline & $\begin{array}{l}\text { kembali ke keadaan } \\
\text { positif }\end{array}$ & $\begin{array}{l}\text { dampak negatif } \\
\text { kesedihan }\end{array}$ & Total \\
\hline X bangkit dari NP_emo & 3 & & 3 \\
\hline $\begin{array}{l}\text { X menghilang ke/jatuh terguling-guling di } \\
\text { dasar NP_emo }\end{array}$ & & 2 & 2 \\
\hline $\mathrm{X}$ tenggelam dalam/oleh NP_emo & & 5 & 5 \\
\hline $\mathrm{X}$ terperosok ke dalam jurang NP_emo & & 1 & 1 \\
\hline $\mathrm{X}$ terpuruk (ke) dalam NP_emo & & 2 & 2 \\
\hline Total & $3(6.5)$ & $10(6.5)$ & 13 \\
\hline
\end{tabular}




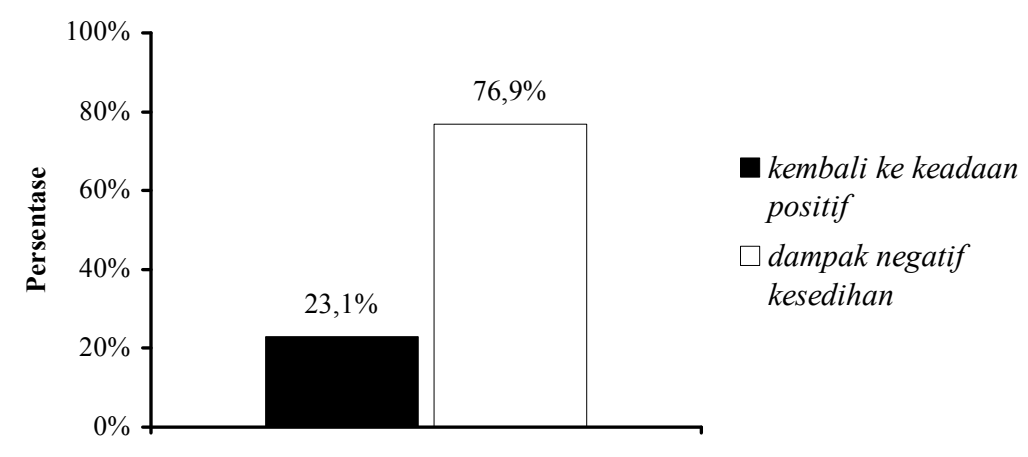

Bagan 7.8.1

\section{Distribusi Pengikutan Metaforis Unsur Makna 'kenegatifan' dari MK KESEDIHAN ADALAH BERADA DI BAWAH}

Tabel 7.8.1 menunjukkan bahwa dari 13 pola metaforis, sepuluh pola metaforis merealisasikan pengikutan DIRI BERGERAK KE POSISI BAWAH, muncul lebih sering daripada yang diharapkan atas dasar kebetulan, dan hanya tiga pola bagi pengikutan DIRI BERGERAK KE POSISI ATAS, muncul lebih sedikit daripada yang diharapkan. Apakah penyimpangan kekerapan masing-masing pengikutan tersebut dari kekerapan harapannya cukup besar dan dapat dianggap bermakna/signifikan? Uji Binomial menunjukkan ketidakcukupan bukti dari data terhadap perbedaan kekerapan kedua pengikutan metaforis tersebut $(P$ binomial $=0.09229)$. Dengan kata lain, di antara kedua pengikutan metaforis tersebut, berdasarkan data pola metaforis yang ditemukan, tidak ada yang secara signifikan lebih menonjol dibandingkan pengikutan yang lain. 


\subsubsection{Metafora KESEDIHAN ADALAH BEBAN}

RS BEBAN secara teoretis menurut Kövecses (2000:38) memang secara jelas digunakan secara metaforis oleh RT KESEDIHAN. Teori Kovecses (2000:38) tadi ditemukan secara empiris berlaku secara signifikan bagi RT KESEDIHAN atas dasar data korpus BI pada penelitian ini. Kövecses (2000:45) menyatakan bahwa "kebanyakan emosi (misalnya, amarah, ketakutan, kesedihan, malu) dipandang sebagai keadaan yang sulit bagi pengalam emosi tersebut untuk ditanggulangi. Inilah unsur dari konsep emosi yang disoroti oleh ranah sumber beban". Jadi, SMU metafora KESEDIHAN ADALAH BEBAN adalah 'kesulitan emosional'.

Hubungan antara beban dan kesulitan sebagai motivasi dari metafora KESEDIHAN ADALAH BEBAN dapat dilandasi secara eksperiensial (Kövecses, 2002:69). Ketika seseorang diberikan suatu objek beban secara fisik, misalnya barbel besi, galon berair, karung berisi beras, dan sebagainya, perihal kesulitan akan muncul. Kesulitan tersebut bisa berupa mengendalikan objek beban itu atau pemanipulasiannya, seperti mengangkat, memanggul, dan sebagainya. Tekanan eksternal dari objek beban terhadap diri tersebutlah yang memberikan kesulitan pada diri. Gambaran ini yang umumnya dicerminkan oleh seluruh pola metaforisnya yang ditemukan pada data korpus. Konstituen pemetaan dasar metafora KESEDIHAN ADALAH BEBAN berikut dibangun dari pemaparan Kövecses (2000:82).

Ranah Sumber

a. Beban

b. Tekanan fisik eksternal oleh $\rightarrow$ Tekanan atau kesulitan pada diri beban terhadap diri

\section{Ranah Target}

$\rightarrow$ Emosi karena emosi 
Terdapat sejumlah pengetahuan tambahan terkait RS BEBAN yang ditangkap oleh pola metaforisnya dalam bentuk pengikutan metaforis dan yang juga dipetakan ke RT KESEDIHAN. Pertama, ketika tekanan ditimpakan pada diri melalui beban, diri akan mengalami kesulitan emosional. Kedua, ketika objek beban yang ditimpakan tidak bisa dilepas, diri harus menyangganya. Ketiga, kadar tekanan dari objek beban terhadap diri menunjukkan kadar kesulitan emosional yang dialami. Terakhir, pengurangan tekanan beban yang disangga oleh diri ditafsirkan sebagai usaha diri untuk mengurangi kesulitan emosionalnya. Tabel 7.8.2 mendaftar distribusi pola metaforis berdasarkan pengikutan metaforisnya.

Tabel 7.8.2

PM dan Pengikutan Metaforis Unsur Makna 'kesulitan emosional' dari MK KESEDIHAN ADALAH BEBAN

\section{Pengikutan Metaforis Unsur Makna 'kesulitan emosional'} dari RS BEBAN

\begin{tabular}{|c|c|c|c|c|c|}
\hline Pola Metaforis & $\begin{array}{l}\text { penyanggaan } \\
\text { objek beban } \\
\text { oleh diri }\end{array}$ & $\begin{array}{l}\text { penimpaan } \\
\text { objek beban } \\
\text { pada diri }\end{array}$ & $\begin{array}{l}\text { kadar } \\
\text { tekanan } \\
\text { objek beban } \\
\text { pada diri }\end{array}$ & $\begin{array}{l}\text { pengurangan } \\
\text { objek beban }\end{array}$ & Total \\
\hline NP_emo menimpa $\mathrm{X}$ & & 1 & & & 1 \\
\hline NP_emo menjadi beban & & 1 & & & 1 \\
\hline $\begin{array}{l}\text { NP_emo sedemikian } \\
\text { hebat untuk ditanggung }\end{array}$ & & & 1 & & 1 \\
\hline $\begin{array}{l}\text { NP_emo yang } \\
\text { ditanggung } X\end{array}$ & 1 & & & & 1 \\
\hline NP_emo yang menimpa & & 1 & & & 1 \\
\hline timpaan NP_emo & & 1 & & & 1 \\
\hline $\begin{array}{l}\text { X berat tertimpa oleh } \\
\text { tekanan NP_emo }\end{array}$ & & & 1 & & 1 \\
\hline $\begin{array}{l}\text { X ditimpa } \\
\text { oleh/dirundung NP_emo }\end{array}$ & & 5 & & & 5 \\
\hline $\mathrm{X}$ menanggung $\mathrm{NP}$ _emo & 2 & & & & 2 \\
\hline $\begin{array}{l}\text { X mengurangi beban } \\
\text { NP_emo }\end{array}$ & & & & 1 & 1 \\
\hline $\begin{array}{l}\text { X merundung Y dengan } \\
\text { NP_emo }\end{array}$ & & 1 & & & 1 \\
\hline Total & $3(4)$ & $10(4)$ & $2(4)$ & $1(4)$ & 16 \\
\hline
\end{tabular}




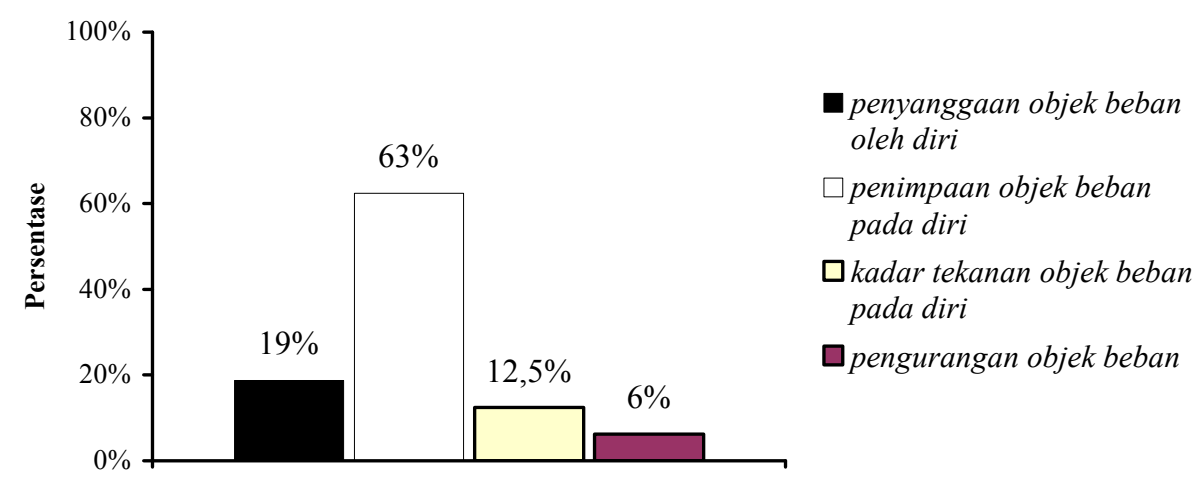

\section{Bagan 7.8.2}

\section{Distribusi Pengikutan Metaforis Unsur Makna 'kesulitan emosional' dari MK KESEDIHAN ADALAH BEBAN}

Secara kasat mata terlihat bahwa terdapat perbedaan di antara keempat pengikutan metaforis dari SMU 'kesulitan emosional' RS BEBAN. Pengikutan 'ketika tekanan ditimpakan pada diri melalui beban' direalisasikan oleh pola metaforisnya lebih sering daripada yang diharapkan dibandingkan dengan pengikutan yang lainnya. Kecondongan utama dari pengikutan metaforis tersebut bukanlah sesuatu yang bersifat manasuka $(P$ multinomial $=0.00011)$.

\subsubsection{Metafora KESEDIHAN ADALAH CAIRAN}

RS CAIRAN secara khusus tidak tercantum dalam daftar metafora bagi RT KETAKUTAN yang ditampilkan oleh Kövecses (2000:23) kecuali RS CAIRAN DALAM WADAH. Dengan menggunakan metode APM pada data korpus yang cukup besar, lebih banyak jenis metafora yang ditemukan. RS CAIRAN ini adalah salah satunya yang ditemukan dengan metode analisis APM (periksa juga Stefanotisch (2006a:77) terkait pengelompokan pola metaforis ke dalam metafora 
konseptual tertentu). Tabel 7.8 .3 berikut menampilkan pola metaforis dari metafora KESEDIHAN ADALAH CAIRAN dan makna RT yang diungkapkannya.

Tabel 7.8.3

PM untuk MK KESEDIHAN ADALAH CAIRAN

\begin{tabular}{lccc}
\hline & \multicolumn{3}{c}{ Unsur Ranah Target } \\
\hline Pola Metaforis & respon kesedihan & daya kesedihan & Total \\
air mata/tangis NP_emo & 10 & & 10 \\
lautan NP_emo & & 1 & 1 \\
X (ter)larut dalam/dengan NP_emo & 12 & & 12 \\
Total & $22(11.5)$ & $1(11.5)$ & 23 \\
\hline
\end{tabular}

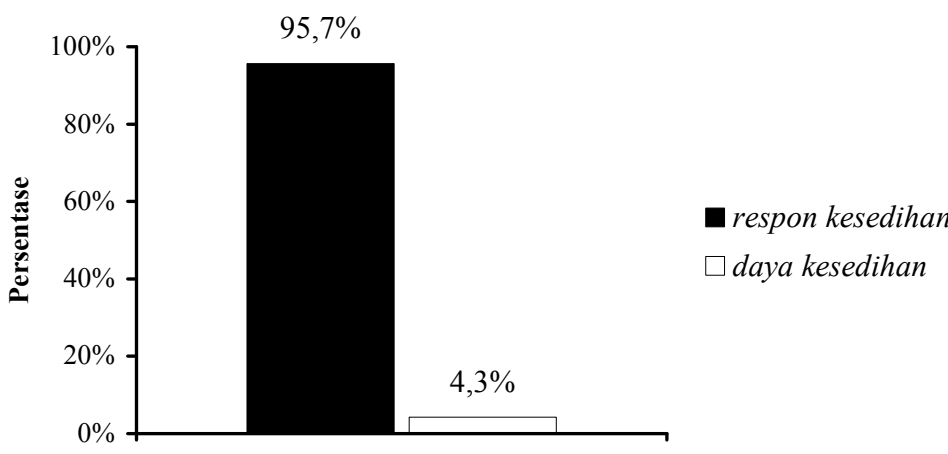

Bagan 7.8.3

Distribusi Unsur Makna MK KESEDIHAN ADALAH CAIRAN

Unsur yang dipilih dari RS CAIRAN dan yang dicerminkan oleh pola metaforisnya ialah 'daya' cairan dan 'efek' atau 'tanggapan' emosional yang dialami diri akibat daya cairan. Pola yang mengacu pada unsur 'tanggapan' emosional muncul secara sangat signifikan lebih sering daripada yang diharapkan dibandingkan dengan pola yang mengacu pada unsur 'daya' emosi $\left(P_{\text {binomial }}=\right.$ 5.72E-06). Ini berarti bahwa berdasarkan data yang diperoleh RS CAIRAN 
dipetakan ke RT KESEDIHAN dengan utamanya menyoroti unsur 'tanggapan' emosional diri. Konstituen pemetaan dasar metafora KESEDIHAN ADALAH CAIRAN yang dapat diajukan atas dasar bukti pola metaforisnya ialah sebagai berikut:

Ranah Sumber

a. Cairan

b. Potensi daya cairan untuk memberi efek pada entitas

c. Entitas yang terpengaruh oleh/tidak mampu mengendalikan daya cairan
Ranah Target

$\rightarrow$ Emosi

$\rightarrow$ Potensi daya/kekerapan emosi untuk mempengaruhi diri

$\rightarrow \quad$ Diri yang menanggapi secara emosional/ menjadi emosional

Dua gambaran yang tercermin dari pola yang mengacu pada unsur 'tanggapan' emosional ialah larutnya suatu entitas dalam cairan dan keluarnya cairan dalam bentuk air mata/tangis. Ketidakmampuan entitas, yaitu diri, terhadap daya melarutkan cairan mencerminkan bagaimana diri pada RT tidak mampu untuk bertahan dari kesedihan melainkan mengalami emosi kesedihan itu. Sedangkan pola terkait air mata/tangis kesedihan mengindikasikan cairan bersifat internal dan ketika cairan itu keluar, yang kali ini dalam bentuk air mata dan tangis, kejadian itu mencerminkan diri yang menanggapi kesedihan. Pemetaan (c) dari metafora KESEDIHAN ADALAH CAIRAN yang berperan utama dalam memetakan SMU ‘tanggapan’ kesedihan tersebut.

\subsection{Sorot Makna Utama dan Pemetaan Utama Metafora CINTA}

Enam metafora secara signifikan khas bagi RT CINTA BI. Dari keenam metafora tersebut hanya satu metafora yang memang telah diidentifikasi dan 
dinyatakan oleh Kövecses (2000) sebelumnya menjadi metafora khas RT CINTA, yaitu CINTA ADALAH IKATAN. Lima metafora tersisa ialah murni metafora baru yang ditemukan pada korpus. Keenam anak subbab berikut membahas SMU yang dicerminkan oleh masing-masing metafora.

\subsubsection{Metafora CINTA ADALAH PERGERAKAN AKSIDENTAL}

Satu-satunya pola metaforis yang mencerminkan metafora PERGERAKAN AKSIDENTAL bagi RT CINTA yang ditemukan ialah ekspresi lazim $X$ jatuh cinta (ke/[ke]pada/[s]ama Y) (91 sitiran). RS PERGERAKAN AKSIDENTAL ialah pengikutan metaforis dari salah satu subpemetaan metaforis MSP, yaitu PERUBAHAN ADALAH PERGERAKAN. Unsur 'perubahan' secara umum yang menjadi SMU metafora PERUBAHAN ADALAH PERGERAKAN pada RT (Kövecses, 2002:136). Hal itu juga berarti bahwa RS PERGERAKAN AKSIDENTAL secara alamiah dan utama menyoroti unsur makna 'perubahan aksidentil atau tidak terduga'. Hal yang ingin dan akhirnya dapat dipahami dengan memetakan unsur 'pergerakan aksidental', seperti jatuh, ke RT CINTA ialah 'perubahan' seseorang dari tidak memiliki perasaan cinta menjadi memiliki perasaan cinta terhadap seseorang. Perubahan perasaan tersebut secara lebih rinci dipahami sebagai 'perubahan yang tidak terduga'.

\subsubsection{Metafora CINTA ADALAH IKATAN}

Terdapat 20 pola metaforis yang merealisasikan metafora CINTA ADALAH IKATAN. Kövecses (2000:27) menyatakan bahwa salah satu unsur inti dalam 
sistem metafora CINTA ialah 'kebersatuan' (unity), yang dapat ditonjolkan melalui metafora CINTA ADALAH IKATAN. Berdasarkan data pola metaforis yang ditemukan, terdapat dua unsur dari RS IKATAN yang digunakan, yaitu: keadaan 'keterhubungan dua objek' dan 'pengikat/penghubung dua objek'. Melalui kedua unsur RS yang digunakan dalam pola metaforis tersebut, pemetaan metaforis metafora CINTA ADALAH IKATAN dapat dibangun.

Tabel 7.9.1a

PM untuk MK CINTA ADALAH IKATAN

\begin{tabular}{|c|c|c|c|}
\hline \multirow[b]{2}{*}{ Pola Metaforis } & \multicolumn{3}{|c|}{ Unsur Ranah Target } \\
\hline & $\begin{array}{l}\text { keterhubungan dua sejoli } \\
\text { secara emosional }\end{array}$ & $\begin{array}{l}\text { cinta yang } \\
\text { menghubungkan } \\
\text { dua sejoli }\end{array}$ & Total \\
\hline (terjalin) hubungan NP_emo & 2 & & 2 \\
\hline jalinan NP_emo & 2 & & 2 \\
\hline NP_emo mempersatukan X & 1 & & 1 \\
\hline NP_emo terjalin & 1 & & 1 \\
\hline tali/pengikat NP_emo & & 4 & 4 \\
\hline $\begin{array}{l}\mathrm{X} \text { (ber/men)jalin (hubungan) } \\
\mathrm{NP} \text { _emo (dengan Y) }\end{array}$ & 4 & & 4 \\
\hline $\mathrm{X}$ diikat oleh tali NP_emo & 1 & & 1 \\
\hline X dilibat NP_emo & 1 & & 1 \\
\hline $\begin{array}{l}\text { X putus/memutus(kan) } \\
\text { (hubungan) NP_emo }\end{array}$ & 4 & & 4 \\
\hline Total & $16(10)$ & 4 (10) & 20 \\
\hline
\end{tabular}

Ranah Sumber

a. Dua objek

b. keterhubungan dua objek

c. pengikat/penghubung dua objek
Ranah Target

$\rightarrow$ Pencinta

$\rightarrow$ keterhubungan dua sejoli secara emosional

$\rightarrow$ Cinta yang menghubungkan dua sejoli 
Kedua unsur RS IKATAN yang diungkapkan oleh pola metaforis sebelumnya mengacu pada pemetaan (b) dan (c). Tabel 7.9.1a di atas menunjukkan distribusi pola metaforis metafora CINTA ADALAH IKATAN berdasarkan unsur RT yang diungkapkannya.

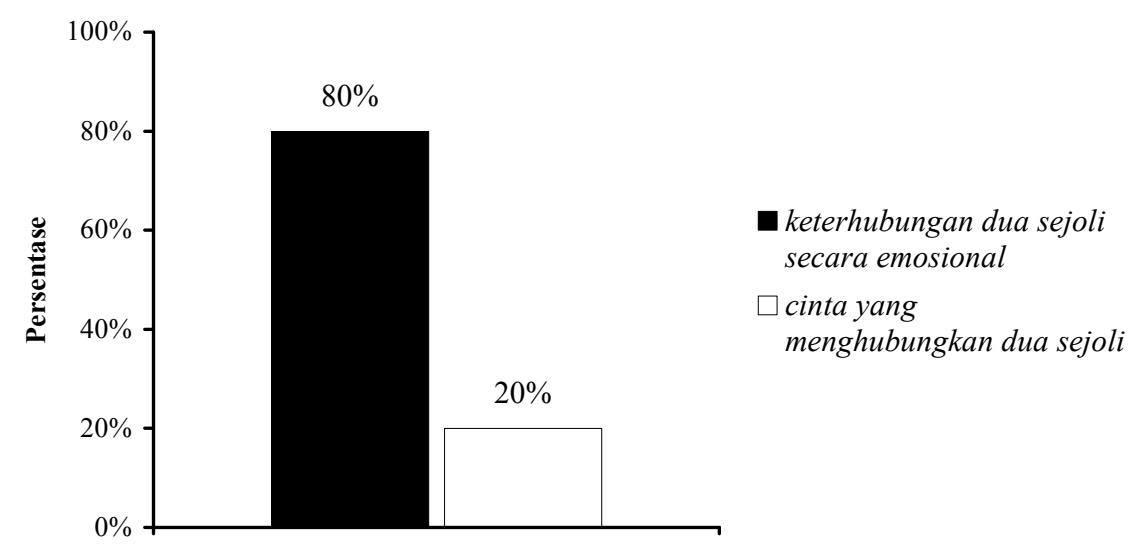

\section{Bagan 7.9.1a}

Distribusi Unsur Makna MK CINTA ADALAH IKATAN

Perbedaan kekerapan nyata dan harapan munculnya kedua unsur RT pada Tabel 7.9.1a mengindikasikan adanya penyimpangan yang begitu signifikan $(P$ binomial $=0.01182)$. Artinya, unsur 'keterhubungan dua sejoli secara emosional' cenderung lebih mendapat sorotan yang begitu signifikan dibandingkan dengan unsur 'cinta yang menghubungkan dua sejoli'. Hal ini sekaligus menunjukkan bahwa pemetaan (b) merupakan pemetaan utama dari metafora CINTA ADALAH IKATAN. Pada tingkat yang lebih umum, hasil ini dipandang dapat mendukung pernyataan Kövecses (2000:27) bahwa ide sentral bagi RT CINTA ialah tentang 'kebersatuan emosional' melalui metafora konseptual CINTA ADALAH IKATAN. 
Selain dominasi kuantitatif, ciri lain yang dapat mendukung unsur 'keterhubungan dua sejoli secara emosional' sebagai SMU dan PU metafora CINTA ADALAH IKATAN ialah adanya pengikutan metaforis yang dibawanya. Pengikutan tersebut tercermin dalam pola metaforisnya. Unsur makna 'kebersatuan emosional' mengikutkan dua hal: keadaan ketika kedua sejoli terikat asmara dan keadaan ketika kedua sejoli tersebut terpisah secara emosional atau yang umum dikenal dengan istilah 'putus cinta'.

Tabel 7.9.1b

PM dan Pengikutan Metaforis Unsur Makna 'kebersatuan emosional' dari MK CINTA ADALAH IKATAN

\begin{tabular}{lccc}
\hline & \multicolumn{3}{c}{$\begin{array}{c}\text { Pengikutan Metaforis Unsur Makna } \\
\text { 'kebersatuan emosional' dari RS IKATAN }\end{array}$} \\
\hline Pola Metaforis & $\begin{array}{c}\text { ketika dua sejoli } \\
\text { terikat asmara }\end{array}$ & $\begin{array}{c}\text { ketika dua sejoli } \\
\text { putus cinta }\end{array}$ & Total \\
(terjalin) hubungan NP_emo & 2 & 2 \\
jalinan NP_emo & 2 & 2 \\
NP_emo mempersatukan X & 1 & 1 \\
NP_emo terjalin & 1 & & 1 \\
X (ber/men)jalin (hubungan) & 4 & 4 \\
NP_emo (dengan Y) & 1 & 1 \\
X diikat oleh tali NP_emo & 1 & 4 & 1 \\
X dilibat NP_emo & & $4(8)$ & 16 \\
X putus/memutus(kan) & & \\
(hubungan) NP_emo & $12(8)$ & \\
Total & & & 1 \\
\hline
\end{tabular}




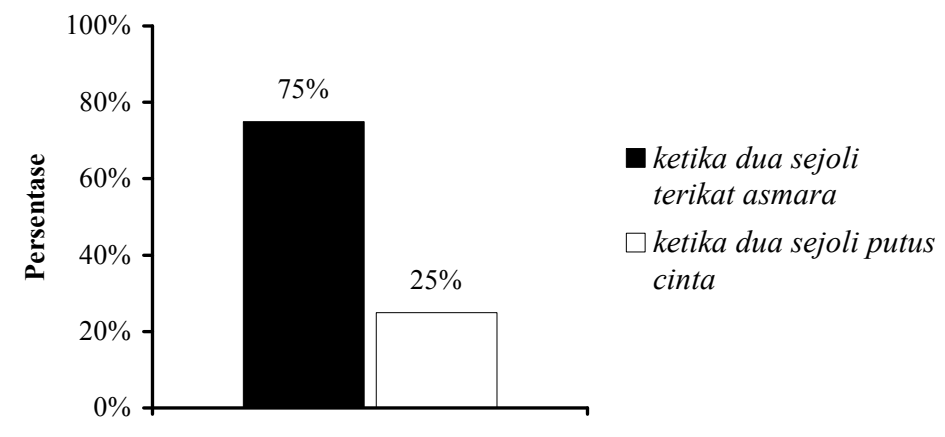

\section{Bagan 7.9.1b}

\section{Distribusi Pengikutan Metaforis Unsur Makna 'kebersatuan emosional' dari MK CINTA ADALAH IKATAN}

Data menunjukkan bahwa kedua pengikutan metaforis di atas muncul secara berbeda. Pengikutan 'ketika dua sejoli terikat asmara' muncul lebih sering daripada yang diharapkan dibandingkan dengan pengikutan 'ketika dua sejoli putus cinta'. Namun, uji binomial menunjukkan bahwa perbedaan tersebut tidaklah signifikan secara statistik $\left(P_{\text {binomial }}=0.07681\right)$. Dengan kata lain, tidak ditemukan bukti yang cukup kuat dalam data bahwa pengikutan 'ketika dua sejoli putus cinta' cenderung menjadi pengikutan yang tidak menonjol dari unsur makna 'kebersatuan' emosional di dalam BI.

\subsubsection{Metafora CINTA ADALAH CERITA}

Metafora ini dan tiga metafora berikutnya bagi RT CINTA belum pernah sebelumnya ditemukan dalam literatur-literatur utama kajian metafora emosi seperti Kövecses $(2000,2002)$ maupun Stefanowitsch (2006a). Kali ini, keempat metafora tersebut muncul melalui sudut pandang BI. Untuk metafora CINTA ADALAH CERITA, hanya ditemukan 13 pola metaforis yang merealisasikannya: 
cerita cinta (dua kemunculan) dan kisah cinta (sebelas kemunculan). Untuk RS CERITA, Kövecses memberikan contoh bagaimana biografi merupakan realisasi non-linguistik yang mencerminkan metafora KEHIDUPAN ADALAH CERITA: dalam biografi kehidupan seseorang ditampilkan bagai sebuah cerita (2002:65).

Logika tersebut dapat digunakan untuk menjelaskan apa yang menjadi SMU dari RS CERITA yang dipetakan ke RT CINTA. Khususnya, metafora CINTA ADALAH CERITA menekankan unsur 'penceritaan kisah kasih sejoli'. Jadi, tokoh dalam cerita tersebut berkorespondensi dengan dua sejoli dan tindakan serta kejadian atau plot dari cerita tersebut berkorespondensi dengan tindakan serta kejadian dari asmara dua sejolinya.

\subsubsection{Metafora CINTA ADALAH UNGKAPAN VERBAL}

Pada umumnya salah satu cara yang digunakan oleh seseorang dalam mengungkapkan apa yang dipikirkan atau dirasakannya ialah secara verbal. Dengan begitu, pikiran serta perasaan orang itu dapat diketahui oleh lawan bicaranya atau orang lain. Ide inilah juga yang ditangkap oleh RS UNGKAPAN VERBAL guna memahami RT CINTA. Khususnya, SMU metafora CINTA ADALAH UNGKAPAN VERBAL ialah 'keterungkapan perasaan cinta' secara verbal. Jadi, perasaan cinta seseorang dapat dilihat dan diketahui. Tabel 7.9 .2 berikut mendaftar pola metaforis cerminan RS UNGKAPAN VERBAL. 
Tabel 7.9.2

PM untuk MK CINTA ADALAH UNGKAPAN VERBAL

\begin{tabular}{lcc}
\hline & Unsur Ranah Target & \\
\hline Pola Metaforis & $\begin{array}{c}\text { keterungkapan perasaan cinta } \\
\text { secara verbal }\end{array}$ & Total \\
bahasa NP_emo & 1 & 1 \\
bait-bait syair NP_emo & 1 & 1 \\
idiom NP_emo & 1 & 1 \\
kalimat NP_emo & 1 & 1 \\
kata(-kata) NP_emo & 5 & 5 \\
NP_emo hanya ucapan/adalah kata sakral & 2 & 2 \\
penyair NP_emo & 1 & 1 \\
sajak NP_emo & 2 & 2 \\
sapa NP_emo menjadi seribu gagu & 1 & 1 \\
X melantunkan syair/mengucapkan NP_emo & 2 & 2 \\
Total & 17 & 17 \\
\hline
\end{tabular}

\subsubsection{Metafora CINTA ADALAH OBJEK BERWARNA}

Metafora khas CINTA ini dicerminkan oleh 20 pola metaforis. Secara umum, pola metaforis tersebut merujuk pada dua unsur dari RS WARNA, yaitu 'pencirian warna' itu sendiri dan 'berkurangnya kualitas warna'. Oleh karena itu, pemadanan unsur RS WARNA terhadap unsur RT CINTA dalam pemetaannya ialah sebagai berikut:

Ranah Sumber

a. Objek dengan warna berbeda $\rightarrow$ Pencirian cinta

b. Berkurangnya kualitas warna $\rightarrow$ Berkurangnya kualitas cinta 
Tabel 7.9.3

\section{PM untuk MK CINTA ADALAH OBJEK BERWARNA}

\begin{tabular}{lccc}
\hline & \multicolumn{3}{c}{ Unsur Ranah Target } \\
\hline Pola Metaforis & berkurangnya kualitas cinta & pencirian cinta & Total \\
memudarnya NP_emo & 1 & 2 & 1 \\
NP_emo (berwarna) merah & & 2 & 2 \\
NP_emo (serupa) warna X & 2 & & 2 \\
NP_emo (yang) pudar & & 2 & 2 \\
NP_emo dengan warna kuning & & 1 & 1 \\
NP_emo diberi warna oleh X & 1 & 1 & 1 \\
NP_emo hanya pemulas & & 2 & 2 \\
NP_emo kuning & & 1 & 1 \\
NP_emo memudar & & 3 & 3 \\
NP_emo merah kuning hijau & $4(10)$ & 2 & 2 \\
NP_emo pink & & $16(10)$ & 20 \\
NP_emo yang polos & & & 2 \\
Total & & & 2 \\
\hline
\end{tabular}

Tabel 7.9.3 menunjukkan bahwa metafora CINTA ADALAH OBJEK BERWARNA lebih didominasi secara kuantitatif oleh pola metaforis yang merujuk pada unsur 'pencirian cinta' dibandingkan dengan yang merujuk pada unsur 'berkurangnya kualitas cinta'. Perbedaan distribusi ini secara statistik begitu signifikan $\left(P_{\text {binomial }}=\right.$ 0.01182). Hasil ini berarti bahwa unsur 'pencirian cinta' memiliki kecenderungan yang sangat signifikan sebagai SMU dari metafora CINTA ADALAH OBJEK BERWARNA.

Bagan 7.9.3 berikut menunjukkan distribusi kedua unsur makna tersebut seperti tercermin pada pemetaan di atas berdasarkan pola metaforisnya. 


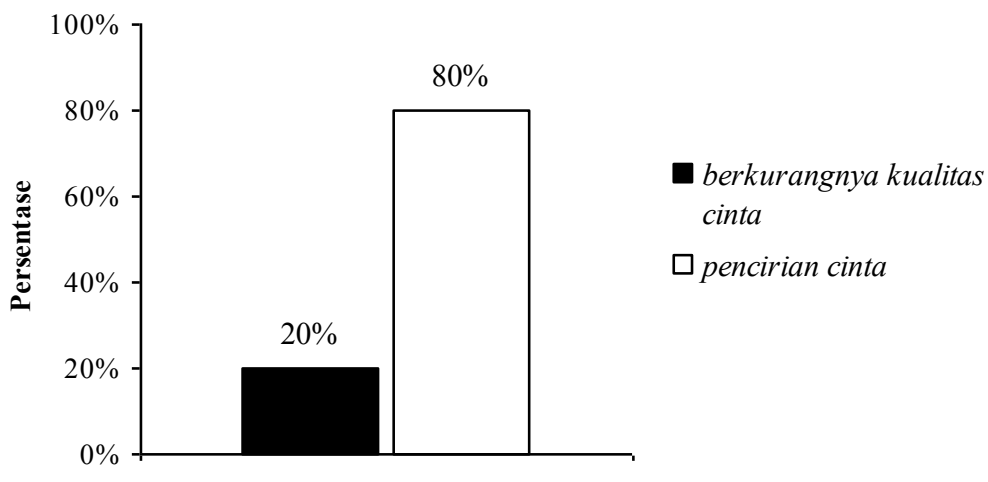

\section{Bagan 7.9.3}

Distribusi Unsur Makna MK CINTA ADALAH OBJEK BERWARNA

\subsubsection{Metafora CINTA ADALAH OBJEK BERKEILAHIAN}

Terdapat 12 sitiran pola metaforis yang mewujudkan metafora konseptual CINTA ADALAH OBJEK BERKEILAHIAN. Pola-pola metaforis tersebut bertujuan untuk menunjukkan unsur tertentu yang dimiliki cinta, yaitu 'kualitas cinta' sebagai SMU-nya. Unsur pemetaan metaforis utama dari metafora CINTA ADALAH OBJEK BERKEILAHIAN hanyalah "objek atau entitas dengan kualitas ilahi" $\rightarrow$ "cinta dengan kualitas ilahi". Secara lebih rinci, terdapat beberapa kualitas ilahi yang dicerminkan oleh masing-masing pola metaforisnya. Kualitas ilahi spesifik ini mencirikan pengikutan metaforis SMU 'kualitas cinta'. Tabel 7.9.4 berikut menunjukkan distribusinya. 
Tabel 7.9.4

\section{PM dan Pengikutan Metaforis Unsur Makna 'kualitas cinta' dari MK CINTA} ADALAH OBJEK BERKEILAHIAN

\begin{tabular}{|c|c|c|c|c|c|c|c|}
\hline \multirow[b]{2}{*}{$\begin{array}{l}\text { Pola } \\
\text { Metaforis }\end{array}$} & \multicolumn{7}{|c|}{$\begin{array}{l}\text { Pengikutan Metaforis Unsur Makna 'kualitas cinta' dari RS OBJEK } \\
\text { BERKEILAHIAN }\end{array}$} \\
\hline & keilahian & kekekalan & kesejatian & kesempurnaan & kuasa & pengertian & Total \\
\hline dewa NP_emo & 1 & & & & & & 1 \\
\hline $\begin{array}{l}\text { NP_emo } \\
\text { (yang) abadi }\end{array}$ & & 6 & & & & & 6 \\
\hline $\begin{array}{l}\mathrm{NP} \text { _emo } \\
\text { mengubah } \\
\text { segala-galanya }\end{array}$ & & & & & 1 & & 1 \\
\hline $\begin{array}{l}\text { NP_emo } \\
\text { sempurna }\end{array}$ & & & & 1 & & & 1 \\
\hline $\begin{array}{l}\mathrm{NP} \text { _emo tidak } \\
\text { egois }\end{array}$ & & & & & & 1 & 1 \\
\hline $\begin{array}{l}\text { NP_emo tidak } \\
\text { pernah salah }\end{array}$ & & & 1 & & & & 1 \\
\hline $\begin{array}{l}\text { Tuhan adalah } \\
\text { sumber } \\
\text { NP_emo }\end{array}$ & 1 & & & & & & 1 \\
\hline Total & $2(2)$ & $6(2)$ & $1(2)$ & $1(2)$ & $1(2)$ & $1(2)$ & 12 \\
\hline
\end{tabular}

Bagan 7.9.4 menunjukkan adanya perbedaan distribusi munculnya masing-masing pengikutan metaforis daripada yang diharapkan. Secara umum, hal ini merupakan ketimpangan yang sangat signifikan $(P$ multinomial $=0.000153)$. Efek utamanya ialah pengikutan 'kekekalan' cinta muncul secara sangat signifikan lebih sering daripada yang diharapkan, berbeda dengan pengikutan yang lain. Hasil ini dapat ditafsirkan sebagai adanya kecenderungan penonjolan unsur 'kekekalan' ketika mengonseptualisasikan 'kualitas' cinta. 


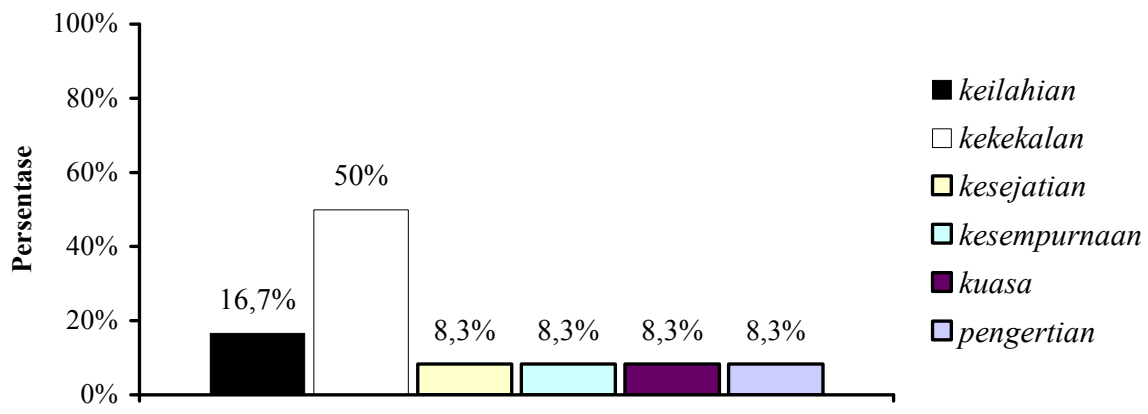

Bagan 7.9.4

Distribusi Pengikutan Metaforis Unsur Makna 'kualitas cinta' dari MK CINTA ADALAH OBJEK BERKEILAHIAN 


\section{BAB VIII}

\section{TEMUAN PENELITIAN}

\subsection{Pengantar}

Kajian metafora emosi BI dalam bentuk disertasi, utamanya penerapan TMK pada korpus modern merupakan kajian pertama. Oleh karena itu, semua hasil penelitian ini merupakan temuan baru.

Temuan yang dipaparkan berikut ini, yaitu temuan teoretis yang berkenaan dengan penerapan teori metafora konseptual, temuan metodologis yang menyangkut praktik pemanfaatan metode LKorp dan APM untuk menemukan dan mengkaji data, dan temuan empiris yang berhubungan dengan fakta-fakta kebahasaan yang diteliti.

\subsection{Temuan Teoretis}

Secara teoretis, penelitian ini menemukan bahwa TMK dapat diterapkan pada data BI dengan sangat tepat dan tanpa kendala. Hal ini membuktikan bahwa TMK masih relevan untuk digunakan sehingga modifikasi teori tidak diperlukan.

Hasil penerapan TMK pada data BI berimplikasi positif terhadap pembelajaran bahasa, khususnya pembelajaran metafora. Pertama, TMK dapat dimanfaatkan untuk tujuan pembelajaran metafora secara lebih sistematis, baik untuk pembelajaran ML maupun MK. Dengan menentukan satu leksikon ranah tertentu, misalnya ranah emosi, pembelajar dapat menemukan leksikon ranah lain yang memetakan leksikon ranah emosi secara sistematis. Secara lebih konkret, 
dapat dijelaskan bahwa dengan menentukan satu leksikon RT (misalnya amarah), pembelajar dapat menemukan leksikon RS yang memetakannya, seperti leksikon api dan bahang dalam api amarah dan bahang amarah.

Kedua, TMK dapat dimanfaatkan untuk menjelaskan motivasi pembentukan sebuah kata. Misalnya, kata meledak-ledak dan meletup-letup memiliki motivasi metaforis. Maksudnya, pemakaian kata-kata tersebut didorong oleh MK AMARAH ADALAH UNSUR DALAM WADAH BERTEKANAN.

Ketiga, TMK dapat digunakan untuk menjelaskan kewajaran suatu kolokasi tertentu. Misalnya, bagaimana kata bahang, panas, padam, bakar, dan sulut, berkolokasi dengan kata amarah; bagaimana juga kata badai, angin, topan, gelombang, reda, dan landa berkolokasi dengan amarah. Jika dipandang dari sudut linguistik, tampak tidak ada hubungan kedekatan (kolokasi) antara amarah dengan bahang atau badai. Akan tetapi, jika dilihat dari MK AMARAH ADALAH API dan AMARAH ADALAH KEKUATAN ALAM yang melatarbelakangi hubungan tersebut, maka kolokasi itu menjadi wajar.

Keempat, TMK dapat digunakan untuk menjeaskan konsep-konsep absrtak yang sulit dejelaskan secara literal. Misalnya, konsep emosi amarah dijelaskan dengan konsep kekuatan alam, seperti gelombang. Ketika seseorang diterjang gelombang, maka orang tersebut berusaha melawan. Akan tetapi, karena kuatnya gelombang tersebut, maka orang itu tidak mampu melawannya. Dalam keadaan seperti ini seseorang akan pasrah dan membiarkan dirinya dihempas gelombang. Konsep kekuatan alam ini, salah satunya, digunakan untuk menjelaskan konsep emosi amarah. Ketika seseorang mengalami emosi amarah, maka dia akan 
mencoba mengatasi amarahnya. Akan tetapi karena kuatnya tekanan emosi, maka seseorang akan membiarkan dirinya mengalami amarah itu tanpa perlawanan.

\subsection{Temuan Metodologis}

Penerapan metode kualitatif yang didukung dengan metode kuantitatif, LKorp dan APM, pada data BI menghasilkan temuan baru. Kebaruan temuan yang dimaksud terletak pada keterpatrian konsep atau ideologi yang memotivasi ML, kekhasan MK, dan makna metafora. Pertama, derajat kekerapan pemakaian suatu pola metaforis emosi tertentu menunjukkan derajat keterpatrian relatif suatu MK yang memotivasi pola metaforis tersebut. Kedua, tingginya kekerapan pemakaian MK emosi tertentu secara signifikan dibandingkan dengan emosi yang lain menunjukkan kekhasan MK tersebut bagi emosi itu. Ketiga, tingginya kekerapan pemakaian suatu pola metaforis emosi tertentu menunjukkan kejelasan aspek makna utama yang ditonjolkan atau disoroti.

Temuan ini membuktikan pentingnya metode kuantitatif LKorp dan APM sebagai pendukung metode kualitatif untuk disinergikan dengan TMK. Kekuatan serta pentingnya metode ini terletak pada kemampuannya untuk menjelajah, mengidentifikasi, dan menghitung data dalam waktu yang singkat pada korpus yang sangat besar. Suatu hal yang kemungkinannya kecil dilakukan dengan metode introspektif atau metode bukan korpus lainnya. 


\subsection{Temuan Empiris}

Penerapan TMK, metode kualitatif yang didukung dengan metode kuantitatif LKorp, dan APM menemukan fakta-fakta kebahasaan seperti berikut ini.

\subsubsection{Pola Metafora Emosi}

Hasil analisis menunjukkan bahwa RT EMOSI jauh lebih sering diungkapkan secara metaforis dibandingkan dengan cara-cara literal. Hasil ini menegaskan bahwa pemakaian metafora dalam BI, khususnya metafora emosi, sangat berlimpah. Hal ini dibuktikan dengan fakta bahwa dari 5.000 sampel sitiran mengandung kata kunci RT EMOSI yang diharapkan, ditemukan 3.999 sitiran, 3.059 sitiran di antaranya berupa pola metaforis dan 940 sitiran bermakna literal.

\subsubsection{Tingkat Pemakaian Leksikon RT EMOSI}

Dilihat dari tingkat pemakaian leksikon RT EMOSI, penelitian ini berhasil menemukan bahwa emosi ketakutan paling sering digunakan $(24,5 \%)$, disusul berturut-turut oleh emosi cinta (23,7\%), amarah/kemarahan (23,6\%), kebahagiaan $(15,1 \%)$, dan kesedihan $(13,1 \%)$. Hal ini mengindikasikan bahwa pemakai BI paling sering memikirkan dan mengatakan hal-hal yang menyangkut ketakutan. Disadari bahwa kemungkinan ada alasan atau variabel-variabel penjelas mengapa satu emosi seperti ketakutan lebih sering dipikirkan dan dibicarakan oleh pemakai BI dalam kehidupan sehari-hari dibandingkan dengan emosi yang lain, seperti kesedihan tetapi tidak dibicarakan dalam penelitian ini. 


\subsubsection{Tingkat Pemakaian Metafora Emosi}

Dipandang dari tingkat pemakaian metafora emosi, ditemukan bahwa pemakai BI paling sering bermetafora ketika berpikir dan berbicara tentang emosi amarah/kemarahan (30,5\%) diikuti oleh cinta (22,7\%), kebahagiaan (18,5\%), kesedihan (16,2\%), dan ketakutan (12,1\%). Paling tingginya pemakaian metafora dalam kasus emosi amarah/kemarahan mengindikasikan bahwa emosi ini kemungkinan paling sulit dipahami dan diungkapkan secara literal sehingga pemakai BI memilih lebih banyak bermetafora tentang emosi itu. Selain itu, faktor budaya berperan penting pada hal tersebut.

\subsubsection{MK Emosi BI}

Ditemukan 258 MK emosi yang terpakai dalam BI dan direpresentasikan oleh 3.059 metafora linguistik menyangkut emosi. Misalnya, AMARAH/KEMARAHAN ADALAH CAIRAN PANAS DALAM WADAH,

KETAKUTAN ADALAH BEBAN, (3) KEBAHAGIAAN ADALAH OBJEK DI SUATU LOKASI, (4) KESEDIHAN ADALAH (MENJADI) BERADA DI BAWAH, dan (5) CINTA ADALAH PERJALANAN. Temuan ini membuktikan bahwa ungkapan metaforis tidak digunakan secara acak, tetapi dimotivasi oleh MK. Karena panjangnya daftar temuan, maka secara lengkap temuan ini disajikan pada lampiran 2. 


\subsubsection{RS Metaforis BI}

Ditemukan 88 RS metaforis yang digunakan untuk memetakan RT EMOSI, beberapa di antaranya API, BEBAN, WADAH, KEKUATAN ALAM, dan MUSUH/LAWAN. Daftar lengkapnya disajikan pada lampiran 3.

\subsubsection{MK Khas Emosi BI}

Metode LKorp dan APM yang dipadukan dengan evaluasi statistik berhasil menemukan konfigurasi metafora, baik yang signifikan ditarik maupun ditolak oleh RT EMOSI BI. Temuan ini sedikitnya mengesahkan pentingnya penyertaan suatu metode statistik untuk mengevaluasi seperangkat data kuantitatif yang bersifat kompleks. Berikut ini ditampilkan metafora yang secara signifikan, baik ditarik maupun ditolak oleh RT EMOSI.

\subsubsection{MK Khas Emosi AMARAH}

Penelitian ini menemukan delapan MK yang khas emosi AMARAH, yaitu (1) AMARAH/KEMARAHAN ADALAH KONTROL OBJEK BERGERAK (menahan/menghentikan amarah), (2) AMARAH/KEMARAHAN ADALAH UNSUR DALAM WADAH BERTEKANAN (X penuh (dengan) amarah) , AMARAH/KEMARAHAN ADALAH CAIRAN DALAM WADAH (X menumpahkan amarah), (4) AMARAH/KEMARAHAN ADALAH CAIRAN PANAS DALAM WADAH (amarahnya mendidih), (5) AMARAH/ KEMARAHAN ADALAH API (X terbakar oleh amarah), (6) AMARAH/ KEMARAHAN ADALAH PANAS/DINGIN (X menyejukkan panas amarah), (7) AMARAH/KEMARAHAN ADALAH TINGGI/RENDAH (amarah/ kemarahannya memuncak/menubun), dan (8) 
AMARAH/KEMARAHAN ADALAH KEKUATAN ALAM (badai kemarahan, $X$ meredakan kemarahan).

\subsubsection{MK Khas Emosi KETAKUTAN}

Ditemukan dua MK yang khas emosi KETAKUTAN, yaitu (1) KETAKUTAN ADALAH MUSUH/LAWAN (perlawanan atas ketakutan) dan (2) KETAKUTAN ADALAH MELAKUKAN SESUATU/DISERTAI/TEMANI OBJEK PENYERTA (X $\boldsymbol{V}(\boldsymbol{e} \boldsymbol{r} \boldsymbol{b} \boldsymbol{a})$ dengan/tanpa ketakutan).

\subsubsection{MK Khas Emosi KEBAHAGIAAN}

MK khas KEBAHAGIAAN ditemukan berjumlah sembilan metafora, yaitu (1) KEBAHAGIAAN ADALAH KEPEMILIKAN (X memiliki/kehilangan kebahagiaan), (2) KEBAHAGIAAN ADALAH (SECARA POTENSIAL) MEMBERIKAN SUATU OBJEK (X memberi(kan) kebahagiaan ([ke]pada/buat Y), (3) KEBAHAGIAAN ADALAH (SECARA POTENSIAL) MENDAPAT/MENERIMA SUATU OBJEK (X menerima kebahagiaan), (4) KEBAHAGIAAN ADALAH OBJEK RAPUH/PECAH BELAH (X menghancurkan kebahagiaan), (5) KEBAHAGIAAN ADALAH MENCARI/MEMBURU SUATU OBJEK (X mencari/mengejar kebahagiaan), (6) KEBAHAGIAAN ADALAH MENEMUKAN/MERAIH SUATU OBJEK (X menemukan kebahagiaan), (7) KEBAHAGIAAN ADALAH PERJALANAN (X mencapai kebahagiaan), (8) KEBAHAGIAAN ADALAH SANTAPAN (X menikmati kebahagiaan), dan (9) KEBAHAGIAAN ADALAH BERADA DI ATAS/MELAYANG (X membawa Y ke puncak kebahagiaan). 


\subsubsection{MK Khas Emosi KESEDIHAN}

Ditemukan tiga MK yang khas emosi KESEDIHAN, yaitu (1) KESEDIHAN ADALAH BERADA DI BAWAH (X tenggelam dalam kesedihan), (2) KESEDIHAN ADALAH BEBAN (kesedihan menimpa X), dan (3) KESEDIHAN ADALAH CAIRAN (X (ter)larut dalam kesedihan).

\subsubsection{MK Khas Emosi CINITA}

Penelitian ini menemukan enam MK yang khas emosi CINTA, yaitu (1) CINTA ADALAH PERGERAKAN AKSIDENTAL (X jatuh cinta (ke/[ke]pada/[s]ama Y), (2) CINTA ADALAH IKATAN (hubungan/jalinan/tali/pengikat cinta), (3) CINTA ADALAH CERITA (cerita/kisah cinta), (4) CINTA ADALAH UNGKAPAN VERBAL (bahasa/idiom/kalimat/kata(-kata)/sajak cinta), (5) CINTA ADALAH OBJEK BERWARNA (memudarnya cinta), dan (6) CINTA ADALAH OBJEK BERKEILAHIAN (dewa cinta).

\subsubsection{MK EMOSI Universal}

Kajian lintas bahasa yang telah dilakukan oleh Kövecses (2000) menunjukkan bahwa keberagaman budaya ternyata menyimpan konsep emosi yang universal, selain kekhasan konsep yang telah dipaparkan sebelumnya. Keuniversalan konsep emosi tersebut dapat disebabkan oleh kemiripan cara pandang yang disebut pemahaman masyarakat (the folk understanding) (Kövecses, 2000 dan 2005). MK universal yang ditemukan dalam penelitian ini dipaparkan pada subbab berikut. 


\subsubsection{MK Universal Menyangkut Emosi CINTA}

Ditemukan empat MK universal yang menyangkut emosi CINTA dalam BI, yaitu (1) CINTA ADALAH API, seperti direalisasikan pada pola metaforis api cinta, (2) CINTA ADALAH SIHIR (MAGIC), seperti pada pola metaforis pesona cinta, (3) CINTA ADALAH KEKUATAN FISIK, seperti pada ekspresi metaforis cinta di $X$ cuma kekuatan yang mendorong ke arah $Y$, dan (4) CINTA ADALAH MUSUH, seperti direalisasikan pada pola metaforis rasa cinta mengalahkan $Y$. Keempat metafora di atas telah diidentifikasi keberadaannya pada BIng dan bahasa Hungaria dan dipaparkan dalam Kövecses (2000). Contoh ML untuk keempat MK di atas ditampilkan pada lampiran 4.

\subsubsection{MK Universal Menyangkut WADAH}

Penelitian ini berhasil menemukan MK universal yang berkenaan dengan WADAH, seperti TUBUH ADALAH WADAH BAGI EMOSI dan AMARAH ADALAH SUATU UNSUR (CAIRAN/GAS) DI DALAM WADAH yang direpresentasikan dengan ML, seperti (a) Sidik berteriak-teriak penuh amarah dan (b) Benaknya yang tadi dipenuhi amarah berangsur menjernih. Keuniversalan metafora WADAH ditemukan melalui kajian lintas bahasa sebagaimana telah didiskusikan dalam Kövecses (2000 dan 2005) terhadap bahasa-bahasa lain, seperti BIng., bahasa Hungaria, bahasa China, dan bahasa Jepang. MK WADAH yang univesal beserta contoh-contoh ML-nya ditampilkan pada lampiran 5. Kelima bahasa dengan latar belakang budaya yang berbeda ini secara universal memanfaatkan tubuh manusia sebagai WADAH untuk EMOSI. 


\subsubsection{Metafora WADAH Khas BI}

Penelitian ini menemukan leksikon anggota tubuh "hati $(66,9 \%)$ dan dada (20,4\%)" sebagai WADAH metaforis untuk EMOSI yang secara signifikan khas BI pada tingkat yang lebih terperinci secara semantis, seperti tergambar pada contoh ML: (1) Hatinya penuh amarah, 2) ...ketakutan dalam hati Srintil mulai terkikis, (3) Dadanya terasa akan meledak karena ketakutan dan kengerian, (4) Ada kebahagiaan yang mengalir dalam hati peremuan tua itu, dan (5) Cinta yang selalu ada dalam hatiku.

\subsection{8"Model" EMOSI dalam BI}

Model emosi yang dimaksudkan dalam temuan ini adalah alur berpikir yang paling menonjol (selient) dari pemakai BI dalam memahami emosi. Model emosi ini dirumuskan berdasarkan hasil analisis kekhasan metafora emosi pada bab sebelumnya, seperti berikut ini.

\subsubsection{Model Emosi AMARAH/KEMARAHAN}

AMARAH/KEMARAHAN dalam BI dapat dipahami sebagai unsur atau cairan dan manusia dipahami sebagai wadah dari unsur atau cairan. Ketika unsur atau cairan mendapat panas, maka suhu dan intensitas cairan meningkat. Ketika suhu dan intensitas meningkat, maka dinding wadah terdesak oleh makin kuatnya suhu dan intensitas unsur atau cairan. Wadah yang tertekan berusaha menahan/mengontrol tekanan dari dalam yang terus menguat. Apabila wadah tidak mampu lagi menahan/mengotrol tekanan, maka wadah akan meledak. 
Ketika wadah meledak, unsur atau cairan keluar seketika dan wadah hanya pasrah tanpa daya dan mengalami kuatnya aliran unsur atau cairan tersebut.

\subsubsection{Model Emosi KETAKUTAN}

KETAKUTAN dalam BI dipahami sebagai musuh dan manusia dipahami sebagai lawan dari musuh. Musuh berada sangat dekat dengan lawan dan musuh berusaha menyerang lawan. Ketika musuh menyerang, lawan mencoba mengendalikan dan mengalahkan musuh. Karena besarnya kekuatan musuh, maka lawan lebih sering dikendalikan dan dikalahkan oleh musuh.

\subsubsection{Model Emosi KEBAHAGIAAN}

KEBAHAGIAAN dalam BI dipahami sebagai objek dan manusia dipahami sebagai pencari, pengejar, pemberi, dan penerima objek. Manusia mengejar, mencari, dan mendapatkan objek untuk dimiliki dan dinikmati. Ketika objek tersebut diperoleh, diterima, atau diberikan kepada orang lain, maka manusia akan merasa berada di atas dan objek akan dipertahankan, dijaga dari kemungkinan kehancuran karena objek tersebut rapuh adanya.

\subsubsection{Model Emosi KESEDIHAN}

KESEDIHAN dalam BI dipahami sebagai beban dan manusia dipahami sebagai penyandang beban. Ketika beban bertambah berat, manusia berusaha menyangga dengan lebih kuat untuk mengurangi tekanan beban. Ketika beban bertambah, manusia akan semakin tertekan dan ketika manusia tidak mampu lagi menyangga, maka ia terpuruk. 


\subsubsection{Model Emosi CINTA}

CINTA dalam BI dipahami secara beragam. Pertama, cinta dipahami sebagai objek yang dapat diungkapkan. Kedua, cinta dipahami sebagai objek dengan kualitas dan ciri tertentu (objek berwarna dan objek berkeilahian). Ketiga, cinta dipahami sebagai kejadian seketika yang dialami oleh manusia.

\subsubsection{Makna Metafora EMOSI BI}

Aplikasi TMK beserta metode LKorp dan APM berhasil menemukan SMU dan PU metafora EMOSI BI. Tanpa metode ini kekuatan sorot makna yang penting dan PU dari sebuah MK tidak dapat diukur secara pasti. Metode ini mampu memfasilitasi penentuan unsur makna tersorot suatu metafora melalui kekuatan kekerapan pemakaiannya.

\subsubsection{Makna Metafora AMARAH}

Penelitian ini menemukan dua jenis SMU metafora AMARAH, yaitu (1) pengendalian tindakan emosional dan (2) intensitas emosi. Secara lebih terperinci dapat dikatakan bahwa MK (1) KONTROL AMARAH ADALAH KONTROL OBJEK BERGERAK menyoroti unsur "pengendalian tindakan emosional”, (2) AMARAH ADALAH UNSUR DALAM WADAH (BERTEKANAN) menyoroti unsur "intensitas emosi", (3) AMARAH ADALAH CAIRAN DALAM WADAH menyoroti unsur “intensitas emosi", (4) AMARAH ADALAH CAIRAN PANAS DALAM WADAH menyoroti unsur "intensitas emosi", (5) AMARAH ADALAH PANAS/DINGIN menyoroti unsur "intensitas emosi", (6) AMARAH ADALAH API menyoroti unsur "intensitas emosi", (7) AMARAH ADALAH TINGGI/RENDAH menyoroti unsur 
“intensitas emosi”, dan (8) AMARAH ADALAH KEKUATAN ALAM menyoroti unsur "intensitas emosi"

\subsubsection{Makna Metafora KETAKUTAN}

Ditemukan dua jenis SMU metafora KETAKUTAN, yaitu unsur "keberadaan emosi pada diri" untuk MK KETAKUTAN ADALAH MELAKUKAN SESUATU DISERTAI OBJEK PENYERTA dan unsur "pergumulan diri dan emosi" untuk MK KETAKUTAN ADALAH MUSUH/LAWAN.

\subsubsection{Makna Metafora KEBAHAGIAAN}

Metafora KEBAHAGIAAN memunculkan sembilan SMU, yaitu (1) KEBAHAGIAAN ADALAH (SECARA POTENSIAL) MEMBERIKAN SUATU OBJEK menyoroti unsur "potensi untuk menyebabkan penerima menjadi bahagia", (2) KEBAHAGIAAN ADALAH (SECARA POTENSIAL) MENERIMA SUATU OBJEK menyoroti unsur "potensi perubahan keadaan menjadi bahagia", KEBAHAGIAAN ADALAH KEPEMILIKAN menyoroti unsur "keberadaan emosi pada diri”, (4) KEBAHAGIAAN ADALAH MENCARI/MEMBURU SUATU OBJEK menyoroti unsur "usaha/upaya menjadi bahagia", (5) KEBAHAGIAAN ADALAH MENEMUKAN/MERAIH SUATU OBJEK menyoroti unsur "menjadi bahagia", (6) KEBAHAGIAAN ADALAH PERJALANAN menyoroti unsur "tahapan menjadi bahagia", (7) KEBAHAGIAAN ADALAH SANTAPAN menyoroti unsur "merasakan kebahagiaan", (8) KEBAHAGIAAN ADALAH OBJEK RAPUH/PECAH BELAH menyoroti unsur "ketahanan keadaan bahagia", dan (9) KEBAHAGIAAN ADALAH BERADA DI ATAS/MELAYANG menyoroti unsur "kepositifan keadaan bahagia". 


\subsubsection{Makna Metafora KESEDIHAN}

Ditemukan bahwa metafora KESEDIHAN memiliki tiga jenis SMU, yaitu (1) unsur "kenegatifan keadaan sedih" untuk MK KESEDIHAN ADALAH BERADA DI BAWAH, (2) unsur "kesulitan emosional" untuk MK KESEDIHAN ADALAH BEBAN, dan (3) unsur "tanggapan emosional untuk MK KESEDIHAN ADALAH CAIRAN.

\subsubsection{Makna Metafora CINTA}

Metafora CINTA memunculkan enam SMU, yaitu (1) "perubahan emosional secara aksidental/tidak terduga" untuk MK CINTA ADALAH PERGERAKAN AKSIDENTAL, (2) "keterhubungan dua sejoli secara emosional" untuk MK CINTA ADALAH IKATAN, (3) “penceritaan kisah kasih sejoli” untuk MK CINTA ADALAH CERITA, (4) "keterungkapan perasaan cinta secara verbal" untuk MK CINTA ADALAH UNGKAPAN VERBAL, (5) "pencirian cinta" untuk MK CINTA ADALAH OBJEK BERWARNA, dan (6) "kualitas cinta" untuk MK CINTA ADALAH OBJEK BERKEILAHIAN. 


\section{BAB IX}

\section{SIMPULAN DAN SARAN}

\subsection{Simpulan}

Secara linguistik, pengalaman emosi pemakai BI lebih banyak diekspresikan secara metaforis dibandingkan dengan cara-cara literal. Hasil penelusuran korpus kuantitatif membuktikan bahwa 3.999 sitiran ditemukan mengandung unsur leksikal emosi amarah/kemarahan, ketakutan, kebahagiaan, kesedihan, dan cinta. Sebagian besar, yaitu $3.059(76,50 \%)$ sitiran tersebut diidentifikasi berupa ungkapan metaforis atau ML yang berhubungan dengan emosi. Sisanya, yaitu 23,50\% (940) sitiran diungkapkan secara literal. Ungkapan metaforis tersebut mencerminkan $258 \mathrm{MK}$ yang menyangkut emosi.

Profil pola metaforis BI berupa ungkapan multikata yang terdiri atas leksikon RS dan satu leksikon RT EMOSI atau lebih. Pola motaforis tersebut direalisasikan dari unsur leksikon RT EMOSI amarah/kemarahan, ketakutan, kebahagiaan, kesedihan, dan cinta dengan leksikon RS berupa verba, seperti pola amarahnya menggelegak/meluap; nomina, seperti pola api/luapan/korban amarah, gelombang cinta; dan adverbia, seperti pola di dalam ketakutan dan di bawah kemarahan.

Untuk emosi BI, MK yang khas emosi AMARAH ialah metafora (1) KONTROL EMOSI ADALAH KONTROL OBJEK BERGERAK, (2) EMOSI ADALAH UNSUR DALAM WADAH BERTEKANAN, (3) EMOSI ADALAH CAIRAN DALAM WADAH, (4) EMOSI ADALAH CAIRAN PANAS DALAM WADAH, (5) EMOSI ADALAH 
API, (6) EMOSI ADALAH PANAS/DINGIN SUATU OBJEK, (7) INTENSITAS EMOSI ADALAH TINGGI/RENDAH, dan (8) EMOSI ADALAH KEKUATAN ALAM.

MK yang khas emosi KETAKUTAN ialah (1) EMOSI ADALAH MUSUH/LAWAN dan (2) (BERTINDAK) EMOSI(ONAL) ADALAH MELAKUKAN SESUATU/DISERTAI/TEMANI OBJEK PENYERTA.

MK yang khas emosi KEBAHAGIAAN, yaitu (1) EMOSI ADALAH KEPEMILIKAN, (2) MENYEBABKAN EMOSI ADALAH (SECARA POTENSIAL) MEMBERIKAN SUATU OBJEK, (3) MENJADI EMOSI ADALAH (SECARA POTENSIAL) MENDAPAT/MENERIMA SUATU OBJEK, (4) MENCOBA MENJADI EMOSI ADALAH MENCARI/ MENGEJAR/MEMBURU SUATU OBJEK, (5) MENJADI EMOSI ADALAH MENEMUKAN/MERAIH SUATU OBJEK, (6) PROSES MENJADI EMOSI ADALAH PERJALANAN, (7) EMOSI ADALAH OBJEK RAPUH/PECAH BELAH, (8) MENJADI EMOSI ADALAH (MENJADI) BERADA DI ATAS/MELAYANG, dan (9) EMOSI ADALAH SANTAPAN (MAKANAN/ MINUMAN).

MK yang khas emosi KESEDIHAN ialah (1) EMOSI ADALAH (MENJADI) BERADA DI BAWAH, (2) EMOSI ADALAH BEBAN, dan (3) EMOSI ADALAH CAIRAN.

Sementara itu, MK yang khas emosi CINTA ialah (1) MENJADI EMOSI ADALAH PERGERAKAN AKSIDENTAL, (2) EMOSI ADALAH IKATAN, (3) EMOSI ADALAH CERITA, (4) EMOSI ADALAH UNGKAPAN VERBAL, (5) EMOSI ADALAH (OBJEK BER)WARNA, dan (6) EMOSI ADALAH OBJEK BERKEILAHIAN.

Ditinjau dari makna, metafora AMARAH menunjukkan makna 'pengendalian tindakan emosional' dan 'intensitas emosi'; metafora KETAKUTAN menunjukkan makna 'keberadaan emosi pada diri' serta 'pergumulan diri dan emosi'; metafora KEBAHAGIAAN menunjukkan makna 'potensi untuk 
menyebabkan penerima menjadi bahagia', 'potensi perubahan keadaan menjadi bahagia', 'keberadaan emosi pada diri', 'usaha/upaya menjadi bahagia', 'menjadi bahagia', 'tahapan menjadi bahagia', 'merasakan kebahagiaan', 'ketahanan keadaan bahagia', dan 'kepositifan keadaan bahagia'; metafora KESEDIHAN menunjukkan makna 'kenegatifan keadaan sedih', 'kesulitan emosional', dan 'tanggapan emosional'; dan metafora CINTA menunjukkan makna 'perubahan emosional secara aksidental/tidak terduga', 'keterhubungan dua sejoli secara emosional', 'penceritaan kisah kasih sejoli', 'keterungkapan perasaan cinta secara verbal','pencirian cinta', dan 'kualitas cinta'.

\subsection{Saran}

Menilik bukti empirik dari penelitian ini, dapat diusulkan beberapa saran penting yang dapat dilakukan oleh peneliti berikutnya yang tertarik dengan metafora, khususnya metafora kognitif atau konseptual.

Pertama, aplikasi padu antara TMK, metode kualitatif yang didukung dengan metode kuantitatif, LKorp, APM, dan penyertaan uji statistik dapat dilakukan lebih lanjut karena penelitian ini telah membuktikan keberhasilannya dalam menemukan, mengolah, dan menganalisis data secara tuntas sepanjang berhubungan dengan masalah yang diajukan.

Kedua, penelitian dengan melibatkan jumlah korpus yang lebih besar dari apa yang telah dilakukan pada penelitian ini akan dapat menguatkan kemampuan kombinasi teori dan metode yang telah diaplikasikan pada penelitian ini. Pemeriksaan korpus yang lebih besar, representatif, dan seimbang juga akan 
dapat membuktikan lebih jauh tentang kekuatan metafora, khususnya metafora emosi oleh pemakai BI.

Ketiga, penelitian metafora dengan melibatkan RT yang lebih banyak, misalnya dengan mengikutkan emosi nafsu, kebanggaan, kemaluan, keheranan, dan lain-lain sangat disarankan untuk memperkaya pola-pola metaforis emotif BI dan daftar MK yang mencerminkannya. Selain itu, kekayaan metafora yang khas emosi dapat digali lebih banyak untuk mengetahui secara lebih lengkap kekayaan model budaya yang berhubungan dengan emosi pemakai BI.

Keempat, isu keuniversalan dan kekhasan metafora secara lintas bahasa dan budaya menjadi isu yang sangat menarik untuk diteliti, mengingat isu ini telah menjadi daya tarik para peneliti metafora kognitif di beberapa belahan dunia, terutama Eropah dan Amerika.

Kelima, penelitian ini belum mempertimbangkan ukuran, keseimbangan, dan keterwakilan korpus karena demikian luasnya cakupan BI untuk diteliti dalam waktu yang singkat. Oleh karena itu, penyertaan bahan korpus yang berasal dari tuturan lisan untuk mengimbangi bahan korpus yang bersumber dari bahan tertulis dapat menjadi rekomendasi penting dalam penelitian selanjutnya. 


\section{DAFTAR PUSTAKA}

Albertazzi, L. 2000. Meaning and Cognition: A Multidisciplinary Approach. Amsterdam/Philadelphia: John Benjamins Publishing Company.

Angouri, J. 2010. Quantitative, Qualitative or Both? Combining Methods in Linguistic Research. In: Litosseliti Lia, editor. Research Methods in Linguistics. New York: Continuum International Publishing Group. $29-45$.

Anonim. 2013. The Columbia Electronic Encyclopaedia. Columbia. Columbia University Press. (seri online) [dikutip 19 Agustus 2013). Tersedia di URL: http://cup.columbia.edu/.

Antara, I G.P. 2007. "Metafora Bahasa Bali di Kabupaten Buleleng” (Disertasi). Denpasar. Universitas Udayana.

Baayen, R. H. 2008. Analyzing Linguistics Data: A Practical Introduction to Statistics Using R. Cambridge: Cambridge University Press.

Baker, P. 2010. Corpus Methods in Linguistics. In: Litosseliti Lia, editor. Research Methods in Linguistics. New York: Continuum International Publishing Group. 93-113.

Bernard, H. Russell. 2006. Research Methods in Anthropology: Qualitative and Quantitative Approach. Edisi keempat. New York. AltaMira Press.

Berez, A.L. \& Gries, S.Th., 2010. Correlates to Middle Marking in Dena'ina Iterative Verbs. International Journal of American Linguistics, 76(1): $145-165$.

Black, J. C. 2004. Corpus Approach to Critical Metaphor Analysis. New York: Palgrave Macmillan.

Booij, G. 2007. The Grammar of Words: An Introduction to Morphology. Oxford: Oxford University Press.

Bublitz, W. 2007. Metapragmatics in Use. Amsterdam/ Philadelphia: John Benjamin Publishing Company.

Bungin, M. B. 2007. Penelitian Kualitatif: Komunikasi, Ekonomi, Kebijakan Publik, dan Ilmu Sosial Lainnya. Jakarta: Kencana.

Cienki, Alan. 2005. "Researching Conceptual Metaphors that (may) Underlie Political Discourse". (Makalah ECPR Workshop on Metaphor in Political Sciences).Grenada Spain

Cormac, Earl R. Mac. 1985. A Cognitive Theory of Metaphor. London: The MIT Press.

Crawley, M. J. 2007. The R Book. Chichester: John Wiley and Sons.

Creswell, J. W. 2009. Research Design: Qualitative, Quantitative, and Mixed Methods Approaches. London. SAGE Publications Ltd. 
Croft, W. and D. Alan Cruse. Cognitive Linguistics 2004. New York: Cambridege University Press (e-Library)

Daldiyono, Prof. DR. Dr. 2011. Hemat Emosi: Strategi Meraih Keberhasilan dan Kebahagiaan yang Optimal. Jakarta: PT Bhuana Ilmu Populer Kelompok Gramedia.

Dardjowidjojo, S. 2005. Psikolinguistik: Pengantar Pemahaman Bahasa Manusia. Edisi Kedua. Jakarta: Yayasan Obor Indonesia.

Darma Laksana, I K. 2009. Tabu Bahasa Salah Satu Cara Memahami Kebudayaan Bali. Denpasar: Udayana University Press.

Darma Laksana, I K. 2010. Majas dalam Bahasa Pers: Analisis Tajuk Berita/ Artikel secara Stilistik dan Gramatikal. Denpasar: Udayana University Press.

Deignan, A. 1997. A Corpus-Based Study of Some Linguistic Features of Metaphor (Disertasi Ph.D). Birmingham: The University of Birmingham.

Deignan, A. 2005. Metaphor and Corpus Linguistics. Amsterdam/Philadelphia: John Benjamin Publishing Company.

Dirven, R dan Parings, R (Editor). 2003. Metaphor and Metonymy in Comparison and Contrast. Berlin · New York: Mouton de Gruyter.

Evans, V. and Melanie Green. 2006. Cognitive Linguistics An Introduction. Edinburgh: University Press Ltd.

Evans, V. 2007. A Glossary of Cognitive Linguistics. Edinburgh: Edinburgh University Press.

Fauconnier, G dan Turner, M. 2003. The Way We Think: The Conceptual Blending and the Mind's Hidden Complexities. New York: Basic Book.

Feldman, J. A. 2006. From Molecule to Metaphor: A Neural Theory of Language. Cambridge: The MIT Press. (e-Library)

Fiumara, G. C. 2005. The Metaphoric Process: Connection between Language and Life. USA: Routledge. (e-Library)

Foley, W. A. dan R. D. Van Valin. 1984. Functional Syntax and Universal Grammar.Cambridge: Cambridge University Press.

Frawley. W. 1992. Linguistic Semantics. New Jersy: Lawrence Erlbaum.

Geeraerts, D. and Hubert Cuyckens. 2007. The Oxford Handbook of Cognitive Linguistics. New York: Oxford University Press.

Geeraerts, D. 2010. Theories of Lexical Semantics. New York: Oxford University Press.

Gevaert, C. 2007. "The History of ANGER: The Lexical Field if ANGER from Old to Early Modern English (disertasi). Leuven: Katholieke Universiteit Leuven. 
Gibbs, Jr. Raymond, W. (Editor) 2008. The Cambridge Handbook of Metaphor and Thought. New York: Cambridge University Press.

Givon, T. 1984. Syntax: A Functional-Typology Introduction. Vol. 1. Amsterdam/ Philadelphia: John Benjamins.

Goddard, C. 1994. "Semantics Theory an Semantics Universal". Dalam C. Goddard (ed.) 1996. Cross-Linguistic Syntax from a Semantic Point of View (NSM Approach), 1-5. Canberra: Australian National University.

Gries S. Th. \& Stefanowitsch, A. 2004. "Extending Collostructional Analysis: A Corpus-based Perspective on 'Alternations'. International Journal of Corpus Linguistics 9:1”. John Benjamins Publishing Company.

Gries, S.Th., 2004. HCFA 3.2 - A Program for Hierarchical Configural Frequency Analysis for $R$ for Windows.

Gries, S.Th., Hampe, B. \& Schönefeld, D., 2005. Converging Evidence: Bringing Together Experimental and Corpus Data on the Association of Verbs and Constructions. Cognitive Linguistics, 16(4): 635-676.

Gries, S. Th. 2009a. Quntitative Corpus Linguistics with R: A Practical Introduction. New York. Routledge.

Gries, S.Th., 2009b. Statistics for Linguistics with R: A Practical Introduction, Berlin \& New York: Mouton de Gruyter.

Günter, R. Cs. 2007. Aspect of Meaning Construction. Amsterdam: John Benjamin Publishing Company.

Gunter, S. (Editor). 1997. Referring to Space: Studies in Austronesian and Papuan Languages. Oxford: Clarendon Press.

Hampe, B. (Editor) 2005. From Perception to Meaning: Image Schemas in Cognitive Linguistics . New York: Mouton de Gruyter Berlin. (e-Library)

Harris, R.A. 1993. The Linguistics Wars. New York: Oxford University Press.

Hauf, P. (Editor) 2007. Making Minds: The Shaping of Human Minds Through Social Context. Amsterdam / Philadelphia: John Benjamins Publishing Company

Hester, M.B. 1976. The Meaning of Poetics Metaphor. The Hague: Mouton Coy

Hilpert, M. 2006. Keeping an Eye on the Data: Metonymies and Their Patterns. Dalam: Stefanowitsch, A \& Gries, S.Th., penyunting, Corpus-Based Approaches to Metaphor and Metonymy. Berlin: Mouton De Gruyter. 123-151

Hilpert, M., 2009. The German mit-Predicative Construction. Constructions and Frames, 1(1): .29-55. 
Hoffmann, T., 2011. Preposition Placement in English: A Usage-based Approach, Cambridge: Cambridge University Press.

Hunston, S \& Francis, G. 2000. Pattern Grammar. A Corpus-driven Approach to Lexical Grammar of English. Amsterdam/ Philadelphia: John Benjamin.

Hunston, S. 2002. Corpora in Applied Linguistics. Cambridge: Cambridge University Press.

King, B. 1989. "The Conceptual Structure of Emotional Experience in Chinese" (Disertasi Ph.D). Ohio: The Hoio State University.

Knowles, Murry and Rosamund Moon. 2005. Introducing Metaphor. New York: Tylor \& Francis e-Library.

Kövecses, Zoltán. 1986. Metaphors of Anger, Pride and Love: a Lexical approach to the Structure of Concepts. Amsterdam \& Philadelphia: John Benjamins.

Kövecses, Z. 1995. “Anger: Its Language, Conceptualization, and Physiology in the Light of Cross-Cultural Evidence." dalam Language and the Cognitive Construal of the World. [Trends in Linguistics. Studies and Monographs 82], John R. Taylor \& Robert E. MacLaury (editor),182-196. Berlin: Mouton de Gruyter.

Kövecses, Z. \& Péter Szabó. 1996. "Idioms: A View from Cognitive Semantics". Applied Linguistics 17: 326-355.

Kövecses, Z. 2000. Metaphor and Emotion: Language, Culture, and Body in Human Feeling. Cambridge: Cambridge University Press.

Kövecses, Z. 2002. Metaphor: A Practical Introduction. New York: Oxford University Press.

Kövecses, Z. 2005. Metaphor in Culture: Universality and Variation. Cambridge: Cambridge University Press.

Kövecses, Z. 2006. Language, Mind, and Culture: A Practical Introduction. New York: Oxford University Press.

Kövecses, Z. 2008. "Universality and Variation in the Use of Metaphor." Selected Papers from the 2006 and 2007 Stockholm Metaphor Festivals, eds. N. L. Johannesson \& D.C Minugh. 51-74 . Stockholm: Department of English, Stockholm University.

Kövecses, Z. 2008a. Conceptual Metaphor Theory: Some Criticisms and Alternative Proposals. Annual Review of Cognitive Linguistics 6: 168184.

Kövecses, Z. 2008b. "The Conceptual Structure of Happiness. In Happiness: Cognition, Experience, Language", ed. Heli Tissari, Anne Birgitta Passi \& Mikko Salmela, 131-143. Helsinki: Helsinki Collegium for Advanced Studies. 
Kövecses, Z. 2010. Metaphor: A Practical Introduction. Second Edition. Oxford: Oxford University Press.

Kramadibrata, K. 2003. "Embodiment. Human Bodily Experience Through Metaphor: A comparison in the Indonesian and German Languages" KOLITA 1. Jakarta: PKBB Unika Atmajaya.

Kristiansen, G. and Cs. 2006. Cognitive Linguistics: Current Applications and Future Perspectives. New York: Mouton de Gruyter Berlin. (e-Library).

Kristiansen, G. dan Rene D. (Editor). 2008. Cognitive Sociolinguistics: Language Variation, Cultural Models, Social Systems. New York: Mouton de Gruyter Berlin. (e-Library)

Lakoff, G. and M. Johnson. 1980. Metaphors We Live By. Chicago: University of Chicago Press.

Lakoff, G. and Z. Kovecses. 1987. "The Cognitive Model of Anger Inherent in American English". Dalam: Holland D dan N. Quinn, editor Cultural Model in Language and Thought. New York, Cambridge University Press, halaman 195-222

Lakoff, G. 1987. Women, Fire, and Dangerous Things: What Categories Reveal about the Mind. Chicago: University of Chicago Press.

Lakoff, G. dan Turner, Mark. 1989. More Than Cool Reason: A Field Guide to Poetic Metaphor. Chikago: University of Chikago Press.

Lakoff, George (1990) 'The Invariance Hypothesis: Is Abstract Reason Based on Image Schemas?', Cognitive Linguistics, 1, 1, 39-74.

Lakoff, G. 1993. The Contemporary Theory of Metaphor. In A. Ortony (ed) Metaphor and thought (2nd ed) (pp. 202-251). New York: Cambridge University Press.

Lakoff, G. 2006. "The Contemporary Theory of Metaphor." dalam Cognitive Linguistics: Basic Readings. [Cognitive Linguistics Research 34], Dirk Geeraerts (editor), 185-238. Berlin: Mouton de Gruyter.

Langacker, R. W. 2007. Cognitive Grammar. Dalam: Geeraerts, D. \& Cuyckens, H., penyunting. The Oxford Handbook of Cognitive Linguistics. Oxford: Oxford University Press. 421-462

Langacker, R. W. 2008. Cognitive Grammar: A Basic Introduction. New York: Oxford University Press. (Google Book Library).

Langlotz, Andreas. 2006. Idiomatic Creativity: A Cognitive-Lingistic Model of Idiom- Representation and Idiom-Variation in English. Amsterdam/ Philadelphia: John Benjamin Publishing Company.

Lyons, J. 1977. Semantics (vol. 2). Cambridge: Cambridge University Press.

Mahsun. 2005. Metode Penelitian Bahasa. Jakarta: Raja Grafindo Perkasa. 
Matsuki, K. 1995. "Metaphors of Anger in Japanese." dalam Language and the Cognitive Construal of the World. [Trends in Linguistics. Studies and Monographs 82], John R. Taylor \& Robert E. MacLaury (editor),137-151. Berlin: Mouton de Gruyter.

Mauch, J. E. \& Namgi Park. 2003. Guide to Succesful Thesis and Dissertation: A Handbook for Students and Faculty ( $5^{\text {th }}$ edition). New

York/Basel: Marcel Dekker, Inc.

Moleong, L. J. 1995. Metodologi Penelitian Kualitatif. Bandung: Remaja Rosdakarya.

Moreno, R.E.V. 2007. Creativity and Convention: The Prgamatics of Everyday Figuratif Speech. Amsterdam/ Philadelphia: John Benjamin Publishing Company.

Muhajir, N. 1989. Metodologi Penelitian Kualitatif: Telaah Positivistik, Rasionalistik, dan Fenomenologik. Yogyakarta: Rake Sarasin.

Mulyadi. 1998a. "Makna Malu dalam Bahasa Indonesia". (Kajian "Wacana Kebudayaan"). Linguistika, 8: 46-57.

Mulyadi. 2010. "Metafora Emosi dalam Bahasa Indonesia.” Makalah disajikan Pada Seminar Internasional Austronesia V di Denpasar, Bali. Indonesia, 19 - 20 Juli 2010.

Ortony, A. (Editor) 1979. Metaphor and Thought. London: Cambridge University Press.

Oster, U. 2010. Using Corpus Methodology for Semantic and Pragmatic Analyses: Whan can corpus tell us about the linguistic expression of emotions?. Cognitive Linguistics Volume 21 No. 4: 727-763.

Palmer, G.B. 1996. Toward a Theory of Cultural Linguistics. USA: The University of Texas Press.

Phillip R. S., Upekkha Murdaya dan R. Chris Fraley. 2001. "Structure of the Indonesian Emotion Lexicon". Asian Journal of Social Psychology Volume 4, No. 3: 201-224.

Rajeg, I M. 2009. “Cintanya Bertepuk Sebelah Tangan: Metaphoric and Metonymic Conceptualisation of LOVE in Indonesian". Makalah yang disajikan dalam KIMLI 1 (Kongres Internasional Masyarakat Linguistik Indonesia I) di Batu, Malang, Indonesia, 5 - 7 November 2009.

Rajeg, I M. 2010a. "Kebus Basange: Metaphoric and Metonymic Conceptualisation of ANGER in Balinese." Makalah disajikan dalam Seminar Nasional Bahasa Ibu III di Denpasar, Bali. Indonesia, 24 - 25 Februari 2010.

Rajeg, I M. 2010b. “Amarahnya Membara: Metaphoric and Metonymic Conceptualisation of ANGER in Indonesian." Makalah disajikan dalam Seminar Internasional Austronesia V di Denpasar, Bali. Indonesia, 19 - 20 
Juli 2010 .

Rajeg, I M. 2012. “Nikmatilah Kebahagiaan Ini.” "Metafora Emosi KEBAHAGIAAN dalam Bahasa Indonesia: Analisis Pola Metafora Berbasis Korpus". Makalah disajikan dalam Seminar Nasional Bahasa Ibu V di Denpasar, Bali. Indonesia, 17 - 18 Februari 2012.

Ritchie, L.D. 2013. Metaphor. Cambridge.Cambridge University Press

Rosch, E. 1977. "Human Categorization" in N. Warren (ed.), Studies in Cross-Linguistics Psychology. London: Academic Press, hal 1-49

Samarin, W. J. 1988. Ilmu Bahasa Lapangan. Yogyakarta: Kanisius.

Sandström, K. 2006. "When Motion Becomes Emotion: A Study of Emotion Metaphors Derived from Motion Verbs." Linguistics in the Midnight Sun. Report No. 3.

Scott, Mike. 2012. WordSmith Tools Version 6.0. Liverpol: Lexical Analysis Software Ltd.

Siahaan, Poppy. 2008. "Did he break your heart or your liver? A contrastive study on metaphorical concepts from the source domain ORGAN in English and in Indonesian". In Culture, Body, and Language. Conceptualizations of Internal Body Organs across Cultures and Languages, Farzad Sharifian, René Dirven, Ning Yu and Susanne Niemeier (eds.), 45-74. Berlin and New York: Mouton de Gruyter.

Siregar, B. U. 2004. "Metafora Kekuasaan dan Metafora Melalui Kekuasaan: Melacak Perubahan Kemasyarakatan Melalui Perilaku Bahasa” PELBA 17. Jakarta: Yayasan Obor Indonesia.

Stefanowitsch, A., 2004a. HAPPINESS in English and German: A Metaphoricalpattern Analysis. In M. Achard \& S. Kemmer, eds. Language, Culture, and Mind. Stanford: CSLI Publication, 137-149.

Stefanowitsch, A., 2004b. Quantitative Thinking for Corpus Linguists. Available at: http://www1.uni-hamburg.de/stefanowitsch/qnt/qnt_dist.html [Accessed February 12, 2012].

Stefanowitsch, A., 2005. The Function of Metaphor: Developing a Corpus-based Perspective. International Journal of Corpus Linguistics, 10(2): 161-198.

Stefanowitsch, A., 2006a. Negative Evidence and The Raw Frequency Fallacy. Corpus Linguistics and Linguistic Theory, 2(1):.61-77.

Stefanowitsch, A., 2006b. Words and Their Metaphors: A Corpus-based Approach. In A. Stefanowitsch \& S. Th. Gries, eds. Corpus-based Approaches to Metaphor and Metonymy. Berlin \& New York: Mouton de Gruyter, 63-105.

Stefanowitsch, A., 2011. Cognitive Linguistics Meets the Corpus. In M. Brdar, S. Th. Gries, \& M. Ž. Fuchs, eds. Cognitive Linguistics: Convergence and 
Expansion. Amsterdam \& Philadelphia: John Benjamins, 257-289.

Stefanowitsch, A. \& Gries, S.Th., 2003. Collostructions: Investigating the Interaction of Words and Constructions. International Journal of Corpus Linguistics, 8(2): .209-243.

Stefanowitsch, A. \& Gries, S.Th., 2005. Covarying Collexemes. Corpus Linguistics and Linguistic Theory, 1(1): 1-43.

Stefanowitsch, A. \& Gries S. T. 2006. Corpus-Based Approaches to Metaphor and Metonymy. New York: Mouton de Gruyter.

Stefanowitsch, A. Naskah. Cfa.pl (Version 0.9 beta) Configural Frequency Analysis. Availabel at: URL: www1.uni-hamburg.de/ stefanowitsch/ qnt/cfa.zip.

Steinberg, D. D. 1982. Psycholinguistics: Language, Mind, and World. New York: Longman Group Limited.

Stern, J. 2000. Metaphor in Context. England: The MIT Press.

Sudaryanto, 1993. Metode dan Teknik Analisis Bahasa: Pengantar Penelitian Wahana Kebudayaan secara Linguistis. Yogyakarta: Duta Wacana University Press.

Sudipa, I N. 2004. "Verba Bahasa Bali: Sebuah Kajian Metabahasa Semantik Alami”. (Disertasi). Denpasar: Universitas Udayana.

Sullivan, K. S. 2007. “Grammar in Metaphor: A Construction Grammar Account of Metaphoric Language" (Disertasi Ph.D). Berkeley: University of California.

Sunderland, J. 2010. Research Questions in Linguistics. In: Litosseliti Lia, editor. Research Methods in Linguistics. New York: Continuum International Publishing Group: 9-28.

Sutjiati Beratha, N. L. 1995. "Natural Semantic Metalanguages dalam Proses dan Proses Budaya”. Linguistika. Tahun III. Edisi 5: 11 - 16.

Sutjiati Beratha, N. L. 1997. "Basic Concepts of a Universal Semantic Metalanguages". Linguistika, 6: 110-115.

Talmy, L. 2000. Toward A Cognitive Semantics Volume I: Concept Structuring Systems. Massachusetts:The MIT Press.

Talmy, L. 2000. Toward A Cognitive Semantics Volume II:Typology and Process in Concept Structuring. Massachusetts:The MIT Press.

Van Valin, R. D. 2005. Exploring the Syntax-Semantics Interface. Cambridge: Cambridge University Press.

Van Valin, R. D. dan R. LaPolla. 1999. Syntax: Structure, Meaning, and Function. Cambridge: Cambridge University Press. 
Von Eye, A., 2002. Configural Frequency Analysis: Methods, Models, and Applications, Mahwah, NJ: Lawrence Erlbaum Associates.

Von Eye, A., Mair, P. \& Mun, E.-Y., 2010. Advances in Configural Frequency Analysis, New York: The Guilford Press.

Wahab, A. 1986. "Javanese Metaphor in Discourse Analysis" (Disertasi). Urbana Champaign: The University of Illinois.

Wiechmann, D., 2010. Understanding Complex Constructions: A Quantitative Corpus-Linguistic Approach to the Processing of English Relative Clauses. PhD Dissertation. Jena: Friedrich-Schiller-Universität.

Wierzbicka, A. 1991. Cross-Cultural Pragmatics: The Semantics of Social Interaction. Berlin: Mouton de Guyter.

Wierzbicka, A. 1992. Semantics, Cultural and Cognition. Oxford:Oxford University Press.

Wierzbicka, A. 1996c. Semantics: Primes and Universals. Oxford:Oxford University Press.

Wierzbicka, A. 1999. Emotions Across Languages and Cultures. Cambridge:Cambridge University Press.

Yuditha, T. 2012. "Indonesian Metaphorical Conceptualization of Anger: Does Anger Taste Delicious or Disgusting?". International Conference on Austronesian Languages (12 ICAL). Bali. Udayana University

Yumarnanto, M. 2003. "Componential Mapping and Conceptual Metaphor: Two Approaches to Understand Complex Metaphors". KOLITA 1. Jakarta: PKBB Unika Atmajaya.

Yu, N. 1995. "Metaphorical Expressions of Anger and Happiness in English and Chinese." Metaphor and Symbolic Activity 10 (2): 59 - 92.

Yu, N. 2002. "Body and Emotion." Pragmatics and Cognition. 10 (1/2): 341367.

Zanotto, M. S. (Editor) 2008. Confronting Metaphor in Use: An Apllied Linguistics Approach. Amsterdam/ Philadelphia: John Benjamin Publishing Company. 
LAMPIRAN 1: Hasil Analisis CFA untuk Variabel Metafora dan Emosi

\begin{tabular}{|c|c|c|c|c|c|c|c|c|}
\hline Metafora & Emosi & $\begin{array}{l}\text { Frek. } \\
\text { Riil }\end{array}$ & $\begin{array}{l}\text { Frek. } \\
\text { Har. }\end{array}$ & $\begin{array}{l}\text { Kontr. pd } \\
\text { chi-kwadrat }\end{array}$ & $\begin{array}{l}\text { Riil- } \\
\text { Har }\end{array}$ & P.adj.Holm & Put & $\mathrm{K}$ \\
\hline PERGERAKAN (AKSIDENTAL) MENUJU SUATU LOKASI & CINTA & 91 & 20,6453 & 239,7535 & $>$ & $8,96 \mathrm{E}-28$ & $* * *$ & 0,023 \\
\hline KEPEMILIKAN & KEBAHAGIAAN & 103 & 44,7767 & 75,708 & $>$ & $1,81 \mathrm{E}-11$ & $* * *$ & 0,019 \\
\hline KEPEMILIKAN & AMARAH/KEMARAHAN & 23 & 73,8895 & 35,0488 & $<$ & $1,21 \mathrm{E}-09$ & $* * *$ & 0,017 \\
\hline KONTROL OBJEK BERGERAK & AMARAH/KEMARAHAN & 75 & 27,4796 & 82,1769 & $>$ & $1,86 \mathrm{E}-11$ & $* * *$ & 0,016 \\
\hline UNSUR DALAM WADAH (BERTEKANAN) & AMARAH/KEMARAHAN & 95 & 51,9059 & 35,7782 & $>$ & $1,65 \mathrm{E}-05$ & $* * *$ & 0,014 \\
\hline (SECARA POTENSIAL) MEMBERIKAN SUATU OBJEK & KEBAHAGIAAN & 54 & 17,5776 & 75,4706 & $>$ & $8,75 \mathrm{E}-10$ & $* * *$ & 0,012 \\
\hline API & AMARAH/KEMARAHAN & 50 & 17,4037 & 61,0513 & $>$ & $5,39 \mathrm{E}-08$ & $* * *$ & 0,011 \\
\hline KEKUATAN ALAM & AMARAH/KEMARAHAN & 60 & 27,4796 & 38,4859 & $>$ & $1,98 \mathrm{E}-05$ & $* * *$ & 0,011 \\
\hline MUSUH/LAWAN & KETAKUTAN & 47 & 17,0085 & 52,8847 & $>$ & $6,32 \mathrm{E}-07$ & $* * *$ & 0,01 \\
\hline PERGERAKAN (AKSIDENTAL) MENUJU SUATU LOKASI & AMARAH/KEMARAHAN & 0 & 27,7849 & 27,7849 & $<$ & $3,30 \mathrm{E}-10$ & $* * *$ & 0,009 \\
\hline CAIRAN DALAM WADAH & AMARAH/KEMARAHAN & 42 & 18,0144 & 31,9361 & $>$ & 0,0003771 & $* * *$ & 0,008 \\
\hline MENEMUKAN/MERAIH SUATU OBJEK & KEBAHAGIAAN & 29 & 5,7359 & 94,3563 & $>$ & 1,79E-09 & $* * *$ & 0,008 \\
\hline MUSUH/LAWAN & KEBAHAGIAAN & 3 & 26,0889 & 20,4339 & $<$ & $6,12 \mathrm{E}-06$ & $* * *$ & 0,008 \\
\hline (SECARA POTENSIAL) MEMBERIKAN SUATU OBJEK & AMARAH/KEMARAHAN & 8 & 29,0062 & 15,2126 & $<$ & 0,0016456 & $* *$ & 0,007 \\
\hline CAIRAN PANAS DALAM WADAH & AMARAH/KEMARAHAN & 30 & 9,1599 & 47,4142 & $>$ & $1,61 \mathrm{E}-05$ & $* * *$ & 0,007 \\
\hline KONTROL OBJEK BERGERAK & CINTA & 0 & 20,4184 & 20,4184 & $<$ & $5,47 \mathrm{E}-07$ & $* * *$ & 0,007 \\
\hline MUSUH/LAWAN & CINTA & 12 & 31,9889 & 12,4905 & $<$ & 0,0179395 & $*$ & 0,007 \\
\hline TINGGI/RENDAH (KEKERAPAN) & AMARAH/KEMARAHAN & 27 & 8,5492 & 39,8203 & $>$ & 0,0001477 & $* * *$ & 0,006 \\
\hline UKURAN/KUANTITAS & CINTA & 10 & 28,1321 & 11,6868 & $<$ & 0,0295025 & $*$ & 0,006 \\
\hline UNSUR DALAM WADAH (BERTEKANAN) & CINTA & 21 & 38,5682 & 8,0025 & $<$ & 0,5259086 & ns & 0,006 \\
\hline (SECARA POTENSIAL) MENDAPAT SUATU OBJEK & KEBAHAGIAAN & 29 & 10,5466 & 32,2879 & $>$ & 0,0008399 & $* * *$ & 0,006 \\
\hline PERGERAKAN (AKSIDENTAL) MENUJU SUATU LOKASI & KEBAHAGIAAN & 0 & 16,8375 & 16,8375 & $<$ & $1,98 \mathrm{E}-05$ & $* * *$ & 0,006 \\
\hline
\end{tabular}


OBJEK (TAK)TERSEMBUNYI/TAMPAK

MELAKUKAN SESUATU/MENJADI DISERTAI/TEMANI DENGAN OBJEK

ADANYA/KEBERADAAN/KEHADIRAN FISIK SUATU OBJEK

\section{CAIRAN}

MUSUH/LAWAN

OBJEK DI SUATU LOKASI

\section{IKATAN}

KEKUATAN ALAM

KONTROL OBJEK BERGERAK

MENCARI/MENGEJAR/MEMBURU SUATU OBJEK

OBJEK (TAK)TERSEMBUNYI/TAMPAK

SANTAPAN (MAKANAN/MINUMAN)

UNSUR DALAM WADAH (BERTEKANAN)

ADANYA/KEBERADAAN/KEHADIRAN FISIK SUATU OBJEK

\section{CAIRAN}

PERGERAKAN (AKSIDENTAL) MENUJU SUATU LOKASI

(SECARA POTENSIAL) MENDAPAT SUATU OBJEK

CAHAYA

PANAS/DINGIN (SUATU OBJEK)

PERJALANAN

UKURAN/KUANTITAS

(OBJEK BER)WARNA

CAIRAN DALAM WADAH

OBJEK DI SUATU LOKASI
KESEDIHAN

KETAKUTAN

AMARAH/KEMARAHAN

AMARAH/KEMARAHAN

AMARAH/KEMARAHAN

AMARAH/KEMARAHAN

CINTA

CINTA

KEBAHAGIAAN

KEBAHAGIAAN

KEBAHAGIAAN

KEBAHAGIAAN

KEBAHAGIAAN

KESEDIHAN

KESEDIHAN

KESEDIHAN

AMARAH/KEMARAHAN

AMARAH/KEMARAHAN

AMARAH/KEMARAHAN

AMARAH/KEMARAHAN

AMARAH/KEMARAHAN

CINTA

CINTA

CINTA
50

$15 \quad 31,1435$

$0 \quad 15,5718$

94,0513

$1 \quad 26,2583$

$20 \quad 4,7643$

$6 \quad 20,4184$

$0 \quad 16,6525$

$19 \quad 4,6257$

$22 \quad 37,0056$

8,3263

31,4547

16,5387

8,2694

$0 \quad 14,7551$

$4 \quad 17,4037$

$28 \quad 14,9611$

64,8853

$0 \quad 10,6865$

$27 \quad 37,8607$

$1 \quad 13,3854$

$31 \quad 19,511$
$9,5206>$

0,8731969 ns $\quad 0,006$

$26,2036>0,0047174 * * \quad 0,006$

$8,3681<0,3846111$ ns 0,005

$15,5718<7,02 \mathrm{E}-05 * * * 0,005$

$5,9083>3,9071039$ ns 0,005

$8,8664<0,2471219$ ns 0,005

$48,7221>6,71 \mathrm{E}-05 \quad * * * \quad 0,005$

$10,1815<0,0714243 \mathrm{~ms} 0,005$

$16,6525<2,38 \mathrm{E}-05 \quad * * * 0,005$

$44,6679>0,0001841 * * * 0,005$

$6,0847<1,8877709$ ns 0,005

$33,3897>0,0009308 * * * 0,005$

$7,5934<0,6584225$ ns 0,005

$12,6448>0,3527359$ ns 0,005

$26,2402>0,0074992 * * 0,005$

$14,7551<0,0001584 * * * 0,005$

$10,323<0,0513593 \mathrm{~ms} 0,004$

$11,3637>0,6003273$ ns 0,004

$25,2874>0,0207111 * 0,004$

$10,6865<0,0091057 * * 0,004$

$3,1155<11,744986$ ns 0,004

$27,376>0,0075691 * * 0,004$

$11,4601<0,0087765 * * 0,004$

$6,7653>3,3193879$ ns 0,004 
UNGKAPAN VERBAL/BAHASA

KEKUATAN ALAM

PERJALANAN

(MENJADI) BERADA DI BAWAH

BEBAN

UKURAN/KUANTITAS

KONTROL OBJEK BERGERAK

LOKASI (TERKUNGKUNG/WADAH)

PERGERAKAN (AKSIDENTAL) MENUJU SUATU LOKASI

BINATANG TAWANAN/BUAS

MENCARI/MENGEJAR/MEMBURU SUATU OBJEK

MENEMUKAN/MERAIH SUATU OBJEK

OBJEK YANG DIARAH/GERAKKAN (KE SESEORANG)

ADANYA/KEBERADAAN/KEHADIRAN FISIK SUATU OBJEK

\section{CAHAYA}

CAIRAN

CERITA

MELAKUKAN SESUATU/MENJADI DISERTAI/TEMANI DENGAN OBJEK

OBJEK BERSIFAT ILAHI/KEILAHIAN

PERJALANAN

TANAMAN

(MENJADI) BERADA DI ATAS/MELAYANG

API

CAIRAN DALAM WADAH

MELAKUKAN SESUATU/MENJADI DISERTAI/TEMANI DENGAN OBJEK
CINTA

KEBAHAGIAAN

KEBAHAGIAAN

KESEDIHAN

KESEDIHAN

KESEDIHAN

KETAKUTAN

KETAKUTAN

KETAKUTAN

AMARAH/KEMARAHAN

AMARAH/KEMARAHAN

AMARAH/KEMARAHAN

AMARAH/KEMARAHAN

CINTA

CINTA

CINTA

CINTA

CINTA

CINTA

CINTA

CINTA

KEBAHAGIAAN

KEBAHAGIAAN

KEBAHAGIAAN

KEBAHAGIAAN

$\begin{array}{rrrlrlll}17 & 5,218 & 26,6032 & > & 0,0131972 & * & 0,004 \\ 4 & 16,6525 & 9,6133 & < & 0,091657 & \mathrm{~ms} & 0,004 \\ 19 & 6,476 & 24,2203 & > & 0,0188047 & * & 0,004 \\ 13 & 2,1079 & 56,2825 & > & 0,0001537 & * * * & 0,004 \\ 16 & 4,0536 & 35,2073 & > & 0,0023332 & * * & 0,004 \\ 32 & 20,1059 & 7,0362 & > & 2,9240276 & \mathrm{~ns} & 0,004 \\ 0 & 10,8565 & 10,8565 & < & 0,0077154 & * * & 0,004 \\ 19 & 7,9614 & 15,3052 & > & 0,2322112 & \mathrm{~ns} & 0,004 \\ 0 & 10,9771 & 10,9771 & < & 0,006886 & * * & 0,004 \\ 17 & 7,6332 & 11,4941 & > & 0,8514908 & \mathrm{~ns} & 0,003 \\ 0 & 7,6332 & 7,6332 & < & 0,185569 & \mathrm{~ns} & 0,003 \\ 0 & 9,4652 & 9,4652 & < & 0,0303208 & * & 0,003 \\ 16 & 8,2439 & 7,2972 & > & 3,6176361 & \mathrm{~ns} & 0,003 \\ 13 & 23,1409 & 4,444 & < & 5,2301776 & \mathrm{~ns} & 0,003 \\ 3 & 11,1167 & 5,9263 & < & 1,6069188 & \mathrm{~ns} & 0,003 \\ 1 & 11,5704 & 9,6568 & < & 0,0460208 & * & 0,003 \\ 13 & 2,9493 & 34,251 & > & 0,0054996 & * * & 0,003 \\ 14 & 21,7797 & 2,7789 & < & 14,62031 & \mathrm{~ns} & 0,003 \\ 12 & 2,7225 & 31,6151 & > & 0,0113915 & * & 0,003 \\ 16 & 7,9405 & 8,1803 & > & 2,6550582 & \mathrm{~ns} & 0,003 \\ 16 & 6,5793 & 13,4892 & > & 0,4857328 & \mathrm{~ns} & 0,003 \\ 10 & 1,8503 & 35,8956 & > & 0,0097916 & * * & 0,003 \\ 0 & 10,5466 & 10,5466 & < & 0,0104266 & * & 0,003 \\ 3 & 10,9166 & 5,741 & < & 1,8591923 & \mathrm{~ns} & 0,003 \\ 10 & 17,7627 & 3,3925 & < & 10,122387 & \mathrm{~ns} & 0,003\end{array}$


OBJEK RAPUH/PECAH BELAH

UKURAN/KUANTITAS

API

(SECARA POTENSIAL) MEMBERIKAN SUATU OBJEK

BERTINDAK/MELAKUKAN SESUATU DI DALAM SUATU LOKASI

CAIRAN

KEPEMILIKAN

UKURAN/KUANTITAS

(OBJEK BER)WARNA

GANGGUAN FISIK

IKATAN

KEGELAPAN/GELAP

LOKASI (TERKUNGKUNG/WADAH)

MANUSIA/ORGANISME (TERTIDUR/TENANG)

OBJEK ASLI/PALSU

OBJEK BERGERAK

PERGERAKAN TERDORONG SUATU OBJEK

PERILAKU AGRESIF BINATANG

SANTAPAN (MAKANAN/MINUMAN)

(SECARA POTENSIAL) MENDAPAT SUATU OBJEK

API

BEBAN

BINATANG TAWANAN/BUAS

CAIRAN PANAS DALAM WADAH

KESALAHAN

MABUK

KEBAHAGIAAN
KEBAHAGIAAN
KESEDIHAN
KETAKUTAN
KETAKUTAN
KETAKUTAN
KETAKUTAN
KETAKUTAN
AMARAH/KEMARAHAN
AMARAH/KEMARAHAN
AMARAH/KEMARAHAN
AMARAH/KEMARAHAN
AMARAH/KEMARAHAN
AMARAH/KEMARAHAN
AMARAH/KEMARAHAN
AMARAH/KEMARAHAN
AMARAH/KEMARAHAN
AMARAH/KEMARAHAN
AMARAH/KEMARAHAN
CINTA
CINTA
CINTA
CINTA
CINTA
CINTA
CINTA
22,9434 9,2422

11,4596

3,3776

6,152

29,1919

14,9578

28,8545

3,0533

6,4119

$8 \quad 14,0451$

20,1517

37,2501

4,8853

$1 \quad 16,4877$

3,6639

3,0533

13,7398

\begin{tabular}{ll}
13,7398 \\
\hline
\end{tabular}

$6 \quad 12,9317$

5,6718

$0 \quad 5,6718$

$0 \quad 6,8061$

$7 \quad 1,5881$

$8 \quad 1,815$

$\begin{array}{rlrll}27,2593 & > & 0,0426337 & * & 0,003 \\ 2,8291 & > & 17,045238 & \mathrm{~ns} & 0,003 \\ 7,3504 & < & 0,3747281 & \mathrm{~ns} & 0,003 \\ 9,5469 & < & 0,0508513 & \mathrm{~ms} & 0,003 \\ 22,0114 & > & 0,0811854 & \mathrm{~ms} & 0,003 \\ 10,0116 & > & 1,6107119 & \mathrm{~ns} & 0,003 \\ 2,2988 & < & 19,303258 & \mathrm{~ns} & 0,003 \\ 5,4661 & > & 6,007191 & \mathrm{~ns} & 0,003 \\ 5,3062 & < & 2,4382338 & \mathrm{~ns} & 0,002 \\ 8,0142 & > & 4,3592005 & \mathrm{~ns} & 0,002 \\ 4,5679 & < & 4,0810588 & \mathrm{~ns} & 0,002 \\ 2,6018 & < & 16,75812 & \mathrm{~ns} & 0,002 \\ 2,5381 & < & 17,040106 & \mathrm{~ns} & 0,002 \\ 1,2231 & > & 32,278151 & \mathrm{~ns} & 0,002 \\ 4,8853 & < & 2,6271779 & \mathrm{~ns} & 0,002 \\ 1,8265 & < & 25,471271 & \mathrm{~ns} & 0,002 \\ 7,7715 & > & 4,3177352 & \mathrm{~ns} & 0,002 \\ 15,8047 & > & 0,4707511 & \mathrm{~ns} & 0,002 \\ 3,3061 & < & 10,773163 & \mathrm{~ns} & 0,002 \\ 3,8634 & > & 11,867721 & \mathrm{~ns} & 0,002 \\ 3,7156 & < & 8,2003933 & \mathrm{~ns} & 0,002 \\ 3,8481 & < & 7,252272 & \mathrm{~ns} & 0,002 \\ 5,6718 & < & 1,2462027 & \mathrm{~ns} & 0,002 \\ 6,8061 & < & 0,4163652 & \mathrm{~ns} & 0,002 \\ 18,4426 & >0,4808565 & \mathrm{~ns} & 0,002 \\ 21,0767 & >0,2273648 \mathrm{~ns} & 0,002\end{array}$


MANUSIA/ORGANISME (TERTIDUR/TENANG)

MENEMUKAN/MERAIH SUATU OBJEK

OBJEK (TAK)TERSEMBUNYI/TAMPAK

OBJEK BERGERAK

TINGGI/RENDAH (KEKERAPAN)

(KUATNYA AKIBAT DARI SUATU) KEKUATAN FISIK

(OBJEK BER)WARNA

ADANYA/KEBERADAAN/KEHADIRAN FISIK SUATU OBJEK

BEBAN

CAIRAN PANAS DALAM WADAH

LOKASI (TERKUNGKUNG/WADAH)

MANUSIA/ORGANISME (TERTIDUR/TENANG)

OBJEK ASLI/PALSU

OBJEK BERHARGA DAN METAFORA KOMERSIL LAINNYA

OBJEK DAMBAAN

OBJEK FISIK

OBJEK YANG DIARAH/GERAKKAN (KE SESEORANG)

SUARA/BUNYI/NADA

TINGGI/RENDAH (KEKERAPAN)

(SECARA POTENSIAL) MEMBERIKAN SUATU OBJEK

(SECARA POTENSIAL) MENDAPAT SUATU OBJEK

CAHAYA

CAIRAN PANAS DALAM WADAH

KEDALAMAN

MELAKUKAN SESUATU/MENJADI DISERTAI/TEMANI DENGAN OBJEK

OBJEK FISIK

\begin{abstract}
CINTA
CINTA

CINTA

CINTA

CINTA

KEBAHAGIAAN

KEBAHAGIAAN

KEBAHAGIAAN

KEBAHAGIAAN

KEBAHAGIAAN

KEBAHAGIAAN

KEBAHAGIAAN

KEBAHAGIAAN

KEBAHAGIAAN

KEBAHAGIAAN

KEBAHAGIAAN

KEBAHAGIAAN

KEBAHAGIAAN

KEBAHAGIAAN

KESEDIHAN

KESEDIHAN

KESEDIHAN

KESEDIHAN

KESEDIHAN

KESEDIHAN

KESEDIHAN
\end{abstract}

$\begin{array}{rrrlrlll}34 & 27,6783 & 1,4439 & > & 30,079589 & \mathrm{~ns} & 0,002 \\ 1 & 7,033 & 5,1752 & < & 2,4654991 & \mathrm{~ns} & 0,002 \\ 38 & 45,3743 & 1,1985 & < & 32,39303 & \mathrm{~ns} & 0,002 \\ 18 & 12,2511 & 2,6977 & > & 19,627099 & \mathrm{~ns} & 0,002 \\ 0 & 6,3524 & 6,3524 & < & 0,6439631 & \mathrm{~ns} & 0,002 \\ 1 & 7,2161 & 5,3547 & < & 2,1230565 & \mathrm{~ns} & 0,002 \\ 0 & 5,3658 & 5,3658 & < & 1,6746206 & \mathrm{~ns} & 0,002 \\ 26 & 18,8728 & 2,6915 & > & 18,652568 & \mathrm{~ns} & 0,002 \\ 0 & 4,6257 & 4,6257 & < & 3,3485749 & \mathrm{~ns} & 0,002 \\ 0 & 5,5508 & 5,5508 & < & 1,4028795 & \mathrm{~ns} & 0,002 \\ 7 & 12,2118 & 2,2243 & < & 21,101816 & \mathrm{~ns} & 0,002 \\ 18 & 22,5734 & 0,9266 & < & 38,616898 & \mathrm{~ns} & 0,002 \\ 8 & 2,9604 & 8,5791 & > & 3,7509616 & \mathrm{~ns} & 0,002 \\ 10 & 2,4054 & 23,9785 & > & 0,0795197 & \mathrm{~ms} & 0,002 \\ 8 & 2,2203 & 15,0452 & > & 0,7702048 & \mathrm{~ns} & 0,002 \\ 4 & 9,2514 & 2,9809 & < & 13,67127 & \mathrm{~ns} & 0,002 \\ 0 & 4,9958 & 4,9958 & < & 2,372151 & \mathrm{~ns} & 0,002 \\ 1 & 6,2909 & 4,4499 & < & 4,4777906 & \mathrm{~ns} & 0,002 \\ 0 & 5,1808 & 5,1808 & < & 1,9988373 & \mathrm{~ns} & 0,002 \\ 8 & 15,4037 & 3,5585 & < & 9,1496668 & \mathrm{~ns} & 0,002 \\ 3 & 9,2422 & 4,216 & < & 5,7343942 & \mathrm{~ns} & 0,002 \\ 1 & 7,9451 & 6,071 & < & 1,1510004 & \mathrm{~ns} & 0,002 \\ 0 & 4,8643 & 4,8643 & < & 2,6674377 & \mathrm{~ns} & 0,002 \\ 7 & 1,6214 & 17,8422 & > & 0,5362721 & \mathrm{~ns} & 0,002 \\ 10 & 15,5659 & 1,9902 & < & 23,499753 & \mathrm{~ns} & 0,002 \\ 14 & 8,1072 & 4,2832 & > & 11,065832 & \mathrm{~ns} & 0,002\end{array}$


OBJEK/BENDA TAJAM

\section{PERJALANAN}

SANTAPAN (MAKANAN/MINUMAN)

(SECARA POTENSIAL) MENDAPAT SUATU OBJEK

ADANYA/KEBERADAAN/KEHADIRAN FISIK SUATU OBJEK

API

CAIRAN DALAM WADAH

HALANGAN (BAGI PERGERAKAN)

KEGELAPAN/GELAP

KEKUATAN ALAM

MANUSIA/ORGANISME (TERTIDUR/TENANG)

OBJEK (TAK)TERSEMBUNYI/TAMPAK

\section{PENYAKIT/SAKIT}

UNSUR DALAM WADAH (BERTEKANAN)

(KUATNYA AKIBAT DARI SUATU) KEKUATAN FISIK

(MENJADI) BERADA DI ATAS/MELAYANG

(MENJADI) BERADA DI BAWAH

ATASAN SOSIAL

BEBAN

BERTINDAK/MELAKUKAN SESUATU DI DALAM SUATU LOKASI

CERITA

DURASI

GAS/UDARA/NAFAS

HALANGAN (BAGI PERGERAKAN)

KEBEBASAN

KEDALAMAN

$\begin{array}{lrrrlrll}\text { KESEDIHAN } & 9 & 2,1079 & 22,5348 & > & 0,1335021 & \mathrm{~ns} & 0,002 \\ \text { KESEDIHAN } & 0 & 5,6751 & 5,6751 & < & 1,2455403 & \mathrm{~ns} & 0,002 \\ \text { KESEDIHAN } & 2 & 7,2965 & 3,8447 & < & 7,4436425 & \mathrm{~ns} & 0,002 \\ \text { KETAKUTAN } & 1 & 6,8758 & 5,0212 & < & 2,7973707 & \mathrm{~ns} & 0,002 \\ \text { KETAKUTAN } & 17 & 12,304 & 1,7923 & > & 28,010382 & \mathrm{~ns} & 0,002 \\ \text { KETAKUTAN } & 0 & 6,8758 & 6,8758 & < & 0,3893237 & \mathrm{~ns} & 0,002 \\ \text { KETAKUTAN } & 1 & 7,117 & 5,2575 & < & 2,3097781 & \mathrm{~ns} & 0,002 \\ \text { KETAKUTAN } & 7 & 2,4126 & 8,7226 & > & 4,0101996 & \mathrm{~ns} & 0,002 \\ \text { KETAKUTAN } & 11 & 5,5489 & 5,355 & > & 8,1785205 & \mathrm{~ns} & 0,002 \\ \text { KETAKUTAN } & 6 & 10,8565 & 2,1725 & < & 21,841317 & \mathrm{~ns} & 0,002 \\ \text { KETAKUTAN } & 10 & 14,7166 & 1,5116 & < & 29,899548 & \mathrm{~ns} & 0,002 \\ \text { KETAKUTAN } & 29 & 24,1255 & 0,9849 & > & 36,528066 & \mathrm{~ns} & 0,002 \\ \text { KETAKUTAN } & 8 & 2,6538 & 10,7702 & > & 2,1214191 & \mathrm{~ns} & 0,002 \\ \text { KETAKUTAN } & 14 & 20,5067 & 2,0646 & < & 22,177127 & \mathrm{~ns} & 0,002 \\ \text { AMARAH/KEMARAHAN } & 15 & 11,9078 & 0,803 & > & 40,138244 & \mathrm{~ns} & 0,001 \\ \text { AMARAH/KEMARAHAN } & 0 & 3,0533 & 3,0533 & < & 13,691749 & \mathrm{~ns} & 0,001 \\ \text { AMARAH/KEMARAHAN } & 0 & 3,9693 & 3,9693 & < & 6,0283453 & \mathrm{~ns} & 0,001 \\ \text { AMARAH/KEMARAHAN } & 8 & 6,1066 & 0,5871 & > & 43,581599 & \mathrm{~ns} & 0,001 \\ \text { AMARAH/KEMARAHAN } & 5 & 7,6332 & 0,9084 & < & 40,832075 & \mathrm{~ns} & 0,001 \\ \text { AMARAH/KEMARAHAN } & 4 & 8,5492 & 2,4207 & < & 19,495929 & \mathrm{~ns} & 0,001 \\ \text { AMARAH/KEMARAHAN } & 0 & 3,9693 & 3,9693 & < & 6,0283453 & \mathrm{~ns} & 0,001 \\ \text { AMARAH/KEMARAHAN } & 1 & 3,0533 & 1,3808 & < & 37,662829 & \mathrm{~ns} & 0,001 \\ \text { AMARAH/KEMARAHAN } & 4 & 2,4426 & 0,993 & > & 40,282589 & \mathrm{~ns} & 0,001 \\ \text { AMARAH/KEMARAHAN } & 2 & 6,1066 & 2,7616 & < & 15,961324 & \mathrm{~ns} & 0,001 \\ \text { AMARAH/KEMARAHAN } & 0 & 1,832 & 1,832 & < & 33,04203 & \mathrm{~ns} & 0,001 \\ \text { AMARAH/KEMARAHAN } & 0 & 3,0533 & 3,0533 & < & 13,691749 & \mathrm{~ns} & 0,001\end{array}$




\begin{tabular}{|c|c|c|c|c|c|c|c|c|}
\hline KERAS/LEMBUT & AMARAH/KEMARAHAN & 6 & 3,3586 & 2,0774 & $>$ & 28,806878 & $\mathrm{~ns}$ & 0,001 \\
\hline KESALAHAN & AMARAH/KEMARAHAN & 0 & 2,1373 & 2,1373 & $<$ & 28,115542 & ns & 0,001 \\
\hline MABUK & AMARAH/KEMARAHAN & 0 & 2,4426 & 2,4426 & $<$ & 22,319752 & ns & 0,001 \\
\hline MELAKUKAN SESUATU/MENJADI DISERTAI/TEMANI DENGAN OBJEK & AMARAH/KEMARAHAN & 33 & 29,3115 & 0,4642 & $>$ & 43,809709 & ns & 0,001 \\
\hline OBJEK BERHARGA DAN METAFORA KOMERSIL LAINNYA & AMARAH/KEMARAHAN & 0 & 3,9693 & 3,9693 & $<$ & 6,0283453 & $\mathrm{~ns}$ & 0,001 \\
\hline OBJEK BERSIFAT ILAHI/KEILAHIAN & AMARAH/KEMARAHAN & 0 & 3,6639 & 3,6639 & $<$ & 7,9538369 & ns & 0,001 \\
\hline OBJEK DAMBAAN & AMARAH/KEMARAHAN & 0 & 3,6639 & 3,6639 & $<$ & 7,9538369 & ns & 0,001 \\
\hline OBJEK RAPUH/PECAH BELAH & AMARAH/KEMARAHAN & 0 & 3,6639 & 3,6639 & $<$ & 7,9538369 & ns & 0,001 \\
\hline OBJEK/BENDA PENGHIAS & AMARAH/KEMARAHAN & 0 & 2,1373 & 2,1373 & $<$ & 28,115542 & ns & 0,001 \\
\hline OBJEK/BENDA TAJAM & AMARAH/KEMARAHAN & 1 & 3,9693 & 2,2212 & $<$ & 23,615211 & ns & 0,001 \\
\hline PENYAKIT/SAKIT & AMARAH/KEMARAHAN & 3 & 6,7172 & 2,057 & $<$ & 24,472621 & ns & 0,001 \\
\hline SIHIR & AMARAH/KEMARAHAN & 0 & 1,832 & 1,832 & $<$ & 33,04203 & $\mathrm{~ns}$ & 0,001 \\
\hline TANAMAN & AMARAH/KEMARAHAN & 6 & 8,8545 & 0,9202 & $<$ & 40,032657 & ns & 0,001 \\
\hline UNGKAPAN VERBAL/BAHASA & AMARAH/KEMARAHAN & 4 & 7,0226 & 1,301 & $<$ & 34,296648 & ns & 0,001 \\
\hline UNSUR CAMPURAN/MURNI & AMARAH/KEMARAHAN & 14 & 11,9078 & 0,3676 & $>$ & 43,19662 & $\mathrm{~ns}$ & 0,001 \\
\hline (MENJADI) BERADA DI ATAS/MELAYANG & CINTA & 0 & 2,2687 & 2,2687 & $<$ & 25,632774 & $\mathrm{~ns}$ & 0,001 \\
\hline (MENJADI) BERADA DI BAWAH & CINTA & 0 & 2,9493 & 2,9493 & $<$ & 14,696393 & ns & 0,001 \\
\hline (SECARA POTENSIAL) MEMBERIKAN SUATU OBJEK & CINTA & 24 & 21,5528 & 0,2779 & $>$ & 43,404227 & $\mathrm{~ns}$ & 0,001 \\
\hline BANGUNAN & CINTA & 2 & 0,4537 & 5,2701 & $>$ & 20,388303 & ns & 0,001 \\
\hline BERTINDAK/MELAKUKAN SESUATU DI DALAM SUATU LOKASI & CINTA & 2 & 6,3524 & 2,9821 & $<$ & 13,769794 & ns & 0,001 \\
\hline DURASI & CINTA & 0 & 2,2687 & 2,2687 & $<$ & 25,632774 & ns & 0,001 \\
\hline GANGGUAN FISIK & CINTA & 0 & 2,2687 & 2,2687 & $<$ & 25,632774 & $\mathrm{~ns}$ & 0,001 \\
\hline GAS/UDARA/NAFAS & CINTA & 0 & 1,815 & 1,815 & $<$ & 33,364722 & $\mathrm{~ns}$ & 0,001 \\
\hline HALANGAN (BAGI PERGERAKAN) & CINTA & 2 & 4,5374 & 1,419 & $<$ & 34,179229 & ns & 0,001 \\
\hline KEBEBASAN & CINTA & 5 & 1,3612 & 9,7273 & $>$ & 4,2860006 & ns & 0,001 \\
\hline KEGILAAN & CINTA & 3 & 1,1344 & 3,0681 & $>$ & 25,895436 & ns & 0,001 \\
\hline
\end{tabular}




KEHANGATAN
KERAS/LEMBUT
KESATUAN (DARI BAGIAN-BAGIAN)
LANDASAN/DASAR
LOGAM/BESI
LOKASI (TERKUNGKUNG/WADAH)
MISTERI
NODA/KOTORAN
OBJEK ASLI/PALSU
OBJEK BERHARGA DAN METAFORA KOMERSIL LAINNYA
OBJEK/BENDA PENGHIAS
OBJEK/BENDA TAJAM
PANAS/DINGIN (SUATU OBJEK)
PERANG
PERGERAKAN TERDORONG SUATU OBJEK
PERILAKU AGRESIF BINATANG
PERMAINAN
SIHIR
SUARA/BUNYI/NADA
TEORI/ILMU
UNSUR CAMPURAN/MURNI
(MENJADI) BERADA DI BAWAH
ATASAN SOSIAL
BINATANG TAWANAN/BUAS
CAIRAN
CERITA

$\begin{array}{lrrrrrrr}\text { CINTA } & 4 & 0,9075 & 10,5384 & > & 4,5662395 & \mathrm{~ns} & 0,001 \\ \text { CINTA } & 0 & 2,4956 & 2,4956 & < & 21,414672 & \mathrm{~ns} & 0,001 \\ \text { CINTA } & 4 & 0,9075 & 10,5384 & > & 4,5662395 & \mathrm{~ns} & 0,001 \\ \text { CINTA } & 4 & 1,5881 & 3,663 & > & 20,439974 & \mathrm{~ns} & 0,001 \\ \text { CINTA } & 4 & 0,9075 & 10,5384 & > & 4,5662395 & \mathrm{~ns} & 0,001 \\ \text { CINTA } & 12 & 14,9735 & 0,5905 & < & 43,880101 & \mathrm{~ns} & 0,001 \\ \text { CINTA } & 3 & 0,6806 & 7,9042 & > & 9,6379505 & \mathrm{~ns} & 0,001 \\ \text { CINTA } & 0 & 2,2687 & 2,2687 & < & 25,632774 & \mathrm{~ns} & 0,001 \\ \text { CINTA } & 8 & 3,6299 & 5,2612 & > & 9,6616189 & \mathrm{~ns} & 0,001 \\ \text { CINTA } & 1 & 2,9493 & 1,2884 & < & 39,169674 & \mathrm{~ns} & 0,001 \\ \text { CINTA } & 6 & 1,5881 & 12,2567 & > & 2,0711291 & \mathrm{~ns} & 0,001 \\ \text { CINTA } & 1 & 2,9493 & 1,2884 & < & 39,169674 & \mathrm{~ns} & 0,001 \\ \text { CINTA } & 0 & 3,6299 & 3,6299 & < & 8,1763138 & \mathrm{~ns} & 0,001 \\ \text { CINTA } & 4 & 0,9075 & 10,5384 & > & 4,5662395 & \mathrm{~ns} & 0,001 \\ \text { CINTA } & 0 & 2,7225 & 2,7225 & < & 17,983553 & \mathrm{~ns} & 0,001 \\ \text { CINTA } & 0 & 2,2687 & 2,2687 & < & 25,632774 & \mathrm{~ns} & 0,001 \\ \text { CINTA } & 2 & 0,4537 & 5,2701 & > & 20,388303 & \mathrm{~ns} & 0,001 \\ \text { CINTA } & 4 & 1,3612 & 5,1155 & > & 14,106723 & \mathrm{~ns} & 0,001 \\ \text { CINTA } & 6 & 9,4364 & 1,3458 & > & 32,84685 & \mathrm{~ns} & 0,001 \\ \text { CINTA } & 6 & 7,7136 & 0,3807 & < & 44,361397 & \mathrm{~ns} & 0,001 \\ \text { CINTA } & 4 & 1,3612 & 5,1155 & > & 14,106723 & \mathrm{~ns} & 0,001 \\ \text { KEBAHAGIAAN } & 5 & 8,848 & 1,6735 & < & 28,721639 & \mathrm{~ns} & 0,001 \\ \text { KEBAHAGIAAN } & 0 & 2,4054 & 2,4054 & < & 23,032701 & \mathrm{~ns} & 0,001 \\ \text { KEBAHAGIAAN } & 0 & 3,7006 & 3,7006 & < & 7,7168582 & \mathrm{~ns} & 0,001 \\ \text { KEBAHAGIAAN } & 1 & 4,6257 & 2,8419 & < & 15,397158 & \mathrm{~ns} & 0,001 \\ \text { KEBAHAGIAAN } & & & 2,4054 & < & 23,032701 & \mathrm{~ns} & 0,001\end{array}$


DURASI

GANGGUAN FISIK

HALANGAN (BAGI PERGERAKAN)

IKATAN

KEDALAMAN

KEGELAPAN/GELAP

KERAS/LEMBUT

NODA/KOTORAN

OBJEK (TAK) LENGKAP/DIRI YANG TERPISAH

OBJEK BERSIFAT ILAHI/KEILAHIAN

OBJEK DI SUATU LOKASI

PANAS/DINGIN (SUATU OBJEK)

PENYAKIT/SAKIT

PENYEBAB

PERGERAKAN TERDORONG SUATU OBJEK

PERILAKU AGRESIF BINATANG

UNGKAPAN VERBAL/BAHASA

UNSUR CAMPURAN/MURNI

(KUATNYA AKIBAT DARI SUATU) KEKUATAN FISIK

(MENJADI) BERADA DI ATAS/MELAYANG

BINATANG TAWANAN/BUAS

CAIRAN DALAM WADAH

CERITA

DURASI

HALANGAN (BAGI PERGERAKAN)

IKATAN

KEBAHAGIAAN
KEBAHAGIAAN
KEBAHAGIAAN
KEBAHAGIAAN
KEBAHAGIAAN
KEBAHAGIAAN
KEBAHAGIAAN
KEBAHAGIAAN
KEBAHAGIAAN
KEBAHAGIAAN
KEBAHAGIAAN
KEBAHAGIAAN
KEBAHAGIAAN
KEBAHAGIAAN
KEBAHAGIAAN
KEBAHAGIAAN
KEBAHAGIAAN
KEBAHAGIAAN
KESEDIHAN
KESEDIHAN
KESEDIHAN
KESEDIHAN
KESEDIHAN
KESEDIHAN
KESEDIHAN
KESEDIHAN
KENAN

$\begin{aligned} & 5,3616> \\ & 1,8503< \\ & 0,7815< \\ & 3,8856< \\ & 1,8503< \\ & 0,741< \\ & 2,0353< \\ & 1,8503< \\ & 17,9492> \\ & 2,2203< \\ & 1,05> \\ & 2,9604< \\ & 4,0706< \\ & 0,7263< \\ & 2,2203< \\ & 1,8503< \\ & 1,1955< \\ & 0,6806< \\ & 0,4444> \\ & 1,6214< \\ & 1,0404< \\ & 0,619> \\ & 2,1079< \\ & 3,4894> \\ & 4,3528> \\ & 3,405< \\ &\end{aligned}$

$\begin{array}{rll}11,79057 & \text { ns } & 0,001 \\ 33,070709 & \text { ns } & 0,001 \\ 43,630237 & \text { ns } & 0,001 \\ 6,5142886 & \text { ns } & 0,001 \\ 33,070709 & \text { ns } & 0,001 \\ 42,519233 & \text { ns } & 0,001 \\ 29,765874 & \text { ns } & 0,001 \\ 33,070709 & \text { ns } & 0,001 \\ 0,9652864 & \text { ns } & 0,001 \\ 26,09074 & \text { ns } & 0,001 \\ 36,224834 & \text { ns } & 0,001 \\ 14,585517 & \text { ns } & 0,001 \\ 5,5317437 & \text { ns } & 0,001 \\ 43,337242 & \text { ns } & 0,001 \\ 26,09074 & \text { ns } & 0,001 \\ 33,070709 & \text { ns } & 0,001 \\ 39,137331 & \text { ns } & 0,001 \\ 42,963449 & \text { ns } & 0,001 \\ 43,121253 & \text { ns } & 0,001 \\ 38,419201 & \text { ns } & 0,001 \\ 40,507879 & \text { ns } & 0,001 \\ 42,313501 & \text { ns } & 0,001 \\ 28,530696 & \text { ns } & 0,001 \\ 21,376453 & \text { ns } & 0,001 \\ 13,635937 & \text { ns } & 0,001 \\ 9,9759722 & \text { ns } & 0,001\end{array}$


KEGELAPAN/GELAP

\section{KERAS/LEMBUT}

LOKASI (TERKUNGKUNG/WADAH)

MANUSIA/ORGANISME (TERTIDUR/TENANG)

MENCARI/MENGEJAR/MEMBURU SUATU OBJEK

MENEMUKAN/MERAIH SUATU OBJEK

MUSUH/LAWAN

NODA/KOTORAN

OBJEK ASLI/PALSU

OBJEK BERGERAK

OBJEK BERSIFAT ILAHI/KEILAHIAN

OBJEK DAMBAAN

OBJEK RAPUH/PECAH BELAH

PANAS/DINGIN (SUATU OBJEK)

PENYAKIT/SAKIT

PERILAKU AGRESIF BINATANG

SUARA/BUNYI/NADA

TANAMAN

TINGGI/RENDAH (KEKERAPAN)

UNGKAPAN VERBAL/BAHASA

UNSUR CAMPURAN/MURNI

UNSUR DALAM WADAH (BERTEKANAN)

(MENJADI) BERADA DI BAWAH

ATASAN SOSIAL

BINATANG TAWANAN/BUAS

CAHAYA

\begin{tabular}{|c|c|c|c|c|c|c|c|}
\hline KESEDIHAN & 11 & 7,4586 & 1,6815 & $>$ & 30,144265 & ns & 0,001 \\
\hline KESEDIHAN & 5 & 1,7836 & 5,8002 & $>$ & 10,520686 & ns & 0,001 \\
\hline KESEDIHAN & 15 & 10,7015 & 1,7266 & $>$ & 28,817709 & ns & 0,001 \\
\hline KESEDIHAN & 16 & 19,7816 & 0,7229 & $<$ & 40,595081 & ns & 0,001 \\
\hline KESEDIHAN & 0 & 4,0536 & 4,0536 & $<$ & 5,609396 & ns & 0,001 \\
\hline KESEDIHAN & 1 & 5,0265 & 3,2254 & $<$ & 11,673027 & ns & 0,001 \\
\hline KESEDIHAN & 20 & 22,8624 & 0,3584 & $<$ & 44,071677 & ns & 0,001 \\
\hline KESEDIHAN & 4 & 1,6214 & 3,4894 & $>$ & 21,376453 & ns & 0,001 \\
\hline KESEDIHAN & 0 & 2,5943 & 2,5943 & $<$ & 20,03415 & ns & 0,001 \\
\hline KESEDIHAN & 5 & 8,7558 & 1,6111 & $<$ & 29,732702 & ns & 0,001 \\
\hline KESEDIHAN & 0 & 1,9457 & 1,9457 & $<$ & 31,700245 & ns & 0,001 \\
\hline KESEDIHAN & 0 & 1,9457 & 1,9457 & $<$ & 31,700245 & ns & 0,001 \\
\hline KESEDIHAN & 0 & 1,9457 & 1,9457 & $<$ & 31,700245 & ns & 0,001 \\
\hline KESEDIHAN & 0 & 2,5943 & 2,5943 & $<$ & 20,03415 & ns & 0,001 \\
\hline KESEDIHAN & 6 & 3,5672 & 1,6591 & $>$ & 32,524775 & ns & 0,001 \\
\hline KESEDIHAN & 0 & 1,6214 & 1,6214 & $<$ & 38,419201 & ns & 0,001 \\
\hline KESEDIHAN & 9 & 5,5129 & 2,2057 & $>$ & 25,998426 & ns & 0,001 \\
\hline KESEDIHAN & 3 & 4,7022 & 0,6162 & $<$ & 42,969502 & ns & 0,001 \\
\hline KESEDIHAN & 0 & 4,54 & 4,54 & $<$ & 3,627212 & ns & 0,001 \\
\hline KESEDIHAN & 0 & 3,7293 & 3,7293 & $<$ & 7,5217179 & ns & 0,001 \\
\hline KESEDIHAN & 10 & 6,3236 & 2,1374 & $>$ & 26,082406 & ns & 0,001 \\
\hline KESEDIHAN & 24 & 27,5646 & 0,461 & $<$ & 43,448708 & ns & 0,001 \\
\hline KETAKUTAN & 0 & 1,5682 & 1,5682 & $<$ & 38,960449 & ns & 0,001 \\
\hline KETAKUTAN & 4 & 2,4126 & 1,0444 & $>$ & 40,517998 & ns & 0,001 \\
\hline KETAKUTAN & 5 & 3,0157 & 1,3056 & $>$ & 37,085051 & ns & 0,001 \\
\hline KETAKUTAN & 8 & 5,9108 & 0,7384 & $>$ & 41,182678 & ns & 0,001 \\
\hline
\end{tabular}




\author{
CAIRAN PANAS DALAM WADAH \\ CERITA \\ IKATAN \\ MENEMUKAN/MERAIH SUATU OBJEK \\ NODA/KOTORAN \\ OBJEK ASLI/PALSU \\ OBJEK BERGERAK \\ PANAS/DINGIN (SUATU OBJEK) \\ PENYEBAB \\ PERJALANAN \\ ROH/MAHKLUK SPIRITUAL \\ SANTAPAN (MAKANAN/MINUMAN) \\ SUARA/BUNYI/NADA \\ TANAMAN \\ TINGGI/RENDAH (KEKERAPAN) \\ UNGKAPAN VERBAL/BAHASA \\ (MENJADI) BERADA DI SURGA \\ (OBJEK BER)BAU \\ BANGUNAN \\ CATATAN \\ GARIS \\ GELEMBUNG \\ KEGILAAN \\ KEHANGATAN
}

MENCARI/MENGEJAR/MEMBURU SUATU OBJEK

OBJEK BERHARGA DAN METAFORA KOMERSIL LAINNYA

\begin{tabular}{|c|c|c|c|c|c|c|c|}
\hline KETAKUTAN & 0 & 3,6188 & 3,6188 & $<$ & 8,1875374 & $\mathrm{~ns}$ & 0,001 \\
\hline KETAKUTAN & 0 & 1,5682 & 1,5682 & $<$ & 38,960449 & ns & 0,001 \\
\hline KETAKUTAN & 0 & 2,5332 & 2,5332 & $<$ & 20,941208 & ns & 0,001 \\
\hline KETAKUTAN & 0 & 3,0157 & 3,0157 & $<$ & 14,045518 & ns & 0,001 \\
\hline KETAKUTAN & 0 & 3,7395 & 3,7395 & $<$ & 7,469498 & $\mathrm{~ns}$ & 0,001 \\
\hline KETAKUTAN & 3 & 1,2063 & 2,6671 & $>$ & 28,511211 & ns & 0,001 \\
\hline KETAKUTAN & 0 & 1,93 & 1,93 & $<$ & 31,839276 & ns & 0,001 \\
\hline KETAKUTAN & 10 & 6,5139 & 1,8657 & $>$ & 28,794764 & ns & 0,001 \\
\hline KETAKUTAN & 0 & 1,5682 & 1,5682 & $<$ & 38,960449 & $\mathrm{~ns}$ & 0,001 \\
\hline KETAKUTAN & 0 & 1,93 & 1,93 & $<$ & 31,839276 & $\mathrm{~ns}$ & 0,001 \\
\hline KETAKUTAN & 8 & 3,9807 & 4,0583 & $>$ & 14,165411 & ns & 0,001 \\
\hline KETAKUTAN & 0 & 4,222 & 4,222 & $<$ & 4,7976654 & $\mathrm{~ns}$ & 0,001 \\
\hline KETAKUTAN & 4 & 0,965 & 9,5453 & $>$ & 5,5093166 & ns & 0,001 \\
\hline KETAKUTAN & 2 & 5,4282 & 2,1651 & $<$ & 23,55026 & $\mathrm{~ns}$ & 0,001 \\
\hline KETAKUTAN & 7 & 4,1013 & 2,0487 & $>$ & 28,640715 & ns & 0,001 \\
\hline KETAKUTAN & 0 & 3,4982 & 3,4982 & $<$ & 9,178134 & ns & 0,001 \\
\hline KETAKUTAN & 1 & 3,3776 & 1,6737 & $<$ & 32,537782 & ns & 0,001 \\
\hline KETAKUTAN & 0 & 2,7744 & 2,7744 & $<$ & 17,134193 & ns & 0,001 \\
\hline AMARAH/KEMARAHAN & 0 & 0,3053 & 0,3053 & $<$ & 21,000795 & ns & 0 \\
\hline AMARAH/KEMARAHAN & 2 & 0,916 & 1,2828 & $>$ & 40,605904 & ns & 0 \\
\hline AMARAH/KEMARAHAN & 0 & 0,6107 & 0,6107 & $<$ & 39,093182 & ns & 0 \\
\hline AMARAH/KEMARAHAN & 0 & 0,3053 & 0,3053 & $<$ & 21,000795 & ns & 0 \\
\hline AMARAH/KEMARAHAN & 0 & 0,3053 & 0,3053 & $<$ & 21,000795 & ns & 0 \\
\hline AMARAH/KEMARAHAN & 0 & 0,3053 & 0,3053 & $<$ & 21,000795 & ns & 0 \\
\hline AMARAH/KEMARAHAN & 1 & 1,5266 & 0,1817 & $<$ & 37,32551 & ns & 0 \\
\hline AMARAH/KEMARAHAN & 0 & 1,2213 & 1,2213 & $<$ & 43,773426 & $\mathrm{~ns}$ & 0 \\
\hline
\end{tabular}


KESATUAN (DARI BAGIAN-BAGIAN)

\section{KURANGNYA KEHANGATAN}

LANDASAN/DASAR

LOGAM/BESI

MISTERI

NODA/KOTORAN

OBAT/PENYEMBUH

OBJEK (TAK) LENGKAP/DIRI YANG TERPISAH

OBJEK (TAK)TERSEMBUNYI/TAMPAK

OBJEK FISIK

PASIR

PENYEBAB

PERANG

PERMAINAN

RACUN

ROH/MAHKLUK SPIRITUAL

SUARA/BUNYI/NADA

TEORI/ILMU

UNSUR PELEDAK

(KUATNYA AKIBAT DARI SUATU) KEKUATAN FISIK

(MENJADI) BERADA DI SURGA

(OBJEK BER)BAU

ATASAN SOSIAL

CATATAN

GARIS

GELEMBUNG

AMARAH/KEMARAHAN
AMARAH/KEMARAHAN
AMARAH/KEMARAHAN
AMARAH/KEMARAHAN
AMARAH/KEMARAHAN
AMARAH/KEMARAHAN
AMARAH/KEMARAHAN
AMARAH/KEMARAHAN
AMARAH/KEMARAHAN
AMARAH/KEMARAHAN
AMARAH/KEMARAHAN
AMARAH/KEMARAHAN
AMARAH/KEMARAHAN
AMARAH/KEMARAHAN
AMARAH/KEMARAHAN
AMARAH/KEMARAHAN
AMARAH/KEMARAHAN
AMARAH/KEMARAHAN
AMARAH/KEMARAHAN
CINTA
CINTA
CINTA
CINTA
CINTA
CINTA
CINTA

$\begin{array}{rlrll}1,2213 & < & 43,773426 \mathrm{~ns} & 0 \\ 0,3053 & < & 21,000795 \mathrm{~ns} & 0 \\ 0,3482 & > & 45,415835 \mathrm{~ns} & 0 \\ 1,2213 & < & 43,773426 \mathrm{~ns} & 0 \\ 0,916 & < & 47,607995 \mathrm{~ns} & 0 \\ 9,00 \mathrm{E}-04 & < & 28,588035 \mathrm{~ns} & 0 \\ 0,6107 & < & 39,093182 \mathrm{~ns} & 0 \\ 1,5266 & < & 39,96132 & \mathrm{~ns} & 0 \\ 1,00 \mathrm{E}-04 & < & 40,856026 \mathrm{~ns} & 0 \\ 0,1051 & < & 48,213478 \mathrm{~ns} & 0 \\ 0,3053 & < & 21,000795 & \mathrm{~ns} & 0 \\ 6,00 \mathrm{E}-04 & < & 36,706339 & \mathrm{~ns} & 0 \\ 1,2213 & < & 43,773426 \mathrm{~ns} & 0 \\ 0,6107 & < & 39,093182 \mathrm{~ns} & 0 \\ 1,5808 & > & 43,416448 \mathrm{~ns} & 0 \\ 0,1272 & > & 48,116292 \mathrm{~ns} & 0 \\ 0,0369 & >47,390815 \mathrm{~ns} & 0 \\ 0,3779 & < & 48,051803 \mathrm{~ns} & 0 \\ 3,1606 & 28,718899 \mathrm{~ns} & 0 \\ 0,0026 & 41,9457 \mathrm{~ns} & 0 \\ 0,2269 & < & 15,940329 \mathrm{~ns} & 0 \\ 0,6806 & 44,55153 \mathrm{~ns} & 0 \\ 0,0472 & > & 47,981194 \mathrm{~ns} & 0 \\ 0,2269 & < & 15,940329 \mathrm{~ns} & 0 \\ 2,6341 & 38,871347 \mathrm{~ns} & 0 \\ 0,2269 & < & 15,940329 \mathrm{~ns} & 0\end{array}$


KEDALAMAN

KEGELAPAN/GELAP

KEPEMILIKAN

KURANGNYA KEHANGATAN

MENCARI/MENGEJAR/MEMBURU SUATU OBJEK

OBAT/PENYEMBUH

OBJEK (TAK) LENGKAP/DIRI YANG TERPISAH

OBJEK DAMBAAN

OBJEK FISIK

OBJEK RAPUH/PECAH BELAH

OBJEK YANG DIARAH/GERAKKAN (KE SESEORANG)

PASIR

PENYAKIT/SAKIT

PENYEBAB

RACUN

ROH/MAHKLUK SPIRITUAL

SANTAPAN (MAKANAN/MINUMAN)

UNSUR PELEDAK

(MENJADI) BERADA DI SURGA

(OBJEK BER)BAU

BANGUNAN

BERTINDAK/MELAKUKAN SESUATU DI DALAM SUATU LOKASI

CAHAYA

CATATAN

GARIS

GAS/UDARA/NAFAS
CINTA

CINTA

CINTA

CINTA

CINTA

CINTA

CINTA

CINTA

CINTA

CINTA

CINTA

CINTA

CINTA

CINTA

CINTA

CINTA

CINTA

CINTA

KEBAHAGIAAN

KEBAHAGIAAN

KEBAHAGIAAN

KEBAHAGIAAN

KEBAHAGIAAN

KEBAHAGIAAN

KEBAHAGIAAN

KEBAHAGIAAN
2,2687

10,4361

54,9029

0,2269

$6 \quad 5,6718$

0,4537

1,1344

2,7225

11,3436

2,7225

6,1255

0,2269

4,9912

7,4868

0,2269

1,815

9 10,2092

0,4537

0,185

0,5551

0,3701

$5,5,1808$

9,0664

$0 \quad 0,185$

$0 \quad 0,185$

$0 \quad 1,4802$

\begin{tabular}{|c|c|c|c|}
\hline 0,7095 & $<$ & 43,604809 & ns \\
\hline 0,0182 & $<$ & 41,227442 & ns \\
\hline 0,0219 & $>$ & 47,731555 & ns \\
\hline 0,2269 & $<$ & 15,940329 & ns \\
\hline 0,019 & $>$ & 44,533718 & ns \\
\hline 0,6578 & $>$ & 45,232155 & ns \\
\hline 1,1344 & $<$ & 43,089174 & ns \\
\hline 0,5995 & $>$ & 43,916514 & ns \\
\hline 0,038 & $>$ & 47,560489 & $\mathrm{~ns}$ \\
\hline 0,1917 & $<$ & 44,901593 & ns \\
\hline 0,2068 & $<$ & 48,513359 & ns \\
\hline 2,6341 & $>$ & 38,871347 & ns \\
\hline 0 & $>$ & 36,834525 & ns \\
\hline 0,2953 & $<$ & 45,94581 & $\mathrm{~ns}$ \\
\hline 0,2269 & $<$ & 15,940329 & ns \\
\hline 0,366 & $<$ & 48,124172 & $\mathrm{~ns}$ \\
\hline 0,1432 & $<$ & 47,929332 & ns \\
\hline 0,4537 & $<$ & 29,22033 & ns \\
\hline 3,5904 & $>$ & 34,375924 & ns \\
\hline 0,5551 & $<$ & 35,874719 & ns \\
\hline 0,3701 & $<$ & 27,281879 & ns \\
\hline 0,0063 & $<$ & 35,054829 & ns \\
\hline $5,00 \mathrm{E}-04$ & $<$ & 35,297806 & ns \\
\hline 0,185 & $<$ & 12,466148 & ns \\
\hline 0,185 & $<$ & 12,466148 & ns \\
\hline 1,4802 & $<$ & 40,495992 & ns \\
\hline
\end{tabular}




GELEMBUNG
KEBEBASAN
KEGILAAN
KEHANGATAN
KESALAHAN
KESATUAN (DARI BAGIAN-BAGIAN)
KURANGNYA KEHANGATAN
LANDASAN/DASAR
LOGAM/BESI
MABUK
MISTERI
OBAT/PENYEMBUH
OBJEK BERGERAK
OBJEK/BENDA PENGHIAS
OBJEK/BENDA TAJAM
PASIR
PERANG
PERMAINAN
RACUN
ROH/MAHKLUK SPIRITUAL
SIHIR
TANAMAN
TEORI/LMMU
UNSUR PELEDAK
(MENJADI) BERADA DI SURGA
(OBJEK BER)BAU

$\begin{array}{lrrrrrrl}\text { KEBAHAGIAAN } & 1 & 0,185 & 3,5904 & > & 34,375924 & \mathrm{~ns} & 0 \\ \text { KEBAHAGIAAN } & 0 & 1,1102 & 1,1102 & < & 43,321049 & \mathrm{~ns} & 0 \\ \text { KEBAHAGIAAN } & 1 & 0,9251 & 0,0061 & > & 33,800432 & \mathrm{~ns} & 0 \\ \text { KEBAHAGIAAN } & 0 & 0,7401 & 0,7401 & < & 46,509272 & \mathrm{~ns} & 0 \\ \text { KEBAHAGIAAN } & 0 & 1,2952 & 1,2952 & < & 42,434272 & \mathrm{~ns} & 0 \\ \text { KEBAHAGIAAN } & 0 & 0,7401 & 0,7401 & < & 46,509272 & \mathrm{~ns} & 0 \\ \text { KEBAHAGIAAN } & 0 & 0,185 & 0,185 & < & 12,466148 & \mathrm{~ns} & 0 \\ \text { KEBAHAGIAAN } & 0 & 1,2952 & 1,2952 & < & 42,434272 & \mathrm{~ns} & 0 \\ \text { KEBAHAGIAAN } & 0 & 0,7401 & 0,7401 & < & 46,509272 & \mathrm{~ns} & 0 \\ \text { KEBAHAGIAAN } & 0 & 1,4802 & 1,4802 & < & 40,495992 & \mathrm{~ns} & 0 \\ \text { KEBAHAGIAAN } & 0 & 0,5551 & 0,5551 & < & 35,874719 & \mathrm{~ns} & 0 \\ \text { KEBAHAGIAAN } & 0 & 0,3701 & 0,3701 & < & 27,281879 & \mathrm{~ns} & 0 \\ \text { KEBAHAGIAAN } & 10 & 9,9915 & 0 & > & 40,04951 & \mathrm{~ns} & 0 \\ \text { KEBAHAGIAAN } & 0 & 1,2952 & 1,2952 & < & 42,434272 & \mathrm{~ns} & 0 \\ \text { KEBAHAGIAAN } & 1 & 2,4054 & 0,8211 & < & 43,308945 & \mathrm{~ns} & 0 \\ \text { KEBAHAGIAAN } & 0 & 0,185 & 0,185 & < & 12,466148 & \mathrm{~ns} & 0 \\ \text { KEBAHAGIAAN } & 0 & 0,7401 & 0,7401 & < & 46,509272 & \mathrm{~ns} & 0 \\ \text { KEBAHAGIAAN } & 0 & 0,3701 & 0,3701 & < & 27,281879 & \mathrm{~ns} & 0 \\ \text { KEBAHAGIAAN } & 0 & 0,185 & 0,185 & < & 12,466148 & \mathrm{~ns} & 0 \\ \text { KEBAHAGIAAN } & 0 & 1,4802 & 1,4802 & < & 40,495992 & \mathrm{~ns} & 0 \\ \text { KEBAHAGIAAN } & 1 & 1,1102 & 0,0109 & < & 25,726141 & \mathrm{~ns} & 0 \\ \text { KEBAHAGIAAN } & 4 & 5,3658 & 0,3476 & < & 46,190802 & \mathrm{~ns} & 0 \\ \text { KEBAHAGIAAN } & 0 & 1,1102 & 1,1102 & < & 43,321049 & \mathrm{~ns} & 0 \\ \text { KEBAHAGIAAN } & 0 & 0,3701 & 0,3701 & < & 27,281879 & \mathrm{~ns} & 0 \\ \text { KESEDIHAN } & 0 & 0,1621 & 0,1621 & < & 8,5031468 & \mathrm{~ns} & 0 \\ \text { KESEDIHAN } & 0 & 0,4864 & 0,4864 & < & 33,506135 & \mathrm{~ns} & 0\end{array}$


(OBJEK BER)WARNA

\section{ATASAN SOSIAL}

BANGUNAN

BERTINDAK/MELAKUKAN SESUATU DI DALAM SUATU LOKASI

CATATAN

GANGGUAN FISIK

GARIS

GAS/UDARA/NAFAS

GELEMBUNG

KEBEBASAN

KEGILAAN

KEHANGATAN

KEKUATAN ALAM

KEPEMILIKAN

KESALAHAN

KESATUAN (DARI BAGIAN-BAGIAN)

KONTROL OBJEK BERGERAK

KURANGNYA KEHANGATAN

LANDASAN/DASAR

LOGAM/BESI

MABUK

MISTERI

OBAT/PENYEMBUH

OBJEK (TAK) LENGKAP/DIRI YANG TERPISAH

OBJEK BERHARGA DAN METAFORA KOMERSIL LAINNYA

OBJEK DI SUATU LOKASI

KESEDIHAN
KESEDIHAN
KESEDIHAN
KESEDIHAN
KESEDIHAN
KESEDIHAN
KESEDIHAN
KESEDIHAN
KESEDIHAN
KESEDIHAN
KESEDIHAN
KESEDIHAN
KESEDIHAN
KESEDIHAN
KESEDIHAN
KESEDIHAN
KESEDIHAN
KESEDIHAN
KESEDIHAN
KESEDIHAN
KESEDIHAN
KESEDIHAN
KESEDIHAN
KESEDIHAN
KESEDIHAN
KESEDIHAN

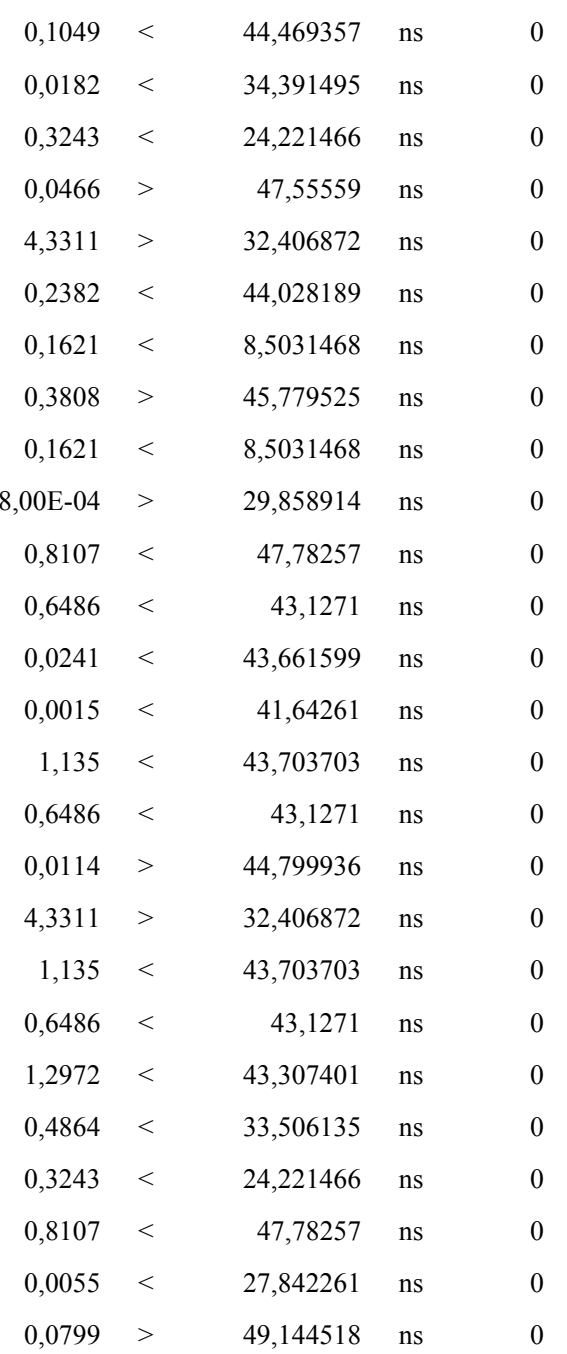




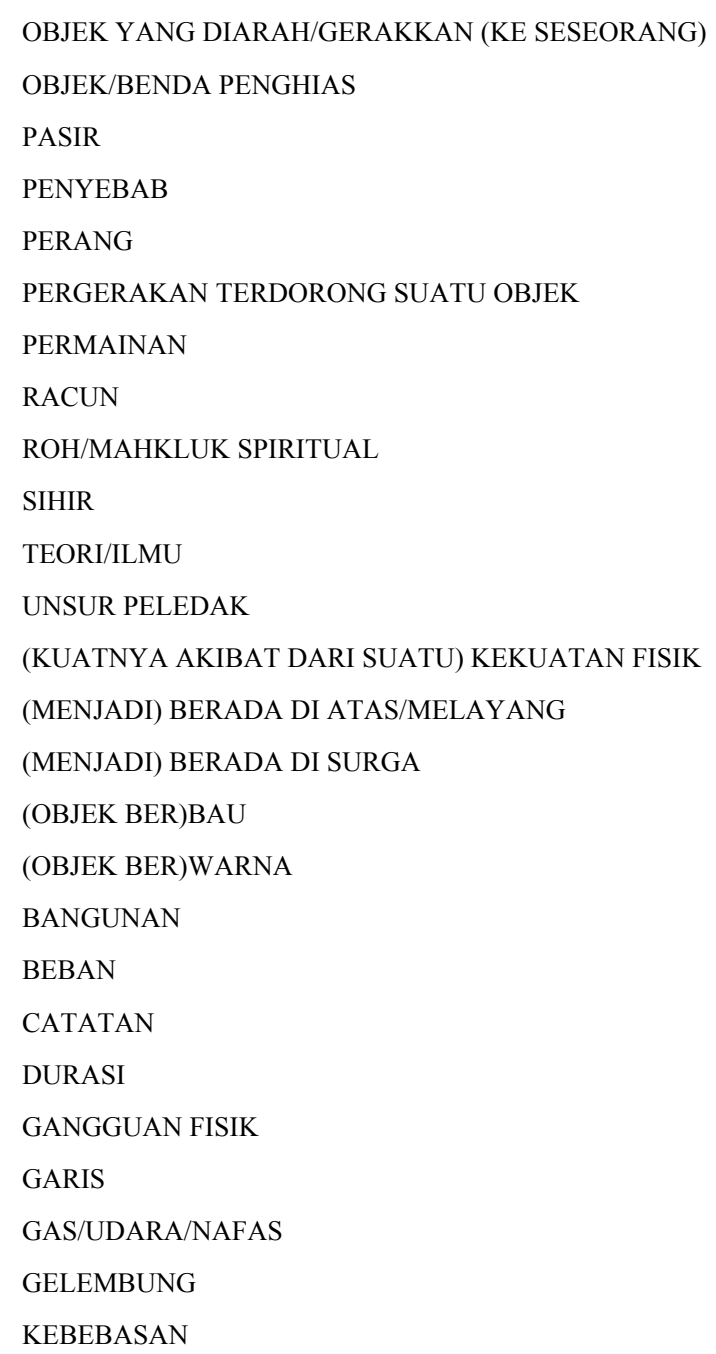

$\begin{array}{lrrrrrrr}\text { KESEDIHAN } & 3 & 4,3779 & 0,4337 & < & 45,392503 & \text { ns } & 0 \\ \text { KESEDIHAN } & 0 & 1,135 & 1,135 & < & 43,703703 & \text { ns } & 0 \\ \text { KESEDIHAN } & 0 & 0,1621 & 0,1621 & < & 8,5031468 & \text { ns } & 0 \\ \text { KESEDIHAN } & 5 & 5,3508 & 0,023 & < & 37,158342 & \text { ns } & 0 \\ \text { KESEDIHAN } & 0 & 0,6486 & 0,6486 & < & 43,1271 & \text { ns } & 0 \\ \text { KESEDIHAN } & 1 & 1,9457 & 0,4597 & < & 49,23473 & \text { ns } & 0 \\ \text { KESEDIHAN } & 0 & 0,3243 & 0,3243 & < & 24,221466 & \text { ns } & 0 \\ \text { KESEDIHAN } & 0 & 0,1621 & 0,1621 & < & 8,5031468 & \text { ns } & 0 \\ \text { KESEDIHAN } & 0 & 1,2972 & 1,2972 & < & 43,307401 & \text { ns } & 0 \\ \text { KESEDIHAN } & 1 & 0,9729 & 8,00 \mathrm{E}-04 & > & 29,858914 & \text { ns } & 0 \\ \text { KESEDIHAN } & 1 & 0,9729 & 8,00 \mathrm{E}-04 & > & 29,858914 & \text { ns } & 0 \\ \text { KESEDIHAN } & 0 & 0,3243 & 0,3243 & < & 24,221466 & \text { ns } & 0 \\ \text { KETAKUTAN } & 6 & 4,7045 & 0,3567 & > & 43,19907 & \text { ns } & 0 \\ \text { KETAKUTAN } & 0 & 1,2063 & 1,2063 & < & 43,389578 & \text { ns } & 0 \\ \text { KETAKUTAN } & 0 & 0,1206 & 0,1206 & < & 3,5454473 & \text { ns } & 0 \\ \text { KETAKUTAN } & 1 & 0,3619 & 1,1251 & > & 43,118449 & \text { ns } & 0 \\ \text { KETAKUTAN } & 3 & 3,4982 & 0,071 & < & 40,271938 & \text { ns } & 0 \\ \text { KETAKUTAN } & 0 & 0,2413 & 0,2413 & < & 18,855205 & \text { ns } & 0 \\ \text { KETAKUTAN } & 3 & 3,0157 & 1,00 \mathrm{E}-04 & < & 28,323446 & \text { ns } & 0 \\ \text { KETAKUTAN } & 0 & 0,1206 & 0,1206 & < & 3,5454473 & \text { ns } & 0 \\ \text { KETAKUTAN } & 0 & 1,2063 & 1,2063 & < & 43,389578 & \text { ns } & 0 \\ \text { KETAKUTAN } & 1 & 1,2063 & 0,0353 & < & 27,734499 & \text { ns } & 0 \\ \text { KETAKUTAN } & 0 & 0,1206 & 0,1206 & < & 3,5454473 & \text { ns } & 0 \\ \text { KETAKUTAN } & 2 & 0,965 & 1,1101 & > & 42,230797 & \text { ns } & 0 \\ \text { KETAKUTAN } & 0 & 0,1206 & 0,1206 & < & 3,5454473 & \text { ns } & 0 \\ \text { KETAKUTAN } & 0 & 0,7238 & 0,7238< & 45,578823 & \text { ns } & 0\end{array}$




KEDALAMAN
KEGILAAN
KEHANGATAN
KERAS/LEMBUT
KESALAHAN
KESATUAN (DARI BAGIAN-BAGIAN)
KURANGNYA KEHANGATAN
LANDASAN/DASAR
LOGAM/BESI
MABUK
MISTERI
OBAT/PENYEMBUH
OBJEK (TAK) LENGKAP/DIRI YANG TERPISAH
OBJEK BERSIFAT ILAHI/KEILAHIAN
OBJEK DAMBAAN
OBJEK DI SUATU LOKASI
OBJEK FISIK
OBJEK RAPUH/PECAH BELAH
OBJEK YANG DIARAH/GERAKKAN (KE SESEORANG)
OBJEK/BENDA PENGHIAS
OBJEK/BENDA TAJAM
PASIR
PERANG
PERGERAKAN TERDORONG SUATU OBJEK
PERILAKU AGRESIF BINATANG
PERMAINAN

$\begin{array}{llllllll}\text { KETAKUTAN } & 2 & 1,2063 & 0,5222 & > & 43,475812 & \mathrm{~ns} & 0 \\ \text { KETAKUTAN } & 0 & 0,6031 & 0,6031 & < & 38,020634 & \mathrm{~ns} & 0 \\ \text { KETAKUTAN } & 0 & 0,4825 & 0,4825 & < & 31,786228 & \mathrm{~ns} & 0 \\ \text { KETAKUTAN } & 0 & 1,3269 & 1,3269 & < & 43,496233 & \mathrm{~ns} & 0 \\ \text { KETAKUTAN } & 0 & 0,8444 & 0,8444 & < & 48,34888 \mathrm{~ns} & 0 \\ \text { KETAKUTAN } & 0 & 0,4825 & 0,4825 & < & 31,786228 & \mathrm{~ns} & 0 \\ \text { KETAKUTAN } & 0 & 0,1206 & 0,1206 & < & 3,5454473 & \mathrm{~ns} & 0 \\ \text { KETAKUTAN } & 0 & 0,8444 & 0,8444 & < & 48,34888 & \mathrm{~ns} & 0 \\ \text { KETAKUTAN } & 0 & 0,4825 & 0,4825 & < & 31,786228 & \mathrm{~ns} & 0 \\ \text { KETAKUTAN } & 0 & 0,965 & 0,965 & < & 45,710053 & \mathrm{~ns} & 0 \\ \text { KETAKUTAN } & 0 & 0,3619 & 0,3619 & < & 25,068562 & \mathrm{~ns} & 0 \\ \text { KETAKUTAN } & 1 & 0,2413 & 2,3855 & > & 39,657795 & \mathrm{~ns} & 0 \\ \text { KETAKUTAN } & 0 & 0,6031 & 0,6031 & < & 38,020634 & \mathrm{~ns} & 0 \\ \text { KETAKUTAN } & 0 & 1,4475 & 1,4475 & < & 40,196868 & \mathrm{~ns} & 0 \\ \text { KETAKUTAN } & 0 & 1,4475 & 1,4475 & < & 40,196868 & \mathrm{~ns} & 0 \\ \text { KETAKUTAN } & 9 & 10,374 & 0,182 & < & 48,594673 & \mathrm{~ns} & 0 \\ \text { KETAKUTAN } & 6 & 6,0314 & 2,00 \mathrm{E}-04 & < & 34,27166 & \mathrm{~ns} & 0 \\ \text { KETAKUTAN } & 0 & 1,4475 & 1,4475 & < & 40,196868 & \mathrm{~ns} & 0 \\ \text { KETAKUTAN } & 3 & 3,2569 & 0,0203 & < & 34,800363 & \mathrm{~ns} & 0 \\ \text { KETAKUTAN } & 1 & 0,8444 & 0,0287 & > & 37,065091 & \mathrm{~ns} & 0 \\ \text { KETAKUTAN } & 1 & 1,5682 & 0,2059 & < & 40,67747 & \mathrm{~ns} & 0 \\ \text { KETAKUTAN } & 0 & 0,1206 & 0,1206 & < & 3,5454473 & \mathrm{~ns} & 0 \\ \text { KETAKUTAN } & 0 & 0,4825 & 0,4825 & < & 31,786228 & \mathrm{~ns} & 0 \\ \text { KETAKUTAN } & 2 & 1,4475 & 0,2109 & > & 48,81739 & \mathrm{~ns} & 0 \\ \text { KETAKUTAN } & 0 & 1,2063 & 1,2063 & < & 43,389578 & \mathrm{~ns} & 0 \\ \text { KETAKUTAN } & 0 & 0,2413 & 0,2413 & < & 18,855205 & \mathrm{~ns} & 0\end{array}$


RACUN

\section{SIHIR}

TEORI/ILMU

UNSUR CAMPURAN/MURNI

UNSUR PELEDAK

chi-kwadrat $=2812.898$

G-kwadrat $=2668.658$

$\mathrm{df}=348$

$\mathrm{p}$ untuk chi-kwadrat $=0$

p untuk G-kwadrat $=0$

$\begin{array}{llllllll}\text { KETAKUTAN } & 0 & 0,1206 & 0,1206 & < & 3,5454473 & \mathrm{~ns} & 0 \\ \text { KETAKUTAN } & 0 & 0,7238 & 0,7238 & < & 45,578823 & \mathrm{~ns} & 0 \\ \text { KETAKUTAN } & 0 & 0,7238 & 0,7238 & < & 45,578823 & \mathrm{~ns} & 0 \\ \text { KETAKUTAN } & 5 & 4,7045 & 0,0186 & > & 44,049782 & \mathrm{~ns} & 0 \\ \text { KETAKUTAN } & 0 & 0,2413 & 0,2413< & <18,855205 \mathrm{~ns} & 0\end{array}$




\section{LAMPIRAN 2: Metafora Konseptual Emosi BI}

\section{No. METAFORA AMARAH/KEMARAHAN}

1. AMARAH/KEMARAHAN ADALAH (KUATNYA AKIBAT DARI SUATU) KEKUATAN FISIK 1. (MENGHANCURKAN/DESTRUKTIF)

2. AMARAH/KEMARAHAN ADALAH (OBJEK BER)BAU

3. AMARAH/KEMARAHAN ADALAH (OBJEK BER)WARNA

4. AMARAH/KEMARAHAN ADALAH (SECARA POTENSIAL) MEMBERIKAN/MENTRANSFER SUATU OBJEK

5. AMARAH/KETAKUTAN ADALAH (SECARA POTENSIAL) MENERIMA/MENDAPAT SUATU OBJEK

6. AMARAH/KEMARAHAN ADALAH ADANYA/KEBERADAAN/KEHADIRAN FISIK SUATU OBJEK

7. AMARAH/KEMARAHAN ADALAH API

8. AMARAH/KEMARAHAN ADALAH ATASAN SOSIAL

9. AMARAH/KEMARAHAN ADALAH BEBAN

10. AMARAH/KEMARAHAN ADALAH BERTINDAK/MELAKUKAN SESUATU DI DALAM SUATU LOKASI

11. AMARAH/KEMARAHAN ADALAH BINATANG TAWANAN/BUAS

12. AMARAH/KEMARAHAN ADALAH CAHAYA

13. AMARAH/KEMARAHAN ADALAH CAIRAN DALAM WADAH

14. AMARAH/KEMARAHAN ADALAH CAIRAN PANAS DALAM WADAH

15. AMARAH/KEMARAHAN ADALAH DURASI

16. AMARAH/KEMARAHAN ADALAH GANGGUAN FISIK

17. AMARAH/KEMARAHAN ADALAH GAS/UDARA/NAFAS

18. AMARAH/KEMARAHAN ADALAH HALANGAN (BAGI PERGERAKAN)

19. AMARAH/KEMARAHAN ADALAH IKATAN

20. AMARAH/KEMARAHAN ADALAH KEGELAPAN/GELAP

21. AMARAH/KEMARAHAN ADALAH KEGILAAN

22. AMARAH/KEMARAHAN ADALAH KEKUATAN ALAM

23. AMARAH/KEMARAHAN ADALAH KEPEMILIKAN

24. AMARAH/KEMARAHAN ADALAH KERAS/LEMBUT

25. AMARAH/KEMARAHAN ADALAH KONTROL OBJEK BERGERAK

26. AMARAH/KEMARAHAN ADALAH LANDASAN/DASAR

27. AMARAH/KEMARAHAN ADALAH LOKASI (TERKUNGKUNG/WADAH)

28. AMARAH/KEMARAHAN ADALAH MANUSIA/ORGANISME (TERTIDUR/TENANG)

29. AMARAH/KEMARAHAN ADALAH MELAKUKAN SESUATU/MENJADI DISERTAI/TEMANI DENGAN OBJEK

30. AMARAH/KEMARAHAN ADALAH MUSUH/LAWAN (DALAM SUATU PERJUANGAN/PERTARUNGAN)

31. AMARAH/KESEDIHAN ADALAH NODA/KOTORAN

32. AMARAH/KESEDIHAN ADALAH OBJEK (TAK)TERSEMBUNYI/TAMPAK

33. AMARAH/KEMARAHAN ADALAH OBJEK BERGERAK

34. AMARAH/KEMARAHAN ADALAH OBJEK DI SUATU LOKASI

35. AMARAH/KEMARAHAN ADALAH OBJEK FISIK

36. AMARAH/KEMARAHAN ADALAH OBJEK YANG DIARAH/GERAKKAN (KE SESEORANG)

37. AMARAH/KEMARAHAN ADALAH OBJEK/BENDA TAJAM

38. AMARAH/KEMARAHAN ADALAH PANAS/DINGIN (SUATU OBJEK)

39. AMARAH/KEMARAHAN ADALAH PENYAKIT/SAKIT

40. AMARAH/KEMARAHAN ADALAH PENYEBAB

41. AMARAH/KEMARAHAN ADALAH PERGERAKAN TERDORONG SUATU OBJEK 
42. AMARAH ADALAH PERILAKU AGRESIF BINATANG

43. AMARAH/KEMARAHAN ADALAH RACUN

44. AMARAH/KEMARAHAN ADALAH ROH/MAHKLUK SPIRITUAL

45. AMARAH/KEMARAHAN ADALAH SANTAPAN (MAKANAN/MINUMAN)

46. AMARAH/KEMARAHAN ADALAH SUARA/BUNYI/NADA

47. AMARAH/KEMARAHAN ADALAH TANAMAN

48. AMARAH/KEMARAHAN ADALAH TEORI/ILMU

49. AMARAH/KEMARAHAN ADALAH TINGGI/RENDAH (KEKERAPAN)

50. AMARAH/KEMARAHAN ADALAH UKURAN/KUANTITAS

51. AMARAH/KEMARAHAN ADALAH UNGKAPAN VERBAL/BAHASA

52. AMARAH/KEMARAHAN ADALAH UNSUR CAMPURAN/MURNI

53. AMARAH/KEMARAHAN ADALAH UNSUR DALAM WADAH (BERTEKANAN)

54. AMARAH/KEMARAHAN ADALAH UNSUR PELEDAK

\section{METAFORA KETAKUTAN}

55. KETAKUTAN ADALAH (KUATNYA AKIBAT DARI SUATU) KEKUATAN FISIK (MENGHANCURKAN/DESTRUKTIF)

56. KETAKUTAN ADALAH (OBJEK BER)BAU

57. KETAKUTAN ADALAH (OBJEK BER)WARNA

58. KETAKUTAN ADALAH (SECARA POTENSIAL) MEMBERIKAN/MENTRANSFER SUATU OBJEK

59. KETAKUTAN ADALAH (SECARA POTENSIAL) MENERIMA/MENDAPAT SUATU OBJEK

60. KETAKUTAN ADALAH ADANYA/KEBERADAAN/KEHADIRAN FISIK SUATU OBJEK

61. KETAKUTAN ADALAH ATASAN SOSIAL

62. KETAKUTAN ADALAH BEBAN

63. KETAKUTAN ADALAH BERTINDAK/MELAKUKAN SESUATU DI DALAM SUATU LOKASI

64. KETAKUTAN ADALAH BINATANG TAWANAN/BUAS

65. KETAKUTAN ADALAH CAHAYA

66. KETAKUTAN ADALAH CAIRAN

67. KETAKUTAN ADALAH CAIRAN DALAM WADAH

68. KETAKUTAN ADALAH GANGGUAN FISIK

69. KETAKUTAN ADALAH GAS/UDARA/NAFAS

70. KETAKUTAN ADALAH HALANGAN (BAGI PERGERAKAN)

71. KETAKUTAN ADALAH KEDALAMAN

72. KETAKUTAN ADALAH KEGELAPAN/GELAP

73. KETAKUTAN ADALAH KEKUATAN ALAM

74. KETAKUTAN ADALAH KEPEMILIKAN

75. KETAKUTAN ADALAH LOKASI (TERKUNGKUNG/WADAH)

76. KETAKUTAN ADALAH MANUSIA/ORGANISME (TERTIDUR/TENANG)

77. KETAKUTAN ADALAH MELAKUKAN SESUATU/MENJADI DISERTAI/TEMANI DENGAN OBJEK

78. KETAKUTAN ADALAH NODA/KOTORAN

79. KETAKUTAN ADALAH MUSUH/LAWAN (DALAM SUATU PERJUANGAN/PERTARUNGAN)

80. KETAKUTAN ADALAH OBAT/PENYEMBUH

81. KETAKUTAN ADALAH OBJEK (TAK)TERSEMBUNYI/TAMPAK

82. KETAKUTAN ADALAH OBJEK BERGERAK

83. KETAKUTAN ADALAH OBJEK DI SUATU LOKASI

84. KETAKUTAN ADALAH OBJEK FISIK 
85. KETAKUTAN ADALAH OBJEK YANG DIARAH/GERAKKAN (KE SESEORANG)

86. KETAKUTAN ADALAH OBJEK/BENDA PENGHIAS

87. KETAKUTAN ADALAH OBJEK/BENDA TAJAM

88. KETAKUTAN ADALAH PENYAKIT/SAKIT

89. KETAKUTAN ADALAH PENYEBAB

90. KETAKUTAN ADALAH PERGERAKAN TERDORONG SUATU OBJEK

91. KETAKUTAN ADALAH ROH/MAHKLUK SPIRITUAL

92. KETAKUTAN ADALAH SANTAPAN (MAKANAN/MINUMAN)

93. KETAKUTAN ADALAH SUARA/BUNYI/NADA

94. KETAKUTAN ADALAH TINGGI/RENDAH (KEKERAPAN)

95. KETAKUTAN ADALAH UKURAN/KUANTITAS

96. KETAKUTAN ADALAH UNSUR CAMPURAN/MURNI

97. KETAKUTAN ADALAH UNSUR DALAM WADAH (BERTEKANAN)

\section{METAFORA KEBAHAGIAAN}

98. KEBAHAGIAAN ADALAH (KUATNYA AKIBAT DARI SUATU) KEKUATAN FISIK (MENGHANCURKAN/DESTRUKTIF)

99. KEBAHAGIAAN ADALAH (MENJADI) BERADA DI ATAS (MELAYANG) (UP/OFF THE GROUND)

100. KEBAHAGIAAN ADALAH (MENJADI) BERADA DI SURGA

101. KEBAHAGIAAN ADALAH (SECARA POTENSIAL) MEMBERIKAN/MENTRANSFER SUATU OBJEK

102. KEBAHAGIAAN ADALAH (SECARA POTENSIAL) MENERIMA/MENDAPAT SUATU OBJEK

103. KEBAHAGIAAN ADALAH ADANYA/KEBERADAAN/KEHADIRAN FISIK SUATU OBJEK

104. KEBAHAGIAAN ADALAH BERTINDAK/MELAKUKAN SESUATU DI DALAM SUATU LOKASI

105. KEBAHAGIAAN ADALAH BINATANG TAWANAN/BUAS

106. KEBAHAGIAAN ADALAH CAHAYA

107. KEBAHAGIAAN ADALAH CAIRAN

108. KEBAHAGIAAN ADALAH CAIRAN DALAM WADAH

109. KEBAHAGIAAN ADALAH DURASI

110. KEBAHAGIAAN ADALAH GELEMBUNG

111. KEBAHAGIAAN ADALAH HALANGAN (BAGI PERGERAKAN)

112. KEBAHAGIAAN ADALAH KEGELAPAN/GELAP

113. KEBAHAGIAAN ADALAH KEGILAAN

114. KEBAHAGIAAN ADALAH KEKUATAN ALAM

115. KEBAHAGIAAN ADALAH KEPEMILIKAN

116. KEBAHAGIAAN ADALAH LOKASI (TERKUNGKUNG/WADAH)

117. KEBAHAGIAAN ADALAH MANUSIA/ORGANISME (TERTIDUR/TENANG)

118. KEBAHAGIAAN ADALAH MELAKUKAN SESUATU/MENJADI DISERTAI/TEMANI DENGAN OBJEK

119. KEBAHAGIAAN ADALAH MENCARI/MENGEJAR/MEMBURU SUATU OBJEK

120. KEBAHAGIAAN ADALAH MENEMUKAN/MERAIH SUATU OBJEK

121. KEBAHAGIAAN ADALAH MUSUH/LAWAN (DALAM SUATU PERJUANGAN/PERTARUNGAN)

122. KEBAHAGIAAN ADALAH OBJEK (TAK) LENGKAP/DIRI YANG TERPISAH

123. KEBAHAGIAAN ADALAH OBJEK (TAK)TERSEMBUNYI/TAMPAK

124. KEBAHAGIAAN ADALAH OBJEK ASLI/PALSU

125. KEBAHAGIAAN ADALAH OBJEK BERGERAK

126. KEBAHAGIAAN ADALAH OBJEK BERHARGA (DAN METAFORA KOMERSIL LAINNYA)

127. KEBAHAGIAAN ADALAH OBJEK DAMBAAN

128. KEBAHAGIAAN ADALAH OBJEK DI SUATU LOKASI 
129. KEBAHAGIAAN ADALAH OBJEK FISIK

130. KEBAHAGIAAN ADALAH OBJEK RAPUH/PECAH BELAH

131. KEBAHAGIAAN ADALAH OBJEK/BENDA TAJAM

132. KEBAHAGIAAN ADALAH PENYEBAB

133. KEBAHAGIAAN ADALAH PERJALANAN

134. KEBAHAGIAAN ADALAH SANTAPAN (MAKANAN/MINUMAN)

135. KEBAHAGIAAN ADALAH SIHIR

136. KEBAHAGIAAN ADALAH SUARA/BUNYI/NADA

137. KEBAHAGIAAN ADALAH TANAMAN

138. KEBAHAGIAAN ADALAH UKURAN/KUANTITAS

139. KEBAHAGIAAN ADALAH UNGKAPAN VERBAL/BAHASA

140. KEBAHAGIAAN ADALAH UNSUR CAMPURAN/MURNI

141. KEBAHAGIAAN ADALAH UNSUR DALAM WADAH (BERTEKANAN)

\section{METAFORA KESEDIHAN}

142. KESEDIHAN ADALAH (KUATNYA AKIBAT DARI SUATU) KEKUATAN FISIK (MENGHANCURKAN/DESTRUKTIF)

143. KESEDIHAN ADALAH (MENJADI) BERADA DI BAWAH

144. KESEDIHAN ADALAH (OBJEK BER)WARNA

145. KESEDIHAN ADALAH (SECARA POTENSIAL) MEMBERIKAN/MENTRANSFER SUATU OBJEK

146. KESEDIHAN ADALAH (SECARA POTENSIAL) MENERIMA/MENDAPAT SUATU OBJEK

147. KESEDIHAN ADALAH ADANYA/KEBERADAAN/KEHADIRAN FISIK SUATU OBJEK

148. KESEDIHAN ADALAH API

149. KESEDIHAN ADALAH ATASAN SOSIAL

150. KESEDIHAN ADALAH BEBAN

151. KESEDIHAN ADALAH BERTINDAK/MELAKUKAN SESUATU DI DALAM SUATU LOKASI

152. KESEDIHAN ADALAH BINATANG TAWANAN/BUAS

153. KESEDIHAN ADALAH CAHAYA

154. KESEDIHAN ADALAH CAIRAN

155. KESEDIHAN ADALAH CAIRAN DALAM WADAH

156. KESEDIHAN ADALAH CATATAN

157. KESEDIHAN ADALAH DURASI

158. KESEDIHAN ADALAH GANGGUAN FISIK

159. KESEDIHAN ADALAH GAS/UDARA/NAFAS

160. KESEDIHAN ADALAH HALANGAN (BAGI PERGERAKAN)

161. KESEDIHAN ADALAH KEBEBASAN

162. KESEDIHAN ADALAH KEDALAMAN

163. KESEDIHAN ADALAH KEGELAPAN/GELAP

164. KESEDIHAN ADALAH KEKUATAN ALAM

165. KESEDIHAN ADALAH KEPEMILIKAN

166. KESEDIHAN ADALAH KERAS/LEMBUT

167. KESEDIHAN ADALAH KONTROL OBJEK BERGERAK

168. KESEDIHAN ADALAH KURANGNYA KEHANGATAN

169. KESEDIHAN ADALAH LOKASI (TERKUNGKUNG/WADAH)

170. KESEDIHAN ADALAH MANUSIA/ORGANISME (TERTIDUR/TENANG)

171. KESEDIHAN ADALAH MELAKUKAN SESUATU/MENJADI DISERTAI/TEMANI DENGAN OBJEK

172. KESEDIHAN ADALAH MENEMUKAN/MERAIH SUATU OBJEK 
173. KESEDIHAN ADALAH MUSUH/LAWAN (DALAM SUATU PERJUANGAN/PERTARUNGAN)

174. KESEDIHAN ADALAH NODA/KOTORAN

175. KESEDIHAN ADALAH OBJEK (TAK)TERSEMBUNYI/TAMPAK

176. KESEDIHAN ADALAH OBJEK BERGERAK

177. KESEDIHAN ADALAH OBJEK BERHARGA (DAN METAFORA KOMERSIL LAINNYA)

178. KESEDIHAN ADALAH OBJEK DI SUATU LOKASI

179. KESEDIHAN ADALAH OBJEK FISIK

180. KESEDIHAN ADALAH OBJEK YANG DIARAH/GERAKKAN (KE SESEORANG)

181. KESEDIHAN ADALAH OBJEK/BENDA TAJAM

182. KESEDIHAN ADALAH PENYAKIT/SAKIT

183. KESEDIHAN ADALAH PENYEBAB

184. KESEDIHAN ADALAH PERGERAKAN TERDORONG SUATU OBJEK

185. KESEDIHAN ADALAH SANTAPAN (MAKANAN/MINUMAN)

186. KESEDIHAN ADALAH SIHIR

187. KESEDIHAN ADALAH SUARA/BUNYI/NADA

188. KESEDIHAN ADALAH TANAMAN

189. KESEDIHAN ADALAH TEORI/ILMU

190. KESEDIHAN ADALAH UKURAN/KUANTITAS

191. KESEDIHAN ADALAH UNSUR CAMPURAN/MURNI

192. KESEDIHAN ADALAH UNSUR DALAM WADAH (BERTEKANAN)

\section{METAFORA CINTA}

193. CINTA ADALAH (KUATNYA AKIBAT DARI SUATU) KEKUATAN FISIK

(MENGHANCURKAN/DESTRUKTIF)

194. CINTA ADALAH (OBJEK BER)WARNA

195. CINTA ADALAH (SECARA POTENSIAL) MEMBERIKAN/MENTRANSFER SUATU OBJEK

196. CINTA ADALAH (SECARA POTENSIAL) MENERIMA/MENDAPAT SUATU OBJEK

197. CINTA ADALAH ADANYA/KEBERADAAN/KEHADIRAN FISIK SUATU OBJEK

198. CINTA ADALAH API

199. CINTA ADALAH ATASAN SOSIAL

200. CINTA ADALAH BANGUNAN

201. CINTA ADALAH BEBAN

202. CINTA ADALAH BERTINDAK/MELAKUKAN SESUATU DI DALAM SUATU LOKASI

203. CINTA ADALAH CAHAYA

204. CINTA ADALAH CAIRAN

205. CINTA ADALAH CAIRAN DALAM WADAH

206. CINTA ADALAH CERITA

207. CINTA ADALAH GARIS

208. CINTA ADALAH HALANGAN (BAGI PERGERAKAN)

209. CINTA ADALAH IKATAN

210. CINTA ADALAH KEBEBASAN

211. CINTA ADALAH KEDALAMAN

212. CINTA ADALAH KEGELAPAN/GELAP

213. CINTA ADALAH KEGILAAN

214. CINTA ADALAH KEHANGATAN

215. CINTA ADALAH KEKUATAN ALAM

216. CINTA ADALAH KEPEMILIKAN 
217. CINTA ADALAH KESALAHAN (WRONGDOING)

218. CINTA ADALAH KESATUAN (DARI BAGIAN-BAGIAN) (UNITY OF PARTS)

219. CINTA ADALAH LANDASAN/DASAR

220. CINTA ADALAH LOGAM/BESI

221. CINTA ADALAH LOKASI (TERKUNGKUNG/WADAH)

222. CINTA ADALAH MABUK (RAPTURE/HIGH)

223. CINTA ADALAH MANUSIA/ORGANISME (TERTIDUR/TENANG)

224. CINTA ADALAH MELAKUKAN SESUATU/MENJADI DISERTAI/TEMANI DENGAN OBJEK

225. CINTA ADALAH MENCARI/MENGEJAR/MEMBURU SUATU OBJEK

226. CINTA ADALAH MENEMUKAN/MERAIH SUATU OBJEK

227. CINTA ADALAH MISTERI

228. CINTA ADALAH MUSUH/LAWAN (DALAM SUATU PERJUANGAN/PERTARUNGAN)

229. CINTA ADALAH OBAT/PENYEMBUH

230. CINTA ADALAH OBJEK (TAK)TERSEMBUNYI/TAMPAK

231. CINTA ADALAH OBJEK ASLI/PALSU

232. CINTA ADALAH OBJEK BERGERAK

233. CINTA ADALAH OBJEK BERHARGA (DAN METAFORA KOMERSIL LAINNYA)

234. CINTA ADALAH OBJEK BERSIFAT ILAHI/KEILAHIAN

235. CINTA ADALAH OBJEK DAMBAAN

236. CINTA ADALAH OBJEK DI SUATU LOKASI

237. CINTA ADALAH OBJEK FISIK

238. CINTA ADALAH OBJEK RAPUH/PECAH BELAH

239. CINTA ADALAH OBJEK YANG DIARAH/GERAKKAN (KE SESEORANG)

240. CINTA ADALAH OBJEK/BENDA PENGHIAS

241. CINTA ADALAH OBJEK/BENDA TAJAM

242. CINTA ADALAH PASIR

243. CINTA ADALAH PENYAKIT/SAKIT

244. CINTA ADALAH PENYEBAB

245. CINTA ADALAH PERANG

246. CINTA ADALAH PERGERAKAN (AKSIDENTAL) MENUJU SUATU LOKASI

247. CINTA ADALAH PERJALANAN

248. CINTA ADALAH PERMAINAN

249. CINTA ADALAH ROH/MAHKLUK SPIRITUAL

250. CINTA ADALAH SANTAPAN (MAKANAN/MINUMAN)

251. CINTA ADALAH SIHIR

252. CINTA ADALAH SUARA/BUNYI/NADA

253. CINTA ADALAH TANAMAN

254. CINTA ADALAH TEORI/ILMU

255. CINTA ADALAH UKURAN/KUANTITAS

256. CINTA ADALAH UNGKAPAN VERBAL/BAHASA

257. CINTA ADALAH UNSUR CAMPURAN/MURNI

258. CINTA ADALAH UNSUR DALAM WADAH (BERTEKANAN)

Jumlah: 258 MK 


\section{LAMPIRAN 3: 88 Ranah Sumber Metaforis BI yang Ditemukan}

\section{No. Ranah Sumber Metaforis}

\section{Kekerapan}

1. (KUATNYA AKIBAT DARI SUATU) KEKUATAN FISIK (MENGHANCURKAN/DESTRUKTIF) 5

2. (MENJADI) BERADA DI ATAS (MELAYANG) (UP/OFF THE GROUND) 1

3. (MENJADI) BERADA DI SURGA

4. (MENJADI) BERADA DI BAWAH

5. (OBJEK BER)BAU

6. (OBJEK BER)WARNA

7. (SECARA POTENSIAL) MEMBERIKAN/MENTRANSFER SUATU OBJEK

8. (SECARA POTENSIAL) MENERIMA/MENDAPAT SUATU OBJEK

9. ADANYA/KEBERADAAN/KEHADIRAN FISIK SUATU OBJEK

10. API

11. ATASAN SOSIAL

12. BANGUNAN

13. BEBAN

14. BERTINDAK/MELAKUKAN SESUATU DI DALAM SUATU LOKASI

15. BINATANG TAWANAN/BUAS

16. CAHAYA

17. CAIRAN

18. CAIRAN DALAM WADAH

19. CAIRAN PANAS DALAM WADAH

CATATAN

CERITA

DURASI

GANGGUAN FISIK

GARIS

GAS/UDARA/NAFAS

GELEMBUNG

HALANGAN (BAGI PERGERAKAN)

IKATAN

KEBEBASAN

KEDALAMAN

KEGELAPAN/GELAP

KEGILAAN

KEHANGATAN

KEKUATAN ALAM

KEPEMILIKAN

KERAS/LEMBUT

KESALAHAN (WRONGDOING)

KESATUAN (DARI BAGIAN-BAGIAN) (UNITY OF PARTS)

KONTROL OBJEK BERGERAK

KURANGNYA KEHANGATAN 
41. LANDASAN/DASAR 2

42. LOGAM/BESI 1

43. LOKASI (TERKUNGKUNG/WADAH) 5

44. MABUK (RAPTURE/HIGH) 1

45. MANUSIA/ORGANISME (TERTIDUR/TENANG) 5

46. MELAKUKAN SESUATU/MENJADI DISERTAI/TEMANI DENGAN OBJEK 5

47. MENCARI/MENGEJAR/MEMBURU SUATU OBJEK 2

48. MENEMUKAN/MERAIH SUATU OBJEK

49. MISTERI 1

50. MUSUH/LAWAN (DALAM SUATU PERJUANGAN/PERTARUNGAN) 5

51. NODA/KOTORAN 3

52. OBAT/PENYEMBUH 2

53. OBJEK (TAK) LENGKAP/DIRI YANG TERPISAH

54. OBJEK (TAK)TERSEMBUNYI/TAMPAK 5

55. OBJEK ASLI/PALSU 2

56. OBJEK BERGERAK

57. OBJEK BERHARGA (DAN METAFORA KOMERSIL LAINNYA) 3

58. OBJEK BERSIFAT ILAHI/KEILAHIAN 1

59. OBJEK DAMBAAN 2

60. OBJEK DI SUATU LOKASI 25

61. OBJEK FISIK

62. OBJEK RAPUH/PECAH BELAH 2

63. OBJEK YANG DIARAH/GERAKKAN (KE SESEORANG) 4

64. OBJEK/BENDA PENGHIAS 2

65. OBJEK/BENDA TAJAM 25

66. PANAS/DINGIN (SUATU OBJEK) 1

67. PASIR 1

68. PENYAKIT/SAKIT 4

69. PENYEBAB $\quad 5$

70. PERANG 1

71. PERGERAKAN (AKSIDENTAL) MENUJU SUATU LOKASI $\quad 1$

72. PERGERAKAN TERDORONG SUATU OBJEK 3

73. PERILAKU AGRESIF BINATANG 1

74. PERJALANAN 2

75. PERMAINAN 1

76. RACUN 1

77. ROH/MAHKLUK SPIRITUAL 3

78. SANTAPAN (MAKANAN/MINUMAN)

79. SIHIR 3

80. SUARA/BUNYI/NADA 25

81. TANAMAN 4

82. TEORI/ILMU

83. TINGGI/RENDAH (KEKERAPAN) 2

84. UKURAN/KUANTITAS

85. UNGKAPAN VERBAL/BAHASA 3 
86. UNSUR CAMPURAN/MURNI

5

87. UNSUR DALAM WADAH (BERTEKANAN)

5

88. UNSUR PELEDAK 


\section{LAMPIRAN 4: Metafora Konseptual Universal untuk Emosi Cinta}

MK CINTA ADALAH API dan contoh MLnya

\section{Bahasa Inggris}

With time we will see what this was; a flare-up, or a feeling on which a lasting relationship can be built. (Kövecses, 2000:140)

'Dengan waktu kita akan melihat apa ini, sebuah suar, atau perasaan di mana hubungan yang abadi dapat dibangun.'

\section{Bahasa Hungaria}

Idövel majd elválik, hogy mi volt ez, fellángolás, vagy olyan érzelem, amire tartós kapcsolatot épithetnek. (Kövecses, 2000:140)

'Dengan waktu kita akan melihat apa ini, sebuah suar, atau perasaan di mana hubungan yang abadi dapat dibangun.'

\section{MK CINTA ADALAH SIHIR (MAGIC) dan contoh Mlnya}

\section{Bahasa Inggris}

We met. And an inconceivable magic overpowered me. (Kövecses, 2000:141)

'Kami bertemu. Dan keajaiban yang tak terbayangkan menguasai saya.'

\section{Bahasa Hungaria}

Találkoztunk.És valami megfoghatatlan varázslat kerített hatalmába. (Kövecses, 2000:141)

'Kami bertemu. Dan keajaiban yang tak terbayangkan menguasai saya.'

\section{Bahasa Indonesia} ... tapi yang paling berbahaya adalah pesona cinta itu sendiri.

MK CINTA ADALAH KEKUATAN FISIK dan contoh MLnya

\section{Bahasa Inggris}

The girl attracts me as a magnet.

(Kövecses, 2000:141)

'Gadis itu menarik saya bagai sebuah magnet.'

\section{Bahasa Hungaria}

A lány mágnesként vonz.

(Kövecses, 2000:141)

'Gadis itu menarik saya

bagai sebuah magnet.'

\section{Bahasa Indonesia}

Toh cinta di situ cuma

kekuatan yang mendorong ke arah perkawinan. 
MK CINTA ADALAH MUSUH dan contoh Mlnya

\section{Bahasa Inggris}

Love or the empire? The dilemma is taking its toll on Antonius's life. Not good sense, but blind love wins. (Kövecses, 2000:141)

'Cinta atau kekaisaran? Dilemanya, korbannya adalah kehidupan Antonius. Bukan akal yang baik, tapi cinta buta menang.'

\section{Bahasa Hungaria}

Szerelem vagy birodalom? Antonius életét felórli a dilemma. Nem a józan ész, a vak szerelem gyöz.

(Kövecses, 2000:141)

'Cinta atau kekaisaran?

Dilemanya, korbannya

adalah kehidupan Antonius.

Bukan akal yang baik, tapi

cinta buta menang.'

\section{Bahasa Indonesia}

Ia tahu kalau kadang apa yang aku lakukan di luar nalar manusia biasa namun rasa cinta mengalahkan semuanya. 


\section{LAMPIRAN 5: Metafora Universal "WADAH” dan Contoh MLnya}

\section{Bahasa: Contoh ML}

Inggris 1. He was filled with anger. (Kövecses, 2000:147)

'Dia dipenuhi amarah'.

2. Try to get your anger out of your system. (Kövecses, 2000:147) 'Cobalah keluarkan amarahmu dari sistemmu'.

Hungaria 1. Tele van dühvel [penuh adalah düh-dengan]. (Kövecses, 2000:147) Dia penuh dengan amarah.

2. Nem tudta magában tartani dühét [tidak dapat dia sendiri-dalam simpan amarah-nya]. (Kövecses, 2000:147)

'Dia tidak dapat menyimpan amarahnya di dalam'.

China 1. man qiang fen nu [penuh lubang amarah] (Kövecses, 2000:147) 'memenuhi ruang dalam tubuh dengan amarah'

Jepang 1. Ikari ga karadajyu ni jyuman shita [amarah dalam tubuh saya dipenuhi (lampau)]. (Kövecses, 2000:147)

'Tubuh saya dipenuhi dengan amarah'.

2. Ikari o uchi ni himeta [amarah di dalam mengunci]. (Kövecses, 2000:147)

'Saya mengandung kemarahan saya'.

Indonesia 1. Sidik berteriak-teriak penuh amarah.

2. Benaknya yang tadi dipenuhi amarah berangsur menjernih. 


\section{LAMPIRAN 6: Persebaran Leksikon "Anggota Tubuh" RT Emosi}

\begin{tabular}{|c|c|c|c|c|c|c|c|c|}
\hline WADAH & EMOSI & $\begin{array}{c}\text { Frek. } \\
\text { Riil }\end{array}$ & $\begin{array}{r}\text { Frek. } \\
\text { Har }\end{array}$ & $\begin{array}{l}\text { Kont. pd chi- } \\
\text { kwadrat }\end{array}$ & Riil-Har & P.adj.Holm & Put & $\mathbf{K}$ \\
\hline Hati & amarah & 25 & 34,1197 & 2,4376 & $<$ & 1,002753 & $\mathrm{~ns}$ & 0,09 \\
\hline Dada & amarah & 16 & 10,4155 & 2,9943 & $>$ & 1,263564 & $\mathrm{~ns}$ & 0,04 \\
\hline Dada & cinta & 0 & 5,3099 & 5,3099 & $<$ & 0,111603 & $\mathrm{~ns}$ & 0,04 \\
\hline Hati & cinta & 22 & 17,3944 & 1,2194 & $>$ & 2,939917 & $\mathrm{~ns}$ & 0,04 \\
\hline Hati & kesedihan & 32 & 28,0986 & 0,5417 & $>$ & 4,206355 & $\mathrm{~ns}$ & 0,03 \\
\hline kepala & amarah & 4 & 1,4366 & 4,574 & $>$ & 1,311143 & $\mathrm{~ns}$ & 0,02 \\
\hline Mata & kesedihan & 1 & 3,5493 & 1,831 & $<$ & 2,677522 & $\mathrm{~ns}$ & 0,02 \\
\hline Hati & kebahagiaan & 10 & 8,6972 & 0,1952 & $>$ & 5,571648 & $\mathrm{~ns}$ & 0,01 \\
\hline kepala & kesedihan & 0 & 1,1831 & 1,1831 & $<$ & 5,181832 & $\mathrm{~ns}$ & 0,01 \\
\hline Mata & ketakutan & 2 & 0,8451 & 1,5783 & $>$ & 3,939134 & $\mathrm{~ns}$ & 0,01 \\
\hline Mata & cinta & 3 & 2,1972 & 0,2933 & $>$ & 5,277157 & $\mathrm{~ns}$ & 0,01 \\
\hline Mata & amarah & 5 & 4,3099 & 0,1105 & $>$ & 5,620963 & $\mathrm{~ns}$ & 0,01 \\
\hline kepala & cinta & 0 & 0,7324 & 0,7324 & $<$ & 5,758155 & $\mathrm{~ns}$ & 0,01 \\
\hline Dada & kebahagiaan & 2 & 2,6549 & 0,1615 & $<$ & 4,528778 & $\mathrm{~ns}$ & 0,01 \\
\hline Hati & ketakutan & 6 & 6,6901 & 0,0712 & $<$ & 4,942435 & $\mathrm{~ns}$ & 0,01 \\
\hline jantung & cinta & 1 & 0,3662 & 1,0969 & $>$ & 4,911389 & $\mathrm{~ns}$ & 0 \\
\hline jantung & kesedihan & 0 & 0,5915 & 0,5915 & $<$ & 3,8695 & $\mathrm{~ns}$ & 0 \\
\hline kepala & kebahagiaan & 0 & 0,3662 & 0,3662 & $<$ & 3,465191 & $\mathrm{~ns}$ & 0 \\
\hline Dada & kesedihan & 9 & 8,5775 & 0,0208 & $>$ & 5,389762 & $\mathrm{~ns}$ & 0 \\
\hline jantung & amarah & 1 & 0,7183 & 0,1105 & $>$ & 4,106499 & $\mathrm{~ns}$ & 0 \\
\hline kepala & ketakutan & 0 & 0,2817 & 0,2817 & $<$ & 2,262889 & $\mathrm{~ns}$ & 0 \\
\hline Jantung & kebahagiaan & 0 & 0,1831 & 0,1831 & $<$ & 1,665175 & $\mathrm{~ns}$ & 0 \\
\hline Mata & kebahagiaan & 1 & 1,0986 & 0,0088 & $<$ & 2,797625 & $\mathrm{~ns}$ & 0 \\
\hline Jantung & ketakutan & 0 & 0,1408 & 0,1408 & $<$ & 0,868563 & $\mathrm{~ns}$ & 0 \\
\hline Dada & ketakutan & 2 & 2,0423 & $9,00 \mathrm{E}-04$ & $<$ & 3,990977 & $\mathrm{~ns}$ & 0 \\
\hline
\end{tabular}

chi-kwadrat $=26.035$

$\mathrm{G}-\mathrm{kwadrat}=32.919$

$\mathrm{df}=16$

p utk chi-kwadrat $=0.05354265$

p utk G-kwadrat $=0.007575393$ 


\section{LAMPIRAN 7: Riwayat Hidup}

\begin{tabular}{|c|c|}
\hline Nama & : I Made Rajeg \\
\hline Jenis Kelamin & : Laki-laki \\
\hline $\begin{array}{l}\text { Tempat \& Tanggal Lahir } \\
\text { Alamat }\end{array}$ & : Klungkung, 19 Oktober 1958 \\
\hline Rumah & $\begin{array}{l}\text { : Jalan Dewata II No. } 5 \text { Denpasar } \\
\text { Telpon 0361-722759 }\end{array}$ \\
\hline Kantor & $\begin{array}{l}\text { : Fakultas Sastra Universitas Udayana } \\
\text { Jalan P. Nias No. } 13 \text { Denpasar } \\
\text { Telpon 0361-257415 } \\
\text { E-mail: } \underline{\text { mrajeg@ffs.unud.ac.id }} \\
\underline{\text { imaderajeg@gmail.com }}\end{array}$ \\
\hline Pangkat/Golongan & : Pembina/IVa \\
\hline Jabatan & : Lektor Kepala \\
\hline NIP & : 195810191986031001 \\
\hline Anggota Keluarga & \\
\hline Istri & : Dra. Luh Putu Laksminy, M.Hum. \\
\hline Anak-anak & $\begin{array}{l}\text { 1. Gede Primahadi Wijaya R., S.S., M.Hum. } \\
\text { 2. Kadek Dedy Prawira Jaya R., S.S. } \\
\text { 3. Komang Surya Bhuana R., S.Ked. }\end{array}$ \\
\hline
\end{tabular}

\section{Riwayat Pedidikan}

1965--1971 SD No. 1 Timuhun Klungkung

1971--1974 SMP Dharmayasa Timuhun Klungkung

1977--1980 SMA Vijaya Kusuma Inmindam XVI Udayana

1980--1985 Sarjana Strata 1 Jurusan Sastra Inggris

Fakultas Sastra Universitas Udayana

2002--2006 Program Magister (S2) Linguistik Universitas Udayana

2008--2013 Program Doktor (S3) Linguistik Universitas Udayana

\section{Kursus}

\begin{tabular}{|l|l|l|l|}
\hline No & Nama Kursus & Tahun & Penyelenggara/Tempat \\
\hline 1. & Kursus Bahasa Jepang & $1991-1992$ & Reitaku University Japan \\
\hline & $\begin{array}{l}\text { Teaching English as a } \\
\text { Foreign Language (TEFL) }\end{array}$ & 1993 & $\begin{array}{l}\text { Macquarie University and } \\
\text { Udayana University }\end{array}$ \\
\hline 3. & $\begin{array}{l}\text { Building Teaching Skill } \\
\text { Through the Interactive Web } \\
\text { (WebSkills) (online course) }\end{array}$ & 2013 & $\begin{array}{l}\text { University of Oregon } \\
\text { American English Institute, } \\
\text { America }\end{array}$ \\
\hline
\end{tabular}


Riwayat Pekerjaan

\begin{tabular}{|l|l|l|}
\hline No & Tahun & Deskripsi Pekerjaan \\
\hline 1. & $1986-$ Sekarang & Staf pengajar Jurusan Sastra Inggris Unud \\
\hline 2. & $1992-1998$ & $\begin{array}{l}\text { Sekretaris Lab Jurusan Sastra Inggris Fakultas Sastra } \\
\text { Unud. }\end{array}$ \\
\hline 3. & $1999-2002$ & $\begin{array}{l}\text { Sekretaris Program D3 Bahasa Jepang Fakultas Sastra } \\
\text { Unud. }\end{array}$ \\
\hline 4. & $2002-2006$ & Sekretaris Pusat Studi Jepang Unud \\
\hline 5. & $2005-2009$ & Sekretaris Program BIPA Fakultas Sastra Unud \\
\hline 6. & 2010 sekarang & $\begin{array}{l}\text { Ketua Bali International Program on Asian Studies } \\
\text { Fakultas Sastra Unud }\end{array}$ \\
\hline
\end{tabular}

Pengalaman Penelitian (5 Tahun Terakhir)

\begin{tabular}{|c|l|l|}
\hline No & Judul Penelitian & Tahun \\
\hline 1. & $\begin{array}{l}\text { Kemudahan dan Kesulitan Fonologis Belajar Bahasa Indonesia } \\
\text { Sebagai Bahasa Asing oleh Penutur Bahasa Jepang. }\end{array}$ & 2008 \\
\hline 2. & $\begin{array}{l}\text { Profil Ibu Rumah Tangga Jepang dalam Pasangan Kawin } \\
\text { Campur Etnis Bali dengan Wisatawan Jepang di Kawasan } \\
\text { Wisata Ubud. }\end{array}$ & 2008 \\
\hline 3. & $\begin{array}{l}\text { Hindu Ritual of Ngotonin in Bali (A Discourse Analysis } \\
\text { Approach). }\end{array}$ & 2009 \\
\hline 4. & $\begin{array}{l}\text { CINTANYA BERTEPUK SEBELAH TANGAN: Metaphoric } \\
\text { and Metonymic Conceptualisation of LOVE in Indonesian. }\end{array}$ & 2009 \\
\hline 5. & $\begin{array}{l}\text { Interferensi Bahasa Ibu dalam Berkomunikasi Tulis Mahasiswa } \\
\text { Sastra Inggris di Bali. }\end{array}$ & 2010 \\
\hline 6. & $\begin{array}{l}\text { Penelitian Buku Ajar Bahasa Inggris Siswa Sekolah Dasar di } \\
\text { Bali. }\end{array}$ & 2010 \\
\hline 7. & $\begin{array}{l}\text { "NIKMATILAH KEBAHAGIAAN INI.” Metafora Emosi } \\
\text { Kebahagiaan dalam Bahasa Indonesia: Analisis Pola Metafora } \\
\text { Berbasis Korpus. }\end{array}$ & 2011 \\
\hline
\end{tabular}

Pengalaman Seminar (5 Tahun Terakhir)

\begin{tabular}{|c|l|l|l|}
\hline No. & Tema Seminar & Tahun & Peran \\
\hline 1. & Seminar Nasional Bahasa Ibu II & $\begin{array}{l}27-28 \text { Feb } \\
2008\end{array}$ & Pemakalah \\
\hline 2. & $\begin{array}{l}\text { The 3rd SSEASR Conference of South and Southeast } \\
\text { Asian Association For The Study of Culture and Religion } \\
\text { on Waters in South and Southeast Asia: Interaction of } \\
\text { Culture And Religion, Denpasar, Bali, Indonesia. }\end{array}$ & $\begin{array}{l}\text { 03-06 Jun } \\
2009\end{array}$ & Pemakalah \\
\hline 3. & $\begin{array}{l}\text { Konferensi Internasional Masyarakat Linguistik } \\
\text { Indonesia (KIMLI) I, Batu, Malang }\end{array}$ & $\begin{array}{l}\text { 5-7 Nop } \\
2009\end{array}$ & Pemakalah \\
\hline
\end{tabular}




\begin{tabular}{|c|c|c|c|}
\hline 4. & $\begin{array}{l}\text { The } 6^{\text {th }} \text { Asia TEFL International Conference: } \\
\text { "GLOBALIZING ASIA : THE ROLE OF ELT", } \\
\text { Denpasar Bali }\end{array}$ & $\begin{array}{l}1-3 \text { Agst } \\
2008\end{array}$ & Peserta \\
\hline 5. & $\begin{array}{l}\text { Seminar Nasional Bahasa Ibu III “ Menguatkan } \\
\text { Bahasa Ibu sebagai Ciri Kepribadian, Identitas } \\
\text { Kelokalam dan Keindonesiaan di tengah gerusan } \\
\text { Globalisasi”. }\end{array}$ & $\begin{array}{l}24-25 \\
\text { Feb } 2010\end{array}$ & Pemakalah \\
\hline 6. & $\begin{array}{l}\text { The } 5^{\text {th }} \text { International Seminar on Austronesian } \\
\text { Language and Literature "Discovering The } \\
\text { Linguistic Potential of The Austronesian } \\
\text { Languages for the Linguistic Advencement and for } \\
\text { The maintenance of the Language" }\end{array}$ & $\begin{array}{l}20 \mathrm{Jul} \\
2010\end{array}$ & Pemakalah \\
\hline 7. & $\begin{array}{l}\text { Seminar Nasional Bahasa Ibu V dalam Rangka } \\
\text { Memperingati Hari Bahasa Ibu Internasional. }\end{array}$ & $\begin{array}{l}17-18 \\
\text { Feb } 2012\end{array}$ & Pemakalah \\
\hline
\end{tabular}

Publikasi Jurnal Ilmiah (5 Tahun Terakhir)

\begin{tabular}{|c|l|l|l|}
\hline No. & Judul Naskah & Nama Jurnal & Tahun \\
\hline 1. & $\begin{array}{l}\text { Pelatihan Bahasa Inggris } \\
\text { Komuikatif Bagi } \\
\text { Kelompok Sadar Wisata di } \\
\text { Desa Carang Sari Badung } \\
\text { Utara }\end{array}$ & $\begin{array}{l}\text { Jurnal Pengabdian Kepada } \\
\text { Masyarakat” Udayana Mengabdi” } \\
\text { Volume 9 nomor 2 tahun 2010, } \\
\text { LPM Unud }\end{array}$ & 2010 \\
\hline 2. & $\begin{array}{l}\text { Novel “Tarian Bumi” } \\
\text { Karya Oka Rusmini, } \\
\text { Kajian bahasa dan Gender }\end{array}$ & $\begin{array}{l}\text { Pustaka: Jurnal Ilmu-Ilmu Budaya } \\
\text { ISSN 0215-9198 Volume X. No.2 } \\
\text { Tahun 2010 }\end{array}$ & 2010 \\
\hline 3. & $\begin{array}{l}\text { Hindu Ritual of Ngotonin } \\
\text { in Bali (A Discourse } \\
\text { Analysis Approach) }\end{array}$ & $\begin{array}{l}\text { South and Southeast Asia Culture } \\
\text { and Religion: The SSEASR } \\
\text { Journal Volume V 2011 }\end{array}$ & 2011 \\
\hline 4. & $\begin{array}{l}\text { Pengenalan Etika } \\
\text { Berbahasa Inggris untuk } \\
\text { Kelompok Sadar Wisata di } \\
\text { desa Pangsan Petang } \\
\text { Badung Utara }\end{array}$ & $\begin{array}{l}\text { Jurnal Pengabdian Kepada } \\
\text { Masyarakat" Udayana Mengabdi” } \\
\text { Volume 11 nomor 2, LPM Unud }\end{array}$ & 2012 \\
\hline
\end{tabular}

Publikasi Buku dan Monograf (5 Tahun Terakhir)

\begin{tabular}{|c|l|l|l|}
\hline No. & Judul Buku & Deskripsi & Tahun \\
\hline 1. & "Hatinya Membara": & Buku monograf 5 ${ }^{\text {th }}$ International & 2010 \\
& Metaphoric and & Seminar on Austronesian & \\
& Metonymic & Language and Literature: & \\
& Conceptualisation of & Perspektif Bahasa-Bahasa & \\
& ANGER in Indonesian & Austronesia dan Non-Astronesian & \\
& & (Kajian Bahasa Dan Sastra). ISBN & \\
& & $978-602-8566-797 /$ Denpasar & \\
\hline
\end{tabular}




\begin{tabular}{|c|c|c|c|}
\hline 2. & $\begin{array}{l}\text { "Kebus Basange" } \\
\text { Metaphoric and } \\
\text { Metonymic } \\
\text { Conceptualisation of } \\
\text { ANGER in Balinese }\end{array}$ & $\begin{array}{l}\text { Buku Monograf : Menguatkan } \\
\text { Bahasa Ibu sebagai Ciri } \\
\text { Kepribadian, Identitas Kelokalam } \\
\text { dan Keindonesiaan di tengah } \\
\text { gerusan Globalisasi" ISBN : 978- } \\
602-8566-49-0\end{array}$ & 2010 \\
\hline 3. & $\begin{array}{l}\text { Communicative English } \\
\text { for Primary School } \\
\text { Students Grade 1: } \\
\text { Students' Book }\end{array}$ & $\begin{array}{l}\text { Buku Ajar Bahasa Inggris } \\
\text { Sekolah Diswa } \\
\text { untuk Siswa }\end{array}$ & 2011 \\
\hline 4. & $\begin{array}{l}\text { Communicative English } \\
\text { for Primary School } \\
\text { Students Grade 2: } \\
\text { Students' Book }\end{array}$ & $\begin{array}{l}\text { Buku Ajar Bahasa Inggris } \\
\text { Sekolah Dasar Kelas } \\
\text { untuk Siswa }\end{array}$ & 2011 \\
\hline 5. & $\begin{array}{l}\text { Communicative English } \\
\text { for Primary School } \\
\text { Students Grade 3: } \\
\text { Students' Book }\end{array}$ & $\begin{array}{l}\text { Buku Ajar Bahasa Inggris } \\
\text { Sekolah Daswa } \\
\text { untuk Siswa }\end{array}$ & 2011 \\
\hline 6. & $\begin{array}{l}\text { Communicative English } \\
\text { for Primary School } \\
\text { Students Grade 4: } \\
\text { Students' Book }\end{array}$ & $\begin{array}{l}\text { Buku Ajar Bahasa Inggris } \\
\text { Sekolah Diswa } \\
\text { untuk Siswa }\end{array}$ & 2011 \\
\hline 7. & $\begin{array}{l}\text { Communicative English } \\
\text { for Primary School } \\
\text { Students Grade 5: } \\
\text { Students' Book }\end{array}$ & $\begin{array}{l}\text { Buku Ajar Bahasa Inggris } \\
\text { Sekolah Daswa } \\
\text { untuk Siswa }\end{array}$ & 2011 \\
\hline 8. & $\begin{array}{l}\text { Communicative English } \\
\text { for Primary School } \\
\text { Students Grade 6: } \\
\text { Students' Book }\end{array}$ & $\begin{array}{l}\text { Buku Ajar Bahasa Inggris } \\
\text { Sekolah Daswa } \\
\text { untuk Siswa }\end{array}$ & 2011 \\
\hline 9. & $\begin{array}{l}\text { Communicative English } \\
\text { for Primary School } \\
\text { Students Grade 1: } \\
\text { Teachers' Book }\end{array}$ & $\begin{array}{l}\text { Buku Ajar Bahasa Inggris } \\
\text { Sekolah Daswa } \\
\text { untuk Guru }\end{array}$ & 2011 \\
\hline 10. & $\begin{array}{l}\text { Communicative English } \\
\text { for Primary School } \\
\text { Students Grade 2: } \\
\text { Teachers' Book }\end{array}$ & $\begin{array}{l}\text { Buku Ajar Bahasa Inggris } \\
\text { Sekolah Daswa } \\
\text { untuk Guru }\end{array}$ & 2011 \\
\hline 11. & $\begin{array}{l}\text { Communicative English } \\
\text { for Primary School } \\
\text { Students Grade 3: } \\
\text { Teachers' Book }\end{array}$ & $\begin{array}{l}\text { Buku Ajar Bahasa Inggris } \\
\text { Sekolah Daswa } \\
\text { untuk Guru }\end{array}$ & 2011 \\
\hline 12. & $\begin{array}{l}\text { Communicative English } \\
\text { for Primary School } \\
\text { Students Grade 4: } \\
\text { Teachers' Book }\end{array}$ & $\begin{array}{l}\text { Buku Ajar Bahasa Inggris } \\
\text { Sekolah Daswa } \\
\text { untuk Guru }\end{array}$ & 2011 \\
\hline
\end{tabular}




\begin{tabular}{|c|c|c|c|}
\hline 13. & $\begin{array}{l}\text { Communicative English } \\
\text { for Primary School } \\
\text { Students Grade 5: } \\
\text { Teachers' Book }\end{array}$ & $\begin{array}{l}\text { Buku Ajar Bahasa Inggris Siswa } \\
\text { Sekolah Dasar Kelas 5: Buku } \\
\text { untuk Guru }\end{array}$ & 2011 \\
\hline 14. & $\begin{array}{l}\text { Communicative English } \\
\text { for Primary School } \\
\text { Students Grade 6: } \\
\text { Teachers' Book }\end{array}$ & $\begin{array}{l}\text { Buku Ajar Bahasa Inggris Siswa } \\
\text { Sekolah Dasar Kelas 6: Buku } \\
\text { untuk Guru }\end{array}$ & 2011 \\
\hline 15. & $\begin{array}{l}\text { INTERFERENSI } \\
\text { Pengaruh Bahasa } \\
\text { Indonesia dalam Bahasa } \\
\text { Inggris }\end{array}$ & $\begin{array}{l}\text { Udayana University Press } \\
\text { ISBN: 978-602-9042-27-6 }\end{array}$ & 2011 \\
\hline 16. & $\begin{array}{l}\text { "NIKMATILAH } \\
\text { KEBAHAGIAAN INI." } \\
\text { Metafora Emosi } \\
\text { Kebahagiaan dalam } \\
\text { Bahasa Indonesia: Analisis } \\
\text { Pola Metafora Berbasis } \\
\text { Korpus }\end{array}$ & $\begin{array}{l}\text { Buku Monograf: Bahasa Ibu } \\
\text { Sebagai Pilar Jati Diri \& } \\
\text { Pembentukan Karakter Bangsa } \\
\text { yang Majemuk ISBN 978-602- } \\
9042-62-7\end{array}$ & 2012 \\
\hline
\end{tabular}

